\title{
ECONOMIA SOLIDÁRIA E IDENTIDADE
}

\section{A AUTOGESTÃO NO TRABALHO COMO EXPERIÊNCIA EMANCIPATÓRIA}

(Versão original)

Dissertação apresentada ao Instituto de Psicologia da Universidade de São Paulo, como parte dos requisitos para obtenção do título de Mestre em Psicologia.

São Paulo 


\section{AUTORIZO A REPRODUÇÃO E DIVULGAÇÃO TOTAL OU PARCIAL DESTE TRABALHO, POR QUALQUER MEIO CONVENCIONAL OU ELETRÔNICO, PARA FINS DE ESTUDO E PESQUISA, DESDE QUE CITADA A FONTE.}

Catalogação na publicação Biblioteca Dante Moreira Leite

Instituto de Psicologia da Universidade de São Paulo

Nicolletti, Mariana Xavier.

Economia solidária e identidade: a autogestão no trabalho como experiência emancipatória / Mariana Xavier Nicolletti; orientadora Sylvia Leser de Mello. -- São Paulo, 2011.

$523 \mathrm{f}$.

Dissertação (Mestrado - Programa de Pós-Graduação em Psicologia. Área de Concentração: Psicologia Social) - Instituto de Psicologia da Universidade de São Paulo.

1. Psicologia social 2. Trabalho 3. Autogestão no trabalho 4. Cooperativismo 5. Economia solidária 6. Identidade 7. Grupos 8. Emancipação I. Título. 


\section{ECONOMIA SOLIDÁRIA E IDENTIDADE}

\section{A AUTOGESTÃO NO TRABALHO COMO EXPERIÊNCIA EMANCIPATÓRIA}

Dissertação apresentada ao Instituto de Psicologia da Universidade de São Paulo, como parte dos requisitos para obtenção do título de Mestre em Psicologia.

Área de concentração: Psicologia Social

Orientadora: Profa. Dra. Sylvia de Mello Leser

São Paulo 


\section{ECONOMIA SOLIDÁRIA E IDENTIDADE A AUTOGESTÃO NO TRABALHO COMO EXPERIÊNCIA EMANCIPATÓRIA}

\section{Banca Examinadora:}

Profa. Dra. Sylvia Leser de Mello

(Orientadora)

Universidade de São Paulo

Profa. Dra. Leny Sato

Universidade de São Paulo

Prof. Dr. Antônio da Costa Ciampa

Pontifícia Universidade Católica de São Paulo 
Se dependesse de mim, do meu pensamento, o mundo era outro. (...) Emprego é salário todo mês, mas bitola, você consegue apenas olhar para frente e não para os lados.

Luís, grupo Mãos na Massa

Estou no grupo para fundar alguma coisa, para deixar alguma coisa, porque não sou mais criança não.

Rosa, grupo Mãos na Massa

Eu penso em um futuro bonito, eu vejo isso aqui crescer, gerar frutos...

Vicença, grupo Mãos na Massa 
A quem me mostou, primeiro o mundo. A quem devo meu interesse, minha curiosidade, meu amor pelo outro. Gerson e Maria Ignez.

A Fábio, Com quem, de mãos dadas, a caminhada tornou-se mais firme, livre, mágica. 


\section{Agradeço}

Ao grupo Mãos na Massa, a todos os que fazem desse projeto uma realidade dia após dia, por permitir que o projeto de pesquisa se tornasse esta dissertação. Obrigada pelo acolhimento, pelo reconhecimento e pelo espaço em suas vidas. Agradeço especialmente aos cooperados que me abriram suas histórias de vida com uma franqueza, dedicação e poesia comoventes; pela possibilidade de experimentar, eu mesma, um outro "outro". Sem vocês nada disso teria acontecido.

À Professora Sylvia Leser pela generosidade em partilhar ideias e a riqueza de sua experiência e conhecimento. Pela imensa sabedoria. Pela paciência também nos momentos de maior ansiedade e angústia. Seus conselhos foram guia para que pudesse concluir esta pesquisa.

Ao Professor Antônio Ciampa pela atenção desde o início, quando nasciam as primeiras perguntas fundantes deste projeto, pela disponibilidade, pela abertura para a conversa. Lembro sempre de suas aulas, inspiração para cada passo da pesquisa.

À Professora Leny Sato pela leitura atenta do texto de Qualificação, pelos valiosos conselhos nesse momento do trabalho. Também, pelas indicações de leitura, pelo espaço de discussão, leve e verdadeiramente disponível, de suas aulas; pelos novos horizontes, mais amplos. Aí nasceu minha paixão, mais que interesse, pelo tema trabalho.

A todos os formadores da ITCP-USP, especialmente a Nadir, Silvia e Werner com quem foram inestimáveis os aprendizados, além do processo de formação, sobre as relações humanas e a dedicação ao outro. Sem a oportunidade que me ofereceram, de trabalhar com vocês e com o grupo Mãos na Massa, e de discutir a construção coletiva, não teria sido esta a minha pesquisa.

À Maíra Lopes pela amizade firme, pela personallidade marcante, por dar voz, de forma tão autêntica, às suas personagens. Pela disposição bem humorada, cheia de energia, em ajudar. Como na revisão do Abstract, mesmo que implicando, em tal momento, menos horas de sono.

A Camila Appel, Carolina De Jongh e Cristine Rosa pela personificação do companheirismo. Pela presença, sempre, nas conquistas e decepções, nos passos em qualquer direção, enganos e 
encontros, com igual lealdade e franqueza. Pela sublime combinação de sensibilidade e força. Por serem tão humanas. A convivência com vocês foi impulso para superar os desânimos e dificuldades, para terminar este trabalho.

Ao Fábio Mesquita, pelas conversas a qualquer hora, a toda hora. Pela compreensão da falta de tempo e pelo aproveitar verdadeiro do tempo que há. Com você aprendi a beleza do presente, sua fugaz intensidade. Aprendi que sempre há alternativas, seu companheirismo é fonte de força para lançar-me a elas.

Aos meus pais, agradeço pelo afeto inesgotável, pelo colo onde encontrei, tantas vezes, a justa força, pela liberdade, quando por ela ansiei. Com vocês aprendi a disciplina, a dedicação, o inestimável potencial contido em cada pessoa, em mim e em cada um com quem encontrei. Por vocês levei-me a sério nas brincadeiras e acreditei em um mundo diferente. Em vocês senti, pela primeira vez, a arte. Continuo vivendo-a até hoje.

Ao meu irmão, Marcelo, com quem aprendi que o "faz de conta" junto é muito mais encantador que o sozinho. Experimentei com você o primeiro compartilhar, discutir, ceder, apego e desapego. Repertório para toda vida.

À Universidade de São Paulo e a todos os cidadãos que tornam possível a existência desse ambiente fervilhante de ideias, de conhecimento, de iniciativas que transbordam os muros da Cidade Universitária; matéria orgânica para a construção coletiva de uma nova ciência e de uma sociedade diferente, mais humanas. A todas as pessoas com quem, aí, pude encontrar e trocar. 


\section{SUMÁRIO}

LISTA DE TABELA GRÁFICO E FOTOGRAFIAS........................................................v

RESUMO................................................................................................................................vi

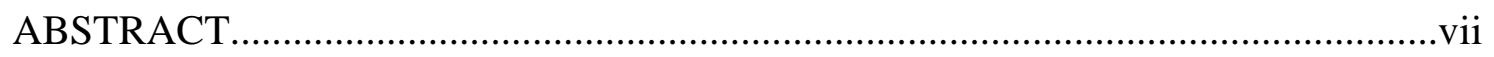

Apresentação................................................................................................................................................ 1

Capítulo I - Introdução .......................................................................................................................................

1.1. Os sujeitos da pesquisa..................................................................................

1.2. Milhões de motivos para a pesquisa................................................................

Capítulo II - O trabalho.........................................................................................................................16

2.1. A categoria trabalho no contexto contemporâneo.................................................17

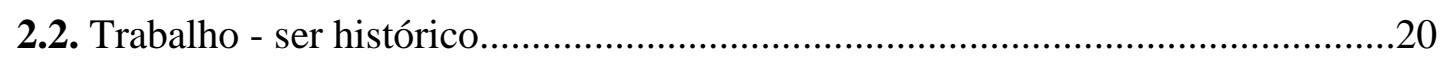

a. Os movimentos do trabalho no contexto histórico mundial.............................20

b. História recente do trabalho no Brasil............................................................29

2.3. O trabalho na sociedade contemporânea - aprofundamento e ampliação de tendências nada animadoras .33

2.4. O trabalhador e a classe que vive do trabalho.......................................................38

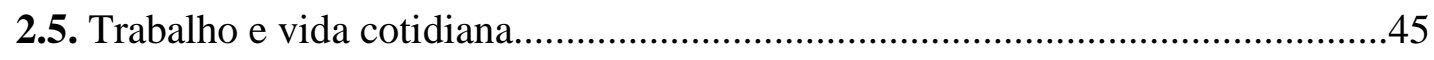

Capítulo III - Ser social - política e subjetividade na sociedade contemporânea.........50

3.1. Objetividade e subjetividade - os sentidos das relações sociais

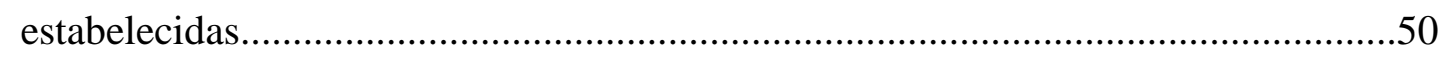

3.2. (Não)Dialética e (a)política na sociedade contemporânea..................................59

3.3. Identidade como metamorfose constante - categoria e fenômeno..........................79

a. Identidade - apresentação............................................................................. 80

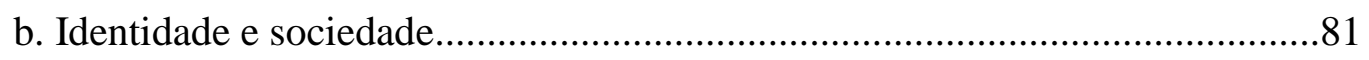

c. O esforço de autodeterminação, a luta de "ser para si".....................................84

d. Identidade como metamorfose constante e a aparência de não metamorfose .86 
e. O "fetichismo da personagem", "identidade mito" e "mesmice" - as faces da reificação humana. .89

f. "Mesmidade" e "alterização" como negação de um mundo que não merece ser vivido. 91

3.4 O esgotamento da crítica - uma perspectiva ameaçadora.....................................93

3.5 A identidade e as organizações - o enrijecimento pela institucionalização. .94

3.6. Da utopia para um mundo em construção. .95

Capítulo IV - Economia Solidária e cooperativismo como alternativa de trabalho, renda e relações sociais. .99

4.1. A Economia Solidária e o Cooperativismo - apresentação.

4.2. Cooperativas endógenas e cooperativas exógenas: mais que um esforço classificatório.

a. A base para a compreensão das divergências e convergências - os percussores da economia solidária. .109

b. Potencialidades do apoio externo nem sempre exploradas. 115

c. Divergências empíricas entre as experiências endógenas e exógenas. 117

d. Convergências empíricas entre as experiências endógenas e exógenas

4.3. Cooperativismo e inter-subjetividade - os sentidos da autogestão. 126

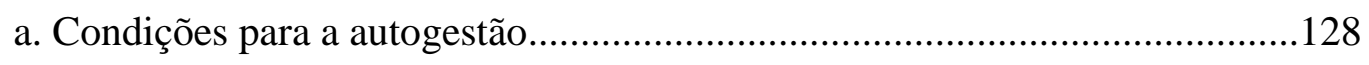

b. Autogestão e necessidades básicas............................................................130

c. Autogestão, capital relacional e capital social..............................................132

d. Autogestão, empoderamento e autonomia...................................................133

e. Autogestão, luta de classes e identidade coletiva............................................138

f. Autogestão, trabalho e vida cotidiana..............................................................140

g. Autogestão, afetividade e autoestima.........................................................144

h. Lacuna entre a teoria e prática autogestionárias...............................................145

Capítulo V - Mãos à massa - autogestão e identidade em três histórias de vida.

5.1. Mãos na Massa - muito prazer. 149 
5.2. A organização cooperativa em formação - uma história recente.

a. O caminho da pesquisa nessa história

5.3. Luís, Joana e Márcia - a cena a quem a merece, os protagonistas. 161

Márcia. 161

Infância, as primeiras memórias. 161

A casa da madrinha - nova família, primeiros patrões...........................165

O casamento - "era feliz e não sabia". .168

O espiritismo, mistério, curiosidade, medo, sentido, segurança, reconhecimento

A história com o trabalho - "eu gosto, eu amo" 176

O emprego em Floriano - soma de mudanças quantitativas 176

... São Paulo - "o único lugar que não queria vir" 180

Favela, movimento social, cooperativismo 185

O grupo, as dificuldades para a autogestão. 191

Luís.

As primeiras memórias, onde muitas personagens fundamentam-se.........198

A descoberta da incoerência do mundo..................................................200

A negação do que não merece ser vivido..................................................201

A história como pilar para compreensão do mundo...................................203

O limite da contradição, a alterização.....................................................204

A luta pelo reconhecimento afetivo, legal... solidário..............................206

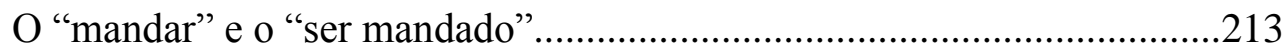

A contradição, força motriz do movimento............................................2215

O Luís que se apresenta à experiência autogestionária...........................217

Luís e o grupo Mãos na Massa...............................................................2220

Joana...................................................................................................................2224

As primeiras histórias, as primeiras personagens..................................225

A Joana-que-vende-a-força-de-trabalho-e-a-expressão-de-si-mesma........226

A Joana-ex-esposa-serva e a Joana-dona-de-sua-força-de-trabalho-e-dos-meios-deprodução. .231

Mudança radical - da objetividade para a subjetividade .233 
O grupo Mãos na Massa e a Joana-cooperada.........................................238

O trabalho em grupo e autogestão.......................................................240

As outras Joanas: a Joana-cooperada e um grupo de novas personagens...247

Joana-cooperada e a organização de apoio: disputa pela determinação.....253

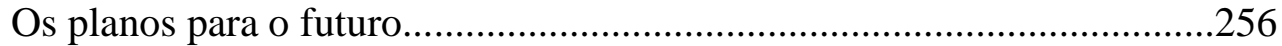

5.4. As questões vividas pelo e com o grupo Mãos na Massa................................259

a. Momento inicial - conglomerado de interesses individuais........................259

b. Segundo momento - quando o conflito adentra o coletivo.........................264

c. Terceiro momento - em que o grupo e os sujeitos-cooperados conformamse.

5.5. Processo de formação - indicadores, sugestões práticas e pontos de atenção.

Considerações Finais - o fim de um texto, o início de uma nova história.....................283

Referências Bibliográficas ..................................................................................296

ANEXO 1 


\section{LISTA DE TABELA, GRÁFICO E FOTOGRAFIAS}

Tabela 1 - Número de cooperativas por região do Brasil.................................................

Gráfico 1 - Internalidades e externalidades - experiências endógenas e exógenas............126

Fotografia 1 - Jardim Jaqueline, Distrito Vila Sônia Zona / Oeste de São Paulo............149

Fotografia 2 - Mãos na Massa - grupo em formação em 2008...........................................149

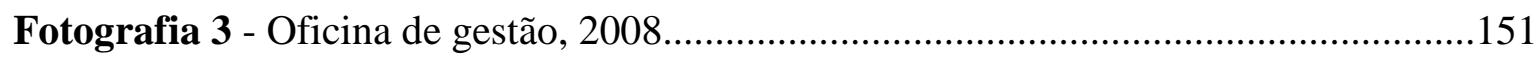

Fotografia 4 - Tarjetas usadas na discussão da gestão da cooperativa, 2008....................151

Fotografia 5 - Atividade lúdica, oficina de gestão, 2008...............................................151

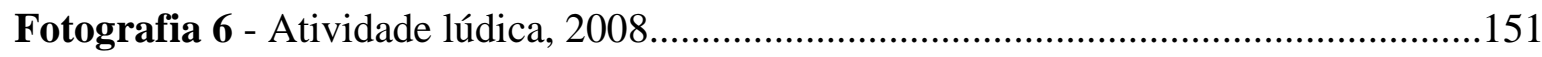

Fotografia 7 - Oficina de gestão - exercício com tarjetas, 2008 ………………………...152

Fotografias 8, 9 e 10 - Produção das barras de cereal Mãos na Massa, 2008......................155

Fotografia 11 - Amigo secreto Mãos na Massa................................................................157

Fotografia 12 - Lanche solidário do amigo secreto - todos levaram alguma coisa............158

Fotografia 13 - Grupo Mãos na Massa, 2009 ................................................................160 


\section{RESUMO}

NICOLLETTI, Mariana Xavier. Economia solidária e identidade: a autogestão no trabalho como experiência emancipatória. São Paulo, 2011. 523 p. Dissertação (Mestrado). Instituto de Psicologia, Universidade de São Paulo.

Nascida de minha história com o trabalho, fundamentada na vivência junto a grupos hétero e autogestionários, esta pesquisa busca a aproximação à experiência subjetiva, particular, única, vivenciada pelos sujeitos-cooperados de uma cooperativa popular exógena em formação, a Mãos na Massa. Sujeitos que fazem o dia a dia do empreendimento, que vivenciam a construção cotidiana da autogestão, em seus desafios e oportunidades.

O prisma adotado a fim de compreender o sentido das transformações experimentadas pelos sujeitos é o da Identidade como metamorfose constante. A partir da observação participante ao longo do trabalho de nove meses junto ao grupo e das entrevistas em profundidade, de história de vida, com três cooperados, foi possível traçar pontos de inflexão ou de manutenção do sentido em que a metamorfose das identidades, nesses três casos, pôde dar-se. A matéria-prima desta pesquisa é o repertório de cada um, os sonhos, desejos, interesses. O encontro com a proposta de uma nova organização do trabalho pode ressoar de infindáveis maneiras, ganhar diversos significados; conformar-se ou não em um vetor para a concretização dos projetos de autonomia.

Parte-se do papel central do trabalho para a formação e transformação da subjetividade, atividade de interação com o outro e com o ambiente que abre caminho para a transformação de si mesmo e do mundo. Trabalho que se concretizou, historicamente, como emprego, como trabalho informal, precarizado, contratado etc. A economia solidária e o cooperativismo popular propõem uma outra organização do trabalho e, portanto, uma diferente concretização das relações entre os homens e mulheres e deles como o mundo. Organização marcada pela solidariedade, cooperação, participação, equidade, pela construção conjunta, pela autogestão. Teoria e prática juntaram-se na formulação e no estudo da pergunta fundadora desta pesquisa: se, e de que maneira, a vivência do cooperativismo popular impulsiona um novo sentido, emancipatório, à metamorfose constante da identidade dos sujeitos-cooperados.

Não se chega a uma única e definitiva resposta, mas aos caminhos seguidos por cada narrador de sua própria história. Entende-se como, nesses três casos, a economia solidária representou alternativas aos valores e ideologias enrijecidos, e como, assim, despontam espaços para novas personagens, para um outro "outro" que clama por vida. A vivência autogestionária apresenta-se, sim, como oportunidade para o reconhecimento de habilidades, conhecimentos, potencialidades, do que há em comum e de particular em cada um; para reconhecimento de toda a humanidade contida em cada homem e em cada mulher. A partir dos símbolos e significados compartilhados, recupera-se a confiança em si mesmo, estabelece-se a base para a posição de sujeito-ativo, autodeterminado que se lança à mudança do que não merece ser vivido, à construção de uma nova objetividade, não apenas no trabalho, na vida, na comunidade, no mundo.

Palavras-chave: Trabalho. Autogestão. Cooperativismo. Economia Solidária. Identidade. Grupo. Metamorfose. Emancipação. Vida. 
NICOLLETTI, Mariana Xavier. Solidarity-Based Economy and Identity. The self-managed work as emancipator experience. São Paulo, 2011, 523 p. M.A. Thesis, Institute Psychology Institute, USP.

Originated in my own working story, and based on the experience with hierarchical and self-managed groups, this study seeks a closer approach to the subjective, particular, and unique experience lived by individual members of Mãos na Massa, an exogenous and communal cooperative in process of formation. These individuals, this community are responsible for the business day by day; they are the one who experience the construction of self-managed on a daily basis, along with its challenges and opportunities.

In order to comprehend trends of their transformation, the Identity as constant metamorphosis was the perspective adopted in the analysis. Through continuous observation during nine months of work with the group and in-depth interviews of three cooperative members about their life stories, it was possible to plot points of inflection and maintenance of the direction their identities' metamorphosis in these three cases. The raw material of this survey is the repertoire of each individual - his or her dreams, desires, and interests. The encounter with a proposal of new work structure can reverberate in endless ways, have several meanings, and comply, or not, with a vector towards the achievement of their autonomy projects.

The central role of work in the formation and transformation of subjectivity is a premise of this research, taking into account work as an activity of interaction with the other and with the environment. Therefore, the work is considered the activity that paves the route for the transformation of oneself and of the world. The concept of work that has been materialized, historically, as employment, as precarious and informal work, as hired work, etc. Solidarity economy and communal cooperatives propose another organization of work and, thus, different relationships between men and women, between them and the world. Their proposal is focused in work organization marked by solidarity, cooperation, participation, equity, by co-construction, by self-management. Theory and practice have created the foundation question of this survey: whether, and in what manner, the experience in communal cooperatives propels a new direction towards constant metamorphosis of their participants' identity and emancipation.

The result is not a single and definitive answer, but the comprehension of paths trailed by each being, narrator of his or her own story. It is possible to recognize how, in the three cases analyzed, solidarity economy represented alternatives to rigid values and ideologies, and as a result it also signified a new scenario for new characters, a new space for another "other" that alleges for life. Therefore, the self-management experience can connote an opportunity for recognition of their own skills, knowledge, capabilities, not to mention their similarity and particularity. Finally, it can symbolize recognition of all mankind inside each one. From shared symbols and meanings, it seems to be possible to retrieve self-confidence, to establish the basis for an active-subject position and self-determined being who throws oneself to real change - to change what is not worth to live, to the construction of a new objectivity, not just at work, in life, in the community, in the world.

Keywords: Work. Self-management. Communal cooperatives. Solidarity-Based Economy. Identity. Group. Metamorphosis. Emancipation. Life. 


\section{$\underline{\text { Apresentação }}$}

Há experiências que nos formam, outras deformam. (construção coletiva em conversas e experiências diversas ao longo da vida)

A fonte primeira de interesse pelo tema de pesquisa foi minha própria história de vida. As pessoas com quem estabeleci relações, as organizações das quais fiz e faço parte, os livros, teses, estudos que caíram em minhas mãos, as músicas que pude ouvir; principalmente as pessoas com quem tive a sorte de encontrar e relacionar-me. História essa que permitiu uma composição de encantamento com a riqueza de potencialidades, sentimentos e anseios humanos junto à frustração e ao desapontamento frente aos mecanismos que barram ou deprimem a realização dessa força de vida.

Dispositivos esses que foram compreendidos, ao longo do tempo, como derivados da ausência. Espaço vazio deixado pela falta de educação, falta de espaço para a participação, falta de voz, de alimento, de acesso a bens materiais e imateriais; quase todos eles, no mundo em que vivemos, compráveis. No limite, a falta de renda para acessar esses bens. Foi assim que se deu o envolvimento na Incubadora de Cooperativas Populares da FGV ${ }^{1}$ (ITCP-GV), quando era ainda apenas uma ideia, uma vontade de um grupo de pessoas de contribuir com a formação de outra economia. Nessa época pouco tinha ouvido e lido sobre a economia solidária, estava fora de minha compreensão; foi aos poucos que passei a compreender que se tratava de mais, bem mais, do que gerar renda, mas da construção de novas relações entre as pessoas.

Durante os anos de trabalho como formadora dessa nova incubadora e das cooperativas junto aos grupos que me aconteceu o trabalho. Esse trabalho praticamente impôs-se em meus dias de forma espelhada: nos grupos, para os cooperados, como alternativa ao desemprego como caminho único de obtenção das condições básicas à sobrevivência, deles e dos seus, para mim como meio de efetiva interação com o de fora, de possível mudança e de autorealização. Muito maior do que minha capacidade de compreensão, naquele tempo e sempre, a vivência levou-me a buscar saber mais sobre o tema, a estudar para tentar ler a prática, conhecer mais das teorias para aproximar-me da vida.

O trabalho impôs em diversos outros momentos, por vezes mágico, como nesse primeiro momento, por outras, duro, sólido, opressor. Uma breve experiência em organizações do Setor

\footnotetext{
${ }^{1}$ Instituição ligada à Escola de Administração de Empresas de São Paulo Fundação Getúlio Vargas em que Mariana Nicolletti atuou por pouco mais de dois anos.
} 
Privado, e as consequências dela para todas as minhas outras "faces", foi, ao mesmo tempo, sombria e esclarecedora: era preciso lançar-me à busca da maior compreensão do ser humano para, ao menos, tentar responder alguns dos infindos porquês nos quais me imergia. Por que as pessoas organizavam-se assim? Por que ninguém questionava? O que sentiam? Quais os sentimentos daquelas pessoas ao meu redor? O que isso tem de contínuo e descontínuo em relação à autogestão, às cooperativas?

Mudando de emprego e dedicando-me a outro trabalho, foi possível voltar ao centro, resgatar-me da ditadura dos questionamentos e priorizar as questões. O trabalho, de volta, com grupos na formação de negócios sustentáveis com o objetivo de gerar renda e melhorar a qualidade de vida em comunidades rurais tinha sentido. É apenas com um trabalho cheio de sentido que consigo relacionar-me comigo mesma e, portanto, com os outros e com o mundo.

Puderam também aproximar-se as perguntas fundamentais, surgidas durante o trabalho na incubadora, junto aos trabalhadores, e que me acompanhavam sempre, surgindo como lembretes que pulam no meio da tela do computador em meio a outro tema, com relação muitas vezes obscura com o assunto de que lembrado, avisando de que é preciso voltar-se àquilo mais cedo ou mais tarde. A que se referiam essas questões? À ligação entre trabalho e subjetividade.

Os resultados objetivos das cooperativas formadas junto à ITCP (incubadora de cooperativas populares) eram observáveis, podiam ser notados, tanto os positivos quanto aqueles aquém dos esperados pelos formadores e pelo grupo. Mas o que se passava com as pessoas era o que eu queria saber, sem conseguir acessar esse outro nível do trabalho sentia falta de ar. Esse era o principal objetivo do trabalho de fomento à economia solidária, as pessoas, e, no entanto, não tínhamos conhecimento, ferramentas, experiência, ou as três coisas, para compreendê-las em sua relação com aquelas atividades propostas, com o trabalho, bem como para entender o emaranhado de relações estabelecidas em torno dele. Nós nos defrontamos com a falta, e com todas as consequências dela.

Parecia-me que enquanto os trabalhadores das empresas em que estive tinham outras opções (hoje questiono essa colocação), os cooperados, na maior parte das vezes, lançavam-se à autogestão como única saída de uma situação de constrangimento socioeconômico. Antes desempregados, agora cooperados. Antes sem renda, agora com direito às sobras, resultado de seu trabalho. 
Surgia, durante os encontros de formação, a busca por notícias de emprego, a esperança de que aparecesse uma vaga em uma empresa heterogestionária, capitalista, que os aceitasse. Perguntei uma ou outra vez o que fariam nesse caso; deixariam a construção da cooperativa, como alguém que abandona um prato de comida por outro cardápio que lhe apetece mais. Não sabia se estavam ali, nos encontros, realmente participando e envolvendo-se, em que nível se dava esse envolvimento ao longo do desenvolvimento da cooperativa e do trabalho coletivo e, portanto, que tipo de transformação essas pessoas estariam vivenciando.

É daí que nasce o projeto de pesquisa sobre sujeito-autogestão-transformação. A relação entre os três conceitos estava posta em forma de pergunta; era só preciso formulá-la. 


\section{Capítulo I - Introdução}

A fim de compreender um pouco mais sobre a possível transformação vivida pelos cooperados, sua existência e em que direção se daria, era necessário que outra visão pudesse ser formada na relação com esses sujeitos. Na busca pelo reposicionamento da observação e da interação com os cooperados e com a cooperativa, a noção de Identidade mostrava-se certeira. Isso não apenas porque acreditava que alguma transformação deveria dar-se no sentido de como o cooperado enxergava a si mesmo e como os outros de sua família e comunidade o viam, portanto, suas relações, mas também porque logo entrei em contato com a tese de Antônio da Costa Ciampa (1987).

Defendendo que Identidade é metamorfose constante, que esse movimento contínuo de configuração e reconfiguração tem como motor a interação social e, como fundadoras, a atividade e a consciência, a integração da teoria com a experiência a ser pesquisada estabeleceu-se fecundamente. Fundamentando-se na Teoria da Ação Comunicativa de Habermas (1983) e no Interacionismo Simbólico, Mead (1938), Ciampa apresenta os problemas de uma organização social, a nossa, contemporânea, em que as identidades de seus sujeitos são estancadas, a metamorfose impedida; mecanismo esse de manutenção do status quo.

A economia solidária se propõe, ao menos a partir de alguns de seus pensadores mais consistentes como Singer (2000 e 2002), Kraychete, Lara e Costa (2000) e Santos (2002), a fomentar transformações no âmbito da ação e das relações. Afirmando e demonstrando outra forma de organização, baseada em valores distintos aos disseminados no sistema do capital, e maneiras diferentes de relacionar-se, esse movimento inaugura espaços de participação coletivos em que todos colocam-se igualmente; são, juntos, donos dos meios de produção e constroem no dia a dia os processos e condições de trabalharem e de serem. Portanto, a aproximação a um dos principais expoentes da economia solidária, a cooperativa, a fim de compreender se e como os sujeitos-cooperados transformam-se pela experiência, seria apoiada na teoria da Identidade como metamorfose constante.

Na composição da questão central da pesquisa faltava ainda um elemento: esclarecer que cooperativa seria essa. É fato que existem alguns tipos de cooperativas, essencialmente distintas, nos seus objetivos e na relação capital-trabalho estabelecida; as agrocooperativas, por exemplo, fazem parte da história do cooperativismo no Brasil (MARTINS de OLIVEIRA, 2006). As 
chamadas "coopergatos" se utilizam da legislação regulatória do cooperativismo para terceirização da mão-de-obra, driblando os direitos trabalhistas e precarizando ainda mais o trabalho e ampliando os lucros; precisamente definidas por Oliveira (2007) como "venda de mãode-obra". Não são esses modelos o foco da pesquisa, mas sim de cooperativas de trabalho pautadas pelos princípios da economia solidária, efetivamente geridas pelos trabalhadores, as cooperativas populares.

Outra característica definidora dos empreendimentos aos quais se volta essa pesquisa é serem cooperativas exógenas (VIEIRA, 2006). Grande parte dos questionamentos formulados durante a atuação na ITCP-GV punha-se em torno do cooperativismo ser a "solução" trazida de fora, não imaginada ou desejada previamente pelo grupo, mas oferecida pelos formadores. A participação na cooperativa era, algumas vezes, declaradamente paliativa, enquanto o emprego não aparecia. Também por isso, parcela dos grupos, ao perceber que a formação é processual, leva tempo até que renda seja gerada, e que não haveria um salário mensal fixo enquanto isso, optava por sair do grupo.

Vieira (op. cit.), ao estudar cooperativas exógenas e endógenas ${ }^{2}$ em assentamentos do Movimento dos Sem Terra (MST), identificou haver discrepâncias relevantes em relação à utopia e à consciência da luta de classes entre as duas experiências. Estudos de caso considerados pelo autor evidenciariam que no primeiro tipo (exógeno) não seriam desenvolvidas tão solidamente como no segundo (endógeno) as críticas ao capitalismo e que estas, por sua vez, são essenciais para a emancipação dos trabalhadores, pois só assim se livrariam do sentimento de culpa pela própria condição de pobreza.

Enquanto os "militantes" da economia solidária, os formadores, têm como objetivo a superação do capitalismo, os cooperados podem estar buscando um caminho para o acesso a suas benesses, incluindo-se nele e fortalecendo o sistema vigente. Embora para o movimento ${ }^{3}$ como um todo isso possa não se configurar um problema na medida em que, de qualquer forma, tanto militantes quanto cooperados parecem caminhar em direção à formação de organizações autogestionárias, maior distribuição de renda, ampliação dos direitos e adoção de rituais

\footnotetext{
${ }^{2}$ As experiências "endógenas" são aquelas cuja origem advém da iniciativa do próprio grupo de futuros cooperados enquanto as "exógenas" são iniciadas pelo trabalho de organizações ou pessoas que não fazem parte do grupo, que o convocam para a formação de empreendimentos autogestionários.

${ }^{3}$ A economia solidária deve ser vista como movimento social e assim se configura principalmente pela influência da crítica academicista de seus percussores que apontavam para a necessidade de, além de formular, exercer as teorias como militante e ativista (VIEIRA, 2006).
} 
participativos e democráticos, para o estudo da Identidade o problema está configurado. Ciampa (1987) aponta que a metamorfose da identidade tem como impulsionador o compartilhamento de significados entre os indivíduos, o que não acontece caso estejam grupo apenas por falta de opções, pró-forma, interessados exclusivamente no acesso à renda.

A importância de compreender melhor como isso dá-se ou não se dá é sublinhada pela apresentação da economia solidária e das cooperativas populares como sintetizado por efetiva alternativa ao desemprego crescente, à pobreza, à exclusão, à desigualdade, enfim, à condição de privação em que uma imensa parcela da população dos chamados "países em desenvolvimento" encontra-se como decorrência da falta de trabalho e renda (COSTA 2002). Movimento com esse sentido, na contramão do cenário que vemos acirrando-se na atual fase do capitalismo, merece um mergulho no universo dos indivíduos que o fazem no dia a dia, nas vidas possíveis na e a partir da autogestão. Afinal, é a favor da vida que se coloca a economia solidária.

A autogestão é o principal componente teórico e prático do cooperativismo: os trabalhadores, sujeitos-cooperados, são os proprietários dos meios de produção e tomam todas as decisões democraticamente, em reuniões e assembleias. Tal gestão compartilhada junto ao vigor dos valores de ajuda mútua, responsabilidade, igualdade, equidade e solidariedade, remetem às condições defendidas por Habermas (1990) e Mead (1972) como necessárias para o desenvolvimento de um nível superior de autonomia, diretamente relacionado a uma consciência mais apurada, crítica, universal e ao sentido emancipatório da metamorfose da identidade.

Está constituída a pergunta sobre a qual me debruço em pesquisa de campo e teórica: a participação em cooperativas de trabalho exógenas é experiência propícia à metamorfose da identidade com sentido emancipatório, dos sujeitos-cooperados em oposição à organização do trabalho, e da sociedade, desumanizadora em vigor no sistema capitalista contemporâneo? A fim de explorar possíveis respostas, sentidos da autogestão para os sujeitos-cooperados, lanço-me a pesquisar o trabalho autogestionário em cooperativa popular exógena, buscando indícios dessa vivência como impulsionadora à metamorfose das identidades com sentido emancipatório.

\subsection{Os sujeitos da pesquisa}

$\mathrm{Na}$ construção desse caminho relacionam-se, intrinsecamente, cooperados, formadores e pesquisadora atuando em conjunto para a constituição do empreendimento autogestionário exógeno; é dessa relação que nasce a dissertação. Todos os envolvidos possuem histórias de vida, como não poderia deixar de ser, particulares: foram socializados junto a determinados outros 
sujeitos, compuseram uns e não outros grupos, fizeram parte de determinadas organizações, militaram e militam por certas causas. Por isso mesmo, compõem relações específicas formadorcooperado, cooperado-cooperado, cooperado-pesquisador. Subjetivamente, essas relações perpassam os momentos com o grupo, nelas imergem o material de pesquisa, emerge a dissertação.

É para os cooperados que voltamos nossa atenção, em torno de seu passado, presente e futuro aplicamo-nos à pesquisa e ao processo de formação. Mas também a nossos próprios anseios, interesses, medos e angústias. É preciso considerar que a dissertação em elaboração é resultado do encontro de todos esses elementos, nem sempre transparentes ou expressos. Portanto, é na articulação entre o texto e os lugares sociais ocupados pelos sujeitos que se dá a pesquisa.

\subsection{Milhões de motivos para a pesquisa}

"Que tempos são estes, em que é quase um delito falar de coisas inocentes. Pois implica silenciar tantos horrores!" $\left(\right.$ BRECHT $\left.^{4}\right)$

Formulada a questão, a propulsão ao trabalho de pesquisa veio de sua relevância, refletida em evidências quali e quantitativas. O crescimento do número e da representatividade das cooperativas populares no Brasil e no mundo é um primeiro fato. A partir de obras de diversos autores pode-se assumir, também, o crescimento da quantidade de organizações de fomento às iniciativas da economia solidária nos últimos anos, como as incubadoras tecnológicas de cooperativas populares (MARTINS de OLIVEIRA, 2006).

Ao final de 2005, segundo pesquisa realizada pelo Governo Federal ${ }^{5}$ no mesmo ano, as cooperativas integravam 1.251.882 trabalhadores; entre 2000 e 2005 foram criadas, em média, 1.500 cooperativas por ano. Dados mais recentes, de 2007, encontram-se no Atlas de Economia Solidária ${ }^{6}$, elaborado e divulgado pelo Ministério do Trabalho e Emprego: só no Estado de São Paulo eram 1.155 as cooperativas mapeadas. Contabilizando os empreendimentos em todo o país, totalizam 21.859, distribuídas por região de acordo com a tabela abaixo:

\footnotetext{
${ }^{4}$ Fonte: Caderno "Mais!", jornal Folha de São Paulo - São Paulo (SP), edição de 07/07/2002, tradução Manuel Bandeira.

${ }^{5}$ MANCE, E. A. Ética, Responsabilidade Social, Economia Solidária e Comércio Justo.Artigo disponível em: http://etica-social.blogspot.com/2007/07/as-redes-de-economia-solidria-no-brasil.html. Acesso em 20/10/2009.

${ }^{6}$ Publicação disponível no site do Ministério do Trabalho e do Desenvolvimento Social: http://www.mte.gov.br/sistemas/atlas/tabcgi.exe?AtlasGEOSP2.def, acesso em 19/10/2009.
} 


\begin{tabular}{|l|r|}
\hline TABELA 1 \\
\hline Número de cooperativas por região do Brasil - 2007 \\
\hline Região & Quantidade \\
\hline TOTAL & 21.859 \\
\hline Norte & 2.656 \\
\hline Nordeste & 9.498 \\
\hline Sudeste & 3.912 \\
\hline Sul & 3.583 \\
\hline Centro-Oeste & 2.210 \\
\hline
\end{tabular}

Fonte: Atlas de Economia Solidária (2007)

Infere-se daí que aproximadamente $21 \%$ das cooperativas estão na região Nordeste, que apresenta os menores números do Índice de Desenvolvimento Humano do país desde a década passada, segundo o "Relatório Emprego, Desenvolvimento Humano e Trabalho Decente - A experiência brasileira recente" ${ }^{\natural}$. Faz sentido ao considerarmos que os empreendimentos solidários são impulsionados em épocas de crise financeira. Evidência de que o cooperativismo é encarado como alternativa, possível salvação, em situações de desassistência, carência em relação a bens materiais e imateriais. Diversas pesquisas apontam a correlação entre aumento das taxas de desemprego e fortalecimento da economia solidária ${ }^{9}$.

Por outro lado, apenas $2.706,12 \%$ dos empreendimentos, geram, segundo mesma fonte, renda maior que um salário mínimo, $15 \%$ entre meio e um salário; as cooperativas, em maior parte, vêm se consolidando efetivamente como alternativa de renda, complementar a outras fontes de renda acessadas pelos cooperados.

Maria Nezilda Culti ${ }^{10}$ afirma que são os "excluídos" quem majoritariamente organizam-se em cooperativas a fim de atender às suas necessidades e traçar novas possibilidades de trabalho e

\footnotetext{
${ }^{7}$ Dados disponíveis em: http://www.mte.gov.br/sistemas/atlas/tabcgi.exe?QtdEES.def. Acesso em 19/10/2009.

${ }^{8}$ Relatório lançado em 2008 por três agências da ONU: CEPAL (Comissão Econômica para América Latina e Caribe), OIT (Organização Internacional do Trabalho) e PNUD. Disponível para download em: http://www.pnud.org.br/administracao/reportagens/index.php?id01=3034\&lay=apu. Acesso em 19/10/2009.

${ }_{9}$ Para mais informações consultar CULTI, M. N. O Cooperativismo Popular no Brasil: Importância e Representatividade. Artigo escrito para Ecosol, disponível em http://www.institutoapoiar.org.br/imagens/bibliotecas/texto_1_COOPOP.DOC+O+COOPERATIVISMO+POPULA R+NO+BRASIL:+Import\%C3\%A2ncia+e+Representatividade+Maria+Nezilda+Culti1\&cd=3\&hl=pt-BR\&ct=clnk. Acesso em 20/10/2009.

${ }^{10}$ CULTI, M. N. O Cooperativismo Popular no Brasil: Importância e Representatividade. Artigo escrito para Ecosol, disponível em

http://www.institutoapoiar.org.br/imagens/bibliotecas/texto_1_COOPOP.DOC+O+COOPERATIVISMO+POPULA
} 
de vida. O nascimento de diversas entidades importantes de apoio à economia solidária no Brasil denota, para a autora, a representatividade do movimento, encorpado pela camada mais pobre da população, no Brasil. Pode-se citar entre essas organizações: ANTEAG - Associação Nacional de Trabalhadores em Empresas Autogestionárias, o MST - Movimento dos Trabalhadores sem Terra, as ITCPs - Incubadoras Tecnológicas de Cooperativas Populares, a ADS - Agência de Desenvolvimento Solidário, a FETRABALHO - Federação das Cooperativas de Trabalho.

Passando à dimensão mundial, segundo Ivano Barieri, da Aliança Cooperativista Internacional (ACI), nos últimos 160 anos os números do cooperativismo se multiplicaram: já são 800 milhões de sócios, 400 milhões de agricultores associados em cooperativas, 50\% da produção agrícola mundial passando por atividades das cooperativas e presença dos empreendimentos em mais de 100 países $^{11}$.

Na Índia são cinco milhões de cooperativas, envolvendo 236 milhões de pessoas; nos Estados Unidos, são 26 milhões os sócios de cooperativas apenas de eletrificação e $40 \%$ da população tem alguma ligação com cooperativas de crédito; na Estônia, 45\% das famílias vivem em casas de cooperativas; e na Holanda, as cooperativas agrícolas cobrem $75 \%$ do mercado.

As informações qualitativas seguem na mesma direção, apontando a crescente representatividade do cooperativismo na sociedade contemporânea: os empreendimentos já tomam parte de diversos setores da economia, entre os quais são destacados no Atlas de Economia Solidária (op. cit.) serviços, produção agropecuária, extrativismo e pesca, produção de artefatos artesanais, fitoterápicos, limpeza e higiene, alimentos e bebidas, industrial, mineral, têxtil e confecção, coleta e reciclagem de materiais, serviços relativos a crédito e finanças. Junte-se a isso a inclusão da economia solidária, oficialmente, na política pública, por meio da entrada do tema, e de suas práticas, nas propostas de geração de emprego e renda de algumas prefeituras e do próprio Governo Federal. Em 2003 foi criada a Secretaria Nacional de Economia Solidária (Senaes) como componente do Ministério Nacional do Trabalho e do Emprego.

A partir da visão documentada por Fabio Oliveira (2007), a prática do cooperativismo é tomada, aqui, com suas mais amplas potencialidades; como uma pedra (forma organizacional)

R+NO+BRASIL:+Import\%C3\%A2ncia+e+Representatividade+Maria+Nezilda+Culti1\&cd=3\&hl=pt-BR\&ct=clnk. Acesso em 20/10/2009.

${ }^{11}$ MATIAS, B. (2004) Cooperativismo social é a nova geração de cooperativas no mundo. Artigo disponível no site:

http://www.administradores.com.br/noticias/cooperativismo_social_e_a_nova_geracao_de_cooperativas_no_mundo/ 1385/, acesso em 19/10/2009. 
que jogada no rio (aplicada à organização produtiva, de trabalho) gera ondas maiores, as quais chegam às margens e repercutem no além mar (outras esferas da vida que não apenas a do trabalho). Segundo o autor, o cooperativismo é uma forma de organização social do trabalho, também uma proposta de intervenção sobre problemas sociais, parte de políticas públicas e propõe como parte de seu exercício novas formas de interpretação da realidade.

A fim de contribuir, com a reflexão a respeito de questões relacionadas às transformações no âmbito da subjetividade vivenciadas a partir da experiência cooperativista, essa pesquisa põe em destaque uma das principais características das cooperativas populares, a autogestão, cuja prática parece ter relação direta com o conceito de Identidade como metamorfose constante desenvolvido por Ciampa (1987). Os trabalhadores são os proprietários dos meios de produção e tomam todas as decisões democraticamente, em assembleias; tal gestão compartilhada e o vigor dos valores de ajuda mútua, responsabilidade, igualdade, equidade e solidariedade, remetem às condições defendidas por Habermas (1990) e Mead (1972) como necessárias para o desenvolvimento de um nível superior de autonomia.

Antônio Ciampa (1987) parte desses dois autores e propõe a interação social como o meio, e a atividade e a consciência como condições necessárias, para a configuração e reconfiguração das identidades individuais e, portanto, ao sentido emancipatório da metamorfose da identidade. Sabendo que a formação dos empreendimentos cooperativos desencadeia uma sequência complexa de atividades que tem como um de seus fins o resgate da consciência a respeito do contexto econômico, político e social e do potencial de ação dos trabalhadores, a adoção de tal noção, de Identidade, parece capaz de colaborar para o entendimento da interação entre as condições objetivas das cooperativas de trabalho e a subjetividade dos cooperados.

Indício de que o estudo da subjetividade por meio da Identidade como metamorfose constante pode ser rica relaciona-se à visão de que a razão interesseira, voltada para objetivos individuais e relacionados ao poder administrativo e ao capital, é dominante na sociedade capitalista, em oposição à comunidade em que cada indivíduo afirmaria seu interesse a partir de uma interpretação universalista permitida pela comunicação fluidificada. Essa última Ciampa (1987) relaciona à "velha democracia" e instiga o questionamento a respeito da possibilidade de que as cooperativas sejam como "ilhas de democracia", em que a razão interesseira não dominaria, em resistência firme ao que se passa fora de suas fronteiras. Uma forma de adentrar a questão, mesmo que ainda timidamente, é compreender como se dá a questão da identidade dos 
cooperados; no caso de ser encontrado um sentido emancipatório de metamorfose estabelecer-seá um indicativo de que esses empreendimentos merecem um estudo mais aprofundado, considerando a interação dos microsistemas (cooperativas) e o macrosistema (sociedade capitalista).

Outro elemento de destaque desse projeto de pesquisa é a consideração de um elemento pouco abordado nas discussões encontradas sobre o cooperativismo, com o qual me deparei durante o período de atuação na Incubadora de Cooperativas Populares da FGV e que foi trabalhado por Vieira (2006): as possíveis diferenças no processo de formação dos empreendimentos e dos cooperados em experiências endógenas e exógenas ${ }^{12}$. Estudos de caso considerados pelo autor evidenciariam que nas cooperativas exógenas não seriam desenvolvidas tão solidamente quanto nas endógenas as críticas ao capitalismo e que estas, por sua vez, seriam essenciais para a emancipação dos trabalhadores, pois só assim se livrariam do sentimento de culpa pela própria condição de pobreza.

Esse ponto é relevante na medida em que diversas organizações, entre elas as incubadoras de cooperativas, entidades do Terceiro Setor e políticas públicas de fomento ao cooperativismo, atuam na formação de experiências exógenas, em que a proposição de formar os empreendimentos parte delas e não dos grupos; em algumas vezes os grupos ainda nem existem, seus membros não se conhecem, são formados especificamente para os projetos. Segundo Souza (2000) a imensa maioria dos negócios comunitários nasce de iniciativas de instituições e agentes externos.

A questão precisa ser pesquisada em profundidade porque mesmo na tese em que a ideia foi encontrada (VIEIRA, 2006), são apresentados resultados importantes desse mesmo tipo de iniciativa. O autor coloca que a atuação em empreendimentos autogestionários em geral tem como consequências:

“(...) as relações humanas deixam de ser coisificadas, há uma recuperação da identidade humana, há um fortalecimento da capacidade inventiva, uma recuperação das condições para exercício da práxis, uma reconstrução do tecido social e uma extensão das redes reciprocitárias."

(VIEIRA, 2006, p. 378).

\footnotetext{
${ }^{12}$ As experiências "endógenas" são aquelas cuja origem advém da iniciativa do próprio grupo de futuros cooperados enquanto as "exógenas" são iniciadas pelo trabalho de organizações ou pessoas que não fazem parte do grupo, que o convocam para a formação de empreendimentos autogestionários.
} 
No caso das iniciativas exógenas, apesar de reconhecer que não é possível obrigar o trabalhador a se emancipar, Vieira (2006) defende os benefícios da militância como um esforço efetivo, no mínimo, para que outra forma de relacionamento e novos vetores comportamentais sejam conhecidos como possibilidade objetiva.

A comprovação de que a organização autogestionária do trabalho pode impulsionar o movimento vital de metamorfose de identidade dos indivíduos seria mais um argumento em favor de intervenções sociais e políticas, coordenadas, de incentivo ao cooperativismo. Considerando que, além da transformação no nível individual, os empreendimentos autogestionários têm se mostrado financeiramente viáveis (em pesquisa realizada pelo Governo Federal ${ }^{13}$, apenas $16 \%$ das cooperativas mapeadas não haviam pagado as despesas relacionadas ao mês anterior), importante entender seus diversos impactos, todo seu potencial, preparando-nos para a atuação mais consciente possível, tanto sobre os meios quanto sobre os esperados resultados.

Por fim, essa pesquisa justifica-se pela própria realidade em que estamos inseridos; realidade analisada sócio, econômica e politicamente por diversos autores, entre os quais Habermas (1989). O agir estratégico estaria, a partir da sociedade moderna, dominando as relações, estabelecendo a ordem instrumental a partir da qual o empenho de praticamente toda ação dedica-se ao sucesso (este relacionado ao "código dinheiro"); o agir comunicativo, em contraposição, mostrar-se-ia cada vem mais escasso. Portanto, pode-se entender que o egocentrismo permeie as relações; o ponto é que esse modo de relacionar-se é assumido como natural pelos indivíduos, o único existente.

Parte-se de um contexto desanimador para a análise: a sociedade decomposta, resultado, segundo o mesmo autor, da modernização social que a segmentou em seus sistemas funcionais, criando um indivíduo isolado frente às infindas possibilidades de escolha e que se vê impulsionado a ajustar-se a meios de direção como o do capital e do poder administrativo. Ao contrário da independência apontada como ganho da sociedade capitalista por alguns, novas relações de dependência estariam sendo vivenciadas, agora em relação ao mercado de trabalho, ao consumo, à formação as quais aprisionam a identidade dos indivíduos em papéis estanques, que, ao serem mantidos rompem o ciclo vital dialético de metamorfose e mantém a ordem do sistema (CIAMPA, 1987).

\footnotetext{
${ }^{13}$ MANCE, E. A. Ética, Responsabilidade Social, Economia Solidária e Comércio Justo. Artigo disponível em: http://etica-social.blogspot.com/2007/07/as-redes-de-economia-solidria-no-brasil.html. Acesso em 20/10/2009.
} 
A clemência por novos horizontes, bem como indícios de que o trabalho autogestionário pode criar condições objetivas para que novas identidades se concretizem, negando os elementos que as negavam, foram encontrados em diversas fontes, em meio aos quais se destacam:

- Quando Mead (1938) defende a individuação progressiva para que seja atingida uma identidade pós-convencional, refere-se à evolução na percepção do indivíduo em relação a si mesmo a partir do grupo, à sua autoafirmação; o trabalho autogestionário contraria a individualização no sentido do isolamento do sujeito, ao propor a direção oposta, ressaltando a importância de cada um, junto ao outro para o alcance de um resultado satisfatório.

- A "burocratização do espírito" é encontrada em "A representação do eu na vida cotidiana" (Goffman, 1999) como decorrência da coerência exigida pelas representações em ambientes de trabalho competitivos (discrepância entre nosso "eu" humano e nosso "eu" socializado). Nas organizações autogestionárias não há razão para a competição, além disso, há espaço para que o indivíduo se expresse e comunique aquilo em que acredita, para que tenha representados seus interesses, o que pode romper o ciclo de alienação em que, segundo o próprio autor, são criados os "ganchos" que colam a "máscara" de atitude imposta pela disciplina social à forma como enxergamos a nós mesmos.

- A teoria defendida por Habermas (1983) considera que a emancipação só pode tornar-se realidade com o atingir do nível da "liberdade moral e política" em que as normas passam a não ser mais aceitas como verdades absolutas, mas sim questionadas e construídas em um processo comunitário a partir da interpretação das necessidades de forma universalizada; nas cooperativas estruturadas a partir dos princípios da economia solidária, as regras são construídas em conjunto, por todos os cooperados, e rediscutidas nas assembleias de maneira que todos entendam como e por que elas existem.

- Por fim, é possível até mesmo, em um esforço associativo, pensar na criação das redes solidárias, tendência marcante da economia solidária, como um emaranhado crescente de fomento à criação de identidades do Eu em metamorfose constante, aproximando-se da "sociedade mundial" de Habermas (1983). De acordo com pesquisa realizada pelo Governo Federal no ano de 2005 , cerca de $42 \%$ das cooperativas fazem parte de alguma rede de economia solidária ou fórum de articulação. ${ }^{14}$

\footnotetext{
${ }^{14}$ Mance, E. A. (op. cit.)
} 
Por outro lado, assim como Severina (“A estória de Severino e a história de Severina”, 1987) foi capaz de permanecer sendo rotulada como doente-mental, embora esse papel não mais lhe coubesse, devido a seu interesse (agir estratégico) em continuar recebendo a pensão do INSS, não se pode descartar a possibilidade de que, diante da única possibilidade que lhe é apresentada de gerar renda para si e para sua família, o cooperado mantenha-se no grupo, representando um papel sem representação de sua subjetividade. Nesse caso, desconfia-se de que a experiência não colaborou e nem contribuirá para a mudança de sentido da metamorfose de sua identidade, para a libertação em relação às personagens repostas, para a superação do que não merece ser vivido.

Uma pesquisa estruturada em torno das narrativas de histórias de vida dos sujeitos-cooperados, como a que essa se propõe, assume profundidade suficiente para entender essa dinâmica de articulação entre objetividade e subjetividade. Encontrar um ponto de reafirmação das políticas de fomento ao cooperativismo popular, ou indicativos que permitam uma reformulação e potencialização da possibilidade de emancipação dos indivíduos, poderá, no limite, aumentar o número de pessoas questionando o sistema, pensando em valores universalizantes e criando as normas de convivência a partir dos princípios da moral universal.

Como já sabemos as cooperativas populares são formadas por trabalhadores, isso é, por aqueles que vivem de suas forças de trabalho. A geração de renda, um dos objetivos desses empreendimentos, é o fogo que reúne homens e mulheres em círculo, mais ou menos epicêntrico. Chega, cada um, com sua história de vida, experiências, conhecimentos, habilidades, sonhos, repertório próprio que os fazem únicos. Trazem tudo isso mais a força e disponibilidade de trabalho como quota parte, massa sobre a qual erige-se o empreendimento coletivo. É pelo trabalho e para o resultado do trabalho que chegam ali e é pela organização autogestionária de trabalho que vivenciam o diferente, que questionam o padrão, que passam a buscar uma nova forma não apenas de trabalhar, mas de relacionar-se, de viver.

O trabalho e sua organização, a maneira como é concretizado, são elementos fundamentais da experiência sobre a qual nos debruçamos. Seria ele a faísca para a mudança de rumo da metamorfose constante da identidade. Por isso, comecemos por ele. 


\section{Capítulo II - O trabalho}

"Se dependesse de mim, do meu pensamento, o mundo era outro. (...) Emprego é salário todo mês, mas bitola, você consegue apenas olhar para frente e não para os lados.” (Luís, grupo Mãos na Massa ${ }^{15}$ )

O trabalho nem sempre foi assim e não será sempre assim. É difícil pensar, mais ainda vivenciar, outra organização do trabalho quando estamos mergulhados em uma específica, quando se experimenta durante longos anos a forma como o trabalho está organizado em determinado momento hitórico e estrutura-se a vida em torno dela. Isso porque além do trabalho ser central para a formação e transformação da subjetividade ${ }^{16}$, dedica-se, aqueles que vivem da venda de suas forças de trabalho, muitas horas do dia, da semana, da vida, às atividades assim nomeadas. Considerando que as cooperativas de trabalho são uma alternativa à organização do trabalho mais comum, ao emprego e ao subemprego, o objetivo desse capítulo é trazer a reflexão sobre o que é o "trabalho", mas principalmente sobre o que pode ser. Para tanto volto-me ao método genealógico, ao passado a fim de regatar outras possibilidades de concretização dessa categoria, organizações que já existiram e existem, portanto não utópicas, mas históricas, reais.

Por esse caminho é inevitável questionar a atual organização do trabalho e, inseparavelmente, a organização social contemporânea a partir de suas consequências para os homens e mulheres que vivem do trabalho; é preciso perguntar se o trabalho está a favor da vida humana, recolocando-a como eixo para a reflexão e para a ação, acredito ser esse o primeiro passo para a mudança.

A reorganização do trabalho com base em novo modo de produção é encarada como meio para estabelecimento de novas relações e de dinâmicas objetivas e subjetivas diferenciadas das que caracterizam a sociedade contemporânea. Trabalho, importante destacar logo de início, distinto, mais amplo que noção de "emprego", antecessor e sucessor a essa formalização da relação de trabalho. Dá-se a defesa de um trabalho central e potencialmente diferente, formado por e formador de outros sujeitos e de uma nova sociedade. O cooperativismo, principal unidade concreta da economia solidária, será discutido mais adiante a partir dessa perspectiva.

\footnotetext{
${ }^{15}$ Citação de segunda entrevista, realizada em 24/10/2009.

${ }^{16}$ Premissa da qual parto aqui a partir do proposto por Lukács (1979), reafirmado por Antunes (1997 e 1998) e Mészaros (1999), e que será melhor explorada mais adiante.
} 


\subsection{A categoria trabalho no contexto contemporâneo}

As mudanças pelas quais o próprio conceito de trabalho passou ao longo da história denotam as metamorfoses de sua práxis ${ }^{17}$, do sujeito que trabalha e da própria sociedade, disso lembra-nos Bauman (2001). Segundo o Oxford English Dictionary o primeiro uso do termo, registrado em 1776, foi com o significado de "exercício físico dirigido a suprir as necessidades da comunidade", um século depois assumiu também o sentido de "o corpo geral dos trabalhadores e operários que participam da produção”. Os dois puderam, então, ser unidos ganhando conotação política principalmente na ação dos sindicatos e outras associações vinculadas à organização do "trabalho" em voga.

O vínculo entre "labuta física", principal fonte de riqueza e bem-estar da sociedade e autoafirmação do movimento trabalhista foi historicamente construído de forma diretamente ligada às transformações sociais como um todo. Assim como a enorme desigualdade entre as nações seria um fenômeno dos últimos dois séculos, no mesmo período, em paralelo, o trabalho passou a ser visto como fonte de riqueza e, por isso, como alvo da sede por saberes, técnicas e ferramentas de controle. É contra a naturalização e legitimação desse fenômeno por um processo de repetição sem memória sobre o passado que esse capítulo se coloca; é preciso quebrar os muros que nos cercam para que novos caminhos sejam vislumbrados.

Indiscutível que sociedade contemporânea vem vivenciando profundas transformações objetivas articuladas, sempre, a mudanças na subjetividade; transformações cujo epicentro relaciona-se às crises, cíclicas, do capital e suas respostas a ela. As consequências da organização do trabalho e da sociedade em torno do capital, capitalista, alcançam níveis intoleráveis e urgem por alternativas. O desemprego estrutural, a massa crescente de trabalhadores enfrentando condições precarizadas de trabalho e a degradação da relação entre o homem e a natureza, com a produção de mercadorias em ritmo e intensidade nunca imaginados, não para atender as necessidades humanas, mas à reprodução do capital, são sintomas da situação limítrofe de nossa organização societal.

Marcada pela lógica do capital, a vida coloca-se como competição e o lema da produtividade pinta um cenário em que não apenas os países do chamado Terceiro Mundo, mas todos os países capitalistas encontram-se afundados. As chamadas formas de (des)sociabilização

\footnotetext{
${ }^{17}$ Práxis entendida como a "totalidade das objetivações do ser social, constituída e constituinte" (Netto, 1987: 59$60)$.
} 
denunciadas por István Mészáros (1999) como as “mediações de segunda ordem” sobrepõem-se à atividade produtiva essencial aos indivíduos sociais e à mediação primária ${ }^{18}$ existente entre eles, apresentando-se como o ponto de partida e o ponto final das relações, não deixando, portanto, espaço para a contestação ou consciência crítica a esse respeito. É assim que se inverte a lógica societal a serviço do metabolismo social do capital, o homem sai do papel de protagonista: renegado à coxia trabalha para que as personificações do capital façam seu show, um espetáculo

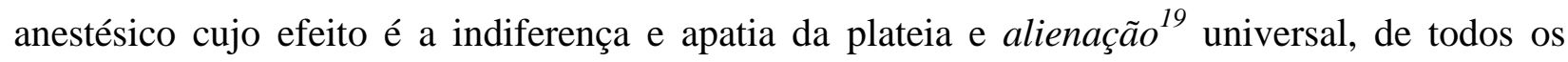
envolvidos.

Essa disposição dos atores e elementos em cena, no entanto, não são "naturalmente" ou imutavelmente assim; o trabalho não precisa ou deve estar subordinado ao capital. Como coloca Ricardo Antunes, "não sendo consequência de nenhuma determinação ontológica inalterável" (1999: 19). Trata-se de um contexto historicamente constituído, em que os seres sociais relacionam-se mediados pelo capital, de uma totalidade social estruturada em torno de um sistema de produção e de trocas estabelecido.

Frente à ideologia da imutabilidade e natualidade dessa tal organização, coloca-se o caráter ontologicamente humano, essencial, do trabalho. É em torno dele que a autoprodução e a reprodução societal se desenvolvem, que o homem fez-se e faz-se ser-social. Pelas funções primárias de mediação é possível que necessidades humanas, hoje pautadas em mediações de segunda ordem, sejam garantidas, como aponta Mészáros (1995). A regulação da atividade biológica e reprodutiva face aos recursos existentes no meio, do processo de trabalho, a estruturação e o funcionamento de um sistema efetivo de trocas e a constituição de regulamentos sociais necessários à convivência e à coordenação da multiplicidade de atividades envolvidas no sistema de reprodução societal são plenamente atendidas. As mediações do capital, assim como sistemas de hierarquia ou de subordinação não são indispensáveis, mas historicamente instituídos.

\footnotetext{
${ }^{18}$ As mediações primárias, ou de primeira ordem, têm como fim a preservação das funções vitais de reprodução individual e societal (Antunes, 1999: 19).

19 “Alienação", e suas variantes, sempre que tratada nessa dissertação referir-se-á ao conceito desenvolvido por Marx principalmente em duas de suas obras: Manuscritos Econômico-Filosóficos de 1844 e Elementos para a Crítica da Economia Política (1857-8). Sendo o trabalho a objetivação primária do ser social, primeira entre outras objetivações que formam a subjetividade, e a atividade produtiva a base para a formação da consciência, na medida em que o produto do trabalho aparece para o homem como algo estranho, que o domina, dá-se a alienação do trabalhador. A alienação do homem parte do trabalho, da atividade alienada, que não se constitui mais em autoatividade, não pertence ao trabalhador, mas sim a outro, ao capital, deixando de ser consciente e livre (Mészáros, 1981; Naves, 2000).
} 
As mediações de segunda ordem indicam a introdução de elementos fetichizadores ${ }^{20}$ e alienantes de controle social metabólico afetando profundamente as mediações de primeira ordem. O capital, na estrutura social em que nos encontramos hoje, é uma dinâmica, um modo totalizante e dominante de mediação da reprodução da vida. Tal estrutura é garantida e replicada por instrumentos e práticas que estão a serviço de determinados interesses. Entre os elementos que permitem a permanência e reprodução dessa ordem está a própria estrutura hierárquica, a divisão do trabalho e a estrutura de mando vertical (MÉSZÁROS, op. cit.).

Entre os outros instrumentos que garantem a vigência das mediações de segunda ordem e que merecem destaque estão a apresentação para os trabalhadores de suas condições de trabalho como imutáveis, passíveis apenas de aceitação, como um "poder separado que exerce mando sobre eles" e o processo de "personificação do trabalho", dos trabalhadores como o trabalho, cerceando a identidade dos sujeitos que trabalham nos limites das funções que assumem na divisão do trabalho dada.

É assim que o sistema vigente descolou-se das necessidades sociais, ganhando total liberdade, acima, além da vida. Esse foi o passo dado a partir do sistema socioeconômico capitalista, forma específica de realização do capital $^{21}$. As medidas para controle ou amenização das consequências à vida implicadas pela organização em que o capital é soberano, o capitalismo, mostram-se apenas soluções aparentes; a incontrolabilidade, a ausência de limites à sua reprodização, é pilar de sua estrutura, compõe cada uma de suas microestruturas. Portanto, as contradições não podem ser superadas dentro do sistema, são estruturais; os antagonismos são reproduzidos. Qualquer forma de controle do capital seria anacrônica considerando que o próprio sistema se apresenta como uma estrutura "totalizante", em que todos os envolvidos são coagidos a adaptar-se à sua dinâmica, tendo como outra opção apenas a de perecer, física e simbolicamente. O termo "totalitário" mostra-se preciso em sua força ao notarmos que se trata de um sistema de capital globalmente dominante, que domina desde as pequenas unidades,

\footnotetext{
${ }^{20}$ O "fetichismo" é utilizado aqui como "uma teoria geral das relações de produção na economia mercantil", a partir da qual as relações sociais de trabalho assumem o caráter de coisa e só podem existir por meio da troca entre as mercadorias produzidas pelo trabalho privado, só nessa troca haveria espaço para que as características eminentemente sociais do trabalho aparecessem (Rubin, 1980:19; Marx, 1983). O "fetiche da mercadoria" elaborado por Marx reforça a oposição entre valor de uso e valor de troca; o fetiche relaciona-se à ilusão da qual um objeto está embebido e partir da qual recebe a projeção de uma relação social definida que, na verdade, ocorre entre os homens e não entre produtos (Marx, 1971)

${ }^{21}$ Importante lembrar que o capital é um fenômeno que antecede e procede o capitalismo, não existe apenas nesse sistema, mas torna-se seu centro, protagonista.
} 
organizações e elementos, até as maiores empresas, passando por todos os tipos de relações interpessoais.

Para atender à necessidade de um pseudo-sujeito, o capital assume infinitas personificações, mutáveis de acordo com a situação, impondo e mediando seus próprios fins, aos quais os sujeitos reais devem subordinar-se passiva e resignadamente. Os critérios de eficiência, produtividade e racionalidade ganharam tom de profecia e aplicam-se a todas as esferas da vida contemporânea.

A pergunta que me coloco frente a essa fotografia é como teríamos chegado aqui. Quais fatos e fenômenos teriam contribuído e definido a inversão da lógica societal e colocado o trabalho e o ser humano a serviço do capital?

\subsection{Trabalho - ser histórico}

Ao estar no mundo o homem cria e recria seu contexto; a natureza ontológica ganha condição concreta a partir do momento em que é realizada pelos sujeitos modificando todos os elementos envolvidos, no processo "trabalhar". A criação de uma ordem lógica para tal processo, para que a interação que modifica o ambiente e ao próprio homem alcance determinados resultados, funda a "organização do trabalho.

A institucionalização do trabalho deriva da aceitação de determinada lógica, certa organização, como eficiente no cumprimento dos objetivos aos quais os homens direcionam seus esforços; é assim que vinha se dando, até o momento em que tais objetivos passam a ser postos pelo capital. O trabalho foi institucionalizado de várias maneiras ao longo da história: cata, escravidão, feudalismo, emprego, à distância, consultoria. Sua tranformação vem sendo constante, começou a ser organizado na forma cata, caminhou até a indústria no século XVIII e continua se modificando. Essa certeza que advém da análise histórica impulsiona estudo de novas organizações do trabalho e diferentes relações homem-trabalho, dos homens e mulheres com o outro e com o mundo que os cerca.

\section{a. Os movimentos do trabalho no contexto histórico mundial}

Partindo-se do trabalho artesão, em que o produtor era, ao mesmo tempo, proprietário de sua força de trabalho, de seu tempo, dos instrumentos empregados na produção, da técnica e do conhecimento, a sua transformação para o trabalho industrial pode ser entendida com base em uma enorme pressão econômica, advinda do crescimento da população mundial, da falta de 
produtos e da inflação. A isso se juntam o conceito de progresso proveniente da Renascença e os avanços tecnológicos que pipocam freneticamente nos tempos modernos. O emprego conforma o contrato de trabalho requisitado nessa nova organização do trabalho.

Com o confinamento de artesãos na indústria, a partir do novo contexto de produção e de trabalho, transforma-se toda a sociedade: de rural para urbana, a família passa de patriarcal para nuclear. Dentro da fábrica a realidade é completamente outra, com a instituição da supervisão, a adoção do ritmo da máquina e a adoção das tecnologias de trabalho pelos capitalistas, o trabalhador sente escorrer por entre os dedos o domínio sobre seu tempo e seu corpo. O processo de criação do produto final de seu trabalho está agora fora dele e além de sua compreensão.

O trabalhador foi separado de seu meio de sustento se antes ganhava sentido pela interação com a terra, com os materiais e ferramentas de produção, agora é peça avulsa a ser encaixada no aparato preparado pelo capitalista. Para Bauman (2001), deu-se a separação entre a produção e a troca e "um modo de vida mais geral"; por isso, e apenas porque isso ocorreu, o trabalho pôde começar a ser considerado e tratado como uma mercadoria. Tal desconexão teria sido o elemento fundante da mobilidade atribuída à capacidade de produção humana e, portanto, da possibilidade de alocá-la em diferentes usos, recombinada em diferentes estruturas, aplicada como meio para fins alheios a ela.

É assim que a era industrial, inaugura uma nova sociedade em que o campesinato torna-se operário e desfaz-se o vínculo entre terra, trabalho humano e riqueza. O processo poderia ser confundido, a princípio, com a emancipação das capacidades humanas em relação às condições naturais, no entanto, logo evidenciou-se uma nova dependência, em relação a uma ordem construída pelo próprio homem, "produto do pensamento e da ação racional" (BAUMAN, 2001, p. 30). O ponto de inflexão nesse momento da história dá-se pela constituição do trabalho como alvo de exploração.

Tal ordem instituída usa o trabalho para a multiplicação do capital, acentuando sua concentração, fundando uma jornada incessante em prol do aumento da produtividade, isso é, a redução dos recursos, matéria-prima e trabalho, necessárias à unidade de produto. Regida pelas estratégias de incremento da produtividade, a organização do trabalho é criada por alguns poucos e quebrada em pequenas atividades, essas realizadas operacionalmente por muitos. Surgia a classe de homens que "pensavam" em oposição à dos homens que "faziam". 
O aprisionamento do trabalho ao capital marca o tempo que Bauman (2001) chama de "modernidade pesada". A mutualidade de dependência entre os dois advém do fato de que agora, era necessário submeter-se à organização imposta do trabalho, já que além de não possuírem os meios de produção, os trabalhadores não poderiam competir, por meio do trabalho artesão, com os produtos industrializados. Era necessário ter um emprego. O capital, por sua vez, precisa empregar o trabalho para reproduzir e expandir-se; relação de dependência, em desequilíbrio já que o capital concentra-se, nas mãos de poucos, e cresce o exército de reserva de trabalhadores.

Com a evolução tecnológica, o conhecimento também passa a ser recurso escasso, ao qual o acesso é regulado pelo próprio capital: apenas alguns podem formar-se especialistas, segmento de trabalhadores que passa a ser encarada como a de "escolhidos". O processo de criação da elite do conhecimento é tratado por Foucault em "A Verdade e suas Formas Jurídicas" (2005): são aqueles que acompanham ou trabalham para a criação das novas tecnologias, que escolhem as posições a serem ocupadas por cada homem, a hierarquia entre capital, conhecimento e força de trabalho enrijece-se e estabiliza relações desiguais de poder.

Durante praticamente todo o século XX, foi prática o binômio do taylorismo/fordismo ${ }^{22}$ baseado na produção em massa e por uma organização produtiva homogeneizada e verticalizada, a tendência dominante para a organização do trabalho. É nesse período, de fragmentação das tarefas de trabalho e invasão das máquinas das plantas fabris, que se dá o processo de "desantromorfização" do trabalho; o trabalhador passa a atuar como um apêndice da máquina. A exploração ganha novos níveis, tanto em extensão, com o alongamento das jornadas de trabalho, quanto em intensidade, com o fortalecimento da expropriação da mais-valia.

Dessa fase, da maquinaria, de separação radical entre elaboração e execução, é fruto o "operário-massa". Junto com ele nasce um sistema de "compromisso" e "regulação" da relação entre trabalho e capital que, nos países centrais principalmente, trouxe a ilusão de que o desenvolvimento capitalista poderia incluir um pacto entre as duas partes regulado pelo Estado. Assim estabelecer-se-ia um limite à exploração, garantindo os direitos básicos dos trabalhadores. A instauração dos ganhos sociais e da seguridade social arrefeceu a luta de classes, deixou de lado projetos que passassem por mudanças mais profundas na estrutura societal. O movimento

22 Quando mencionado o binômio taylorismo/fordismo, remete-se a algumas características marcantes da organização produtiva vigente ao longo de praticamente todo o século XX, quais sejam: a produção em massa de mercadorias, produção verticalizada e homogeneizada, utilizando a esteira e o relógio, impondo o ritmo de trabalho (Antunes, 1999). 
operário assumiu nesse período o papel de mediador do comando do capital sobre o proletariado, tomando como norte os termos do "compromisso social", e recusando insatisfações e propostas que pudessem estar além dele ${ }^{23}$.

O "Estado de bem-estar social", como o chama Bauman (2001), funcionou como mecanismo para lidar com as anomalias geradas pela relação de dominação capital-trabalho, abafando suas consequências nefastas e evitando sua análise. As mutações desse período foram amplas e abrangentes, econômicas, sociais, políticas, ideológicas; as repercussões para a classeque-vive-do-trabalho passam pela esfera do ideário, da subjetividade e dos valores, de acordo com Ricardo Antunes (1999).

Fundamentado no compromisso social, o "fetichismo de Estado" difunde-se no movimento operário, isto é, passa-se a crer que a libertação em relação ao domínio do capital passava pelo fortalecimento do Estado. Atribui-se um sentido "coletivo", de exterioridade ao antagonismo capital e trabalho, a essa instância, ideologia que ainda hoje embasa a percepção de que o Estado é o responsável por tudo o que "falta", pelas ausências enfrentadas na vida do cidadão; desloca-se o foco dos antagonismos do sistema ao Estado ineficiente e corrupto, como se não fossem vertentes da mesma questão.

Provando-se incapaz do prometido, entra em crise o "Estado de bem-estar social" e com ele a da ideologia que mantinha controlado o movimento operário. Novas ofensivas ao sistema parte do mundo do trabalho alimentadas por uma nova identidade assumida pelo trabalhor, base para reaviver a consciência de classe. Os movimentos pelo controle social da produção foram, no final dos anos 60, forte expressão do esforço desse trabalhador por romper e superar o "compromisso social democrático" a que se atinha.

Foram duas, entre um mundo de contradições, as mais importantes para a saturação do modelo taylorista/fordista de produção: entre autonomia e heteronomia e entre produção e consumo. A primeira resume-se ao choque entre a total expropriação da participação do operáriomassa na organização do processo de trabalho e a sua convocação para a correção dos erros cometidos pela "gerência-científica" e pelos quadros administrativos. No que concerne à produção, as técnicas de disciplinamento para a exploração intensiva do trabalho nas plantas

\footnotetext{
${ }^{23}$ Resultado desse arrefecimento da luta de classes apontado por Antunes (1999) é a burocratização das organizações de representação do proletariado, favorecimento do corporativismo e da hierarquização na medida em que as negociações eram realizadas pela cúpula, cada vez mais distante da base, autonomização crescente das direções e redução das iniciativas da base.
} 
fabris, em oposição à exaltação do individualismo e autossuficiência incentivados ao papel de consumidor.

Nessa altura a resistência ao trabalho despótico manifestou-se em diversas formas, entre as práticas individualizadas encontram-se o absenteísmo, a fuga do trabalho, o turn over, a busca pela condição não operária de trabalho. Entre as soluções coletivas, que visavam à conquista do poder sobre o processo de trabalho, despontam propostas de controle autogestionárias como recusa do controle do capital e defesa do controle social da produção e do poder operário (ANTUNES, 1999: 42).

Era final dos anos 60, início da década de 70, o esgotamento do modelo de compromisso social era evidenciado pela redução do crescimento econômico pautada na expansão do capital, a luta de classes que sempre estivera ali, latente, não podia mais ser calada. A tendência da luta operária fazia-se no deslocamento em relação às organizações sindicais que ainda se atinham ao modelo social democrata de representação (BIHR, 1998); os trabalhadores afirmavam a autoorganização coletiva como caminho à resistência ao poder institucionalizado nas corporações, ao poder burocratizado.

Pelas características peculiares dessa forma de resistência, Bernardo (1996) conta que as greves desse período ficaram conhecidas como "movimentos autônomos". O alvo do ataque era mais profundo que o antagonismo entre "ricos" e "pobres", alçava a crítica à forma de organização das relações sociais de trabalho, à expropriação da autodeterminação daqueles que participam da equação com suas forças de trabalho. Desdobravam-se ações de tomada de empresas mantidas em funcionamento pelos trabalhadores, sem participação de patrões ou da classe administradora. Despontava como realidade concreta, possível, a ideia do "controle social do trabalho sem o capital" (MÉSZÁROS, 1986: 96-7).

$\mathrm{O}$ insucesso no alcance de mudanças estruturais desses movimentos dos trabalhadores parece dever-se à permanência das ações no espaço produtivo-fabril, sem proposta alternativa ao projeto societal, mais amplo, do capital. Ao mesmo tempo em que não houve articulação com outros movimentos sociais em pauta, as formas de organização propostas como alternativa não foram consolidadas, não ganharam escala; "as práticas auto-organizativas acabaram por se limitar ao plano microcósmico da empresa ou dos locais de trabalho, e não conseguiram criar mecanismos capazes de lhes dar longevidade" (ANTUNES, 1999: 44). 
Apesar do refluxo da ação trabalhadora, Bernardo (1996) indica a capacidade de autoorganização estabelecida nesse processo como elemento residual, que permaneceu como "ameaça" à estrutura social de exploração do trabalhador e ganha novo ar na eclosão da crise dos anos 70, a chamada "crise do fordismo e do keynesianismo". Momento histórico em que ganha a cena o esgotamento do modelo de expansão e multiplicação do capital frente ao limite da destruição do homem e do meio ambiente.

Embora a crise fosse estrutural, sintoma da lógica essencialmente destrutiva do capital e da incontrolabilidade de seu metabolismo social, as soluções seguidas tiveram caráter paliativo, ficaram na superfície. As mutações deram-se no padrão de acumulação e não em sua lógica, procurando dar nova dinâmica ao processo produtivo, recuperando os índices de lucratividade. A crise foi contornada com a reestruturação do capital por dois caminhos, ideológica e politicamente pelas postulações neoliberais ${ }^{24}$, e de produção e do trabalho com a instauração de soluções flexibilizadoras e precarizadoras. As respostas apontaram para novas técnicas de gerenciamento da força de trabalho, para a liberalização comercial, ainda maior desregulamentação do capital, combinada a novas formas de domínio técnico-científicas. A exploração sucedeu em extrapolar o âmbito da força muscular dos trabalhadores, avançou pela imaginação, repertório subjetivo, capacidade de cooperação, de auto-organização. O resultado para o capital, lucro, acumulação, para o trabalhador, para a mulher e para o homem isolados e fragilizados nessa relação mediada por novas tecnologias, angústia, conflito abafado entre suas vontades, valores, desejos, entre o potencial humano de criação, e o enquadramento em papéis estabelecidos, no padrão de comportamento exigido.

O "trabalhador polivalente" passou a ser o novo ideal de funcionário; realizando maior número de operações o trabalhador possibilita o "ganho humano de escala". (BERNARDO, 1996). A dedicação à empresa é cada vez mais de toda a força vital, seja ela do corpo, da mente, do tempo de vida. Fenômeno intensificado no final dos anos 80 com a compreessão do espaço e técnicas de gestão em prol da apropriação do poder criativo do trabalhador. A mais-valia chega às alturas, nada pode ser desperdiçado, toda a matéria humana é processada na produção, vira lucro, consumo e lixo.

\footnotetext{
${ }^{24}$ A política neoliberal envolve como principais medidas a privatização do Estado, a desregulamentação dos direitos trabalhistas e a desmontagem do setor produtivo estatal (Antunes, 1999, p. 31).
} 
A partir do vínculo intelectual, emocional, no nível da subjetividade, a prisão na fábrica não é mais necessária para a segurança do capital, a organização do trabalho entra em uma curva mais grave de transformação. A era da "flexibilidade", na visão de Bauman (2001), é o tempo em que o "emprego" perde espaço para contratos de curto prazo, contratos precários ou ausência de qualquer contrato entre capital e trabalho. Face do mesmo fenômeno analisado por Geert van der Lan (1998): o incremento do exército de reserva, excedente a partir do salto de produtividade permitido pelo desenvolvimento tecnológico, o trabalho remunerado como artigo de luxo. Os homens e mulheres que conseguem viver de suas forças de trabalho dedicam-se inteiramente, trabalham duro, entregam tudo o que têm e não têm para o capital temendo o descarte.

Movimento esse da transformação da organização do trabalho chega no final da década de 90, às chamadas "empresas-rede" 25 . O contrato com o trabalhador passa estar quase que completamente no nível psicológico, "comprotimento" é a palavra de ordem, a entrega total ao trabalho é naturalizada, o "anormal" é não viver assim; os materiais de trabalho para os gestores e seus superiores hierárquicos são, definitivamente, a emoção, os sentimentos, o universo simbólico, a "motivação".

O discurso de que essa nova organização do trabalho, "pós-moderna", e as relações estabelecidas em torno dela são de alguma forma benéficas ao trabalhador, permitindo-lhe maior participação e realização no espaço de trabalho, é contraposto por Tomaney (1996). O autor argumenta em contraposição à falácia do trabalhador "livre" lembrando da angústia gerada pela dicotomia entre a produção em massa e a especialização flexível, pela incapacidade de dar conta dos resultados esperados e da intensificação do trabalho sem que haja necessidade de maior qualificação do trabalhador; as maiores mudanças encontravam-se mesmo na gestão, nas formas de controle da produção, pouco na estrutura do processo produtivo (op. cit.: 175-6).

As principais marcas da "flexibilização do trabalho", inclusive que parecem diferenciá-la do padrão taylorista/fordista de acumulação, são a (des)estrutura de produção, muitas vezes configurada na desconcentração produtiva, com a terceirização de parte da mão-de-obra (geralmente a parcela menos capacitada) e a conformação dos grupos de trabalho, células de

\footnotetext{
${ }^{25}$ As empresas-rede, abordadas por Woogar (2003), são nada mais do que as pessoas trabalhando em mais de um projeto, para diversas organizações, ao mesmo tempo. No limite da flexibilização dos vínculos de trabalho não há mais a exclusividade da relação empregador/empregado, os trabalhadores mais intelectualizados podem "prestar serviços" para diversas empresas, vendendo o tempo de trabalho ou o tanto de seu intelecto, de sua subjetividade, dedicado a cada uma delas.
} 
produção, dos quais são requeridos "envolvimento participativo" na melhoria constante da produtividade. É por meio da entrega de suas subjetividades, por parte dos trabalhadores, que as empresas intensificam a exploração da força de trabalho, eliminando qualquer improdutividade e incorporando funções de acompanhamento da qualidade, manutenção e inspeção ao mesmo trabalhador que produz.

Na visão de Antunes (1995), porém, essas "novas" condições fomentam o mesmo trabalho alienado e estranhado ${ }^{26}$. Enquanto o único objetivo de tudo isso seria a redução do tempo de trabalho para a produção da mesma quantidade, a difusão de que se requereria um trabalhador qualificado, polivalente, multifuncional teria como função muito mais o campo psicológico, de cooptação do trabalhador em relação à empresa, que prático. Tratar-se-ia de uma composição ideológica e não de uma demanda efetiva do processo produtivo.

Ao contrário, os impactos da organização do trabalho em vigor em uma fase anterior do sistema produtivo capitalista para aquele-que-vive-de-sua-força-de-trabalho teriam sido intensificadas: a interiorização da responsabilidade pelo controle da qualidade de produção no trabalho do mesmo trabalhador que produz e a intensificação do ritmo de trabalho dentro do mesmo período de tempo ritmado pelo sistema de luzes e da operção de diversas máquinas pelo menos operário teria marcado a origem do chamado management by stress (GOUNET, 1997). A forte combinação das formas relativa e absoluta de extração da mais-valia resultam, para o trabalhaodor, no chamado "estress", o qual assume sintomas diversos, todos apontando a degradação da saúde física e psíquica do homem e da mulher que vendem suas forças de trabalho.

Quanto mais a colocação do trabalhador se distancia da empresa "matriz" maior tende a ser a precarização de seu trabalho, passando, por exemplo, pelo turno de trabalho mais longo, subcontratação, menor remuneração. A dissociação entre teoria e prática fazia-se pelo distanciamento da retórica participacionista em relação à intensificação do ritmo de trabalho na fábrica (NETTO, 1987).

\footnotetext{
${ }^{26}$ Embora MacLellan (1990) indique que Marx teria usado em sua obra as ideias de depossessão (Entäusserung) e de estranhamento (Entfremdung) indiscriminadamente, por vezes juntas, exprimindo a mesmo fenômeno de alienação, ao contrário para Ranieri (2001) Marx utiliza esses dois termos de forma articulada, mas distinta: a alienação (Entäusserung) está relacionada à atividade, objetivação e às "exteriorizações históricas do ser humano"; o estranhamento (Entfremdung) concerne aos obstáculos sociais impostos à objetivação, à exteriorização do trabalho e que fazem com que, a partir das formas de organização do trabalho por meio da propriedade privada e de exploração do trabalho, historicamente construídas, a alienação apareça como "elemento concêntrico" ao estranhamento (p. 8-9).
} 
Esse novo cenário, evidente, teve impacto direto na consciência de classe dos trabalhadores e em sua organização. A desregulamentação dos direitos do trabalho emplacadas pela política neoliberal não encontrou, nesse momento, resistência coletiva, foi acompanhada pela fragmentação da classe trabalhadora, pela transformação do sindicalismo de classe em um "sindicalismo dócil". A burocratização das organizações sindicais que entram na lógica partindo para o estabelecimento de "parcerias" com o capital para que a força de trabalho seja "qualificada" e ganhe "empregabilidade" é sentida ainda hoje.

Assim como nos outros países do "Terceiro Mundo", o trabalho no Brasil seguiu os principais movimentos efetuados nos países centrais. As manobras do capital na borda do sistema também foram semelhantes, nas grandes linhas, às assistidas em seu epicentro. Os pontos de singularidade em destaque estão, infelizmente, voltados à posição ainda mais frágil do trabalho diante das intempéries do capital junto à degradação ainda mais crítica daquele que vive do trabalho. Pela posição enfraquecida na divisão internacional do trabalho, o esvaziamento da organização dos trabalhadores para a resistência marca uma história triste de desvalorização do ser humano e exaltação do capital.

A busca por alternativas à relação desequilibrada entre trabalho e capital e por condições mais dignas de serem vividas pelos homens e mulheres que possuem apenas suas forças de trabalho como moeda de troca por suas sobrevivências teve avanços em alguns momentos específicos da história, mas tantos outros de retrocesso. A busca continua e ganha novo impulso a cada homem que lança mão de sua criatividade para contornar as situações de humilhação, a cada mulher que muda a si mesma para que a objetividade também se transforme.

No Brasil, assim como em outras nações que compõem a ordem ditada pelo capital, o cooperativismo é vivido, por diversos grupos em distintos momentos, como tal resistência, na procura por uma organização mais humana, solidária, criativa, de trabalho. Fortalecendo-se em momentos de crise econômica, quando as limitações do sistema socioeconômico em vigor desvendam-se, a história do cooperativismo continua sendo parte da história do trabalho no Brasil e no mundo e permanece esbarrando na história de alienação e isolamento, de enfraquecimento da consciência crítica de cada e de todos os trabalhadores, como principal barreira a seu desenvolvimento estrutural.

\section{b. História recente do trabalho no Brasil}


O processo mundialmente vivido, de implosão do estado de bem estar social pela desregulamentação neoliberal, de mãos dadas com a flexibilização do sistema de produção, marca do "toyotismo" 27 , assume ritmo e características próprias no contexto brasileiro, embora siga tendências comuns a toda essa manobra do capital para recuperação de seu crescimento em momentos de eclosão da crise estrutural: precarização sem antecedentes à altura dos trabalhadores e a degradação da relação metabólica do homem com a natureza, repercutindo na enorme degradação do meio ambiente.

O capitalismo brasileiro, em seu processo de "desenvolvimento" e acumulação iniciado na década de 50, foi marcado por um processo de superexploração do trabalho, dado pela articulação de baixos salários, jornada de trabalho prolongada e extremamente intensa. Esse foi o padrão de acumulação brasileiro dentre as décadas de 50 e 70 (ANTUNES, 1998); foi durante os anos 80, em ritmo mais lento que os países centrais, que se deram algumas das principais mudanças organizacionais e tecnológicas no interior do processo produtivo e de serviços.

Tal processo foi acelerado nos governos de Fernando Collor e Fernando Henrique Cardoso, durante a década de 90, com a implementação do contrato neoliberal. Podem ser destacados nesse período os processos de downsizing de empresas, diminuição da força de trabalho empregada com o enxugamento das equipes e processo de tecnologização e informatização das organizações. As formas de gestão flexível também foram implementadas, em um híbrido de fordismo com alguns principais elementos do toyotismo.

Assim como no resto do mundo, no Brasil passou a ser necessário o trabalho conjunto de uma força de trabalho qualificada, que opera os equipamentos microeletrônicos, e de outra subremunerada, ambas exploradas intensificadamente, seja pela flexibilização, seja pela dissolução dos direitos trabalhistas e dos mecanismos de estabilidade e segurança no trabalho.

Ainda durante a década de 80, antes de essas tendências acentuarem-se, o sindicalismo brasileiro dos trabalhadores passou por um momento de grande força. No ano de 1987, por exemplo, houve um total de 2.259 greves, sendo que no ano seguinte 63,5 milhões de jornadas de trabalho foram paralisadas (ANTUNES, 1995a). O sindicalismo entre assalariados médios e do

\footnotetext{
${ }^{27} \mathrm{O}$ "modelo japonês", "toyotismo", experiência de afastamento do binômio taylorismo/fordismo, tem como um de seus direcionamentos a organização dos Círculos de Controle da Qualidade (CCQ), isto é, a constituição de grupos de trabalhadores que são instigados a pensar sobre seu próprio desempenho, com o objetivo de melhorar a produtividade da empresa. A apropriação, assim, do intelecto, da inteligência do trabalhador, antes descartada no fordismo, torna-se prática.
} 
setor de serviços cresceu consideravelmente, bem como o sindicalismo rural e nasceram as centrais sindicais, como a Central Única dos Trabalhadores (CUT). Houve o esforço por instaurar organizações nos locais de trabalho, como as comissões de fábrica, e para alcance de maior autonomia entre dos sindicatos em relação ao Estado.

Por todos esses elementos a década de 80 foi favorável ao "novo sindicalismo", movimento social dos trabalhadores com forte caráter de classe. A tendência reverteu-se na década seguinte com as mutações de caráter flexibilizador e neoliberal no processo produtivo e na estrutura das empresas, cujos principais resultados para a classe operária já sabemos: desproletarização de grandes contingentes operários, precarização das condições de trabalho e exploração mais acentuada da massa de trabalhadores ${ }^{28}$.

O sindicalismo brasileiro, em resposta, seguiu dois caminhos, um do arrefecimento e adequação, por meio de um "sindicalismo neoliberal", outro a aproximação da corrente socialdemocrata. O que não pode ser considerando um avanço qualitativo no movimento sindical, nem mesmo uma proposição de alternativas efetivas ao modelo de exploração dos trabalhadores, enquadra-se em adaptações a fim de manter a posição de suas instituições. Assistiu-se, durante a década de 90, ao que Antunes definiu como:

“diminuição crescente da vontade política de romper com elementos persistentes da estrutura sindical atrelada ao Estado e sua consequente relativa adaptação a essa estrutura sindical de cúpula, institucionalizada e burocratizada, que caracterizou o sindicalismo brasileiro pós-30.” (ANTUNES, 1999: 241)

A postura de conivência em relação aos mecanismos de controle e de expansão do sistema de metabolismo do capital por parte do movimento sindical se dá no âmbito político e ideológico. Na prática, os interesses do mundo do trabalho ficam sem representação.

O desafio para a articulação dos trabalhadores pela superação desse cenário, no Brasil, assim como nos outros países do Terceiro Mundo, passa pela desmontagem do aparato de superexploração do trabalho, caracterizado por salários ultrajantemente baixos e por um nível crescente de industrialização, e pelo confronto com a lógica da globalização, que se mostra integradora para fora, para o capital, e destrutiva e desintegradora para os trabalhadores. Esse caminho, na visão de Ricardo Antunes (ibidem), apenas pode ser traçado por experiências de base, articuladas, e reflexões coletivas que busquem amarrar os interesses imediatos a uma

\footnotetext{
${ }^{28}$ Especialmente no governo de Fernado Henrique Cardoso foram desmontados os direitos trabalhistas, ainda mancos, conquistados em todas as lutas históricas, afirmando seu direcionamento político neoliberal.
} 
estratégia de médio e longo prazo de orientação anticapitalista, com foco em uma nova estrutura societal, emancipada.

É necessário, para tanto, que as organizações de representação e dos próprios trabalhadores assumam como uma única classe os assalariados, os que trabalham em tempo parcial, precarizados, subempregados, mulheres, homens, jovens. A atuação em conjunto, unindo e não segregando, parece ser a única maneira de ganhar força contra valores semeados e colhidos a todo momento pelo capitalismo, o individualismo extremado e a competição que ganham todas as esferas da vida, que dominam as relações humanas.

Exatamente por isso o movimento dos trabalhadores não pode ficar contido e limitado à fábrica, ou à empresa, como tende a acontecer a partir do toyotismo; é necessário que se articule a outras lutas, tornando-se menos vulnerável à pressão patronal. Deve romper também a barreira erigida entre a luta econômica e a política a fim de construir uma nova estrutura societal, trata-se de uma única luta por uma nova estrutura societal em que o o homem e o trabalho, sua relação entre si e com o mundo, possam emancipar-se, voltar-se à manutenção da vida, acima e além da acumulação do capital.

O desafio é maior ainda considerando, como propõe Peyrefitte (1998), que a empresa que oferece empregos tornou-se, ao longo da história moderna, a principal âncora para o estabelecimento e desenvolvimento de relações de confiança; confiança essa sempre buscada pela humanidade, confiança em si mesmo, nos outros, nas instituições, nas leis. Na visão do autor era justamente porque essas empresas, ou os empregos nelas ofereciam a base para essas relações e para reconhecimento de si próprio e pelos outros, que os trabalhadores organizavam-se para brigar por seus direitos ou por mudanças nas condições de trabalho. A crença na estrutura e na lógica em que estavam inscritos era combustível para a mobilização.

A estreita relação entre a dissolução da confiança e a minguada mobilização para a ação coletiva é sugerida por Pierre Bourdieu (1998). Para ele a capacidade de planejar, de pensar o futuro, é condição indispensável, pedra fundadora de todo o pensamento "transformador" e de toda ação com o sentido de mudança do status quo. Porém, anterior à projeção de futuro e condição para ela é o controle do presente. Em um momento em que o emprego desmilingui-se, o que caracteriza a relação entre trabalhador e empresa é a desconfiança e o que pondera a vida como um todo é a insegurança a respeito da própria sobrevivência, especialmente para os 
produtores assalariados, proletariado em dissolução, chamados por Reich (1991) de "trabalhadores de rotina".

Com possibilidade mais restrita de controle sobre seu presente, esse grupo da classe-quevive-do-trabalho encontra-se desprovido de poder barganha frente ao capital, sem perspectiva de mudança nessa condição e, portanto, subtraído em sua vontade política. A luta não vale a pena já que a única segurança que tem é a de que perderá a disputa com o capital e pela insolência será punido.

O desafio de proporcionar uma nova condição objetiva suficientemente estável para que se possa buscar a autodeterminação no presente, planejar o futuro, engajar-se na mudança do que não merece ser vivido coloca-se à economia solidária, bem como a todos aqueles se propõem a construir e difundir uma alternativa à engrenagem social e ambientalmente degradante do país e do mundo. Para que sua única ação voltada à "política" não seja a demanda aos órgãos "políticos" por compensações, é fundamental que seja possível a articulação coletiva, que o isolamento individual seja rompido, que as barreiras que impedem que sejamos vistos e vejamos o outro sejam desconstruídas.

A história do trabalho denota a passagem de uma sociedade em que o trabalho não era penoso e as relações sociais não eram conflitivas para uma situação oposta, da relação de reciprocidade para a de autoridade, reforça a importância da reflexão sobre caminhos alternativos ao trabalho estranhado, alienado e explorado; assim também à subjetividade aprisionada e empobrecida e à vida esvaziada. É com base em sua materialidade histórica que vale o exercício sobre novas formas de organização do trabalho. Estas como fundamento para outras relações entre os homens e mulheres e, portanto, de uma forma diferente de colocar-se no mundo.

A organização do trabalho é tomada como ponto de partida para se pensar em uma sociedade mais humana, a experiência cooperativista será estudada, mais adiante, como uma alternativa ao cenário desenhado pelas relações mediadas pelo capital. A partir do trabalho autogestinário, coletivo, dotado de sentido, buscaremos indícios de que as mudanças aí vividas extrapolem para outras esferas da vida, de que sejam outros os desdobramentos objetivos e subjetivos para os sujeitos que vivem do trabalho, estes como agentes de transformação da estrutura societal. 
Para tanto é preciso explorar as tendências, continuístas ou inflexivas, que se mostram nos dias de hoje, mais especificamente no século XXI. É frente a esses elementos que qualquer sentido de mudança precisa impor-se.

\subsection{0 trabalho na sociedade contemporânea - aprofundamento e ampliação de tendências nada animadoras}

Alimentando os mesmos fenômenos e tendências sociopolíticoeconômicas e suas respectivas engrenagens no mundo do trabalho, alguns novos elementos surgem no sistema de metabolismo do capital e outros se fortalecem na sociedade do século XXI. Sempre voltados à amenização dos problemas estruturais do sistema por meio de medidas conjunturais, defendo que tais novidades não representam mudanças efetivas na condição de alienação e fetichização do trabalho e por isso mesmo não serão abordadas em profundidade, apenas relembradas para continuarmos aqui nosso trajeto.

O foco em resultados, assumido pelo trabalho e exaltado mais recentemente, demanda que o trabalhador desenhe os caminhos para alcançá-los, sempre, claro, da maneira mais inovadora possível desde que respeitando os valores da empresa, a eficiência, a eficácia e a efetividade. Portanto, muito além de não ser mais possível ignorar o trabalhador como sujeito pela organização, requer-se, agora mais do que nunca, que tal sujeito esteja a serviço, implicado nos objetivos da empresa. Em um jogo que chega a ser irônico, o sujeito encontra-se totalmente comprometido, mais do que nunca antes, com o sistema de reprodução e expansão do capital, completamente alheio às suas próprias necessidades biológicas, sociais, e é demandado por assumir-se e colocar-se o tempo todo como sujeito autônomo, independente, autêntico, "senhorde-si”.

Para atender completamente às expectativas da organização, o indivíduo precisa, também por conta própria, "proatiovamente", como diz o jargão, capacitar-se, buscando cursos, treinamentos, leituras, contatos com pessoas importantes na área de atuação, o que agora lhe toma ainda mais tempo de vida e absorve parte substancial de seu poder de compra; os cursos, leituras, eventos, são produtos. Mesmo o espaço de suas casas, antes vinculada à "vida privada", à intimidade, é hoje o quintal da empresa. A prática de trabalhar em casa ganha força, repercutindo 
na diminuição de custos para as empresas além da total flexibilização do trabalho; é assim que o trabalhador acorda e dorme em seu local de trabalho (SENNET, 2000).

O contexto é volátil, a comunicação informatizada e a alta velocidade em que o desenvolvimento tecnológico avança, por meio da subsunção da ciência, trazem à baila mudanças constantes nas condições de trabalho. O trabalhador é cobrado, portanto, pelo emprego de sua criatividade atada a uma aguçada capacidade de percepção, interpretação e atuação frente a incertezas e ambiguidades.

No entanto, o mais importante de tudo isso, é que mesmo a partir da influência rearticuladora da lógica de produção pactuada pelas empresas-rede, pela virtualização do local de trabalho e mediação das tecnologias de comunicação e informação no desenho das tarefas, o resultado do trabalho e o seu fim permanecem sendo de domínio da empresa, do capitalista empregador (BECK \& BECK-GERSHEIN, 2002). Também por isso Marchington, Grimshaw, Rubery e Willmott (2004) acrescentam que apesar desse movimento de acentuação das mudanças no mundo do trabalho, não se trata de uma nova lógica: atrás do disfarce de liberdade do sujeito em entender, avaliar e escolher por conta própria, a empresa continua controlando o corpo e o tempo dos indivíduos. Repaginados, os mecanismos de dominação e controle por parte do capital passam pela imposição de uma racionalidade em que o indivíduo enquadra-se e age como o esperado $^{29}$.

Segundo Bendassoli (2007), fala-se muito em diferenças e peculiaridades de cada um como riqueza, mas trata-se de um discurso ideológico. O esforço seria para categorizar, classificar, as diferenças para, depois de conhecidas e sob controle, neutralizá-las aproximando-as de um padrão, o qual leva o nome de "perfil” no discurso ideológico.

O nome dado nos dias de hoje ao instrumento ideológico de dominação e controle do sujeito, da subjetividade do trabalhador, é a "cultura organizacional". As empresas trabalham frequente no remodelamento e reforço da cultura com o fim de resolver problemas de comprometimento dos indivíduos ou de esgotamento de sentido dos dogmas compartilhados. Os componentes tratados nesse processo de revigoramento da dominação estão diretamente

\footnotetext{
${ }^{29}$ Um desses mecanismos é a "carreira". De acordo com artigo de Christopher Grey (2006), carreira pode ser entendida como o enquadramento do projeto do "eu" nos planos da empresa, portanto uma ferramenta poderosa de influência desse projeto pessoal que, justamente por ser um plano de si para si mesmo, tem como principal característica o envolvimento da subjetividade. Por meio dessa ferramenta a subjetividade do indivíduo é redirecionada.
} 
relacionados à esfera da subjetividade humana: "comprometimento", "representação social”, "valores" e "identidade".

O isolamento e a insegurança também ganham nova magnitude. Com as empresas-rede, o enfraquecimento do emprego e reinado do trabalho autônomo, Rifkin (1995) indica que se multiplicam os pontos de interface no dia a dia de trabalho e as relações tornam-se mais efêmeras já que o outro se resume ao fornecedor ou receptor, pontual, de uma informação ou produto. Ao mesmo tempo em que o outro não é conhecido e em que não será possível estabelecer qualquer tipo de relação com ele, depende-se dele para que seu próprio desempenho seja o "adequado", levando à sensação de insegurança e vulnerabilidade. $\mathrm{O}$ outro é visto como objetificação do produto ou do recurso buscado, não há espaço para cumplicidade ou reconhecimento de si mesmo no outro, trata-se de pontos de uma cadeia de produção.

A insegurança no trabalho é tomada por Bauman (2001) como de uma nova magnitude, essencialmente diferente daquela com a qual o trabalho sempre esteve imbuído, e para além do contato efêmero com o outro. Para o autor os "desastres" que podem destituir a família de seu sustento e destroçar os planos para o futuro não seguem mais nenhuma lógica, parecem aleatórios, impossibilitando que se tenha ao menos uma intuição sobre quem será jogado aos leões, engrossando a marcha do desemprgo, e quem continuará digladiando-se com outros homens. Essa incerteza é individualizante, "divide em vez de unir", faz com que esteja cada um por si, já que nada pode ser feito contra esse poder maior que se coloca sobre os homens e, portanto, não há "interesses comuns” (op. cit., p. 36).

Enquanto os mecanismos de dominação tornam-nos prisioneiros da gestão por resultados e da supervalorização da "carreira de sucesso", o que há de diferente agora é a sensação de que o chão da prisão desmancha-se. As estruturas ruindo, a implicação do indivíduo por inteiro nos interesses do capital e a gestão estratégica se fortalecendo têm consequências diretas não apenas na organização do trabalho, mas na inserção dos indivíduos no mundo.

O extremo da "flexibilidade" é traduzida por Bauman (2001) como o rompimento unilateral do aprisionamento entre capital e trabalho: o capital obtém uma liberdade quase sem limites, "sua reprodução e seu crescimento se tornaram, de modo geral, independentes da duração de qualquer união local particular com o trabalho" (p. 38). A política se transforma em uma luta contínua entre a velocidade de movimentação do capital e a tentativa dos poderes locais de freálo. A fim de mantê-lo localmente submete-se à concorrência com outras comunidades, cidades, 
distritos, Estados ou países cedendo a todas as demandas do capital, inclusive a garantia de uma mão-de-obra disposta a condições quase escravas de trabalho e, acima de tudo, dócil, sob a perspectiva de uma situação ainda mais degradante caso decida-se mudar. Por sua vez, o capital foge a qualquer mínima intenção de controle de sua liberdade, reina como monarca absolutista subjugando o trabalho como seu servo.

Voltando-nos para o sujeito que vive do trabalho, Barley, em Gurus, hired guns and warm bodies, expõe o enfraquecimento de sua autodeterminação diante da complexificação das relações e do mundo. A demanda pela constante adaptação da atuação às diferentes culturas organizacionais e papéis esperados encontra-o desprovido de instrumentos, de condições para lidar com a alta complexidade. Segundo o autor a cultura pragmática e individualista dificulta o desenvolvimento de competências coletivas necessárias para lidar com a situação.

O "enfraquecimento subjetivo" é tratado também por Bendassoli (2007) considerando que a relação homem-trabalho é ditada pelo grau de autonomia que o indivíduo tem ou não para usar a sua força de trabalho. O cenário atual de (des)estrutura ad hoc, de tecnologia invisível, e fortalecimento do discurso ideológico, é ainda menos propício que os anteriores ao exercício reflexivo sobre o próprio trabalho. O homem toma maior distância de suas próprias capacidades humanas aplicadas ao trabalho, alheio ao que produz diariamente; a angústia vem da falta de sentido no tempo que passa desenvolvendo trabalho estranhado que ocupa quase todo seu tempo de vida.

As mesmas implicações catastróficas da estrutura social erigida sob e para a dominação do capital, cantadas por Antunes (1999) e tantos outros delatores do sistema vigente, são tão atuais quanto o jornal do dia. Prova disso são as inúmeras notícias, diárias, denunciando o desemprego estrutural que oprime, marginaliza, coloca em situação degradante enorme massa de homens e mulheres.

Por tudo isso, me sinto à vontade em concluir que, ao contrário da independência e liberdade apontada por alguns como ganho da sociedade capitalista, novas relações de dependência são agora vivenciadas em relação ao mercado de trabalho, ao consumo, à (con)formação continuada. A perenidade do aprisionamento dos sujeitos em situações que não merecem ser vividas, desumanas, humilhantes, angustiantes, é assegurada pelos mecanismos mais complexos de dominação e, para além deles, pela constante ameaça da aniquilação física e simbólica. 
Os mecanismos ideológicos de manutenção do trabalhador na relação de trabalho estabelecida, de venda de sua força de trabalho, de suas ideias, de seu tempo, para o capital por um preço e em condições injustos, seguem a tendência de complexificação, atuando cada vez mais subjetivamente, transvestido de fantasias tão sutis quanto eficientes. São discursos que reforçam a submissão, direcionam a reflexão impondo premissas, afastam a resistência, a revolta, evitam qualquer tipo de mobilização coletiva. Esse é o caso, por exemplo, do discurso ideológico em torno da "sustentabilidade". Onda atual que saiu da boca dos ambientalistas, foi apropriado pela diretoria das corporações, reforçada pelos meios de comunicação e, então, propagada pelas diversas classes sociais. Esse é um discurso que traz elementos típicos desses mecanismos de dominação subjetiva, como, um dos mais representativos, a atribuição das responsabilidades e da culpa pelo que não está funcionando bem, pelas repercussões desastrosas da ditadura do capital, sobre os indivíduos. A culpa enfraquece, desmobiliza, deprime.

De quem estou falando? Quem são os "trabalhadores" degradados como seres humanos no processo de desenvolvimento, o chamado "crescimento econômico", capitalista? Diante da complexificação da sociedade e do grupo dos que vivem a partir do trabalho, é preciso desanuviar o assunto a fim de enxergar as pessoas para quem se volta nosso olhar.

\section{4 $\underline{\mathrm{O} \text { trabalhador e a classe que vive do trabalho }}$}

"O novo rico busca consolar-se com o pensamento de que sua fortuna vem do trabalho, como se nunca houvesse dependido também do trabalho alheio. A fortuna dos que enriquecem ou dos que nascem ricos encontra sempre a classe dos que a sustentam. A riqueza, material e simbólica, não é nunca um bem a título privado."

(GONÇALVES FILHO, 1998 ${ }^{30}$ )

Para discutir o trabalho, ou melhor, a subjetividade daqueles que trabalham hoje se aceita a categoria de "classe-que-vive-do-trabalho"31, proposta por Ricardo Antunes (1999). Isso porque não pretendo adentrar, aqui, a discussão a respeito da validade ou anacronismo do termo "classe trabalhadora" levada adiante por tantos autores, como Méda (1997), Rilfkin J. (1995), Pakulski, J.

\footnotetext{
30 Artigo disponível em: http://www.scielo.br/scielo.php?script=sci_arttext\&pid=S010365641998000200002\&lng=en\&nrm=iso. Acesso em 08/04/2010.

31 Grupo que abarca todos os homens e mulheres que vivem da venda da sua força de trabalho e que são despossuídos dos meios de produção, hoje não mais restrita aos trabalhadores manuais diretos, engloba a totalidade do trabalho social, a totalidade do trabalho coletivo que vende sua força de trabalho em troca de salário.
} 
e Waters M. (1996) e Robert Castells (1998). Refiro-me, simplificadamente, ao ser social que trabalha, aos sujeitos que exercem ações com sentido de trabalho ${ }^{32}$. A luz, nesse estudo, coloca-se sobre a subjetividade desse trabalhador, sua "concretude", "processualidade" e "efetividade" (ANTUNES, 1999: 101) são analisadas como caminho de acesso a esse ser subjetivo, como será melhor elaborado mais adiante.

Por hora, faz-se importante apresentar esse grupo de pessoas que trabalham e garantem suas sobrevivências, por vezes também de suas famílias, pelo trabalho. Tal noção proposta a fim de pontuar claramente a quem me refiro, engloba três principais categorias definidas a partir da visão marxista do tema (MARX, 1994): os assalariados que criam diretamente mais-valia, atuando no processo de valorização do capital e que vivenciam as condições dadas pela subsunção real do trabalho ao capital ("trabalhadores produtivos" segundo Marx em seu Capítulo VI, Inédito, de O Capital, 1985); conjunto de assalariados que vendem sua força de trabalho em troca de salário no setor de serviços ("trabalho improdutivo", consumido como valor de uso e não como criador de valor de troca); e os desempregados pela vigência da lógica destrutiva do capital. O que os liga, todos, como fio condutor, é o fato de venderem sua força de trabalho em troca de salário; os trabalhadores da chamada "economia informal” também são assalariados na medida em que são indiretamente subordinados ao capital.

As transformações da organização do trabalho, com a maior interrelação, no mundo contemporâneo, entre as atividades produtivas e improdutivas, entre produção e conhecimento científico, sem dúvida refletem-se em mudanças na classe-que-vive-do-trabalho ao mesmo tempo em que assistimos ao aumento no número de pessoas que compõem esse grupo. Olhando com atenção aos países do Terceiro Mundo, industrializado e intermediário, é aí onde se encontram dois terços da força de trabalho mundial e onde as mudanças e tendências do mundo do trabalho assumem peculiaridades e um ritmo próprio.

Antunes (1999) destaca, entre elas, a diminuição do proletariado estável e especializado, acompanhado pelo incremento do novo proletariado fabril e de serviços, isto é, dos trabalhadores imbricados no chamado "trabalho precarizado": trabalho parcial, temporário, terceirizado,

\footnotetext{
32 Trabalho definido, de acordo com Antunes (1999) como processo de transformação da natureza e de si mesmo praticado com o objetivo de atender as necessidades de autorreprodução e de reprodução da espécie.
} 
informatizado, subcontratado ${ }^{33}$. Também, o crescimento no número de mulheres trabalhadoras, absorvidas, ainda principalmente, no universo de trabalho "part time", precarizado e desregulamentado, é outra mudança visível no mundo do trabalho.

A força de trabalho feminina é, geralmente, pior remunerada e encontra piores condições de efetivação e demanda por trabalho intensivo. É por isso que a chamada "divisão sexual do trabalho", resultado da reestruturação produtiva do capital, está relacionada à exploração ainda mais intensificada da trabalhadora. Exemplos de discriminação são a prática de sistemas de remuneração distintos para cada sexo, além da política de não contratação de mulheres casadas.

Em relação à adoção dos sistemas de gestão participativa, tal processo mostra-se muito menos avançado nos países "em desenvolvimento" como o Brasil e mais fraco quando se trata das mulheres: elas não são chamadas a sugerir melhorias no plano técnico e são frequentemente excluídas do processo de tomada de decisão. Os organismos de representação sindical, por sua vez, tornam-se ainda mais distante da realidade trabalhista por não abrirem espaço para as mulheres e para os trabalhadores terceirizados e precarizados.

O autor alerta que a emancipação do "gênero humano" é um caminho a ser trilhado em conjunto por homens e mulheres que trabalham; o sentido para a vida, e o afloramento de uma subjetividade autêntica devem ser buscados por meio da luta contra esse sistema de metabolismo social, "da luta de classe do trabalho contra o capital".

Outra tendência em voga é a expansão do trabalho assalariado médio e de serviços. No entanto esse setor também cada vez mais se submete à lógica do capital, passando por mudanças na forma de gestão e pela tecnologização. Um dos resultados é o aumento do nível de desemprego. Assim, dá-se a reconfiguração da classe trabalhadora.

A classificação das pessoas que vivem do trabalho proposta por Reich (1991) também reflete o crescimento do grupo que atua no setor de serviços e o enfraquecimento do proletariado. São quatro as categorias elencadas pelo autor: dos "manipuladores de símbolos" os quais trabalhariam criando ideias e tornando-as atraentes ao capital, "vendáveis", dos que atuam na "reprodução do trabalho", como os educadores, por exemplo, das pessoas envolvidas em "serviços pessoais", atividade que requer contato direto com aqueles que pagam pelo serviço prestado e, por fim, a categoria dos que chamou de "trabalhadores de rotina".

\footnotetext{
${ }^{33} \mathrm{O}$ grupo de subproletariados alcançou, segundo dados da OIT, na década de 90, o marco de mais de um bilhão de trabalhadores precarizados, subempregados como consequência direta da acentuação do caráter destrutivo da lógica do capital.
} 
Esses últimos são os trabalhadores ligados às linhas de montagem, ao chão-de-fábrica, e constituem para Bauman (2001) a parcela que mais sofreu com o desenvolvimento capitalista, tornando-se facilmente intercambiável, por isso descartável. Por saberem que sua posição de trabalho é insegura, como já comentamos, esses trabalhadores não teriam chance de apegar-se a ela, nem mesmo para desenvolver laços mais consistentes e duradouros com os outros trabalhadores, como a constituição de associações para a luta por objetivos em comum, por exemplo. Do mesmo modo qualquer projeto sobre si mesmo, como projeções para o futuro, não pode mais estar atrelado ao trabalho.

Em relação ao processo de globalização do capital, mudanças também são implicadas no mundo do trabalho, este torna-se transnacional, pode ser empregado e explorado em países distantes, rompendo os limites geográficos enquanto a classe trabalhadora ainda não alcança uma resposta internacional na relação com o capital, mantém-se predominantemente em sua estruturação nacional; a ação dos trabalhadores ainda encontra-se limitada. Trata-se de um novo desafio ao mundo do trabalho já que o capital utiliza-se com magnificência dos mecanismos globalizados e dispõe de órgãos internacionais de suporte; a solidariedade da classe do capital está bem à frente da ação dos trabalhadores (MÉSZÁROS, 1995).

Outra tendência do mundo do trabalho é a crescente imbricação entre trabalho material e imaterial: expansão do trabalho dotado de maior dimensão intelectual, nas atividades industriais mais informatizadas, nas esferas do setor de serviços, comunicações, entre outras. Por outro lado, no universo do trabalho precarizado e terceirizado, principalmente nos países industrializados do Terceiro Mundo, assiste-se à expansão de atividades laborativas manuais. Fato é que o caráter desigualmente combinado do sistema global do capital diferencia a incidência dessa tendência na divisão internacional do trabalho, embora ela seja realidade em todos os países com núcleos de produção industrial moderna ${ }^{34}$.

Considerando que é o trabalho imaterial que inova continuamente a forma e as condições de comunicação, e assim também do trabalho e do consumo, é ele também que cria e transforma o ambiente cultural e ideológico do consumidor, produzindo a própria relação do capital. Muito além do valor econômico, o trabalho imaterial produz subjetividade, e constitui prova maior da

\footnotetext{
34 Isso acontece, segundo Lazzarato (1993[2]), principalmente pela demanda por atividades de pesquisa, comunicação e marketing para que sejam levantadas antecipadamente informações sobre o mercado, já que um produto, antes de ser fabricado, precisa estar vendido; o trabalho imaterial encontra-se na interfase entre produção e consumo, ele ativa e organiza essa relação.
} 
invasão do sistema socioeconômico capitalista em toda a vida, rompendo todas as oposições entre economia, poder e conhecimento (LAZZARATO, 1993[2]).

Em relação ao trabalhador, especificamente falando, o trabalho imaterial implica interseção clara entre a subjetividade (esfera intelectual e cognitiva) e o processo produtivo. $\mathrm{O}$ trabalhador passa a ser demandado pela tomada de decisões, analisar situações e oferecer soluções frente a acontecimentos não previstos. $\mathrm{O}$ trabalhador passa de comandado a coordenador de diferentes funções de produção e tem sobre suas costas a responsabilidade de gerar “cooperação produtiva”. É assim que com o toyotismo a exploração do trabalhador ganha outra conotação, nova amplitude de expropriação. O papel de chefe de si mesmo é assumido pelo trabalhador em um sentido autopunitivo, em prol de um objetivo que não é seu, mas estranho, do capital, a "qualidade total" de sua produção. Processo esse nomeado por Antunes como “envolvimento manipulado", leva a alienação do trabalho ao limite, "interiorizada na alma do trabalhador"; seu intelecto e subjetividade são agora cooptados pelo capital, funcionam a seu favor, como em um corpo de aluguel, o do trabalhador.

Tertulian (1993) denuncia a "subjetividade inautêntica" por estar totalmente direcionada e enquadrada na valorização e autorreprodução do capital. Subjetividade essa modulada pela lógica da "forma/mercadoria" e sua realização. A força de trabalho intelectual é, também, absorvida como mercadoria pelo capital, atendendo à necessidade de inovação contínua da produção material e de serviços; o próprio conhecimento converte-se em mercadoria e capital (VINCENT, 1993).

Para Antunes (1999), trabalhos material e imaterial estão intrincados, este último interagiria, sempre, com o mundo produtivo do trabalho material, assim também se encontrando aprisionado pelo sistema de metabolismo social do capital; não haveria disjunção entre os dois. Embora tenha sido reduzida a distância entre elaboração e execução e enxugados os níveis hierárquicos, a subjetividade absorvida pelas empresas é expressão de uma existência inautêntica ou estranhada. $\mathrm{O}$ estranhamento em relação ao que se produz e para quem se produz permanece variável e comum.

Posso contribuir com um depoimento, saído de minha própria história, sobre o problema. Trabalhando em uma multinacional do setor de telefonia na área de "planejamento estratégico", o sentimento de vazio era constante, não apenas ao trabalhar, mas em pensar sobre minhas atividades rotineiras, ou mesmo preparar-me para ir à empresa diariamente. Embora tivesse em 
mãos parte das decisões e alguma liberdade sobre a forma como as tarefas seriam realizadas, ao final dos dias, meses e ano não havia nada de novo em mim mesma além do cansaço e a sensação de que o tempo de vida passava mais depressa. Os produtos e serviços da empresas multiplicavam-se, mas o fato é que eu continuava sem identificar as minhas infindas horas de trabalho em tais produtos e serviços, os quais eu mesma acabava por consumir.

A compensação pelo esvaziamento se dá pelo salário e "benefícios" junto à aparência de maior liberdade no espaço de trabalho. Exige-se, porém, a personificação do trabalho mais próxima possível das personificações do capital. Antunes (1999) sublinha que "vontade", “desejo" e "aptidão" a esses modelos institucionalizados devem ser demonstrados pelo trabalhador diante da ameaça de ser trocado por outro que tenha "perfil" e "atributos" mais adequados.

A construção de uma subjetividade autêntica é também constrangida na vida fora do trabalho. Além das fetichizações e reificações do mundo do trabalho que repercutem no restante da vida, o consumo de mercadorias também está estruturado pela lógica do capital. Ao saírem da empresa os trabalhadores são aqueles mesmos consumidores mapeados e "compreendidos" pelo departamento de marketing e transformados em alvos para a venda. São, portanto, reféns do próprio bombardeio que ajudaram a erigir. O capital domina também fora da vida do trabalho.

Assim como a classe trabalhadora encontra-se mais explorada, mais fragmentada, mais heterogênea e complexificada, o mesmo aplica-se à própria atividade produtiva em que o mesmo trabalhador dirige e supervisiona mais de duas ou três máquinas. Além disso, os mecanismos também se complexificarão, suprimem o sujeito-que-trabalha em todas as suas facetas. Contexto esse ríspido à consciência de classe, em meio a tantas especificidades e características peculiares de cada grupo e de cada trabalhador, por homens e mulheres que, antes de não se reconhecerem nos outros, não se reconhecem em sua atividades, em si mesmos. Por isso a emancipação por meio da revolução do trabalho, única possível, encontra um caminho difícil de percorrer: recuperar, resgatar o sentimento e a consciência de pertencimento de classe que o capital e suas diversas formas de dominação encobrem. A resistência precisa considerar essas diversas peculiaridades do trabalho, nacionalmente diferenciado e socialmente estratificado (MÉSZÁROS, 1995).

Em relação ao ganho de força do chamado "Terceiro Setor", outra tendência do mundo do trabalho, o que efetivamente nos interessa aqui é o tratamento dado à Economia Solidária, situada 
pelo autor como parcela de tal setor. Como ponto positivo é apresentada sua atuação, por vezes, fora da lógica mercantil, no entanto, Ricardo Antunes vê o movimento como impossibilitado de constituir-se uma "real alternativa transformadora da lógica de capital e seu mercado" (p. 113), incapaz de "minar os mecanismos da unidade produtiva capitalista". Seguindo nessa ideia, a expansão da Economia Solidária, pelas margens do sistema, não teria como futuro próspero a mudança estrutural na lógica vigente de produção de mercadorias e de valorização do capital.

A crítica vai além ao situar o enquadramento dos desempregados no Terceiro Setor e nas iniciativas da Economia Solidária como uma colaboração ao sistema, ocupando-se dessa massa que consiste em incômodo público e social. Por meio do resgate à sociabilidade, por meio dessas ações, que o trabalho deveria propiciar, os participantes veem-se realizando atividades efetivas às margens dos mecanismos de acumulação, deixando de enxergar-se como desempregados. As "associações" ou "empresas solidárias" estariam ocupando lacunas deixadas pela queda do "Estado de bem estar social".

Tais iniciativas, complementando, teriam algum efeito, ainda que muito limitado, segundo o mesmo autor, na minimização do desemprego. No entanto, em relação às possibilidades de transformação social em profundidade, elas podem "substituir" as formas de transformação radical e profunda da lógica societal atual por mecanismos mais apropriados e parciais, de algum modo assimiláveis pelo capital. Acabam por evitar transformações capazes de eliminar o capital.

Essa é uma crítica importante em relação à atuação do movimento de economia solidária para a superação das contradições essenciais do sistema capitalista, na proposição de mudanças estruturais no sentido de organizações do trabalho e societal que tenham a vida como norte. $\mathrm{O}$ foco nessa pesquisa lançar-se-á sobre as experiências vividas por alguns sujeitos-cooperados e as representações e desdobramentos alçados por essas experiências no âmbito individual, da subjetividade, da indentidade. Nesses casos específicos buscaremos indícios de um vetor, talvez encontrado a partir da atuação na cooperativa popular de trabalho, para o desenvolvimento de uma posição em crítica a respeito do sistema e de sua própria função como parte dele. Se não é suficiente para a transformação da estrutura, certamente é passo indispensável, na contramão da alienação e da submissão passiva.

Partindo de Marx, a humanidade é atividade e alienação é o processo que transmuta sujeitos humanos a objetos, por meio do qual a subjetividade de cada um é apropriada por outros, no limite, por um outro, pelo objeto que assume o papel de sujeito, pelo capital (HOLLOWAY, 
1997). A desalienação é a revolta da atividade contra sua condição estranhada, contra a passividade, contra o sofrimento imposto por um outro genérico.

Assim como a alienação é fenômeno que parte do trabalho estranhado, também sua negação nasce na atividade de trabalhar, por um trabalho diferente, composição de outra organização do trabalho. A defesa disso é premissa para abordagem das experiências nas cooperativas populares autogestionárias assumida nessa pesquisa: a centralidade do trabalho na formação e transformação da subjetividade e sua transversalidade na formação da sociedade contemporânea. Já defendida por Ricardo Antunes, libero-me de entrar nessa discussão. O importante é que essa ideia seja levada à leitura dos capítulos subsequentes.

De qualquer forma, a conexão entre a vida dentro e fora do trabalho é tão clara quanto a vivência empírica de como um dia de trabalho pode resultar no mau-humor em casa, na convivência com parentes e amigos. As consequências do trabalho alienado e estranhado para as relações "pessoais" e para o modo de colocar-se em outros espaços, no tempo de vida fora do trabalho, são tantas quantas comporta toda uma vida. Por outro lado, justamente por estarem atrelados, as elaborações sobre transformações na relação trabalho-capital ficam desprovidas de caráter prático se não considerado o sujeito como um todo, passando pela totalidade dos papéis desempenhados e por suas representações subjetivas, pela totalidade de sua práxis.

\subsection{Trabalho e vida cotidiana}

É na vida cotidiana que estão em constante interrelação os dois pólos humanos da realidade social: a particularidade e a genericidade. Recorre-se a essa esfera com a finalidade de acessar a consciência mais propícia aos valores emancipados, livres e universais, transcendendo àquela espontânea, próxima à imediatidade. Por Tertulian (1993), é nesse âmbito que aflora a "subjetividade autêntica".

A chamada vida cotidiana merece atenção na medida em que o sujeito de uma sociedade surge e manifesta-se no interior da totalidade de suas ações e relações. Ela pode ser entendida como forma imediata da genericidade humana, conjunto formado pela composição de todas as reações espontâneas dos homens em relação a seu ambiente social. Assim é formada a sua "universalidade extensiva", pelas particularidades das reações dos indivíduos que indicam um todo cheio de sentido sócio-histórico. 
Por isso, Antunes (1999) defende a indispensabilidade de buscar relações, no processo analítico, entre mundo do trabalho e vida cotidiana. Apenas por essas conexões é possível compreender o ser social de forma um pouco mais ampla e complexa. É nesse sentido que esse esforço aqui se faz: para que indícios mais consistentes sejam encontrados em relação à consciência do ser-social-que-vive-do-trabalho e seus movimentos entre o âmbito da imediatidade, "genericidade em-si", e as formas mais autênticas, mais próximas à "genericidade para-si".

Voltando a Marx (1974), encontramos a elaboração de que quando o trabalho deixa de ser determinado por necessidade e por utilidade exteriormente imposta, e os produtores associados passam a regular racional e coletivamente o intercâmbio com a natureza, realizando-o da melhor forma possível, estabelecem-se as condições para a liberdade. No entanto, para o autor, ela só pode ser desenvolvida quando, para atender necessidades genuínas, as forças humanas começam a ser trabalhadas como fim em si mesmas; este sim seria o "reino da liberdade".

Com base nesse cenário, é reconhecidamente acertado o papel estratégico que a luta pela redução da jornada de trabalho tem ocupado nos movimentos trabalhistas desde o início do capitalismo. Este ponto, diretamente relacionado à esfera da vida cotidiana, é a partida, segundo Antunes (1999), para uma reflexão sobre o tempo, "tempo de trabalho, o autocontrole sobre o tempo de trabalho, e o tempo da de vida", e para que uma vida dotada de sentido possa nascer e estabelecer-se fora do trabalho. A busca por uma vida emancipada tem, portanto, essa luta como cerne.

A articulação da resistência contra a opressão do capital no tempo de trabalho acompanha a luta contra a opressão exercida no tempo de vida. Antunes lembra-nos que a "temporalidade" é uma categoria criada pelo homem, uma construção "histórico-social", não absoluta. Foi na Era Moderna, e nas sociedades surgidas nesse contexto, que nasceu também o "tempo opressor"; aquele que exerce o controle de fora para dentro, por meio de instrumentos como o relógio e o calendário. Trata-se de uma coerção que instiga certo autocontrole por parte dos indivíduos e que, segundo Elias (1998, p. 21-2), “exerce uma pressão relativamente discreta, comedida, uniforme e desprovida de violência, mas que nem por isso se faz menos onipresente, e à qual é impossível escapar".

Pressão essa exercida dentro e fora do mundo do trabalho, força que extrapola a esfera produtiva. O ponto é que a vida fora do trabalho também se encontra dominada pelo metabolismo 
do capital e forma o que chamamos de "sociedade do consumo". É assim que para uma vida dotada de sentido fora do trabalho, é necessária uma vida cheia de sentido no trabalho: a contradição entre trabalho assalariado, fetichizado e estranhado e tempo verdadeiramente livre descende dessa relação. A vida na sociedade contemporânea encontra-se fetichizada em seu existir histórico dentro e fora do trabalho, e seu processo de descolonização depende do avanço da revolução nos dois âmbitos, da produção das coisas e do consumo das mercadorias.

Assim como qualquer luta coletiva, a voltada à redução da jornada de trabalho precisa estar fundamentada contra as formas de (des)sociabilização do mundo do capital. Essa luta tornase confluente com o direito ao trabalho, a redução da jornada deve implicar a manutenção dos salários, e a redução do "tempo opressivo de trabalho"35.

A barreira entre tempo de trabalho e tempo de não trabalho foi erigida historicamente, assim como a forma em que o trabalho se faz, concretizado, hoje, tal separação não tem caráter de naturalidade, mas foi legitimado pelo discurso ideológico. Uma nova sociabilidade exige que essa barreira seja implodida e que os indivíduos sociais e livremente associados possam atender às suas necessidades e, em conformidade com suas aspirações mais autênticas, suscitadas no interior da vida cotidiana, encontrem condições para a concretização plena de suas humanidades. A jornada de trabalho pré-estabelecida, em torno da qual o sujeito-trabalhador deve organizar toda sua vida, abrindo mão durante oito horas diárias, ou mais, do atendimento de qualquer outra necessidade, de voltar-se a demandas de todas as outras áreas de sua vida, é invariavelmente uma violência, transfiguração do sujeito a uma peça da linha de montagem.

Por fim, estar fora do mundo do trabalho, mesmo que assalariado, alienado e alienante, é estar fora do universo do capitalismo vigente e significa, para a massa de desempregados que constituem mais de dois terços da humanidade, uma "desefetivação, desrealização e brutalização" ainda maiores do que as presentes nas condições enfrentadas por aqueles que encontram espaço na organização do trabalho (ANTUNES, 1999). De qualquer forma são alvo do sistema de metabolismo social do capital, o qual converte todo o tempo em tempo de consumo, e responsabiliza o próprio homem e mulher pela sua exclusão do mercado de trabalho, compelindoos a "capacitar-se" para voltar a competir por uma vaga de trabalho.

\footnotetext{
${ }^{35}$ A redução aparente do tempo de trabalho pode corresponder à maior intensidade (e exploração) de trabalho em um período igual ou menor (BERNARDO, 1996).
} 
Na formulação de Ricardo Antunes, os fundamentos de um novo sistema de metabolismo social necessários a uma nova vida, dotada de sentido, colocam-se por meio de:

"um novo meio de produção fundado na atividade autodeterminada, baseado no tempo disponível (para produzir valores de uso socialmente necessários), na realização do trabalho socialmente necessário e contra a produção heterodeterminada (baseada no tempo excedente para a produção exclusiva de valores de troca para o mercado e para a reprodução do capital)" (ANTUNES, 1999: 179).

O foco da organização societal precisa voltar-se ao atendimento das necessidades humanas e o trabalho deve ser exercido por meio de autoatividade, atividade livre, baseada no tempo disponível. Nessa nova sociedade serão resgatados os valores qualitativos, valores de uso, éticos, as relações humanas e os sentimentos, destituídos pelo capitalismo e sua regulação pelo valor de troca, com objetivo único e exclusivo de acumulação de lucro. As reais necessidades societais voltarão a ser o centro do modo de produção, atendendo às efetivas demandas de autorreprodução da humanidade, antes do capitalismo centrais nas organizações socioeconômicas.

Urge a inversão de uma lógica que, como ressalta Bihr (1998), baseia-se em forças produtivas que se convertem em forças destrutivas da natureza e dos homens e que, de fonte de enriquecimento, transforma-se em mecanismo de empobrecimento ao desativar o valor de uso em prol do "valor", uma abstração. A dicotomia entre tempo necessário para a reprodução social e tempo excedente, voltado à reprodução do capital, é imposta e precisa ser negada para que sejam as funções vitais da sociedade, exercidas por produtores autônomos, associados coletivamente, que controlem seu sistema de metabolismo social (MÉSZÁROS, 1995).

O tempo disponível ganha nova conotação nesse cenário a ser conquistado: de alvo de exploração para valorização e expansão do capital, para condição necessária à realização das demandas e necessidades efetivamente sociais e, assim, ao aflorar de uma subjetividade dotada de sentido. A reestruturação do ser social implica a desestruturação do capital. Uma sociabilidade superior, cenário propício à subjetividade autêntica, é antagônica ao capitalismo atual; não é possível a coexistência, como em uma gangorra, a ascendência de um só é experimentada com a descendência da outra ponta. 
Apresentado o trabalho na sociedade contemporânea, passemos ao sujeito que trabalha, imbricado nessa organização societal. Esse é o lugar do qual olharemos para a Economia Solidária e para as experiências, objetivas e subjetivas, únicas dos sujeitos-cooperados. Posição em que se encontra o homem e a mulher que se faz e que faz essa sociedade, lugar em que nos encontramos, nós mesmos. Daremos o próximo passo para compreender e trazer à consciência o que significa estar nesse lugar, quais as implicações de nossa organização do trabalho e societal para os seres humanos e mais especificamente para aqueles que vivem de suas forças de trabalho. Assim compreenderemos de onde partimos e de ondem partem aqueles que se organizam em cooperativas populares.

Será que essa vivência corre na contramão do cenário estabelecido e das implicações dessa realidade para cada um de nós? Será essa experiência capaz de resgatar o trabalho dotado de sentido, as relações desinteresseiras, colaborativas, de troca e uma vida com espaço para a realização de a humanidade que há em cada sujeito? Questões que nos levam aos próximos capítulos, à aproximação em relação organização societal e subjetividade, Economia Solidária e Identidade. 


\title{
Capítulo III - Ser social - política e subjetividade na sociedade contemporânea
}

\author{
"O mundo me condena \\ E ninguém tem pena \\ Falando sempre mal do meu nome \\ Deixando de saber \\ Se eu vou morrer de sede \\ Ou se vou morrer de fome. \\ Mas a filosofia \\ Hoje me auxilia \\ A viver indiferente assim. \\ Nesta prontidão sem fim \\ Vou fingindo que sou rico \\ Para ninguém zombar de mim"
}

(Noel Rosa e André Filho, composição "Filosofia", 1933)

\subsection{Objetividade e subjetividade - os sentidos das relações sociais estabelecidas}

A realidade é sempre síntese do objetivo e do subjetivo; os conflitos sempre se expressam e são decididos sob a forma historicamente dada. É necessário entender como o indivíduo se individualiza nas condições presentes (GIANNOTTI, 1983).

São diversos os pensadores que passam, em suas obras, pela reflexão de como se dá a ponte entre o mundo objetivo, externo ao indivíduo, e a esfera da subjetividade, o mundo simbólico em que o sujeito baseia sua subjetividade. Essa interação faz parte da vida, começa com o nascimento do novo indivíduo, que chega com infinitas possibilidades de ser e de agir (ARENDT, 1993) em um mundo em constante mudança, mas já com expectativas diversas préconcebidas em relação a essa criança (CIAMPA, 1987).

Para compreender esse processo vale, assim como Berger \& Berger (1977), refletir sobre a "socialização primária" e sobre a "socialização secundária". Enquanto a primeira volta-se à constituição inicial do repertório simbólico do sujeito, a socialização secundária diz respeito às interações sociais do indivíduo em todos os anos seguintes de vida e à relação dialética estabelecida entre o mundo exterior e o interno. Nessa pesquisa interessamo-nos especialmente por esse segundo momento, contexto em que o trabalho posiciona-se em lugar de grande relevância, como veremos adiante. Portanto, como alternativa de trabalho, renda e relação com o 
outro e com o mundo, os sentidos do cooperativismo poderão ser estudados com a profundidade que o tema requer.

Ao aproximarmo-nos da forma como se dá essa troca constante entre o ser humano e o ambiente e como, assim, o sujeito se forma e se transforma, será possível a aproximação em relação às possibilidades e limitações intrínsecas ao trabalho cooperado, autogestionário e solidário. Passaremos muito brevemente pela socialização primária, apenas para elucidar o fenômeno, base para a socialização secundária.

Berger \& Berger (op. cit.) denominam o processo pelo qual um indivíduo passa a fazer parte de uma sociedade como "socialização"; ao compor um novo grupo, como os comunitários e a própria cooperativa popular, os sujeitos vivenciam a "socialização secundária" 36 . Tal processo sempre incorreria em alterações no "microcosmo" do indivíduo, ligando a estruturas complexas, pré-existentes, do "macrocosmo". Nesse mesmo sentido, da conexão com o já existente, que Bakhtin (2002) considera que a socialização acontece em um território social determinado, pois será conformada pela situação social mais imediata.

George Mead é retomado por Honneth e Habermas quando se trata da questão de entender a relação entre indivíduo e sociedade (LIMA, 2009). Voltemos nossa atenção para o autor por algumas linhas.

A consciência, categoria que se mostrará fundamental nessa pesquisa, é, para Mead (1962), social; a interação social, a linguagem e os objetos físicos do mundo material seriam centrais no processo de formação do "self" e da construção das identidades sociais. A comunicação se dá com base nos processos sociais dos quais os indivíduos fazem parte, é nesse campo que surgem os sinais e os símbolos e, a partir deles, as convenções semânticas válidas intersubjetivamente (LIMA, 2009).

É com base na incorporação desses referenciais, intersubjetivamente compartilhados, que se cria o sujeito individual, o "Eu" de si mesmo; assim se dá o processo de socialização e de individuação apresentados por Mead (1962). Em um primeiro momento de sua vida, a criança interage com objetos externos, testando suas ações e reações, posteriormente desenvolve a capacidade de lidar com regras, obedecendo-as, compreendendo-as e, depois as construindo. A regra passa, então, a ser criada e mudada pelo próprio indivíduo. Esse é o caminho de

\footnotetext{
36 Termo usado por Berger \& Berger (1977) referindo-se não à socialização por meio da qual a criança recémchegada é introduzida na sociedade (essa seria a primária), mas sim àquelas por todas as quais o sujeito passa ao longo da vida ao ser introduzido em um novo mundo social específico.
} 
desenvolvimento do que o autor chama "outro generalizado", referindo-se à generalização das expectativas de comportamento de todos os membros da sociedade, em geral. Esse outro faz parte do indivíduo, estabelecendo com o "Eu” um "diálogo interiorizado" (SASS, 2004).

Isso porque o "Eu" representa as demandas individuais, particulares, em relação ao "outro generalizado", enquanto o "mim" conforma as atitudes e valores organizados dos outros que o indivíduo adota para si.

O "self" emerge da dualidade entre o "Eu" e o "mim", o "self" individualiza-se pelo primeiro e socializa-se pelo segundo, constituindo no processo de interação social, especificamente na "interação simbólica" nele presente. O mergulho total do indivíduo em uma comunidade, por vezes perdendo sua individualidade, estaria ligado ao fenômeno que Mead entende com a fusão entre o "mim" e o "eu" (LIMA, 2009). Isso poderia acontecer frente à necessidade de um "outro generalizado" ou de uma instituição em que ancoremos nossas angústias e nos sintamos seguros de que adotamos atitudes socialmente válidas. Assim, o potencial de criação, de inovação do sujeito está vinculado ao nível de autonomia do "Eu" em relação ao "mim", ao grau em que o indivíduo percebe e coloca suas vontades, desejos e interesses próprios na relação com os outros.

$\mathrm{O}$ indivíduo, à medida que vai adquirindo a capacidade de agir e de falar, vai também passando a se reconhecer e a ser reconhecido como alguém que pode afirmar "eu" de si mesmo. O homem insere-se no mundo pré-organizado iniciando com ele uma relação dialética a partir da palavra e do ato. É por meio deles que a presença inicialmente física torna-se humana (ARENDT, 1993).

A subjetividade do indivíduo, a partir de Habermas, é entendida como em articulação permanente com a objetividade da natureza, a normatividade da sociedade e a intersubjetividade da linguagem (LIMA, 2009). Diferente de Lukács (1980), o autor vê a emancipação do ser humano em relação à natureza, sua humanização, não pelo trabalho, mas por sua por sua "competência comunicativa" que seria um atributo inerente ao ser humano, uma "competência universal". Seria essa competência comunicativa a criadora de todas as possibilidades para a individuação, socialização e desenvolvimento cultural dos indivíduos (HABERMAS, 1974).

O discurso bem-sucedido, que se traduz em "ação comunicativa", alcança o reconhecimento intersubjetivo, contando com algumas condições favoráveis e assim incorrendo em um processo de "reprodução cultural, integração social e socialização" (HABERMAS, 1992, 
p. 196). Portanto, em outras palavras, a ação comunicativa é apresentada como um processo cooperativo de interpretação, em que os participantes voltam-se, simultaneamente, a algum aspecto do mundo objetivo, do mundo social e do mundo subjetivo, com o objetivo de alcançar o entendimento por meio de um "reconhecimento intersubjetivo da pretensão de validade" dos enunciados feitos (ibidem, p. 171).

Assim, a ação comunicativa estaria ligada a três aspectos fundamentais da vida humana: ao entendimento coletivo - por meio do qual o conhecimento tradicional pode perpetuar-se, bem como o saber cultural renovado, à coordenação da ação - necessária à integração social e à solidariedade, e à socialização - no que tange à formação das identidades pessoais (ibidem, p. 187-188).

Ancorada na vida cotidiana, as condições necessárias à concretização da ação comunicativa encontram-se, segundo Habermas, no "mundo da vida"37, instância que possui o caráter de "comunidade em sentido radical" e que se encontra uma situação e um equilíbrio sociais compartilhados intersubjetivamente a priori das ações comunicativas que nele se desenvolvem. Os limites desses valores e interpretações partilhados coincidem com os limites do mundo da vida, ele não tem forma ou espaço pré-definidos para sua existência.

"Enquanto "lugar transcendental", o mundo da vida se manifesta nas infinitas possibilidades de interação linguísticas empreendidas socialmente, podendo ser entendido como um "horizonte" em que os agentes comunicativos se movem "desde sempre"” (LIMA, 2009, p. 141).

O mundo da vida seria uma "espécie de pano de fundo compartilhado intersubjetivamente" (LIMA, 2009, p. 141-142), a partir do qual os atores assumem a dianteira e fazem a vida humana acontecer. Por ser o lugar em que se dá a socialização dos novos membros que surgem a cada geração, constituindo identidades pessoais, e o âmbito em que as identidades dos grupos tornam-se estáveis, é fundamentalmente o espaço de construção e realização da relação dialética entre as esferas objetivas e subjetivas, em que, junto a outros homens é possível interpretar o mundo com riqueza de visões e ter força para posicionar-se diante dele.

A racionalização e a burocratização dessa esfera, do mundo da vida, denunciadas por Habermas (1983), sujeitariam seus participantes a intervenções sistêmicas que corroborariam

\footnotetext{
37 O "mundo da vida" é formado por três componentes: a Cultura, a Sociedade e a Personalidade. Juntos, em interação, esses elementos garantem a estabilidade do processo de socialização e individualização.
} 
com a neutralização do mundo da vida pela ação instrumental, distorcendo a ação comunicativa e corrompendo o sentido da articulação entre as condições objetivas do mundo e a subjetividade humana. O "sistema" e a "razão instrumental" relacionam-se às esferas econômica e burocrática; esse é o lugar que dominam, tendo como meios o dinheiro e o poder, e do qual extrapola, multiplicando-se sobre a vida cotidiana.

Quando a razão instrumental determina a comunicação, e o dinheiro e o poder tomam o lugar da linguagem, impondo-se a qualquer outro símbolo, se dá a "tecnização do mundo da vida" (HABERMAS, 1992, p. 259). As patologias da sociedade moderna estão, para Habermas, relacionadas a esse processo, à violência do dinheiro e do poder (meios “a-linguísticos") ao universo intersubjetivo.

Lembrando que é no tempo-espaço do mundo da vida em que os homens socializam-se, a partir da tradição e das instituições que aí habitam, é fácil imaginar que se esse mundo, posto, não oferecer condições à ação comunicativa, a construção de símbolos e significados comuns será enfraquecido ou abortado. É isso que para Habermas (1995 apud LIMA, 2009) acontece em nosso tempo, os indivíduos, "semiformados", abandonam uns aos outros, o mundo comum, despovoando o espaço público ${ }^{38}$, isolando-se ao mesmo tempo em que se massificam, e sendo facilmente doutrinados e dominados por chefes despóticos por meio facilmente doutrináveis, dominados por chefes (ibidem).

Compreendo o fenômeno que Deetz (1992) sintetiza como o transbordamento das agendas empresariais para as outras esferas da vida com a dominação do mundo da vida pelo agir estratégico, pela razão instrumental que Habermas (1983) denuncia. Para o autor a linguagem, "criadora" de identidade na medida em que atribui simbolicamente características, direitos e deveres aos objetos e às pessoas, em nosso tempo é manipulada, criada ou endossada, pelas “organizações flexíveis”. Os significantes são propagados pelo discurso gerencial nos principais meios de comunicação tornando-se reconhecidos como o jeito sério, correto de se falar e de ver o mundo. Essa hierarquia de discursos, do empresarial em relação à do dia a dia, reflete a divisão

\footnotetext{
${ }^{38}$ Lima (2009) traz que em "Direito e Democracia”, volume II, a esfera pública é repensada por Habermas, o autor propõe que seus horizontes externos são abertos, permeáveis e deslocáveis (HABERMAS, 1992, p. 92 apud LIMA, op. cit.), muito próximo ao seu entendimento sobre o mundo da vida, principalmente por se reproduzir por meio do agir comunicativo. É na esfera pública em que os conteúdos são comunicados, as posições e “opiniões” formadas, é onde os fluxos comunicacionais condensam-se nas opiniões públicas sobre temas específicos (ibidem).
} 
social do trabalho, da dominação dos proletários pelos seus gerentes e do capital sobre o trabalho de todos.

Como antes dito, assumo aqui o trabalho como central para a formação e conformação da subjetividade humana, atividade por meio da qual o ser humano relaciona-se com o mundo externo a ele, com o exercício de realizar um desejo, uma vontade, um plano em contato com as condições concretas encontradas. A linguagem representa a relação com esse mundo e consigo mesmo a partir da interação com o mundo, seus símbolos apenas podem ser criados e compartilhados depois de experimentado o trabalho. Evidente que não o trabalho assalariado, não o "emprego", não o trabalho como socialmente controlado e determinado, mas em seu potencial ontológico.

Por Dejours e Abdoucheli (1994) o trabalho é encarado como um espaço de "construção de sentido", forte influenciador das direções percorridas na história do sujeito e, portanto, de seu repertório de símbolos, sentimentos, representações. "Lugar significativo no processo de reapropriação e de emancipação" (DEJOURS e ABDOUCHELI, 1994 apud HABERMAS, 1976), central nas transformações experenciadas pelo sujeito. Porém, o trabalho exercido pela grande maioria da população ${ }^{39}$ é atividade desprovida desse sentido, trabalho alienado e alienante, do qual provém a reificação em lugar da emancipação. São faces do mesmo fenômeno o transbordamento do discurso empresarial, originário do mundo sistêmico, sobre o mundo da vida e a replicação das relações violentas, em que não há escuta entre indivíduos, nas outras esferas da vida. Como antes mencionado, os espaços da vida, assim como as diversas personagens que compõem a identidade individual, não estão separadas por baias, como as empresas e os celeiros; o mundo da vida e o mundo sistêmico são o mesmo mundo, esse mundo cada vez mais marcado pelas características e peculiaridades do sistema.

Espaço para a construção de sentido, atividade por meio da qual o homem coloca-se no mundo, forma é transforma sua subjetividade, o trabalho é o elemento inicial, também central, nas cooperativas populares. Primeiramente porque em nossa sociedade é o que possibilita o

\footnotetext{
${ }^{39}$ No Brasil, 89,9\% da população economicamente ativa (FONSECA, 18/04/2010), de 2000 a 2007, entre os trabalhadores empregados, 51,1\% estiveram no mercado informal (Último Segundo, 08/04/2009), isso é, em um formato de trabalho, por vezes, ainda mais precário e exploratório. O "emprego informal" é aquele em que não existe vínculo legal entre patrão e funcionário (carteira assinada), no caso do trabalhor autônomo, não há empresa legalizada, não são recolhidos impostos sobre essas atividades e não há benefícios legais reconhecidos ao trabalhador.
} 
acesso ao capital e assim ao consumo, portanto, ao reconhecimento pelo restante da sociedade, à cidadania.

Sabendo ser direta a relação da organização do trabalho com as relações estabelecidas, a possibilidade de construir coletivamente e compartilhar interpretações e símbolos, a autogestão deve ter desdobramentos evidentes, objetivos e subjetivos, para os trabalhadores cooperados. Recuperar a importância do trabalho, seu potencial papel como impulso com sentido emancipatório, perdido com a expropriação dos meios de produção e do poder de decisão e escolha dos trabalhadores, é entendida como a coluna vertebral das experiências cooperativistas da Economia Solidária. A partir daí devem dar-se mudanças na linguagem, na comunicação, nas relações em sentido mais amplo. Nessa perspectiva, vou adiante nessa pesquisa.

Para Mead, uma nova identidade pessoal sempre acompanha a identidade social em formação: "uma pessoa é uma personalidade porque pertence a uma comunidade, porque incorpora as instituições da comunidade em sua conduta" (MEAD, 1992, p. 162). O ingrediente aglutinador na receita do cooperativismo é o trabalho, autogestionário e solidário, é ele quem traz as pessoas para o espaço comum.

O enlace entre o mundo externo e interno ao homem é tratado também por Gonçalves Filho (1995) ao estudar a "humilhação social" como um problema político e psicológico, disparado pela desigualdade de classes, sentida como angústia pelos pobres inferiorizados ${ }^{40}$. O modo como qual cada época organizou as relações humanas, dos homens com o espaço público e com a natureza é, para o autor, insumo para a aproximação com os processos psíquicos.

A forma assumida psiquicamente por essa organização social, comum, das relações é particular; a experiência comum do sofrimento afeta a cada um dos homens e mulheres com "traços originais, por qualidades surpreendentes que tornam irredutível a fisionomia de cada homem” (GONÇAVES FILHO, 1998). Nesse sentido que a humilhação social historicamente reproduzida, sofrida por toda a ancestralidade dos pobres desde o início da organização societal capitalista, efeito da desigualdade política, habita o interior do humilhado; a angústia nasce de

\footnotetext{
${ }^{40}$ Voltaremos ao fenômeno político e psíquico da "humilhação social” (GONÇAVES FILHO, 1995) novamente um pouco mais a frente na dissertação, mas vale pontuar que sua gênese está na desigualdade política intrínseca à sociedade de classes e que submete os indivíduos das classes econômicas menos favorecidas a um conjunto de "mensagens enigmáticas e traumáticas" afirmando e reafirmando-os como inferiores. Por isso a humilhação quando não concretizada em ato, faz-se presente para os pobres como ameaça constante, como iminência em cada situação vivida.
} 
dentro, do contexto interiorizado, do equilíbrio de forças enrijecido entre o "mim" e o "Eu", do “self” nascido da violência da dominação.

As condições objetivas da desigualdade tornam-se angústia e assim tomam conta inteiramente do sujeito, apropriam-se de seu corpo, de sua voz, olhar, da imaginação do humilhado. A situação concreta de bloqueio de sua humanidade se faz presente e identificável nele mesmo, também nos espaços dos quais participa, de trabalho, na casa, no bairro. O ciclo está posto, um círculo vicioso, chapado no tempo e no espaço, as condições objetivas de humilhação acomodam-se como dinâmica interna, estendem ao sujeito o mesmo ar triste e árido absorvido pela inspiração do mundo e expirado ao ocupar esse mesmo mundo, ao habitá-lo.

"Os processos políticos informam a subjetividade, desdobram-se internamente, desdobram-se "para dentro" (...). As duas condições estão presentes na humilhação social: o rebaixamento político internaliza-se no oprimido com força traumática extraordinária, ao mesmo que, exteriormente, constitui a exclusão do homem para fora do âmbito do reconhecimento intersubjetivo." (GONÇALVES FILHO, 1998)

Os significados que a humilhação assume para cada um infestam a subjetividade, sendo fonte de processos inconscientes como o que gera a angústia. Manifesta-se também nas situações em que se está na companhia de outros homens descaracterizando-a, suprimindo a capacidade de reconhecimento do outro, de identificação da dignidade humana. Os afetos originados por essas situações “externo-internas" (ibidem) são difíceis de nomear, fazem parte de uma nebulosa de sentimentos doloridos, compõem um sentimento comum enquanto solitário.

É essa mesma dinâmica perversa de dominação, descrita no estudo da humilhação social, que toma conta do cenário da fábrica, do escritório, da empresa. A desigualdade social e política está explicitada na divisão social do trabalho, na relação entre chefes e patrões, entre funcionários e capitalistas. A humilhação se efetiva no dia a dia de exploração do trabalho, na posição hierárquica inferior, na inferioridade fundada na diferença de classes, na falta do capital, e que inaugura a inferioridade totalizadora do sujeito, impedindo o reconhecimento entre pessoas que se colocam a cargo da mesma instituição.

Desafio do exercício autogestionário de transformar essa relação interiorizada, essa posição inferior assumida como verdade, de driblar angústia que paralisa o humilhado. Fazer o caminho inverso, na contramão da sociedade erigida sobre a desigualdade, é missão ousada e corajosa, certamente por vezes desgastante. Agora cooperados, os homens e mulheres que se lançam à 
autogestão de seu trabalho e de suas vidas, foram por muito tempo (e continuam sendo fora da cooperativa), assim como seus pais e avós, humilhados diariamente, relembrados interna e exteriormente de sua inferioridade. Instaurar uma nova dinâmica por meio de outras condições materiais, se uma nova organização do trabalho, que devem ser transportadas ao universo interior de cada cooperado, quebrando a inércia e o automatismo das relações instauradas é a que se propõe o cooperativismo popular.

Teoria e prática guiam, nesse ponto da pesquisa, para além do estabelecimento do espaço público de comunicação fluída com espaço para a livre expressão entre iguais proposto por Habermas (1983) na "teoria da ação comunicativa". Como nos alerta Deetz (1992), ao adentramos essa arena como idealizada já estamos socializados, trazemos as relações anteriormente estabelecidas, os valores, princípios, controles e limitações interiorizados; é preciso que outras condições façam-se presentes nesse espaço e tempo para que uma postura diferente da desempenhada por muitos anos, em diversas organizações, seja modificada. Condições essas talvez presentes na autogestão.

Inclino-me, seguindo a trilha de Hanna Arendt (1993), a ver o fomento à prática "política" e o resgate do conflito, intrínseco e necessário ao seu exercício, como caminho necessário para essa quebra. Certamente há outros componentes na paisagem desse caminho, como o olhar crítico em relação ao contexto socioeconômico e à história pela qual ele se formou, e a que dedicaremos a atenção devida em outro momento.

A fim de compreender alguns sentidos de transformação inaugurados por essa prática usarei o ponto de vista da Identidade. Em sintonia com as reflexões até esse ponto, seguirei a proposta de identidade como fenômeno social, como materialidade que reflete, em cada indivíduo, a estrutura social (CIAMPA, 1987). Identidade como a particularização do geral, normatizada pela superestrutura ao mesmo tempo em que carrega em potência a reação sobre esse status quo.

Na tese de Antônio Ciampa (op. cit.), a identidade é destrinchada na articulação entre diferença e igualdade (ou semelhança), justamente entre objetividade e subjetividade. "Sem essa unidade, a subjetividade é desejo que não se concretiza, e a objetividade é finalidade sem realização" (ibidem, p. 145). O sujeito transformar-se-ia, nessa concepção, frente às novas condições objetivas, o universo subjetivo transformado, por sua vez, voltaria a transformar o contexto sociopolítico; relação dialética em que o indivíduo intervém sobre o ambiente, recriando ele e a si mesmo de forma conscientemente ativa. 
A dialética aí posta é traduzida por Almeida (2005) como o processo em que a submissão e a luta por emancipação encontram-se. Para o autor esse movimento articula-se à tensão entre as esferas públicas e privada: a primeira é o lugar onde as "aberrações" despontam, as desvios aos modelos pressupostos apresentam-se, chocando-se com os padrões. Depois representados normativamente como "outro generalizado", essas "anamorfoses" reensinam a cada um de nós a reconhecer outros membros da coletividade como portadores de direitos, inclusive a nós mesmos. Pensaremos aqui a esfera pública como reconstruída pela materialização dos princípios da Economia Solidária na cooperativa popular, cujo elemento central é a autogestão. Se essa instância aponta para um outro "outro" é o que veremos mais adiante.

Antes, iniciemos uma reflexão sobre o que, quem e como é o Outro, que se coloca como condição objetiva, concreta aos homens e mulheres de nosso tempo-espaço, constituindo um sistema societal dominante e coercitiva sobre cada um de nós. Um outro formado por relações entre pessoas, embora, em grande parte, não sejam voltadas a essas pessoas; outro, embora contraditório, enrijecido.

\section{2 (Não) Dialética e (a)política na sociedade contemporânea}

"A modernidade, primeiro, pulverizou as grandes narrativas, depois tentou consolidar utopias mortíferas da razão e agora procura recobrir a face do mundo com imagens industrializadas. Mas ainda não foi capaz de inventar narrativas à altura da complexidade das forças humanas que ela própria liberou." (KHEL, 2010).

São diversos os aspectos reconhecidos como marcas da era moderna ${ }^{41}$, ainda resguardados pela sociedade contemporânea, que compõem como um quebra-cabeça, um retrato do mundo que se forma a partir dela. Alguns desses elementos serão aqui resgatados a fỉm de trazer à tona a objetividade com a qual o ser humano depara-se ao adentrar o mundo, que mundo posto é esse com qual interage, ao longo de sua história, em relação dialética, mudando ao mundo e de novo a si mesmo. Esse exercício é importante para que possamos adentrar com cuidado, aos poucos, o universo da identidade como fenômeno e categoria nesse mesmo contexto. Se a identidade é

\footnotetext{
${ }^{41}$ Hannah Arendt (1992) define a "era moderna" como período que se inicia com as ciências naturais, no séc. XVII, e tem seu clímax nas revoluções do séc. XVIII. Para a pensadora, o "mundo moderno", por sua vez, inicia-se no séc. XX, a partir da cadeia de catástrofes deflagrada pela Primeira Guerra Mundial, politicamente seu começo é marcado pelas explosões atômicas.
} 
metamorfose constante, é transformação que se faz na interação, do contato entre subjetividade (repertório subjetivo) e objetividade (realidade concreta, ambiente).

Como lembra-nos Galeão (2009), para evitar a submissão do conhecimento a finalidades particulares, escapando à tendência massificadora de manutenção da dominação, da minoridade e do não esclarecimento, é necessário uma teoria crítica da sociedade, questionando as aparências da chamada "realidade". É isso a que me proponho a fazer nessa sessão, voltar a atenção ao que não é natural, apesar de naturalizado, o que precisa ser mudado para que atenda ao interesse da razão e não à razão interesseira.

Corrente em nosso mundo é o esforço pela separação entre teoria e prática, o tratamento das duas esferas de forma segregada, não apenas no discurso científico, também no chamado senso comum, no discurso corriqueiro da vida cotidiana, todos sabem o que se enquadra em de um lado e o que fica de outro. Separação essa proposta e implementada pelo que Ciampa (1987) chama de interesse da "desrazão", da razão interesseira, a partir da qual "o trabalho, que é humanização, inverte-se em desumanização pela divisão (ir)racional do trabalho em manual e intelectual" (p. 216). A divisão do trabalho, imbuída de valor, inaugura a ideologia.

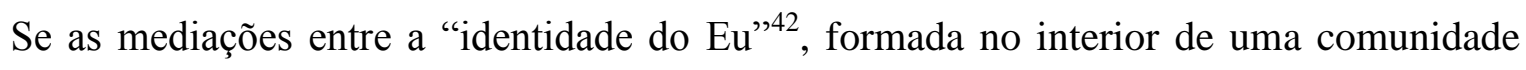
universalista, e a identidade coletiva referente a um povo ou um Estado, antes da era moderna, eram garantidas pelas grande religiões mundiais e pelas fortes ideologias, para Habermas (1982), o novo momento histórico é marcado pela inevitável cisão entre essas partes. Isso porque as mediações tornaram-se ineficazes.

Em extinção, as identidades coletivas são artificialmente postas, pré-determinadas, por uma sociedade em prol do capital. Assim tanto as formações individuais quanto as coletivas são orquestradas, separadamente, pela ideologia do capital, a identidade coletiva forjada para o acesso ao capital e organizada pelo consumo, a identidade do Eu no esforço de realização das potencialidades, vontades e vocações individuais em meio à sociedade de massas.

Esse poderia ser um teaser do chamado "capitalismo tardio", tempos em que o consumo toma o lugar da produção na classificação dos indivíduos, na organização da sociedade; a impossibilidade de autorealização pessoal, o sofrimento pela indeterminação do Eu é

\footnotetext{
${ }^{42}$ A identidade do "Eu" seria formada a partir de uma "identidade natural" que nasce do estabelecimento do limite entre o corpo e o ambiente, depois consolidada pela representação dos papéis assumidos pelo indivíduo, exercício esse sempre simbolicamente mediatizado (HABERMAS, 1982).
} 
administrada por meio do consumo de produtos também indeterminados (HEGEL, 2003 apud LIMA, 2009).

É nessa mesma sociedade ("moderna"), vista por muitos como "desenvolvida", o exercício da melhor organização socioeconômica em que poderíamos chegar, em que o espaço público é dominado pelas questões originariamente privadas (ARENDT, 1993). As trocas comerciais organizadas em torno do capital, possibilitadas pela precificação de tudo e de todos que há no mundo $^{43}$, ocupam não apenas o âmbito do trabalho, mas as relações interpessoais em geral.

Esse é reflexo do processo que marca esse período histórico, descrito por Hannah Arendt (ibidem) como transmutação da esfera privada ${ }^{44}$ na única preocupação comum: subjugada ao acúmulo de riquezas, esse âmbito da vida, ao tornar-se pública ${ }^{45}$, perde suas características próprias determinantes. Antes lugar de proteção do que íntimo, da subjetividade, seu caráter sagrado de privatividade, em que se nasce e morre, constituindo o lugar que o homem e a mulher possuíam no mundo, agora, desvirtuada, suplanta a esfera pública. A diretriz de ordem, como consequência, se torna o atendimento das necessidades individuais, para tanto, a violência é o único meio de vencer a necessidade e alcançar a liberdade.

Aprisionado no espaço privado, é arrematada do ser humano a possibilidade de efetivamente ouvir e ver os outros, bem como de ser visto e ouvido por eles. É o isolamento na ideologia dominante, sem espaço de abrir novos horizontes.

A esfera pública, como pensada por Arendt (1993), como espaço essencialmente político comum, lugar da igualdade, da convivência entre pares, encontra-se esvaecida. Apesar da ocupação por "iguais", é essa também a esfera da individualidade, para a diferenciação de si mesmo em relação a esses outros. Originalmente é essa a esfera da ação e do discurso, depois, na transição para a era moderna, banidos para a esfera do íntimo, do privado.

\footnotetext{
${ }^{43}$ Absurdo da reificação, realidade essa em que o próprio capital tem preço, é comercializado ele mesmo, virtualmente, como não poderia deixar de ser, em forma de mercadoria, sem algum valor de uso. Capital assume as posições de sujeito e objeto em seu próprio reinado; ao homem resta o papel de operador de suas transações!

${ }^{44}$ A esfera privada associa-se ao núcleo constituído pela casa e pela família, lugar do que é útil e necessário à manutenção da vida e à sobrevivência da espécie, em que a força e as ordens determinam as decisões, são ditadas por chefes com poderes despóticos. Esse é originalmente o espaço do labor, mas não apenas dele, também da bondade (que ao se tornar pública se perde) e do encantamento (ARENDT, 1997).

${ }^{45}$ Essa esfera, pública, foi pensada pela autora com base na polis grega (bios politikos) em que a política era feita entre iguais, apenas os cidadãos gregos, livres, participavam. Representa o lugar da liberdade, da honra, das realizações. É o lugar comum a todos, mas diferente do lugar de cada um no mundo; como todos os presentes ocupam lugares distintos no espaço público, é a esfera da diversidade de pontos de vistas; presença de inúmeros aspectos e perspectivas nos quais o mundo comum se apresenta e que não podem ser reduzidos a um denominador comum (ARENDT, 1997).
} 
É na vida pública onde se daria a relação objetiva com os outros homens, os quais veem o que vemos, ouvem o que ouvimos e, assim, garante-nos a "realidade" do mundo e de nós mesmos. Espaço da grandeza, da luz, onde as coisas relevantes ganham notoriedade, e constroem-se as obras que perpetuam a vida humana, transcendendo a vida do homem; a preocupação com a imortalidade é encaminhada nessa esfera.

Na pesquisa de Gonçalves Filho (1995), é retratado o sentimento de "despencar" derivado da impossibilidade de compartilhar o mundo vivenciada pelos cidadãos e cidadãs da Vila Joanisa. Angústia advinda do sentimento de não existência em meio a outros, da não comprovação da própria existência.

Se antes o exercício político estava atrelado, era imprescindível à cidadania, na era moderna quem pode exercer a cidadania são os que possuem a riqueza necessária para participar da sociedade, isso é, para consumir. Assim vivemos o enfraquecimento da durabilidade do mundo, já que o consumo é fugaz, os bens consumidos esgotam-se em um prazer momentâneo. $\mathrm{O}$ consumo, originariamente componente da esfera privada, domina a esfera pública, e o Estado, antes mediador do exercício político, conforma-se em instituição garantidora de alguns interesses privados. "O Estado não têm outra função senão controlar o fluxo e o refluxo da força de trabalho no mercado, para atender às necessidades conjunturais e estruturais do capital privado" (LIMA, 2009, p. 151).

A instância do social surge nesse contexto, na mistura e perda das características marcantes das esferas públicas e privadas, marca da sociedade moderna como um grande e complexo sistema de administração dos interesses privados. Ao tratar desse novo contexto, Arendt (1993) pontua a perda de um elemento fundamental ao homem: o testemunho da vida humana, de cada homem e mulher, por outros seres humanos. Para a autora, na sociedade moderna o mundo perde a força de manter as pessoas juntas, de relacioná-las, é justamente por não se enxergarem que estendem o sistema de classificação dos produtos para as relações pessoais, rotulando o outro e aceitando seu próprio rótulo.

Estabelece-se, a partir daí, uma oposição ideológica entre liberdade e "vida social" (GOLÇALVES FILHO, 1998). A liberdade passa a ser afirmada como uma questão puramente individual enquanto a noção de justiça torna-se o direito de cada indivíduo fazer o que quiser na esfera de sua liberdade privada, desde que não interfira na liberdade dos outros (GOLDMANN, 1979). Tal redução, até certo ponto, ridicularização, da liberdade e da justiça, essencialmente 
políticas, trazem uma falsa ideia de que as condições sociais nada têm a ver com a liberdade e desviam nossa atenção, fazendo-nos ignorar que, ao contrário, as condições libertadoras estão na vida social. Os relacionamentos sociais tornaram-se maquinais a partir das determinações do mercado, deixando de serem guiados pelos imperativos da vida em comum; a inter-relação fora esvaziada pela atomização de valores que apenas fazem coletivamente.

A partir desse mesmo sistema de inter-relação e de relação com o mundo, a ação ${ }^{46}$ política, antes, de acordo com a visão pré-filosófica e pré-platônica, o mais admirado dos componentes da vida ativa, na sociedade moderna passa a ser valorizada apenas quando atinge resultados duradouros e, de preferência estanques. Arendt (ibidem) associa essa característica, de durabilidade, ao trabalho do artesão que produz bens duráveis, que povoam o mundo; marca essa do trabalho teria avançado sobre a ação que, portanto perde seus componentes de criação, da iniciativa que começa sem que se saiba onde terminará e desencadeia tantas outras ações e desdobramentos em rede. A ação torna-se rara em nossa sociedade e a atividade política é encarada como movimentadora do processo histórico, de uma história que deverá chegar a um produto final, insuperável e fixo.

Se ação esfacela-se, o que acontece com o trabalho $^{47}$ e com o labor ${ }^{48}$, os outros dois componentes da vida ativa descrita por Hannah Arendt? Essas duas atividades, trabalho e labor têm alguns de seus elementos próprios misturados na era moderna: o trabalho ganha caráter de sobrevivência e entra, muitas vezes, no ciclo repetitivo de produção e consumo, típico do labor, enquanto este passa a ser valorizado, não em seu caráter de subsistência, de servilismo, mas sim como trabalho produtivo.

Assumindo algumas das principais marcas do labor, o trabalho, como o conhecemos hoje, é dominado pelo movimento de um processo externamente estabelecido e determinado pelo ritmo que ele impõe ao homem que labora; o corpo e a ferramenta seguem o mesmo movimento

\footnotetext{
${ }^{46}$ A ação é apresentada como indispensável à organização de uma vida em comum entre os homens, sem ela não há a paz, nem criação, é nela que a criatividade humana se realiza (ARENDT, 1997).

${ }^{47} \mathrm{O}$ trabalho é necessário no sentido em que, é por meio dele, pela "fabricação", que o homem produz, tudo para que o corpo humano seja abrigado nesse mundo e tenha espaço, é por meio dele que o homem sente-se senhor da natureza, interferindo nos fenômenos naturais e garantido a melhor estadia possível diante de todas as forças que não pode controlar.

${ }^{48}$ O labor, segundo a análise de Hannah Arendt (1964) produz bens de consumo, assim "laborar" e consumir são dois estágios o ciclo repetitivo da vida biológica que respondem à necessidade de subsistência. Enquanto o labor está relacionado ao corpo, cria os bens de consumo de pouca duração e implica esforço desgastante e doloroso durante sua realização, o trabalho é a manifestação e sensação da força humana, está relacionado às mãos e origina o artifício humano, composição dos objetos de uso que, se usados adequadamente, não somem.
} 
repetitivo. Embora não possa substituir completamente o trabalho humano, é a máquina que dita o ritmo do trabalhador. O trabalho adentra o ciclo de exaustão / satisfação, característico do labor como analisado por Arendt (1964), perdendo, nessa transição, os seus próprios elementos.

Há outras evidências dessa inversão a partir da análise da organização do trabalho atual com base na autora. O ciclo ininterrupto, enquanto há vida, do labor se dá pela efemeridade do que é por ele gerado, seu resultado é rapidamente consumido pelo ciclo vital humano, sanando uma necessidade que logo se fará presente de novo, ou se deteriora. Em contraposição, o que é criado pelo trabalho, como entendido por Arendt (ibidem) a partir da sociedade clássica grega, é durável, pelo processo de criação do homem ganha materialidade e objetividade, tornando-se relativamente independente em relação a seu criador; é o trabalho que gera a estabilidade e solidez necessárias ao mundo para abrigar a humanidade.

Os homens e mulheres, com sua natureza em mudança constante, reencontrariam a estabilidade de sua "identidade" na relação com a identidade duradoura dos objetos. O trabalho permitiria a construção de um mundo entre o ser humano e a natureza, protegendo-o desta última, de sua arbitrariedade, instabilidade e imprevisibilidade, e possibilitaria um encontro do homem com ele mesmo, contrabalanceando sua própria instabilidade e efemeridade, seu temor em relação ao desconhecido, ao que foge do controle, à morte. É no trabalho que o homem fabricante se apresenta senhor da natureza, de si mesmo e do que produz, sua mão domina o material, o processo e o produto (ARENDT, op. cit.).

No entanto, ou até mesmo pela perda de espaço para o trabalho, o labor também não é plenamente experimentado na sociedade atual: quando após a exaustão a satisfação não é necessariamente experimentada, quando o ciclo é rompido, o labor perde seu sentido. Além disso, torna-se, por vezes, insuficiente, por maior o esforço, para garantir a sobrevivência de si mesmo, muito menos da espécie. O labor não se coloca mais em relação à natureza, seguindo suas leis, mas sim ao outro homem que, pelo capital acumulado e pela colocação social conquistada, conquista o poder de mandar, de determinar as regras, de comandar as máquinas que, por sua vez, comandam outros homens. O capital comprou o lugar da natureza, sobrepondo-se a ela como força máxima na atividade do labor.

Como consequência do rompimento do ciclo ou da impossibilidade de sua formação como resultado do aprisionamento em uma das etapas, o acesso à felicidade mais básica da vida humana é impedido. Isso porque o labor integra e participa das fadigas e penas da vida, mas 
também da felicidade de estarmos vivos. Felicidade essa relacionada à sensação de que, como resultado do labor, do sofrimento, das penas aí implicadas, o homem permanece uma parte na natureza e faz um pouco do futuro de seus descendentes. A felicidade seria concomitante, nesse caso, ao próprio processo de produção e consumo, intrínseca ao círculo de exaustão seguida de regeneração, indefinidamente.

Assim, o impulso de repetição do trabalho vem do elemento de labor nele contido, pela busca pela subsistência e pela demanda de multiplicação do mercado. O labor, contando com a organização pós taylorista / fordista do trabalho e com a evolução tecnológica, produz mais bens de consumo do que a sua própria sobrevivência e de sua família necessitam, permitindo que alguns homens sejam escravizados, explorados, e livrando a classe dominante do esforço por atender às necessidades da vida biológica (ARENDT, 1964).

O processo do labor é repetido pelo homem-que-vive-do-trabalho por razões externas e ele e permanece sujeito às necessidades de sua vida. Ao contrário do que lhe seria permitido pelo trabalho como atividade humana, não se torna mestre do processo vital, nem experimenta ser senhor da natureza. Pior ainda, está à deriva não apenas frente às intempéries da natureza, mas também do movimento do capital.

Quais os desdobramentos dessa descaracterização das esferas pública e privada e das atividades humanas, ação, trabalho e labor, para os homens e mulheres que vivem, constroem e são formados por esse contexto? A hipótese aqui defendida é que ao mesmo tempo em que a segurança, antes alcançada pelo trabalho, é obtida de outra forma, por meio das classificações e rotulações estanques e da negação do conflito, a escassez da ação e do exercício político facilita a dominação, o aprisionamento do próprio homem nas categorias criadas por ele mesmo. A sociedade como administração dos interesses privados prescinde de controle para que todos colaborem, mesmo sem consciência disso, para que esses mesmos interesses sejam beneficiados. Interesses esses, como já explorado no primeiro capítulo, do capital.

As instituições capitalistas modernas desempenham importante papel nesse sistema, é por meio delas que os indivíduos engajam-se, funcionalmente, na manutenção da ordem dominante, da hierarquia colocada. É por meio delas que trabalhamos, ou melhor, laboramos, em prol do capital, mas também somos socializados; desde muito cedo somos "institucionalizados", a escola é uma dessas instituições. Nesse sentido, Deetz (1992) enxerga que o modo como somos socializados forja corpos e mentes dóceis avessos à discórdia, massa programada para o 
consenso. O discurso é sempre voltado ao conflito negativo, como aquela situação que deve ser evitada por causar a desordem.

Pratica-se a antecipação dos possíveis pontos de conflito para que sejam maquiados, ganhem uma nova roupagem, geralmente de decisão institucionalmente já tomada, de acordo com as "políticas institucionais", ou da pasteurização, o discurso do "estamos todos falando a mesma coisa". Porém, são as relações de confronto que trazem à tona o movimento dialético e que, assim, desvendam o novo passo, a possibilidade de se alcançar o inusitado, um patamar diferente.

Quando o conflito não pode ser evitado, apesar de todas as táticas institucionalizadas com esse fim, o que se passa é a redução da questão ao individual, a individualização do problema. O discurso não é direcionado a construção conjunta de uma alternativa, de um novo ponto de vista ou espaço para ação, mas para a responsabilização do sujeito pelo seu "não enquadramento" na realidade dada. Absurdos cometidos são reduzidos ao individual, descolados do contexto. Exemplo disso é trazido por Ciampa (1987) ao apontar o tratamento de "doente mental", encontrado por Severina, implicando a desconsideração de toda sua história de vida e das particularidades das experiências vividas, na falta de reconhecimento de sua totalidade e de sua dignidade humanas pela sociedade ${ }^{49}$.

Difícil haver questionamento por parte daquele que é rotulado doente, excluído, inapto, ou qualquer coisa nesse sentido, ou mesmo nos outros atores envolvidos na cena discursiva ${ }^{50}$. Isso porque, como descreve Galeão (2009), a ideologia é reafirmada e disseminada pelas "estruturas e formas de socialização da sociedade administrada", desde que inseridos nesse mundo estamos em contato com esse jeito de pensar e agir, somos, em parte, isso. Aí a dificuldade em voltar-se contra o que sempre foi assim, contra o naturalizado.

"De agora em diante, salvo iniciativas em contrário, o homem valorizará o seu ingresso em instituições sociais apenas considerando vantagens a título privado: a conveniência, nenhum motivo a mais, torna-se a magra justificativa do homem burguês para ainda tolerar sua dedicação à cidade e aos outros homens." (GONÇALVES FILHO, 1998)

\footnotetext{
${ }^{49}$ Esse tratamento é definido como "perverso" por Lima (2009) justamente por desconsiderar a humanidade daquele se apresenta em uma situação que não se encaixa no padrão, que foge ao comportamento massificado.

${ }^{50}$ Cena discursiva é um termo utilizado por Guirado (2006) tratando da situação em que os indivíduos que ocupam determinados lugares institucionais encontram-se, cada um com suas expectativas próprias da posição a partir da qual enxerga a situação.
} 
Concretamente a ideologia é reforçada por uma dinâmica irrefutável, cruelmente simples: os seres humanos aplicam-se em fazerem-se úteis ao sistema em prol da sobrevivência, reforçando o mecanismo que o domina. Eduardo Bittar, em palestra proferida como parte do seminário "Violência e Sociedade, Psicologia e Violência" (2009), denunciou a impotência do indivíduo frente ao sistema social imobilizado pelo medo da violência final, da sanção social, da aniquilação simbólica, das punições sociais severas, como o desabrigo, a fome.

A necessária recuperação da dialética da história, anunciada por István Mészaros ${ }^{51}$, parece indicar o caminho para fugir dessa arapuca. Olhar a história da civilização e a história cotidiana enxergando o movimento dialético em que os diferentes interesses de classes se articulam e se recriam, em relação constante com a realidade objetiva mostra-se exercício indispensável ao fomento do questionamento e da reflexão. Para que o manto que cobre os acontecimentos e situações seja retirado e os olhos possam enxergar os interesses que os constituem, é preciso que a diversidade presente na história, a diversidade de possibilidades, de contextos, de ações, seja relembrada. A diversidade precisa ser redescoberta para que depois possa ser revalorizada.

$\mathrm{O}$ consenso ou a aceitação do mundo como colocado, a obediência à organização do trabalho e das outras esferas da vida como pré-determinadas repercutem na sensação de estabilidade a qual, mesmo que irreal, ameniza a angústia deixada pela desestruturação do potencial realizado com o trabalho e pela atomização dos indivíduos sem repertório para lidar com as infinitas possibilidades e decisões a serem tomadas por sua própria vida em risco. Afinal, todos os resultados são consequências unicamente das ações de cada um de nós, somos responsáveis por nossas escolhas, mesmo que não haja escolha.

Em um mundo em permanente transformação, a ideologia da imutabilidade faz com que parte da população possa suportar essa situação, desistindo de engajar-se na mudança. Fato é que a segurança mínima, apesar de ilusória, é necessária para que o ser humano consiga encontrar-se e interar-se desse mundo; o problema é que essa necessidade de segurança, atendida historicamente pelo trabalho (ARENDT, 1993) e pelo pertencimento coletivo é, em nossa época, manipulada em favor de um grupo economicamente dominante.

Gonçalves Filho (2009) tratando do caráter essencialmente social e coletivo da vida do homem, nos lembra que ela transcende a mera condição de quem "está vivo", o homem precisa

\footnotetext{
51 “A Necessária Reconstituição da Dialética Histórica”, palestra proferida por István Mészaros em 21 de agosto de 2009 na Universidade de São Paulo. III Seminário Internacional Margem Esquerda. Boitempo Editorial.
} 
existir. "É por meio da palavra e do ato que o homem insere-se no mundo humano, confirmando e assumindo sua presença inicialmente física. E existência, em sua mais rica acepção psicossocial, supõe participação no mundo" (ibidem).

O que o autor chama de "participação no mundo" relaciona-se diretamente com o “enraizamento" apresentado por Simone Weil:

“O enraizamento é talvez a necessidade mais importante e mais desconhecida da alma humana. É uma das mais difíceis de definir. Um ser humano possui uma raiz por sua participação real, ativa e natural na existência de uma coletividade que conserva vivos certos tesouros do passado e certos pressentimentos do futuro.” (WEIL, 1979, p.347)

A efetiva participação do homem em grupos, que compartilham heranças do passado e perspectivas para o futuro, o "enraizamento", é fundamental, portanto, na concretização do potencial humano de existência. Para que seja efetiva, é necessário que a participação seja informada, consistente e espontânea, que homens e mulheres encontrem as condições objetivas para isso, sem deparar-se com formas rigidamente fixadas, mas sim com o espaço para a cocriação.

Em sintonia com o processo de enraizamento, a partir do resgate das ideias de Arendt (1993), é possível ressaltar que as condições para a realização da vida humana são aquelas que garantem a comunicação do homem com os outros homens e com o mundo: "são condições que garantem a "palavra" e o seu mais livre exercício" (GONÇALVES FILHO, 2009). Pela palavra os homens ressignificam, de acordo com seu universo subjetivo, as ações e símbolos do mundo comum, base para o exercício político.

Mais do que isso, os seres humanos são sujeitos intrinsecamente políticos, nascem prédispostos à ação na medida em que já estão, no primeiro segundo, entre outros semelhantes e começam desde aí a construir uma nova história (ARENDT, 1972 e 1993). O não exercer essa potencialidade ontológica é uma violência contra esse ser, impedido de desenvolver-se. O enraizamento caminha de ombros colados ao exercício político, a sua não concretização advém da dificuldade em compartilhar símbolos entre iguais, em espaços públicos onde os interesses 
possam ser contrapostos para se chegar a um terceiro caminho ${ }^{52}$; sua ausência identifica, pela negação da humanidade, nossa organização social.

A ação e a palavra, os principais instrumentos para o exercício político, meios do enraizamento, não são condicionadas pelas necessidades do corpo, nem motivadas pelos desejos e carências, como a fabricação; são incondicionadas. Agir significa começar, tomar iniciativa, e o que empurra o homem para isso é seu próprio nascimento em meio a outros, entre iguais, a inserção no mundo que o recebe. A vida no sentido não biológico manifesta-se na fala e na ação, pois é assim que o homem apresenta-se em relação com seus semelhantes, assume efetivamente seu lugar no mundo, conhecendo a si mesmo, aos outros e sendo conhecido por eles.

A ação, ao contrário do trabalho, tem seu sentido atrelado ao nome ligado a ela, o nome de seu autor, daquele que age. Assim o homem deixa sua "marca" entre os outros homens, tornandose imortal. É pelo enraizamento que ele sente esse processo em andamento, que percebe que é mais do que um corpo, mais do que suas necessidades fisiológicas, sente-se parte de algo maior, de uma obra coletivamente construída, na qual contribui por meio da ação.

As histórias, resultado da ação, embora não sejam produtos, palpáveis, contam mais a respeito dos sujeitos agentes do que qualquer produto da mão humana é capaz de contar sobre aquele que o fabricou (ARENDT, 1964). É exatamente nessas histórias que o significado da vida humana se revela, elas não são perecíveis, nem se desgastam, permanecem na história, ganham vida própria, independente do agente, por isso trazem o sentido de imortalidade de cada homem e mulher. Na medida em que se dá na esfera política, entre iguais, que estão dispostos a trocar, ouvir o outro, e juntos construir algo comum, a ação implica avanço de nível de consciência. É por meio dessa real participação no grupo que se passa da posição do que segue as normas préconcebidas, do nível de obediência, para o lugar de elaboração das normas de acordo com os interesses colocados em pauta, considerando suas próprias necessidades e desejos. O sentido emancipatório das experiências humanas vincula-se, para Habermas (1983) e Ciampa (1987), à evolução no nível de consciência. Como será melhor explorado mais a frente, atividade, consciência e identidade são categorias correlacionadas, inseparáveis na vida humana.

Podemos já por agora, portanto, apontar que o exercício político e o enraizamento do homem na história de um grupo e até na história da humanidade, que o acompanha, são

\footnotetext{
52 O planejamento organizacional é visto, a partir de Sato (1999), como "atividade dialógico-discursiva" já que os diversos envolvidos apresentam suas ideias em um exercício de argumentação e contra-argumentação em que algumas delas são escolhidas, outras descartadas, chegando a um consenso sobre o caminho a ser seguido.
} 
indispensáveis para que um sentido emancipatório seja impresso no desenvolvimento do homem, ao longo de sua vida individual e, também, na trajetória da humanidade. Assume-se a história assim composta, em interminável movimento dialético em que se contrapõem as condições materiais, concretas, colocadas como empecilhos, por um lado, e como incentivos, por outro, à verdadeira evolução humana, aquela que aponta para a emancipação de cada homem e de cada mulher.

Proponho que a sociedade de classes capitalista em que a razão instrumental (HABERMAS, 1983), em prol dos interesses soberanos do capital, domina todas as esferas da vida $^{53}$, a sociedade em que nos organizamos hoje, seja encarada por esse prisma. Parte de uma história que continua, momento histórico em que o "mundo da vida" está submetido à razão instrumental, sistêmica, situação à qual outras materialidades se opõem, entre elas a própria razão humana que aponta à sobrevivência e à reprodução da espécie.

A não realização do conteúdo racional da história é uma circunstância de um dado momento histórico. O potencial humano para superá-la está na própria contradição entre momento histórico e a realização das finalidades humanas, a emancipação e a liberdade. A ameaça à existência humana vem agora do sistema capitalista e sua resistência frente a sua superação advém do medo de aniquilação dos sujeitos caso não continuem submetendo-se a esse sistema social (ADORNO, 1969 apud GALEÃO, 2009).

Como cada tempo e espaço, esse momento histórico com todas as suas condições objetivas à vida humana, tem desdobramentos importantes ao sujeito que faz parte da sociedade contemporânea. O fenômeno da "humilhação social", problema político e psicológico, estudado por Gonçalves Filho (1995) desde sua dissertação de mestrado, é definida como o tipo de angústia resultante do impacto traumático da desigualdade de classes. A diferença de classes determina a desigualdade política, em outras palavras, os pobres não encontram espaço para a representação de seus interesses em quaisquer espaços políticos, são alijados da possibilidade de ação e de fala. Esse impedimento violento do exercício político, desdobramento do inacesso ao

\footnotetext{
53 Aqui se faz referência a conceitos e análises desenvolvidas por Habermas em "Para a reconstrução do materialismo histórico" (1983) em que o "mundo da vida" é entendido como o espaço para o "agir comunicativo" em que a comunicação fluidificada, interessada e não interesseira, pode se dar entre os sujeitos. Em oposição, o "mundo sistêmico" é tomado pelo "agir interesseiro" em que, como o termo denota, a interação entre os homens e mulheres é dominado por interesses específicos, contribuindo para a manutenção do sistema.
} 
capital, traz consigo, segundo o autor, "um círculo de mensagens enigmáticas e traumáticas" para os (não) sujeitos.

“A humilhação crônica, longamente sofrida pelos pobres e seus ancestrais, é efeito da desigualdade política, indica a exclusão recorrente de uma classe inteira de homens para fora do âmbito intersubjetivo da iniciativa e da palavra." (GONÇALVES FILHO, 1998).

Tal divisão política, entre ricos e pobres, é, assim, para Gonçalves Filho (1998), um fato "sobredeterminado". Isso porque é mais antiga do que a vida dos homens e mulheres que a herdaram, sua origem e determinação perderam-se na história esquecida ou nunca apreendida; sua formação está fora, bem anterior, à cena atual em que são reproduzidos sem reflexão, cegamente, renovando-se e deformando-se. Damos continuidade à representação de dominadores e dominados como se tratando de um roteiro universal, como única opção, assim, naturalizado.

A humilhação social é efeito da desigualdade política posta e inquestionada, e constitui-se em um fato também psicossocial, sempre referente à relação de um homem com outro homem. Para Gonçalves Filho (1998) o problema da desigualdade é o problema humano, talvez, mais urgente, "aquele cuja solução precede a de todos os outros". O humilhado tem seu sentimento de dignidade desfeito, a sensibilidade e a imaginação ficam estancadas na situação de rebaixamento. Situação essa encenada no momento presente, que parece imediata, mas que atravessa a classe social e as famílias, mediada ao longo de sua história. Herdada como uma corrente que passa entre as gerações, a submissão é assumida e desempenhada automaticamente na condição proletária (ibidem).

Espoliado da concretização de seu caráter político, impedido de exercer o trabalho, condenado ao labor, sem que necessariamente a exaustão seja seguida pela satisfação, ao trabalhador resta apenas sua força muscular, como mercadoria com algum valor de mercado. É por isso que é comum a excessiva preocupação, entre os trabalhadores proletarizados, com a saúde. Como observado por Gonçalves Filho (ibidem), a reificação ${ }^{54}$ vivida pelo homem e pela mulher que vivem do trabalho é refletida na hierarquização de suas necessidades: os salários e a saúde vêm antes de qualquer outra questão. Não se pode estranhar essa prioridade, quando a continuidade da própria sobrevivência e daqueles que dependem do trabalhador está em risco o

\footnotetext{
${ }^{54}$ Eduardo Bittar, em sua palestra "Violência e Sociedade", que compôs o seminário Psicologia e Violência, em 18 de abril de 2009, tratou o fenômeno da reificação como a redução dos homens ao caráter de mercadoria, implicando sua desumanização espiritual e corporal.
} 
inesperado seria que houvesse a preocupação com as próximas gerações ou as condições mais amplas da existência e do mundo. A saúde do corpo é âncora da mínima segurança psicossocial.

Não apenas a ação, mas a consciência do trabalhador são absorvidas pelo trabalho mercadoria, suas mãos e suas palavras são igualmente implicadas no fenômeno da alienação. Trabalha-se para comer, come-se para trabalhar, ciclo infindável, não se pode quebrá-lo, ser caráter de verdade assenta-se sobre a sobrevivência (Weil, 1993).

As implicações são sentidas não somente pelo próprio homem e pela mulher-que vive-dotrabalho, também seus interlocutores são "esvaziados". Sem a possibilidade de ouvir o outro, de fazer parte de uma comunidade, de um grupo, de um coletivo, é negada a realização de quaisquer ser humano que partilhe da sociedade desigual.

Nesse sentido, o sofrimento é de todos, não são apenas os pobres os angustiados, todos os que vivenciam a exclusão em relação à consolidação de seus direitos, à impotência em relação aos abusos de poder, ao valor ínfimo conferido à vida humana. São amargurados todos os que têm consciência de que para que alguns se livrem da necessidade do labor e não precisem trabalhar, seus familiares, amigos, companheiros, são servilizados (GONÇALVES FILHO, 1998).

Aquele que pratica a humilhação social no nível do micro, trazendo a tendência histórica para a relação interpessoal, também não questiona o tratamento dedicado ao pobre, não saberia dizer em que ponto começou esse modus operandi, em que se ancora sua imaginária superioridade. Falta-lhe, igualmente a consciência a respeito de quando, como, por que isso se fez automático. A desigualdade se constituiu em um universo simbólico encarnado em todos os que participam da gangorra da humilhação, universo já enrijecido.

Fechados no papel de dominantes e dominados, todos estão distantes da liberdade e da igualdade Mesmo quando se esforça para sair do ciclo da desigualdade, intencionando a igualdade, a traição vem pela concretização do simbólico, seja pelas roupas, pelos gestos, pela arquitetura da fala. Senhores e escravos encontram-se na mesma prisão (GONÇALVES FILHO, op. cit.). Estão ambos aprisionados na má-infinidade da reposição de personagens predicadas (CIAMPA, 1987) como entenderemos melhor um pouco mais adiante.

Também a reficação não atinge apenas o trabalhador proletário, é fenômeno mais amplo e profundo do que se pode imaginar em princípio, todos são coisificados a ponto de que outros homens não conseguem identificar um outro homem ali. A compaixão esvai-se. É preciso, mais 
que nunca, lembrar que o reconhecimento do homem por outros homens faz parte da essência humana, vem primeiro do que a conjuntura que estão postas entre os outros e que nos cegam. "A máquina social e a máquina inconsciente interpõem-se entre nós e impedem a irrupção do que vem por si mesmo" (GONÇALVES FILHO, 1998).

Impedido de ser reconhecido e de reconhecer-se como homem, perde-se o poder de aparição; a reificação interrompe a aparição do homem e do mundo como um todo, dos animais e também dos objetos. As aparências são necessárias para que as experiências sejam compreendidas, para que se possa viver concretamente, em um mundo de aparições. A vida é reificada é abstrata, é estar em um “mundo de aparências sem aparições” (ibidem).

Para Gonçalves Filho (1998), o descolamento em relação às coisas é condição de humanidade, ela também é o que se possui, mas é necessário certo desapego para que se possa existir em meio aos bens, sem que coincida, o próprio homem, com eles. Para o mesmo autor o potencial resgate da humanidade está na vida comunitária, na "amizade inter-humana", em consonância com o exercício político encontrado em Hannah Arendt (1993) e com o enraizamento apontado por Simone Weil (1979), é o que pode tirar o véu de nossos olhos para que voltemos a enxergar. As condições materiais para que o mundo e os outros possam concretizar-se, para que a aparição seja retomada, encontram-se em comunidades de homens livres, iguais, em que possam exercer sua singularidade (GONÇALVES FILHO, 1998).

Coletivos esses em que a fala e a escuta sejam realizadas em prol da multiplicação dos pontos de vista e não da pasteurização das dissonâncias, ao contrário de evitar o conflito, o espaço para os diferentes interesses esteja aberto. Âmbito esse em que as pessoas possam apresentar-se de acordo com suas próprias determinações, sendo identificadas pelos seus nomes e não por cargos ocupados ou não ocupados; tendo espaço para dar vida às novas personagens que querem voz. Que se volte a ser, antes de tudo, alguém e não algum.

A vida na comunidade precisa do risco, elemento central da ação, ele permite que convivência seja constituída também por aquilo que a contradiz, pelo "será" e pelos "senãos"; para Gonçalves Filho (op. cit.) a vivência profunda da igualdade depende disso. A fuga do risco, o bloqueio à dissonância, ao diferente abre as cortinas da violência e o palco da vida comunitária é por ela tomado, ganhando caráter artificial, falso. O risco precisa ser enfrentado, experenciado e assimilado repetidas vezes, tantas quantas ele se apresentar no horizonte do grupo, isso porque a 
igualdade não é absoluta, ela se faz no seu exercício continuado, se reafirma no cotidiano da comunidade.

Estar disponível para o diferente, aberto à dissonância, requer reflexão a respeito da materialidade que se apresenta nas diversas situações, contextos interno e externo, vontades, desejos e interesses. A disponibilidade para esse jogo é contradita pela posição de estar a cargo de outrem, o que parece bem difícil de ser rompido em uma sociedade de classes, sistema em que a satisfação pessoal se faz pela insatisfação de outros, pela dominação. Para que se esteja em cima na gangorra, concentrando poder e capital, é preciso que outro esteja na posição oposta. Isso porque não há limite para a acumulação do capital, é sua posse quem confere valor ao homem, a substância humana foi convertida na substância do capital, esse com valor absoluto, o indivíduo, relativo.

A profunda mudança de mentalidade requerida, perpassa a ação, transformação material na realidade do grupo e de seu entorno, das relações intergrupais e com todos com quais se relacionam. Vivenciar o risco, jogar-se na pluralidade do mundo, implica mudanças fora do âmbito do grupo, no mundo da vida em geral em que as pessoas, cada indivíduo, transita. Eis o poder da ação: propaga-se em rede, por um percurso nunca previamente imaginado, espalhandose sem controle, propondo o inusitado a pessoas aparentemente distantes, tecendo histórias inéditas e florescendo o caminho da vida.

A retomada do espaço para o trabalho e para a ação é questão política, não há dúvida. Precisa ser discutida e ter possíveis soluções planejadas no nível da macropolítica, já que o problema é estrutural e estruturante, mas a visão e a atuação pela micropolítica são indispensáveis para que possam pressionar a atuação nas esferas do macro e do meso. A micropolítica deslumbra a compreensão de como políticas públicas chegam à vida cotidiana das pessoas, como interagem com um contexto pré-estabelecido.

As cooperativas populares, autogestionárias, são estudadas nessa pesquisa em sua potencial contribuição para a quebra dos padrões cujos alguns traços foram aqui retomados, como proposta alternativa de visão e mundo e como propulsora de relações de outra espécie. Isso porque a partir desse mesmo panorama pelo qual passamos pode-se pensar algumas cujas condições concretas da organização do trabalho cooperativo como convergentes com a materialidade clamada para a retomada do labor, do trabalho e do exercício político, para a sua inserção e participação efetiva em uma comunidade. As cooperativas populares, são organizações, como todas as outras, já que 
compostas e representadas por pessoas, fundamentalmente políticas ${ }^{55}$, no sentido de que defendem determinados interesses no patamar das instituições, com a diferença de que esses interesses são construídos coletivamente, por todos os que formam a organização, interesses declarados, compartilhados.

Portanto, é válido lançar o olhar para as cooperativas populares como processo social (SATO, 1999) que se revela na vida cotidiana dos cooperados, e que só ocorre porque esses mesmos sujeitos uniram-se para alcançar objetivos comuns. O processo social, inserido em circunstâncias específicas, determinadas em um tempo e espaço históricos, forma a situação social que se desenvolve no cotidiano. A situação social, por sua vez, é conformada pelas características do "grupo social" envolvido e pelas circunstâncias do "ambiente" em que ela se dá. O grupo de cooperados conta com uma "base técnica" e um "repertório cognitivo" específicos, de acordo com as histórias de vida dos sujeitos que o compõem.

A cooperativa se concretiza por meio de e para as pessoas, as quais são influenciadas de alguma forma pela proposta de organização autogestionária do trabalho, de relações solidárias, de atuação coletiva. Não apenas os cooperados, mas todos aqueles com quem estes se relacionam. De qualquer forma, também pela Escola Sócio-técnica (SATO, op. cit.), fica evidente que essas pessoas não estão vagando pelo vazio, mas já inseridas em diversas outras instituições, nas quais mantêm relações com outras diversas pessoas, e em que participam de outra dinâmica com a qual já estão acostumadas.

A relevância do contexto social, econômico, cultural para a compreensão das transformações possibilitadas aos cooperados está nítida tanto no campo teórico quanto no prático; o espaço para satisfazer as necessidades de sobrevivência da espécie, de realização do trabalho, de prática política, do reconhecimento e do enraizamento, precisa de determinadas condições reais para que seja concretizado. A visão sócio-técnica colabora com o encontro da forma de considerá-lo na análise.

A esperança de que o cenário posto pode ser desestabilizado pelo exercício autogestionário embasado nos princípios da Economia Solidária tem seu embasamento inicial na ideia de que as novas interações sociais propiciadas por essa organização do trabalho, nem sempre pacíficas e uníssonas, por meio das quais se dá o compartilhar de significados e interesses, são o caldo para o

\footnotetext{
${ }^{55}$ O termo "político" aqui usado no sentido aplicado por Sato (2002) a partir da Escola Sócio-técnica e da visão a partir da micropolítica.
} 
surgimento de novas relações. A pedra mestra para o erigir de uma cultura solidária dentro dessas organizações seria, também, o insumo para a quebra da aceitação de padrões impostos como certos nas diversas esferas da vida, e a recuperação de uma consciência reflexiva embasada na singularidade de si mesmo, trazendo o sujeito de volta ao papel de senhor de suas escolhas.

"Nenhuma intimidade liga os operários aos lugares e aos objetos entre os quais a sua vida se esgota, e a fábrica faz deles, e em sua própria terra, estrangeiros ou exilados, desenraizados. (...) Os operários só se sentirão realmente em suas casas, em seu país, membros responsáveis pelo país, quando se sentirem em casa na fábrica, enquanto trabalham." (WEIL, 1979, p.138 apud GOLÇALVES FILHO, 1998)

Como já pontuado antes, não há separação entre as esferas da vida, pelo contrário, e não é viável exercer toda a substância humana caso não se seja senhor de si em todas elas. Assim como uma vez desestruturado o labor, o trabalho perde sua potencialidade e o exercício político tornase utópico, o pensar e fazer o futuro como pensado por Cris Andrada (2005) requer que o passado e o presente sejam trazidos à consciência. É partir daí, desse voltar-se ao futuro como sujeito, que se daria "alargamento de visão" advindo de um poder de intervenção maior nos campos de ação de cada indivíduo.

Desse ponto em diante, parte-se para a busca de fazer história e estória em outros territórios, além do trabalho, do bairro e da moradia; a prática de "projetar o novo", fruto da ação política (ARENDT, 1964), mostra-se recompensador e desperta a sede por experimentá-la repetidamente, em intensidade e quantidade crescentes. A ampliação do espaço e do tempo vem junto a essa vivência, passa-se a vislumbrar a potencialidade que todo ser humano possui de mudar a realidade ampliada em que se vive (ANDRADA, 2005).

Propõe-se, na prática da Economia Solidária, que esse novo posicionamento dos homens e mulheres seja fomentado a partir do trabalho, mas não se limite a ele. O "campo compartilhado" do qual fala Oliveira (2001) e que compõe a base comum sobre a qual as interações sociais fundamentam-se estabelece-se como desdobramento da convivência propiciada pelo trabalho coletivo, o qual faz necessário que se tomem decisões conjuntas para que as necessidade individuais e grupais possam ser atendidas. Acredito que isso apenas pode ser dar por meio de encontros entre os sujeitos em que, como trazido por Ecléa Bosi (1987), as condições da atenção e da dialética da identidade são mantidas e assim o sentido e a troca acontecem. Para a autora, as 
situações em que isso não ocorre são de "silenciamento", partem de relações concretas de exploração do trabalho (BOSI, op. cit.).

Está claro que o cooperativismo popular, nessa oposição ao status quo, parte da liberação dos sujeitos do temor da aniquilação biológica e simbólica, principal razão já apontada aqui para que não se aventurem na resistência à violência praticada pela organização societal contemporânea. A geração de trabalho e renda é colocada, concretamente, como objetivo dos empreendimentos solidários; o movimento com sentido emancipatório de cada sujeito apenas pode se iniciar garantida a sobrevivência. "Quando se pergunta pelo objetivo da sociedade emancipada, obtêm-se respostas tais como a realização das possibilidades humanas ou a riqueza da vida. (...) A única resposta delicada seria a mais grosseira: que ninguém mais passe fome" (ADORNO, 1992, p. 138).

O desenvolvimento da consciência crítica como negação determinada e dialética da opressão existente (MARCUSE, 1999) precisa ser trabalhada nos empreendimentos cooperativos, evidente; assim como aqui estamos fazendo, é fundamental que os cooperados encontrem outros prismas pelas quais a realidade pode (ou não) ser vista. Uma vez superado o medo da aniquilação eles poderão lançar-se à crítica. No entanto, importante lembrar que mesmo com uma visão crítica e na prática de uma outra proposta de organização e de relação, como são as cooperativas populares, não se pode separar do sistema socioeconômico do qual fazemos parte; qualquer núcleo, empreendimento, movimento, estará inserido nesse "ambiente" e isso terá consequências ao que se consegue ou não ser e realizar. O sentido da metamorfose da identidade de cada um e de todos relaciona-se diretamente a esse contexto; pode encontrar respiro dentro da cooperativa, do grupo, mudar a direção a partir dessa vivência e, a partir disso, lançar-se, aos poucos, à transformação do cenário, da realidade objetiva, aqui discutido.

Exemplo simples é a legislação da Economia Solidária brasileira, construídas em outras instâncias, implica de forma contundente a viabilidade dos empreendimentos. Assim como a sociedade civil envolvida com o tema tem pressionado para alterações nessa lei, é indispensável o objetivo de atuar no ambiente externo, modificando as relações que aí se dão, para que as próprias cooperativas tenham horizontes amplos em suas histórias.

A dialética nos empresta recursos para ater-nos justamente às tensões presentes nessas contradições, entre elas a que se faz entre as práticas de cooperação, solidariedade e do cotidiano da autogestão, internas às cooperativas populares e mundo exterior, em que a competição, o 
individualismo, a exploração e a reificação são dominantes. Nessa pesquisa nos interessa especialmente os desdobramentos dessas tensões para o movimento em que se colocam as identidades dos sujeitos envolvidos, do cooperado.

Para avançar nesse enfoque passemos à compressão da Identidade como categoria e fenômeno, como metamorfose constante.

\subsection{Identidade como metamorfose contínua - categoria e fenômeno}

Chegamos ao ponto de voltarmo-nos com total atenção à Identidade como categoria e como fenômeno, à Identidade que aglutina em seu átomo o mundo todo, representa em cada indivíduo, todas as possibilidades e impossibilidades desse mundo; ajuda-nos ver como cada ser é, por si só, um universo que congrega as contradições objetivas em sua subjetividade. A posição da qual olhamos para a Identidade, proposta por Ciampa (1987), fundamenta-se no materialismohistórico e traz, imbricada em seu conceito, a relação dialética entre as condições socioeconômicas que compõem uma situação objetiva, estrutural e estruturante, e a subjetividade de cada sujeito, de cada ator. Articulação dialética faz com que o espetáculo nunca termine.

A exploração e a violência sociais se concretizam, por meio de mediações, no particular; os universos particulares formam, coletivamente, o conjunto das relações sociais que materializa um mundo, o nosso mundo capitalista (CIAMPA, 1987). As identidades pessoais são configuradas a partir da encarnação das relações sociais de forma particular, individual, compondo uma "vida-que-nem-sempre-é-vivida". É nesse sentido que Ciampa (op. cit.) afirma que "uma identidade concretiza uma política, dá corpo a uma ideologia" (ibidem, p. 127).

A ontologia de Antônio Ciampa, e também a aqui assumida, é materialista-histórica. A identidade é, sobretudo, uma questão social, uma questão política, suas manifestações são sempre manifestações materiais. A substância humana se realiza como história e como sociedade; a metamorfose constante é vida e a sua história é a história da autoprodução humana. Impossível olhar para o sujeito e sua identidade descolados da estrutura social e do momento histórico. $\mathrm{Na}$ sociedade capitalista nossas ações e relações são mediadas pelo capital, esse fato tem repercussões muitas e marcantes para os sujeitos de suas identidades, para a forma como os seres humanos podem concretizar-se, fazer sentir sua presença no mundo.

A Identidade arremata em, uma única, complexa, categoria o que viemos trazendo até esse ponto, o homem como sujeito eminentemente político, mas nem sempre capaz de fazer política, 
por vezes apenas dando corpo às normas criadas por outrem. Entendermos a partir de agora os fundamentos dessa proposta e, assim, como ela nos empresta seus "óculos" para uma visão analítica do problema central dessa pesquisa.

\section{a. Identidade - apresentação}

Associamos a singularidade de cada subjetividade à noção de "identidade", de identificação pela unicidade. Exemplo dessa singularidade é trazido por Dejours e Abdoucheli (1994) ao olharem para a relação sujeito-trabalho quando fonte de sofrimento: "entre as pressões do trabalho e a doença mental interpõe-se um indivíduo (...) as reações de defesa são fortemente singularizadas em função do passado, da história e da estrutura de personalidade de cada sujeito" (p. 123). Essa é a essência da contradição "social/privado"; apesar das condições objetivas semelhantes, mesmo tipo de pressão, mesmos instrumentos de exploração, a que trabalhadores de uma mesma organização estão submetidos, suas reações de defesa são específicas, particulares.

Ainda, uma boa introdução ao que seja a identidade nos oferece Lane (2000) ao considerar que lançar luz à subjetividade implica tratar de identidade. Para a autora identidade é a "categoria que leva ao conhecimento da singularidade do indivíduo que se exprime em termos afetivos, motivacionais, através das relações com os outros - ou seja, na vida grupal" (ibidem, p. 31). Portanto, ceara que envolve necessariamente a vida junto aos outros homens e a identificação deles como iguais e diferentes ao mesmo tempo.

A teoria de identidade de Ciampa (1987) parte da articulação da Psicologia Social de George Mead, da filosofia hegeliana e da Teoria Crítica de Habermas e adensa a chamada Psicologia Social Crítica (LIMA, 2009). Na medida em que, segundo o conceito desenvolvido pelo autor, "compreender a identidade é compreender a relação indivíduo-sociedade" (CIAMPA, 1977), pela identidade é possível compreender como se dá a formação das desigualdades e dos

problemas sociais e, nesse contexto, como se constituem as resistências individuais aos processos de massificação, como são erigidas as lutas emancipatórias. Assim, a identidade carrega em si a relação indivíduo-sociedade e por meio dela é possível lançar luz sobre a "realidade social". Essa é a missão à qual se coloca o autor (ibidem) e em destino a que ofereço essa pesquisa como contribuição.

\section{b. Identidade e sociedade}


Depois de associar, em sua dissertação de Mestrado, a Psicologia Social, a pesquisa de identidade e a ação política (CIAMPA, 1977), é no Doutorado que a ideologia da não transformação, da identidade constante e estável, é exposta como paradigma para a não transformação da sociedade em uma leitura crítica da sociedade capitalista moderna (CIAMPA, 1987). Nessa tese a identidade ${ }^{56}$ é apresentada como articulação entre diferença e igualdade (ou semelhança), entre objetividade e subjetividade: "sem essa unidade, a subjetividade é desejo que não se concretiza, e a objetividade é finalidade sem realização" (ibidem, p. 145).

$\mathrm{Na}$ concepção assim constituída a identidade humana “é construção, reconstrução e desconstrução constantes, no dia a dia do convívio social, na multiplicidade das experiências vividas" (KOLYNIAK \& CIAMPA, 1994, p.9). Assim metamorfose contínua, sempre em transformação na relação do sujeito com o grupo e com o ambiente. Em nosso tempo histórico essa metamorfose estabelece-se como "luta por reconhecimento" frente a uma sociedade capitalista que tende a reduzir a identidade a personagens fetichizadas que negam sua totalidade em favor do universal dominante: o Capital” (LIMA, 2009, p.134).

Como constitutivamente social, o desenvolvimento da identidade passa por diversas formas de reconhecimento. A partir dele, sempre na articulação entre o objetivo e o subjetivo, o sujeito reconhece-se a si mesmo pela afirmação e negação do que o constitui. $O$ não reconhecimento, ou o reconhecimento desumano, leva à experiência de aprisionamento naquilo em que já se foi, em uma imagem reconhecida, mas que não corresponde mais à verdade subjetiva do sujeito. Nesse caso encontra-se com a chamada "mesmice" (CIAMPA, 1987), fenômeno em que domina a cena uma personagem fetichizada e que não permite a alternância do palco, já que a plateia recusa-se a reconhecer qualquer outra que ganhe corpo.

\footnotetext{
${ }^{56}$ Habermas diferencia "singularidade" e a "individualidade" da identidade. A individualidade é construída em conjunto com a realidade social, é a negação de todas as determinidades, é ela quem nos dá acesso à subjetividade e possibilita uma reconstrução do Eu a partir das diferenças. "singularidade" do indivíduo é a indiferença de todas as determinidades, exibindo-se enquanto totalidade , a "individualidade" é construída com base na diferença de todas as determinidades, o Eu é assim afirmado como um vivente formal e reconhece-se como tal. (HABERMAS, 1983).

${ }^{57}$ Axel Honneth (2003) considera a identidade como inevitável luta por reconhecimento; este seria indispensável ao exercício da "alteridade". O problema do reconhecimento, explorado por Hegel e por Mead e que aparece em Habermas como elemento necessário para a constituição do Eu, é retomado por Honneth como conceito central que possibilita potencializar a Teoria Crítica e direcioná-la para o entendimento das mudanças sociais proporcionadas pela imposição do capital. Honneth, explorando o fenômeno do reconhecimento, retorna às três formas encontradas em Hegel: a emotiva, responsável pelo desenvolvimento da confiança em si, a jurídico-moral, responsável pelas relações baseadas no direito e possibilita o autorrespeito e a estima social, baseada na solidariedade social e que potencializa os projetos de autorrealização a ponto de torná-los universalizáveis (LIMA, 2009).
} 
Social, a identidade está sujeita às mudanças pelas quais estrutura societal passa. A identidade é metamorfose constante porque ao mesmo tempo em que o contexto nunca permanece estático, por mais que a ideologia dominante esteja a esse favor, as experiências humanas em um mesmo contexto são infindas, irrestritas, passando por todos os estímulos sensoriais, alcançado as mais diversas conexões cognitivas e simbólicas.

A fim de elucidar esse fenômeno, seus insumos e desdobramentos, Ciampa (op. cit.) recorre a uma metáfora com elementos da dramaturgia: as personagens representam a expressão empírica da identidade, uma de suas facetas concretizadas em situações do cotidiano, assim a identidade é formada pela articulação das várias personagens vividas pelo sujeito. O movimento em que se encontra, permanentemente, a identidade, é constituído pela dinâmica das personagens, pela configuração que formam como "momentos da identidade, degraus que se sucedem, círculos que se voltam sobre si em um movimento, ao mesmo tempo, de progressão e de regressão" (ibidem, p. 198).

Para Ciampa viver implica vestir, dar vida a personagens, isso porque sempre nos apresentamos como representantes de nós mesmos frente aos outros, expressamos apenas uma parte, uma face do que somos; a "cada momento, é impossível expressar a totalidade de mim" (CIAMPA, 1987, p. 170, 171). As personagens interagem contribuindo para a constituição e reconstituição uma da outra, como a personagem pai apenas existe e se transforma pela relação com a personagem filho. Simultaneamente, a identidade das personagens de conformam a identidade de seu autor e vice-versa.

Aproximando essa representação à teoria de Mead, enfoca-se a relação entre "mim" e o "eu" "58; este se articula, em movimento, com vários "mim(s)" permitidos ou requeridos pelas diversas situações vivenciadas pelo sujeito (MEAD, 1912 apud LIMA, 2009). Essa relação entre "eu" e "mim", como explica Ciampa, é de contraposição, pois enquanto o primeiro é a exteriorização da individualidade em relação às atitudes externas, o "mim", na contramão, a internalização dessas atitudes (SASS, 2004). É por isso que para Honneth (1996), a partir da visa meadiana, identidade é conflito; por estabelecer oposição, por gerar dissonância, é que essa

\footnotetext{
${ }^{58} \mathrm{O}$ "Eu", na teoria de Mead, consiste na reação espontânea do sujeito frente a novas situações, é o potencial criativo do indivíduo, impulso para a expressão do outro "outro" que também é o sujeito (CIMPA 1987), possibilitando que haja surpresa com sua própria ação. O "mim", por sua vez, é o conjunto organizado das atitudes dos outros que o indivíduo adota para si; é a expressão da convencionalidade, da tradição e da adaptação, em oposição à novidade, à transgressão e à originalidade representadas pelo "Eu” (MEAD, 1992 apud LIMA, 2009).
} 
dinâmica traz imbricada a possibilidade de negação da identidade pressuposta ao indivíduo e de representação de uma nova identidade, original, a qual exige um reconhecimento "pósconvencional"'.

“(...) o sujeito sentirá em si, reiteradamente, o afluxo de exigências incompatíveis com as normas [ponto fixo, inscrição simbólica] intersubjetivamente reconhecidas de seu meio social, de sorte que ele tem que pôr em dúvida seu próprio "Me"." (HONNEH, op. cit., p. 141).

A tensão entre a vontade geral internalizada e a necessidade de individuação está posta: para colocar em prática os interesses e vontades pessoais é indispensável que haja espaço no grupo social, assim o "mim" não deixa alternativas ao sujeito senão engajar-se na construção de novas formas de reconhecimento social, para que o seu "Eu" possa encontrar-se e ser visto como parte dessa sociedade. A ampliação dos direitos e da autonomia do indivíduo vem desse embate, acompanhando a construção de novas referências, símbolos, regras e valores pela atuação no meio social. Acreditando que há algumas circunstâncias em que o sujeito sente-se mais ou menos confiante, disposto a entrar nessa luta, a organização autogestionária pode ser analisada frente a essa possibilidade, do estímulo a situações em que, menor o temor de não mais atender às necessidades de sobrevivência e reprodução da espécie, sentido-se parte de um grupo, enraizado na história em construção junto a ele, o sujeito sinta-se mais livre para dar voz ao "Eu".

Voltaremos ao assunto mais à frente, o que podemos adiantar é que nas cooperativas populares novos grupos são formados em torno de uma comunhão, a força que atrai cada sujeito parece ser a carência por reconhecimento; a compreensão das raízes dessa espécie de abandono por parte dos outros homens de seu tempo passa pela crítica a essa estrutura societal e os valores que a embasam, o reconhecimento, por fim, pode nascer nesse mesmo grupo, reconhecimento de novas personagens criadas a partir das novidades encontradas no dia a dia de formação e de trabalho no empreendimento autogestionário.

\section{c. O esforço de autodeterminação, a luta de "ser para si"}

Está posto, assim, no diálogo entre esses pensadores que Ciampa (1987) e, depois, Lima (2009) colocam sentados na mesa, o potencial humano de propor novas conformações identitárias que, por vezes, consegue ser realizado. Esses são os eventos de autodeterminação do sujeito e de renovação da tradição de acordo com o que faz sentido para o homem e para a mulher no 
contexto histórico presente. A "alterização"59 vivida a partir dessa negação do que nega o sujeito, tornando-se o outro “outro" que também há nele, indica, para Ciampa (1987), um conjunto de mudanças quantitativas que se acumulam e convertem-se em transformações qualitativas.

O esforço pela autodeterminação perpassa a ampliação da consciência, é a partir dela que o sujeito começa a, efetivamente, chamar-se, a refletir sobre si mesmo e sobre o mundo. “À medida que vão ocorrendo transformações na identidade, concomitantemente ocorrem transformações na consciência” (CIAMPA, 1987, pg. 186), bem como na atividade. A personagem constitui-se pela atividade, e o fazer é sempre atividade no mundo, na e em relação com os outros. O indivíduo é o que faz no mundo, é relação, determinado também pelo que não é ele, por aquilo que o nega; identidade é relação entre o diferente e o igual.

Ciampa (ibidem) propõe o trinômio atividade-consciência-identidade considerando que as três categorias estão sempre acompanhadas uma das outras; já sabemos que é com a interação com o mundo externo, testando suas reações, pela socialização e pelo trabalho, que o ser humano conhece o a si mesmo e ao outro, cria a imagem de si e do outro generalizado, alcança algum nível de consciência. A identidade, ganhando sentido nesse âmago, só existe e se transforma pela atividade e pela consciência ${ }^{60}$.

O esforço de autodeterminação é a luta por "ser para si", por fazer-se sujeito, sempre buscando a unidade entre subjetividade e objetividade. Nesse jogo, o sujeito, ator ${ }^{61}$ na metáfora da dramaturgia, é um "eterno dar-se", que se insere no mundo dos humanos pelos fazer e pelo dizer, dando vida a diversas personagens. A maneira como essas personagens relacionam-se, conservando-se ou sucedendo-se, fortalecendo ou enfraquecendo umas às outras, configuram diversos "modos de produção da identidade" (CIAMPA, 1987, p. 156). Atrelada à articulação entre subjetividade e objetividade, a composição entre as várias personagens vividas pelo ator, as relações entre igualdades e diferenças experienciadas, constitui a história pessoal, particular, original e irreproduzível de cada homem e de cada mulher.

\footnotetext{
${ }^{59}$ O conceito de "alterização", é proposto por Ciampa a partir do fenômeno de "alternação" analisado por Peter Berger, em que as identidades individuais transformam-se fugindo dos caminhos pré-supostos. Isso implicaria a migração da identidade do sujeito de um universo simbólico para outro, radicalmente diferente (LIMA, 2009).

${ }^{60}$ A proposta de Ciampa (1987), do trinômio atividade-consciência-identidade, tem sua base em Heidegger (1979), entendo identidade como "mesmidade" de pensar e ser, e do sujeito concebido pela unidade entre conceito, pensamento e ser encontrada em Hegel e Garaudy (1983) (LIMA, 2009).

61 “O homem é um ator", ator participante, ativo e solidário, de uma produção coletivamente realizada (CIAMPA, 1987), da vida em sociedade em prol da sobrevivência e reprodução da espécie, voltada ao interesse da razão humana.
} 
"Cada biografia deve adquirir uma história única que possa tanto identificá-la como uma singularidade dotada de direitos individuais, quanto uma universalidade que expressa uma coletividade" (LIMA, 2009, p. 124).

$\mathrm{O}$ ator não tem vida sem personagem, sua energia vital está alocada no movimento de encontrar personagens e incorporá-las, quando não encontra nenhuma possível e as velhas não são mais acessíveis, encontra a morte, simbólica ou biológica. Personagens simbolizam, aí, os momentos da identidade, degraus que se sucedem, círculos que se voltam sobre si em um movimento de progressão e de regressão. Cada uma das personagens é um momento do todo, do movimento que é a identidade.

Conceito central para Ciampa (1987), a metamorfose da identidade, é o movimento contínuo de inter-relação entre as personagens, expressão do outro "outro" que também sou eu, superação de minha identidade pressuposta na medida em que as personagens não são previsíveis, as interpretações encenadas por cada sujeito são inéditas. A identidade como metamorfose constante coloca-se como tendência de concretização de toda humanidade contida no homem e na mulher de acordo com as condições históricas, materiais determinadas.

Identidade assim compreendida ultrapassa a esfera do individual e do social, é uma questão política. Isso fica evidente ao considerarmos que as identidades são alterizadas "pela aprendizagem de novos valores, novas normas, produzidas no próprio processo em que a identidade está sendo produzida, como mesmidade de aprender (pensar) e ser (agir)" (CIAMPA, 2001, p. 241). Na medida em que o desenvolvimento de normas intersubjetivas válidas, e a progressiva concretização de identidade humana, depende das possibilidades de exercício da liberdade de escolha do que seja uma vida que vale a pena ser vivida, a identidade como metamorfose coloca-se sempre como potencial humano contra as estratégias de dominação.

Ciampa sintetiza essa questão, da identidade como fenômeno político, composto e componente do mundo socialmente compartilhado, no seguinte trecho de "A estória de Severino e a história de Severina":

"Não ter uma identidade humana é não ser homem. Pois como o singular materializa o universal na unidade do particular, quando o particular (que no nosso caso é a identidade de um indivíduo dado, como Severina) não concretiza essa unidade, o universal permanece abstrato, falso (que no nossa caso é a sociedade capitalista). (...) Mas esse mesmo mundo que o nega, é um mundo produzido por ele; por mais paradoxal que isso possa parecer, nosso mundo - que é um mundo desumanizador - é um mundo 
humano, produzido pelo próprio homem, que assim se faz homem (como produtor do mundo humano), ao mesmo tempo em que o faz não homem (como produto do mundo desumanizador). A contradição, enquanto não for superada, sempre será reposta como mau infinito." (CIAMPA, 1987, p. 227-228)

O aprisionamento na mesma relação, de refém do mundo criado por ele mesmo é sintoma do reinado do "interesse da razão interesseira", da "desrazão". Termos utilizados pelo autor para denunciar que a razão em voga na sociedade capitalista é substancialmente irracional, pois inaugura e mantém um mundo que não merece ser vivido já que se constitui como ameaça à autoconservação da espécie. O homem instrumentalizado, transformado em ferramenta, é utilizado pelas coisas, em vez do contrário; cada indivíduo, em vez de devir-homem, devém não homem.

\section{d. Identidade como metamorfose constante e a aparência de não metamorfose}

A identidade é pensada em "A estória de Severino e a história de Severina" (CIAMPA, 1987) a partir de Hegel (1974), como resultado de uma contradição superada, em movimento contínuo de novas contradições e superações, na dialética de posição-reposição formada pela construção do que o indivíduo faz a partir do que fizeram e fazem dele em cada momento e em todos os momentos. A identidade sempre é pressuposta, não há como fugir disso, mesmo quando a desconhecemos, a pressupomos: como um recém-nascido, que mesmo antes de nascer, já é associado a um "ele”. A dialética é parte da história e da vida, o que precisamos compreender é seu sentido, ela pode ter sentidos positivo e negativo.

Mas, se a identidade é sempre movimento, metamorfose que se dá pela contradição entre as particularidades dos desejos interesses e vontades e o padrão, que ganha expressão pela articulação entre diversas personagens, como é possível a aparência de não metamorfose, a partir da qual acreditamos, por vezes, que permanecemos os mesmos?

Ciampa (1987), e nós, retornamos a Mead para compreender como, na articulação entre "mim" e o "eu", pode ocorrer um tipo de mecanismo que impede o indivíduo de autodeterminarse; no jogo linguístico por meio do qual o "Eu" o sujeito é individualizado e socializado se faz a nomeação, processo pelo qual o homem passa a reconhecer-se, em que o "bicho-humano" se humaniza e se determina (Ibidem, p. 132). A nomeação é feita de fora para dentro, a partir dos outros, e com ela o sujeito identifica-se, no entanto ela ultrapassa o nome próprio, chega aos 
atributos físicos e de personalidade, às fases da vida, às ocupações e funções; determinam o que se espera do indivíduo nos mais diversos aspectos.

Na sociedade do consumo, a nomeação está atrelada ao poder de compra e, já que parcela esmagadora da população depende de sua força de trabalho para acessar as mercadorias necessárias a sobrevivência, ao lazer e ao reconhecimento como cidadão, o rótulo recebido também se vincula ao cargo de trabalho ocupado. O emprego, apesar de decadente como contrato de trabalho, é ainda sonho de muitos, pois significa receber o nome, ser parte de uma classificação que não a de desempregado ou inútil; o padrão ainda está pautado nesse modelo.

Fausto (1983) aponta claramente, no capitalismo, o capital como sujeito e o homem sempre reduzido a personagem que oculta todas as outras facetas do indivíduo não contidas, sem espaço, na identidade pressuposta e reposta. As diversas personagens representadas seriam, para o autor, mediações do movimento do capital, permitidas por serem úteis à sua rota. A padronização das personagens pré-supostas tem como interlocutoras as instituições modernas, os papéis institucionais determinam as personagens que encontrarão espaço nas diversas organizações, também a do trabalho. Mead (1992) já alertava que as instituições, enquanto "Outros generalizados", poderiam interferir negativamente no desenvolvimento dos "selves". Elas podem “esmagar" a individualidade, inibir expressões de conduta e pensamento originais das pessoas, as personalidades individuais (ibidem, p. 262).

A aparência de não metamorfose, de constância de algo que é a mudança, dá-se, na sociedade capitalista, pela pressuposição e da re-posição da atividade; em vez de "presentificar" os sujeitos representam, na metáfora do teatro pensada por Ciampa, é o ator que não alcança a espontaneidade, sem atingir o "estado criador", em que personagem e ator identificar-se-iam em uma "metamorfose miraculosa". O ator representa sem que o papel ${ }^{62}$ lhe faça sentido.

Recorrendo a Stanislavisk (1983), teórico e prático do teatro, pode-se seguir com a mesma figura de linguagem recordando que o ator pode apenas ter sucesso em determinadas condições, necessárias. O homem como ser temporal é "ser-no-mundo", é formação material, e sua identidade é síntese das diversas determinações atuantes nesse mundo; assim como o concreto apresenta-se como síntese de múltiplas e distintas determinações, o desenvolvimento da identidade é guiado pelas condições históricas, sociais, materiais, além das características

\footnotetext{
${ }^{62} \mathrm{O}$ papel é apresentado como uma atividade padronizada previamente, uma tentativa de controle, administração e reprodução da identidade pressuposta. A personagem descola-se da atividade, exercendo um poder sobre o indivíduo, mantendo e reproduzindo sua identidade (CIAMPA, 19870).
} 
próprias de cada indivíduo. São essas mesmas condições que podem impulsionar o sujeito em direção a outros níveis de consciência e aí está a diferença entre o ator criador e qualquer outro, no nível de consciência acessado (CIAMPA, 1987).

Ao mesmo tempo em que é um "ser-posto", em relação no mundo, o homem é também um “vir-a-ser", um horizonte ilimitado de possibilidades pela articulação do que é e do que não é. Como a personagem vestida pelo ator, a identidade de concreta torna-se abstração ao deixar de ser a articulação entre igualdade e diferença da subjetividade em relação com a objetividade para tornar-se uma determinação de fora, uma pré-determinação. Lembrando que o "o singular materializa o universal na unidade do particular" (ibidem, p. 215), quando a identidade individual não pode concretizar essa unidade, o universal também se torna abstrato, falso, toda uma obra teatral fingida, sem verdade e despropositada; eis a sociedade capitalista.

É assim que a aparência de não metamorfose da identidade, a sensação de que estamos sempre iguais, mais do mesmo, está em função do interesse da razão interesseira, permitindo a manutenção de um mundo que ameaça a autoconservação da espécie.

Para que os papéis, isso é as atividades previamente padronizadas, não sejam reformulados a partir do encontro com a subjetividade do ator e os objetivos sociais sejam mantidos, a identidade pressuposta é reatualizada em rituais sociais e assumida como realidade dada e imutável, destituída, portanto, de seu caráter histórico. Em tais rituais interiorizamos a personagem que nos é atribuída, fazendo o esforço para domar nosso "eu" e identificar-nos com ela. Em cada momento da vida manifesta-se uma parte do sujeito, como desdobramento das múltiplas determinações a que está sujeito, uma personagem, um "representante de si mesmo", o problema é quando um conjunto de papéis pelo qual sou reconhecido é rigidamente imposto, sem possibilidade de troca com o universo subjetivo, asfixiando o "eu".

\section{e. O "fetichismo da personagem", "identidade mito" e "mesmice" - as faces da reificação humana}

A necessidade de normatização de determinadas personagens, de acordo com os papéis funcionais (como de pai, mãe, filho) caminha de ombro colado ao risco de que tal personagem se torne pura determinidade em infinita reposição, com aparência de nãometamorfose. A identidade é aprisionada à personagem pela predicação de uma atividade anterior, que não é mais desempenhada, mas que resulta em proposições substantivas, como “é lavrador e não lavra mais a 
terra". A atividade coisifica-se, assim, em forma de personagem, e é ela quem passa a ser conhecida: a identidade assume a forma de personagem, personagem substancial, traduzida por proposições substantivas e não mais constituída pela atividade, por proposições verbais (CIAMPA, 1987).

É na jogada de descolar-se da atividade que a personagem torna-se soberana sobre o indivíduo, determinando sua identidade e não mais a compondo pelo movimento constante de articulação com outras personagens criadas e recriadas a partir da consciência e da atividade sobre e no mundo. Fenômeno esse chamado "fetichismo da personagem" constitui o que Ciampa (op. cit.) apresenta como "identidade mito" da qual decorre a aparência de ser estático, o sujeito coisificado. A personagem-fetiche inverte o processo de busca de reconhecimento, implica o jogo em que a identidade seja determinada por sua pressuposição e reposta indiscriminadamente, até que as expectativas de fora em relação a ela mudem ou que o sujeito se rebele quebrando o ciclo.

Da reposição permanente da identidade como pré-suposta decorre a "mesmice", a qual se desenvolve pela assimilação rotineira do passado, que se torna hábito, ocultando a metamorfose da identidade (CIAMPA, op. cit. p. 140); a mesmice, o fetichismo da personagem e a identidade mito compõem o mesmo fenômeno o de reificação do homem. Paródia do relatado sobre a mercadoria, em "O Capital" (MARX, 1984) ${ }^{63}$, a personagem fetichizada comparece agora pela forma de valor social, levando os indivíduos a reproduzirem-se como réplicas de si mesmos. $\mathrm{O}$ ser humano passa a ser um ator preso à mesmice imposta na preservação dos interesses estabelecidos, de situações convenientes ao capital.

"De certa forma, reatualizamos, através de rituais sociais, uma identidade pressuposta, que é vista como algo dado (e não como se dando continuamente através da reposição). Com isso, retira-se o caráter de historicidade da mesma, aproximando-a mais da noção de um mito que prescreve as condutas corretas, reproduzindo o social" (CIAMPA, 1987, p. 163).

Assim a identidade parece ter único momento temporal, aquele em que surge como uma "revelação" de algo preexistente e permanente. O que acontece de fato é que nos ornamos de nossas predicações, interiorizando a personagem que nos é atribuída, identificando-nos com ela. O que parece pauta de discussão é o grau de liberdade que o sujeito tem para escolher, ou ser

\footnotetext{
${ }^{63}$ Em O fetichismo da mercadoria: o seu segredo, texto de “O Capital”, Marx descreve como a mercadoria assume valor de troca, desvinculando-se do valor de uso, e ganhando poder sobre o homem. Pela sua reificação o homem é coisificado, passando a representar, ele mesmo, uma mercadoria no sistema socioeconômico capitalista.
} 
escolhido, por suas personagens. A reposição da identidade pressuposta instaura a inércia no sentido de que para sair desse movimento cíclico e repetitivo é necessária uma força propulsora; é possível que esse impulso venha pela mudança de contexto imediato, da qual o cooperativismo popular é possibilidade, mas não é garantia, é possível que algumas personagens que compõem nossa identidade sobrevivam mesmo quando a condição objetiva mudou radicalmente.

A inércia, por ser monotonamente repetitiva, camufla a noção de temporalidade. Na medida em que a reposição da identidade deixa de ser vista temporalmente, tomada como manifestação constante do ser, sempre idêntico a si mesmo, a história parece perder seu papel nesse processo, já que sempre teria sido e sempre será o mesmo. A situação ganha ar de naturalidade refletida no discurso de que "a pessoa é o que ela é", sendo que, de fato, a reposição que sustenta o fenômeno da mesmice tem seu ponto nevrálgico na submissão da identidade individual a condições socioeconômicas desumanas, construídas ao longo da história, estruturas formadas pelo próprio homem em sociedade. Nunca voltada ao ser humano, ao contrário, a mesmice configura-se como fenômeno desumano e desumanizante e desemboca em uma "má-infinidade", isto é, na repetição pela não superação das contradições (CIAMPA, 1987).

\section{f. "Mesmidade” e "alterização" como negação de um mundo que não merece ser vivido}

Em contraste à mesmice se coloca a "mesmidade", isto é, a possibilidade de tornar-se outro, de alterizar-se por uma mudança significativa, um "salto qualitativo" resultante do acúmulo de mudanças quantitativas, graduais e não radicais (ibidem, p. 234). No caso de Severina, sujeito de sua tese, a alterização desemboca em movimento emancipatório de identidade pela negação de um mundo que não merece ser vivido; pela construção de uma nova personagem, Severinabudista, é possível a negação do que a negava, a superação das contradições antes postas, e o alcance do reconhecimento na relação com um mundo mais humano.

Almeida (2005) sintetiza como processo de alterização pode repercurtir na metamorfose da identidade com sentido emancipatório:

"A nova identidade, desejada ou conquistada, expressa um reposicionamento dos sujeitos frente àquela a que se espera que eles devem se conformar. Expressa nesse sentido, um processo de metamorfose dotado de características emancipatórias, pois as modificações identitárias representam, na busca da autonomia frente aos preceitos dados, o assumir um lugar de sujeito do olhar, uma 
(re)colocação do sujeito ante as condições pessoais e sociais restritivas que lhe são impostas(...)" (ALMEIDA, op.cit., p. 113; 160).

Os indivíduos que resistem à política de identidade proposta, ao enquadramento e buscam ser reconhecidos a partir de sua posição, geralmente são considerados anormais, problemáticos, por serem anamorfoses em relação à política de identidade instituída, colocando a ordem em perigo. A anamorfose é apresentada por Almeida (ibidem) como a inovação que, por ser diferente do que padrão, do conhecido, não pode ser incorporado no discurso coletivo causando "curtocircuito" na percepção.

Nesse sentido, as "identidades anamórficas" têm a potencialidade emancipatória ao propor uma nova equação entre as exigências de reposição do instituído e o clamor humano pela alterização. Para que a personagem anamórfica encontre espaço no grupo, é necessário que uma nova ordem e outra lógica entrem em cena para que um reconhecimento chamado por Lima (2009) de pós-convencional, reconhecimento efetuado a partir da própria diferença, seja possível.

Tal processo, no qual a anamorfose, reconhecida, deixa de ser anamorfose para tornar-se referência na esfera pública exige, para Lima (op. cit, p. 161), uma "luta incessante", a aplicação de grande energia, de forma persistente em sentido contrário ao interesse do capital, isso para que uma soma de mudanças quantitativas, graduais, possa converter-se em significativa transformação qualitativa do convencionado. A ação política constitui-se assim, a partir do questionamento do instituído em nome da expressão da identidade do sujeito que age, de sua personagem, que "embora inerente à ordem universal existente, não encontra nela um lugar próprio" (ibidem, 162).

A inércia instaurada pela estabilidade dos signos que mantêm a mesmice, servindo à manutenção e reprodução do capital, é a mesma que inaugura a relação perversa entre o indivíduo e a sociedade: atingido pelo sofrimento da indeterminação, o sujeito busca o reconhecimento de sua personagem anamórfica por um Outro que, a partir de um ponto de vista reducionista da identidade, apenas consegue relacionar-se com o já estabelecido (LIMA, 2009). Por isso, um grito no vazio, sem eco, proporciona a angústia de se estar à beira do buraco negro; aí a perversidade.

A força propulsora da mudança, de rompimento da inércia, requer mais do que o fortalecimento do mundo da vida, precisa trazer em seu âmago o desenvolvimento da razão crítica como "giro de discurso, como mudança das possibilidades de inscrição simbólica no 
espaço social discursivo" (PRADO, 1996, p. 167). O surgimento das anarmofoses mostra-se caminho ao tensionar a estrutura no sentido de sua renovação e atualização por colocar em xeque os conteúdos tradicionais do mundo da vida e da racionalidade em vigor nessa esfera ao longo sua luta por reconhecimento da alteridade de identidade.

Dessa forma, "a interpretação que o indivíduo faz da realidade é antes uma antecipação do discurso internalizado, cuja subversão, alterização, é dada a partir do reconhecimento de sua individualidade, de sua anamorfose" (LIMA, 2009, p. 169).

\section{4 $\underline{\mathrm{O} \text { esgotamento da crítica - uma perspectiva ameaçadora }}$}

Uma vez reconhecido, uma vez que não pôde ser calado, outro fenômeno tende a iniciarse, pelo qual o discurso anamórfico começa a ser absorvido pela administração social e gradualmente fetichizado, indicando o esgotamento de um regime de crítica; aquilo que Ciampa (2003) e Habermas (2005) chamaram de esvanecimento do horizonte utópico (LIMA, 2009). Para Zigmunt Bauman (1977), esse processo denota a falta da liberdade dessa época, a privação da chance de se construir significados objetivos e normas.

Considerando a colonização do mundo da vida pela lógica sistêmica, e assim superação dos fins econômicos em relação à solidariedade, há uma poderosa força de conversão da personagem anamórfica em pré-suposição por um papel padronizado. Instaura-se um novo padrão para que possa enquadrar-se nas relações mercadológicas, forma dominante de reconhecimento social. Portanto, para que o sentido emancipatório da metamorfose da identidade não seja novamente rompido, caindo em outro ciclo de reposição, novamente na má-infinidade, é preciso que o contexto mais amplo, que a organização socioeconômica seja transformada.

A negação da negação dificilmente é alcançada pela batalha individual, é mais provável pela luta coletiva, ainda que dura. O grupo, quando em posição crítica em relação ao status quo, é instância de reconhecimento das personagens propostas pelos indivíduos. No entanto, não se pode ignorar que ações estruturais e estruturantes precisam acompanhar esse confronto, apenas por meio delas esses coletivos alcançarão mais alto patamar em quantidade e em qualidade; serão em maior quantidade e terão vida mais longa para seu posicionamento crítico.

A “invencibilidade da substância humana, como produção histórica e material" (CIAMPA, 1987, p. 228) é fato, garante que os sujeitos vão se transformando, a contragosto dos interesses dominantes, aqui e ali, reafirma que a história não para, é vida, e vida é transformação. 
Continuamos humanos, mesmo em um mundo desumanizador, a humanidade encontra brechas para vir à tona e precisa ser instrumentalizada, precisa de suporte para impor-se sobre as estruturas.

Como Severina (CIAMPA, 1987), milhões de indivíduos dramatizam personagens pressupostas até chegar ao zero, à morte simbólica; em seu caso, tornando-se "louca". Alguns, como ela, buscam alternativas, a alterização da identidade, e conseguem reconhecimento; o desafio é fazer com que esse seja o padrão, torna-se o outro "outro" em relação com os outros homens sempre que uma personagem, que também é o sujeito, queira se mostrar. O "normal", mais comum, precisa ser a racionalidade humana, a metamorfose da identidade com sentido emancipatório.

A identidade concretizando-se não mais como mesmice, mas como mesmidade entre pensar e $\operatorname{ser}^{64}$ requer, para que se configure como tendência em uma sociedade, algumas condições concretas, só com elas presentes o ator pode representar com êxito, como ator-criador. As organizações com conteúdos previamente definidos, que possuem sua política de identidade estabelecida e imposta, vão na contramão do contexto para o desenvolvimento da "identidade pós-convencional": como alerta Ciampa (1987), a "razão interesseira", que quase sempre preside uma organização, orienta sua atuação no sentido da sobrevivência própria. Na medida em que se institucionaliza, volta-se para interesses de autoconservação, raramente convergentes com o interesse da razão humana.

\section{5 $\underline{\text { A identidade e as organizações - o enrijecimento pela institucionalização }}$}

Conformam-se na maior parte das organizações modernas institucionalizadas, situações de coerção entendidas como "objetivação, cujo poder repousa unicamente sobre o fato de o sujeito não se reconhecer nela como em seu outro" (CIAMPA, op. cit., p. 208). Em outras palavras, tais organizações dão origem a condições concretas, objetividades, em que a subjetividade humana não se reconhece e que não podem ser modificadas, tão enrijecidas e naturalizadas se encontram.

O trabalho organizado e institucionalizado pela mesma organização moderna tem papel importante nessa rede formada entre subjetivo e objetivo, entre o mundo que não merece ser

\footnotetext{
${ }^{64}$ Justamente por ser mesmidade entre pensar em ser, a identidade é metamorfose constante, nas palavras de Ciampa: "se identidade é identidade de pensar e ser, a resposta que buscamos é uma resposta sempre vazia, como um salto, pois é metamorfose” (CIAMPA, 1987, p. 241-242)
} 
vivido e a identidade que quer concretizar o desejo por liberdade. É por meio do trabalho que o homem transforma sua condição de existência e seus próprios desejos, produzindo-se a si mesmo, no trabalho o sujeito concretiza sua identidade. "O devir humano é o homem ao se concretizar" (ibidem, pg. 201), a identidade humana é concreta, social e histórica, desenvolve-se a partir do desejo e pelo trabalho.

Como nos lembra Ciampa (1987), "nossa inserção no mercado de trabalho quase sempre sela um destino" (op. cit., p. 232), e a tendência universal dentro do sistema capitalista é a proletarização de todos os que vivem de suas forças de trabalho. Por isso, nessa visão, a busca de uma identidade profissional dentro dessa sociedade pode ser encarado como movimento regressivo, bem como tornar-se membro de uma organização religiosa; tratar-se-ia da "alienação da alienação".

Olhando para a organização do trabalho, é fato que ela tem influência direta nas personagens às quais o trabalhador pode dar vida. $O$ discurso de que é possível separar a experiência das oito horas (ou mais) no emprego do que se é no restante do tempo, no tempo que resta para dormir, comer e estar entre amigos e familiares, é ideológico e desprovido de sentido. Com a categoria de identidade proposta por Antônio Ciampa fica claro que papel, personagem e identidade estão imbricados uns nos outros, são interdependentes, organismo vivo. Assim, a ideia de separação entre trabalho e vida cotidiana ${ }^{65}$ é tão ilusória quanto a de independência entre papel e identidade.

Em outras palavras, não é impunemente que vestimos os papéis; as características objetivas imbricadas em cada papel e em toda a "cena discursiva" (GUIRADO, 1994), em toda a situação social da qual faz parte, refletem na formação e transformação do ser social seja pela voz que esse papel permite ao “eu”, pela abertura ou rigidez em relação aos padrões que representa, seja pela forma de articulação de personagens que ele exige para que seja crível e para que o ator possa suportá-lo.

\subsection{Da utopia para um mundo em construção}

\footnotetext{
${ }^{65} \mathrm{Na}$ cooperativa estudada por Certeau (1994), apresentada rapidamente na introdução de "A invenção do cotidiano - artes de fazer", um dos pontos que chamam a atenção é a vida produzida coletivamente, em seu sentido amplo, sem divisão entre trabalho o que seriam suas outras esferas. A separação entre trabalho e vida cotidiana parece estar vinculada à dominação dos interesses econômicos sobre as outras instâncias, a qual se dá com o avanço do capitalismo, sua expansão, dentro das organizações cooperativistas.
} 
A identidade metamorfose com sentido emancipatório é aproximada por Ciampa, à “identidade pós-convencional”66 de Habermas (1982). A partir de Mead e Kohlberg, Habermas propõe níveis de desenvolvimento da "consciência moral", o último estágio seria o da "liberdade moral e política", esfera de "todos enquanto membros de uma fictícia sociedade mundial", a humanidade inteira. Seria esse o cenário de máxima valorização da liberdade e máxima valorização da igualdade (LIMA, 2009).

Considerando que o nível primeiro dessa linha evolutiva da consciência seria o de maximização do prazer, em que se evita a dor por meio da obediência acrítica, a transição partiria do "hedonismo ingênuo" para a "ética universalista da linguagem" (CIAMPA, 1987, p. 221). Aí, nesse estágio avançado, o que se encontraria seriam procedimentos comunitários que permitissem interpretações universalizadas das necessidades e dos interesses de seus participantes e não mais um conteúdo normativo construído a priori e aceito pelos membros da comunidade como única possibilidade, como verdade.

Para Habermas (1982), na era moderna, com a queda do poder das religiões e ideologias mundiais, seria apenas possível a identidade pós-convencional, fundada nas oportunidades iguais e gerais de participar dos processos de comunicação e na consciência necessária para que essa participação seja ativa, efetiva. Tal identidade se constituiria como processo contínuo de aprendizagem, baseada em um sistema de interpretação em constante revisão. Sabemos serem muitos os obstáculos colocados por nossa organização socioeconômica a esse ideal proposto por Habermas, à comunicação fluidificada e tudo que poderia se desdobrar até que vivêssemos em um mundo capaz do reconhecimento de identidade pós-convencionais. Isso fica claro na obra de Ciampa (1987), assim como que não se trata de um mundo impossível, mas humano, que precisa ser construído.

Não à toa a identidade como metamorfose constante aproxima-se de Habermas, Ciampa parte daí, considerando suas contribuições, na preparação de sua teoria, trazendo alguns conceitos para a realidade contemporânea, aproximando os conceitos das histórias de vida humana reais. Esse pensador nos dá a dica do que seria, em sua visão, um mundo em que o movimento da identidade não precisasse ser historicamente regressivo:

\footnotetext{
66 Aluisio Lima (2009) olha criticamente para a proposição de Habermas de identidade pós-convencional como chegada do processo de emancipação (HABERMAS, 1993), notando que isso se coloca como uma espécie de convenção, de predeterminação da emancipação humana. Os ideais, na visão de Lima, devem ser explicitados em meio aos conflitos que se dão no mundo da vida e não de forma equilibrada, sem coerção, sem conflitos.
} 
“(...) em que o interesse da razão, numa progressiva execução revolucionário-crítica, sempre a título de ensaio, sem certeza totalizante, e que progressivamente realize as grandes ilusões da humanidade, nas quais os motivos recalcados estão burilados em fantasias de esperanças" (CIAMPA, 1987, p. 235).

Mundo esse em que as fantasias deixam de ser bobagem para se tornarem visão de futuro, o início da mudança, em que o erro não é pavoroso, mas faz parte do "ensaio", é necessário para que possibilidades melhores possam ser tocadas, em que as ilusões não sejam sinal de loucura, de nãoenquadramento, mas de saúde, de alma humana, do outro "outro" que quer se concretizar. O interesse racional é aquele que coincide com o interesse pela autoconservação da espécie e que emerge em espaços em que existe a liberdade de alterar as condições concretas, recusando a coerção e dando voz à subjetividade. Interesse pela libertação, “interesse racional e não razão interesseira" (CIAMPA, 1987, p. 209), aquele que determina o que merece ser vivido nas condições (estruturas e sistemas) dadas.

Em minhas palavras, o mundo em que a identidade pode se concretizar como metamorfose em sentido emancipatório é aquele em que as relações são baseadas na igualdade, na solidariedade, na cooperação e não mais hierarquizadas pela mediação do capital. Realidade em que os indivíduos compartilham símbolos e, a partir do diálogo entre as diversas interpretações, constroem histórias coletivas em busca de caminhos para negação daquilo que os nega, para a superação de condições desumanas que os impedem de serem senhores de si. Contexto em que a ameaça de aniquilação simbólica e física, a ameaça da miséria, é enfraquecida, rompendo, assim, com principal fonte de poder para a dominação do capital, isso com base em alternativas viáveis de labor e de trabalho cheio de sentido. Iniciativas essas que, com tal libertação, abrem espaço para a ação política, para a transformação da realidade de acordo com as necessidades e anseios humanos.

A efetiva concretização de uma identidade humana será sempre uma questão política: questão que se coloca em relação a quais condições reais devem ser favorecidas e que condições necessárias precisam ser produzidas para que a autoconservação da espécie seja favorecida. A Economia Solidária e, mais especificamente, o cooperativismo popular, ao proporem algumas condições bem alinhadas com esse mundo humano idealizado como cenário para a emancipação humana, desenham uma utopia capaz de unir milhões de pessoas em uma luta comum. Luta que 
vem transformando em real parcela dos elementos de tal utopia, como veremos um pouco mais adiante.

"Não há nada real que não mantenha a si próprio na existência, em uma luta de vida ou morte com as situações e condições de existência. A luta pode ser cega ou até inconsciente, como um assunto inorgânico; ela pode ser consciente e coletiva, como a luta da humanidade com suas condições e sua própria natureza. A realidade é o resultado constantemente renovado do processo de existência - o processo, consciente e inconsciente, em que "o que isso é" transforma-se "em outro dele mesmo"; e a identidade é apenas a constante negação da inadequação da existência, o sujeito mantendo a si próprio como o seu outro. Cada realidade, consequentemente, é a realização - o desenvolvimento da "subjetividade". O último "transforma-se em si mesmo" em história, na qual o desenvolvimento do conteúdo racional; Hegel define isso como "o progresso na tomada da consciência da liberdade"." (MARCUSE, 1969 apud GALEAO, 2009, p. 13).

Para abordar os possíveis (ou não) desdobramentos para os sujeitos que experimentam a organização solidária, autogestinária, cooperativa de trabalho, é preciso, aproximarmo-nos dessa configuração objetiva, ou de como é vista por aqueles que bucam na teoria e na prática recursos para sua descrição. Passemos a esse universo, ou a uma pincelada a seu respeito, a fim de recolhermos material para a reflexão a respeito das representações subjetivas constituídas pela vivência de uma organização do trabalho, de uma formação coletiva, da semente de uma organização societal distinta da que entendemos até aqui. 


\section{Capítulo IV - Economia Solidária e cooperativismo como alternativa de trabalho, renda e relações sociais}

"Esqueceram que a dignidade humana não é só patrimônio dos que têm resolvidas suas condições elementares de vida, também os que nada têm de material possuem o que os faz diferente das coisas e dos animais: a dignidade." (DUSSEL, 1998)

Adentremos a Economia Solidária e sua principal unidade organizativa, a cooperativa. Entramos em um campo em que visões distintas cruzam-se, complementam-se e, por muitas vezes, chocam-se. Para alguns, o horizonte é a transformação radical, a superação do capitalismo; para outros a construção de uma vida menos dolorida, mais digna, como parte do mesmo sistema, uma mudança para o indivíduo, mais que por e no indivíduo. A economia solidária no dia a dia, no trabalho e na vida cotidiana, é diferente da ordem que vigora, da vida pela qual somos lavados quando na inércia; é construção, abrir trilha em mata fechada. Não basta saber para onde leva, é preciso entender para onde poderíamos, cada um dos que a fazem, conduzi-la.

O interesse aqui, como já sabem, é pela transformação do sujeito por ele mesmo na experiência solidária. A mudança estrutural começa na transformação de cada um como parte de um coletivo diferente, diante de condições objetivas diferentes. Passa pela articulação desses muitos uns em um movimento de negação do que não merece ser vivido.

Esse é o prisma pelo qual olharemos a Economia Solidária nesse capítulo. Para abordar os possíveis (ou não) desdobramentos para os sujeitos que experimentam a organização solidária, autogestinária, cooperativa de trabalho, é preciso, aproximarmo-nos dessa configuração objetiva, ou de como é vista por aqueles que bucam na teoria e na prática recursos para sua descrição.

\subsection{A Economia Solidária e o Cooperativismo - apresentação}

"Eu sou o grupo, se estiver falando do grupo estará falando de mim também.” (Vicença, grupo Mãos na Massa ${ }^{67}$ )

A Economia Solidária é um tema, uma prática, uma práxis diariamente em construção no Brasil e no mundo, por isso mesmo sua definição é abrangente e apresenta diversidade. Aqui remontarei àquela elaborada coletivamente no Fórum Brasileiro de Economia Solidária (FBES) com base na ideia de que:

${ }^{67}$ Citação de entrevista realizada em 25/10/2009. 
"Por economia solidária se compreende um projeto emancipatório que não se restringe à mitigar os problemas sociais gerados pela globalização neoliberal, mas trata-se de um projeto de desenvolvimento integral que visa a sustentabilidade, à justiça econômica, social, cultural e ambiental e à democracia participativa. Ela se fundamenta na cultura da cooperação, da solidariedade e da partilha, rejeitando as práticas da competição, da exploração e da lucratividade capitalista." (Documentos oficiais do FBES $^{68}$ )

Vale pontuar que os nomes aplicados a essa proposta de outra economia, de alternativa de trabalho, geração de renda e organização social, que discutiremos nesse capítulo, são diversos. Utilizarei "Economia Solidária", difundida principalmente pela ECOSOL, Gaiger e Singer $\left(\right.$ COLAGGIO, 2007) ${ }^{69}$. A nomenclatura não aparece como questão central do debate sobre o conteúdo, as fronteiras, práticas e perspectivas do movimento. Sua diversidade denota que se trata de propostas em construção, em constante evolução e transformação, como parte de um processo democrático, do debate aberto em que esse caminhar vem se dando.

O movimento da economia solidária é feito no dia a dia no Brasil pelos empreendimentos populares, pelas cooperativas industriais, movimentos sociais, sindicatos, fóruns estaduais, municipais e FBES, políticas públicas e de extensão universitária de fomento a essa economia e pela Secretaria Nacional de Economia Solidária (SENAES). Alocada no Ministério do Trabalho e do Emprego, essa secretaria, com o papel de articulação de políticas públicas, apoio a projetos e mobilização de atores do próprio governo federal para apoio a projetos, é um marco da tomada pela economia solidária de caráter de política pública ${ }^{70}$.

Para Paul Singer (2000), a economia solidária constitui uma das estratégias de luta do movimento popular e operário contra o desemprego e a exclusão social, utilizando como base as relações de produção estabelecidas pelo capital para inaugurar outra possibilidade de organização de produção baseada em valores e princípios opostos à capitalista. A economia solidária inauguraria:

"Outro modo de produção, cujos princípios básicos são a propriedade coletiva ou associada do capital e o direito a liberdade individual. A

\footnotetext{
${ }^{68}$ Documentos disponíveis em:

http://www.fbes.org.br/index.php?option=com docman\&task=cat_view\&gid=98\&Itemid=216..$\quad$ Acesso em $30 / 08 / 2009$

${ }^{69}$ também conhecida por Economia Social (ES), Economia de Solidariedade, Economia Social y Solidária, Economia Popular, Economia Solidária e Popular, Sócioeconomia Solidária, Economia do Trabalho, Economia da Vida, etc.

${ }^{70}$ Fonte: www.itcp.usp.br. Acesso em 29/08/2009.
} 
aplicação desses princípios une todos os que produzem numa única classe de trabalhadores que são possuidores de capital por igual em cooperativas ou em uma outra sociedade econômica. O resultado natural é a solidariedade e a igualdade, cuja reprodução, no entanto, exige mecanismos estatais de redistribuição solidária de renda." (SINGER, 2002: 10)

Não é consensual a visão da relação entre economia solidária e sistema capitalista. Coraggio (2007) entende que a proposta desse movimento, ao mesmo tempo em que não considera reforçar o avanço e modernização capitalistas, não coloca como condição necessária supressão do mercado do capital. Seria ele uma construção contínua que tem como guia o estabelecimento da "solidariedade orgânica" entre os que a fazem, mas, justamente por ser orgânica, não poderia ter seu caminho e seu fim pré-determinados (op. cit.: 5).

Esse é um dos pontos de debate que o movimento desperta, mostra dessa mesma construção contínua, que se faz não apenas na prática, também na teoria; levantaremos alguns outros mais adiante. Faz-se importante antes mais algumas pinceladas que revelem um pouco mais sobre esse objeto, a economia solidária, mesmo que não seja possível revelar uma forma clara, arte abstrata. Sua origem é um ângulo interessante de aproximação.

Diante da questão sobre o surgimento da economia solidária, Martins de Oliveira (2006) afirma, a partir de Singer (2002), os chamados "socialistas utópicos", dos quais são representantes Owen, Buchez, Fourrier, Proudhon, entre outros, como essenciais aos primeiros passos do movimento como tal. Sendo realizado continuamente pelos trabalhadores em sua luta contra o capitalismo, a economia solidária teve sua semente nos primórdios do capitalismo industrial, na resistência revelada ou iminente, sempre presente ao longo dos séculos.

"A economia solidária surge como modo de produção e distribuição alternativo ao capitalismo, criado e recriado periodicamente pelos que se encontram (ou temem ficar) marginalizados do mercado de trabalho. A economia solidária casa o princípio da unidade entre posse e uso dos meios de produção e distribuição (da produção simples de mercadorias) com o princípio da socialização destes meios (do capitalismo)". (SINGER, 2000, p. 13, apud MARTINS de OLIVEIRA, 2006, p. 87):

A economia solidária colocar-se-ia como outra possibilidade de organização, de relação, de vida, embora imersa no sistema socioeconômico capitalista. Sua massa crítica viria justamente daqueles que não encontram espaço no âmago da estrutura societal capitalista ou que vislumbram a falta de oportunidade, de voz, nesse sistema e convivem com a ameaça da negação do acesso às 
condições, à manutenção da própria vida. Questão trazida por Singer, o temor e a resistência parecem ser um só fenômeno tanto no nível macro quanto no microeconômico: as adesões mais maciças a essa outra economia são evidenciados principalmente nos momentos de eclosão da crise estrutural do capital quando a ameaça aproxima-se, senta-se na mesa de jantar. As instituições da economia solidária ganham, ao menos de início, a cara daqueles que não buscam, desesperadamente, por alternativas de trabalho e renda.

Nesse processo, passagem de uma posição de desempregado para a de militante, Singer, identifica o caráter de luta de organização e luta dos trabalhadores que seria a marca da economia solidária; organização que ganha forma, institucionaliza-se, como cooperativa. A partir dessa interprestação, embora valores, princípios e relações capitalistas misturem-se aos solidários nos empreendimentos cooperativos, a combinação seria como a de pó de café com água: o resultado do mix supera a justaposição dos ingredientes, resulta no novo, poção com características próprias, a vivência solidária.

A cooperativa é unidade em que se concretiza a economia solidária ${ }^{71}$. Seus princípios organizativos são: a posse coletiva dos meios de produção pelos trabalhadores cooperados, a gestão democrática do negócio por participação direta, quando o número de cooperados não é muito grande, ou por representação, a divisão da receita líquida entre os cooperados de acordo com critérios acordados coletivamente e a destinação das "sobras" de cada exercício também por critérios acertados pelo grupo, da forma que parecer melhor a todos (SINGER, 2000).

Em contexto em que, a partir de dados do Instituto Brasileiro de Geografia e Estatística (IBGE), pode-se identificar o gradual esfacelamento do emprego e, portanto, o fechamento da porta, ainda a mais a comum, de acesso à sobrevivência, o cooperativismo constitui-se uma janela que se abre ${ }^{72}$. Não à toa Nakano (2000) chamou os últimos anos de 90 como a "década do desemprego"; os fenômenos relacionados à crise do capital, já antigos conhecidos, acentuaram-se e como resposta multiplicaram-se as micro e pequenas empresas informais e as cooperativas.

\footnotetext{
${ }^{71}$ Embora, como mencionado, a cooperativa seja vista como a unidade constituinte, o átomo da economia solidária, outras organizações foram indispensáveis para seu despontar e sua sustentação ao longo a história e, ainda mais, atualmente. A associação livre dos cidadãos em busca de outras formas de vida em sociedade seria a característica transversal a elas.

${ }^{72}$ Se a década de 90 foi marcada pelo empobrecimento da maior parte da população mundial (MARTINS de OLIVEIRA, 2006), hoje a pobreza atinge três bilhões de pessoas, isto é, homens, mulheres e crianças que vivem com menos de dois dólares por dia segundo dados da Organização Internacional do Trabalho (OIT), da Food and Agriculture Organization of theUnited Nations (FAO) e do Programa das Nações Unidas para o Desenvolvimento (PNUD). Ao menos 50 milhões de pessoas encontram-se nessa situação no Brasil (PNUD, 2006).
} 
Por essa correlação, principalmente, o cooperativismo afirmou-se como importante foco de análise para o desenho de políticas de intervenção econômica. As estatísticas denotam que a população economicamente ativa cresce em ritmo maior que as vagas de emprego formal desembocando no inchaço do setor informal fonte das possibilidades negadas de trabalho na economia central; afinal, os "desempregados" continuam precisando sobreviver, atender às mesmas necessidades básicas que quando desempenhavam o papel de trabalhadores-empregados.

É ao lado da colocação no setor informal que surgem outras alternativas de inserção econômica, social e política, entre elas as que se desdobram da vivência da economia solidária. Caminhos esses que, como retratado por Martins de Oliveira (2006), por vezes são institucionalizados, como as cooperativas e as associações legalmente fundadas, sem entrarem por isso no ciclo da economia formal.

O cooperativismo conforma-se importante saída para a situação de exclusão ${ }^{73}$ em que pessoas que nunca tiveram (ou que não encontram mais) acesso ao trabalho remunerado, a um emprego, encontram-se (NAKANO, 2000). Frente ao desemprego e às diversas formas de marginalização, estruturalmente semelhantes às vivenciadas nos dias de hoje, decorrentes da Revolução Industrial, as formas de trabalho cooperativo já se apresentavam como alternativa importante para a sobrevivência de grupos inteiros e suas famílias (COLE, 1964). Portanto, não é novidade que o cooperativismo constitua-se respiro em meio aos efeitos das crises cíclicas do capitalismo, mas também que seja, em sua vivência cotidiana, um exercício cotidiano da cooperação com solidariedade $^{74}$ (SINGER, 2002 e SANTOS, 2002).

Entre as formas organizacionais chamadas cooperativas, enfoco, aqui, as populares, que inseridas em diversos setores representam o pilar de desenvolvimento da economia solidária no Brasil. Diferencia-se das outras pela incorporação dos princípios da economia solidária e pelo vínculo com os grupos mais populares da sociedade, trabalhadores desempregados, em situação precária de trabalho e aqueles que não podem suprir suas necessidades básicas com a ocupação que possuem no mercado formal ou informal. Já citada acima, a cooperação ${ }^{75}$ é um de seus traços

\footnotetext{
${ }^{73}$ Para Pochmann e Amorim (2003), excluídos são aqueles que não possuem acesso, ou possuem de forma precária, à educação, ao trabalho, à renda, à moradia, ao transporte e à informação.

${ }^{74}$ A solidariedade entendida como um valor intrínseco à cooperação e que é refletida nas diversas práticas de ajuda e de confiança mútua. A autogestão e a democracia são elementos fundamentais para a prática da cooperação.

${ }^{75}$ Para saber mais a respeito, consultar Marx (1983) e Borgadus (1964).
} 
mais elementares, bem como o privilégio das práticas de autogestão e da distribuição coletiva dos resultados financeiros dos empreendimentos, as sobras (MARTINS de OLIVEIRA, 2006).

Na visão de Arrighi, Hopkins e Wallerstein (1989) esse movimento teria superado o embate entre classe operária e capital e seria suportado atualmente por grupos com interesses diversos que buscam relações mais igualitárias e justas entre os segmentos sociais. Isso pela proposta de uma nova estrutura societal, de Estado e de mercado. Os enfrentamentos estariam, nesse momento histórico, dando-se entre capital e todos os grupos engajados no desenvolvimento de estratégias de negação das violências impostas pelas condições socioeconômicas em funcionamento; o desafio é a articulação desses grupos, mesmo que militantes todos da economia solidária.

Apesar de serem reais dissonâncias na teoria e na prática em que se faz o cooperativismo popular, por vezes em quesitos essenciais ${ }^{76}$, são seus elementos estruturais, transversais às diversas iniciativas, que podem ser evocados para conferir uma identidade aos empreendimentos. Além da motivação comum de propiciar alternativas à organização do trabalho, às relações interesseiras, formas alternativas de manutenção e reprodução da vida em seu sentido mais amplo, as inicitiavas unem-se por serem marcadas por: não separação entre o trabalho, a posse e gestão dos meios de produção e o produto, livre associação, autogestão e o trabalho cooperativo tendo por base a socialização dos meios de produção, estabelecimento de laços interpessoais entre os envolvidos compondo também as relações sociais de produção e formando uma sociedade mais ampla entre as pessoas, reorganização da ordem entre valor de troca e valor de uso, subordinando o primeiro ao segundo e não o contrário como acontece na lógica capitalista, e resignificação do conceito de "eficiência", com a valorização de resultados que não estão limitados ao processo produtivo e à relação entre gastos e receitas.

Enquanto o cooperativismo popular adere aos princípios da economia solidária ${ }^{77}$, o "cooperativismo coorporativo" é um atalho para o corte de custos e aumento da lucratividade do

\footnotetext{
${ }^{76}$ Entre os exemplos merece destaque a colocação do cooperativismo como caminho alternativo ao capitalismo e ao socialismo, em um cenário de inovação, por Pinho (1962 e 1965) e Maurer Junior (1966), em contraposição ao seu entendimento meios de distribuição e de reprodução de bens e serviços à disposição tanto ao capitalismo quanto ao socialismo para o fortalecimento de suas estratégias de desenvolvimento. Argumentos para esta última posição podem ser encontrados em diversas obras, referência para o estudo do assunto: Singer e Souza (2000), Alencar (1993), Oliveira (1996), Bursztyn (1985), Albarran e Ramirez (1989), Pinho (1977), entre outros.

77 Inicialmente, os sete os princípios da economia solidária foram articulados pelos pioneiros de Rochdale, sistematização de experiências e movimentos anteriores, esses princípios foram sendo refraseados, tomando novas formas de acordo com o contexto histórico. São eles: adesão livre e voluntária, gestão democrática e livre,
} 
capital, uma carapaça que torna seu sistema de exploração ainda mais cruel. Terceirizando mãode-obra, empresas formam "cooperativas",78 por seus funcionários contratando-os como prestadores de serviços e isentando-se do pagamento dos encargos trabalhistas, usurpando os direitos dos agora subempregados-cooperados.

Portanto, embora as formas de concretização do cooperativimo popular sejam diversas em tantos preceitos e práticas, a recolocação da reprodução ampliada da vida em seu trono, reinando sobre a produção, o comércio e o serviço e determinante para a "econmia popular" (CORAGGIO, 2007). A Teologia da Libertação é forte influência no que concerne seu posicionamento crítico em relação à racionalidade instrumental da modernidade justamente em sua consequente sujeição da vida aos fins objetivos, aos interesses econômicos, colocando a vida humana em risco e destruindo-a em diversas circunstâncias. A defesa é pela valorização da vida como o fim maior de todos os fins, e a subordinação da racionalidade instrumental à reprodutiva (HINKELAMMERT, 2003). Tal inversão é um dos componentes centrais da economia solidária como quase consenso entre os núcleos em que o movimento se desenvolve.

A vida em comunidade é prioritária frente à concorrência individual também porque atende melhor ao ciclo longo da vida se comparada aos benefícios imediatos e de curto prazo das vantagens individuais. Os valores da reciprocidade, da redistribuição e solidariedade podem reinar em coletividades voltadas à garantia da vida e não em indivíduos que vêm a si mesmos e a todos os outros como unidades concorrentes (ou potencialmente concorrentes) em uma lógica expandida de mercado.

Bem como outras vertentes de resistência e de transformação da ordem vigente, o cooperativismo também fora, em determinado momento, parcialmente fagocitado pelo capital. Resultado disso são os sistemas de produção participativos e a terceirização da mão-de-obra adotados nas instituições capitalistas como resposta à eclosão da crise do sistema de produção. Quijano relembra essa história e aponta que as respostas às reviravoltas travessas do capital, no século XIX, deram-se dois sentidos, o da estatização da economia, vinculada ao socialismo, e do

participação econômica dos sócios, autonomia e independência, educação, treinamento e informação, cooperação entre as cooperativas e preocupação com a comunidade (artigo de Mônica Rique disponível em http://www.itcp.usp.br/drupal/node/208, acesso em 17/08/2009 e ITCP-UFRJ, Portal do Cooperativismo Popular, http://www.cooperativismopopular.ufrj.br/princ_basico.php, acesso em 17/08/2009).

${ }^{78}$ Chamadas "coopergatos" essas cooperativas são formadas e reguladas pela mesma base legal, sem diferenciação frente aos órgãos governamentais e mesmo em algumas estatísticas dessa economia. 
cooperativismo tomado "reformas do capitalismo para moderar a exploração e administrar as relações entre capital e trabalho" (CORAGGIO, 2007, p. 31).

Analisando o capital em sua faceta "globalizada", o mesmo autor identifica que traços conjunturais cheiram a novo, mas a relação de poder entre capital e trabalho permanece a mesma. O que se destaca efetivamente nessa história é a ideologia anticapitalista, contida na economia solidária, que se opõe, também, à estatização da economia ${ }^{79}$ e fundamenta-se na crítica às relações de poder cristalizadas. Também historicamente a resistência oferecida pelos trabalhadores ao sistema teria tomado dois caminhos, o de garantir a sobrevivência, recorrendo à informalidade, sob "formas pré-salariais de exploração", submetendo-se, em desespero, às regras do mercado, e pela organização solidária a fim de recuperar o controle dos meios de produção e reapropriar-se da determinação de seus trabalhos e da direção de suas vidas. Enquanto no primeiro caso, estrondoso até o final dos anos 80, dificilmente cabe a consciência ou o exercício crítico em relação à realidade, no segundo têm maior chance de existirem, embora isso não seja regra. A prática vai construindo novos sentidos à economia solidária e, aos poucos, o movimento passa da "resistência" à "busca de alternativas" (ibidem, p. 32).

O alerta trazido por Quijano, insumo para a questão central sobre a qual se lança essa pesquisa, é que mesmo que o cooperativismo popular seja uma realização de base, cujo traço marcante é a solidariedade, encontra-se distante da superação do capitalismo principalmente porque a identificação ideológica e política daqueles que engrossam as iniciativas solidárias, bem como, o caráter revolucionário de suas visões de mundo, quando existentes, são frágeis. A solidariedade e a cooperação nesses casos, podem não ser genuínas, dotadas de sentido, mas sim uma imposição à entrada em projetos e grupos, e uma requisição de alguns processos do dia a dia do empreendimento, enquanto outras tantas práticas, mesmo no interior da cooperativa, permaneceriam ponderadas pela lógica da competição e do individualismo.

\subsection{Cooperativas endógenas e cooperativas exógenas: mais que um esforço classificatório}

\footnotetext{
79 O Estado, como ator endógeno à relação posta de poder, é alvo das principais reivindicações populares, coordenando a tarefa de estabelecer as regras, os limites, para a exploração e a dominação, ao mesmo tempo em que a legitima. É por isso que Quijano alerta à inconsistência de construir uma outra economia apoiada ao, ou no Estado. Premente é romper com toda uma relação de poder naturalizada e legitimada pela repetição sem acrítica.
} 
A economia solidária desponta, nos anos 90, como um modelo ideal, propositivo, descrição de trajetórias otimistas para que um mundo melhor seja compartilhadamente construído. Foi a partir de 2000, segundo Vieira (2006), que a economia solidária passou a ser um projeto efetivamente em realização, com iniciativas e ações empiricamente verificáveis ${ }^{80}$. Desse ponto em diante teria começado a ser elaborada sua teoria descritiva, além da teoria propositiva de transição. No final desse mesmo ano ganhou força um movimento social global com ações alinhadas às teorias desenvolvidas até em então; nesse momento a economia solidária, na visão do autor, evidencia sua natureza tripla como teoria, movimento social e objeto. Como objeto, desde início, apresentava suas duas faces: as experiências endógenas e as exógenas ${ }^{81}$.

As organizações de apoio, bem como as iniciativas de fora para dentro dos empreendimentos solidários, ganham fôlego com o reconhecimento de que as experiências de economia solidária não surgiam, com o ritmo esperado, do interior do sistema capitalista, do descontentamento e da organização dos trabalhadores. Por isso, passou a entrar em uso o termo “implantação" desses empreendimentos e a discussão a respeito do papel do poder público no fomento à economia solidária foi adensada.

O Primeiro Fórum Social Mundial foi importante marco para a mistura da utopia com a prática, em que as iniciativas em andamento puderam ser postas ao lado das teorias propositivas (VIEIRA, op. cit.). Ao mesmo tempo em que esse diálogo rico foi estabelecido, pôde-se perceber o movimento como um campo de poder em que, à imagem e semelhança dos outros empreendimentos capitalistas, o capital público e privado competem pelas oportunidades de investimento com maior retorno.

A complexidade originada por essas mudanças de paradigma, junto às confusões e aos conflitos conceituais e estratégicos, envolve, como uma das novidades, a opção por enfatizar as experiências endógenas ou as exógenas.

É justamente essa multicomposição da economia solidária e, mais especificamente de seu objeto, que incorrem na falta de rigor das discussões sobre o tema que Vieira (op. cit.) denuncia

\footnotetext{
${ }^{80}$ Olhando para o Brasil, segundo dados da Organização das Cooperativas do Brasil (OCB), a década de 90 foi marcada pelo surgimento em massa dos empreendimentos solidários, 3.340 novas cooperativas foram fundadas nesse período. Em 2003 foram contabilizadas, pela mesma organização, 7.355 cooperativas em atuação no país, isso considerando que grande parte da chamada "vertente solidária" não está incluída nesses números (OLIVEIRA, 2007).

${ }^{81}$ Experiências endógenas são aquelas constituídas como resposta dos próprios grupos à situação de pobreza e desassistência, as exógenas são a resposta ao estímulo à organização autogestionária.
} 
em sua tese de Doutorado. Isso pelos interlocutores não indicarem a qual natureza do fenômeno e de seu objeto estão referindo-se. Assim precisa estar claro qual é o campo de convergência, de intersecção, entre as diversas experiências e suas facetas e quais os pontos de dissonância que precisam ser assumidos e denotados nos textos, pesquisas e discursos em geral.

Focaremos então, nesse tópico da pesquisa, depois de apresentada a economia solidária em sua utopia, teoria e movimento histórico, na compreensão das características marcantes, distintivas e aglomeradoras das experiências endógenas e exógenas. Isso é fundamental na medida em que buscaremos, mais a frente, compreender se o exercício autogestionário vem sendo elemento de fomento à metamorfose da identidade com sentido emancipatório para três cooperados do Grupo Mãos na Massa e em que nos prevenirá do risco de afundar em uma narrativa nebulosa ou muito genérica; é importante considerarmos as condições concretas às quais a experiência específica, vivenciada por esse sujeito, liga-se. Entre elas, sua exogenia. Fato é que parte dessa experiência foi influenciada pela história da cooperativa em formação, e como parte dessa história, seu início de fora para dentro, de um ator externo para o interior do grupo. É preciso lançar luz à base dessa experiência, bem como às suas particularidades e generalidades.

a. A base para a compreensão das divergências e convergências - os percussores da economia solidária

Enquanto teoria, a economia solidária volta-se ao caminho e à natureza da transformação socioeconômica, influenciada por autores conhecidos como seus percussores: Marx, Owen e Yunus. Vieira (2006) a vê composta por três partes: "uma crítica ao capitalismo, uma teoria de transição e uma utopia" (ibidem, p. 2).

A teoria sempre fora, inclusive pelos seus percussores, colocada em função da prática; a economia solidária é movimento social e experiência concreta, realizada por meio de seu objeto, os empreendimentos solidários. Tanto os pontos de convergência, quanto de divergência das duas vertentes do objeto da economia solidária relacionam-se à visão sobre o homem, sobre o mundo, da história que os pensadores que mais a influenciaram propuseram. Comecemos pelos pontos de divergência das experiências endógenas e exógenas, compreendendo as influências de cada um dos dois grupos. Sem seguir ordem de importância, em primeiro lugar tomemos a origem da mudança social como elemento a partir do qual mirar essas experiências: enquanto para Robert Owen e Muhammad Yunus a transformação advém da força de vontade do homem, Karl Marx a enxerga como um desdobramento de conflitos de classe. Enquanto para os primeiros seriam as 
ações práticas derivadas dessa vontade, coordenadas pelo voluntarismo, que guiariam a superação dos problemas sociais, para Marx o homem bem intencionado, individualmente, pouco espaço teria para manobra e não alcançaria mudanças estruturais.

Assim, nesse ponto, visão de Owen e Yunus tem relação direta com a economia solidária de origem exógena; Marx influencia de forma mais aguda as experiências endógenas. A luta de classes pode ser considerada divisor de águas na análise dessas iniciativas, isso porque enquanto para Marx ela é inegável e inevitável, será reposta mesmo quando o modo de produção capitalista for superado, nas novas estruturas de poder que emergirão, para Owen ela decorre da distância excessiva entre capitalistas e trabalhadores e pode ser extinta pela paz entre as classes, pelos bons hábitos e pelo trabalho e comércio justos.

Em relação a essa questão, se no estudo de Vieira (2006) as experiências endógenas parecem assumir a luta de classes como elemento norteador e indispensável às ações da economia solidária, as exógenas vivem uma amenização dessa ideia que decorre, naturalmente, da atuação em conjunto com agentes externos, representantes de outras classes sociais. Portanto, neste caso, a luta de classes não assume de forma clara ou enfática a função de caminho para a melhoria na qualidade de vida e para a libertação.

No que se refere à mudança cultural, como componente indispensável à transformação, as experiências exógenas aproximam-se geralmente à posição de Yunus, isto é, da concepção de que ela pode acontecer de fora para dentro com a assimilação de elementos culturais "superiores" por meio de postulações, do seu ensino. Owen e Marx, ao consideraram que a mudança vem da alteração das estruturas às quais esses elementos culturais estão atrelados, conversam melhor com as experiências endógenas. Para eles os símbolos culturais vinculam-se ao meio hostil em que o ser humano se encontra no sistema capitalista e, assim, apenas seriam modificados pela transformação social. Marx é mais radical ao entender que a mudança social como resultado da práxis, da mudança na organização do trabalho e das condições materiais; a tomada do poder pelos proletários e a eclosão da luta de classes instauraria a mudança estrutural necessária.

É possível que as cooperativas exógenas também sigam essa linha ao tentarem, em primeira instância, a mudança radical na organização do trabalho e a geração de renda, com a esperança de que a partir daí uma cultura diferente possa emergir, com novas relações estabelecidas entre os cooperados, pela nova situação material que se configura. No entanto, é comum que essa cultura diferente, solidária, cooperativa, da abundância, seja defendida por meio 
de exposições, discussões propostas e vivências, jogos e dinâmicas, ao longo do processo de formação do grupo. Partindo de Marx, esse esforço seria pouco efetivo, ingênuo.

Essas são algumas das principais divergências com desdobramentos práticos que podem ser observados e sentidos nos empreendimentos da economia solidária. No entanto, pode-se dizer que elas são conciliadas por uma força maior: a autogestão. Construção e prática central nas experiências endógenas e exógenas, nos dois casos ela seria derivada de um esforço de superação das tradições e de aprendizado de uma forma diferente de atuar. Pela sua prática uma cultura democrática e participativa deve ganhar corpo.

A autogestão também é consenso entre os três autores. Marx, especialmente, defende que seja estendida a todo o mercado, opondo-se completamente ao liberalismo, propondo que ele seja socialmente controlado e submeta-se aos interesses da vida. A importância desse elemento, da autogestão é transversal, como já mencionamos, às vertentes teóricas da economia solidária; ocupa o lugar de elemento coesivo da teoria, do objeto e do movimento: "a autogestão surge como elemento aglutinador das experiências exógenas e endógenas, unificando identidades e relevando suas diferenças" (VIEIRA, 2006, p. 84).

O desafio, no entanto, se mostra um pouco mais duro para as exógenas, chegar à autogestão de fato, na prática, passando pelo desligamento em relação às organizações de suporte, vem se mostrando um processo longo e nem sempre realizável ${ }^{82}$. Mesmo considerando as exógenas, esse desafio continua real: levantamento nacional realizado pela SENAES ${ }^{83}$ em 2006 aponta que 14.555 empreendimentos (67,6\% do 21.859 identificados no levantamento) praticam a participação nas decisões cotidianas do empreendimento e 10.529 (48,2\% do total) tem como realidade a participação dos cooperados na decisão sobre o destino das sobras e fundos ${ }^{84}$.

A dificuldade intrínseca ao processo de formação e de manutenção dessas iniciativas autogestionárias não é decorrente, para os percussores e para os pensadores da economia solidária, de uma possível natureza egoísta do homem. Essa ideia, defendida pelos economistas

\footnotetext{
${ }^{82}$ Entre todos os grupos incubados pela Incubadora Tecnológica de Cooperativas Populares da USP (ITCP-USP), desde 1998, seis atuam autonomamente depois de desincubados (fonte: Nadir Moraes, formadora da ITCP-USP, em maio de 2010), no caso da Incubadora Tecnológica de Cooperativas Populares da GV (ITCP-GV), atuando desde 2001, são três as cooperativas desincubadas (fonte: Felipe Bannitz, coordenador da ITCP-GV em junho de 2010).

${ }^{83}$ Secretaria Nacional de Economia Solidária, vinculada ao Ministério do Trabalho e Emprego.

${ }^{84}$ Website do Ministério do Trabalho e do Emprego: http://www.mte.gov.br/tca_contas_anuais/2006/senaes.asp. Acesso em 08/05/2010.
} 
clássicos, é rechaçada pela compreensão de que o comportamento egoísta, competitivo e individualista é derivado do meio capitalista e das circunstâncias históricas que a produziram. $\mathrm{O}$ ser humano, tanto para Owen quanto para Marx, seria dotado de "natureza plástica", capaz de se formar pelo incentivo de habilidades e potencialidades latentes, com diversas possibilidades, de acordo com o meio. Em alguns pontos da produção teórica da economia solidária, como aponta Vieira (op. cit.), a natureza humana chega a ser tratada como naturalmente cooperativa, altruísta, porém silenciada e violentada pelo sistema socioeconômico em voga.

A influência do positivismo é outro lugar de onde vale olhar as cooperativas exógenas e endógenas ${ }^{85}$. Enquanto nas formadas de dentro para fora, por iniciativas dos próprios cooperados, o positivismo manifesta-se na ideia de que a evolução da tecnologia da informação e o acesso ao conhecimento colaboram com a emancipação e tornam possíveis ações sociais essencialmente novas, nas exógenas serve para legitimar as ações externas de fomento ao empreendimento e à economia solidária como um todo, ancorando a crença de que tais ações sejam efetivas na melhoria da qualidade de vida dos envolvidos e da comunidade.

Vieira (ibidem) analisa também qual seria o Estado ideal frente às demandas e valores da economia solidária e de suas manifestações. Embora haja discordâncias e a diversidade de visões de seus percussores ressoe dentro no movimento, o Estado regulador é o mais aceito. Tanto nas experiências endógenas quanto exógenas, faz-se necessária ou esperada a captação de recursos junto ao poder público, considerada indispensável à competitividade e sobrevivência dos empreendimentos colocados no contexto do capitalismo. Portanto, o Estado mínimo não atenderia ao papel requisitado. O Estado redistributivo também desagrada às duas correntes, seja porque, no caso da exógena, é contraditório à existência e ao fortalecimento do Terceiro Setor, seja porque a autonomia dos movimentos sociais e a independência das iniciativas populares em relação aos órgãos públicos é considerada fundamental pela corrente endógena.

Dessa maneira, o Estado é entendido como ator indireto fundamental ao desenvolvimento da economia solidária pelo seu papel financiador já exercido, mas também como parceiro a ser ainda mais aproximado no futuro. A chave da equação delicada está em exercer essa função da forma mais eficaz e contundente possível, sem ameaçar a autonomia e independência das organizações populares.

\footnotetext{
${ }^{85}$ O positivismo, nesse caso, na proposição de Vieira, (2006), manifesta-se como crença na ciência, no conhecimento racional, na evolução tecnológica, em contraposição à religião e ao misticismo.
} 
A importância da articulação em redes, facilitada pela tecnologia, bem como a inexorabilidade da integração entre a dimensão econômica e a família e comunidade na vida dos indivíduos e na conformação da sociedade são encontrados na obra dos percussores da economia solidária. Marx explicita isso ao colocar que superar o capitalismo não é somente avançar em outro modelo de produção, mas também recuperar a dimensão humana das relações entre os homens. Essa preocupação evidencia-se na economia solidária pela atenção voltada a todos os que se encontram em situações de violência a seus direitos e à sua humanidade, não apenas aos que ficam de fora do mercado de trabalho, homens, mulheres, crianças, jovens, idosos; a mudança nas relações entre os homens é preocupação central, conquistada a partir, mas não somente, de transformações econômicas.

A economia solidária é considerada a "utopia das utopias" por conciliar as propostas utópicas de seus percussores e diferentes movimentos com viés socioeconômico estrutural com base na agência humana. Vieira (ibidem) destaca que embora a bricolagem de utopias variadas seja característica da economia solidária, ela é marcante principalmente nas experiências exógenas. Nesses casos as iniciativas são diretamente influenciadas pelas crenças e linhas de ação das organizações de apoio e dos sujeitos que disparam a formação e acompanham o grupo. Por vezes mais de uma organização está próxima à iniciativa nesse trabalho; é na relação entre a diversidade de culturas e de visões e de interesse imbricados em cada situação que se formam esses empreendimentos.

Como coloca Vieira (2006), como a teoria da economia solidária é formada por uma gama de linhas críticas, de proposições de caminhos a serem seguidos e de utopias de onde se chegar ${ }^{86}$, a prática ganha certa liberdade embasada na bricolagem que pode ser feita pelos agentes em suas aplicações práticas. Os componentes teóricos seriam combinados de acordo com o momento e o campo de debate que se formou, com relativa aleatoriedade na equação formada. As diversas instituições e grupos de economia solidária podem, por vezes, usando mesmos termos e classificando-se nas mesmas categorias, estarem alimentando interesses muito distintos; essa variedade de objetivos tende a ser mais complexa nas experiências exógenas.

No mais, a teoria perde relevância prática na medida em que os projetos costumam ter um horizonte temporal curto, com recursos escassos e metas objetivas a serem alcançadas em prazo

\footnotetext{
${ }^{86}$ Para quem quiser saber mais a respeito, Vieira (2006) propõe, em sua tese de doutorado, um quadro com alguns dos principais autores da economia solidária, as bases de suas críticas, da transição e da utopia que apresentam. Seriam quatro linhas diferentes representadas por Singer, Arruda, Mance e Coraggio/Gaiger (p. 62-63).
} 
pré-estabelecido. Esse é o limite para uma prática vinculada às preocupações teóricas de longo prazo que se coloca para as organizações de suporte, principalmente em relação à utopia. Para os grupos apoiados, o limite se faz de tão concreta quanto: na necessidade de sobrevivência em um horizonte temporal curtíssimo, em que não cabem apego metodológico e reflexões sobre a utopia.

A pergunta em neon é qual a relação dessas influências e características específicas e compartilhadas das experiências exógenas, como a estudada nessa pesquisa, com o potencial de que colaborem para a emancipação e a desalienação dos trabalhadores. Claro é que não há uma única resposta para isso e que diversas outras variáveis aqui não mencionadas têm sua quota de responsabilidade no processo vivido por cada sujeito junto à economia solidária. De qualquer forma a centralidade da questão é irrefutável, mesmo os autores desse movimento, de suas diversas vertentes, concordam que a construção desse caminho, da emancipação e da desalienação, precisa ser buscado pelas experiências em conjunto (VIEIRA, op. cit.).

O alinhamento entre os autores também é real quando se trata da ideia de que as revoluções devem ser feitas “de baixo para cima” (ibidem), isto é, devem nascer dos grupos comunitários e movimentos sociais, a partir de uma demanda ou necessidade compartilhada e conscientemente conhecida que os move. As experiências exógenas fogem desse "ideal" na maior parte das vezes, surgem de um grupo social, sim, mas em respeito, sobre, em relação a outro grupo, posicionado fora do limite daquele que age, que toma a iniciativa. Quais as chances e percursos de apropriação desse ímpeto por parte do grupo que ocupa o palco a partir de então é uma outra questão.

De acordo com a linha histórico-estruturalista, seguida por Singer por exemplo, a classe trabalhadora encontra-se alienada e enfraquecida pela crise neoliberal, o que a dificulta que haja uma reação endógena por parte desse grupo. Assim, a transição dependeria mesmo da iniciativa de militantes ${ }^{87}$ e do apoio do Estado para que os meios de produção sejam conquistados e para que a produção seja autogerida. As experiências exógenas são, portanto, indispensáveis, necessárias ao momento histórico sociopolítico em que estamos. Não se pode dizer o contrário, mas considerando esse contexto, trata-se de voltar esforços para a concretização dos pontos fortes intrínsecos a essas experiências, como a multiplicidade de opiniões, visões, ideias, quando todos os atores efetivamente participam de todo o processo e a possível aproximação entre iniciativas

\footnotetext{
${ }^{87}$ Militante é o indivíduo engajado em um movimento social com vínculo ideologicamente estabelecido.
} 
apoiadas pelas mesmas organizações, passo para a atuação em rede e para uma visão mais geral, menos imediatista e localista da economia solidária.

\section{b. Potencialidades do apoio externo nem sempre exploradas}

O projeto claro de desenvolvimento econômico revela sua importância ao dificultar, como mostra Vieira (2006), a submissão aos projetos, programas e agências externas. Além do desafio de construir esse projeto de forma que represente, de fato, as ansiedades e desejos do grupo, a dimensão de um projeto sócio-histórico transformador pode ser difícil de sobreviver frente às necessidades básicas não atendidas ou precariamente contempladas daqueles que encontram na economia solidária uma alternativa de trabalho, renda e reconhecimento. Entre os militantes e organizações de apoio, as razões para o descomprometimento em relação a uma visão mais ampla, de transformação estrutural, são outras e merecem reflexão a respeito de sua coerência ${ }^{88}$.

Como denuncia Vieira (2006), a metodologia de construção de tipologias da economia solidária tem sido empirista, com base na realidade imediata dos empreendimentos e de suas características distintivas.

Uma das potenciais forças das experiências exógenas reside justamente na diferença de posições em relação ao dia a dia do empreendimento ocupadas pelos militantes e pelos membros do grupo empreendedor. Produzindo diariamente na cooperativa, participando ativamente das tomadas de decisão, adentrando um mundo novo, acontece de a energia ser totalmente canalizada para que esse cotidiano funcione.

Os militantes podem dispor de um distanciamento um pouco maior, olhando para a economia solidária em seus três principais componentes: a produção autogerida como princípio de uma nova percepção sobre as estruturas sociais e para a recuperação do papel histórico dos sujeitos, o consumo solidário a partir da consciência da importância de se mudar hábitos para que uma melhor qualidade de vida seja propiciada a todos, e a educação indispensável para que a cultura de autogestão e a capacidade crítica sejam realidade.

A possibilidade de atuar, logo de início, nessas três linhas é pedir demais para um grupo que se encontra sobrecarregado com as novas responsabilidades, com compromissos ainda

\footnotetext{
${ }^{88} \mathrm{O}$ estudo de caso desenvolvido por Vieira (2006) identifica que ações e pensamentos dos militantes e dos sujeitos envolvidos nos empreendimentos solidários são, por vezes, desencontrados: enquanto os primeiros anseiam pela superação do capitalismo, os grupos querem acessar as benesses do sistema vigente. A consequência é que a absorção ou apropriação dos cooperados em relação ao espírito da economia solidária, dos valores cooperativos, de novas atitudes perante o trabalho e da solidariedade universal parece ser um processo raro, difícil de percorrer e de ser fomentado pelas organizações de apoio.
} 
amedrontadores assumidos recentemente. Pode-se esperar essa posição das organizações de apoio. É por isso que mesmo as experiências endógenas, em muitos casos, buscam apoio das organizações de suporte.

A importância dessas potencialidades é destacada pelo seu papel de catalisadoras das transformações esperadas a partir da economia solidária. Vieira (op. cit.) apresenta entre os elementos catalisadores a formação de redes e a visão crítica em relação à sociedade contemporânea. Uma cooperativa isolada tem grande chance de definhar, em rede sua resistência é adensada, após conectada as cooperativas engendram uma dinâmica de sustentação endógena na rede criada. Quando a sociedade é vista sobre a o prisma da luta de classes, as cooperativas autogestionária ganham conotação política, de organização do trabalhador em prol de seus interesses.

Tanto nas experiências exógenas quanto nas endógenas o apoio externo pode colaborar na resistência em relação aos "arrefecedores" das iniciativas apresentados por Vieira (ibidem), sejam eles de origem interna ou externa aos empreendimentos; entre os fatores internos encontram-se, por exemplo, a carência por conhecimento técnico e gerencial, o isolamento de outras iniciativas e a degeneração da prática autogestionária com o sucesso e crescimento dos empreendimentos solidários. Os fatores de natureza externa às experiências que podem ser destacadas são a oposição do poder privado aos valores e princípios solidários, apresentando resistência à implantação e articulação das iniciativas e as imposições de "cima para baixo" de decisões ou relações de dependência colocadas e mantidas pelo poder público.

O que muda essencialmente nos dois casos é o poder de influência das organizações de apoio. Nascendo por proposição dessas instâncias, a tendência é que, nas experiências exógenas, tais organizações participem ou determinem questões viscerais do empreendimento, como a divisão do trabalho, correndo o risco de inibir a participação dos cooperados nessas decisões. Ao chegarem já com papel de apoio, para suprir deficiências específicas, a relação com as experiências endógenas tende a ser diferente.

Além disso, é possível que as próprias organizações de apoio se percam no caminho em meio a tamanha complexidade e a tantas pressões de interesses já dominantes, como o do poder privado, desviando-se do desenvolvimento das principais potencialidades desse apoio e esquecendo o compromisso com a autonomia dos grupos. Esse é um ponto de atenção, mas que não encontra espaço de discussão nessa pesquisa. 


\section{c. Divergências empíricas entre as experiências endógenas e exógenas}

A primeira fonte de diversidade é o próprio nascimento dos empreendimentos, tanto no que concerne sua faísca inicial, isso é o motivo pelo qual o trabalho foi iniciado, quanto pela forma, o método utilizado para sua formação. Segundo o ATLAS (2006), os motivos mais fortes para a criação das cooperativas populares são:

"alternativa ao desemprego (45\%), complemento da renda dos sócios (44\%) e obtenção de maiores ganhos (41\%). Dois outros motivos têm destaque: possibilidade da gestão coletiva da atividade $(31 \%)$ e condição para acesso a crédito (29\%). Essa situação modifica-se de acordo com as várias regiões. O motivo "alternativa ao desemprego" é o mais citado nas regiões Sudeste (58\%) e na região Nordeste $(47 \%)$. Por sua vez, na região Sul o motivo mais citado é a possibilidade de "obter maiores ganhos" $(48 \%)$ e "fonte complementar de renda" (45\%). Nas regiões Norte e Centro-Oeste, o principal motivo citado é o "complemento de renda" ( $46 \%$ e 53\% respectivamente)" (op. cit.: 26 ).

$\mathrm{Na}$ pesquisa de doutorado de Vieira (2006), estudo de caso junto aos grupos autogestionários em Mato Grosso do Sul, coletivos de produção do Movimento dos Trabalhadores sem Terra e apoiados externamente por outras organizações, foram documentadas algumas diferenças empíricas entre as iniciativas exógenas e endógenas entre as quais retomarei as mais marcantes, que são consideradas nessa pesquisa ao olharmos para o Grupo Mão na Massa. A primeira delas relaciona-se à autonomia e independência ${ }^{89}$ dos coletivos: quando começam regidos por uma organização externa, "de cima-para-baixo", o risco considerável é de que a dependência cristalize-se e até aumente ao longo do tempo, a manutenção do apoio e conquista de novos benefícios pode, inclusive, tornar-se o principal objetivo do funcionamento do grupo.

A não reflexão a respeito do papel dessas organizações, seu papel, por vezes, indispensável, mas também o fato de terem objetivos específicos institucionais, nem sempre alinhados com os do grupo, tende a fomentar a posição submissa dos sujeitos como estratégia para maximizar a ajuda obtida. Por outro lado, um projeto claro, compartilhado de desenvolvimento do grupo, fortalece o grupo em relação aos projetos de outras organizações, possibilitando uma negociação de interesses e o suporte desvinculado da submissão.

\footnotetext{
${ }^{89}$ A importância desse tema é evidente, mas vale ressaltá-la lembrando que autonomia e independência é um dos princípios da economia solidária que vem sido defendido e exercitado desde as origens do movimento, com os Pioneiros de Rochdale. A ideia central é que em acordos e parcerias com outras entidades, inclusive governamentais, ou recebendo capital de origem externa, elas devem fazê-lo em termos que preservem o controle democrático pelos sócios e mantenham sua autonomia.
} 
Em uma lógica semelhante, nos grupos exógenos movimento comum da liderança é o enriquecimento e personalização do poder, isso devido, principalmente, à carência de vivência política dos membros do grupo e à dificuldade ou resistência à rotatividade de funções. Casos esses em que grande parte dos indivíduos se conhece a partir da mobilização da organização que lidera o processo de formação dos empreendimentos, ou, se já se conhecem de outros espaços da comunidade, aprofundam seus laços ao longo da formação. A dificuldade em posicionar-se politicamente diverge das experiências endógenas porque é um percurso comum à luta política para que o grupo chegue, por si mesmo, a lançar-se ao cooperativismo; os exemplos mais evidentes, lembrados instantaneamente, são os das fábricas, declara massa-falida, assumidas pelos trabalhadores depois de uma longa e dura luta pelo recebimento de seus direitos, entre eles o salário, mas também o reconhecimento de si mesmos como seres humanos e cidadãos.

Nos coletivos endógenos o lugar mais comum é que seja praticado o rodízio de papéis e que a vivência política compartilhada, baseada no reconhecimento mútuo e na autoconfiança, sejam empecilhos a abusos das lideranças. Nos grupos estudados por Vieira (2006) a posse igualitária da terra, do capital e o trabalho são a base para a noção e prática da equidade entre os indivíduos. A "pobreza política" dos membros das experiências exógenas ancorar-se-ia, justamente, na percepção de que não se é capaz de fazer algo, de falar, de ouvir, de se relacionar, de que nunca poderia agir como aquele que ocupa o papel de liderança naquele momento. Tratase de uma visão desigual e demérita de si mesmo; da falta de segurança em seus corpos e mentes ${ }^{90}$.

O temor da perda do apoio das agências externas é outro elemento que pode ser encontrado nos empreendimentos de origem exógena enquanto nos endógenos a apropriação efetiva dos meios de produção e do trabalho em si parece ser mais rápida, assim os sujeitos envolvidos sentem mais claramente os benefícios relacionados principalmente à segurança.

\footnotetext{
${ }^{90}$ Para essa compreensão a referência é Honneth (2007) ao tratar três níveis de reconhecimento, sendo o primeiro o amor, o segundo a da moralidade e das leis e, por fim, o da solidariedade. Os tipos mais básicos de humilhação privam os serem humanos de "uma parte de sua confiança elementar em seu mundo" (ibidem, p. 85). O contrário, a relação de reconhecimento positivo nesse nível mais básico, do cuidado emocional (que Hegel chama amor) proporcionaria o desenvolvimento da autoconfiança. É a partir daí que o sujeito pode entrar na arena da luta pelo reconhecimento na esfera das relações legalmente fundamentadas, pelos direitos materiais e sociais universalizados, e na instância da autorrealização, pelo reconhecimento de sua individualidade que é possível pela relação de solidariedade. Ao incorporar o princípio da diferença igualitária, essa relação permite aos indivíduos a autoestima originária do reconhecimento de que suas experiências e habilidades particulares têm valor para o grupo.
} 
Diferentes níveis de crítica ao capitalismo foi outro ponto de análise encontrado por Vieira (2006). Essa posição e exercício constante em relação ao sistema são entendidos pelo autor como fundamentais para que a emancipação do trabalhador possa ser trilhada por representar a porta pela qual se pode sair do quarto escuro em que a culpa pela própria situação de pobreza tortura do indivíduo. A libertação dessa culpa, ideologicamente disseminada, tem relação direta com um novo nível de autoestima, além da possibilidade de engajar-se ativamente em uma luta consciente por condições diferentes de trabalho e de vida.

Para Vieira (op. cit.), a crítica ao capitalismo é tão ou mais importante que a própria proposta de mudança: “a crítica é, em si, uma emancipação, ao desnaturalizar um conjunto de proposições naturalizadas que cegam, oprimem e excluem" (ibidem, p. 383).

A conclusão é que nos empreendimentos exógenos essa crítica é mais difícil de ter lugar; as possíveis razões para tanto passam pelo desejo e pelos planos de voltar a trabalhar em organizações heterogestionárias, no formato de emprego, e pela possibilidade de que uma hierarquia seja estabelecida em relação à organização de apoio, mantendo a lógica do sistema vigente. Os endógenos, em contraposição, enxergariam os valores e práticas capitalistas como opostos às suas crenças e práticas (ibidem), o que, em parte, decorre da história de conflitos com os patrões, às humilhações vividas coletivamente e à recomposição possível em grupo. Nesses casos a organização cooperativa nasce de um movimento político, é fruto da ação política de sujeitos que enxergam outras possibilidades e engajam-se em sua construção.

Diretamente relacionada à visão crítica em relação ao status quo, e tão relevante quanto, coloca-se a luta de classes. Derivado desse exercício crítico, esse elemento apenas tem espaço nas iniciativas endógenas, chegando, mesmo nesses casos, a parte dos cooperados. Para Vieira (op. cit.) a luta de classes poderia ser apropriada pelos sujeitos a partir de um longo período de formação crítica, a partir de "projetos pedagógicos revolucionários”. Forte aglutinador dos trabalhadores, catalisador das relações de solidariedade e impulso para o afastamento da competição intraclasse, esse elemento merece fazer parte dos planos de formação, alvo da metodologia das organizações de apoio. "O desafio é como ensinar, de cima-para-baixo, luta de classes, crítica ao capitalismo e a noção de barreiras estruturais" (ibidem, p. 88).

Como consequência das diferenças em relação à visão crítica ao capitalismo e à consciência sobre a luta de classes, as interpretações sobre razões de fracasso ou sucesso dos empreendimentos solidários também apontam em direções distintas. Nos grupos endógenos 
tende-se a ter maior consideração aos fatores estruturais, empecilhos à viabilidade econômica dos negócios, que não podem ser superados por meio da boa gestão. Já nos exógenos, o comum parece ser o entendimento do insucesso como inexperiência, ineficiência, fragilidade gerencial dos grupos. A visão míope, circunscrita ao negócio, repercute na reafirmação da ideologia individualista, de que as oportunidades são dadas e o sucesso depende então do desempenho de cada um e do grupo; a responsabilização do indivíduo é reafirmada, além do peso excessivo sobre os ombros dos cooperados, esse pode ser um caminho perigoso de legitimação do poder baseado no conhecimento técnico, da competição em vez da cooperação, e de implosão dos laços grupais.

Pode-se imaginar, seguindo a mesma linha de raciocínio, que enquanto nos grupos endógenos a busca seja por superar o caráter intersticial da economia solidária, propondo mudanças estruturantes, exigindo o rompimento do equilíbrio de forças posto, os exógenos tenham planos de ocupar esses interstícios, essas arestas deixadas pelo sistema capitalista (VIEIRA, 2006). Processo sem confronto, sem incômodo, submisso, por vezes fortalecendo a lógica vigente pela colaboração com o disfarce de uma rachadura que poderia correr as vigas, ruindo a organização socioeconômica presente: o descontentamento originado pela situação de pobreza material, simbólica, afetiva, humana.

Os militantes carregam o elemento utópico nas experiências exógenas, são eles quem tem uma visão crítica sobre o capitalismo e reconhecem a luta de classes. É a utopia que move o trabalho dos agentes das organizações de apoio. Tendo em vista benefícios no nível individual, de curto prazo, sem vislumbrar mudanças socioeconômicas, o que há entre os cooperados são sonho de inserção no mercado de trabalho, de acesso ao capital e ao reconhecimento por ele possibilitado. A utopia está vinculada à percepção de que a condição individual está condicionada por determinantes estruturais (VIEIRA, op. cit.).

Os grupos exógenos distanciam-se da teoria propositiva da economia solidária, não refletem empiricamente os argumentos de crítica, utopia e transição socioeconômica discorridos pelos autores como indicativo de caminhos e práticas (ibidem).

\section{d. Convergências empíricas entre as experiências endógenas e exógenas}

Com base nas definições sobre o cooperativismo popular propostas por alguns atores, entre eles Guimarães (1998 e 1999), Singer (2000 e 2002), Tiriba (2000), Souza (2000) e Gaiger (2000), indica-se que a identificação de uma cooperativa popular dá-se por meio das suas práticas no campo econômico, social e político. Esse exercício comum é que faz dos cooperados um 
grupo e coloca-os no papel de atores de suas próprias ações. Olhando especificamente para as cooperativas endógenas e exógenas, é evidente que há um eixo estrutural, identificador, comum entre os diversos coletivos refletido nos traços transversais às vivências e em suas repercussões aos sujeitos cooperados.

Muito importante, ponto de convergência entre as duas experiências, parece ser o enfraquecimento da razão instrumental nos grupos solidários. Abre-se oportunidade, efetivamente, para que uma nova forma de pensar, agir, relacionar-se seja experimentada; os sujeitos passam a atuar mais com foco na relação por si do que pela condição objetiva e interesseira presente em determinadas situações. O sentido de universalidade parece mais difícil de conquistar, ainda mais nos grupos exógenos, embora tenha sido identificado, timidamente nas experiências estudadas por Vieira (2006).

A não condicionalidade, a gratuidade, nas relações que aos poucos vão se estabelecendo nos grupos é condição para que a organização produtiva tenha como base a aceitação e até valorização das diferenças individuais, flexibilizando as relações de poder, ampliando a percepção para novos conhecimentos, competências e habilidades que passam a ser valorizados. Assim, essa condição, que pode ser alcançada tanto pelas experiências endógenas quanto exógenas, serve como proteção, salvaguarda, para a governança democrática e participativa das cooperativas. O desafio é como colaborar com o seu surgimento, ampliação e consolidação, isso porque não se trata de um processo que possa diretamente fomentado, mas que geralmente é derivado de exterioridades, as quais também compõem a identidade dos cooperados, e que indicam um comportamento solidário, como a religião.

É por isso que Vieira (op. cit.) afirma o limitado escopo de mudança cultural da economia solidária; essa transformação deriva de processos sócio-históricos. A necessidade imediata dos indivíduos é a realidade aterradora, capaz de esmagar qualquer utopia. A superação da razão instrumental deve, dessa forma, ser trabalhada junto com alternativas econômicas, em uma formação contínua e prolongada que propicie a vivência empírica da cooperação em paralelo ao fortalecimento da viabilidade do empreendimento, de uma visão de negócios que propicie o incremento significativo na renda e melhora efetiva da qualidade de vida dos cooperados e de suas famílias.

Compartilhada também, em geral, pelos empreendimentos solidários, a fraca articulação entre si é comumente vinculada à falta de estímulos à formação de rede por parte das 
organizações de apoio e militantes da economia solidária e do Estado. O fato é que há dificuldades concretas: o alto preço dos meios de comunicação e transporte e a competição de negócios que se encontram próximos. As famílias em situação de pobreza e muitos dos grupos da economia solidária não têm acesso a computador e internet, por exemplo, a tecnologia ainda é cara para essa parte da sociedade. Em relação à concorrência, embora a solidariedade seja exercida internamente, do lado de fora são as leis do capitalismo que continuam dominando e é nesse sistema em que os próprios grupos precisam sobreviver; na lógica capitalista não há espaço sob o sol para todos.

Nenhum dos tipos de experiência, nem endógena, nem exógena, parece conceber fronteiras definidas entre a economia solidária e a capitalista. Reconhece-se que as cooperativas são diferentes das empresas capitalistas, mas não por se tratar de uma essência distinta, de valores voltados às relações humanas e não à acumulação do capital. A escolha entre fazer parte de empreendimentos capitalistas ou solidários é determinada principalmente pela renda obtida e por outros benefícios práticos da posição ocupada. Os princípios entram depois na balança. A participação em projetos de economia solidária não se dá pela ideologia ou cultura, mesmo que os indivíduos estejam engajados no trabalho cooperativo e reconheçam suas vantagens, é certo que isso pode ser superado por um bom salário no mercado formal de trabalho.

O apoio do Estado é esperado, ansiado por todos os grupos. Enxergando a responsabilidade pelo combate à pobreza nessa instância, espera-se que haja investimento direto nos empreendimentos, seja em treinamento, em equipamentos ou capital inicial e de giro. Essa é uma visão arraigada e alimentada pelo discurso do Estado e das agências de apoio, assim como o olhar instrumental voltado à educação. O posicionamento de longo prazo é atravancado pelas necessidades do agora, imediatas, bem como pelo modelo de aprendizagem e de formação que se instituiu na organização social moderna, reafirmada contemporaneamente, e que serve como formação de mão-de-obra para o trabalho heterogestionário.

Além de haver práticas pedagógicas revolucionárias oferecidas, é necessário, para mudar essa prática pedagógica, que os envolvidos tenham tempo livre para tanto e certa abertura para deixar-se envolver. "É preciso desenvolver também, dentro desses movimentos sociais, discussões, debates e posteriores projetos que visem à 'superação radical' dessa forma de sociabilidade." (TOMÉ, 2005, p. 10). 
Vieira (op. cit.) reconheceu como resultados positivos indiretos os dois tipos de iniciativas à ampliação do capital social na comunidade e relacional no grupo, o fortalecimento da autoestima $^{91}$ e o empoderamento dos sujeitos. A capacidade de reivindicação de direitos, do respeito, do reconhecimento, advém desse empoderamento e abre novas possibilidades na vida da comunidade pelo acesso às instâncias de poder, legitimadas por sua representação de determinados poderes institucionalizados, assim como muda as relações domésticas. O capital social, na visão do autor, propicia que os indivíduos componham seu "fundo de trabalho", enquanto a melhoria na autoestima é considerada condição indispensável a qualquer mudança, à defesa dos próprios interesses, à luta por qualquer direito ou sonho.

Outros benefícios indiretos dessas experiências são: a humanização das relações humanas, o resgate da capacidade inventiva dos homens e mulheres e extensão das redes reciprocitárias (VIEIRA, op. cit.). A redução da incerteza econômica é um resultado direto que também merece atenção, nem sempre alcançado, já que a competição no mercado capitalista é ferrenha, geralmente desempatada pela capital disponível para investimento, e que ainda não é uma prática comum o estudo de viabilidade dos empreendimentos e o planejamento de médio e longo prazos. No entanto, quando alcançado, esse resultado, como já mencionado anteriormente, permite que o desespero pelo atendimento às necessidades de sobrevivência seja ultrapassado e que os sujeitos possam lançar-se à ação.

As mulheres, empoderadas, com participação econômica no dia a dia familiar passam a colocar-se de outra forma em casa, alterando a relação de poder estabelecida com o companheiro. Para elas, outro benefício é a possibilidade de melhor conciliação do trabalho fora e do trabalho em casa: a divisão de tempo e energia pode ser feita de acordo com a priorização do indivíduo, por meio da negociação cotidiana com o grupo. O resultado é redução da angústia e melhoria da qualidade de vida, maior convivência com as crianças, com os idosos e com a comunidade em geral.

Por fim, como não poderia deixar de reforçar, o núcleo comum das teorias e das práticas da economia solidária é a autogestão ${ }^{92}$. Consensualmente importante para liberação, emancipação

\footnotetext{
${ }^{91}$ A compreensão do conceito de autoestima aqui, nessa pesquisa, se dá com base em Honneth (op. cit.), na ideia da segurança mínima, corporal e afetiva, possibilitada pelo reconhecimento no nível das relações primárias.

92 A prática da autogestão é ainda mais complexa do que a teoria que a propõe e descreve. Os custos imbricados nessa forma de gestão são altos, envolve mais tempo investido na tomada de decisões e tarefas administrativas, pode derivar em desgaste das relações sociais e o controle se faz bem mais difícil (VIEIRA, 2006). De qualquer forma,
} 
e melhoria da qualidade de vida dos trabalhadores, a autogestão é o eixo que liga todas as iniciativas em uma coluna vertebral. Pode ser aplicada à produção, ao consumo e à educação, gerando convergências e ampliando a experiência.

A aceleração e aprofundamento da autogestão e das experiências solidárias como um todo passa pela conquista de força política, com princípios e ações alinhados a políticas públicas nacionais e internacionais. Esse é o maior desafio, no nível da meso-política, colocado à economia solidária no contexto atual e que só pode ser enfrentado pela articulação das organizações envolvidas, tanto os empreendimentos coletivos quanto as de apoio, adensando a crítica e a proposta de transformação estrutural.

Voltando-nos à micropolítica, o desafio implica atuar contra o processo degenerativo das habilidades autogestionárias ao qual viemos assistindo nos últimos séculos. Religião, nacionalismos e localismos perdem gradualmente a força de impulsionar o compromisso grupal e a gratuidade; a estratégia de resistência e avanço da economia solidária precisa passar pelo fortalecimento de resquícios de comportamentos solidários e cooperativos para que processos endógenos individuais e coletivos de mudança possam impulsionar a transformação socioeconômica.

As atividades econômicas desenvolvidas pelas cooperativas populares têm se mostrado de baixa remuneração, poder restrito de melhora significativa no acesso a bens materiais e serviços. Assim o maior potencial da economia solidária tem se mostrado a reivindicações de direitos, agregando uma grande diversidade de direitos reconhecidos como legítimos em uma luta comum.

Porém, importante terminar com algo que une todos os sujeitos desses coletivos, todos nós, elemento que marca a humanidade por sua força mobilizadora, sem limites, capaz de romper as amarras, mesmo que de aço: o sonho. A inclusão socioeconômica compõe o sonho dos homens e mulheres de qualquer tipo de iniciativa. Inclusão, como não poderia deixar de ser, já que é nesse mundo em que vivemos, capitalista, afirmada pela posse de bens materiais, e por tudo que o dinheiro pode comprar, inclusive educação e saúde (VIEIRA, 2006). O valor simbólico do acesso a essas mercadorias tem como balizador, nos assentamentos, o intercâmbio com o mundo de fora, a compra realizada fora da comunidade; o nível de inclusão quando a troca é feita do lado de

alguns desses custos também estão sendo enfrentados pelas empresas capitalistas, as quais na era da flexibilidade e da "autonomia" instauram grupos de trabalho com pretensão democrática e cocriativa. 
dentro não é satisfatório, perdendo-se a oportunidade de fortalecer os produtores e as relações entre os cidadãos da mesma comunidade.

Está claro que as experiências da economia solidária, entre elas as cooperativas populares, configuram-se instâncias sociais e econômicas em que se dá o exercício da cooperação, da solidariedade, das práticas de democracia e de ajuda mútua, em maior ou menor grau, mas sempre presente. Aparecem como iniciativas efetivas na minimização da falta de trabalho, bem como na proteção social, se não pela renda, pelas relações estabelecidas dentro na comunidade. $\mathrm{O}$ avanço das relações de cooperação e de solidariedade está diretamente vinculado ao dia a dia das cooperativas populares, ao exercício cotidiano da autogestão.

A diversidade que marca outros elementos desses empreendimentos não é aqui encarada com pesar ou reprovação, mas sim como riqueza importante que faz com que o caldo da economia solidária seja mais grosso e nutritivo. É preciso, no entanto, assumir que implica também uma complexidade extra que precisa ser trazida para o bojo da análise; ainda mais quando se fala da relação dessa realidade objetiva com a subjetiva daqueles que fazem da teoria prática, do movimento, concretude.

Vale dar um fechamento, pelo menos por enquanto, para essa discussão com uma síntese das externalidades e internalidades das experiências endógenas e exógenas da economia solidária. Abaixo fica claro em que pontos os dois tipos de empreendimento aproximam-se e em quais se distanciam. Quanto mais ampla a área ocupada mais acentuada é determinada característica naquela iniciativa. 


\section{GRÁFICO 1}

\section{Internalidades e externalidades - experiências endógenas e exógenas}

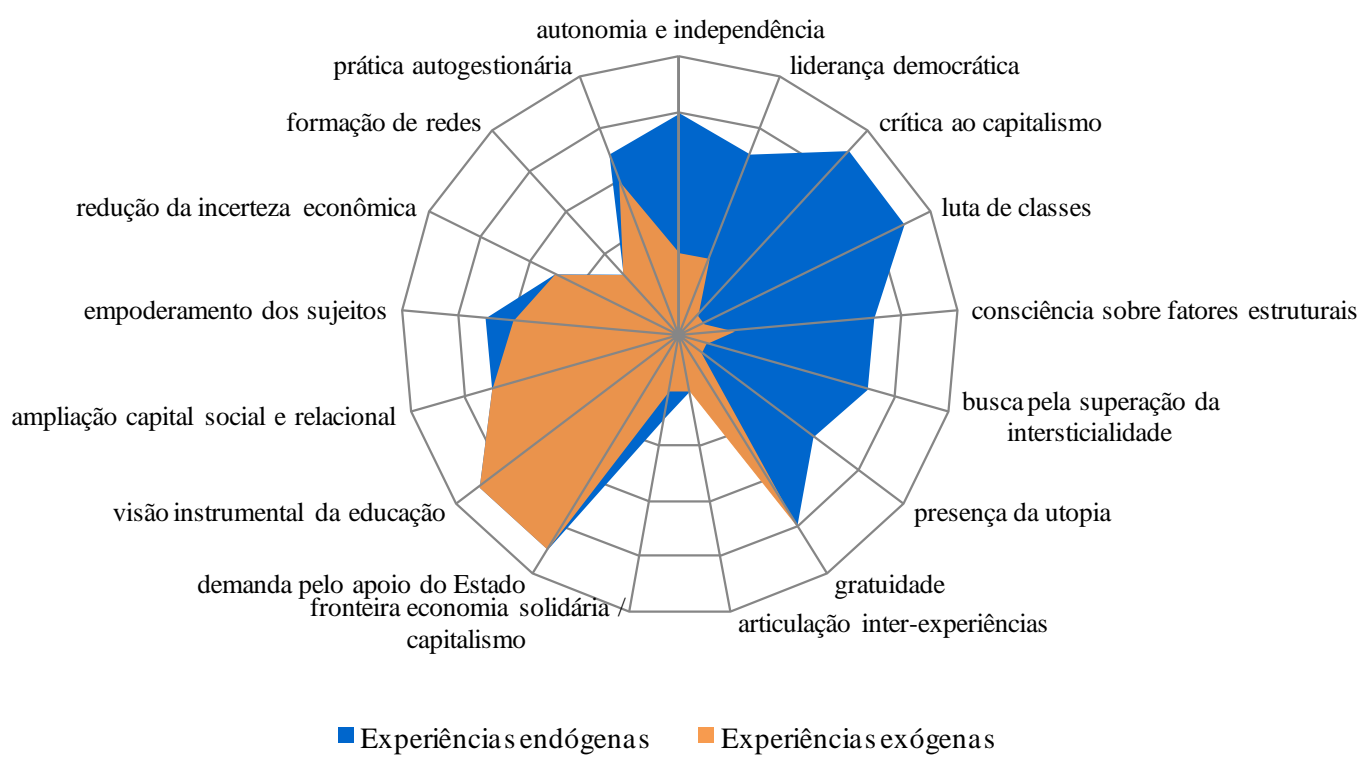

Fonte: autoria própria

\subsection{Cooperativismo e Intersubjetividade - os sentidos da autogestão}

“(...) ao lado da economia das relações amorosas, a dinâmica das relações sujeito-organização do trabalho poderá ocupar um lugar significativo no processo de reapropriação e emancipação (HABERMAS, 1976) de um homem sempre em luta contra a ameaça de tornar-se doente, sempre em luta para conservar sua identidade na normalidade, sempre em busca de trazer uma contribuição original à construção social, num movimento que (...) parece tão essencial quanto aquele que anima sua demanda de amor." (DEJOURS e ABDOUCHELI, 1994: 143).

A autogestão é eixo central do cooperativismo desde sua inauguração, na Grã-Bretanha, com os Pioneiros Equitativos de Rochdale. Como principal regra de funcionamento das cooperativas, a autogestão garante que não sejam repetidos os mesmos vícios de outras formas organizacionais 
(BEATRIZ, 2007), por meio da fundação de um processo organizativo em que se busca a simetria entre o poder econômico e o político ${ }^{93}$ (SATO \& STEVES, 2000).

A gestão democrática baseada no voto de igual peso de todos os cooperados ultrapassa os rituais, assembleias e os processos do negócio, incorre no nível da intersubjetividade, do universo simbólico e de representações individuais e compartilhado, em diversos sentidos; esses são os sentidos da autogestão ao qual voltamos nossa atenção.

Como espaços de sociabilidade, as cooperativas populares podem fortalecer relações sociais diferentes das hegemônicas (OLIVEIRA, 2007). Parte-se do rompimento da base de sustentação da competição: não é mais necessário que um se mostre melhor que os outros para que o trabalho e renda sejam garantidos, pelo contrário, quanto melhor todos forem, maior o ganho de cada um. Retoma-se o espaço, ainda, para a criação de laços, já não há o risco de demissão ou desligamento surpresa ${ }^{94}$, o trabalhador é dono daquilo que constrói, sócio de tantas outras pessoas que possuem os mesmos objetivos. São, desde início, aliados.

De tal maneira, a cooperação está ancorada na autogestão, é a partir dela que deixa de se tornar utópica para fazer parte da cultura da organização, prática individual e coletiva. Derivam também daí as relações sociais e os valores de comensalidade e de reciprocidade: recursos fluindo de acordo com as disponibilidades e necessidades, bilateralmente, sem que haja acordo prévio de intercâmbio, em prol da vida (BEATRIZ, op. cit.). A autogestão e a cooperação são aprendizados alcançados no dia a dia da cooperativa; os cooperados tornam-se efetivamente membros do grupo ao atuarem participativamente em conjunto com os outros cooperados em prol dos interesses coletivos entre os quais estão representados seus próprios interesses. De acordo com Esteves (2004), quando se tornaram membros plenos da cooperativa, passando pela socialização que isso requer, significa que os sujeitos-cooperados desenvolveram "recursos psicossociais" que propiciaram a composição das “condições simbólicas” de cooperado.

Como sabemos, no entanto, a participação e a construção da prática autogestionária requer alta complexidade de formação do empreendimento e grande inflexão cultural para os

\footnotetext{
${ }^{93}$ Esteves (2004) considera o processo organizativo autogestionário como um fenômeno social e técnico na medida em que os cooperados trazem para a cooperativa determinadas bases técnicas e econômicas: conhecimentos, cultura, práticas, vivências que compõem a história dos sujeitos e que delimita as possibilidades de alcançarem seus objetivos no contexto socioeconômico do qual fazem parte. As cooperativas são, assim, vistas pelo autor como fenômenos "sócio-técnicos".

${ }^{94}$ Para Singer (2002), aí reside a capacidade da economia solidária de unir a forma industrial de produção e a vida comunitária: a construção de relações de confiança, estáveis, permite a segurança de que haverá apoio quando for preciso, de que os momentos difíceis serão suportados com a solidariedade do grupo.
} 
trabalhadores envolvidos, historicamente educados e formatados para a relação hierarquizada, para o cumprimento de tarefas. O desenvolvimento dos "recursos psicossociais" mencionados por Esteves (op. cit.) nem sempre é um processo que se inicia com a constituição do empreendimento, naturalmente a partir da configuração do grupo.

"É um trabalho extra, que exige disponibilidade interna para passar alguns meses sem provavelmente receber pagamentos ou, quem sabe, somente para subsistência básica; exige persistência e acreditar que neste novo momento, quem está gerindo os negócios da cooperativa são os próprios trabalhadores e não outro 'alguém' que irá ser responsabilizado se algo acontecer errado".

(ibidem, p. 37)

\section{a. Condições para a autogestão}

Ao mesmo tempo em que consiste em um conjunto de princípios, de igualdade, de autonomia, de coconstrução, de não hierarquia, a autogestão configura-se em práticas sociais que concretizam esses princípios (OLIVEIRA, 2007). Exemplo são os espaços de decisão que extrapolam as instâncias formais, das reuniões e assembleias, e chegam aos processos cotidianos de negociação, de troca de ideias e de replanejamento do trabalho (SATO e ESTEVES, 2002).

O processo de organização autogestionária fundamenta-se na "negociação discursiva dos significados" entre os cooperados a partir da qual as decisões são tomadas e as estratégias coletivas e pessoais são construídas e reconstruídas. Isso se dá com a troca permanente entre o espaço interno da cooperativa e o externo, ambos em mudança contínua (ESTEVES, 2004). Assim, a autogestão parte das condições dadas em determinado tempo-espaço, significa a liberdade de reflexão, negociação, decisão coletiva frente as mais diversas situações, considerando o todo um contexto; espaço para a criação, construção de alternativas inusitadas dadas circunstâncias encontradas.

A autogestão traduz-se de forma orgânica no cotidiano ${ }^{95}$ do empreendimento e na vida dos trabalhadores-cooperados, no entanto, Sato e Esteves (op. cit.) alertam para algumas condições que precisam ser atendidas para que essa transposição, da intenção para a vivência, possa dar-se. Podem ser sintetizadas em quatro requisitos:

\footnotetext{
${ }^{95}$ Para Spink (1996), o cotidiano é o lugar em que todos se reconhecem no sentido comunicativo.
} 
- Formação de grupo - é imprescindível que um grupo de fato seja formado, para além da reunião formal dos trabalhadores por verem essa como única esperança à situação em que se encontram.

- Controle pelos trabalhadores - para que a participação seja efetiva, para que se sintam capazes de interferir, contestar, propor o caminho da cooperativa e da organização do trabalho, faz-se necessário que o controle sobre o processo produtivo e sobre a gestão do empreendimento esteja de fato nas mãos dos trabalhadores.

- Espaço para o conflito e para a discussão - a possibilidade de debate público em que os diversos interesses e visões são postos em jogo é fundamental para se reconhecer e ser reconhecido pelo outro e para que chegue a um novo nível de consciência.

- Plenitude da autogestão - a adoção de outros vínculos de trabalho, em paralelo ao cooperativismo, prejudica a construção da autogestão na medida em que quebra os vínculos de igualdade, replica relações hierárquicas capitalistas, enfraquece a cultura solidária em construção gerando um modus operandi para dentro do grupo, outro para fora e limitando o potencial de transformação dos sujeitos envolvidos.

- Encontro da gestão e da produção - a união daquele que produz com o que gerencia a cooperativa no papel do trabalhador-cooperado é faísca que gera a implosão da crença sobre a distância entre gerenciar e administrar e produzir e trabalhar.

- Alternância de posições - o rodízio de tarefas é um dos incentivadores ao que Esteves (2004) identificou como uma das condições simbólicas para a autogestão. A alternância de posições repercute na capacidade de reconhecer diversas posições de interesses dentro da cooperativa e, a partir daí, transitar entre elas, colocar-se no lugar dos outros, concreta e simbolicamente, experimentando outros interesses. Essa condição simbólica permite que os cooperados identifiquem essas posições de interesses presentes nas negociações, tenham uma visão mais ampla para a participação nas discussões e tomada de decisões tanto no empreendimento quanto em suas vidas pessoais, replicando a experiência.

Parcial ou quase que totalmente em prática, a autogestão relaciona-se com fenômenos sociais e intersubjetivos que merecem nossa atenção. A ideia é que cumpridas as condições acima, o exercício autogestionário desperte transformações nos sujeitos que o fazem e no mundo que compartilham. O resgate do trabalho de alguns autores que discutem esses desdobramentos a partir de estudos de casos nos vale para um panorama sobre o potencial da vivência 
autogestionária, bem como alguns riscos e dificuldades que parecem comuns a diversas experiências.

\section{b. Autogestão e necessidades básicas}

Ao mesmo tempo em que amedronta por incorrer em grande carga de responsabilidade, tornar-se sócio-proprietário da cooperativa vai na contramão de um outro medo, o mais assustador da sociedade da mercadoria: a demissão. A autogestão implica que as decisões não são mais tomadas de "cima-para-baixo" e cada um pode participar da construção do dia seguinte, de seus destinos.

A necessidade de sobrevivência é compartilhada por todos os homens, animais, seres desse mundo, mas a luta diária pela sobrevivência é vivida pelos trabalhadores explorados, malremunerados, precarizados ou desempregados. Ponto este que agrega os cooperados em torno de algo desse primeiro e poderoso objetivo em comum: garantir a sobrevivência própria, da família, da espécie ${ }^{96}$. A partir dele são ponderados os conflitos e disputas internas, de acordo com o risco de fortalecimento ou a capacidade de enfraquecimento econômico do empreendimento que cada um dos possíveis caminhos traz (OLIVEIRA, 2007).

Presente desde o marco zero dos empreendimentos solidários, a luta pela sobrevivência aponta a cooperativa como estratégia para sair do emprego precário ou do desemprego. Daí em diante a experiência é diversa para cada um, são infindas as variáveis, entre as quais, concretamente, encontra-se a renda gerada pelo trabalho cooperado; enquanto nas cooperativas em que a sobrevivência dos trabalhadores e de suas famílias é assegurada Oliveira (ibidem) deparou-se com a repulsa ao trabalho assalariado heterogestionário pela indisposição a voltar a situações de subordinação que já viveram, nos casos em que os cooperados ainda encontram dificuldade em cobrir os custos básicos de sobrevivência com a renda gerada pelo trabalho cooperado, o emprego é visto com outros olhos. A melancolia derivada da distância em relação à segurança propiciada pela legislação trabalhista, aos benefícios como fundo de garantia, férias e décimo terceiro salário, é uma constante.

${ }^{96}$ Em metáfora apresentada por Esteves (2004, p. 159) a partir de frase dita por Neide, ex-cooperada da ITACOOPERARTE, durante Curso de Formação em Cooperativismo (1999), a cooperativa é identificada com o "barco da sobrevivência", as atividades desenvolvidas nesse "barco" seriam responsáveis pelo atendimento das necessidades dos cooperados e de suas famílias; os cooperados estão todos juntos, no mesmo barco, seguindo na mesma direção. 
De qualquer forma, é por essa dependência da atividade econômica da cooperativa para a sobrevivência que Juvenal (2006) entende que, em um primeiro momento ao menos, a autogestão não é revolucionária. Diferente da construção de uma nova cultura, no início os esforços voltamse para a melhoria da eficiência do empreendimento no âmbito do capitalismo "como forma de viabilizar a dignidade do trabalhador" (ibidem, p. 13).

Outra luta compartilhada, que se aplica às condições básicas de sobrevivência (simbólica), oferece sentido, ao mesmo tempo em que recebe reforços, a partir da prática autogestionária: a por reconhecimento. Não apenas espaço para que diversas habilidades sejam desenvolvidas, inclusive as que nem os próprios sujeitos sabiam que tinham, a vivência da cooperativa propicia o estabelecimento de vínculos e de laços afetivos. A possibilidade de reconhecimento é aberta em três níveis: logo de cara o legal, pelas regras estabelecidas na cooperativa todos são iguais em potencial e em importância, cada um é indispensável e único; ao longo da convivência o reconhecimento afetivo e; em mais longo prazo, o solidário, ancorado na consciência a respeito da unicidade de cada sujeito e do que ela representa de riqueza e oportunidades para todo o grupo (HONETH, 2007). Este é o reconhecimento em seu nível mais avançado, complexo, e com impacto na autoestima do trabalhador-cooperado.

A luta por reconhecimento é entendido por Axel Honeth (op. cit.), a partir de Hegel, como a base para o estabelecimento de uma comunidade moral. O conflito social, o embate, cria as condições para o reconhecimento mútuo, não pacífico ou natural, um reconhecer-se pela demonstração das potencialidades, pelas similaridades, mas principalmente pelas diferenças. $\mathrm{O}$ reconhecimento alcançado reciprocamente, pela identificação das habilidades únicas e insubstituíveis permitida pela cooperação, é alimento para a intersubjetividade, para a autoconfiança, autorrespeito e autoestima.

Portanto, da luta pela sobrevivência também faz parte a luta simbólica, a contribuição para a reprodução social é necessária para que a estima-social não seja corroída ou, em alguns casos, para que possa ser reconstruída. A autoconsciência, a partir da visão de Hegel, depende dessa experiência de reconhecimento social, plataforma para que os sujeitos passem a reivindicar a aceitação de sua própria identidade. A partir daí é possível a indignação diante da desigualdade de material, de oportunidades, de reconhecimento, a luta pode então tomar as formas da luta pela redistribuição (HONETH, op. cit.).

\section{c. Autogestão, capital relacional e capital social}


A vivência do dia a dia da cooperativa reflete no engajamento dos sujeitos, que em parte nunca haviam se envolvido em movimentos para mudança da realidade local, em ações coletivas e discussões sobre as condições de vida dos cidadãos da comunidade. Tanto para Oliveira (2006) quanto para Ferraz (2005) essa noção é verdadeira, com base na auto-organização de grupos locais constituem-se movimentos sociais os quais se direcionam para a constituição de espaços de democracia direta na vida comunitária.

A constatação de Benedito Oliveira (2006) ao estudar casos de cooperativas no Rio de Janeiro, estende-se à noção de que, ao proporcionar acesso ao trabalho e à renda, as cooperativas populares acabam por produzir e utilizar capital social $^{97}$ ao se articularem em redes de solidariedade. Quanto mais ampla esse rede maiores as possibilidades de ação em outros níveis, além do local, em prol da melhoria na qualidade de vida das classes populares ${ }^{98}$.

A pesquisa empírica desse mesmo autor revelou que, a partir do engajamento nas cooperativas, os indivíduos passaram, gradualmente, a buscar outros espaços na comunidade, a prática da solidariedade extrapolou as fronteiras da cooperativa repercutindo em iniciativas diversas de apoio e ajuda mútua na comunidade. Assim o capital social seria fortalecido; pelos elementos propulsores desses empreendimentos e da expansão do capital social serem os mesmos, a cooperação ${ }^{99}$ e a solidariedade ${ }^{100}$ na luta contra o desemprego e a carência por reconhecimento social, esses empreendimentos seriam unidades "produtoras de capital social"101 (ibidem, p. 129).

A prática da autogestão e da democracia participativa constitui elemento básico para o exercício da cooperação como ação política. Em sua pesquisa de campo, Oliveira (2006) observou mudanças na forma dos cooperados agirem em suas casas e na comunidade. Quando os membros da cooperativa são vistos como uma "espécie de família" (ibidem, p. 129), a

\footnotetext{
${ }^{97}$ Capital social pode ser definido como o conjunto de relações sociais que propiciam melhoria de qualidade de vida para os envolvidos, por meio do acesso, que possibilitam, a recursos materiais e imateriais.

${ }^{98}$ Essa constatação tem como base teórica os seguintes autores: Gaiger (2004), Marchi (2004), Singer e Souza (2000) e Santos (2002).

${ }^{99}$ Cooperação compreendida aqui como ação política que privilegia as relações de complementaridade entre as ações e entre os atores envolvidos em atividades sociais semelhantes, com fins próximos.

${ }^{100}$ Solidariedade entendida como valor compartilhado e reforçado pela ajuda mútua e pela confiança mútua. A cooperação leva à aproximação entre indivíduos e cooperativas, enquanto a solidariedade é o que os impulsiona a usar essa rede e a reproduzi-la.

101 O capital social é, na visão de Oliveira (2006), no início, meio de proteção social, em um segundo momento instrumento de mudança social.
} 
cooperativa tende a envolver-se no atendimento a diversas demandas da comunidade, de documentação e resgate de direitos básicos a reforço alimentar.

Assim se dão as "verdadeiras revoluções locais" apontadas por Singer (2000) como resultado do resgate da cidadania levado adiante pelo exercício do cooperativismo. A base para tanto são as novas relações construídas entre os sujeitos-cooperados e todos os outros com quem se relaciona cotidianamente. É fácil imaginar que essas mudanças abrangem, no mínimo, a comunidade inteira.

\section{d. Autogestão, empoderamento e autonomia}

As relações de confiança são a plataforma para esse próximo passo, nascidas a partir das atividades diárias da cooperativa, das ações a princípio individuais que se tornam coletivas, propiciam o fortalecimento do indivíduo e do grupo. No entanto, é inevitável que as experiências vividas até então, as decepções, mágoas e frustrações acumuladas em relação ao “outro” sejam trazidas para dentro da cooperativa, para as relações grupais. O mesmo se passa com a lógica individualista, único repertório das relações capitalistas, cultura difícil de transformar. "As pessoas ainda estão muito 'embebidas' pela lógica do individualismo, não deixando transparecer um interesse claro de união para resolução de um problema comum” (BEATRIZ, 2007, p. 91). A repetição do comportamento passivo das mulheres vai no mesmo sentido: a aceitação do que os outros propõem ou defendem é comum no dia a dia das cooperadas as quais, assim, eximem-se da participação ativa, da autogestão.

Entre as condições para que esses fenômenos desenvolvam-se, o autor identificou o já antes mencionado rodízio de tarefas e nas posições gerenciais da cooperativa. Embora não seja garantia, é condição para a democracia, para que as diferenças entre lideranças, dirigente, e os outros cooperados não se cristalize. Para tanto é indispensável a educação ${ }^{102}$ e formação ${ }^{103}$ continuada; não à toa esse é um dos princípios da economia solidária.

\footnotetext{
${ }^{102}$ Aqui não se trata apenas da educação formal, principalmente da educação propiciada em outras instâncias, fora da escola, no processo de formação das cooperativas e na troca de experiências entre cooperados. Como nos lembra Beatriz (2007), embora o emprego esteja em declínio, com tendência à extinção, a escola continua dedicando-se à educação instrumental, formação de mão-de-obra para a sociedade do emprego. Interessante ponto levantado é que os sujeitos que não vivenciaram processos pedagógicos conteudistas, que preparam para o vestibular e para o trabalho heterogestionário tendem a ter maior disponibilidade para autogestão.

103 Faria e Nakano (1997 apud JUVENAL, 2006) alertam sobre a importância do processo de formação dos trabalhadores dos empreendimentos autogestionários estar desprovida de uma "visão idílica" sobre esses trabalhadores já que eles são representantes de uma cultura individualista e competitiva, centrada na preocupação com o emprego e com o salário que apenas poderiam ser garantidos com a superação de outros trabalhadores.
} 
É preciso que seja implementada uma metodologia de promoção da participação efetiva dos cooperados nas reuniões e assembleias, mas não basta que elas aconteçam. Direcionamentos simples, como a disposição dos participantes em roda, a fala individual de como cada um chega, do que traz, das expectativas, fazem diferença para como as relações estabelecem-se ao longo da reunião, promovem a igualdade de posições. A educação tem caráter mais profundo nas mudanças requeridas nas pessoas que tornam sustentável a construção de novas relações e de um novo mundo concreto: para Tiriba \& Picanço (2004b), a educação é o caminho para a reorganização dos saberes sobre a vida em sociedade, para que novos valores, um mais alto grau de consciência, atitudes e comportamentos diferentes sejam adotados.

Um dos principais resultados da pesquisa de Oliveira (2006) é a evidência de que os sujeitos cooperados podem ser, efetivamente, empoderados nesse processo, de prática e educação para a autogestão; isso é, passar a intervir ativamente no ambiente em que vivem. Com base nessa postura, a tendência é que assumam ações para diminuição da pobreza e da falta de trabalho, passando até para a luta pela mudança mais ampla, pela democratização econômica, social e política do país.

O conjunto de mudanças quantitativas que se juntam para um salto qualitativo, passando pelo que o autor chama "empoderamento" parece estar conectado com as diversas solicitações de participação, de posicionamento dos indivíduos dentro da cooperativa, como colocou Fábio Oliveira (2007). Tal requisição parte de diversos lugares, tanto das condições objetivas de organização do trabalho, quanto da imaginação de como seria a cooperativa ideal, que cada um espera ver realizada, bem como da demanda do próprio grupo pela participação, entendida como comprometimento em relação ao projeto comum.

De fato os trabalhadores das empresas flexíveis também são, cada vez mais, demandados por uma atuação criativa, participativa, "proativa" ${ }^{104}$. No entanto, esse posicionamento ao qual os cooperados são, constantemente, impulsionados no dia a dia da cooperativa, difere daquele que se alastra nos intermeios do trabalho heterônomo: indubitável diferença reside na posição de proprietário a ser assumida nos empreendimentos autogestionários, implicando necessidade de

\footnotetext{
${ }^{104}$ Originalmente a autogestão na produção industrial estava intimamente ligada aos ideais socialistas, tendo seu apogeu no pós-guerra, nas economias da Europa do Leste, mas no fim do século XX ela ressurge como contraposição aos males gerados pela extrema concentração do capital atingidos nesse momento do capitalismo e passa a ser aplicada em uma perspectiva anticíclica, compensatória, para a sobrevivência do sistema (JUVENAL, 2006).
} 
cogerenciar o negócio nos papéis de "dono", "patrão", “sócio”, "parceiro”. Ainda, para tornar-se cooperado, é indispensável que alguns conceitos e práticas novas sejam apreendidos e vivenciados; mesmo que o trabalhador aplique habilidades já desenvolvidas nas mesmas tarefas que desempenhara antes em empregos ocupados, seu processo de trabalho, seu cotidiano não será o mesmo. A nova posição exige a intervenção do trabalhador no planejamento da produção, que ele ouça e seja ouvido, ganhando voz e preparando-se para os embates a serem assumidos na sociedade, nas mais diversas situações (PEDRINI, 2000).

A busca de informações, conhecimento, ideias fora da cooperativa, de acordo com dificuldades a serem superadas ou novos passos que se fazem prementes, também compõe essa nova posição ocupada pelo trabalhador cooperado. Se antes bastava resignar-se ou ater-se à prescrição de cargo ocupado, às tarefas e metas impostas, na organização autogestionária do trabalho não há limites de responsabilidade, ela, inclusive, chega a ultrapassar a cooperativa como um todo alcançado seus possíveis impactos para a comunidade e para a sociedade.

As experiências práticas da autogestão e suas representações inauguram canais simbólicos para a comunicação e a relação com outros atores sociais que antes ocupavam outro mundo ou continente distante do mesmo mundo. Uma nova forma de enxergar a economia solidária e cooperativismo também faz parte desse processo, deixam de estar contidas em um limite de resposta às contradições do capitalismo, mesmo que, a princípio, sensitiva, intuitivamente, para depois alcançar a consciência ${ }^{105}$.

O câmbio do papel de vítima para o de quem pode mudar a realidade que se apresenta parece estar relacionado a tal fenômeno. A possibilidade de construir algo a partir do trabalho permite ocupar outra posição a partir da qual se interage com o mundo. Conectado ao alcance desse novo nível de consciência e, assim, de um outro ponto de vista do qual se enxerga e interage-se com o mundo, está o que Andrada (2005) denominou "permanências", isto é a elaboração de um campo estável de referências em que os cooperados podem assegurar a sobrevivência de suas famílias e o espaço físico e simbólico para suas ações cotidianas. A partir da segurança no presente podem passar planejar o futuro e a ampliar suas atuações ${ }^{106}$.

${ }^{105}$ Mance (2003), Arruda (2006), Tiriba (2004), Souza (2006) e Singer (2000) entendem que qualquer mudança estrutural está vinculada a essa mudança na forma como a economia solidária é encarada por aqueles que a fazem todo dia, pelos cooperados (apud BEATRIZ, 2007).

${ }^{106}$ De acordo com fenômeno descrito por Merlau-Ponty (1999), o pensar e o fazer o futuro consiste em um "alargamento de visão", relacionado ao poder de intervenção maior nos campos de ação de cada sujeito, esse 
A autogestão, especialmente quando tem como um de seus resultados concretos a geração de renda suficiente para as necessidades básicas, é uma das fontes de instrumentos e repertório para a prática política (ANDRADA, op. cit.). No mais, o universo simbólico compartilhado, coconstruído, no dia a dia da cooperativa constitui a base subjetiva de segurança necessária à realização das potencialidades humanas ${ }^{107}$; a filiação simbólica a um grupo estável permite aos cooperados sentir-se seguros em relação ao trabalho, apesar das variáveis externas das quais depende o sucesso econômico do empreendimento.

Como ponto de conexão entre as diversas experiências e sentidos que suas diversas repercussões assumem para os sujeitos, Ferraz (2005) propõe o conceito de "autonomia". Entendida pela autora como possibilidade de autoafirmação na disputa por participar da elaboração da norma no trabalho e na vida, a autonomia "está imbricada com a constituição da identidade social do trabalhador" (ibidem, p. 9). Atualmente identificada pela sua oposição com o trabalho assalariado, a autonomia assume as mais diversas apropriações de acordo com o objetivo do discurso.

Nessa leitura, por sua vez, não é possível falar de autonomia sem falar de identidade, de consciência de si nas relações com o mundo. A formação de classe ${ }^{108}$ toma lugar de destaque no estudo de Ferraz (op. cit.) no sentido em que propicia que uma identidade coletiva seja constituída com base nos valores compartilhados e do reconhecimento de si pelo outro. Individual e coletivamente os sujeitos que vivem disputas simbólicas e políticas passam por fases de constituição e de consolidação, nesse processo as representações vão passando por mudanças.

A formação do sujeito político autônomo passa pela reflexão sobre sua história de vida e seus objetivos, pela possibilidade de falar e ser ouvido, pelo diálogo aberto, e pela identificação com outros, seja pela afirmativa ou negativamente. A reflexão sobre a experiência vivida é tecida socialmente. A falta de prática de participação democrática, do livre debate de ideias para a construção de propostas comuns, nem sempre é superada pelo cotidiano da cooperativa; pelo contrário, pode apresentar-se como empecilho ao exercício autogestionário que, por sua vez, não

fenômeno incorre na ampliação do espaço e do tempo, evidenciando a potencialidade de todo ser humano de mudar o contexto em que se vive (ANDRADA, 2005).

107 A segurança é apresentada também por Simone Weil (2001), entre outros autores, como condição necessária aos seres humanos; sem ela a alma parece estar em constante desvanecimento. São necessárias determinadas condições simbólicas para que as realizações humanas alcancem estabilidade e durabilidade e possam lançar-se ao mundo comum em que a singularidade do sujeito pode ser reconhecida (ARENDT, 2000).

${ }^{108}$ Formação de classe é o "processo vivo de constituição dos sujeitos em sua consciência de si, em sua identidade afirmada nas relações que estabelecem frente a seus outros sociais” (FERRAZ, 2005, p. 38). 
pode contribuir para a superação da cultura de mando e obediência, em um ciclo sem fim, ou melhor, com o fim da experiência cooperativa.

Olhando para a vivência cotidiana nas fábricas assumidas pelos trabalhadores, Ferraz (op. cit.) depara-se com alguns fenômenos que refletem os rumos tomados ou inalcançados por essa prática nos empreendimentos estudados. A reprodução das diferenças de posições ocupadas antes da formação do empreendimento, isso é a reprodução, dentro da cooperativa, da hierarquia presente na comunidade e na sociedade. Uma das vertentes dessa dinâmica é a desigualdade em que os que "fazem" e os que "pensam", estes dominando e aqueles subordinados (HOLZMANN, 1990). A hierarquia naturalizada no discurso e assumida como verdade, sem questionamento, interiorizada pelo dominado e pelo dominante, é ameaça à autogestão, implica possibilidade de que ela nunca aconteça de fato para a maior parte dos trabalhadores cooperados.

Nesse sentido a emancipação intelectual é, para Rancière (1985, apud FERRAZ, 2005), um estágio da emancipação do sujeito: a tomada de consciência da igualdade da natureza das habilidades, competências e inteligências é indispensável para a autonomia. A igualdade, necessária à autonomia, por sua vez fundamental para a autogestão, se faz em sua própria verificação, no questionamento da verdade naturalizada e socialmente aceita. "Somente o sujeito - individual e coletivo - que age orientado por si mesmo e se identifica como tal é capaz de um projeto autônomo" (FERRAZ, 2005, p. 229).

A autonomia é, portanto, uma busca constante, quase utópica, mas ao mesmo tempo ponto de partida para o diálogo. Sempre dinâmica, assume sentidos diversos na permanente constituição e transformação dos sujeitos. No caso das fábricas assumidas pelos trabalhadores, esse exercício acompanha a luta pela determinação da norma de trabalho e tem importante marco a declaração, frente aos outros grupos sociais, da posição de responsáveis pela empresa.

Em outro nível, o da micropolítica, a autonomia parece ser um projeto em contínua formação, realização e reformulação. Fábio de Oliveira (2007) reconheceu em todas as cooperativas que acompanhou em seu trabalho de doutorado, conflitos e negociações micropolíticas como parte do cotidiano dos empreendimentos, instâncias em que todos se inseriam e faziam-se representar e onde parcela das decisões era tomada ou encaminhada.

O conflito volta a ser, reconhecidamente, constituinte das relações interpessoais na cooperativa; aí se dá uma mudança concreta e simbólica pela autogestão, se nas empresas capitalistas as relações são determinadas pela concentração do poder que abafa, suprime, o 
conflito iminente, na cooperativa ele é reposicionado e ressignificado já que é componente intrínseco ao processo democrático em que diversos interesses e pontos de vistas se colocam (ANDRADA, 2005).

A autonomia e a participação na tomada de decisão e nos resultados do empreendimento foram relatadas, na pesquisa de mestrado de Andrada (2005), como ponto de partida para a segurança que permite aos cooperados lançarem-se à ação na esfera pública. Desdobramento esse considerado "um dos aspectos mais revolucionários do cooperativismo autogestionário, deste modo socialista de produção: ele pode ser capaz de liberar os sujeitos para as práticas políticas" (ibidem, p. 241).

\section{e. Autogestão, luta de classes e identidade coletiva}

As experiências cooperativistas analisadas por Ferraz (op. cit.) apontam que no exercício de elaboração das formas de autonormatização, os grupos se organizam e constroem uma identidade coletiva assumida pelos indivíduos. Essa identidade se faz na relação entre os cooperados e consolida-se na interação com a alteridade, com outras instituições e movimentos. Em muitos casos isso acontece na negação do patrão, por essa contraposição, pela ausência de chefe, o grupo fortalece a noção de importância de se fazer parte daquele coletivo.

Afirmativamente o contexto compartilhado propicia a conformação do grupo: a desvalorização do trabalho, apesar de sua permanência como fundamental para a sobrevivência, concretizada em sua precarização e no desemprego, é experiência comum. As cooperativas populares surgem desse bojo compartilhado, muitas vezes como medida de emergência na luta pela sobrevivência. A identificação é o substrato com base no qual se pode constituir uma identidade política; as trajetórias e anseios comuns alimentam a identidade coletiva que é institucionalizada no movimento social.

É justamente o repertório comum de conhecimentos e práticas que permite, para Esteves (2004), a construção partilhada de significados que permite que o grupo aja de forma inovadora, modificando mais que aceitando o status quo. A tendência é que, a partir da criação coletiva de conhecimento e de estratégias de atuação, os pensamentos individual e coletivo misturem-se, componham-se em estrutura complexa de complementaridade.

Tal fenômeno ancorado na autogestão, importante ressaltar, não parece ser fácil, exige a exposição do cooperado como sujeito, o posicionamento diante de conflitos e o reconhecimento de que as posições, embora divergentes, não são excludentes, mas aproximam-se e afastam-se de 
acordo com a situação em que a cooperativa se encontra. No dia a dia da cooperativa fica claro que raramente todos os interesses confluirão no objetivo comum de fortalecimento do empreendimento solidário, emergem constantemente os interesses específicos que compõem a micropolítica da organização (ESTEVES, 2004).

Como indica Ferraz (2005), entre as limitações concretas para a expansão da economia solidária estão as "subjetivas", relacionadas à experiência cultural dos trabalhadores. Como já sabemos, grande parte dos empreendimentos são formados por motivações imediatistas e destes muitos permanecem sem um projeto coletivo e solidário de longo prazo. Por falta de exercício da autonomia e de outras formas de organização que não a heterogestionária, além da carência por conhecimentos de gestão, parcela dos empreendedores fica presa à subordinação, ao lugar ocupado historicamente na relação de dominação.

Importante lembrar também, como coloca Andrada (2005), que apesar da identificação por repertórios semelhantes formados a partir das histórias de vida particulares, e das necessidades e objetivos comuns, são diversas, únicas, as experiências de autogestão dentro do mesmo grupo. O ponto de partida, o contexto sociopolítico da comunidade, é capaz de voltar todos esses universos específicos, cada sujeito, para ações comuns, e de traçar sentidos transversais às diversas experiências da autogestão.

O ressurgimento da política entre os cooperados e na comunidade vincula-se à ocupação de um "espaço público" concreto, de um fórum público em que são tratados assuntos de interesse de todos e de cada um, do grupo (ANDRADA, op. cit.). Exercícios e práticas da autogestão correspondem a algumas das mais importantes habilidades políticas, "ouvir", "falar" e "vontade de expor". A necessidade de "disputar a sociedade" pode, então, ser sentida e compartilhada pelos trabalhadores, e se instrumentalizada transforma-se em um nível superior de consciência, que, por sua vez, se reflete em ações contrárias à política institucionalizada (BEATRIZ, 2007).

Nesse sentido, a participação no movimento coletivo implica um aprendizado, para os indivíduos, que os permite participar de outras organizações; a luta pela sobrevivência pode fundar a ação política. Parte importante desse aprendizado, por exemplo, é colocar-se em espaços públicos, representando-se a si mesmo no diálogo com seus iguais. Assim, o despertar da experiência política, bem como de uma nova cultura, mais solidária, relaciona-se amplamente ao exercício da democracia direta participativa (ANDRADA, 2005). 
"Com o processo, você vai descobrindo que dá para fazer coisas muito além do que só aquilo com que você começou. Dá para fazer muita coisa, uma porque tem muito espaço e outra porque é no decorrer da luta que você vai se descobrindo." (cooperada Cida, apud FERRAZ, 2005, p. 228).

\section{f. Autogestão, trabalho e vida cotidiana}

Evidências encontradas nos diversos estudos indicam que trabalho autogestionário, quando real, permite que todo o cotidiano do cooperado seja reinventado. É por meio da experiência mediada pelo trabalho que o lugar na cidade é, aos poucos, conquistado e assumido. Esse processo é vivido pelos migrantes (DURHAM, 1978), mas também pelos cooperados, antes desempregados, assumindo nova posição na família, na comunidade e na sociedade.

O trabalho é central nos projetos de autonomia traçados e trilhados pelos cooperados, tanto em seu papel econômico, quanto simbólico: “o 'movimento' tem na experiência do trabalho um dos elementos fundantes da solidariedade grupal" (FERRAZ, op. cit., p. 231). Em relação aos movimentos de moradia, por exemplo, assim que são assentados os indivíduos organizam-se em um novo coletivo, de trabalho, que oferece o meio para as ações seguintes do grupo.

Quando os empreendimentos se desfazem e os sujeitos recolhem-se às suas individualidades, o que se nota é que a experiência permanece viva na memória em um discurso crítico sobre os sonhos, as potencialidades e as dificuldades de outro tempo. O projeto de autonomia não necessariamente terá sido extinto, ele está continuamente em transformação, assume diversos sentidos e formas de acordo com o momento vivido pelo sujeito. Surge como resposta às experiências de privação do poder de decidir sobre suas vidas, constituindo-se como valor que, assim, direciona a ação do sujeito. O que ele precisa, esse projeto de autonomia, é ser inaugurado e alimentado, em que a prática autogestionária pode ser de grande valia ${ }^{109}$. É no espaço para a produção das representações de si mesmo, do outro e do mundo que mora o sentido elaborado para a autonomia dos sujeitos individuais e coletivos (FERRAZ, op. cit.).

Nessa transformação orgânica de um projeto vivo, a autonomia é ressignificada, antes silenciada, na fábrica, é relacionada a outros conceitos e sentimentos, dos direitos, da segurança,

${ }^{109109}$ Está claro, em diversos momentos até aqui, que isso nem sempre ocorre, que há muitas variáveis envolvidas nessa construção e que o caminho percorrido pelo grupo, desde sua formação, é decisivo para as transformações que poderão ou não ser vividas pelos indivíduos. Algumas dessas variáveis são: endogenia ou exogenia, neste caso, a relação estabelecida com a organização de apoio, abertura dos sujeitos para a transformação cultural, prática do rodízio de tarefas, viabilidade econômica e condições de concorrência da atividade econômica desenvolvida, capacitação gerencial de todos os cooperados, etc. 
da co-construção. Na cooperativa esses novos sentidos da autonomia são institucionalizados, tornando parte dos princípios e da missão da organização.

Da mesma forma que a autonomia se constrói e reconstrói na ação, é na prática participativa que os sujeitos descobrem que são capazes de muito mais do que imaginavam, que a barreira ideológica assumida e irreal. Na medida em que se começa a lutar por determinados objetivos a disponibilidade para a luta torna-se um estado de espírito, uma briga constante pelo que se acredita, pelo que se considera correto.

Outra importante consequência da vivência de uma nova organização do trabalho, voltada à vida, é a apropriação, por parte dos trabalhadores, da contradição entre o "trabalho mercadoria" e "não-mercadoria". A ampliação da visão sobre o trabalho leva à re-valoração das atividades ligadas à casa e ao bairro; também por isso novas atividades passam a ser desempenhadas e encaradas como produtoras de valor, mesmo que não do capital ${ }^{110}$. Nesse sentido, Andrada (2005) entende como elementos do trabalho autogestionário, com implicações em todas as esferas da vida, a superação da divisão sócio-histórica entre "tempo de trabalho" e "tempo liberado do trabalho", com a aproximação entre as atividades consideradas econômicas e as culturais, sociais e educacionais.

Novos valores compartilhados, além da produtividade, retomam as atividades engolidas pela produção de mercadorias. Se o trabalho heterônomo demanda todo o tempo humano voltado à atividade econômica lucrativa, o autogestionário tende a recuperar o valor do bairro e da família na vida cotidiana ${ }^{111}$. No mais, a divisão igualitária das sobras dos empreendimentos solidários é diferenciada, pelos cooperados, em relação ao salário, imbuída do que entendem como justiça social (BEATRIZ, 2007).

Mesmo assim, a herança do trabalho heterônomo mantém-se presente nos empreendimentos autogestionários: o trabalho assalariado é lembrado como uma realidade distante, talvez inalcançável, idealizada. Torna-se, assim, uma ausência presente e que pode desdobrar-se, como já mencionado, na manutenção de relações assimétricas de poder entre os

\footnotetext{
${ }^{110}$ Ao reconhecer essas outras formas de trabalho, que não fazem parte do chamado "mercado", mas que criam valor social, lança-se luz a uma dimensão a essa dimensão menos visível do trabalho, da contribuição social e econômica fornecida por uma parcela da população que não estão no mercado de trabalho (DEDECCA et alli, 2004).

${ }^{111}$ Isso não quer dizer que os cooperados façam turnos menores de trabalho, ao contrário, estudos de caso elaborados por Faria (1997), Lins (2001) e Esteves (2004) revelam empreendimentos em que, depois de tomados os meios de produção pelos trabalhadores, a produtividade do trabalho é elevada e são estendidas e intensificadas as jornadas de trabalho.
} 
trabalhadores. A dificuldade de superação da organização tradicional do trabalho é compreensível ao considerarmos que são as representações sociais que dão forma ao mundo, que delimitam o concebido e o impensável, e as imagens compartilhadas amplamente pela sociedade, reconhecidas como nobres, corretas, apontam para o emprego. Além do que a memória de uma vida inteira não é superável, está sempre em diálogo com as novas possibilidades ${ }^{112}$.

A inércia e a institucionalização contribuem para a persistência das formas, do repetido, em direção oposta fazem-se necessários os espaços de aprendizagem de novas relações, outras possibilidades de expressão. O processo de formação dos grupos e dos empreendimentos ganha destaque nessa discussão, precisa ser encarado como prática educativa, sociocultural, no estímulo à prática da construção coletiva e da autorrepresentação como exercício de constante criação.

"As heranças do modelo heterônomo de organização do trabalho formam os sujeitos. A reprodução de relações sociais na produção de mercadorias obedece à presença da memória dos aprendizados sob o trabalho assalariado" (FERRAZ, 2005, p. 242).

As condições objetivas inauguradas por um outro modo de produção são indispensáveis, mas não suficientes para o alcance de um novo nível de consciência. Está claro que outras experiências, além do trabalho produtor de mercadorias, possibilitam que a atividade econômica de sobrevivência fuja das relações heterônomas e inaugure uma nova norma. Tais experiências partem do desafio de reprodução da vida e transformam a necessidade em liberdade ${ }^{113}$, instaurando uma relação de complementaridade onde havia contraposição. A "liberdade de criar soluções a partir da necessidade" (ibidem, p. 243) inaugura uma nova história em que é permitido ter e existir com valores próprios, criar a norma que faz sentido ser seguida.

Assim, duas rotas podem ser traçadas na análise desse movimento: a expansão da autonomia vivida no trabalho para outras esferas da vida e a transposição das vivências na comunidade e na família para as relações produtivas. O fato é que uma narrativa linear pode ser proposta apenas como exercício teórico, simplificação de um fenômeno complexo que se desenvolve de forma caórdica, dialética, sem começo ou fỉm. Da mesma forma, estabelecer

\footnotetext{
${ }^{112}$ Evocar o passado é vivê-lo novamente, lançar o olhar para trás é atualizar a experiência vivida. O presente é o momento em que ser e consciência coincidem (MARCONDES FILHO, 2005 apud FERRAZ, 2005).

${ }^{113}$ A liberdade, para Hannah Arendt (1972), advém da companhia de outros homens, iguais, em um espaço público comum, acompanhada pela liberação em relação às necessidades de manutenção da vida. Esse seria o cenário modelo, da polis pré-filosófica, a partir da qual se podem compreender as condições humanas potenciais. Para Wagner (2002), a liberdade existe mesmo que nesses potenciais, contida e revivida pela simples "capacidade de começar" a qualquer momento.
} 
relações de causa-efeito é esforço teórico para tornar a questão mais palatável e proporcionar algum conforto.

O que se afirma é que ambas as esferas precisam ser transformadas ao mesmo tempo em que labor, trabalho e ação assumem novas conotações e possibilidades de concretização. Para Ferraz (2005), os trabalhadores não são apenas os que participam ativamente da atividade produtiva, mas também as suas famílias, seus vizinhos do bairro, "num halo que institui também nas suas relações de compadrio e amizade" (ibidem, p. 241).

A autogestão possibilita que um novo tipo de trabalho e de vida social sejam estabelecidos pelos cooperados, transformando tanto o "campo", quanto os "sujeitos" por meio da prática de alguns dos elementos mais fundamentais dessa forma de organização: o diálogo, a negociação, a posição ativa e a pertença ao espaço compartilhado (ANDRADA, 2005). As novas relações com o trabalho e no trabalho são extrapoladas para as outras instâncias, como a família.

A inserção no grupo traz a possibilidade de reconfiguração da identidade do sujeito trabalhador, esse é o alicerce, portanto, para a sólida fundação de seu projeto de autonomia. O sentimento de comunidade parece ser a liga desse movimento identitário com sentido emancipatório.

\section{g. Autogestão, afetividade e autoestima}

Autoestima $^{114}$ é um termo que aparece em diversos dos estudos que se voltam aos sentidos da autogestão. Na tese de Beatriz (2007), a elevação da autoestima surge conectada à consciência de que, ao assumir a cooperativa, os cooperados responderão pelo sustento de suas famílias e, além disso, influenciarão o futuro da comunidade. Ao sentirem-se competentes diante de tal tarefa e responsabilizarem-se diante dela, o nível de reconhecimento alcançado em relação aos outros e a si mesmo galga nova posição.

A causa comum possui maior poder que o objetivo compartilhado; com sentido mais amplo engrandece a missão da cooperativa e de cada um dos sujeitos cooperados. Trata-se de

\footnotetext{
${ }^{114}$ Poucos autores adentram a delimitação desse conceito, ele assume diversos tons, por vezes desencontrados. Aqui o entendo como a segurança em si mesmo, em suas capacidades, habilidades, no potencial individual de pensar, comunicar e realizar. Confiança essa erigida principalmente nas relações primárias, pelo reconhecimento no âmbito da afetividade e que pode ser atendido pela solidariedade (HONETH, 2007).
} 
uma nova personagem que, ao ser reconhecida, implica nova configuração às identidades individuais $^{115}$.

Nas cooperativas em que a implementação da autogestão parece ter um processo melhor sucedido encontra-se mais forte o resgate do ser humano, das relações não interesseiras, do ser além de sua esfera econômica. O empreendimento solidário é entendido por Beatriz (op. cit.) como espaço para a retomada da afetividade humana por meio da risada, brincadeira, conversa, junto com o trabalho que gera renda. Não mais em oposição a realização econômica, social e emocional, maior possibilidade de satisfação das necessidades humanas, menos alimento para os sentimentos de medo e culpa.

Revelador que muitos dos sujeitos ouvidos no mesmo trabalho (BEATRIZ, op. cit.) identifiquem a cooperativa como lugar em que os problemas pessoais podem ser esquecidos, em que é gostoso estar e onde eles podem cuidar de si mesmos. A saúde, uma das mais veementes preocupações dos trabalhadores ${ }^{116}$, tem seu lugar no mesmo espaço em que trabalham: a cooperativa é vista também como lugar de cuidado à saúde.

Além da cooperativa, nos entremeios da economia solidária, as feiras destacam-se como canal de comercialização dos produtos do trabalho cooperado e também meio propício ao fortalecimento das relações personalizadas entre produtores e consumidores. As trocas solidárias recuperam o destaque das relações humanas sobre a mercadoria, colocando-a como meio para atendimento das necessidades da vida, entre elas os laços afetivos.

\section{h. Lacuna entre a teoria e prática autogestionárias}

Tendo por base relatórios e propostas proferidas pelos atores da economia solidária, como o Documento Base da I Conferência Nacional da Economia Solidária ${ }^{117}$, a preocupação com o desenvolvimento social, a globalização solidária, a transformação estrutural, o Estado democrático, é mais ampla, profunda, e elaborada do que ganha corpo no cotidiano das experiências autogestionárias. Na prática, a maior parte do tempo e da energia é investida nas

\footnotetext{
115 Essa consciência de si e do novo papel desempenhado na comunidade nem sempre está atrelada à visão crítica sobre a estrutura societal, mesmo que repercuta em uma noção mais ampla sobre o contexto em que vivem e trabalham e de si mesmo (BEATRIZ, 2007).

${ }^{116}$ Gonçalves Filho (1998) aponta para esse temor, identifica a repetição incessante do tema nas entrevistas com trabalhadores da Vila Joanisa e relaciona-a com a única posse que restou àquele que trabalha, seu corpo, sua força física; dela depende sua sobrevivência e de sua família.

117 Tal documento, segundo análise de Beatriz (2007), tem aderência ao referencial teórico representado por Singer (2006, 2004, 2000, 1999), Mance (2003), Arruda (2006), Tiriba (2004) e Souza (2006), mas está distante dos sentidos da experiência autogestionária do grupo informal acompanhado pela autora.
} 
questões internas do grupo, na sintonização do trabalho conjunto, e em gerar recursos mínimos para que o empreendimento mantenha-se.

Se formar um grupo já é um processo árduo, constituir uma organização cuja gestão esteja igualmente distribuída entre os proprietários-trabalhadores é um objetivo ousado que exige empenho, dedicação. A igualdade de direitos pregada teoricamente mostra-se pouco aderente à realidade dos empreendimentos solidários: como já mencionado, a relação patrão-empregado tende a ser reproduzida como um imã atraído pelo metal, reflete-se a lógica capitalista. O grupo é, em diversos casos, comandado pelo membro mais experiente, com melhor aparência, mais extrovertido, com mais tempo de estudo no sistema de ensino formal (BEATRIZ, 2007).

A dificuldade em participar, formar e expor opiniões, é, por vezes, ignorada em estudos, documentos e eventos sobre o tema. Imagina-se que para a autogestão basta garantir as instâncias formais, previstas em metodologias e estatutos, esquece-se que para a participação é preciso que barreiras subjetivas sejam transpostas, como a falta de confiança em si, a autorrepressão, até a pouca experiência em refletir e assumir uma posição própria. Situação comum é cooperado esperar que a liderança fale por ele, tome a decisão que deve ser a "mais certa" dado o tanto de conhecimento que ela tem.

Questão fundamental à autogestão, parece simples, mas nem sempre concretizada, é que os sujeitos saibam sobre seus direitos, estejam familiarizados com eles. Conhecer os princípios do cooperativismo, participar da construção das regras da cooperativa, é vegetação que pode crescer sobre a planície da cidadania, da consciência sobre os direitos e responsabilidades dos indivíduos dessa sociedade.

Mesmo o consumo consciente e solidário, um dos pilares da economia solidária na visão de alguns autores, mostra-se de difícil realização quando ainda se luta para satisfazer as necessidades vitais. A visão crítica sobre o consumo, parte de diferente posicionamento propiciado pela percepção do poder de influência no mundo, defronta-se com a baixa remuneração do trabalho em parcela considerável das cooperativas. No grupo informal estudado por Beatriz (2007), a renda gerada não permite que sejam priorizados produtos sustentáveis, que não tenham incorrido na exploração do trabalho e na violência ao meio ambiente.

A autora também não encontrou nesse grupo o ator sociopolítico da economia solidária, os debates, análises, ações coletivas são pouco expressivos, a mobilização para o desenvolvimento comunitário não tem ressonância. Os cooperados não identificam a articulação 
com outros grupos, cooperativas, movimentos sociais como algo a ser buscado, não vêm vantagens nisso.

Os conceitos que compõem a base teórica e nomeiam a prática da economia solidária não são familiares para tais cooperados; formação e educação contínuas, não instrumentais, amplas, tracejam a ainda frágil ponte entre a teoria propositiva e o desenrolar do movimento. Para Beatriz (op. cit.), é requerido que a formação em economia solidária aborde, e detenha-se, em questões macro, estruturais, ultrapassando a relação do grupo com o mercado posto; assim como o esforço voltado à constituição do empreendimento autogestionário, é premente que a formação política dos sujeitos envolvidos precisa ser parte do movimento de economia solidária, não apenas dos cooperados, também dos militantes, equipes de projeto e organizações envolvidas. Esse parece ser o caminho para que valores arraigados de nossa organização social possam ser reponderados, inclusive a competitividade que se impõe entre os grupos e instituições de apoio ao movimento ${ }^{118}$.

Vale terminar essa sessão com uma importante recordação trazida por Oliveira (2007): o potencial de transformação sociocultural e intersubjetiva imbricado na prática autogestionária não pode ser efetivado ou compreendido apenas a partir do ambiente interno da cooperativa popular, o limite do empreendimento solidário é irreal, uma especulação, já que o sujeito cooperado é o mesmo que compra comida no mercado da comunidade, que negocia o aluguel de sua casa com o proprietário ou constrói sua moradia em mutirão, com a ajuda de outros moradores da comunidade, que aposta em jogos de azar, come feijoada aos sábados, cede lugar no ônibus para os mais velhos, é olhado de viés pelo modo como se veste e pela sua cor.

Em outras palavras,

"Se a estrutura do mundo não se modifica, isto é, se os elementos que configuram a rede que é a cooperativa não se constituem como um contexto fundamentalmente distinto do trabalho assalariado, não há condições suficientes para que a vivência como funcionário (ou "trabalhador autônomo") se transforme na vivência do sócio-trabalhador, isto é, o sentido do cooperativismo não difere substancialmente do sentido do trabalho assalariado" (OLIVEIRA, 2007, p. 116).

\footnotetext{
${ }^{118}$ Veronese e Guareschi (2005) enxergam como desafio a formação dos profissionais para que estejam preparados para colaborar com as transformações no nível da subjetividade pelas quais a consolidação da cultura solidária perpassa. É comum que os próprios profissionais engajados na economia solidária não vislumbrem alternativas ao capitalismo, já que essa crença alcança enorme aceitação no senso comum (BEATRIZ, 2007).
} 
Cada trabalhador que constrói diariamente a autogestão tem uma vivência distinta, como parte da rede mais ampla da qual faz parte, seja no presente ou nas memórias e feitos. As histórias são únicas, escritas pela vivência cotidiana dos sujeitos em seus contextos sociais e materiais. A autogestão ressoa particularmente, individualmente, com base na experiência coletiva, nos planos co-construídos e correalizados, no reconhecimento de cada um pelos outros e de todos por cada um.

Sobre as experiências individuais, a partir delas e com elas, a autogestão reúne material necessário para combate a uma ideologia dominante: prova que os fatores de produção, quando colocados a favor do homem autônomo e empoderado, podem promover a realização humana pelo e a partir do trabalho. 


\section{Capítulo V - Mãos à massa - autogestão e identidade em três histórias de vida}

"Eu sou assim, tento fazer as coisas certo, mas uma coisinha que acontece comigo é como um vidro que trinca e não cola mais. Eu sou assim.

Quando saí de casa foi assim, nunca mais voltei."

"Estou no grupo para fundar alguma coisa, para deixar alguma coisa, porque não sou mais criança não." (Joana, grupo Mãos na Massa ${ }^{119}$ )

\subsection{Mãos na Massa - muito prazer!}

Mãos na Massa é um grupo formado por alguns moradores do Jardim Jaqueline, bairro da Zona Oeste de São Paulo ${ }^{120}$ marcado pelo contraste gritante entre a favela e as construções luxo que sobem na região. Com, atualmente, oito membros, três homens e cinco mulheres, todos com idade acima de 40 anos, o grupo continua o processo de incubação junto à Incubadora Tecnológica de Cooperativas Populares da

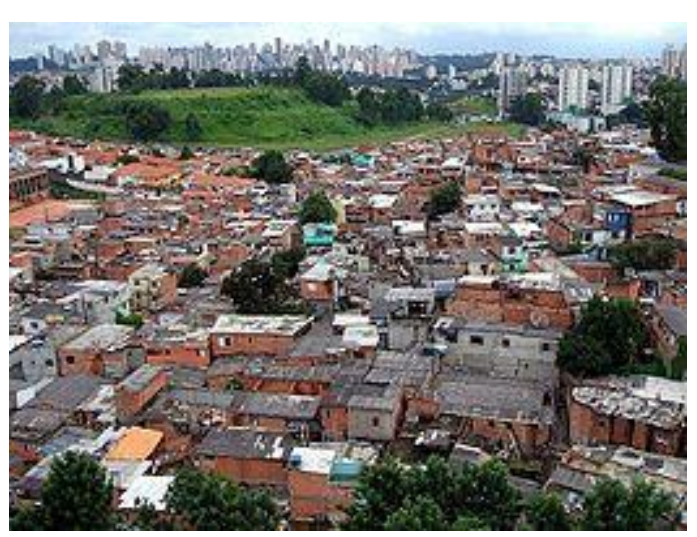

Fotografia 1 - Jardim Jaqueline, Distrito Vila Sônia / Zona Oeste de São Paulo.

Universidade de São Paulo (ITCP-USP) ${ }^{121}$ e pelo Instituto Pólis ${ }^{122}$ iniciado no segundo semestre

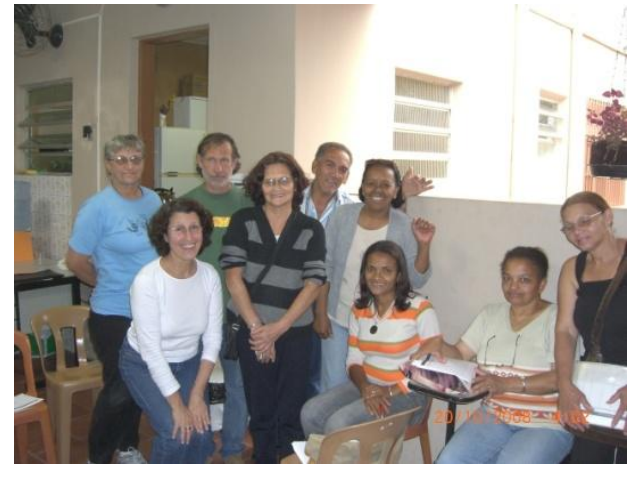

Fotografia 2 - Mãos na Massa - grupo em formação em 2008. de 2007. A atividade econômica desenvolvida pelo grupo é a produção de barras de cereais saudáveis e nutritivas.

O foco do grupo é mais amplo do que as barrinhas, o interesse relaciona-se à segurança alimentar no bairro, à colaboração para a melhoria da alimentação da comunidade por meio da oferta de produtos saudáveis e acessíveis, mas também por ações educativas, principalmente pelo que chamaram de "oficinas de segurança alimentar". No entanto, a missão e a atividade econômica não foram iniciativa do

\footnotetext{
${ }^{119}$ Citação de entrevista realizada em 24/10/2009. Os nomes usados são fictícios.

${ }^{120}$ O Jardim Jaqueline pertence ao distrito Vila Sônia, subprefeitura do Butantã, que faz divisa com Rio Pequeno, Butantã, Morumbi, Campo Limpo e Taboão da Serra. O distrito tinha, em 2008, aproximadamente 90 mil habitantes (fonte: site Prefeitura de São Paulo, http://www.prefeitura.sp.gov.br/cidade/secretarias/subprefeituras/butanta/. Acesso em 18/06/2010.

${ }^{121}$ Para conhecer a organização acesse: http://www.itcp.usp.br.

${ }^{122}$ Para conhecer a organização acesse: http://www.polis.org.br/.
} 
Mãos na Massa, "eles queriam coxinha e pizza, a ITCP barrinhas e comida natural"123. Assim o fortalecimento da segurança alimentar e as barras de cereal são resultado de um processo de persuasão do grupo por parte dos formadores com base nos objetivos do projeto aprovado pelo Instituto Pólis com a FINEP (Financiadora de Estudos e Projetos ${ }^{124}$ ), de que saíram os recursos para o trabalho com o Mãos na Massa.

Quando me aproximei do grupo, por meio da ITCP-USP, em meados de 2008, eles tinham definido há pouco focar nas barras de cereal, como produto, estavam na fase de organização da produção e da gestão do negócio. Ao mesmo tempo, era preciso fortalecer os princípios e práticas da economia solidária com os quais o grupo havia tido contato no início da formação, mas, como eles mesmos diziam, lembravam vagamente. Nesse momento ainda havia participantes intermitentes dos encontros, estavam presentes em alguns, em outros não, buscando compreender melhor a proposta do grupo e quais seriam os possíveis resultados daquele processo.

Voltemos um pouco a como encontramos um ao outro, grupo e pesquisadora. Depois de algum tempo sem contato com a ITCP-USP, a reaproximação se deu por meio de sua coordenação, seguida pela apresentação do projeto de pesquisa em uma reunião de GEPEM (Grupo de Ensino, Pesquisa e Extensão Multidisciplinar). A proposta era identificar um grupo em formação, que estivesse construindo a autogestão em seu dia a dia a partir de uma iniciativa de outra organização, isso é que fosse uma experiência exógena, passando pelas dificuldades e aprendizados intrínsecos desse processo, que tivesse fácil acesso geograficamente e que pudesse beneficiar-se com a pesquisa que se iniciava.

Foram indicados pela própria coordenação dois grupos considerados na passagem do início para o meio do processo de formação, entre os quais, por meio de conversas com os formadores envolvidos, considerando o maior comprometimento dos participantes e maior número de participantes, o Mãos na Massa foi destacado.

O passo seguinte foi de estudar o material de reuniões e definições elaborados pela incubadora junto ao grupo até então, e de participar de algumas reuniões de GEPEM dos formadores envolvidos no trabalho com o grupo. Depois de meu primeiro contato com os membros do Mãos na Massa, em reunião semanal junto com a ITCP e com o Pólis, em momento

\footnotetext{
${ }^{123}$ Palavras de um dos formadores da ITCP-USP envolvidos no trabalho como grupo, frase dita em reunião realizada em 29/06/2009.

${ }^{124}$ Instituição ligada ao Ministério da Ciência e Tecnologia. Site institucional: http://www.finep.gov.br/. Acesso em 05/05/2010.
} 
seguinte, sem a minha presença, o grupo posicionou-se favorável à participação na pesquisa e começou a pensar no que seria a "contrapartida" que gostariam que oferecesse a eles.

Assim, em agosto de 2008 foi iniciada uma sequência de 13 oficinas de gestão de

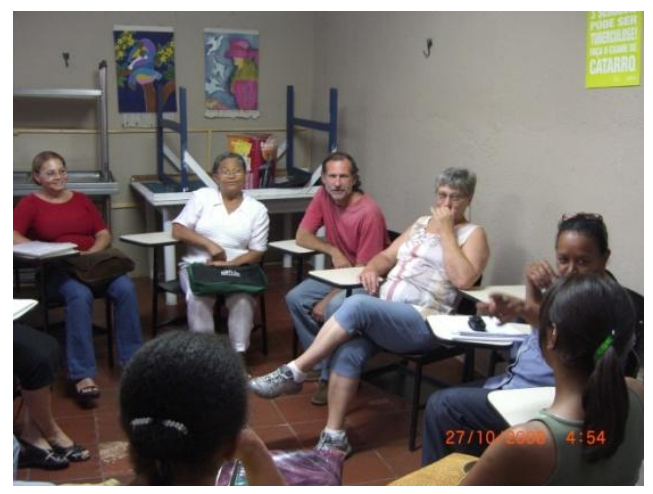

Fotografia 3 - Oficina de gestão, 2008. negócios, com foco em cooperativas, que se estendeu até junho de 2009. O objetivo, além de colaborar, fornecer mais ferramentas para o grupo erigir e gerir o mais autônomo possível seu negócio, foi de conviver com as pessoas, de conhecê-las, imergir na cultura do grupo, e estabelecer laços de confiança com os participantes. Ao longo e depois desse período outros encontros aconteceram, em outras atividades diversas, no bairro.

Os encontros com o Mãos na Massa tinham entre duas horas e meia e três de duração, longo das quais eram propostos alguns jogos cooperativos, discussões sobre cada área e ferramentas do negócio, a integração entre eles na gestão e eram realizados exercícios em grupo. As especificidades da organização cooperativa eram

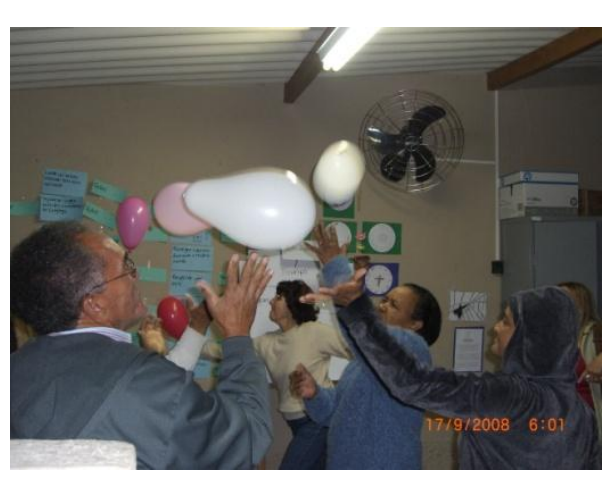

Fotografia 5 - Atividade lúdica, oficina de gestão, 2008. trazidas a

momento,

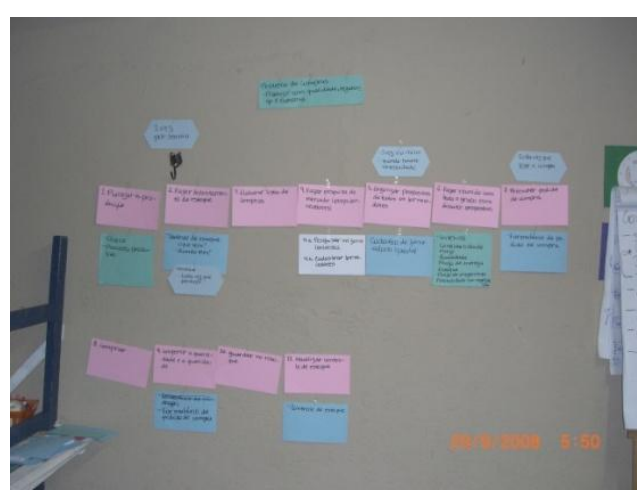

Fotografia 4 - Tarjetas usadas na discussão da gestão da cooperativa, 2008.

todo bem

como a relação da gestão com os princípios do cooperativismo e com as ferramentas que suportam, no dia a dia, a participação democrática.

O alinhamento com essas duas organizações de suporte foi sendo desenhado ao longo do trabalho, mostrando-se indispensável. Depois das primeiras semanas os papéis foram definidos: eu trabalharia os assuntos propostos e realizaria exercícios práticos, mas a implementação seria garantida pelos formadores da incubadora. O Pólis estaria mais envolvido no fortalecimento e desenvolvimento da Rede Local e na participação do grupo nessa e em outras redes. Os desentendimentos entre ITCP e Pólis não chegaram às oficinas, mesmo porque as contribuições no planejamento eram pontuais. 
Começaram sendo quatro os formadores da incubadora e uma do Pólis, depois ficaram apenas dois ITCP e a única representante do Pólis afastou-se,

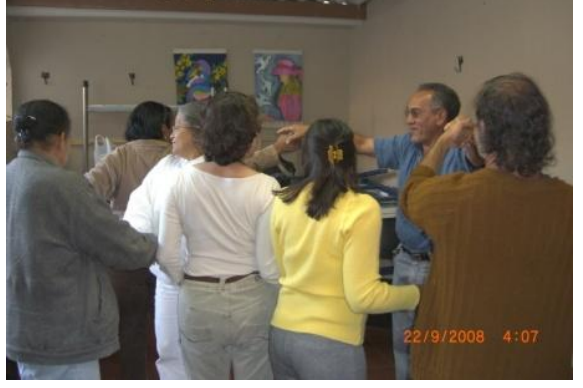

da

Fotografia 6 - Atividade lúdica, 2008. participando apenas de alguns encontros ou eventos. A relação dos formadores com o grupo é um capítulo à parte, apenas será tratada nessa dissertação a partir da visão dos cooperados quando a trazem em suas narrativas.

Foi nesses encontros em que pude praticar a observação participante, ao mesmo tempo em que sugeria e participava das atividades, voltava minha atenção às expressões orais e corporais,

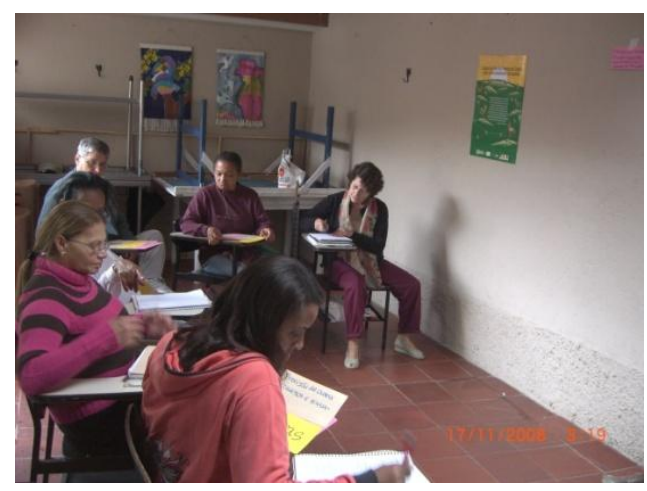

Fotografia 7 - Oficina de gestão - exercício com tarjetas, 2008. bem como às conversas que aconteciam no antes, no intervalo e depois das reuniões. Nessas horas informais aproximei-me de algumas pessoas do grupo, estabelecendo uma relação além de pesquisadoracooperado; era inevitável comover-me com os problemas pelos quais passavam, comemorar junto os dias de alegria, contar sobre a minha vida e ouvir sobre as deles.

Está claro que tal convivência e troca não contribui para a neutralidade das partes da pesquisa, ao contrário, é por meio dela que se estabelecem novas imagens de uma em relação à outra e propicia que se sintam confortáveis uma ao lado da outra. A neutralidade não é, nem poderia ser, pretensão de uma pesquisa como essa. Embora sempre inalcançável, aqui o parâmetro era oposto, quanto menos neutro melhor; quanto mais pudéssemos ultrapassar a posição inicial, de um lado de pesquisadora da universidade, que vem de fora em busca de algo, e de outro de cooperados que se espera estarem vivendo movimento emancipatório de suas identidades, melhor.

\subsection{A organização cooperativa em formação - uma história recente}

O Mãos na Massa teve um antecessor no projeto com ITCP-USP e Pólis, o então chamado Lanche Ecológico. Como já existia antes do projeto começar, foi decidido iniciar o trabalho com esse grupo, no entanto, depois de inúmeras divergências, definiu-se, estrategicamente, que outras pessoas da comunidade seriam convidadas a entrar no grupo. A resistência de algumas lideranças 
autoritárias a compartilhar os equipamentos, informações financeiras e a própria história do grupo com outros membros foi o principal motivo para que se iniciasse a formação de um novo grupo.

O incentivo por trabalhar com alimentação teve influência decisiva da Rede Local de Segurança Alimentar e Nutricional ${ }^{125}$, que já vinha sendo fomentada pelo Instituto Pólis antes de se pensar a formação de negócios solidários, da imagem que se manteve de que o Lanche Ecológico obtinha sucesso econômico pela grande demanda que existiria e da previsão da reforma, pela Subprefeitura do Butantã e pela FINEP, do Centro de Referência em Segurança Alimentar e Nutricional do Butantã $(\mathrm{CRSAN}-\mathrm{BT})^{126}$, incluindo sua cozinha-escola que passaria a atender as condições requeridas para comercialização de alimentos. O mapeamento das potencialidades da região foi elaborado com especial atenção para o setor alimentício, depois, a elaboração da atividade e produto específicos foi desenvolvida por meio de jogos dramáticos em paralelo à pesquisa de receitas (ITCP-USP, $2007^{127}$ ).

A partir desse mapeamento, dos Seminários de Economia Solidária e Segurança Alimentar e da Rede Local de SAN (segurança alimentar e nutricional) que já estava em formação, com reuniões frequentes, uniram-se 30 pessoas interessadas em tocar adiante o projeto produtivo. Dessas 20 pessoas permaneceram depois das primeiras reuniões, chegando mais tarde, como sabemos, a oito.

A maior parte do grupo inicial, formado após o seminário de mobilização, eram donas de casa, com exceção de três homens, subempregados ou desempregados; a maior parte desistiu logo de início, frustrada a expectativa de ganhar dinheiro imediatamente. A principais razões para desistências eram urgência por ganhar dinheiro, para alimentar a família, problemas familiares que requeriam totalidade da atenção do envolvido e a oportunidade de um emprego.

O perfil desses integrantes do Mãos na Massa, segundo relatório de 2007 da ITCP-USP para a FINEP:

“As pessoas que compõem o grupo residem no Jd. Jaqueline e adjacências tanto em vielas no alto da favela ou embaixo na proximidade com o

\footnotetext{
125 A Rede já envolvia diversos atores de setores diferentes na participação da política pública municipal: Poder Público, universidades, ONGs e comunidade (ITCP-USP, Relatório Parcial FINEP, 2007).

${ }^{126}$ O Centro reformado foi inaugurado em maio de 2010, depois de muito tempo de atraso em relação à previsão inicial. O lado positivo disso parece ter sido que os constantes atrasos na reforma do CRSAN-BT, ansiosamente esperado por todos da comunidade e do grupo, levou-os a lidar com essas frustrações coletivamente, fazendo inclusive um esforço de organização social a fim de influenciar a política pública (ITCP-USP, Relatório Parcial FINEP, 2007).

127 Relatório Parcial elaborado para a Financiadora de Estudos e Projetos (FINEP) referente aos "Projetos de Incubação de Empreendimentos Solidários Agroalimentares”.
} 
córrego, como em casas em locais e bairros com melhor estrutura urbana. Os integrantes do grupo estão envolvidos com a comunidade através de trabalho com associações de bairro, de mulheres, sindicato, partido político ou Pastoral da Criança. O grau de escolaridade da maioria é de concluintes do nível I do Ensino Fundamental, e a abrangência de analfabetos a concluintes do Ensino Médio. A faixa etária está entre 16 a 63 anos, sendo que a maioria tem entre 35 e 55 anos. Tem renda ou recebem proventos como beneficiários do programa Bolsa Família, ambulantes, aposentados e prestadores de serviços esporádicos ou temporários. Enfrentam problemas pessoais ou de família com relação ao desemprego, e à saúde (deficiência auditiva, hipertensão, diabetes, consumo de drogas do álcool ao crack)" (op. cit., p. 18).

Chama a atenção nessa descrição algo que continua sendo verdade hoje, grande parte dos envolvidos tem atuação em outras organizações, movimentos e projetos locais, regionais e até nacionais. Nesse momento, também, como consta no mesmo relatório, o grupo começava a apropriar-se dos conceitos e práticas da autogestão, mostrando-se favorável a essa forma de organização, apesar das dificuldades vivenciadas. As diferenças entre trabalho e emprego e a democracia e suas implicações também parecem ter sido discutidas nessa fase da incubação.

Entre os desafios enfrentados estava o analfabetismo e o aspecto novo de conceitos básicos de matemática e a urgência em gerar renda junto ao grupo para melhorar a qualidade de vida de suas famílias. As tentativas contínuas de acesso ao trabalho heterogestionário, do emprego é responsável pela transitoriedade e inconstância das participações ao mesmo tempo em que não estar empregado implica desespero, ansiedade, angústia.

Considerando que, também como reflexo disso, de início a preocupação com a comunidade, com o entorno, registrada nas Normas e Regimento Interno do grupo, restringia-se a não prejudicar qualquer pessoa, sendo este o limiar das ações em relação ao grupo e à comunidade, houve mudanças consideráveis nesse sentido. Como mencionado, quando conheci o grupo, em 2008, havia a preocupação em agir afirmativamente na melhoria da alimentação e nutrição na bairro e, depois, fora dele. 
O esforço por atuar em rede com base na intercooperação para se ganhar força veio, desde o início, das organizações de apoio. ITCP-USP, ITCP-GV, Instituto Pólis e Instituto Kairós, junto a outras organizações, reuniram-se no esforço pela articulação de um clube de compras, que apesar das intenções da própria comunidade, tinha que passar por diversos entraves para concretizar-se. As redes, formadas pelas próprias incubadoras de cooperativas populares, eram entendidas como estratégicas para a articulação dos indivíduos, comunicação e promoção de produtos e serviços.

Em 2007, o CRSAN-BT, incluindo alguns membros do Mãos na Massa, já participava, a convite Instituo Pólis, do "Programa Mercosul Social e Solidário", implementado pelo mesmo instituto. O debate político nessa rede ultrapassa os limites do país, passando por temas como a organização do trabalho comunitário de base, cadeias produtivas, com o objetivo construir coletivamente políticas públicas de fomento a produtos agroecológicos, que valorizem e surjam da diversidade. Todos os dez segmentos da Rede foram representados em encontros do Programa, como o que aconteceu em Assunção, no Paraguai, em 2006, em que pode entrar em contato com questões macroecômicas e sociais vividas por toda a América Latina, expandindo a visão e a compreensão de uma realidade que chega à comunidade, ao cotidiano do Jardim Jaqueline.

Em 2008, quando cheguei junto ao grupo, as atividades da rede local e da rede do Mercosul continuavam em andamento e logo ficou evidente que

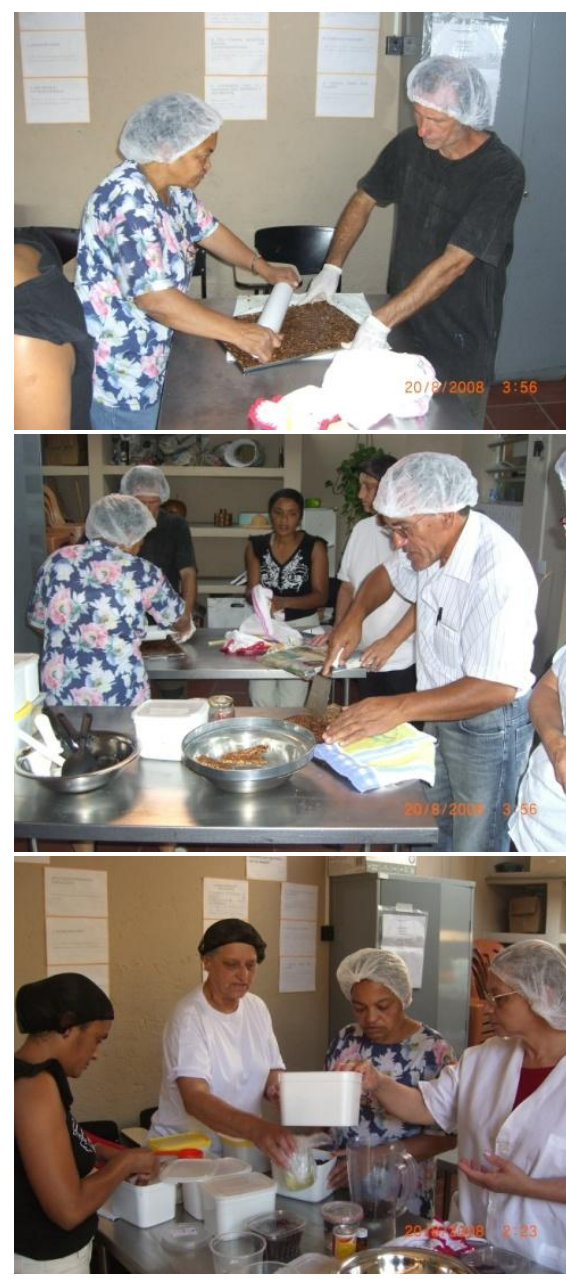

De cima para baixo: Fotografias 8,9 e 10 - Produção das barras de cereal. Mãos na Massa, 2008. eram sempre os mesmos cooperados que participavam. Mais tarde, como aparece um pouco abaixo, os chamados "sujeitos emblemáticos" indicados pelo próprio grupo foram, não coincidentemente, esses mesmos, interface do grupo nas redes, atirados em direção às novidades, interessados, antes do fortalecimento da economia solidária, em vivenciar novas experiências. 


\section{a. O caminho da pesquisa nessa história}

O método dessa pesquisa parte da concepção ontológica do ser humano, como um ser social e histórico, bem como do trabalho, como elemento de transformação do homem e da natureza e que por sua vez também passa por mudanças sociais e históricas. Da visão ontológica desdobra-se o método dialético de análise crítica dos eventos, das relações e das narrativas.

A pesquisa de campo foi iniciada na primeira reunião, de apresentação, com grupo, em julho de 2008. Desde então, guiada pela pesquisa-ação, a observação se fez junto e somente possível com a interação com os cooperados. Os materiais dos quais se parte nessa etapa da dissertação são o diário de campo, elaborado após os encontros com os grupos, e as entrevistas de história de vida transcritas (anexo 1).

Esse método, que passa por esse tipo de entrevista, foi escolhido com base no trabalho de Antônio Ciampa. "Sujeitos emblemáticos" são aqueles que se destacam no grupo, na comunidade, por exprimirem a consciência coletiva de uma forma mais clara, contundente, legível do que as outras pessoas com quem compartilham um universo simbólico (PACHECO E CIAMPA, 2006). Por isso mesmo seriam os sujeitos que, quando entrevistados, trariam mais riqueza de informações e análises sobre si mesmo, o grupo e seu contexto, à tona.

Ninguém melhor que o próprio grupo, que conhece uns aos outros, seus membros, pelo compartilhar de histórias, para indicar aqueles que podem ocupar essa posição proposta: sujeito emblemático. Assim, foi realizada consulta direta, por questionário aberto, a todos os membros do Mãos na Massa; eles apontaram seus pares que, em sua opinião, eram considerados exemplo de vida na comunidade. Haveria espaço nesse instrumento para que os indivíduos expressassem livremente seus pontos de vista sobre as "indicações".

Os três que mais apareceram foram duas mulheres, Márcia e Joana, e um homem, Luís. Consultados a respeito da vontade e disponibilidade de contarem suas histórias de vida, todos eles mostraram-se dispostos. Portanto, foram eles os entrevistados; três apenas porque garantiria uma diversidade satisfatória para análise, já que tantos quantos o número de entrevistados, tantas seriam as vidas, únicas, com as quais entraria em contato, ao mesmo tempo em que não tornaria a análise e a pesquisa desgastante pela extensão e profundidade do material com mais sujeitos envolvidos.

Desenvolve-se, portanto, uma pesquisa essencialmente qualitativa, sem ater-se à preocupação com a representação numérica: a mostra é intencional, os sujeitos são definidos 
pelas suas qualidades, pela sua potencialidade de representação de si mesmo como membro do grupo autogestionário e, claro, pela sua própria disposição em participar da pesquisa. Nas palavras de Thiollent (1985), na antropologia, Márcia, Joana e Luís seriam as "testemunhas privilegiadas".

As oficinas de gestão de negócios, oferecidas como contrapartida, a partir da sugestão do próprio grupo, compõe a metodologia no sentido de abrir caminho para a ação, para a observação e vivência a partir do envolvimento prático com o grupo, no dia a dia, e, também, de estabelecer uma relação de troca equitativa entre as partes, a pesquisadora recebe a colaboração do grupo e vice-versa. Partindo-se desse ponto todos pareceram sentir-se mais confortáveis.

A observação-participante também em eventos comemorativos, como aniversários e amigo

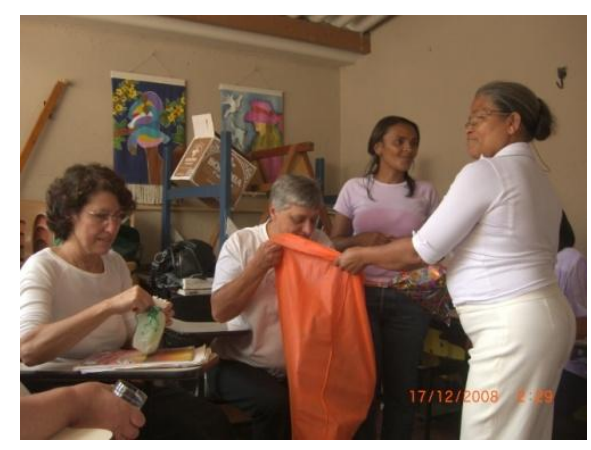

Fotografia 11 - Amigo secreto Mãos na Massa, 2008. secreto de final de ano foi desdobramento dessa convivência e permitiu que o contato se desse a partir de um novo papel, o de amigos, de uma posição marcada pela confiança. As fotos que ilustram essa sessão foram tiradas nos momentos de trabalho e de descontração e compartilhadas com o grupo.

No começo de 2009, depois de algum tempo de trabalho com o grupo, foram identificados, por meio dos questionários respondidos por todos, os três "sujeitos emblemáticos", os quais aceitaram participar, e até ficaram animados com a possibilidade. As entrevistas em profundidade não tinham roteiro, eram iniciadas com o pedido de que cada sujeito contasse sua vida, desde a primeira lembrança até o momento atual. Quando pulavam algum período ou passavam muito rápido por algum episódio aparentemente importante a entrevistadora perguntava a respeito ou pedia para que contassem mais.

Sem tempo determinado de duração, as entrevistas levaram de uma hora e meia a quatro horas, apenas a de Márcia foi dividida em dois momentos, iniciada em um dia e terminada em outro, as outras foram corridas. Uma complementação $^{128}$ foi realizada quando, depois de transcritas, as entrevistas foram impressas e encadernadas e

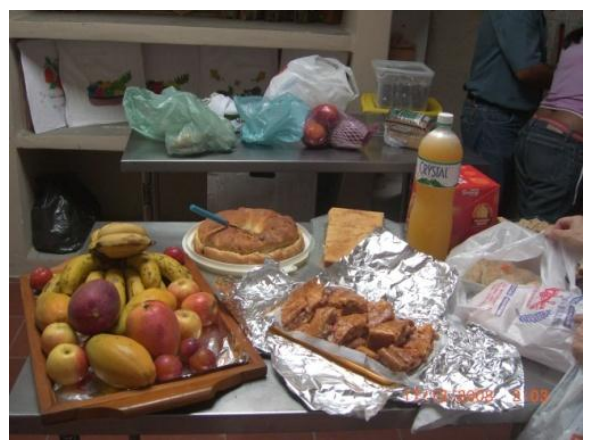

Fotografia 12 - Lanche solidário do

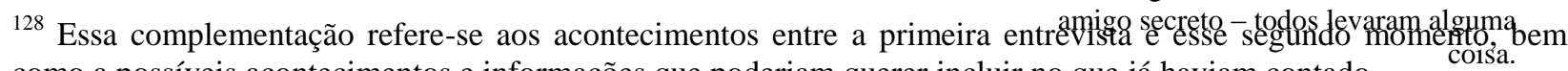
como a possíveis acontecimentos e informações que poderiam querer incluir no que já haviam contado. 
devolvidas a cada um dos participantes. Ao receberem esse material ficaram emocionados e orgulhosos, ansiosos para ler a entrevista; expressaram-se por colocações como "essa é realização de um dos meus grandes sonhos, ter minha vida escrita" (Luís), "agora poderei deixar minha história para quem quiser ler” (Márcia), “tanta coisa vivida, agora está aqui, na mão!” (Joana).

A ideia era que esse material fosse lido e que fossem propostas alterações ou complementações conforme achassem prudentes. Nenhuma observação foi feita nesse sentido, quando perguntei a respeito foi consenso de que era aquilo mesmo, de que uma vez falada não daria mais para mudar, teria virado história.

Nesse capítulo debruçamo-nos, então, sobre esse material. As narrativas são a base para nossa busca por compreender em que momentos dessas três histórias em construção se deram as mais significativas metamorfoses de identidade, as qualitativas resultante do acúmulo de mudanças quantitativas, e quais os sentidos dessas metamorfoses. O exercício autogestionário e as relações solidárias serão identificados nessas trajetórias na intenção de evidenciar se e como repercutiram no trabalho, na vida cotidiana e na identidade (como metamorfose constante) desses sujeitos de acordo, sempre com a percepção de cada um deles. Consideramos aqui que o sentido emancipatório da metamorfose passa, necessariamente, pela consciência em relação ela, pela atribuição de significado para essa experiência (CIAMPA, 1987).

Dessa maneira poderemos nos aproximar de possíveis respostas, para esses três casos, para a questão central dessa pesquisa: o exercício autogestionário em cooperativas exógenas de trabalho, ancorado em práticas cooperativas e em relações solidárias, pode ser impulsionador do movimento de metamorfose da identidade com sentido emancipatório? Impulsionador entendido como desencadeador de novas condições concretas, objetivas, que possibilitam o início de um novo caminho, tal metamorfose.

Outro norte para a leitura das entrevistas vem da teoria crítica: a consideração da realidade como um processo em movimento, em transformação, contraditório. A dialética materialista será o primeiro ponto de vista adotado, perpassando toda a análise, buscando elementos da realidade e da identidade dos sujeitos que se apresentam e originam um novo. A questão aqui é, principalmente, as correspondências do mundo objetivo com o subjetivo e quais os impactos para a identidade desse movimento dialético da realidade com a subjetividade.

A proposta é a análise diacrônica e sincrônica da narrativa, ou de alguns de seus trechos, valorizando o entendimento em profundidade dos fatos narrados que ocorrem no mesmo período, 
bem como de cada um deles na história, no desenrolar dos acontecimentos narrados. Considera-se importante o contexto social, econômico, cultural, político na leitura das narrativas, embora esteja claro que muitos dos elementos que o compõem escapam à análise.

Está claro que o esforço interpretativo estará carregado de minhas próprias expectativas e referências, na maior parte das vezes de forma entrelaçada, inseparável, ao texto. Construo o meu discurso, a partir de minha história de vida, de meus símbolos e parâmetros, da relação com o grupo, com os três sujeitos e de suas narrativas.

Mais importante, as histórias de vida, antes de passar pelo lugar de onde vejo e interajo com o mundo, são memórias já trabalhadas, assimiladas simbolicamente e recompostas a partir de uma perspectiva subjetiva. É exatamente tudo isso que torna esse material tão complexo e rico, mais ainda ao considerarmos, como Bosi (1987) que a memória coletiva, em sua pluralidade de perspectivas, realiza-se nas memórias individuais e, como Ciampa (1987), que a sociedade se concretiza no indivíduo, nas possibilidades e entraves a partir dos quais cria ou não a história humana.

A seleção das memórias e do que contar é colaboração com a pesquisa. "Os trabalhadores dizem o que lhes importa” (FERRAZ, 2005, p. 234). Ainda, na narrativa das histórias sabe-se que a memória é atualizada, recebe novos significados e sentidos, momento esse, portanto, em que uma nova consciência é formada. Sabe-se também que as experiências e acontecimentos da vida assumem um sentido único para cada sujeito (ANDRADA, 2005); partimos dessas indicações já apontadas por outros pesquisadores para seguirmos adiante, mergulharmos no universo de cada um, ou parte dele que nos mostram.

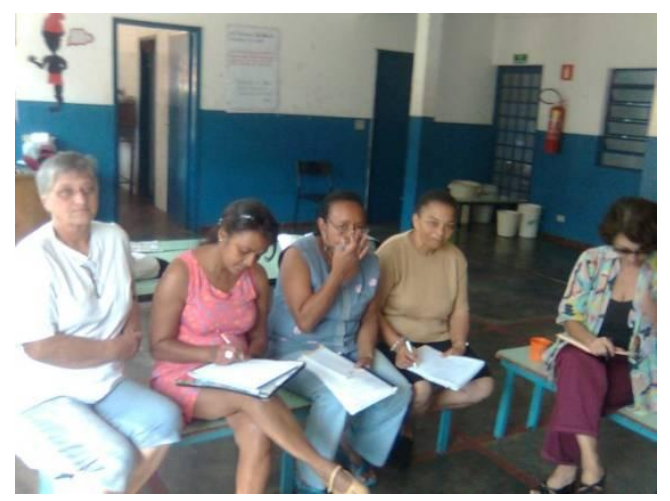

Fotografia 13 - Grupo Mãos na Massa, 2009. 


\subsection{Luís, Joana e Márcia - a cena a quem a merece, aos protagonistas}

\section{Márcia}

\section{Infância, as primeiras memórias}

Nascida no interior do Piauí, Márcia orgulha-se de sua memória acurada, e de sua "esperteza" ${ }^{129}$; essas são características pelas quais foi reconhecida, pelos outros e por si mesma, ao longo de sua história, desde de pequena. Tem lembranças de sua primeira infância, das brincadeiras de suas irmãs, que a jogavam "de um braço para o outro", e de sua avó carregando água dentro de uma "cuiona" para lavar roupa. Segundo diz, devia ter uns dois anos, "quando muito", nesse momento.

O pai trabalhava na roça, com "mandiocada, com engenho, com moagem, com cana", como não era fazendeiro, a família toda tinha mudar de casa às vezes, ficavam uns meses em outros lugares, enquanto o pai prestava seus serviços a outros fazendeiros. "Tínhamos nosso terreno, mas não éramos fazendeiros”. A mãe cuidava da casa, seja lá em qual estivessem.

Foi na família sua primeira socialização, em que conheceu as primeiras barreiras ao reconhecimento do sujeito que se formava: com a irmã de idade mais próxima a relação era pautada pela diferença de cor de pele, por ser "mais clara", por ter nascido "bem branquela", essa sua irmã, "mais preta", maltratava-a. Em uma família de onze filhos, a atenção dos pais tinha que ser disputada, a visão que mantém ainda quando me contava sobre sua infância era de que o pai voltava-se apenas a essa mesma irmã, "puxava muito o saco dela". A mãe olhava-a de fato quando Márcia aparecia doente; do outro lado, a deficiência física de sua mãe (um problema na perta) marcara a relação entre as duas nessa primeira fase da vida, era devido a ele que "não podia ficar pegando ninguém no colo", só se estivesse sentada. Nem assim, Márcia não ficava em seu colo, tinha medo de machucá-la.

A imagem que traz de si quando pequena é composta pelas qualificações que os outros atribuiram-lhe, "pequeninha", "gordinha" e "muito levada". Seu grupo foi logo extendido, desde cedo passava alguns dias na casa de cada desses uns e outros que chegavam a sua casa e levavam-na por uns dias: "o outro chegava, me levava". Foram esses outros que lhe permitiram conhecer-se como criança "esperta, todo mundo gostava de mim, era o xodó de todo mundo". Sentia-se querida, "não tinha vergonha de nada", dançava, rodava, rodopiava, ganhava muitos

\footnotetext{
${ }^{129}$ Todas as citações desse tópico referem-se à narrativa de Márcia durante a entrevista de história de vida realizada em março de 2009.
} 
doces: "começava a dançar, o pessoal me achava bonita dançando, compravam bala, ficavam me agradando, e todo mundo naquele xodó”.

Era essa a personagem que surgia, que tinha espaço, na articulação entre a objetividade de seu núcleo expandido, dos amigos dos pais, dos vizinhos, da comunidade, e a subjetividade que se formava e transformava-se. Era a criança alegre, extrovertida, esperta, levada, pequeninha e gordinha que alcançava o reconhecimento afetivo de todos os outros, fora de sua família.

No núcleo familliar era outra personagem que ganhava a cena, a criança-doente. Lembra a única vez em que a pegaram no colo: quando ficou doente, com uma febre que chegava "todo dia, na virada do sol, quando o sol estava se pondo". Márcia conta que em um desses dias estava na cama quando sentiu preguiça de engolir ou de cuspir a saliva que acumulava na boca e começou a babar, “eu não vou cuspir, fiz porque eu quis, sabe?”. Uma das irmãs desesperou-se diante da cena “corre! A menina está morrendo! A menina está babando!", e assim continuou, babando, mole, não mais por preguiça, mas pelo efeito da cena: “só assim me pegaram no colo, não é?". Nascia a personagem que a acompanharia por algum tempo, repondo-se, mesmo sem representar sua subjetividade.

A relação com os pais tinha barreiras estabelecidas pelas regras rígidas, regras determinadas a partir da autoridade contida nos papéis de mãe e pai; uma distância era, assim, garantida, distância que impedia o reconhecimento, um do outro, em toda sua humanidade. Contava-me que o pai comprava sapatos apenas para as festas, em todas as outras situações era descalça que se virava, inclusive na roça. Queimava e machucava os pés, segundo ela mesma, não sabia que poderia dizer isso para o pai esperando que resolvesse, que a ajudasse. "Eu não sabia que tinha que chegar no pai e dizer 'pai, está queimando meu pé'. Eu não sabia.” Mostra aí ter consciência a respeito dessa impossibilidade de relacionar-se de outra forma naquele momento, contexto em que se colocava com um determinado repertório, e também de uma mudança de sua própria perspectiva, em suas representações, ao longo de sua história, certamente permitida por outras formas de reconhecimento.

O contato com o pai era para pedir a benção, "quando acordava, quando dormia, quando comia, rezava, a gente pedia a benção", mais tarde era ainda mais pontual essa relação, quando o pai fora trabalhar em outra fazenda trazia bala, recebia o pagamento pelo trabalho da família na fazenda em que moravam e logo partia. A mãe era mais próxima, mas "não podia fazer o que o que ela tinha vontade de fazer", respeitava as ordens do marido. Márcia percebe hoje que não era 
essa uma limitação sua, uma questão individual, mas uma situação maior que se colocava, estabelecida.

As limitações da mãe, por não poder superar as contradições vividas, levaram-na à impossibilidade de mantê-la por perto, por isso teve que doá-la para a "mãe verdadeira, que é mãe natureza". Foi já em São Paulo que pôde encontrar essa "mãe verdadeira" e entender sua mãe biológica.

Encontrou na natureza a possibilidade de existência que não tinha chance entre os pais. Márcia não era vista. Um primo, que morava "em um bairro longe", foi o primeiro a notar que nasciam seus "peitinhos"; ele notificou a mãe de Márcia que ela não mais poderia andar sem blusa, que estava começando a "brotar que nem feijão". Ela chorou, “parecia um índio bravo, um caboclinho, um índio, um negócio". A identificação com o que chama "bicho do mato" é trazida também em outros momentos na narrativa; aquele que não tem vínculos, cultura, linguagem, palavra, que se encontra melhor em meio à naureza do que entre outros homens. Já sabemos que a possibilidade de existência humana se dá pela palavra e pela ação (GONÇALVES FILHO, 2009), não foi junto a seus pais onde primeiro encontrou abertura para a realização de seu devir humano.

$\mathrm{Na}$ natureza encontrou a brincadeira, a possibilidade de criar suas próprias regras, o acolhimento. Ali, em meio às plantas e animais construiu um mundo seu, misturava-se ao ambiente: "Onde eu via uma árvore grande, aquilo para mim se tornava um estado, eu queria ficar naquela árvore. Subia naquela árvore, cada galho era uma cidade."

Apesar da clareza com que conta suas impossibilidades, suas limitações objetivas, Márcia sente por ter feito "muito pouco" pelos pais; "eu não considero nem uma ajuda". Sentia ainda pesar por isso e propunha-se compensar, no futuro, essa ausência, "eu tinha esse sonho de ajudar, e se Deus me permitir, eu ainda vou fazer na morte deles. Vou cuidar nem que seja do túmulo deles, cemitério que está abandonado naqueles matos lá.” Assim poderia agradecê-los por terem feito o que puderam, o que lhes era possível diante de suas próprias limitações.

A primeira reflexão que Márcia se lembra de ter elaborado foi em relação à mãe. Por sua deficiência física, não alcançava Márcia, “às vezes fazia arte, ela queria me bater e eu não deixava. Ela não podia andar para me pegar rápido". Em um episódio em que chegara tarde em casa, da volta da casa de uma prima onde fora a pedido da mãe buscar carnaúba, demorou-se demasiadamente deixando a mãe sem notícias. Nesse dia, especialmente, Márcia optara por não 
fugir, apanhara "com a correia do cinto, da cor da saia, (...) até dizer chega". Tomara a decisão de nunca mais fugir da mãe, "não vou correr, mas também não vou sair do lugar, onde eu estiver ela vem e me bate. Porque eu achei que era judiação".

Achara que sua mãe tinha razão em bater-lhe, dar-lhe a lição. Reflexão que parecia, a Márcia, unusual para uma criança daquela idade, orgulha-se disso. "Por que eu demorei? Por que eu não obedeci minha mãe? E não é todo mundo que pensa assim quando é pequena." Depois disso nunca mais apanhou, por falta de motivo, "mas se tivesse necessidade, ela ia me bater e eu não ia sair, nem ela, nem meu pai."

Assim Márcia elaborou, conformou e colocou em prática sua regra, contruída a partir da mudança de seu comportamento diante da regra antes estabelecida por outrem, da percepção de si própria e do outro, dos diversos interesses que se colocavam em equação. Márcia reafirma as personagens do presente lembrando de momentos do passado em que apresentou novas soluções para as mesmas situações, em que exerceu sua criatividade, alterando de alguma forma a realidade objetiva, dando voz ao seu "eu".

Na narrativa de sua história Márcia ressalta situações em que se colocava como sujeito ativo; tinha medo de seu único irmão sofrer um acidente quando saia para caça, por isso o acompanhava, "tinha medo do bicho comer ele. Ele tinha que me levar junto que era para proteger ele". Por outro lado, logo cedo aceitou respostas dogmáticas, extraterrenas, religiosas, para os "mistérios" com os quais se deparava. O entendimento elaborado, inicialmente, para um episódio em que Márcia e uma amiga fugiram de um homem misterioso, com o qual se depararam no meio do mato, comporá uma forma de ver tudo aquilo em que, dali em diante, não pudera compreender com seus próprios recursos. Todos os episódios misteriosos são conectados e dão vida a uma outra estória, como veremos.

Um marco em seu contexto objetivo foi a mudança para Itapecerica da Serra, para estudar. Instalou-se na casa de sua madrinha e sua irmã, a mesma que tinha ciúmes de Márcia pela cor de sua pele, junto à outra família, amiga de seu pai. Márcia tinha nove anos, lembrança que representa essa transição é a "raspa de juá" cedendo lugar à escova de dente e o primeiro chinelo.

\section{A casa da madrinha - nova família, primeiros patrões}

O padrinho era "dono de um comércio lá na cidade, tinha terrenos, propriedades e cultura", a família também plantava e a função de Márcia foi logo estabelecida: trabalhava nos serviços da casa, carregava lenha e água na cabeça, limpava a louça, "aquelas panelas de ferro 
para deixar todas limpinhas". Depois de trabalhar o dia todo ia para a escola, "nunca tive tempo de estudar, e nunca perdi um ano”. Estudou até a quinta série do Ensino Fundamental.

Colocou-se na posição de obedecer a tudo que lhe mandavam fazer, carregou pesos que lhe renderam a dor nas costas que ainda a acompanha; "parece que a cabeça estava enfiando dentro do corpo". Enquanto suas tarefas eram completas, plantava, cozinhava, levava comida para os outros, limpava, recebia os restos.

"Nunca tive boas roupas, nunca tive bons calçados, minha madrinha me dava caderno velho das filhas dela, me dava pedacinho de lápis. Ela não comprava caderno novo, livro novo para mim. Tudo coisas das filhas dela, que já eram mais adiantadas e foi ficando, e eu ia estudando".

Foi assim que a "Márcia-bicho-do-mato" foi cedendo lugar à "Márcia-serva", que não tinha voz para questionar o que lhe mandavam fazer, passsava por cima de suas próprias vontades por sentir-se sempre devendo o favor de morar em uma casa de que não era sua. Quando começou a ser alfabetizada, com 11 anos, passou a entender também os números e a saber o quão pesadas eram as caixas que carregava de casa para o comércio do padrinho. Sem consciência, ainda, sobre o que representaria aquilo para seu corpo, o quão violento era aquele serviço.

A madrinha tinha uma empregada, não era Márcia. Uma mulher que, todos os dias, no trabalho no pilão, às cinco da manhã, exigia que "tivesse força para bater naquilo igual ela". Com 11 anos. Outras meninas foram morar na mesma casa, com o mesmo objetivo, o de estudar; a responsabilidade por elas era de Márcia, "eu como a mais velha me acarretei de muita responsabilidade".

A empregada cansou e Márcia assumiu a responsabilidade por toda a casa, fazia-se, pelas atividades, babá e empregada doméstica, embora nunca dito. Passou a responder também pelas ações das outras meninas, pela louça quebrada, por qualquer "arte". Respondia aos outros, de acordo com o que lhe impunham, a si mesma calava; o "eu" sufocado, calado mantido pelo sentimento de culpa e por não ver opções concretas para sua sobrevivência fora da casa da madrinha. "Aí acho que comecei a ficar adulta muito rápido, muito cedo", a "Márcia-serelepe" era solapada por um mundo em que valia por quanto trabalhava, enquanto mão-de-obra barata, um reconhecimento desumano, situação em que, de novo, não era ouvida nem vista, reposta.

Até o fator que poderia colaborar para sua redenção, contribuia para sua prisão. Era a única "afilhada de verdade" entre todas as meninas, o que entendia como motivo para não recusar os vestidos usados para os quais as outras diziam não. "Sabe aquele negócio de pecado? Não 
pode responder para madrinha, que morre, vira bicho, um monte de barbaridade, e eu acreditava." Ainda, por ser afilhada, a madrinha poderia bater-lhe, o pai havia lhe dado essa liberdade, nas outras meninas não. Calava-se diante da figura que ocupava mais uma vez o papel de autoridade, repunha-se o não questionamento.

Depois, quando me contava, Márcia enxergava a contradição da situação vivida, as ideias que tomou como verdade, o medo do conflito. A culpa outro elemento dessa relação, até mesmo as boas lembranças estão a ela atreladas, como as brincadeiras com a madrinha e com as outras meninas, no quintal, na rua, jogando bola. "Não existia um quintal de amigas para brincar de casinha, mas quando tinha tempo, fim de semana, domingo, feriado, nós fazíamos isso". Os brinquedos eram ditos muito caros pela madrinha; depois de alfabetizada Márcia pôde também começar a ler os preços das coisas por si só.

Ao mesmo tempo em que a leitura trouxe-lhe novo contato com o mundo, acesso a informação, cresceu o sofrimento, já que não foi condição suficiente para se rebelar, mudar a relação. Passou a fazer jejum quando ouviu comentando que chegava em casa sempre na hora da comida. "Se eu escutasse meu padrinho ou minha madrinha falar isso, eram uns três dias sem querer comer."

Era a cobrança do que não poderia devolver, uma dívida que se acumulava. "Eu detestava esse negócio, ou você faz ou não faz (...) principalmente coisa de comida, come não tem nem como vomitar". Era a "Márcia-de-favor", que chegava ao limite de não ser dona nem mais do que comia, cada vez menos dona de si mesma.

A comida ganhou outros significados para que a vida tivesse outros sentidos, o sacrifício da fome foi encarado como meio de merecer a libertação, a mudança da posição ocupada, a transformação da personagem vivida. "Eu casei com 16 anos e ainda achava que se eu parasse de comer eu ia santificar. Ouvia falar de santo, aí eu dizia, não vou comer que é para santificar, para eu sair do meio disso aqui." Essa era a realidade que não merecia ser vivida, mas que se impunha impossibilitando que Márcia se autodeterminasse, reatualizando a identidade pressuposta, e impedindo sua alterização. A luta se fazia quieta, silenciosa, pela greve de fome, pelo apelo à fé, à crença na religião.

Naquele momento negar o alimento era negar a vida que não merecia ser vivida; era o que havia lhe sobrado de si mesma, o resquício de autonomia. Por isso resistia à rapadura cheirosa, 
gostosa, que a madrinha tinha acabado de comprar e colocara um pedaço em seu prato. Márcia chorava, de pé, em frente à rapadura, "mas sem careta".

A fé confortava-lhe pela crença de algo fora, além dela e da madrinha estaria observandonas e puniria a humilhação incorrida, mantinha-se na relação esperando pela justiça do além; a contramão da luta por autodeterminar-se, a alienação na alienação. A esperança pela redenção, justamente por fugir à sua agência, acompanhava o medo: “e eu ouvia falar do cão que é preto. E eu tinha feito malcriação para minha madrinha, eu tinha medo. E caramba! E agora? Será que é o cão?".

A tendência à repetição das mesmas relações confirmava-se, um pouco mais tarde, com 14, 15 anos, "estava ficando mocinha", todas as meninas começavam a namorar, mas Márcia não queria "pegar na mão de um nenhum rapaz" para que não tivessem nada o que falar ou cobrarlhe. A criança-serelepe tornara-se a adolescente-“tímida" pelo foco no que estava fora de si, pela preocupação excessiva, exclusiva com o que os outros, homens e não homens pensariam; “eu fui criada assim, tudo que eu via os outros fazerem que falassem mal, eu já não fazia".

A recompensa não era a esperada, era reposta a contradição das relações vividas: a submissão desembocava em mais dominação já que não tinha sua humanidade reconhecida nem pela madrinha, nem por seu pai. Era época de festa de junina, todas as meninas tinham roupa nova, menos Márcia; seu pai presenteara sua irmã, ela mesma ganhava roupas sim, de sua madrinha, mas "que era remodelada, estava nova para mim, mas eu sabia que tinha sido remodelada da outra para mim”. A irmã:

“(...) fez um vestido de corpinho, de saia, de manga $3 / 4$ porque estava na moda, a coisa mais linda, lembro como se fosse hoje. Ainda sobrou tecido que fez uma sainha justa para mim, porque eu era gordinha, ficava estourando minhas banhas dentro daquela sainha apertada".

Diante do fracasso das tentativas de alcançar uma nova articulação entre subjetividade e objetividade, entre seus desejos e a realidade, Márcia chorou, ficou magoada, e mudou o rumo. O casamento foi tomado como tábua de salvação, superação da contradição. Sairia da casa da madrinha, deixaria de ser a "serva-de-favor", que não é mais dona de nada em si mesma. "Comecei a chorar, e falei comigo, o dia em que um rapaz quiser me namorar, eu vou namorar com ele, vou casar, que é para eu sair do meio das moças".

A sua heterodeterminação passaria então a vir de outro lado, mudaria apenas o patrão.

\section{O casamento - "era feliz e não sabia"}


Aquela situação tinha chegado ao limite, o caminho apontava para a morte simbólica, sem espaço algum para sua singularidade. A mudança precisava vir, mesmo que fosse a do papel para o qual respondia, da posição ocupada por seu dominador. "Pelo menos não vou ficar sofrendo por vontade de sair com as amigas e não poder porque... Eu não trabalho para ganhar dinheiro, e meu pai faz uma coisa dessas comigo." Era uma promessa, de um jeito ou de outro mudaria a correlação de forças estabelecida; "eu deixei sair, eu não falei só com o raciocínio, eu falei."

Conheceu aquele que seria seu marido em uma festa junina. "Seu José"; ele com 22, ela com 15 anos. Casou assim, sem querer, como por acidente, "nunca disse que queria casar com ele", mas como ele foi "logo falando em casamento, não foi nem namorar", insistindo sem esmorecer, casaram-se. Mais uma vez era a Márcia-a-serviço-do-outro quem assumia a cena; no casamento, desde o início, replicava a personagem pressuposta e, assim, a relação estabelecida, perpetuava-se no papel de dominada, à procura de um dominador.

Arrependeu-se Márcia depois, hoje enfaticamente: "foi a pior coisa que aconteceu na minha vida". Considerou-se merecedora de marido diferente, que the tratasse melhor, com quem fosse mais feliz, já que "era uma menina responsável, de confiança, todo mundo queria uma menina como eu, nunca dei trabalho, nunca perdi um ano". Márcia permace valorizando-se pela obediência oferecida, apesar de evidente que não lhe levaria a nenhum lugar imaginado, ao reconhecimento, à realização como mulher e ser humano, a uma vida mais digna de ser vivida.

A razão interesseira parece ter pautado a decisão do casamento por todos os lados, Márcia para sair de onde estava, o pai e os padrinhos no interesse de que o casamento fosse com alguém de mesmo nível social ou acima dos seus, pelo alívio de "encaminhar" a filha, Seu José... não sabemos a visão dele. Começando assim, manteve-se sem grandes mudanças, um casamento em que o outro não pôde ser visto, sem espaço para o diálogo, para palavra ou para a ação, sem lugar para a realização da existência humana.

A contradição dessa nova-velha situação desdobra-se internamente, na unidade de identidade que representa toda sociedade. Sem ver outra alternativa o casamento era parte de um tímido projeto de autonomia, de dar ar aos seus desejos, ao mesmo tempo em que resistia a um casamento que pressentia "ser uma tragédia". Era a mesma resistência, ainda calada, a que Márcia lançava-se; fazia então tudo que o noivo dizia não gostar para, quem sabe, desistisse ele do casamento. Adorava o cabelo, cuidava dele com touca, bobs, mas... "menina, quase raspei o 
cangote. Depois chorei, como eu chorei por causa do meu cabelo." Sem resultado. "Assim que eu fazia, eu agia para me defender."

A anulação vivida no casamento, a supressão de sua dignidade, a humilhação em diversos episódios, abatia-se sobre seu corpo; a Márcia-serva-que-vive-de-favor dá as mãos à Márciadoente-em-busca-de-reconhecimento, outra personagem reposta. Era essa a sua resposta ao tratamento violento: de dor de cabeça, desmaiava na festa, "uma dor fina, gelada, correndo assim... Sangue do nariz".

Diante da desvalorização de si pelo outro, a desvalorização de si por si mesma; frente à impossibilidade de compreender o reconhecimento negado, a culpabilização de si: "nunca briguei com mulher nenhuma por causa de homem, porque eu acho que não é justo. Se ele está comigo e me deixa para ficar com outra, a partir daquele momento já não sirvo mais”. O problema estivera nela, por isso os castigos da mãe, a indiferença por parte do pai, a exploração pela madrinha; a traição de José. Mais uma vez sem enxergar as contradições colocadas, a dinâmica estabelecida, Márcia não pôs seus interesses em jogo, evitou o conflito, anulou-se como sujeito.

A humilhação agora advinha do papel de mulher-esposa, o mesmo que assistira sua mãe desempenhar e por tantas outras mulheres que, sem voz, anularam-se diante das ordens do marido em uma obediência violenta, que as impedia de colocar-se no mundo. A tendência à repetição das mesmas relações vividas por suas ascendentes faz-se realidade, concreta. Se não fosse mulher provavelmente não teria sido reconhecida como "serva-que-vive-de-favor", bem como agora não reatualizaria a personagem pressuposta de "esposa-serva-sem-voz".

“Eu não vou me importar, eu não vou atrapalhar, mas também não vou ficar sem dançar". Aí a contradição entre os desejos, a expressão de sua subjetividade, e o que era esperado a partir dos papéis e suas convenções. Continuara no baile como continuara no casamento, encontrando alguns escapes para o "eu” abafado, lutando para evitar o aniquilamento simbólico. Assim, anos depois, pode olhar para trás, e oferecer compreensão a si mesma: "eu naquela época não tinha palavra, não falava como hoje. Eu queria resolver tudo no silêncio, eu agia, eu não explicava.” E depara-se com sua vida, o que de mais valioso conseguira, efetimente, reguardar: "não sei se foi bom, ou se foi ruim. Foi bom, porque eu estou aqui viva, não é?”.

A angústia do recohecimento perverso, do não reconhecimento personagem de "mulheresposa-digna" a qual tentara, em vão, trazer à cena, é revisitada com pesar. Não guarda fotos, 
"nenhuma, porque eu fiquei tão decepcionada que eu não conseguia nem olhar para aquela foto. Uma criança, linda. Uma situação daquela...”. Desfizera-se dos objetos que encarnavam a humilhação e a angústia vividas. "Um anjo nas garras de um demônio", é essa a metáfora que usa para falar sobre sua relação com o marido.

Se por um lado a Márcia de agora pouco, a Márcia-sujeito-entrevistado, traz a decisão do casamento para si colocando-se de fato como ator dessa história; lembra que afirmara o casamento, mesmo que fosse para sofrer mais. "O dia que um rapaz quiser namorar comigo, eu vou namorar e vou casar nem que seja para sofrer muito mais. Por que eu não falei outra coisa? Eu chamei a coisa para cima de mim." Por outro, ainda projeta no pai a culpa pelo casamento desgraçado, ele é quem, para Márcia, deveria ter-se oposto: “eu era indefesa, inocente, inexperiente. Meu pai tinha que ter me defendido. Me empurrou para cima do cara.”

Na mesma toada, a visão sobre as situações que dialeticamente a formavam e ela mesma formava, apesar de desumanas, eram entendidas por Márcia, no momento da entrevista, como males feitos por algumas pessoas, repetidas vezes, pelo pai. Ele, como os outros, estariam sob a pena de uma justiça sobre-humana:

“(...) ele (o pai) pagou (...) sofreu as consequências (...) ainda hoje não sei o que tem comigo, que mistério é esse, que as pessoas que tentam me prejudicar, terminam se prejudicando. Todo o mal que me deseja vai para a pessoa. Eu não desejo mal para ninguém, Deus é por todos."

A doença da qual sofria também abatia os outros, atores dessas relações; dominantes e dominados padeciam, "terminam ficando doente". Esse era o denominador comum da parceria que Márcia e o marido estabeleceram; uma parceria que, se não se dava na saúde e na alegria, realizava-se na doença. Em sua interpretação, mais um "mistério" que a acompanhou:

“(...) que nós dois tínhamos um negócio que quando um adoecia, o outro adoecia, até nós casarmos era assim. Parece que tinha um vírus que saía de um ia para o outro, a partir desse dia começou esse negócio, essa parceria com a saúde (...). Muito estranho, eu nem sei o que pode ser, porque eu passei por tanta coisa esquisita, podia ser sequela disso, as coisas que eu desconhecia".

Desconhecia muitas coisas que viriam depois do casamento, não sabia o que o papel de namorada-esposa demandava-lhe e oferecia-lhe. Recém-casada, morando na casa da sogra, Márcia percebe que estava "perdida", sem possibilidade de ação ou reação; não havia universo simbólico compartilhado, não havia ressonância em si do que diziam aquelas pessoas, não havia 
papéis disponíveis, palco ou personagem, não era possível entrar em cena. Márcia encontrava-se, nesse começo de casamento, como um ator sem personagem, repondo as personagens anteriores, a "criança-bicho-do-mato", a "serva-sem-voz", a "mulher-esposa-obediente", no ciclo de máinfinidade.

"Não sabia nem planejar uma vida, a casa, o que ia comprar, o que tinha, o que faltava comprar. Eu não sabia de nada disso, eu estava dormindo no tempo. Perdida. Eu estava sentada na porta com ele, se ele não falasse alguma coisa, eu não falava nada, ficava lá sentadinha."

A sogra tomava as decisões sobre a casa e a vida do casal; não existia casal, existiam duas pessoas juntas por alguma conveniência, por um papel assinado, pela razão interesseira, contra o interesse da razão humana. " Márcia contentar-se-ia com pouco, "não me faltando nada (...) eu também não ligo, não me prendo”. Para quem já sentira-se devendo por comer, ser dona de sua própria comida, morar não mais de favor, significava uma melhora mesmo, suficiente para a sobrevivência. Márcia continuava na luta pela sobrevivência.

Se não mais ameaçada pela fome e pela falta de moradia, agora a vida era posta em perigo pela agressividade do marido: "homem ruim demais, tão ruim que eu não vou falar das ruindades dele. Uma tragédia." Voltando-se aos seus dois carrascos prévios, pai e madrinha, não encontra a mesma violência; uma nova característica de seu dominador, "coisa que eu nunca tinha visto na minha vida", na casa de sua madrinha "ninguém via essas coisas".

Ao ver-se mais uma vez, solapada pela desumanidade de sua condição objetiva, em que continuava não encontrando oportunidade de colocar-se, de ser o ator criador de qualquer cena, chorou e adoeceu. A doença como manifestação dessa mesma situação, ambas reproduzidas, foi trazida pela própria Márcia, narradora: "fiquei três dias com febre, acho que era emocional essa doença minha. Três dias na roça, três dias com febre". É “esposa-calada-com-medo" que entra em jogo, que se junta à serva e ao bicho-do-mato sem superá-los, dando as mãos na mesma contradição resposta. Sua anulação era literal, dita por José, quem afirmava-se solteiro a quem quisesse ouvir. Sua negação não precisava de entrelinhas; violência explícita.

Revivendo essa experiência do passado, Márcia lembra de sua reação aos maus tratos, "ele me maltratava, eu ficava com raiva de mim. Ainda bem que nunca passou pela minha cabeça de eu fazer...". Raiva por não ver caminho alternativo à libertação, mesmice em que aprisionada a sua identidade encontrava-se. Apesar das mudanças no contexto e da Márcia, não havia espaço para o outro "outro", para a alterização e negação da identidade pressuposta, na má-infinidade, 
voltava sempre para casa, “os filhos até nem tanto, mas quando eu lembrava da minha mãe que não podia me procurar, que ela tinha um problema físico, parava em algum lugar, começava a chorar, e aí eu voltava para casa." A lembrança da mãe como que lhe resignava à vida que não merecia ser vivida, levava-lhe de volta à prisão, tão desumana quanto a em que vivera a mãe. Chora por ela mesma, pelo que não pode ser.

Ironicamente, a pedido da própria mãe, que "morria de medo de chegar a notícia de que ele tinha me matado, tinha me batido, tinha feito alguma coisa assim”, Márcia busca uma nova mudança, foge para São Paulo.

Trouxe nada, sem os filhos. "Foi um sofrimento que eu não quero para ninguém, que eu vim despedaçada deixando 9 filhos para trás. O mais velho revoltado com o que acontecia na vida, com a separação, começando a beber com 16, 17 anos”. De novo uma decisão que não era sua, uma opção apresentada por sua negação, não pela afirmação; não era isso que queria, mas assim fez, e com isso acostumou-se.

O que faria hoje a Márcia que sentava comigo no sofá do escritório em que atende as clientes da Herbalife, difícil saber, mas como tudo é possível, ela imagina bem diferente: “Ah se é hoje!".

O espiritismo, mistério, curiosidade, medo, sentido, segurança, reconhecimento

Vamos ao elemento "mistério" diversas vezes trazido por Márcia. A esse respeito ela conta-me, detidamente, sobre como encontrara respaldo no Espiritismo. De início ele também um mistério: "nessa época a gente ouvia falar em espiritismo, mas era muito segredo, muito mistério". Depois a explicação para todos os mistérios.

Fora de tudo esse tal "espiritismo", quando criança em Curralinho, ele era a doença do marido da prima, "uma doença esquisita, e disse que era espiritismo". Alvo de curiosidade, intrigada, queria "ver a doença do homem", Mais tarde, era o medo: próxima à "casinha" onde morava, estava lá, a "casa de espiritismo”. Depois música; sem dar-se conta cantava as músicas do terreiro , "eu via aquela menina cantando aquela música, eu achava tão bonito, e decorei a música." Foi então que virou sensação, sentimento, por fim, lugar do qual enxerga o mundo: “comecei a sentir coisa. Eu criava galinha, eu começava a cantar parecia que vinha uma pessoa andando. Aquele vento baixinho parecia barulho de pé. O vento rodeava a casa, e as galinhas voavam, pareciam que tinham visto um bicho." 
O espiritismo trouxe-lhe explicações para o que sentia, para a doença do corpo e da alma, para o filho que não tinha tido até então: "foi uma rodada de 10 moças que se casaram nesse dia e eu tive filho por último, quando eu fui ter filho, as outras todas já tinham tido, já estavam grávidas de novo." O marido rotulava-a estéril, ela respondia com outro rótulo, o de doente, "tinha muita dor de estômago, uma dor terrível que não sabia de onde vinha, chegava a embolar". No terreiro seu mal teria sido sanado, "depois que eu engravidei."

O espiritismo mudara a posição da qual via a si mesma: pela primeira vez o problema não era mais seu, estava na fruta engolida, na música cantada sem querer. Levada ao terreiro "para benzer" acabara sendo "doutrinada":

“O Antônio estava lá, foi fazer as coisas dele, começou a doutrinar e aí baixou um trem lá, cantando a mesma música que a menininha cantava. Cantava e batia com a cabeça na mesa, eu não vou dizer a letra porque coisa ruim não é bom a gente ficar falando. Esse homem ficou doido, esse bicho pulava e foi outra pessoa amparar. Até que desceu um outro trem nele, que um senhor da Boa Trindade, que dizem que é bom. Se tornou meu amigo, me ajudou. Eu nesse dia não tive como fugir."

Disseram que a música que cantara repetidamente por dias, meses, não lhe fazia bem, ela aceitou. Antônio ensinara-na outras músicas, "quando você lembrar daquela, você canta essa, porque eu vou te defender", ela decorou todas na mesma hora; a partir desse momento, finalmente, alguém reconhecia-na e proteger-lhe-ia.

Diferente das outras situações vividas, de fato. Como ela mesma diz, do espiritismo não fugiu. Márcia queria ser salva, buscava segurança, tinha medo da própria extição, mais que do espiritismo, mais do que qualquer coisa. Antônio ofereceu-lhe, no mínimo, a esperança; “eu vou te defender". O espiritismo fora assim sua salvaguarda.

Nesse mundo encontrou também novas regras que, apesar de desconhecidas, de não terem sido por ela elaboradas ("tinha sido criada de maneira completamente diferente (...). Eu gostava de cantar, não sabia que prejudicava") faziam sentido;. No terreiro reconheciam-na mais como outro qualquer, as particularidades de sua história, suas especificidades, finalmente valorizadas. Melhor ainda, em frente a seu marido:

“(...) ela é médium de nascença, ela tem uma mediunidade muito forte, e quando ela era criança os caboclos quase carregaram ela. Se não fosse caboclo tal, ela não estava aqui, não era sua esposa hoje, e era uma menina muito especial. (...)Você está de parabéns! É uma grande mulher". 
Ao encontrar um novo espaço em que uma linguagem diferente era falada, pôde enfim expressar-se, codificar sua história em novos símbolos e encontrando novos significados: "a partir daí foi que eu comecei a entender que existe essa parte espiritual, que hoje eu entendo mais ainda da espiritualidade que todos nós somos". Foi assim que pôde também olhar para os outros, outros homens e para o outro "outro" de si mesma. O espiritismo é explicado por ela como "pensamento e imaginação", como o "bem e o mal" que compartilhamos, que nos permite identificar-nos uns com os outros: "todos nós temos essas partes".

Uma nova personagem nascia, a "Márcia-médium-especial", com conexões além desse mundo e por isso incompreendida, não porque inferior, não porque culpada, mas porque mais sensível, especial. Assim, pelo espiritismo, negou parte do que a negava, o contexto rigidamente interiorizado e reforçado por um arsenal ideológico transmitido entre gerações.

Embora não praticante, Márcia tomou para si os preceitos do Espiritismo para entender o que acontece no mundo, inclusive consigo mesma: "hoje ainda tenho barreira na minha vida, não desenvolvi essa parte [a mediunidade]”.

Teria sido seu encontro com o espiritismo a "alienação na alienação"? Marco da superação de uma ideologia pela adoção de outra, igualmente pronta, assumida como dada? Talvez sim, mas foi esse o caminho do processo dialético de Márcia, o avanço, a partir de uma contradição, em direação à outra.

Considerando o trinômio atividade - identidade - consciência, o que parece é que foram as explicações encontradas no Espiritismo, permitindo o nascimento da Márcia-médium-especial, que possibilitou um novo nível de consciência, ainda dentro das regras contruídas por outrem, mas que sai do individual e alcança o coletivo, que a lança para fora de si e desvenda uma nova relação subjetividade-objetividade. Inaugura-se uma nova forma de produção da identidade em que a nova personagem que convive não é compatível com outras anteriores, pois coloca-se em outra relação com mundo em base diversa, pela articulação entre singularidade e semelhança; compreensão de sua singularidade e do comum a toda humanidade, a partir da noção de que somos todos feitos da mesma matéria, do "bem" e do "mal".

\section{A história com o trabalho - "eu gosto, eu amo"}

A experiência com o que Márcia reconhece como "trabalho", começou com a serva-quevive-de-favor, que trabalhava em troca da comida que não comia, porque nem isso seu trabalho 
parecia valer. A viver de sua força de trabalho começou como arrumadeira do sindicato, passou por monitora e professora do MOBRAL ${ }^{130}$, professora particular, merendeira, lavadeira, empregada doméstica, operária, vendedora de Herbalife, consultora de saúde, cooperada.

\section{O emprego em Floriano - soma de mudanças quantitativas}

Do primeiro emprego, o que a fez sair foi sua saúde. Foi a exceção, todas as outras experiências de trabalho em Floriano foram conturbadas pelo marido. "Sempre ele atrapalhava." Por sua conta, Márcia diz que gostava de todos, em geral de trabalhar, "qualquer um deles (...) eu gosto, eu amo". Depois, mais adiante um pouco, vemos que não é bem assim, ela nos conta o sofrimento trazido por algumas condições de trabalho.

A relação com o marido na equação formada com o trabalho remunerado, que passava a ser parte fundamental em sua vida, permanecia como elemento central: o empenho para prejudicar qualquer resultado positivo que Márcia refletia-se tanto no labor quanto no trabalho, ou em seu caminho em direção à possibilidade de ação. Quanto maior a possibilidade de sucesso de que reconhecimento de outros fosse alcançado e sua autoestima fortalecida, mais contundente a intervenção de José. A história de Márcia com o trabalho remunerado e não remunerado, ainda em Floriano, foi marcada por essa dinâmica.

Além do MOBRAL, Márcia ministrava aulas particulares em sua casa. Como era "muito procurada e o pai dos meninos tudo para me derrubar, ele atrapalhava tudo." Diante de um trabalho que fazia sentido para Márcia e possibilitava-lhe condições para que ela e seus filhos estivessem mais seguros, dependendo menos dos recursos de José, os quais eram escasso e, por vezes, negados, pela primeira vez Márcia contrariou o marido. O comum era que não discutisse nunca, "nunca fui de discutir com ninguém, eu faço o que tenho que fazer, quem quiser brigar, espernear, que esperneie", mas no que concerne às aulas ela colocou-se, manteve-se firme, não queria que José estragasse mais essa "oportunidade".

O conflito não foi tranquilo, ele atacava, "brigava, ficava falando um monte de barbaridade, que eu não estava trabalhando, que eu estava sendo... Um monte de palavra que eu não vou nem te falar." No entanto, era a oportunidade; oportunidade de libertar-se de um mundo

\footnotetext{
${ }^{130}$ Márcia refere-se ao Movimento Brasileiro de Alfabetização (MOBRAL) surgido a partir das campanhas de alfabetização de adultos iniciadas por Lourenço Filho. A crítica ao Movimento baseia-se, principalmente, na ideia de que seu objetivo estaria limitado ao aprendizado funcional de ler e escrever, sem implicar em uma visão mais ampla sobre o homem e seu contexto. Para Corrêa (1979), formam-se não homens, mas mão-de-obra de acordo com a demanda do modelo de desenvolvimento do Brasil de 1970 - 1975. Na década de 80, inviabilizado pela recessão econômica, seus Programas foram absorvidos pela Fundação Estudar (CORRÊA, 1979).
} 
que, mais uma vez, não merecia ser vivido, de alterizar-se, superando as contradições representadas pela esposa-serva-calada-com-medo.

Da posição de sujeito ativo, de protagonista de sua vida, Márcia passou a lutar para não mais se desprender. Identifica como a diferença de classes pesara, por diversas vezes sobre essa posição e como lançou-se à luta para conquistar oportunidades que "essa situação", socioeconômica, confiscou-lhe.

"Sempre eu me encostei numa árvore que tinha sombra. Seu eu preciso saber de alguma coisa, eu não posso me misturar com que não tem aquele conhecimento para passar para mim, como aqui em São Paulo. Cheguei aqui no Jaqueline, já fui logo me entrosando, conhecendo o movimento..."

Márcia cita, pela primeira vez, o Jardim Jaqueline ${ }^{131}$ e o movimento social em que ainda milita. A consciência de que o passado, presente e futuro estão conectados é trazida na reflexão de que se a relação com o marido fosse diferente, se o marido fosse outro, talvez todo o resto seria outra objetividade, "não era para eu estar aqui, ou era, não sei, Deus sabe". Márcia tem dúvidas, no entanto, se suas ações e reações, caso diferentes, poderiam tê-la trazido a outro presente, divide-se entre a autodeterminação e a determinação de "Deus".

O movimento pelo qual fortalecia-se com base no trabalho, no qual a luta por reconhecimento fazia-se menos insólita, encontrou sentido regressivo quando Márcia viu-se passando de professora para merendeira. Afastada do emprego, "estava recebendo todos os meses, morta de vergonha, (...) para mim não era nada bom e nem bonito, se eu tinha capacidade de estar exercendo aquele serviço." Impedida, por uma trapalhada do marido, de realizar a atividade que tornava socialmente útil, que lhe permitia deixar marca no mundo, identificando-se consigo mesma, Márcia via-se em situação oposta: de inválida, inútil, era o rótulo que lhe atribuiam, deconectado de sua verdade subjetiva.

Ajudar na merenda era uma forma de voltar a vender sua força de trabalho, da forma que lhe era possível. O sofrimento então vinha de ter decaído na hierarquia dos papéis determinada pela organização societal e assumida para si ("olha onde eu estava, caí para merendeira”), da atividade que perdia sentido de trabalho e ganhava conotação de labor, e pela situação concreta que ameaçava sua sobrevivência e de seus filhos, "aí o dinheiro da merendeira não dava, não estava dando".

${ }^{131}$ Bairro em que morava em 2009, ainda mora em 2010, e em que foi estruturado o grupo Mãos na Massa. 
O movimento regressivo lançado pelo trabalho estendera-se a outras esferas da vida, trabalho-atividade-econômica-renda enlaçados na luta por reconhecimento, nas condições objetivas e subjetivas que incentivariam ou inibiriam um novo sentido da metamorfose da identidade do sujeito, de Márcia. Como merendeira, faltavam recursos para atender a regras de convivência social: "as professoras começaram a mandar bilhetinho, para lavar os uniformes das crianças, que não lavava porque não encontrava sabão". No mesmo movimento regressivo, Márcia voltara a não ter forças para o conflito, a personagem da esposa-calada-com-medo era resposta no grupo mais amplo, mesmo que no Espiritismo fosse a Márcia-médium-especial”; mesmo que sua subjetividade fosse outra, mesmo que quisesse gritar, calava-se repetidamente diante da violência: "e quando tirava para agredir a gente...".

No limite do que poderia suportar, começou a lavar roupa de outras famílias para poder lavar também a de seus filhos. "Tinha vergonha", no entanto, da atividade desempenhada, reconhecida socialmente como de segundo escalão. Diz ter-lhe rendido a "maior decepção que eu passei na minha vida": lavar a roupa de quem "ocupou o meu lugar (...), era subordinada minha".

O sentimento de queda, a angústia que acompanha a humilhação social remontada, revivida, renarrada: "eu não gosto nem de lembrar disso que me dá um nó na garganta, mexe muito". Márcia representava na unidade do indivíduo um contexto em que as pessoas valem a posição na organização do trabalho em que ocupam, são percebidas e aprisionadas no limite desse papel. Era rotulada e rotulava.

“(...) era uma professora, tive a oportunidade de ser professora, eu era monitora, vivia numa sala de aula, sendo bem aceita pelos meus alunos, numa sala de monitores ajudando eles a preencherem as fichas para mandar para a central do Mobral, e de repente me veem com uma trouxa de roupa, lavando roupa".

O movimeno regressivo tem no fundo do poço o limite da queda. Situação em que nada mais se tem a perder, em que fragilidade desnuda-se e a personagem pressuposta não mais se sustenta: limiar da contradição que exige mudança de sentido. "Foi uma maneira de eu mostrar para a população que eu não era aquela pessoa que achavam que eu era. Porque muita gente via, achava que eu era a mulher mais feliz do mundo, porque eu não demonstrava (o sofrimento)." Aguentara calada até cenas de agressão em público, mas a pela atividade desempenhada expunha, por fim, o assolamento de sua subjetividade. 
Antes ameaças de agressão, inclusive "de facão", juramentos de morte, surras tinham como resposta a reafirmação de sua subserviência, de sua utilidade em vida para continuar servindo. Márcia-esposa-serva-calada-violentada levantava as razões para que não a matasse:

"você não vai me bater, você não vai me matar, porque não tem porquê você me matar, eu não faço nada para você me matar. Não estou fazendo nada de errado. Eu não brigo contigo, não te cobro em nada." Defendia a vida pela obediência, "não vou discutir. Fazia comida, fazia tudo."

Tomada pelo limite da personagem, sua resposta toma outro rumo, reflexo da mudança de sentido de produção de sua identidade: "meu filho, ou tudo, ou nada. Você não está mais morando com aquela criancinha, aquela bebezinha que você casou com ela. Agora eu cresci, eu sei o que é certo, o que é errado. Não preciso de sua preocupação.” Proclama a transformação.

Atribui a libertação não a si mesma, nem ao ambiente ou ao acaso, mas a "Deus, Divino Espírito Santo, o pai dos pais, a mãe das mães”. Apresenta as bordas de sua consciência sobre o movimento: não se estende às forças colocadas em questão, à sua própria reação frente uma situação objetiva. Ao mesmo tempo em que "Deus" a teria empurrado em novo sentido, a Márcia-em-transformação não crê nos santos: "não me apegava mais com santo nenhum, porque não me ajudavam (...) se eu faço tudo para ser boa, todo mundo me acha boa, responsável, um caráter bom, por que o pai dos meus filhos fala um tanto de coisa dessas de mim? Por quê?". Certamente uma das muitas, infindas, contradições materializadas pela identidade de Márcia, naquele momento, bem como em toda vida.

Ressente-se por não ter podido ser em Floriano a outra Márcia que pôde ser em São Paulo, "tive oportunidade, tanto de dar aula, como de estudar (...) eu podia ter concluído lá (...) era para eu estar sendo umas das melhores lá da minha cidade.” A mudança para São Paulo fez, no entanto, parte de seu salto qualitativo possibilitada pela soma das mudanças quantitativas acumuladas em Floriano. Aqui, com mudanças radicais nas condições objetivas, transformações subjetivas puderam dar-se; novas possibilidades de reconhecimento para as personagens que clamavam por expressão.

Márcia conta sobre essa soma de elementos quantitativos os quais permitiram que se preparasse para a transformação qualitativa: "enquanto ele me maltratava, eu me preparava para a separação (...) cada patadinha, uma coisinha que ele me fazia, uma coisinha entre aspas”. Essa percepção de que o processo culminara na ação e fora necessário, como combustível para o movimento, não exclui o pesar pelo que (não) viveu. 
Ao lembrar o passado Márcia passava de novo por diversos níveis de consciência, buscando as diferentes formas de ver o mundo daquelas quem já havia sido, emprestando aos olhos de hoje a uma nova visão. Ao olhar para a Márcia de anos depois reconhece-se diferente, outra, e sente vontade de defender-se, no presente, do que sofrera no passado, de colocar em uma cena anterior a personagem que vive hoje: "porque hoje com o conhecimento que eu tenho, com essas reuniões, que eu estou com vocês, essa coisas aí, que eu participo de muita coisa, eu converso até com o presidente da República, numa boa”. O grupo Mãos na Massa, a formação da cooperativa, faz parte desse reconhecimento, surge assim na história.

Márcia planeja, sonha, projeta-se em um futuro em que continuará estudando, aprendendo, transformando-se e... voltará a Floriano: "se eu voltar para lá... Por isso que eu quero aprender inglês. Porque quando eu voltar para lá, com os cabelinhos brancos, dando aula de Inglês, é o meu sonho." Repete, "é o meu sonho."

... São Paulo - "o único lugar que não queria vir"

“Todo mundo vinha da minha terra para cá, e eu não queria vir para São Paulo.” Apesar de muitos parentes estarem na cidade, Márcia não tinha vontade de vir, "se tivesse que sair, eu queria sair para outro lugar. Brasília, Rio, outro lugar”. Não se sentia atraída pelo destino que se repetia: "a minha família vinha para São Paulo e trabalhava, trabalhava, trabalhava, e eu não via nenhum futuro, mas eu não entendia esse lado da vida, que dinheiro não é tudo". Veio.

O pedido da mãe, de que mudasse de cidade, junto a mais uma expulsão de casa foram o estopim de uma situação limite que exigia transformação; "vim praticamente para agradar minha mãe, que já estava em cima de uma cama para morrer (...) ele praticamente me jogou fora de casa, eu aceitei”. Uma mais engrossando a história da família, de tantas famílias, em São Paulo. Viera com planos de voltar, deixara tudo por lá, "tudo que eu tinha de casa, eu não trouxe nada (...) porque eu vim para passar 3 meses", inclusive os nove filhos.

Embora tenha chegado com "medo até de abrir a boca", esperando encontrar uma cidade em que "ladrão roubava a gente, que o tarado tarava, e tanta conversa feia", Márcia não era mais a "serva-calada-com-medo", sua atividade não mais atenderia a essa predicação do passado. Sofreu na casa da irmã, a mesma que tinha "ciúmes" de sua cor de pele, "comi o pão que o diabo amassou", mas logo lançou-se a "caçar emprego" e trazer os filhos para São Paulo: "eu mandava a passagem e a pessoa trazia". 
Compôs um grupo de amigas, "era fim de semana, não tinha para onde ir, aí amontoava tudo lá em casa". Márcia gostava de estar entre, entre árvores, entre animais, entre pessoas, agora principalmente entre pessoas, ainda gosta. Mesmo que antes seus relacionamentos tenham sido marcados pela falta, falta da relação humana, de reconhecimento afetivo, de troca, orgulha-se por ter, desde sempre, aproximado as pessoas "toda a vida eu tive esse sangue doce das pessoas me procurarem, sabe?”. Márcia queria relacionar-se, sentir-se humana estando, efetivamente, entre homens e mulheres; é esse estar entre que lhe permitira a alterização, deixar para traz o bicho-domato e tornar-se bicho-humano.

Foi na selva de pedras que permaneceu, enraizou-se. Não porque encontrara um ambiente acolhedor, a segurança de sua sobrevivência, um lar confortável, mas porque o pressuposto de sua identidade aqui não existia mais; encontrou espaço para recomeçar sendo sua outra "outra". Aqui fez parte de grupos, formou coletivos, que permitiram reconhecer-se outra e lidar com as novas contradições.

A luta pela sobrevivência, o labor, fez-se no papel de empregada doméstica, emprego que lhe trouxera "uma decepção desgraçada, (...) péssima experiência". Passou por três casas até preferir habilitar-se a operária em uma empresa em Itapecirica da Serra. Na primeira delas, de "um casal de portugueses", logo de início os patrões separaram a louça que Márcia poderia usar, “Será que eles têm nojo de mim? Será que eles acham que eu tenho alguma doença contagiosa?". Depois foi a vez de um "casarão, lá era uma mansão" em que podia tomar café da manhã na copa, mas no jantar e no almoço tinha que "que subir e comer lá em cima”, no seu quarto, "podia estar chovendo, eu tinha que passar naquele terraço com chuva e comer lá em cima.”

Questionava-se o porquê das regras e das rotinas, de uma organização do trabalho sem sentido e segregadora. Márcia, que havia se sentido humilhada pelo trabalho de merendeira, não sentia vergonha do papel de empregada doméstica, questionava-o e remontava-o:

"Aí eu disse, quer saber de uma coisa? Assim como eu posso ter uma doença para pegar neles, eles também podem ter uma doença que pegue em mim. Teve uma festa de aniversário, eles me ofereceram um copo que não era meu, e eu não tomei. Aquele monte de parente dele, amigo, tudo lá bebendo naqueles copos mal lavados, vem me dar?"

Eram igualmente homens e mulheres, nem pior, nem melhor, apenas em uma posição diferente na divisão social do trabalho. Da recusa à inferiorização fazia-se a jornada pela autoderminação, possibilitada por um nível de consciência maior sobre o conflito posto entre 
objetividade e subjetividade: luta por reconhecimento na qual as condições concretas são transformadas. É assim que Márcia era agora a empregada-rebelde que faz suas próprias regras em resposta àquelas nas quais não pode interferir, nas que compõem a organização do trabalho.

Retribuia na mesma moeda, se eles podiam tratá-la de tal maneira era assim que deveriam ser tratados; se rotulada, também rotulava: "sabe essas baianas doidas, que vêm da Bahia, dos cafundós do Judas, faveladas, que conhecem um alemão riquíssimo dono da CCE, diretor da CCE?”. Se sua resistência superara até magia, “eu não sei que diabo que ela usava, um dia ela jogou um pó em mim (...) não conseguiu me hipnotizar”, abalou-se com a agressão direta, a acusação de ladra, a sacola negada para levar suas coisas, a revista antes de sair. "Eu sei que não arrumou, aí eu chorei muito, aquela humilhação (...) tive que abrir tudo que tinha, desdobrar tudo que tinha dentro da mala para ele ver." Vendo-se sem possibilidade de reação, de negação do que lhe negava, chegou a uma nova situação limite, era preciso mudar as condições objetivas para não se deixar levar em movimento com sentido regressivo, devolver a cena à Márcia-serva-sem-voz.

A Márcia-em-busca-do-que-merece-ser-vivido foi trabalhar como operária, "nunca mais, graças a Deus, botei a vista em cima, fiquei traumatizada com emprego doméstico. Nunca mais trabalhei de doméstica". Negação firme, assegurada no presente como decisão do passado, ainda afirmada ou renegada todos os dias; a posição de trabalho a que não mais, nunca mais, submeteuse, submete-se, submeter-se-á.

A falta de sentido do trabalho estranhado é refletida na fala de Márcia:

“(...) o pior de tudo é que eu fui trabalhar com uma pessoa que não sabia arrumar uma casa, não sabia fazer uma comida, e vinha me dar ordens. Por quê? (...) Era muito ruim você ter que fazer uma coisa errada, porque tem que fazer para agradar a patroa, e depois que você termina de fazer, a infeliz chega e diz que não está bom."

A alienação no trabalho foi experimentada em São Paulo em confronto com a Márcia que acabara de libertar-se de uma prisão de muitos anos.

A humanização imersa no trabalho alienado foi buscado em sua fonte, nas pessoas, nas amigas, "gostava, fiz muita amiga lá", na paixão; se ele estava na fábrica, "trabalhava o dia inteiro, a noite inteira se fosse possível.” Até mesmo na relação com chefe, "me adorava, sabe? Me chamava de Vivi, Vic. Vivi”.

No entanto, as mudanças no trabalho são vistas por Márcia como acasos ou problemas pessoais, específicos, assim entende suas demissões,, em nenhum momento ela questiona a 
organização mais ampla do trabalho; a divisão entre os que pensam e que fazem lhe incomodava, de fato, mas sem reflexão sobre seus porques, da distribuição das posições na hierarquia como dada.

Assim como em outras situações fora do alcance de sua compreensão, o acaso, as relações pessoais individualizadas e a religião são os recursos aos quais Márcia recorre para lidar com as intempéries implicadas pelo sistema socioecônomico: a insegurança constante aí contida sintetiza-se no medo de voltar a "casa de família". Começou a "pedir a Deus, Deus me ajuda, me dê uma oportunidade de eu trabalhar.”Márcia era então a trabalhadora-dedicada-que-gosta-detrabalhar-a-procura-de-trabalho-com-sentido que convive com desempregada-com-medo-desubmeter-se-pela-sobrevivência, bem como, entre outras persongens, com a Márcia-católica-que cre-desconfiando-nos-santos. O trabalho alienado era suportado por meio da convivência entre os outros homens e mulheres no ambiente de trabalho, pelos laços construídos, pelo reconhecimento afetivo; como empregada doméstica isso não havia sido possível encontrara apenas a rotulação e predicação de si com base nas alegorias ancoradas na diferença de classes.

A mudança para o Jardim Jaqueline dera-se quando um senhor "apareceu" em sua vida, "chamado Roberto (...) um amor de pessoa, um cearense", e comprou-lhe o "barraquinho" em que conversávamos; não morava mais de aluguel. Ainda desempregada, conheceu a "Herbalife", empresa que ainda representa atendendo as clientes em seu "escritório", casa próxima da sua, alugada para "para trabalhar com saúde, baseado na segurança alimentar" junto à comunidade. Cremes, loções, poções, chás, Márcia sabia qual o ideal para cada pessoa, o que cada um precisava para "desestressar", relaxar, sarar, ser feliz. Foi esse um dos canais que encontrou para dedicar-se ao outro, para entregar um pouco de si para o mundo.

A atuação na "área de saúde" permitiu a reelaboração do trabalho e a elaboração de uma organização em que criava as próprias regras, tomava as decisões a partir do que lhe fazia sentido. A vocação de cuidar dos outros parece ter sido percebida ao longo da sua história, já de muito antes, quando era procurada para "tirar o terço (...) fazer o terço nas casas" e para escrever cartas para quase toda a comunidade. Vocação essa que relaciona à religião, sua devoção e dedicação ao catolicismo foi, em sua visão, elemento que contribuiu para que confiassem nela: “sempre eu fui uma pessoa de confiança, lá eu não tinha muita coisa, mas eu era...ia muito na igreja católica, rezava muito". 
Assim é reforçada, reatualizada a personagem Márcia-católica-que-crê, a qual fortalece a Márcia-em-quem-se-confia, a Márcia-dedicada-ao-outro; três personagens que se fortalecem pelas sinergias. Mesmo que desconfie dos santos, que, contraditoriamente à fé, questione alguns dogmas, a religiosidade continuava sendo recolocada em seu movimento identitário.

Personagens que encontraram reconhecimento em alguns momentos de sua história e continuavam proporcionando a expressão de parte da subjetividade de Márcia, eram reafirmadas nesse novo momento enquanto outras, suprimidas. Personagens que se inter-relacionando com muitas outras, reconhecidas ou não, dão vida à identidade da mulher-mãe-militante-agente-desaúde que nos conta sua história.

\section{Favela, movimento social, cooperativismo}

Ao chegar ao Jardim Jaqueline Márcia nunca tinha visto uma favela, "porque eu nunca tinha morado em favela. Ouvia falar favela, 'pinguela'... Um negócio que eu não sei que diabo que é”. Ela lembra de um bairro com menos infraestrutura, piores situações de moradia: “quando eu vim para o Jaqueline, era favela, favela, favela. Não tinha esse tanto de maravilha que tem aqui não, filha. (...) Na rua do shopping, lá em cima, ali onde é o shopping era mato, e assim por diante. Muito mato aqui ainda." Fato é que a favela apresentava a Márcia determinadas condições objetivas, as quais requeriam uma diferente maneira de colocar-se no mundo; a realidade, mais árida convocara-na a engajar-se na ajuda àqueles que se encontravam em situação de total desassistência.

A "Márcia-dedicada-ao-outro" encontrava ambiente propício para realizar-se: "eu já tinha esse dom de trabalhar com serviço social, porque o projeto Rondon foi para o Piauí, e eu fiz o primeiros socorros, curso de alfabetização, horticultura...". Por outro lado, logo percebera que "não pode fazer um trabalho social sozinho, tem que ter um grupo". Mesmo que já tivesse "no sangue essa coisa de trabalhar assim e de ajudar o próximo", reconhece sua incapacidade de agir sozinha para realizar projetos. Márcia entende logo que a ação só se faz entre outros homens e mulheres, iguais, que suportam e ressoam o discurso individual, a matéria necessária para que qualquer onda propague-se.

O perceber-se dentro de um contexto que para ela não era natural nem havia sido naturalizado, impulsionava-a: "meu Deus, o que eu vou fazer para ajudar esse povo? Essa é a favela, agora eu estou dentro do negócio, o que eu vou poder fazer?”. Foi movendo-se solitariamente, "tirando da rua" uma criança que "catava coisa do lixo" até muito tarde, 
diariamente, que sentiu falta de escala para sua ação, de que seus desdobramentos alcançassem mais indivíduos, grupos, influenciassem a situação mais geral. Foi assim que encontrou "Seu Serafim, que trabalhou na associação aqui”. A associação havia sido abandonada por todos seus colaboradores, “então, vamos renovar esse estatuto, levantar essa situação, porque a gente precisa trabalhar para fazer alguma coisa. Estão acontecendo coisas desagradáveis aqui e a gente pode fazer alguma coisa".

Era a Márcia-agente-social, engajada na mudança da realidade local que passava a entoar o sentido de da metamorfose de sua identidade, era personagem surgida com a mudança para o Jardim Jaqueline, com o choque de um contexto distinto do que já havia vivido, mas também pela segurança da casa própria e pela certeza de seu potencial para agir; autoestima reconstruída.

Márcia trabalhou cinco anos "como tesoureira do Seu Serafim", conta em que todo esse tempo, apesar de levantarem recursos fazendo festas, bingos, tirando dinheiro do próprio bolso, Seu Serafim "não assinava, não autorizava (...), nem trabalhava, nem me deixava trabalhar". Impedida de exercer sua personagem, de objetivá-la, por uma nova relação de dependência, na contramão de seu projeto de autonomia, pela qual colocava-se, de novo, em posição de obediência, voltava à questão: "por onde eu vou (re)começar?”.

A superação das contradições postas colocavam-na em posição de reinício, angústia de não se saber para onde seguir, de sentir-se sozinha de novo, mas necessário para a retomada de seu projeto de autonomia, do sentido emancipatório de sua vida-movimento-identidade. Na "Pastoral da Criança" desenvolveu um trabalho do que se orgulha e guarda registros: "está vendo ali? É filho do meu trabalho (...) tenho até o vídeo, mas não tenho a televisão". Foi aí que encontrou o papel que buscava e que abriu espaço para toda a energia da personagem agentesocial-engajada-na-mudança-das-condições-objetivas que clamava por realização e reconhecimento. Depois da primeira reunião da Pastoral, ouvindo que precisavam de pessoas para trabalhar, "de 20 líderes, eu já arrumei 25"; ela mesma trabalhou exaustivamente, "cheguei a pesar mais de 200 crianças no mês".

Entre os "líderes" comunitários reunidos estavam alguns dos que comporiam, pouco mais tarde, o grupo Mãos na Massa, como Carina, por exemplo. Com algum tempo de militância pela ajuda ao próximo, mesmo que por conta própria, e de trabalho como catadora de materiais recicláveis, Carina acompanhou Márcia em algumas empreitadas fazendo história, como a arrecadação de recursos “de depósito em depósito, comércio em comércio" para a construção de 
um banheiro na sede da Pastoral. "Não tinha banheiro. Hoje é um lixo o banheiro lá, mas tem. Mandamos retelhar, pintamos."

A Márcia-que-trabalha-em-grupo, compartilhou e realizou projetos, elaborou símbolos, contribuiu com a produção de novas regras, enraizou-se na comunidade. Uma ação puxa outra ação; Márcia-agente-social faz parte da história da Jardim Jaqueline. Em outra esfera de sua vida, Márcia separava-se de Roberto, "ele foi embora para procurar meio de vida, estava bebendo muito. Eu pedi para ele procurar recurso, ele foi procurar recurso e até hoje não voltou." Prosseguia, assim, mudando a realidade que não merecia ser vivida, que não lhe permitia realização de seu devir humano.

A construção e implementação de um projeto de autonomia, do movimento constante com sentido emancipatório não garante alegria, claro. Márcia nos conta que nada tem a ver com o projeto de vida tranquila ou sem decepções. Depois da partida de Roberto ficara quase um ano "perdendo sangue (...) morri e renasci (...) porque eu só fiquei a carcaça e o espírito."

A Márcia-que-crê-em-Deus, ainda viva, que lhe oferecia resignação quando sem saída, sem possibilidade de ação diante da humilhação imposta, como a traição por parte de seus, antes, companheiros de associação comunitária.

“(...) a gente que tem um coração bom, que procura viver um pouquinho a realidade da vida com a palavra de Deus. Temos por obrigação escutar e dizer muito obrigado. Levar um chute igual ao que levei e ainda dizer muito obrigado por me chutar... Estava falando hoje na palavra que, quem é de Deus, quem vive a verdade, quem procura viver a verdade... Que tem a proteção divina não precisa levantar a voz nem a mão para bater em ninguém. Porque Deus responde pela gente."

Nesse recomeço, buscando novo ambiente, capaz de oferecer-lhe base para a ação e reconhecimento para a Márcia-que-trabalha-para-a-mudança-das-condições-objetivas, que começou a participar da "reunião lá na Barra Funda, desse negócio de habitação, essas coisas assim...”. Nessas reuniões encontrou o grupo do Instituto Pólis, a partir do qual "fui descobrindo as coisas, já estavam acesas, evoluídas, mas interessadas." Entre elas o tema da "segurança alimentar". O encontro foi com as pessoas, com as ideias que já estavam "acesas" em Márcia e com seu projeto de autonomia que, sabia, desde sempre andara junto com o aprendizado; envolveu-se em diversas oficinas e cursos, "capacitação de ONG's, capacitação de projetos", e assumiu a responsabilidade pela "Feira Solidária" do Jardim Olímpia. Ainda em 2009 era uma 
das três pessoas do grupo que sempre participam das reuniões mensais da Rede Local de Segurança Alimentar e Nutricional.

É por esse processo contínuo de aprendizagem, em que Márcia lançara-se desde antes de mudar-se para São Paulo, que alcançou formas e pontos de vistas diversos, de onde enxerga e compreende o mundo; isso segundo ela mesma nos conta. Principalmente por ter encontrado a possibilidade de prosseguir com esse projeto, que se interessou pelas reuniões propostas pelo Pólis, pelo projeto que delas se seguiu, pela rede, pela segurança alimentar... pelo Mãos na Massa. Segundo Márcia, é por tudo isso que "acerta alguma coisinha lá", nas oficinas que fizemos juntos, sobre gestão da cooperativa.

O conhecimento e a experiência vividos são valorizados por Márcia, todo o material é guardado com notável desvelo: "eu tenho um material riquíssimo que podia ajudar muita gente aqui". Um dos seus deuses, ao longo dos anos, passara a ser o "conhecimento", Márcia dedica todos os recursos que possui no desenvolvimento desse projeto, o de estar sempre trocando conhecimento. Afinal, entende que é ele quem possibilita o desenvolvimento de seu "dom", do trabalho "social", dedicado aos outros e a si mesma, aplicado à mudança da realidade da comunidade universal, da comunidade que representa todas as comunidades do mundo nas quais gostaria de e ainda pode estar.

Assim que a formação do grupo Mãos na Massa compôs seu projeto em andamento, embasado em um trabalho cheio de sentido, na interpretação universalizada possibilitada pelo aprendizado contínuo, comprometido com a autodeterminação e com engajamento da mudança da realidade objetiva; a ideia do grupo encaixou-se com o sentido que já vinha sendo contruído pela Márcia-agente-social-engajada-na-construção-de-uma-realidade-objetiva-mais-digna-de-servivida, em curso. O aprendizado foi a primeira e mais importante razão para sua participação no grupo: "vou participar das coisas porque a menina do aprendizado nunca me enche". Também faz parte da empreitada a vontade gerar renda, melhorar as condições em que vive junto a sua filha adotiva, Lelê. "Se você tem facilidade de ganhar mais lucro do que você está ganhando você vai ganhar. Está meio difícil ainda o Mãos na Massa.”

Márcia havia entrado, antes para outro grupo, com o qual o Instituto Pólis e a ITCP-USP haviam começado formação para o cooperativismo, o Lanche Solidário. Por ser composto por pessoas que se uniam por laços familiares, uma família que não admitia que outros, estrangeiros ao grupo, acessassem os recursos do projeto, Márcia havia sido expulsa. Esse contratempo não 
inibiu sua vontade de fazer parte, acreditou na idoneidade do projeto que recomeçava e participou do seminário de economia solidária e segurança alimentar promovido com o objetivo de debater a proposta e desenvolvê-la com novos interessados. Por esse seminário os profissionais envolvidos no projeto lançaram o convite para a formação de um novo grupo, estava claro que o projeto não se desenvolveria com o Lanche Solidário.

A visão de Márcia sobre esse grupo, composto a partir de então, o Mãos na Massa, é de que enfrenta enfrenta dificuldades para "evoluir", alcançar os resultados esperados, tanto de vendas quanto de ações de fortalecimento da segurança alimentar na comunidade. As razões para isso, estão, segundo nossa narradora, na forma como os sujeitos envolvidos chegam ao e colocam-se no grupo, “algumas pessoas que não se adaptaram no objetivo. Acho que dá para você perceber que aqui tem pessoas que ainda estão se encontrando, pessoas que ainda não confiam nem nelas próprias. Isso é muito ruim.” A falta de confiança em si mesmo, no outro, no grupo e no projeto comum é sentida por Márcia como a principal ameaça ao futuro que vislumbra para o grupo: "imagino nós como uma cooperativa. Mãos na massa, vendendo barrinha para todo mundo".

E o cooperativismo? Márcia lembra de como pediu a Deus para "sobreviver sem ter que ter um emprego que possa me mandar embora", para não ter que voltar para a realidade que negara por negá-la, "viver de faxina eu não vivo porque eu não aguento", e chega ao cooperativismo como a um achado, um caminho alternativo a todos esses que já conhecia e sabe não querer, complementar aos que já escolhera para si em seu esforço de autodeterminação, que compõem seu projeto de autonomia. "Olha, é um dos meus sonhos".

A Márcia-que-se-faz-solidariamente, em relações de cooperação, já vinha sendo formada e transformada em suas experiências até então e encontrava no projeto coletivo da organização cooperativa as circunstâncias que lhe pareciam ideais para a sua realização; projeto esse ainda não concretizado, por isso um "sonho". Márcia já se permitia sonhar antes, a contrução do Mãos na Massa traz novo impulso, novos insumos a um movimento de metamorfose constante que havia encontrado sentido emancipatório, com novas personagens, representantes de sua subjetividade, ganhando vida.

As barrinhas de cereal são a concretização do trabalho coletivo, da geração de renda e da ação em prol da comunidade; dão as mãos às outras atividades desenvolvidas por Márcia, ao trabalho no "Sopão", à venda dos produtos Herbalife e aos diversos serviços de cuidado da saúde 
oferecidos aos seus clientes: "Vida saudável e beleza natural. Venha degustar, é as barras." Importante não dizer tudo na mensagem, "se você mastiga tudo e põem lá as pessoas não têm curiosidade, e eu quero falar com as pessoas, por isso que eu fiz assim." Mais que uma estratégia de vendas, estratégia de estabelecer relações pessoais; estas são a essência de suas vendas. Venda do cuidado pessoal, de uma saúde ampliada, cujo sofrimento pela falta ela mesma cohecera antes, em tantos momentos de sua vida.

Márcia era uma das responsáveis pelas vendas das barrinhas, junto com Joana e Carlos, venda de um produto produzido em grupo e cujos ganhos voltariam ao grupo. "Eu adoro trabalhar em grupo." O aprendizado intrínseco à vivência do trabalho coletivo é ressaltado como principal benefício desse tipo da organização cooperativa:

"Aprende bastante. A gente dá e recebe, é uma troca de aprendizado. Eu não sei se você já percebeu que quando as pessoas começam a reclamar da palestra eu defendo, porque as pessoas que reclamam são justamente aquelas que vão dar mais dor de cabeça na gente futuramente. Que a pessoa não quer aprender, a pessoa não tem paciência, acha que já sabe tudo. Tem pessoas que são inteligentes, mas que se tornam um burrão, que ele não gosta de ouvir, quer chegar e já pôr a mão na massa."

Está claro que nem com todos do grupo Márcia convive em harmonia, ela posiciona-se contrária a ideias e atitudes quando lhe parecem despropositadas ou contrárias aos seus interesses, compartilhados com outra parte do grupo. Nem sempre sua opinião é ouvida, ao menos não por todos; o grupo ainda não havia alcançado relações equitativas em geral, premissas ideológicas e rótulos trazidos da vivência heterogestionária no trabalho, e fora dele, ainda não haviam sido relativizados. A negociação de interesses e visões distintas apenas era possível com uma parte do grupo, aquela que podia enxergar Márcia em toda sua humanidade. Outra parte desconsiderava suas opiniões, buscando replicar a relação de superioridade-inferioridade, dominante-dominado, ancorada em papéis sociais estanques fundamentados pela lógica do capital.

Mesmo Márcia, que valorizava e fortalecia o mundo da vida com relações não condicionais, afeita ao exercício de colocar-se no lugar do outro, não apresenta crítica em relação ao sistema mais amplo, à situação estrutural fundadora da fome, da violência, da humilhação contra as quais lutava em sua comunidade. A economia solidária não é vivida e construída como um caminho alternativo à ordem instaurada, a cooperativa, no Mãos na Massa, é alimentada em sua unidade, como caminho para possível humanizar-se nos interstícios do sistema socioecômico. 
Por estar muito cansada de suas infindáveis ocupações e atribuições, algumas vezes Márcia cochilava nas oficinas. Pedia desculpas, explicava a situação, os problemas familiares com a mãe biológica de Lelê, todas as suas preocupações, ocupações e o pouco tempo para o sono. Apesar disso o bom humor continuava sendo característica marcante.

Márcia termina o dia de conversa com um convite especial para tomar um chá, hidratar a pele, e sair de lá melhor do que entrei; poderia fazer isso por ela mesma, equilibrando um pouco mais a equação entre o tempo dedicado a si e ao mundo.

As horas contando sua história reforçaram sua percepção da riqueza de experiências, sentimentos e feitos vividos; orgulha-se diante de uma narrativa extensa e intensa e de todas as transformações que sabe ter experimentado. Passado, presente e futuro unem-se em torno de seu poder de transformação, de fazer, refazer, remontar, aparar as arestas de sua própria história, em um exercício máximo de autodeterminação, sempre em construção. "Eu nunca voltei para minha cidade porque não tive condição de voltar. (...)hoje se eu quiser ir eu vou, mas tem um negócio aqui em São Paulo que eu tenho que resolver." Decidiu que faz parte de seu futuro, depois de resolvida essa questão, viajar, “dar um tempo”, ir para o Piauí, “aí não sei se eu vou voltar”.

Nesse tempo imagina que o grupo não precisará mais de sua presença, continuará vendendo barrinhas saudáveis para todo mundo e difundindo o conhecimento que ela ajudara a construir: a mensagem de saudabilidade e do cuidado de si para a qual se doa um pouco todos os dias. Ela terá deixado sua contribuição para essa outra história, terá feito história.

\section{O grupo, as dificuldades para a autogestão}

Alguns meses depois de nossa primeira conversa, quando voltamos a encontrar-nos, Márcia dizia-se "triste” com os últimos movimentos do grupo Mãos na Massa. "Joana que está afastada, a Ana parou mesmo de vez", cada uma delas por motivos diferentes: enquanto Ana não conseguia se imaginar trabalhando mais horas por semana na produção das barrinhas e na gestão do negócio que implementavam, Joana estava descontente em relação ao rumo que uma questão prática levava (ou não levava), o rótulo para as barrinhas.

Mesmo pedindo afastamento do grupo, Joana continuava ligada ao grupo; nesse mesmo dia em que estava com Márcia, ela havia procurado-lhe para conversar sobre alguma novidade ou ideia que tivera. Márcia não sabia do que se tratava, mas imaginava algo referente aos rótulos: "porque a Joana ela está muito ligada a esse negócio do rótulo.” Discussão essa puxada por 
Joana, a necessidade de terem os rótulos, com as informações nutricionais e a identidade visual do grupo, o quanto antes, e que agora Márcia começara a tomar para si também.

O rodízio de papéis nas compras, vendas e gestão da cooperativa, que antes não fora vivida no grupo, apesar do rodízio das posições do processo produtivo, foi forçosamente experimentada com o afastamento de Joana:

"Foi até bom porque ela quem tomava a frente nas vendas, ela era coordenadora de venda, as primeiras pessoas sobre o rótulo foi com ela e o Carlos. Como só tem o Carlos de homem no grupo ${ }^{132}$, sempre ele sai para as vendas, sempre quando é um lugar mais difícil, ele acompanha quem vai vender. E hoje eu também tive que assumir o trabalho de venda, eu fique nas finanças com o Carlos. E o Carlos nas vendas enquanto a Joana está afastada, porque as outras para vender são mais devagar, entendeu? Se não a gente não consegue ir para frente, e também tomamos uma pressão...."

Mesmo assim, em seu depoimento fica claro que fora um movimento limitado, uma dança das cadeiras envolvendo três pessoas, ou pouco mais que isso. Isso porque, como ela mesma diz, as outras pessoas do grupo não sairiam para vender, ou pelo menos não haviam aceitado a função até então. A "pressão" a que se refere é dos formadores da ITCP-USP que trabalhavam junto, oferecendo o suporte para a formação da cooperativa: eles esperavam que o grupo alcançasse alguns resultados de produção, venda, atividades realizadas. A pressão é o desapontamento, a bronca no encontro seguinte, ao notar que o grupo não havia cumprido o combinado.

Foi tomando a frente das vendas que Márcia identificou a mesma demanda que Joana, e entendeu sua briga pelos rótulos: "uma nutricionista falou que quem não colocar pelo menos isso, isso e isso, vai ser suspenso das feiras”. Essa compreensão do lugar acupado pelo outro é evidente na narrativa, "aí que caiu a ficha agora, o porque a Joana não quer voltar sem o rótulo. Quantas vezes eu não ouvi isso? (...) O que adianta ficar produzindo se não tem saída a venda?”

Sentindo muito a saída de Joana, já que ela é uma das pessoas com quem compartilhava planos, com quem se identificava nas diferenças e semelhanças de trajetórias, Márcia-agentesocial-cooperada-sujeito-da-pesquisa contava-me o episódio pensando na possibilidade de que eu convencesse Joana a voltar ao grupo, mesmo que fosse "não voltar pra vender". A saída de Joana é vista como uma lição para o grupo, já que "sempre eu estou segurando as pontas com a Joaninha”.

\footnotetext{
${ }^{132}$ Nesse momento da história do grupo Luís já havia se afastado do Mãos na Massa para juntar-se ao seu primo em outro empreendimento.
} 
Tratava-se de um momento crítico para o grupo, em que era exigida maior dedicação de tempo e comprometimento e alguns questionavam o sentido do projeto, que nunca fora totalmente compartilhado. Período também em que o grupo estava indo mal financeiramente, nas palavras de Márcia, "o grupo deu uma falida". Tiveram que parar de retirar as sobras para "repor", porque segundo conta fizeram retiradas nos meses anteriores "sem antes sentar para avaliar". Menciona uma ferramenta discutida e elaborada em conjunto durante as oficinas de finanças, mas não utilizada: "lembra que a gente tinha que fazer aquela avaliação todo mês, para ver como tudo estava? Se chamava balanço, tipo o que as empresas fazem o balanço do que entrou do que saiu... E não foi feito isso." Apesar de saberem da importância do exercício, "nós mesmo, o grupo, nunca sentava para avaliar essas coisas e ver o quanto que podia tirar".

As "finanças" refletem a situação do grupo em si, momento de parar, refletir, questionar, compartilhar, engolidos que haviam sido pelas encomendas de barrinhas com prazos curtos, pela venda nas feiras e outros eventos que sobrecarregavam sempre os mesmos cooperados. Márcia imagina que no final do ano voltariam a fazer retiradas, mas reforça que, na sua opinião, deveriam "tirar menos e sempre deixando uma reserva (...) tem que fazer um cálculo que de para tirar X de cada um, e independente do fundo de caixa, sempre deixar uma reserva do nosso." Isso é, planejar o futuro contando com o comprometimento de todos, apesar das diferenças de interesses e necessidades, encontrar o comum nas divergências; conformar um grupo.

Márcia fala de um grupo em que o conflito não pudera dar-se, ainda não tivera espaço, grupo em que a opiniões de alguns eram desconsideradas por outro como não dignas de valor. Era o caso da própria Márcia. Um grupo ainda não coeso, quebrado em alguns outros grupos menores que se encontravam para produzir e para as oficinas, cuja liga continuava sendo a organização de apoio, a ITCP-USP.

Também Carlos tinha mudado sua intensidade de participação no empreendimento coletivo, "tem vezes que ele some e passa cinco, seis dias, oito dias que ninguém tem notícias dele". Márcia sente-se sozinha, já que eram os dois, ele e Joana, sua companhia nas tarefas que precisavam de contato com o mundo externo, de representação do grupo; era esse o grupo em qual encontrara pertencimento, o grupo de três em quem encontrara ressonância a suas ideias e de quem ouvira outras ideias, com quem pudera trocar.

Ao ver-se nas razões para os sumiços de Carlos, ela também questiona-se quanto à sua participação, se não deveria estar garantindo o atendimento a suas próprias necessidades, sozinha: 
"ele fala que tem que trabalhar para cobrir as coisas dele porque não está tendo nada. Mas eu também sou como ele, eu não tenho nada, não tenho aposentadoria, não tenho quem me dê nada... entendeu?".

Não é de se estranhar que sua maior angústia como parte do grupo Mãos na Massa era, justamente, a falta do grupo, a carência do pertencimento, a ausência do apoio grupal; Márcia não pudera ainda enraizar-se nesse grupo, sua conexão era forte com dois de seus membros, mas não com os outros, ela havia ligado-se à ideia que tinha construído para si sobre objetivos comuns e planos para o futuro.

A negociação discursiva de significados começava, aos poucos, a se fazer no grupo, mesmo porque ao exigir um compromisso mais intenso de cada um, eram obrigados a colocar-se, mais cedo ou mais tarde, em relação ao que estavam imaginando, a como viam o futuro. Em relação às decisões cotidianas ou, até mesmo, estratégicas, do empreendimento, alguns ainda se colocavam nas reuniões, faziam isso quando sozinhos com um ou dois membros do grupo ou com os formadores, o que ganhava o tom de "fofoca". A partir daí eram incentivados a colocar a posição para todo o grupo, ou aquele que havia ouvido, em particular, acabava trazendo o tema para a reunião.

De qualquer forma, enquanto continuava comprometida com o grupo responde ao que entende como suas responsabilidades, como parte do pacto com os outros cooperados, com o coletivo: "mas mesmo assim eu não deixo. Posso chegar atrasada mas eu vou, entendeu? Se não dá para ir, eu dou satisfação". Confirma sua confiança em um futuro comum para o grupo, com as vendas das barrinhas e a ampliação das atividades da cooperativa.

“Eu não sei. Eu acredito nesse negócio. Não sei se é porque eu já nasci com isso no sangue (...). Eu gosto de aprender assim...de querer ser alguma coisa na vida. Às vezes uma coisa que parece uma brincadeira igual esse grupo que foi formado, se torna uma grande coisa na vida da gente."

É assim que para ela o Mãos na Massa deixou de "ser brincadeira", para os outros também, por essa razão teriam sobrado tão poucos no grupo. O que determinava a permanência ou saída era uma conjunção de fatores, não apenas, no caso de alguns, o descompasso entre o atendimento das necessidades básicas e o ritmo com que o empreendimento coletivo gerava renda, também a existência de compreensões diversas do que seria a autogestão, diferentes ainda, cada uma delas, do que começavam a encontrar na prática. 
Estava claro que a autogestão requeria algumas disposições, aberturas e vivências anteriores, trazidas individualmente de outras experiências de cada sujeito. Também a autogestão em construção proporcionava novas condições que nem todos buscavam, a saída do grupo pode ter sentido emancipatório, a negação de algo que não se quer viver.

Há ainda, na construção da autogestão em cooperativas exógenas, como o Mãos na Massa, o que é trazido e proposto ao grupo pelos formadores; contribui também para a formação de uma prática específica, sempre única, da autogestão. Ao aderir ao projeto da cooperativa, Márcia já pudera enraizar-se na comunidade por meio da participação em outros grupos, entre quais alguns membros eram comuns, como a Pastoral da Criança, o Ação e Cidadania e a Associação de Mulheres. Agora, a diferença, é que apostava suas fichas em um novo jeito de trabalhar, em grupo, gerando renda, melhorando sua vida, mas também a da comunidade. O tema da segurança alimentar, para ela, era muito forte, por isso fazia tanto sentido participar das feiras e promover oficinas sobre segurança alimentar.

Essa era sua experiência individual, particular, e que muitos do grupo já conheciam; praticamente todos haviam cruzado antes com Márcia em alguma de suas ações no Jardim Jaqueline. Quase todos os membros do grupo que tentava se formar também haviam participado de algum outro grupo de trabalho voluntário em prol da comunidade. De qualquer forma chegavam ao Mãos na Massa de maneiras, com expectativas, interesses, propostas, dedicações diversas e muitos enxergavam Márcia a partir do que já sabiam a seu respeito, com os rótulos e juízos que haviam lhe atribuído anteriormente; em alguns casos sem abertura para outras de suas personagens, para seu outro "outro".

Márcia, quando questionada sobre a experiência no grupo e sobre o exercício da autogestão, diz que muita coisa mudou, “esse grupo é um sonho que eu estou realizando, parte do meu sonho...você está vendo? Criar um pequeno negócio e poder trabalhar para você mesmo, é uma coisa que eu sempre pedi para Deus. E trabalhar com gente.” A Márcia-cooperada era personagem que se formava em sinergia com suas outras personagens em atuação no período, a agente-social a Márcia-que-dedica-se-ao-outro, a vendedora-da-saúde e, até, a Márcia-que-crêem-Deus. Personagem em formação com base no papel que os formadores incentivavam e para qual o grupo abria, aos poucos, espaço, o papel de cooperado.

Márcia gradualmente encontrava o reconhecimento do grupo para essa nova personagem, mas quando o grupo perdia força, consequentemente o futuro de sua personagem perdia cor. 
Assumir as finanças, depois as vendas do Mãos na Massa reforçava o seu poder de ação pelo grupo, fazia parte da sua luta por reconhecimento de seu outro "outro". Ao mesmo tempo, na medida em que não se fazia possível o rodízio dessa função, por falta de interesse de outros em assumí-la, enfraquecia a personagem cooperada.

Seu depoimento leva-a a considerar, mais uma vez, que apesar das circunstâncias terem mudado, de estar em uma situação diferente, social, econômica, concreta, e de todas as transformações pelas quais passou, algumas atitudes, afeições e sonhos nunca mudaram, como a busca constante pelo aprendizado, o gosto por trabalhar em contato direto com outras pessoas e o sonho de colaborar para que tenham uma vida melhor, seja na educação ou na saúde. "O lugar era uma cidadezinha pequena lá no Piauí. Eu já tinha esse sonho. E lá eu aplicava até injeção na veia (...) ainda hoje eu faço curativo nas pessoas na comunidade aqui, que precisa, que chega ao meu alcance eu faço... e sara!"”

Comparando emprego e cooperativa, "eu prefiro em uma cooperativa. Porque eu estou mais... sabe?". Desde que saíra de sua "última empresa privada, 1995", ela trabalha para si mesma: "sou representante de uma empresa de cosméticos que dá para ganhar muito dinheiro... Eu não ganho muito dinheiro porque eu gosto desse trabalho social comunitário e você sabe que esse trabalho tira muito o tempo da gente." Sobrevive das vendas desses produtos, se saísse para vender todos os dias, ganharia em média R \$ 890,00 mensais, muito mais do que as barrinhas de cereais poderiam lhe render em um futuro não tão distante. Em números a comparação entre as duas atividades é desleal, mas para além deles "sabe porque eu prefiro a cooperativa? Porque...eu já estou dentro do negócio, é uma coisa que já esta viva dentro de mim no momento...”.

A "empresa privada" é associada a "umas pessoas que gostam de pisar na gente. Tem gente que às vezes está fazendo coisas erradas e não admitem que esta errado...”. A última gerente que tivera "queria que eu fizesse tudo ao contrário do que eu já estava acostumada a fazer... é duro né? É apavorante isso.” Márcia sabe que não quer nunca mais ser obrigada a fazer algo de um jeito com o qual não concorda só porque "é patroa e quer daquele jeito", ser submetida a fococas e mal-dizeres que não são falados cara a cara, "porque se eu tiver que falar uma coisa para você, eu não vou falar para outra pessoa, para depois você ficar sabendo pela boca de outra pessoa".

O trabalho de representação de vendas, a fundação, por fim, da Associação de Mulheres, a volta para o Piauí, o cuidado do túmulo dos pais e... o grupo Mãos na Massa, estão em algum 
lugar de seus planos, de um futuro em que pode escolher o que mais lhe interessa fazer, a atividade dotada de sentido, as relações humanas em que é possível a troca, a ação com a qual já está acostumada, à qual lança-se apesar do contrassenso em relação ao uso do tempo de forma eficiente, do tempo de vida em prol do capital.

"Eu penso no futuro tão bonito...eu vejo isso aqui crescer... eu vejo todo mundo tranquilo, tirando o seu salário o seu jeitinho de viver da gente mesmo. Fazendo um negócio legal com segurança. E de repente a gente tá correndo o risco de ver tudo indo por água abaixo não é bom né?”

Conta-nos Márcia que o cooperativismo e os princípios da economia solidária já estão “dentro" dela, vivos, ganharam vida com uma personagem, componente de sua identidade. Personagem que, se não encontrar as condições ideais no Mãos na Massa, certamente dará continuidade à luta por reconhecimento em outros ambientes, em outras situações objetivas. A Márcia-cooperada compunha sua identidade, oferecendo voz efetivamente a desejos, interesses, sonhos, representando-os.

Agora, como Márcia mesma disse-nos tantas vezes ao longo de sua narrativa, "vamos passar para frente"; seguir o rumo da vida traçado por nós mesmos diante das condições objetivas, transformando-as e fazendo história. 


\section{Luís}

Mineiro, de Itapecirica, Luís começa me dizendo "gosto de natureza (...) não sou assim muito admirador de concreto não, sabe" ${ }^{133}$. Filho de família grande, com seis irmãos, nosso sujeito-narrador diz que nasceu "numa família pobre" que se mudou para o Paraná, quando tinha 11, 12 anos, porque a terra que cultivavam em Itapecirica estava cansada. Em Califórnia, norte do Estado, ficaram como "arrendatários nas terras dos outros", isso porque o dinheiro das terras que seu pai vendera antes da mudança "evaporou" com a ajuda dos familiares.

As primeiras memórias, onde muitas personagens fundamentam-se

Ao longo de toda narrativa, começando por essas suas primeiras histórias, Luís relata os acontecimentos de sua vida sempre em relação ao panorama, às vezes em uma análise macro socioeconômica; a mudança para o Paraná é situada no movimento migratório, "em 62 já tinha começado essa mexida das pessoas, de famílias mudando de um canto para outro". A migração é encarada como um "problema do Brasil" entre outros para os quais Luís alertar-nos-á ao longo de sua narrativa.

Assim logo de cara encontramos o Luís-ligado-ao-que-acontece-no-mundo, à história, à política, ao ambiente mais amplo que de sua vida cotidiana e que entende estar ligado à sua vida; essa busca pela compreensão do contexto parece ter começado cedo, como veremos, com conversas que lhe traziam o contato e o encatamento com o novo.

Do Paraná traz como marcos de sua história, referências em memória, o trabalho na roça, o fim dos estudos, a primeira rua calçada de Califórnia, a primeira agência de banco, o contato com a "política", a discordância em relação à situação de sua família... a revolta frente ao "sistema". Luís conta que apesar de ainda não saber o que é "governo", quando passaram à situação de "arrendatários nas terras dos outros, então aí começa um comportamento diferente da minha pessoa", comportamento pautado pelo incômodo, pela não aceitação daquela condição objetiva como digna de ser vivida.

Se estudava em Itapecirica desde muito pequeno, em Califórnia tinha que se ocupar inteiramente do cultivo e da colheita. A família toda trabalhava, os irmãos, a mãe, mesmo assim não davam conta:

"era muita terra, e ele não tinha dinheiro para pagar gente para trabalhar e o patrão também não financiava. Então ele perdia a cabeça. E ia

${ }^{133}$ Luís, 2009. Todas as citações dessa seção têm como fonte a narrativa de Luís ao contar-me sua história de vida. 
preparando a terra, plantando. Então você começa a preparar a terra em julho... você termina a colheita e começa a preparar a terra para plantar. Em final de agosto você começaria a plantar, e ia plantando, ia plantando. Era muita terra e ele não dava conta, ele ia plantando até aqui, quando chegava aqui, que encerrava o término do plantio, que ele voltava para capinar, e esse que tinha plantado aqui, já estava morrendo no meio do mato. E aí você ficava patinando, e eu não concordava com aquilo, ele não aceitava opinião, até que num... isso já no ano de... eu morei lá de 62 a 69, morei pouco tempo, mas nesse período foi suficiente para eu entrar em atrito com ele várias vezes."

Conta também sobre a situação econômica do Paraná, segundo Luís, destoante do resto do Brasil, "não tinha, vamos dizer assim... pobre, pobre de não ter nada, pobre, mendigo, pessoas pedindo na rua, pedinte, você não encontrava essas pessoas na rua". A abundância de terras e de produção agrícola era tamanha que faltava mão-de-obra para a colheita e se "uma pessoa chegava na sua casa, falava para você assim, 'você me dá um pouco de café', 'você me dá um pouco de milho', 'você me dá um pouco de feijão, um pouco de arroz', você falava (...) 'vai lá à roça, pode pegar para você"”.

A abundância em contrataste com a falta de liberdade, com o aprisionamento na terra que não é sua, no trabalho, que mesmo mais intenso possível, não é suficiente para dar conta de toda a plantação, uma plantação para qual se doa exaustivamente e que não é sua. É da consciência sobre essa contradição diretamente relacionada à luta de classes, à concentração da terra e da riqueza que pauta as relações, que se faz o Luís-que-luta-por-aquilo-que-acha-certo, o Luísinconformado, que vê no conflito a possibilidade da mudança. Reconhece-se diferente de sua família também com a partir dessa percepção; enquanto na família é reconhecido por ser trabalhador, pela sua dedicação à terra, é fora dela que busca outro o reconhecimento de sua subjetividade, de novas personagens.

O primeiro contato com a "política", de tempos em tempos, de acordo com os períodos de eleição, foi em Califórnia mesmo, lá começou a acompanhar os comícios, "a época de política ela era como se fosse uma festa, tinha comício por todo lado, naqueles bairros afastados, naquelas vilas afastadas, eu comecei a acompanhar política ali”. Foi a tal da política a razão para a mudança de cidade, para Aruarana, o incômodo de seu pai com o irmão que estava "sempre forçando a barra que os parentes que eram eleitores, tinham que votar no candidato que ele apontava", para por fim nisso sem ter que se impor, a distância.

\section{A descoberta da incoerência do mundo}


Afirmando-se a partir da negação do modelo do pai, Luís encontra o fato mais marcante na elaboração de sua consciência política nas conversas com o sapateiro da cidade. Tão importantes as conversas que, recordando-se, Luís afirma que "você molda um ser humano. $\mathrm{Na}$ infância você molda ele pro futuro, pro futuro dele, você pode traçar...”. As conversas com o sapateiro foram ponto de inflexão para sua mudança na forma de ver e entender o mundo construído pelos homens. Tinha 12, 13 anos e o sapateiro falava muito sobre "comunismo, que no comunismo o Estado era obrigado a dar estudo (...) o Estado é quem tinha que educar. Ele foi conversando aquilo comigo e eu absorvi aquilo, eu comentava com as pessoas sobre aquilo.” Um modelo em que "a terra era de quem trabalhava, não existia exploração da terra, vamos dizer assim... comercialmente" foi tomado como ideal, o "comunismo".

Foi por essas conversas que Luís diz hoje entender o "movimento do Chavez (...) do... enfim, da China e dos partidos comunistas e socialistas... e do capitalismo também, daquela coisa dos americanos." Com a mudança para a cidade vizinha não mais encontrava o sapateiro, mas "gravei aquilo na cabeça, e eu fiquei com a ideia do comunismo na cabeça", hoje embora continue pensando no modelo e comparando com a forma em que nos organizamos, acha impossível... ou "quase impossível, um país comunista, um Estado comunista".

Luís entende que a igualdade completa não é realizável, já que as pessoas são diferentes, usa a religião como mostra disso: "pra isso teria que ter uma religião só (nem sei para que tanta religião, porque deus é um só!) teria que... praticamente, fazer uma lavagem cerebral nas pessoas para aceitarem uma situação dessas de igualdade total". Por outro lado a desigualdade total, sem fundamento que lhe parece compreensível, era inaceitável e tornara-se gritante com a nova relação de arrendamento da terra encontrada em Aruarana:

“a porcentagem é assim, você pegava a terra para moradia. O patrão não te dava nada, ele não te dava semente, não te financiava, certo? E você entrava com a cara e a coragem. E era $30 \%$ milho, feijão e arroz... Era $30 \%$ o patrão e 70 pra você, mas ele não te dava nada. O café era $40 \%$ para você, arrendatário, e para ele, pro patrão, 60.”

O Luís-que-não-confia, desconfiado, nasce da convivência com parentes, que colaboraram para que seu pai gastasse todo o dinheiro da venda da terra que um dia teve, dos pesos, medidas e regras impostas pelo patrão, da medicina, antes de mudar para São Paulo. Se tivesse dinheiro para pagar a cirurgia, teria sido operado de apendicite ainda em Aruarana, não pôde, curou-se depois, 
não pelo remédio do médico, mas por 'um líquido num copo' preparado por 'uma mulher a farmacêutica'.

O único acesso à informação se dava por um "rádio velho (...) não lia jornal, não lia revista, não lia nada", mesmo o rádio, não ouvia. Conhecia aos poucos as regras dos homens, a sociedade e sua lógica, vivendo-as principalmente pela socialização secundária. Foi assim que percebeu que a ideia do comunismo era "perigosa", quando, ao procurar a moeda da União Soviética entre as dos outros países, expostas em uma loja, estranhando sua ausência contou tudo que aprendera sobre o sistema vigente por lá para um homem ao seu lado, “era um país tão falado quanto Estados Unidos, porque eram as duas potências que eram faladas e principalmente...”. Recebeu voz de prisão, mas conseguiu escapar.

\section{A negação do que não merece ser vivido}

As divergências com o pai cresciam e vinham à tona em confllitos mais frequentes entre a aceitação dessa relação com o dono da terra, das regras impostas baseadas, como Luís diz, na exploração "comercial" da terra, pela parte do pai, e sua negação por conformar-se. Ao dar-se conta da dificuldade em mudar as condições postas, considerou que teria que se mudar, por si mesmo, “completado 16 anos, 17 anos, já entrou aquele negócio na cabeça, 'o negócio é sair fora e rodar o mundo', e... 'Não dá, não dá pra ficar!' já fui tomando aquela decisão, mas não podia sair porque era menor de idade".

Encarou como possibilidade dessa mudança o exército, alistou-se, mas foi reprovado, sabe que a razão para isso está atrelada ao momento político do país "porque era época da ditadura, eles enrolavam você. Não servi." Depois de muitos anos, "recentemente", escreveu para o Ministro da Justiça sugerindo a alteração do sistema que deixa o "jovem à disposição do Estado dos 17 aos 19 anos. Isso é um absurdo! Isso é uma violência de direito!”. Julgado "incapaz”, continuou à disposição, esperando que no ano seguinte tivesse uma nova chance de mostrar-se capaz, mas entende que o "contingente" de homens à disposição engrossa de um ano para outro e por isso não teve chance.

Barrado em sua primeira tentativa de negar o que considerava não merecedor de ser vivido, de encontrar espaço para que seu outro "outro" pudesse vir à tona e ser reconhecido, isso é o Luís-inconformado, que quer participar da elaboração das regras, entende a situação como uma conjuntura na qual esteve inserido e não deita a culpa sobre características pessoais. Ao 
menos no momento em que conversavamos, Luís desconstrói o discurso vigente, oficial, a partir de sua visão crítica sobre o contexto.

Fica claro na narrativa que Luís queria servir ao exército para sair da situação de desigualdade, injusta em que ele e sua família estavam para sobreviver, e passar para outra em que, a princípio, todos são iguais, submetidos às mesmas regras, diante das mesmas oportunidades e limitações, direitos e deveres iguais: "o filhinho de papai, cai lá dentro, tem que entrar na linha. Aqueles 'flanelinhas' chegam lá, têm que entrar na linha."

A resposta do Ministro à sua carta não chegou, mas Luís posicionou-se da forma que lhe era possível diante de uma lógica que lhe parece desprovida de sentido, a do exército. Aqui mostra que vive ainda hoje a personagem nascida quando menor, criança ainda, que se inconforma e revolta contra o estabelecido que não faz sentido aos seus olhos, a objetividade que colide com sua subjetividade.

Bem, taxado como "incapaz" pelo Estado, recusando o rótulo conferido por ser baixo e franzino, Luís começou o cultivo de sua própria lavoura em uma parte da terra do mesmo patrão de seu pai; mudou de patrão, se antes trabalhava para seu pai, agora a relação era direta com seu explorador. O ponto é que agora eram dois os exploradores: o além do proprietário da terra, o pai pedia-lhe dinheiro. Assim, plantou, "deu bastante milho, bastante feijão", mas dividiu com mais dois.

Não só a roça, mas tudo em "que punha a mão, que dizia que era meu, ia para frente", ao dizer que tem sorte corrige-se na sequência dizendo não acreditar no fator sorte, no acaso, mas em esforço, em como cada um coloca-se diante das situações da vida. A sua autoconfiança baseia-se na consciência de que nem todos os fatos e experiências da vida dependem apenas de seu desempenho, mas também na percepção de que nenhuma situação é imutável, pode estar enrigecida a ponto de que não possa buscar a mudança colocando-se a si mesmo diante dela.

Luís voltou à sua cidade há dois ou três anos e à casa em que viveu, "só resta o alicerce, porque o alicerce é de pedra então ruiu tudo, menos o alicerce"; diz que gosta de voltar lá porque "viaja no tempo", pode "meditar" sobre sua infância, é mesmo uma viagem ao passado, a cada visita uma nova leitura. Na última vez, tentaram barrá-lo de passar ao lado da antiga casa para não ver a dona da fazenda de biquíni na piscina, Luís não aceitou, não fazia sentido não poder caminhar pelo lugar em que nasceu, mesmo que esse lugar fosse, agora, propriedade de outro: 
'você está vendo aquela serra lá em cima? Eu nasci ali, nasci perto daquela serra. Você está vendo aquelas terras? Aquilo ali pertenceu ao meu pai, pertenceu à minha família. Então hoje, você vai me desculpar, mas hoje eu vou passar por aqui, eu vou passar por aqui porque eu passei centenas de vezes nesse caminho quando eu era garotinho, e ninguém nunca me barrou, então hoje eu vou passar aqui, me desculpa, mas eu vou passar'

Passou, na cerca bateu os sapatos, garantido que não levaria nem um grão da terra que não lhe pertencia, da propriedade alheia. É assim que parte de sua própria história parece ter sido desapropriada, vendida junto com a terra, também mercadoria que agora tem outros donos.

\section{A história como pilar para compreensão do mundo}

O problema enfrentado na venda de sua colheita, a pobreza apesar do esforço e dos resultados na produção, é relacionado à Guerra dos Dez Dias que abalou os preços, assim como crise econômica mundial em pauta em 2009:

"um problema quase semelhante, mais ou menos semelhante, a esse que está acontecendo agora, um blecaute na economia do mundo (...) o porto de Santos, o porto de Paranaguá ficou paralisado com aquela guerra, mais de noventa dias. Os preços das mercadorias caíram lá embaixo, os armazéns ficaram abarrotados até o teto de milho, de café. (...) Não era por causa dos preços, nem de graça, os armazéns não queriam, porque não tinha onde estocar. E aquilo ficou parado um tempão. Foi um blecaute, um desastre na lavoura, por todo mundo, acredito eu que naquele tempo teve uma quebradeira danada de empresa. A gente não via jornal, não via nada, nem televisão tinha."

O surgimento da soja, a invenção da televisão, são outros momentos históricos trazidos por Luís; a soja, ele relaciona ao problema de obesidade no Brasil, já que antes de esse grão estar em alta "você não via pessoas tão obesas em quantidade igual você vê hoje". A televisão conectase com a história de sua cidade, a décima em Minas Gerais a receber o registro de cidade e uma das primeiras a ter as imagens de uma televisão. Por isso viu pela primeira vez o aparelho com sete anos, a idade de seu neto, embora tenha tido um em sua casa bem mais tarde.

A importância histórica de sua cidade é a base para seu orgulho do lugar onde nasceu e do interesse por voltar e fazer uma pesquisa sobre esses fatos e momentos. O passado, a história, desempenha importante papel nas reflexões e na interpretação de mundo de Luís, ele me diz categoricamente, sem que mais explicações sejam requeridas que "um dos problemas sérios da humanidade hoje é a falta de memória". Concordo. Ao buscar confirmação do ano em que a 
televisão chegou ao Brasil, 'em 50, 55 não foi?', decepciona-se diante da minha falta de conhecimento, ou de memória.

A televisão chegara à cidade pela combinação de dois elementos: da riqueza em grafite do solo de Itapecirica, e "um empresário com uma cabeça, uma mente tão avançada no tempo". Essa empresa era "avançada no tempo" não apenas por ter instalado a primeira antena de televisão da região, também porque tinha restaurante para os funcionários, ônibus para levar seus filhos para a escola, mulheres trabalhando, "minha cidade seja talvez no Brasil a primeira cidade que teve... praticamente as primeiras mulheres a trabalhar em indústria”, e muitos postos de trabalho, "ele já dava emprego pra mais de duas mil pessoas". Organização essa que oferecia benefícios ao trabalhador que tornavam, a seu ver, justa a relação de emprego; anos mais tarde ainda referência do que poderia ser a relação de trabalho capitalista, já que o comunismo é "impossível". Ideia essa que Luis levará adiante em suas expectativas sobre o trabalho e em sua visão sobre o que pode ser diferente e o que precisa ser replicado.

\section{O limite da contradição, a alterização}

A relação justa de trabalho parece-lhe possível, diferente da estabelecida com seu patrão, para quem respondia, depois de seu pai. Luís conta como essa relação chegou ao seu limite e teve que ser superada quando foi impedido de realizar um sonho, ter uma bicicleta. Conseguiria uma de segunda mão em troca de alguns porcos e balaios de milho que seriam usados para alimentálos; mesmo não saindo da parcela que lhe cabia, de acordo com as regras por ele mesmo estabelecidas e aceitas por Luís, o arrendador exigiu que o milho fosse debulhado antes, no armazém, inviabilizando o negócio. Essa regra erigida de pronto, saída de último momento do legislador que não precisa de nenhuma outra instância de aprovação, pareceu por demais incoerente, injusta, "é meu e eu não estou negando a parte dele, eu estou sendo justo, eu quero apenas justiça”.

A razão para que o patrão não abrisse mão de que o milho fosse separado depois de passar por ele parece relacionar-se, para Luís, à manutenção do "domínio", do poder sobre o subordinado. Poder esse ancorado na posse da terra, claro, mas instrumentalizado pelo conhecimento unilateral de uma linguagem, da matemática. Era no armazém, pela pesagem, que o proprietário separava o montante da produção destinado a cada parte, assim Luís "pagava o preço que ele queria, ele que conhecia de matemática, porque a matemática comercial é diferente da matemática que você usa, porque lá tem quebra, lá tem umidade do milho eles enfiam um 
negócio lá...”. Sente-se hoje da mesma forma frente ao Estado; o paralelo faz-se não apenas porque é quem paga sua aposentadoria, também porque sente-se impotente da mesma forma, sem armas para lutar por uma relação de maior igualdade, por participar um pouco mais da determinação daquilo que determina a sua vida.

Calar-se parecia impensável diante da situação que sabia ser desequilibrada demais, significava passar por cima dos valores que havia adotado como referência para a compreensão do mundo. Procurou um advogado que aceitou a causa, "eu só não demandei por causa do meu pai", com medo de ter que sair da terra que trabalhava, de sofrer as consequências da revolta do filho contra a situação posta, contra a dominação passada de pais para filhos, o pai impediu Luís de "demandar" contra o patrão:

“meu pai falou pra mim 'você vai estragar o negócio meu?' é que meu pai ia reformar o contrato com ele pra mais um ano, meu pai precisava da terra, e ele não queria mudar de lá (...)disse duas palavras pra mim, "se você acha que o sítio aqui não serve para você", eu não esperei nem ele terminar o restante da frase. (...) Baixei a cabeça, não falei mais naquele assunto e esperei. Fui dormir, amanheceu o dia, fui pra casa do meu irmão. Meu irmão mais velho tinha sítio, estava sempre precisando de gente pra trabalhar..."

A mudança de terra e de patrão ainda não pôde ser o salto qualitativo buscado por Luís, trabalhou para seu irmão mais velho que era dono de um pedaço de terra, seu papel de subordinado parecia-lhe menos insuportável, mas longe da ideal. Soma-se essa mudança às discussões com seu pai, às conversas sobre o comunismo, à idealização de uma forma diferente de viver. O olhar crítico ao contexto já se fazia aí prática do Luís-que-busca-viver-de-acordocom-seus-valores, autodeterminar-se. No entanto, a nova personagem não encontrava, nesse ambiente, possibilidade alguma de reconhecimento; contexto em que os que possuem terra tudo podem e os que usam a terra de favor podem apenas obedecer e que ambas posições são passadas para os descendentes, na manutenção da mesma relação de poder polarizado, essa nova personagem exigia um reconhecimento pós-convencional.

Continuou sobressaindo-se, por mais algum tempo, o Luís-arrendatário-explorado, sem direitos garantidos e sem instância de representação. Hoje entende o quanto as condições de trabalho na roça eram insalubres, “eu com 17 anos pegando saco com $90 \mathrm{~kg}$ na cabeça (...) se fosse hoje você processava o cara, é crime". 
Nova oportunidade de superação da mesmice, de viver um novo contexto em que seu projeto de autonomia tivesse maior chance de realização, veio com o casamento de uma prima, em São Paulo. Luís mudou-se sem saber o que esperar, "isso aqui pra mim foi um uma surpresa, sabe?", em busca de trabalho, de casa, de um papel diferente ao de arrendatário de terra à qual permanecia atado na zona rural de Minas Gerais.

\section{A luta pelo reconhecimento afetivo, legal... solidário}

Seu primeiro emprego na cidade foi em uma abatedouro de aves, ele era um dos abatedores, "coisa que eu não faço hoje nem... se depender de mim para matar um animal para comer eu não como". Matava porque tinha que matar, saiu porque "era um pouco rebelde, vamos dizer assim" e porque queria ter carteira de trabalho assinada. Encontrava-se com uma nova categoria, a do emprego; de arrendatário para empregado, papéis que guardam algumas relações, mas que para Luís deram luz a personagens distintas. A possibilidade de mudar de atividade, de sair de um emprego e começar outro quando issatisfeito fora um avanço em seu projeto de autonomia, mesmo sem encontrar relações mais simétricas, era o Luís-trabalhador-empregado, que vende sua força de trabalho e que, por isso mesmo, tem direitos estabelecidos e socialmente reconhecidos, que entrava em cena.

Começou então uma nova busca, por um lugar em que não apenas os direitos trabalhistas fossem seguidos, já que os valores a partir dos quais analisava o mundo não se estreitavam a essa cartilha. A história de Luís no trabalho, esfera que se sobressai em toda a narrativa, reflete essa busca constante, por uma objetividade em que sua subjetividade tenha expressão, pela mesmidade entre atividade, consciência e identidade.

Superou a dificuldade com a tal da matemática, apesar de seus poucos anos de escola passou no teste para cobrador de ônibus. "Fazia a linha Penha / Vila Mariana. Tinham dois preços, até a Praça da Sé era um preço... quem ia seguir pagava passagem dobrada". Orgulha-se da complexidade de cálculo com que aprendeu a lidar, teria ficado mais na função se não fosse o motorista ter jogado um homem bêbado "lá fora, para baixo da escada, o cara caiu lá embaixo (...) deve ter se arrebentado todo". Descordou, percebeu ser essa atitude parte de uma moral compartilhada entre os profissionais do setor e, sem poder mudá-la, mudou-se: "ele fazia isso, não me serve".

O trabalho pesado, como o da construção civil, era mais palatável que qualquer outro em que as regras, valores, processos fossem violência diante de sua própria moral; uma moral que 
parece basear-se em uma interpretação universalista, pautada por direitos e deveres que são extendidos a todos os homens e mulheres. É possível que seja, essa moral, do Luís-politicamenteengajado-explorador-que-busca-o-conhecimento que me contava sua história, essa possibilidade é inerente a essa análise, acompanha-nos a cada linha.

Como pedreiro ficou por algum tempo, a relação violenta, humilhante que se concretiza na organização contemporânea do trabalho foi encontrada por onde passou, seja com ele ou com o outro, de qualquer forma importa a ele. Na metalúrgica, em que gostava do trabalho, "era para ter sido metalúrgico, era pra ter seguido o ramo", foi demitido por justa causa, de forma brusca e intimidante. Em um ambiente todo de vidro, constantemente vigiado, foi punido por ser responsável por um menor de idade que insistiu para levar um carrinho pesado e carregou-o pelo corredor.

"Ele já estava a fim de mandar alguém embora ali, sabe? Ele falou pra mim, 'Rua!'. Assim. Apontou o dedo para mim e falou, 'Rua!'. Na maior inocência, falei pra ele, 'Não entendi, o senhor pode repetir?'. 'Rua! Você está despedido'. Eu falei, 'Tudo bem, senhor', saí. Quando eu fui voltar por aquela porta, disse 'Por aí não, por aqui!'. E já chamou um dos capangas dele, falou para acompanhar, fui para o departamento pessoal. No caminho fui conversando com o cara, falei 'Vocês estão me dispensando por que?'. Ele disse 'Você sabe porquê. Você não sabe que moleque de menor não pode pegar peso? Você ficou perto do moleque e o moleque empurrando o carrinho'. Eu falei 'Tudo bem'. Andamos mais um pouco, quando chegou perto do departamento pessoal, que ficava do outro lado da rua, eu falei para ele dos meus direitos. Ele falou, 'Direito? Direito você vai procurar, você está sendo despedido por justa causa"”.

A ordem instituída e seus mecanismos claramente não eram capazes de garantir o que considerava seus direitos. Buscou advogado, queria justiça, mas embora muitos na fábrica tivessem se disponibilizado como testemunhas, ninguém apareceu na audiência. As instâncias legais, embora existentes e aparentemente consultáveis, não estavam acessíveis aos empregados da fábrica, o preço pago seria muito alto, não podiam pagar com seu próprio emprego para que outro trabalhador tivesse seus direitos reconhecidos. Luís havia deixado de fazer parte do grupo de empregados da empresa, deixou ser membro do grupo. Os laços afetivos não deram conta do embate com a ruína do reconhecimento legal que lhe era provido pelo enquadramento entre os recursos humanos da empresa.

Isolado, aceitou a proposta da empresa: "fazer o quê? Aceitei o acordo, pra poder receber" fundo de garantia, férias, abono, mas não o aviso prévio. Não estava satisfeito, mas "fazer o 
quê?". Viu-se sozinho, sem armas para mudar a objetividade da situação posta, assim como, no emprego seguinte, não conseguiu fazer valer seus direitos humanos no trabalho pesado que lhe rendeu duas hérnias e uma demissão logo na volta do afastamento para a cirurgia na coluna, isso "com 19 para 20 anos".

A possibilidade de eleger o que merece ser vivido, o espaço expandido para empreenderse na busca por relações de trabalho em que fosse permitido colocar-se e participar da construção das regras a partir de seus desejos e interesses mostrava-se ilusão. Percebia, Luís, que a liberdade de procurar outro emprego nada tinha a ver com autonomia quando em todos a lógica repetia-se; Luís andava em círculos.

Apesar do Luís-sindicalista ter ganhado vida, "sempre fui filiado ao sindicato da categoria", começa a reflexão a respeito do Luís-militante que poderia ter existido e que hoje seria admirado pelo Luís-crítico-político-aposentado-aventureiro que me falava sobre sua vida.

"Nesse período, de tudo isso que aconteceu, lá em Brasília o pau tava comendo. Greves, prisão, assassinato. Os comunistas estavam sendo degolados, enterrados em valas comuns, como houve em Perus. Muita gente tinha sido expulsa do país, muita gente presa. (...) E eu assistindo tudo, porque nesse período eu, simplesmente, me afastei, eu não militei. $\mathrm{Eu}$ era para ter sido um militante daqueles ferrenhos, pela minha trajetória. Eu era para ter chegado aqui e me engajado, principalmente na área sindical. Mas não, eu fiquei..."

Uma época em que mesmo sem contrapor-se à ordem, sem ser "militante", podia-se estar fora da lei. Fora preso por "vadiagem" certa noite em padaria no Jardim Jaqueline. A Rota olhava a carteira de trabalho, "RG não era documento naquele tempo, documento era carteira de trabalho registrada", a de Luís tinha registro, mas sua mão lisa, pelo afastamento devido à hérnia, rendeulhe uma volta no camburão com o policial "zuando" o grupo que mal cabia no cubículo. Imaginando a humilhação ainda maior que seria na cadeia, com medo de não "voltar vivo para casa”, de ser fuzilado na M'Boi Mirim, Luís assim como todos os outros, até agradeceram a soltura inesperada no meio da avenida. Agradecimento ao símbolo de "sistema de governo, que toda a vida eu contestei (...) Faz um resumo disso aí para você ver, e conversa com pessoas da minha época para você ver".

Ao contrário do que a polícia chamava "vagabundo", Luís tentava enquadrar-se no trabalho, na fábrica, adaptava-se ao manejo das máquinas, às repetições, ao ritmo pulsante não humano.O Luís-enquadrado-no-sistema-produtivo reclamava o reconhecimento de seu trabalho e, 
assim, de si mesmo, do salário que não aumentava... da traição de um amigo que "era igual irmão". "Se eu levava uma maçã, nós partíamos no meio, nós tínhamos uma consideração enorme um pelo outro", até que, uma vez promovido, o companheiro mudou a postura, demitiu-o por justa causa. A hierarquia imperava sobre os laços afetivos, sobre a humanidade as relações interesseiras. No ambiente de trabalho, em sua luta por reconhecimento, Luís encontrava uma estrututra não humana soberana e incapaz de suprir as necessidades humanas para além da sobrevivência biológica.

Luís fala da "polêmica da perseguição do empregado dentro de uma empresa"; seja por não ser da Assembleia de Deus, como seu amigo-traidor, seja por não ser judeu, ou pela possibilidade de ocupar um cargo que pertence a outro e onde apenas cabe um, o sentimento de "perseguição" fundamenta-se. Sem questionar a lógica do trabalho competitivo, hierárquico, heterogestionário, Luís restringe sua luta ao respeito poucos direitos que lhe caberiam. O trabalho duro, o sacrifício de seu corpo na labuta pesada não foi suficiente para encontrar espaço em um mundo em que não havia lugar para conflito apesar de tanta inequidade, de tamanha polarização do poder.

"A minha ficha era tão limpa na empresa, sem atraso, sem falta. A minha ficha era tão limpa que o chefe do departamento pessoal falou, 'Sebastião, o que você aprontou lá?'. Eu falei, 'Não aprontei nada'. Ele falou, 'Mas o que eu recebi aqui é para te mandar por justa causa'. Eu falei, 'Vocês estão malucos da cabeça? Não fiz nada, não matei ninguém, eu não esquartejei ninguém, que estória é essa?'. No dia seguinte eu voltei, ele falou para mim, 'Olha Sebastião, a ordem que eu tenho é essa mesmo, te despedir por justa causa."”

Não encontrava lugar para si dentro do ambiente de trabalho que se repetia enfadonhamente nos mesmos moldes. "Eu trabalhava 15 dias numa firma, não dava certo", até que reencontrou um antigo chefe em uma empresa de plástico, "uma pessoa muito boa (...) nós dois tínhamos um certo relacionamento"; Luís diz o que buscava, uma relação humana, além das regras e das posições estabelecidas, dos papéis funcionais do organograma empresarial. Foi por isso que conseguiu ficar mais tempo nesse emprego, pelo espaço, mesmo que restrito, para falar e ser ouvido: "por várias vezes que eu tive atrito na empresa, porque eu queria sair", era o chefe quem ouvia suas razões e conciliava os interesses para que Luís continuasse na empresa. 
Seu desligamento se deu depois que seu chefe saiu da empresa e assim tudo voltou ao que sempre foi, apenas uma empresa com nome diferente, a mesma organização do trabalho. Lançouse então a uma viagem, “uma turnê pelo Brasil”, Minas Gerais, Goiás...

\section{A mesmice das contradições não superadas}

Voltou a São Paulo ainda mais intolerante em relação a alguns elementos da organização heterogestionária do trabalho; na empresa em que foi contratado na volta ficou um mês já que seu supervisor "queria ficar dando palpite, sem saber o que estava falando. E eu, já com uma experiência daquela, não concordava". Era absurdo para Luís realizar o trabalho que outra cabeça lhe ditava, deixando a sua de lado em um trabalho mecânico que desconsiderava a experiência e o conhecimento que tinha acumulado em anos de trabalho maçante. Obedecer apenas pela posição em que se encontra na divisão social do trabalho claramente não era o melhor a ser feito: "você não sabe o que está fazendo rapaz, isso aqui não é assim, isso aqui é desse jeito. Não dá para fazer do jeito que você quer que faça".

Coincidentemente seu chefe anterior, aquele com quem tinha um relacionamento, estava nessa mesma empresa, em um cargo alto, agora era "Dr. Francisco", por isso mantiveram distância, "eu não me aproximei dele, você entende? Ele ficou no lugar dele, eu fiquei no meu lugar". Mesmo a relação antes afetiva, ou a mais próxima disso que encontrara no mundo do trabalho havia se transformado com a mudança do cargo, da posição ocupada pelo chefe: o organograma havia acrescido algumas colocações entre os dois, distanciando-os. "Falei para ele desse jeito. 'Não dá para trabalhar com eles, Francisco', mas sem intimidade.”

Situação essa que se mostra comum no mundo do trabalho fabril pela história de nosso narrador; na Pullman um engenheiro foi contratado para "cuidar" do setor mais moderno da empresa, em que Luís trabalhava, assim se estabeleceu a contraposição entre trabalho intelectual e braçal por uma divisão imposta pela organzação do trabalho em voga, mas que ele identifica, por experiência própria, como impraticável na vida real:

"eu era um simples operador, tinha vindo das outras firmas como operador (...) o engenheiro também não conhecia nada, era só teoria. Você está estudando, não é? Coloca em prática, teoria não funciona. Por exemplo, ser engenheiro que trabalha com esse serviço, tem que ter conhecimento de todo o processo produtivo. Não adianta só ter a teoria, principalmente hoje. O que aconteceu com ele? Ele trabalhava numa empresa muito grande, mas era só assinar papel. Ele falava para nós assim, 'Ah não está bom, o material não está bom, para a máquina'. Nós éramos operadores, nós tínhamos conhecimento técnico do 
funcionamento operacional da máquina. Ele falava 'Para a máquina', mandava desmontar aquilo tudo, imagina a firma, com um equipamento caríssimo daquele montado, e parado.”

Os operadores e "encarregados" estavam cansados de ver o engenheiro, o doutor, "fazendo burrada", mas estavam imobilizados pela hierarquia, "ele era o chefe, ele era o engenheiro (...) tinha que respeitar as ordens dele". Quando o engenheiro foi demitido, por outras razões, não relacionadas ao trabalho, Luís assumiu o comando da operação junto a um companheiro de chão de fábrica a pedido do capitalista, "Aí ele, muito sistemático, e eu também sistemático... Eu sei que aí ele perguntou se nós assumíamos a responsabilidade de tocar os equipamentos, a gente assumiu. Aí nós começamos a tocar a máquina”.

Foi nessa empresa em que o Luís-empregado mais aproximou-se da autodeterminação, aposentou-se aí depois de 21 anos de trabalho. O que havia de diferente para suas experiências anteriores, a possibilidade do conflito com o chefe. Embora visto como um mal necessário para o outro lado da relação, para Luís siginificava a possibilidade de mudar as regras, de tomar parte do rumo que suas oito horas diárias de trabalho levariam. Levava seus descontentamentos ao patrão, "porque lá você podia falar com o patrão, sabe? (...) nesses 21 anos tive vários atritos com o dono da firma". A possibilidade de acesso ao conflito que está implícito, que advém inevitavelmente da diferença de classes, é novidade para Luís, mesmo assim nunca expresso em um diálogo entre iguais:

"uma vez ele me chamou de burro e não me deu direito de defesa, eu fiquei insistindo, ele saiu, me deixou falando sozinho e foi embora. Aí veio aquilo, não aguentei, não consegui trabalhar (...) Eu saí para falar com ele, os colegas todos falaram, 'Você está louco, rapaz? O homem vai te mandar embora' (...) Eu falei 'se mandar tudo bem, não tem problema, mas se eu não falar com ele não vou conseguir trabalhar. Ele não me deixou falar, só ele falou, ele não me deu direito de defesa.' (...) Eu cheguei, ele estava distribuindo serviço para os mecânicos (...) ele parou, dirigiu a atenção para mim, 'O que foi Sebastião?'. Eu falei, 'Posso falar com o senhor?', 'Pode'. E eu falei 'Olha, a partir de hoje eu vou pedir para o senhor uma coisa, não me chame de burro, porque o senhor não me deu o direito de resposta, só o senhor falou.' Quando ele levantou o dedo pra dizer 'Mas você é burro mesmo', eu também levantei a mão para ele, eu falei 'Parado lá, o senhor não me deu o direito de resposta. O senhor simplesmente falou o que o senhor queria falar, virou as costas para mim e foi embora.' (...) Ele caminhou para o meu lado, bateu no meu ombro e falou 'Você está nervoso, volta, vai trabalhar'. Ele não disse 'Tudo bem, fala', ou desculpa, ou coisa assim, mas ele veio, bateu no meu ombro e 
mandou eu trabalhar. Que ali a firma era grande, podia falar 'Você está despedido, eu não tenho obrigação de te ouvir, eu sou dono da empresa, aqui trabalha quem eu quero', podia ter me respondido isso. Voltei."

O reconhecimento do Luís-pensante, com conhecimento, experiência e interesses próprios encontra seu limite as regras que fundamentam a organização capitalista do trabalho servindo a seu objetivo final, a expropriação e acumulação da riqueza gerada pela exploração do trabalho. $\mathrm{O}$ contentamento de Luís por ter dito o que pensava, seu incômodo por não ter tido direito à resposta, sem que o patrão lhe ouvisse, mas também sem que the mandasse embora, ilustra essa relação essencialmente contraditória entre a revolta, o grito, e a obediência, o silêncio.

O Luís-que-busca-justiça, bem como o Luís-crítico, não questionam a hierarquia em si, as bases para as posições de chefe e empregado, lutam por alternativas de reconhecimento dentro da dinâmica estabelecida, por meio das ferramentas disponibilizadas pelo próprio sistema, no limite, a demissão. O Luís-empregado que busca a autoderminação possível no limite do sistema tornase o Luís-aposentado que dá vida a personagens que mantêm algumas características das antes em cena. Para ele o modelo de sucesso profissional e de caminho para o desenvolvimento do país continuam projetados no capitalista que garante seu sucesso por meio da dedicação ao trabalho e à empresa. Falando de seu último patrão: "naquele tempo ele ainda tomava conta de tudo. Produção, manutenção, vendas, compras, tudo era com ele, e já trabalhavam mais de 1000 funcionários na empresa, já pensou o cérebro daquele homem? Se o Brasil tivesse 10\% dos empresários com a mentalidade daquele homem, isso aqui era um paraíso."

Apesar das dificuldades enfrentadas, do embate constante entre "mim" e "eu", entre o esperado para o papel que ocupava e seus valores e desejos, Luís conta que sempre quis trabalhar em empresas grandes, corporações, "quebrei, quebrei cabeça para trabalhar em firmas de nome. Porque eu queria trabalhar em firmas grandes." Mas por quê? A razão é a mais simples e compreensível, a vontade de ser promovido, de ocupar, algum dia, as posições mais altas da hierarquia; Luís adotara o sonho eficazmente vendido por nossa sociedade, ainda hoje galgar a hierarquia do trabalho é o caminho buscado por aqueles que querem subir na estrutura social inspirados nos exemplos totêmicos de indivíduos que teriam sido bem sucedidos em tal feito. Conectadas, a divisão social do trabalho e a estrutura societal são sincrônicas em direção ao acúmulo de capital, é ele a base para o reconhecimento que pode ser conquistado quando se deixa de "ficar empurrando carrinho" para "mandar". 


\section{O "mandar" e o "ser mandado"}

A relação dialética entre o patrão e o subordinado é trazida em diversos momentos do discurso do Luís-que-conta-sua-história. Operário, encarregado, empregado, sincronicamente patrão, chefe para outros. Como subordinado, não submisso, por isso afirma o conflito como marca de sua relação com o chefe; como patrão, a dificuldade de encontrar a base, o argumento para sua autoridade. "E é mais fácil você ser mandado, do que mandar. Mandar é uma função muito ruim." Apesar de ganhar mais dinheiro, e, principalmente por isso, estar em uma posição social mais admirada, reconhecida, pelo "outro" sociedade, é com o "outro" empregado, trabalhador, que convive a maior parte de seu tempo, dentro da fábrica, e por quem costuma ser visto como "chato, de mandão, de autoritário (...) sempre autoritário". Luís viveu isso, "sei muito bem o que eu estou falando".

Incoporado o sonho coletivo de ser o patrão em seu projeto de vida, conta também que “não era assim tanto de mandar, nunca fui uma pessoa de gostar de mandar", uma posição de chefia contrariava essa sua disposição e que deve ter tentado superar, mudar, já que era apontado por alguns como "autoritário". Para ser eficiente, Luís mostrava-se duro, por vezes em seu próprio discurso, cortando brincadeiras ou amenidades. Uma personagem que nascia de fora para dentro, de certa forma violenta ao submeter aquilo que reconhece como seu, como próprio.

A contradição, mesma que se faz entre a concentração do poder e a resistência, estruturase em sua fala: ao mesmo tempo em que se indigna com o mando de alguém, que, a seu ver, não tem a autoridade ancorada no conhecimento e na experiência sobre determinada tarefa, processo ou trabalho, conta que por vezes viu-se obrigado a "mandar pessoas embora porque não tinha mais condições de relacionamento. A pessoa às vezes me desafiava em autoridade (...) então ele me questionava". Uma contradição que não se resolve no indivíduo, que se replica em cada relação patrão-empregado-patrão e que se materializa na identidade daquele que vive-da-forçado-trabalho, que tem sua mais valia-extraída, sua autodeterminação limitada, ao mesmo tempo em que é veículo da alienação do trabalho de outros, em que representa a figura que comanda a força de trabalho e que explora a energia vital de outros.

O ser chefe, na maior parte das situações, afirmativamente na de Luís, implica ser mandado por outro, emprestar sua boca para a expressão daquele a quem obedece, seus ouvidos para que esse outro fique sabendo do que se fala em seu território. Outro esse que, por sua vez, empresta seu corpo e mente a outro, a outro, outro, assim por diante, subindo na hierarquia 
empresarial até alcançar o Capital, aquele que ocupa o topo. A ilusão e desilusão do "ser patrão" está na fala de Luís:

“(...) teve caso também do dono da empresa chegar e falar para mim... (...) se ele olhasse para você e não gostasse... (...) não sei, de alguma coisa em você, falava "Manda embora". O seu profissionalismo para ele não tinha nada a ver, trabalhava na empresa acho que quem ele simpatizava, não sei, ele tinha um comportamento esquisito. Então aconteceu também de eu chegar e ele falar 'Manda aquele cara lá embora'. Aí ele ia embora, eu ficava raciocinando, por que quis mandar essa pessoa embora? O cara trabalha bem, o cara não me dá problema, o cara corresponde àquilo que a empresa exige. (...) Por que eu vou mandar o cara embora? Mas ele pedia, ela era o dono da empresa, tem que mandar. Não dependia só de mim, eu tinha que passar para o meu superior a ordem. Chegava no meu superior e falava... que abaixo do dono ainda tinha mais uma pessoa. Mas para mandar o cara embora, ele não ia lá falar com o cara, ele falava diretamente com você, que estava com as pessoas ali trabalhando. Eu chegava lá, 'Olha, Seu Manoel...', ele chamava Seu Manoel. 'Seu Manoel disse que é para dispensar fulano de tal'."

É então que entra a micropolítica, atividade constante, sabemos, faz-se aí, quando apesar do comando que chegou por outras tantas bocas comandadas, há a possibilidade do questionamento: “'por que ele quer mandar ele embora?'. Eu falava 'Não sei, ele pediu para mandar', 'Mas o cara é bom?', ‘É', 'O cara trabalha direitinho?', ‘Trabalha'”. Oportunidade para a discordância diante de uma decisão que não faz sentido para seu executor torna-se resistência. "Então eu vou arrumar um outro lugar para ele, vou mandar para outro lugar, pego uma pessoa de lá e transfiro para ocupar o lugar dele". Usa-se as ferramentas que se tem para agir diante de seus próprios valores, no limite da autonomia, encontrando liberdade nas brechas da hierarquia.

Frágil, volátil respiro facilmente encerrado pela vigia, pelos dispositivos oficiais da burocracia; "ele passava ali, o cara de novo trabalhando. Ele chegava para mim, 'Por que você não mandou fulano embora?' (...) ‘escuta, você quer que ele vá, ou você quer ir?’”. É aí que, sem saída, resigna-se com a violência que encerra a falta de autonomia diante da dependência em relação ao salário em um contexto de crescente desemprego, "década de 80 que era ruim de emprego, sabe?". Época em que a ameaça do desemprego mantém uma autoridade desprovida de embasamento racional, ameaça que ganhou o nome de departamento pessoal: "vem um aviso para você ir ao DP, você já fica logo preocupado".

A contradição, força motriz do movimento 
O golpe de agir guiado por uma racionalidade que foge à compreensão e de olhar nos olhos do outro homem, desrespeitado em sua humanidade, reconhecendo sua própria humilhação naquela vivida por esse outro é metaforizada por Luís como "uma punhalada que você leva". É defrontar-se com a situação sem outra escolha que não realizar uma objetividade que se contrapõe e impõe-se totalitariamente ao seu "eu": "o cara está trabalhando ali, te obedece, faz tudo que você manda o cara fazer, não chega atrasado, uma pessoa ordeira, e de repente vem uma ordem dessa para você dispensar o cara (...) aquilo deixava você...”.

Não seria possível expressar tal falta de alternativas de forma mais clara que Luís; a relação direta entre a organização hierárquica do trabalho e o projeto de autonomia em ruínas, a alienação transversal e replicada entre os níveis da cadeia, concretizada nas relações de mandoobediência que, apesar de se darem entre pessoas diferentes, repetem sempre o padrão. No discurso que sustenta esse ciclo encontra-se a ideia de quem manda, no fim, no fundo, ou no alto, acima de todos, é a empresa, a organização que ganha vida própria além das pessoas que a compõem, apesar de apenas existir pelas pessoas. A instituição tornando-se um fim em si mesma, ganhando o papel do criador e o homem da criatura.

"O que eu falava era assim 'Aqui quem manda é a empresa, eu não posso fazer nada. Isso aqui é uma empresa, a decisão que é tomada lá em cima, aqui embaixo nós não podemos fazer nada'. Então eu falava assim, 'A decisão deles é de cima para baixo, quando chega aqui, é para dispensar, a gente tem que fazer isso. Quer dizer, tem que passar para vocês o que vem lá de cima'. Era só isso que eu fazia."

Ao mesmo tempo em que se lançava ao conflito, arriscando seu emprego, por vezes, em prol do que reconhecia como seus direitos, Luís respeitava a "empresa", essa entidade com interesses próprios, frente aos quais curva os seus próprios. Essas são faces da mesma personagem, do Luís-que-luta-por-justiça; justiça pautada em regras e valores que interiorizados, entre eles os propostos pela organização capitalista dos homens, do trabalho e da riqueza, pela empresa.

Ainda, é articulado ao Luís-empregado-que-busca-empoderamento dentro do sistema posto que vive o Luís-em-prol-dos-direitos-universais. Justamente em prol de algo comum, do que une todos os empregados em um mesmo ambiente e em uma situação compartilhada, a empresa, que Luís defende a igualdade considerando as diferenças. Um de seus funcionários foi, segundo conta, um morador de rua, contratado em uma época em que "estava uma falta de mão 
de obra", também trabalhou com um homossexual. "Os colegas tiravam sarro, me alugavam, eu falava 'ele é um ser humano igual os outros. Se ele serve para a firma, a firma contratou ele, deixa ele trabalhando aí"”. O fato é que "tolerou" os dois, não contribuiu para que saíssem da empresa, "trabalhou enquanto quis e saiu da empresa, não por minha causa", mas porque não serviam mais para a empresa, não tinham mais razão para estar ali, na convivência com ele e com os outros trabalhadores.

Personagens essa que ganham movimento por isso mesmo, pela articulação entre suas aproximações e distâncias, pelas sintonias e contradições. Também a mesmice de uma personagem que não atende às demandas subjetivas, do empregado-obediente de regras sem sentido, a qual parece impossível superar na atividade de empregado de uma empresa heterogestionária, há o caldo para a construção de relações mais simétricas, para a consciência sobre as diferenças e para o reconhecimento de si no outro. A contradição é marca de nossa organização societal, marca que se concretiza no indivíduo.

Depois de receber o status de aposentado, Luís continuou sua atividade como operário, a aposentadoria de fato e a conformação da nova personagem liga-se ao fim de seu casamento. Aqui vale a observação de que até esse momento da narrativa, a esposa não aparecera, Luís tem filhos, mas também não os apresentou, seguiu sua história com o trabalho, desde pequeno, criança, até o momento da entrevista. Com o trabalho competem as viagens, são elas que ocupam os intervalos de uma vida laboral, abrindo espaço e tempo para o Luís-aventureiro-curiososempre-aprendendo.

\section{O Luís que se apresenta à experiência autogestionária}

Para cuidar do pai, antes cuidado pela esposa, Luís aposentou-se do emprego, sem mais precisar laborar, buscou o trabalho com sentido. Envolveu-se em uma ONG ambientalista, voltada ao plantio de árvores e despoluição das águas do Rio Pinheiros, mesmo assim “eu fiquei muito ocioso em casa, ficava aqui o dia inteiro", faltava-lhe atividade para realizar as personagens que clamavam por vida. Foi convidado a participar de um projeto, já ligado ao Centro de Referência em Segurança Alimentar, de horta orgânica e medicina caseira.

O caminho até o grupo Mãos na Massa começou aí, quando conheceu "o pessoal do Pólis" e participando de alguns projetos do instituto passou por outros tantos grupos, causas e ações. Logo engajou-se no programa voltado à segurança alimentar, "porque eu nasci e me criei na roça, então eu conheço bem da natureza, e amo a natureza." Essa sua relação de proximidade 
com a natureza que foi trazida, ao longo de sua vida em São Paulo, pelas viagens que pôde fazer foi então resgatada. Luís encontrou, nesse projeto, a possibilidade de realizar-se também por duas de suas mais representantes personagens: o Luís-aventureiro-curioso, que adora viajar, e o Luístrabalhador que busca ser reconnhecido e deixar sua marca no mundo pelos resultados de seu trabalho.

"Eu me interessei pelos trabalhos, fui com o Pólis para Argentina, para o Paraguai, para o Uruguai. (...) Fui para o Chile, fui para o Rio de Janeiro com eles, já fui para Diadema duas vezes, já fui lá para Uberlândia, naquela cozinha experimental que tem lá, das freiras. Aqui no Butantã já participei de várias reuniões, vários eventos, lá no Pólis também já participei de vários."

Além da horta e da medicina caseira, Luís é um dos representantes do Brasil no Programa Mercosul Solidário cuja plataforma é composta pelo Pólis junto a outras organizações com o objetivo de levar questões sociais ao processo de integração econômica entre os países. De sua vivência nesse processo, destaca um dos momentos de reconhecimento alcançado por sua contribuição ao grupo, momento em que fez história.

"Nas oficinas, em todos esses eventos foi feita uma carta, e essa carta foi enviada para cada presidente de cada país, presidente da república de cada país. (...) E no dia que foi escrita a carta, foi passada no slide da casa para nós lermos, e eu fui lendo, só que estava em Espanhol. (...)E eu fiquei acompanhando, lendo, e ali você podia alterar. Se você não concordasse com uma frase daquelas, com qualquer coisa que estivesse ali, você podia pedir para tirar, ou acrescentar. E eu fui lendo, quando chegou numa altura lá, apareceu uma coisa que eu achei que não estava bem contemplada, não estava bem específico. E no meio de 300 pessoas, qualquer pessoa de qualquer país ali podia levantar e falar. Então eu levantei sozinho e falei, mas eu falei, é lógico, em nome do nosso grupo aqui do Brasil. Eu olhei aquela coisa que eu achava que precisava melhorar. Eu levantei a mão, parou tudo, aí perguntou para mim o que eu queria falar, 'Olha, é o seguinte, esse item assim, tal tal tal tal tal, eu gostaria que fosse acrescido isso, isso e isso'. 'Terminou? Era isso que o senhor queria?', e continuou, ninguém mais falou nada, pode perguntar para o pessoal. Terminou o evento, voltou aquilo novamente para a mesa de discussão, daquele grupo que estava incumbido de escrever, de elaborar a carta. Então, de tudo aquilo, foi alterado só aquilo.”

A contribuição de Luís "foi aceita na íntegra", assim cada um dos presidentes dos países do Mercosul deve ter ficado sabendo que interessa aos representantes dos cidadãos que o governo ofereça isenção de impostos aos donos de terras, fazendeiros, que deixarem parte de suas terras 
preservadas para "o mato crescer, para criar bicho, criar pássaro, animais, e tal. (...) Eu coloquei que é dever do Estado financiar a preservação da natureza, se ele não faz a parte dele, aqueles que fizerem, você isenta de...”. Luís afirma ter sentido-se bem pela sua contribuição, por suas palavras ressoarem em outros países, em pessoas que provavelmente nunca conhecerá, desdobrando-se em outras ações, completamente fora de seu controle, além de sua vida. Sabe que suas palavras não lhe pertencem mais, estão no mundo, "porque às vezes a gente fala assim... Puxa vida, você lê às vezes determinadas coisas, que lá no meio tem uma frase lá que alguém falou, o nome dele não está lá, por exemplo, o meu nome não foi para lá”.

O reconhecimento por sua contribuição pública foi oferecido por todos que estavam na reunião em que a carta foi elaborada e depois, por todos para quem Luís mostrou a carta. Oportunidade essa de encontrar o reconhecimento solidário, além do afetivo e do legal, dentro de um grupo, reconhecimento ancorado na consciência de algo que só pode ser construído coletivamene justamente pela diversidade de experiências, repertórios e interesses ali presentes. Condições essas para a ação comunicativa, para o fortalecimento do mundo da vida, e para que o Luís-político ganhasse corpo e alma.

Continuou viajando pela América Latina como representante do Brasil, revivendo a experiência da construção coletiva, do exercício político, da oportunidade de ter voz, ouvir e ser ouvido, de fazer história; "porque esse documento é capaz que ele já esteja sendo usado pelo IBAMA”. Os dedobramentos dessa experiência também ganham vida em Luís, são alimento para o Luís-curioso-que-gosta-de-aprender, sempre em movimento. Voltou a estudar: "voltei mais por conta do Mercosul, porque quando eu fui para lá é que eu vi... o que serve para você que está estudando, está se formando, a importância de você saber um segundo idioma, depois do seu”.

No mais, Luís sabe que sua participação política, a possibilidade de elaborar opiniões sobre o que acontece ao seu redor, no mundo, e de poder intervir ancora-se no acesso à informação como aprendizado constante: “eu falo assim porque eu já li muito, nessa firma que eu trabalhava, eu lia jornal todo dia (...) e eu ficava sabendo de tudo que ocorria no mundo, através do jornal, porque televisão não tinha tempo de assistir".

Durante a entrevista ele me conta e mostra-me um canal de televisão "NBR, televisão do governo federal", um de seus prediletos, por onde fica sabendo "tudo o que acontece no governo federal", além dos programas sobre a América Latina que Luís assiste durante às noites. Essas são algumas das fontes de informação que o alimentam para que suas reflexões ganhem novas 
perspectivas, é a partir de seu repertório que lhe pareceu razoável que a carta redigida nas reuniões do grupo de representantes do Mercosul, "é um mal, que inclusive foi pedido, acho que deve ter sido corrigido, que agora vai sair em Português e Espanhol. Que nós poderíamos exigir que seja só em Português, porque nós somos maioria, em termos de população. Mas aí ficou combinado que tem que sair em Português e em Espanhol."

Em sua participação no programa do Mercosul leva a posição crítica de quem se diz "contra a globalização", isso porque os países pequenos são sempre, em sua visão, prejudicados, “os pequenos vão ficar mais pequenos, e os grandes vão ficar mais grandes". Apresenta-me então exemplos da União Europeia para ilustrar seu raciocínio, de como as maiores economias, consolidadas, aproveitam-se das menores para dar continuidade às suas expansões, já que "o que acontece com os tratados de mercados, é vender, vender e vender”.

Luís enxerga no "fracasso da globalização" uma oportunidade de que o cooperativismo seja viável em grande escala. É pela insistência em um modelo fracassado que estaríamos passando por tantas crises, "aquele monte de crises, crise asiática, México, crise da Europa, no mundo está sempre passando por turbulências econômicas". A falência da globalização é percebida em sua vida cotidiana, ilustrada no ferro de passar roupa fabricado na China, quebrado, inutilizado por falta de peça para o conserto. O que poderia ser entendido como um infortúnio individual é, para Luís, a lembrança de que "perdemos empregos para a China".

\section{Luís e o grupo Mãos na Massa}

Ao começar a falar sobre o grupo Mãos na Massa Luís volta-se logo de início à economia solidária como um movimento difícil devido à "extensão do país (...) num país do tamanho do Brasil, é muito escassa". A isso estaria relacionado o grande número de desistências daqueles que se envolvem com os grupos, como o Mãos na Massa. Em sua análise sobre o movimento, aponta também que ele se expande onde as "pessoas têm menos recursos, então ela se apega a esses meios dos quais ela pode trabalhar em casa", assim como a momentos de crise, "agora está vindo uma crise aí, que a economia solidária vai ter uma expansão enorme”. Assim, quando têm acesso a outras possibilidades, elas são preferidas, em sua visão, à economia solidária, "por causa da facilidade".

Essa é sua visão crítica do movimento entendido como nos interstícios do sistema, ao qual se recorre para continuar fazendo parte, sobrevivendo biológica e simbolicamente na ordem vigente. 
A sua vivência no grupo Mãos na Massa, por sua vez, se dá em paralelo à experiência no Programa Mercosul, como parte se seu envolvimento no programa de segurança alimentar, bem como a horta, a participação nas reuniões da rede, o envolvimento nas discussões a respeito do Centro de Referência. Experiência para a qual Luís traz sua ânsia por participar, por ouvir, ser ouvido e por repetir a vivência do compartilhar particularidades na criação de algo comum a partir do qual é possível a ação, mas que se inicia antes, motivada pela ausência de sentido, talvez pelo cansaso da busca do pertencimento e da possibilidade de ação.

É assim que, segundo os formadores da ITCP-USP, Luís "sempre interessado em fazer algo pela comunidade" participara de todo o processo de mapeamento das potencialidades locais, realizado em 2007 depois do rompimento do projeto com o Lanche Solidário, e participou do seminário de mobilização promovido pela ITCP-USP ${ }^{134}$ e Instituto Pólis, sem intenção de fazer parte do empreendimento produtivo. Sua entrada se deu em uma circunstância peculiar, segundo os formadores da ITCP-USP, Luís vivia uma "depressão" e é convidado por alguns membros do grupo a integrar-se a ele, como estímulo a encontrar um novo sentido, talvez uma nova esperança de pertencimento, de lançar-se à ação.

Encontra, porém, um grupo em início do processo de formação, em que a luta é por afirmação dos interesses individuais sobre os dos outros participantes, compostos por pessoas com os mais diversos objetivos em estar ali. A maior parte delas com urgência em levar dinheiro para casa, mais interessada em produzir e entregar encomendas do que em discutir, em fazer oficinas com foco na segurança alimentar para a comunidade, em discutir o trabalho, o rumo do Brasil e da globalização.

Luís reforça que não precisa de fontes alternativas de renda, que consegue suprir suas necessidades com a aposentadoria, "eu sou assim, para mim é o seguinte, tem um lugar para eu morar, está bom, (...) nunca me iludi, por exemplo, de comprar um carro de luxo, essas coisas assim. Mas o que eu ganho de aposentadoria, dá para eu viver”. Portanto essa não é uma ligação forte com o grupo, a renda, mas sim o que vem depois das necessidades básicas atendidas, a luta por reconhecimento solidário, pelo aprendizado, por fazer política no sentido de influciar o rumo da história. Essa demanda parece ter sido mais rápida e intensamente atendida pela participação no grupo do Mercosul; fato é que suas falas durante as reuniões do Mãos na Massa eram muitas

\footnotetext{
${ }^{134}$ Informações levantadas em reunião com três formadores envolvidos no projeto e no trabalho com o Mãos na Massa, em 29/06/2009.
} 
vezes levadas com impaciência por alguns outros participantes, principalmente por serem longas e contarem uma experiência pessoal ou uma posição política, e apesar de muitas vezes constituírem contribuições importantes, uma nova visão para a mesma questão.

Quando da entrevista Luís estava afastado do grupo, "pedi um afastamento de dois meses" para juntar-se ao cunhado em um empreendimento para vender água mineral, mas também porque "queria fazer umas viagens, uns passeios" e para cuidar do transporte dos restos mortais de sua mãe, “a gente quer trazer os restos mortais dela para ficar lá onde meu pai está enterrado". Assim, conta-nos que não faz mais parte de seus planos de futuro a produção e venda de barrinhas e os eventos em prol da segurança alimentar, ou pelo menos não de suas prioridades para o futuro. A avaliação de sua participação no grupo é positiva, passa pela experiência como fonte de aprendizado e com uma construção em que pôde deixar sua marca: "mas me fez muito bem. Nesse tempo que eu fiquei lá, eu preenchi meu tempo, eu conheci pessoas, produzi coisas, e tudo que se aprende é útil".

Sem saber o que acontecerá, se Luís voltará ou não à cooperativa em formação, o que se pode inferir por hora é que seu afastamento acompanha o sentido emancipatório assumido pela metamorfose de sua identidade, cuja bússola vem sendo a busca pelo aprendizado e pela realização de seus desejos governada pelos seus valores. Luís dá oportunidade para que novas personagens ganhem vida empunhadas pela ligação direta com seu "eu", com sua identidade, consciência e atividade. A participação nos primeiros passos do exercício autogestionário, assim como nas discussões a respeito da economia solidária e das oportunidades e dificuldades enfrentadas pelo grupo parece ter contribuído, como novo impulso, à continuidade desse seu movimento.

Assistindo documentários de grupos que estão se desenvolvendo, gerando renda e melhorando suas vidas, como as "rendeiras do Ceará, (...) artesanato de Tocantins", Luís consegue satisfazer algumas de suas necessidades, viajar, aprender, conhecer outras realidades e pessoas. O que vê em comum entre esses grupos que "dão certo" é a falta de alternativas, o grito da sobrevivência, "necessidade, as pessoas não têm alternativa", é também por isso que "ela arrumou um emprego, ela sai [do grupo] (...) por causa do imediatismo, ela precisa de dinheiro hoje". Luís entende que os empreendimentos coletivos levam tempo para gerar resultados financeiros e que esse, por vezes, não é o mesmo tempo da fome e das contas que vencem todo mês. 
Aconselha-nos Luís, a todos aqueles que trabalham no suporte aos grupos autogestionários, a trazermos à baila questões mais amplas, o contexto, como o da globalização. Para ele é preciso saber o que representa o cooperativismo em meio a um emaranhado de empresas multinacionais que movimentam bilhões com apenas um distribuidor no país, sem nenhuma produção por aqui: "que é uma cooperativa, um trabalho compartilhado, um trabalho cooperativo, e uma indústria que, de repente mandar buscar isso aqui, tem um funcionário, só tem o depósito aqui para distribuir os produtos. E você montar uma cooperativa”.

Fazer parte do Mãos na Massa compôs esse caminho, mas em nenhum momento foi entendido por Luís como o ponto final, destino. Uma nova experiência, oportunidade de resgatar a paixão pelo aprendizado, a curiosidade em relação ao mundo, às pessoas e às suas histórias, mas não como projeto de médio, longo prazos, fonte de renda, permanências, enraizamento. No entanto, acrescenta que se a cooperativa "deslanchasse", ele não estaria se afastando agora, gostaria de colher os resultados, de ver crescer, mais pelas mudanças no grupo e em sua dinâmica do que pela complementação na renda. 


\section{Joana}

A apresentação de Joana tem sua melhor forma em suas próprias palavras, assim como ela apresentou-se a mim, entregando logo de início o que achava mais importante ser dito. Depois, ao perceber que havia tempo hábil, delongou-se nos episódios de sua vida, em detalhes, confortavelmente; "minha história é comprida menina, por isso que eu falei pra você...”. Fala sobre si como se sempre tivesse sido igual, de características que teriam acompanhado-na durante toda a vida, atemporais nessa longa história.

Diz-se "meia esquisita", "um pouco estranha", conta que é "assim o tipo de pessoa que tento fazer as minhas coisas certo (...), mas uma coisinha que acontece comigo é como se tivesse trincado um vidro que não cola mais, você entendeu?". Durante a vida que nos conta foi deparando-se com esse ponto de não retorno, em diversas circunstâncias, em um processo de autoconhecimento que passa pela negação, daquilo que não pode aceitar, para chegar à afirmação do que se quer fazer, ser e pensar a cada momento.

Joana não é de muito falar, no grupo Mão na Massa percebe-se isso, fala o que lhe parece complementar e indispensável, por vezes quando não pode mais suportar determinada situação de total incongruência em relação ao que busca para realizar-se a si mesma. Não gosta de ficar parada, “já viu o meu jeito?", fica bem sozinha, não é muito de "ficar acomodada naquele local (...) eu gosto sempre de tá explorando, vendo coisas sabe?”. Sei sim, na cooperativa em formação é a Joana-representante-de-vendas, que não para quieta, sempre em movimento que ganha corpo e institucionaliza-se na posição organizacional desempenhada.

Dá mostras também da determinação que beira, às vezes toca, a teimosia pela adoação de suas ideias e valores como verdade quase absoluta; Joana guia-se por seu próprio radar, esse que trouxe lá de Minas Gerais e qual foi agregando algumas novas direções e ângulos ao longo de sua jornada. O sentido para o qual aponta pode mudar, muda, parece que mais pela experiência vivida do que pelo diálogo. As palavras pouco dizem-lhe, desconfia. A ação e a atividade trazem-lhe mais insumos, esse é o discurso transformador, é nele que acredita e, por isso, é ele seu canal de expressão.

Características essas, trazidas de início ou aos poucos, ao longo da narrativa, que ganham corpo nas diversas personagens de Joana. Personagens que se transformam, adormecem, acordam, mudam de posição, rearticulam-se, morrem e nascem em uma história que parece longa por ser intensa, pela cadência do movimento constante, por vezes ritmado, outras em livre estilo. 


\section{As primeiras histórias, as primeiras personagens}

Fugida da fazenda onde morava com os pais e três irmãs, Joana ficou 24 horas "perdida", voltou laçada por duas vaqueiras. Não lembra, quem conta diz que sua vontade era "ter liberdade", Joana acredita, diz que queria "passear sozinha". Tanto insistiu em ver-se livre, de que ela não sabe, que essa foi uma das razões da mudança da família para a cidade, no mato, pelo menos, Joana não mais se perderia.

Cedo Joana aprendera que as palavras, mesmo quando escritas, de papel passado, registrado em cartório, mudam de sentido, diluem-se e remontam-se de acordo com a situação socioeconômica em que se encontra, frágeis diante dos interesses dessa ordem. Em um incêndio criminoso seu pai perde a casa, o baú de documentos e o cartório também pega fogo, "meu pai era uma pessoa muito conhecida, mas nessa hora ninguém dá mais crédito, que tá sabendo que o cara tá caindo, né?".

Separados os pais, determinada a ficar com seu pai, apesar da incubência de ficar com os irmãos mais novos, junto à mãe, "nossa, mas por que levou só elas e eu fiquei, né? (...) ah não espero mais não, de jeito nenhum", Joana fugiu porta-malas de um jipe, escondida, com destino à cidade vizinha. Da mãe fala da falta de tempo, do pai, a preferência consciente desde cedo: "você sabe que eu gostava mais de meu pai do que de minha mãe? (...) você já viu criança, acontecer uma coisa dessa? E minha mãe me tratava bem. Mas eu não gostava dela." Escolheu outra como sua mãe, a madastra, "uma mulher de ouro, aquela que devia ser minha mãe".

Segunda travessia guiada por sua vontade própria, desconsiderando as regras, fazendo "arte". Ri de si mesma, Joana afaga essa criança "peralta", reconhece-a com admiração, por isso talvez ainda a traga consigo: "menina e eu, eu sou peralta desde, desde pequena. Aí quando decido ninguém me pega, sabe? Eu, eu tenho lá, num sei, minha mente muito evoluída, num sei por que, que é assim." Na sequência fugiu da pensão em que o pai a colocou, "a hora que saiu o primeiro caminhão que ia pra obra que meu pai estava, entrei dentro e fui embora", tanto fez que o pai encontrou uma casa para morarem juntos, "porque eu num dava sossego, né?".

Em oposição à madrasta, que "era mesmo para servir as pessoas, (...) te dava até toalha de banho para se enxugar", Joana servia a seus impulsos e vontades. É assim que vê a si mesma em suas primeiras histórias, é essa a posição em que se coloca ao contá-la. Se hoje não é a mais a mesma Joana, evidente, muito traz ainda dessa personagem, muito inclusive do que ressalta em 
si: Joana que continua seguindo a si mesma, à sua própria bússola, atualmente mais guiada pela razão, por valores e interesses que consideram outras pessoas, ao seu redor, que por impulsos.

A exceção, o contraponto à Joana-que-segue-serve-afirma-a-si-mesma encontra insumos na religião. É ainda quando criança que se nomeia "crente", buscando o pertencimento na "Congregação Cristã”: "como eu fiquei muito... muito assim, com essa separação dos meus pais, aí eu fiquei crente da Congregação Cristã (...) você fica muito sozinha, você quer um apoio pra alguma coisa, né?”. Encontrou-o na pertença ao grupo de evangélicos, por ser reconhecida como um deles tornava-se parte de uma nova família.

O amparo dava-se mais pela presença de pessoas, pelo acompanhamento, físico mesmo, do que pela crença no extra-terreno. Da igreja Joana não fugiu, pela primeira vez permaneceu. "Chegando na igreja, eu olhei todo mundo lá sentadinho ouvindo cantando, falei assim, nossa que lugar legal, né? Achei muito legal, e foi indo". Se tinha medo das imagens da Igreja Católica, na Evangélica encontrava pessoas unidas com todo o poder que a fé pode ter, sem que os santos e deuses tivessem sua presença imposta.

\section{A Joana-que-vende-a-força-de-trabalho-e-a-expressão-de-si-mesma}

A igreja realmente funcionou como uma rede de apoio em diversos momentos, como quando chegaram a São Paulo, Joana e sua irmã, com um endereço na mão que apenas encontraram porque o taxista resolveu ajudá-las ao descobrir que eram os três fiéis da mesma doutrina; não cobrou a corrida. Aqui ficou hospedado na casa de outro fiel, um senhor que conhecera em "missão" por sua cidade. Por outro lado, em meio à maioria de católicos, seguir a Igreja Evangélica implicava assumir-se diferente na sociedade dos padrões, "antigamente se você falasse que você não era católica também tinha... como se fala... as pessoas não gostavam muito não, você nem trabalhava na casa (...) eu nem comentava, certos tipo de coisa assim eu nem comentava não, deixa quieto."

É assim que Joana entra no tema trabalho, mostra-nos um pouco sobre a articulação de duas personagens protagonistas de muitas cenas do teatro de sua vida, a Joana-que-partilha-dacomunidade-evangélica e a Joana-que-vive-de-sua-força-trabalho; conta-nos como teve que calar suas vontades, brecar seus impulsos e ofuscar parte de si para enquadrar-se melhor no que as “casas de família" buscavam para seus empregados.

A Joana-que-vive-da-força-do-trabalho, que luta por sua própria sobrevivência, chegou assim como um barco que chega do mar, invitável, totalmente alheio ao seu arbítrio. Barco que 
atracou em São Paulo com Joana dentro; São Paulo, destino de todos, ao mesmo tempo de ninguém, de todos que chegam aqui e se perdem na multidão, do emaranhado de ruas e avenidas e que deixam as famílias, no interior, imaginando a terra prometida "lá é assim, quando a gente mora no interior, São Paulo pra nós é outro país diferente num é nem aqui no Brasil”. Veio para trabalhar, "porque chegou a hora da gente trabalhar, lá num tinha serviço, e lá não tem serviço." Com a oitava série completa, também não coube a opção de a qual trabalho dedicar-se-ia, "aqui nós fomos trabalhar em casa de família porque não tinha outro jeito”.

Nem só o trabalho era difícil, o contexto maior, a vida em si na cidade grande chocou-se com a Joana que seguia e servia a si mesma; as distâncias, a dificuldade em mover-se sozinha, em voltar para casa, as reações inesperadas das pessoas, os códigos de conduta ilustrados pelas roupas:

“(...) que quando você vem do interior você vem com essas roupinhas tudo simples e você chega aqui não dar pra usar que as roupas aqui é muito diferente é tudo de costureira, sabe? (...) É de fábrica então é tudo diferente, eu quase nem podia sair na rua porque as minhas roupas não davam nem pra sair. (...)É ficavam todo mundo olhando porque agora no meu ponto de vista agora minhas roupas era até muito mais chique (...). É uma roupa feita pra mim que ninguém tinha igual. E eu me sentia mal porque eu fala a sim nossa senhora eu que tô diferente".

A vontade era de perder-se no meio da multidão, não de ser diferente ou distinguir-se, mas de pertencer. Joana percebia que essa sensação apenas seria experimentada ao seguir o padrão, ao agir, comportar-se, reagir como o esperado. Era preciso sentir-se confortável, parte do todo, igual a todos, para depois afirmar-se em sua individualidade. Ganhando corpo, assim, foi tomando acento a Joana-que-se-cala-e-segue, enquadra-se ao estrangeiro para que não seja ela a estrangeira.

Apenas pensar livremente poderia, continuava sonhando, "meu plano era ser médica!", de fato, concretamente, tinha que se sustentar, enfrentava o risco de ficar sem dinheiro para atender suas necessidades básicas; na casa onde se hospedou “todo mundo é pobre”. Quando afirma que "trabalhar em casa de família pra mim foi bom" talvez tenha esse sentido, de que pode manter-se viva, biológica e simbolicamente, também, é possível que identifique, remonte, as muitas mudanças vividas, influenciadas pelo trabalho. Papel importante teve ele na dobradiça que, aos poucos, interpõe-se entre a Joana-que-serve-e-segue-a-si-mesma e a Joana-que-se-cala-e-segue. 
“Trabalhei em um monte de casa". Aos 14 anos, quando serviu à primeira patroa, Joana teve acesso negado aos estudos: “(...) você nessa idade sua, eu vou deixar você sair daqui à noite? Eu tô sendo responsável por você. Eu não vou poder te buscar, te levar e te buscar, e eu vou dar a chave da minha casa na sua mão pra você entrar de noite? Achou que a casa ia ficar aberta também, né?”. A Joana de depois, narradora de sua história, entende que havia algo mais na barreira aos seus estudos, "num sei também porque também que não queria que eu crescesse, porque essas pessoas têm essa, se você estudar não vai ser mais empregado.”

Foi essa experiência em São Paulo, que se impôs voraz e implacidamente à Joana, a provedora, aos poucos, de material para a constituição da Joana-submissa-em-posição-inferior em inter-relação com a Joana-empregada-doméstica e com a Joana-que-partilha-da-comunidadeevangélica. Conta que aprendeu tudo depois que aqui chegou, de emprego em emprego, "porque eu vinha, vinha do interior e a pessoa quando vem do interior ela não sabe fazer nada, nada... nada... nada." Era isso que lhe afirmavam, com força tal, que acreditou. O discurso por inteiro dizia-lhe isso; as situações de constrangimento, ao mesmo tempo em que eram vividas sem rebeldia justamente pela relação de desigualdade já armada, reafirmavam a distribuição de poder aí estabelecida, reforçavam a inferiorização necessária à submissão.

Assim também Joana foi conhecendo o limite, em si mesma, para essa submissão, até que ponto poderia anular-se, a partir de onde a aceitação representaria a morte simbólica. Caberia então usar a criatividade para encontrar alternativa entre o respeito às regras impostas de fora, pelos patrões, no trabalho estranhado, a moral evangélica, fonte de regras muitas vezes aceitas sem compreensão, e sua própria subjetividade, outras personagens que gritavam para entrar em cena, sem que houvesse deixa para tanto.

Conta uma das situações humilhantes a que foi submetida pelo patrão, uma armadilha frente à qual expressou-se, avisou que era demais: “em baixo desse plástico ele pôs um bolo de dinheiro... pra ver que eu pegava o dinheiro, (...) quando eu tenho que falar eu falo na hora. 'Você esta me experimentando?' Que é a maneira de eu falar porque não sabia falar de outro jeito. (...) Porque você presta bem atenção da próxima vez que você por eu vou pegar.” Expressa alto, presta contas ao mundo de que estava falando, oferecendo voz à Joana-impulsiva-que-segue-a-simesma, mas ainda respeirando o pacto da comunidade evangélica: "eu só não peguei o seu dinheiro porque eu sou crente, viu?". 
Por ter estado muitas vezes em situações assim, próxima de uma equação sufocante entre as imposições aceitas e a existência de si mesma, em circunstâncias de combate frontal, choque veloz, entre sua subjetividade e a objetividade, que a Joana-cooperada, aquela que me contava sua história não tinha vontade de aprofundar-se na narrativa sobre as experiências como empregada doméstica. Período em que sua identidade teria ficado aprisionada a um mesmo movimento, o de reposição das duas personagens que, articuladas, quase sempre dominavam a cena, cumprindo como o esperado o papel da trabalhadora com baixa qualificação, pobre, que pouco tem fazer além de atender, incondicionalmente, aos desejos de uma família de classe social mais alta. Resume esse período a marcos do seu sofrimento, extrato dessa vivência, "aquele quartinho que nem respirava", o início do trabalho às cinco da manhã sem razão para isso, "pra massacrar mesmo".

A alterização era procurada, sem sucesso, nas mudanças constantes dos empregadores, ficava pouco tempo junto com cada família, eram "empreguitos": "não ficava muito tempo não que eu não era costumada mesmo, minha casa era diferente, entendeu? Era pobre lá na minha cidade pra mim era uma das melhores, entendeu? Eu vim pra cá eles iam fazer assim o que fazia comigo achei que era muito...!". Não se sabe se por cansaço, por frustração ou por medo de que a negação da situação que não merecia ser vivida desembocasse em outra ainda pior, a Joanaempregada-doméstica estabeleceu-se e permaneceu, durante 17 anos, servindo a um casal de italianos. Personagem que se repôs por longo período servindo de base para e ao mesmo tempo recebendo o suporte da Joana-que-serve-aos-outros.

Soberana torna-se essa personagem a partir da ideia de que não haveria nada melhor que os patrões estrangeiros que

“(...) quando vem pra cá, eles te exploram bastante, né? (...) [mas] nessa casa só era um casal (...) e lá eu cozinhava junto com a mulher, tudo que eu ai fazer ela tava junto porque era assim, você limpava ela passava o dedo (...) pra mim o jeito que tô não tem o que fazer, vou ter que aguentar isso aí (...) uma que eu não tô muito sozinha, se eu quebrasse ou sumia alguma coisa aqui eu não vou nem ser presa (...) aqui por enquanto tá bom pra mim, melhor do que isso é impossível".

Enfim, ainda nova, essa passou a apresentar-se como a melhor opção entre as que lhe eram possíveis, não apenas para que não se tornasse culpabilizável, também passando a considerar importante, e até "positiva”, a coerção externa para que o trabalho fosse realizado. Já que se trata de um enorme esforço, de um sacrifício obrigatório, do "tripalium", e pautado por 
diretrizes externas, trabalho sem sentido, pelo menos que a vigia fosse clara, explícita: "tinha... que eles tinham essa mania. Esse negócio de passar a mão eu acho até legal porque você faz o seu serviço perfeito né? Se a pessoa não morde, você não faz, você relaxa né?".

Percebia e aceitava que as "má-criações" que aguentava, a violência a que se submetia, era parte integrante do chamado "trabalho", e que a recompensa em dinheiro, "esse negócio de salário", pagava não apenas o esforço na labuta, também essa aceitação. "Esse negócio de salário, eles me pagavam muito bem", foi por vender a sua força-de-trabalho e a expressão de si mesma que Joana juntou dinheiro para construir sua casa, comprar seu carro e investir em um negócio seu, um restaurante.

Permanecer e acostumar-se compõem-se, então, de ação em estado; Joana lembra que veio para São Paulo esperando outra realidade, e que se tivessem ficado com seu pai teriam tido casa, comida e... estudo, "nós achamos que aqui a gente ia crescer mais, só que se a gente tivesse ficado lá com ele, a gente não ia ter muitas coisas. A gente tinha aqui roupa, sapatos essas coisa entendeu? Mas ia ter o estudo, que isso aí a gente ia ter mesmo.” Mesmo sem encontrar essas outras coisas que só teriam aqui, voltar não cabia mais, “e depois que a gente chega aqui em São Paulo que volta, você não se acostuma mais no local, mesmo aqui sendo tão ruim, você não se acostuma lá (...) eu voltei não gostei mais de lá tive que ficar aqui mesmo ou seja, vou ficar aqui. E continuo aí". Foi ficando, acostumou, permaneceu.

\section{A Joana-ex-esposa-serva e a Joana-dona-de-sua-força-de-trabalho-e-dos- meios-de-produção}

O marido, apesar de não ser "crente", conhecera na igreja e diante da recusa de Joana de namorar alguém que não fosse da comunidade evangélica, converteu-se a essa religião. A referência aqui em São Paulo eram a igreja e o trabalho, a comunidade evangélica e as casas de família pelas quais passara, por isso "tinha medos, entendeu? (...) sabe como que é né? E eu já fui criada com meus pais então eu não tinha instrução nenhuma, criada em casa de famílias não te falam nada". Ser evangélico significaria comportar-se guiado pelas mesmas regras, pelo pacto da comunidade; não ser de sua igreja implicaria liberdade total, inclusive "bar, cigarro, bebida".

A abstinência do então marido durou algum tempo, "depois de dois anos voltou tudo, 
entendeu? A cachaça, cigarro, bar e é pinguço até hoje.” Pelo vício do marido a Joana-esposa não tinha vontade de ter família grande, de aprofundar a relação, de fortalecer a personagem reafirmada pelas regras sociais e da igreja. Mesmo assim são três seus filhos, seguiu o fluxo, criou uma família; Joana-esposa-e-mãe eram desrespeitadas frequentemente pelo marido, na convivência não tinham vez, voz, vontade.

O limite da situação que não merecia ser vivida deu-se com a rejeição do filho mais novo pelo marido, dizia que não era seu filho. "Diante de tanta humilhação", Joana viu-se sem saída, pediu o divórcio mesmo que a separação fosse probida pela sua Igreja. Colocou-se a si mesma em uma nova encruzilhada entre si mesma e a diretriz imposta, veio a Joana-divorciada-mãetrabalhadora, não mais casada e que não mais vendia sua força de trabalho; a Joana-dona-de-seunegócio, mas ainda não a Joana autodeterminada, a Joana que ainda abria mão da expressão de si mesma. O marido recusou-se de sair de casa, "ele é dessas pessoas paradão sabe?"; até o momento em que conversamos Joana ainda morava com Gilson, dividiam a mesma casa, vivendo em aposentos diferentes, cruzando-se por acaso, inevitavelmente.

Se parada nessa situação, Joana empreendeu um negócio, abriu o restaurante na mesma casa em que moravam, “como a gente não vai pagar o aluguel né, dá pra gente montar o negócio, e deu mesmo, ganhei bastante dinheiro, não deu pra enrica porque trabalhando em sua casa...”. Foi o restaurante que garantiu sua sobrevivência e a dos filhos por cinco anos, que "segurou minha barra nessa época" já que o marido gastava todo o dinheiro que ele ganhava em bebida, ela carregava toda a responsabilidade de manter a casa, os filhos, de cuidar e prover. Era a Joanamãe-provedora de si mesma, dos filhos e do marido, o restaurante foi um passo em seu projeto de autonomia, se a libertação em relação aos maus-tratos implicados no trabalho como empregada doméstica, ainda não representou a superação da relação violenta com o ex-marido.

Sobre a experiência de ser dona de sua força de trabalho e dos meios de produção, Joana fala sobre a libertação em relação ao temor de não conseguir suprir suas necessidades de sobrevivência e de seus filhos, já que no restaurante conseguia gerar renda em proporção direta ao seu trabalho, e da liberação de seu tempo que volta a ser determinado por Joana. Assim, pôde estar em casa, próxima dos filhos, sem um patrão que lhe impusesse as jornadas fixas de trabalho: "eu tinha que acabar desse menino crescer porque o pequenininho era pequeno demais, nessa época ele tinha quatro, cinco anos... muito pequeno, e eu pra mim sair pra trabalhar eu não podia deixar ele." A reunião da vida no trabalho e da vida cotidiana dá-se pela gestão única das duas 
esferas; Joana é a gestora de sua vida e a administra de acordo com seus próprios interesses e necessidades, é o trabalho com sentido.

A casa e o restaurante, simbolica e fisicamente o mesmo espaço, eram seu reinado no mundo, lugar onde ela criava as regras e determinava o funcionamento, no entanto, com um porém: quando o marido desobedecia e deslegitimava a ordem por Joana estabelecida. O contraponto de sua autodeterminação era a submissão às situações propostas pelo marido, com as quais não concordava, e diante das quais via-se impotente. Se mesmo lidando com "bandido, esses que diz que é bandidão feio", nunca fora desrespeitada, "nunca voltou cheque nenhum, nunca me passaram a perna, nunca caíram no chão porque eu já punha a plaquinha, no meu restaurante de jeito nenhum podia na hora da comida", para a relação violenta com o marido não havia fuga, nem mesmo seu restaurante servia de abrigo.

A Joana-ex-esposa convivia com o ex-marido, o qual determinava uma rotina em sua casa, ritmada pela bebida alcóolica, e que dava ordens em seu negócio. Parece ter sido essa cogestão imposta o principal problema do negócio, “chegava aquela mesa bonita que eu ia receber uns quarenta, cinquenta reais de porção, uma cerveja e tal, meu marido chegava lá, tomava um copo de cerveja e dizia: 'essa mesa é minha'”. A mesa era dele, mas era Joana quem pagava; ele não só fazia a fama de boa gente, camarada às custas do restaurante, como também levava marmita para o trabalho. Se separados no papel, unidos por uma relação de poder a partir da qual Joana-que-serve-ao-outro, sem valer seus próprios interesses e valores, mantinha-se viva.

Foi por estar cansada do trabalho pesado e da vulnerabilidade às intervenções do marido, que fechou o restaurante, "tudo o que só sobrava era pra mim, e eu como era dona tinha que fica sustentando a peteca ali né... e foi indo até a hora que eu cansei”. O que a princípio pode parecer um passo para trás em seu projeto de autonomia, constitui-se em um movimento para mais distante do marido, já que ainda não conseguia libertar-se dessa relação completamente; mudando parte do contexto também algo mudar-se-ia na convivência. Em relação ao trabalho e à família, Joana-mãe-provedora e Joana-dona-de-sua-força-de-trabalho-e-dos-meios-de-produção continuaram em cena, como representate de vendas por catálogo, continuava determinando como e quando trabalharia.

\section{Mudança radical - da objetividade para a subjetividade}

A vida seguiu seu passo nesse ritmo, com mudanças quantitativas, com os netos a Joanaavó-dedicada, "eu fui ficando por ali, e o tempo foi passando sabe?". O salto qualitativo, 
mudança radical para a Joana-mãe-avô-capitã-de-si-mesma que se encontrava e acomodava no cuidado com os netos, veio de fora para dentro, da objetividade para a subjetividade: a prisão de um dos filhos.

Conta que o filho do meio, "vendo pai sabe como é que é?”, começou a usar drogas, ela se viu na "contradição" de sua posição, razão e sentimento de mãe em conflito com seu papel de crente: a diretriz evangélica apontava que deveria afastar-se daqueles que insistem em hábitos escusos, como a bebida. O filho em uma situação em que precisava de sua presença junto ao verse diante de uma injustiça, da falta de voz diante da polícia em uma situação armada para que o filho fosse preso, que Joana decidiu, lançou-se completamente ao papel de mãe-em-busca-dejustiça, ou de justiceira-mãe, “(...) aí eu voltei falei assim não! Então eu vou cuidar.”

A mãe-dedicada é papel que conta ter desempenhado com afinco, argumenta para si mesma, enquanto lembra, em favor de sua absolvição pelo filho viciado e preso, não é um julgamento fácil esse do qual a própria Joana fora juíza, dolorido, sofrimento revivido a cada revisita.

"Então, aí minha filha, eles pegaram e... como eu sou um tipo de uma pessoa assim que meus filho eles nunca ficaram doente. Esse outro, esse aí que eu te falei que é envolvido com esse negócio de droga, é uma doença que arrumou na rua! (...) Mas num foi vindo de casa, num foi vindo de berço. Num foi. Aí porque na minha casa é assim, eu gosto de cuidar deles direitinho, né?! Ah tanto da parte limpeza como da alimentação, da saúde, mas a saúde... (...) E meus filhos, a única coisa que eles pegam é só gripe, num tem outra doença. E eu acho que eu... como eu acho que eu faço as coisa direitinho pra eles sempre que é o certo. (...) Aí eu disse assim ó: 'vocês prendeu meu filho, eu vi que a droga não é dele, vocês devia ter me dado uma ajuda, porque meu filho aprendeu a usar droga na rua porque vocês não limparam a rua.' Porque a criança nasce, os pais cuidam, mas a justiça não cuida. As ruas é assim, em toda esquina tem uma droga pra vender, criança com cinco anos usa."

Joana argumenta a favor de si mesma, como mãe, e do filho, como representante da fragilidade de uma socidade, julgamento esse que parece continuar com a sessão aberta. A partir da situação armada a Joana-mãe-dedicada-justiceira ocupa toda a cena, soberana na atividade, consciência e identidade de Joana; o trabalho, a casa, o ex-marido, na coxia.

Foram três anos de prisão, três anos de "luta aí em que quase morri que tô desse jeito acabada por causa disso que eu tava uma pessoa bem conservada." O cansaço decorre do grito contido, alto, porém abafado, sem ressonância no mundo. Joana viveu a contradição, em si 
mesma, da personagem soberana a quem dava vida, todos os dias, por anos: a isenção pretensamente requerida pela Justiça e a parcialidade e completo envolvimento de seu papel de mãe, a Joana-juticeira versos a Joana-mãe, duas faces da mesma personagem. "Não adianta você falar principalmente se for a mãe”.

Debatendo-se, sem possibilidade de mudar a situação objetiva, seguiu o rumo continuado das visitas ao filho, da entrada na cadeia com um sabonete para filho e mais dois para manter o sistema de poder dentro da cadeia. Se não fossem suas provisões o filho seria alimentado com “comida de cachorro", não teria roupa, nada; "é só uma pessoa que vai lá dentro que vê e sabe, e o pior é que não pode falar. Porque se você falar você é denunciada e você acaba na cadeia também”. Já estava ela presa também, aprisionada em uma contradição que não podia superar. Interferia no possível, a comida que o filho gostava, por exemplo, "fazia a comida muito bem feita, levava a comida que você olhava assim, comida boa mesmo, que na minha casa não tem miséria não, sabe."

Como restaurante fechado, dedicava-se integralmente à casa e ao presídio, "ia todo dia, fui todo final de semana, levava as coisas e tudo", tentou gritar mais alto: foi pelas vias abertas, teoricamente, pelo próprio sistema judiciário que Joana engajou-se na mudança. Processou os policiais que armaram a cilada para seu filho, levou um pouco da comida servida aos presidiários ao tribunal, brigou com quem lhe desrespeitou, denunciou as ameaças recebidas. Embora pelos mecanismos constitucionais, recorrendo a instâncias legais, esse pode ser considerado um ato de rebeldia, "eu como sou impulsiva, você tá vendo como eu sou, né?".

Com pouco resultado e com prazos de execução muito mais longos que os tempos da política interna do presídio, pautada em mecanismos outros, paralelos à justiça oficial à qual Joana recorria, era necessário lutar com suas próprias armas, frente a frente com o desrespeito de seus direitos, contra a total impotência diante de ações individuais à revelia. Foram inúmeras as humilhações sofridas, as ameaças na entrada da cadeia, o esforço por estragar, na revista, a comida levada ao filho, a suspensão da visita por um mês. Conseguiu retaliações do poder instituído na cadeia, contra o qual as instâncias às quais recorria surtiam pouco eficientes.

Foi usando todas as ferramentas, meios, caminhos que lhe eram acessíveis que Joanamãe-dedicada impediu que o filho morresse de fome, de abandono, de descaso, ou mesmo como pagamento por uma rebelião que fora plantada pelos funcionários do presídio: "eu tô te falando porque eu vi aconteceu comigo e processei, processei mesmo." Foi também por todos esses 
caminhos seguidos que a justiça foi colocada em xeque, que a Justiça mostrou-se totalmente descolada de sua justiça e a Joana-justiceira ganhou outros contornos.

É enxergando a pesquisa, a narrativa de sua história de vida, como canal de difusão de seu grito que Joana conta em detalhes suas batalhas e denuncia o sistema paralelo de governança dentro da cadeia, e mesmo os procedimentos legítimos, apesar de desumanos, contra os quais não uma infinidade de indivíduos isolados debatem-se: “a revista é que o bicho pega. Aí chega lá tira a roupa, você fica peladinha. (...) essa presilha sai, você abre a boca, você põe a língua pra fora, você bem abre as pernas. É a pior coisa que você tem que fazer."

O filho solto, Joana era, ainda quando conversávamos, o alvo da Justiça; estava sendo processada pela carcereira do presídio por desacato a autoridade. Aproveitara, claro, as audiências às quais já tinha sido convocada para contar sua história, denunciar a sequência de injustiças as quais vinha vivenciando e que não fazem sentido algum em qualquer lógica humana, que não tenha se tornado refém da burocracia. Seu discurso vinha de sua própria boca, sem intermédios, sem advogado que a representasse diante do juiz. Um discurso claro e forte que é repetido por Joana na entrevista com atenção às vírgulas, sem poupar intensidade, entregando emoção para que ganhe novos voos planando para o mais longe possível; um discurso ainda repleto de sentido, real no passado e no presente.

Era Joana-mãe-dedicada-e-justiceira que no momento da entrevista continuava buscando que atenção fosse dada ao seu filho que, mesmo solto, precisava que o Estado cumprisse seu papel, oferecendo-lhe tratamento. Superada a contradição de sua personagem, a mãe e a justiceira andavam juntas com a noção de sua própria justiça referenciada pela noção universalista de direitos humanos, do que faz sentido para a vida, além das convenções institucionais.

'Então eu perguntei pra ele [juiz] 'por que eu vou ser presa?' (...) 'Ah é senhor Juiz, então e a condenação do pessoal lá qual vai ser?’ Eu tive um filho de parto normal, sustentei ele, nunca precisei um centavo do governo, a não ser a vacina pra para, para, como é? (...) Eles não davam leite, não davam sapato, não davam nada pra criança. E eu falei assim: 'a única coisa que vocês fizeram agora depois que eu criei meu filho, vocês vem prender meu filho.' Os policiais mostram a carteirinha, entendeu? Mostra que é policial, joga a droga no seu carro, prende o seu filho. Você fica pelada na frente do seu próprio filho, que eu tive de parto normal, já, já fiquei pelada também, e agora você vem me prender porque eu fiz um gesto obsceno, você sabe que eu fiz gesto com a mão? Eu disse: 'gesto obsceno é você ficar pelada na frente do seu próprio filho, viu?'(...) 'Ó juiz, o problema é esse, porque eu fui conhecer droga foi lá dentro da 
cadeia. Eu não conhecia droga aqui fora, (...) fui ver o negócio lá dentro, que todo lugar que você entra tem um saquinho. (...) 'Ou vocês acham que vocês põem meu filho lá e eu vou levar droga na cadeia? Ia ser uma traficante? Se eu fosse... Se eu fosse traficante vocês podiam bater na minha cara, e eu ia ter que aceitar, tava fazendo coisa errada, né?' (...) 'Sabe por que eu não cheguei na hora? Porque vocês roubaram meu carro, eu tinha um carro. Se não tivessem roubado meu carro eu tinha chegado na hora, eu vim de ônibus, eu não posso pagar jatinho.' (...) 'A senhora fica presa, fica presa, ou então vai dar alguma cesta básica para alguma entidade, ou vai trabalhar em algum serviço voluntário de qualquer entidade aí, durante este um ano.' (...) e eu olho na cara dele e falo: 'Eu não vou fazer nenhuma das três sabe por quê? Pra começar cesta básica eu não tenho, nem aposentada eu sou, e já tô com idade aqui de cinquenta e cinco anos. Num tô conseguindo nem mais trabalhar pra eu sobreviver, eu que tô precisando de cesta básica. Entendeu?? (...) Olha só minhas mãos, mão calejada de tanto trabalhar pra me sustentar e sustentar meus filhos.' (...) Quê? E eu ainda vou trabalhar de graça pro Estado, sendo que ele já roubou meu filho que é a coisa mais importante pra mim, por causa de algumas gramas de maconha? Porque se eu soubesse que maconha dava tanto dinheiro eu tinha plantado uma roça de maconha ao invés de ter um filho. (...) 'Eu tenho um carro que foi roubado pela justiça e a indenização do meu filho, depois que vocês fizer isso vocês podem me prender', eu falei. 'Porque eu não vou criar um filho, e depois ficar pelada pra me verem na cadeia não, por causa de maconha. Você entendeu? Sendo que lá dentro tem muito mais que aqui fora, porque ele fuma, porque agora até maconha ele fuma lá dentro. Quando não tem cocaína ele fuma maconha, lá dentro da cadeia."”

Essa história de desespero, angústia, sofrimento, foi também o processo pelo qual Joana determinou suas próprias crenças, a ela alinhou suas ações, concedendo-a vida própria, destacada dos mandamentos evangélicos e das leis e regras sociais. Joana-em-defesa-de-sua-própria-crença articula-se à Joana-que-fala-por-si-só, personagem essa que faz parte de sua identidade há longo tempo, mas que esteve ocultada pelo silêncio das relações de dominação a que se submetera. Joana, então, recusava-se a ser representada por um advogado, exigia ser representante de si mesma, expressar-se por seu próprio discurso: "dessas outras audiências que tem eu não levo advogado, porque se leva você não fala nada, porque se fala você vai se presa, é só o advogado que fala."

A ameaça de prisão foi por pertubar a ordem ao dizer tudo que lhe fazia sentido contar, aquilo que não se queria ouvir: “o juiz ia decretar minha prisão minha porque eu sou pouco 
bocuda você viu, eu tenho que falar as coisas... porque se você não fala você.. as pessoa lá porque o país tá desse jeito... porque eles não falam.”

Traz à tona a consciência sobre a importância do confrontamento de posições, de colocar em discussão, inserir na equação, seus próprios interesses; seus, mas compartilhado por muitos que assim como ela têm sua humanidade violentada, mas que, por vezes se calam, assumindo para si a posição de inferioridade, de pequenos, insignificantes diante de todo um sistema que gira, sem abalos, ritmado pela proteção dos mesmos interesses dominantes. A consciência sobre a contradição intrínseca ao sistema foi verbalizada pela Joana-que-fala-por-si-mesma-em-defesade-sua-justiça para o juiz, repetiu para mim: "um ser... uma pessoa é menos do que uma maconha, umas graminha... foi dezoito gramas de maconha. Meu filho ficou três anos na cadeia, acabou com a minha vida, acabou com tudo. (...) A pessoa não vale nada... a droga tem mais valor do que a gente."

Joana ainda esperava o resultado do processo que corria na Justiça, do qual era pivô sem participar, do qual não tinha mais notícias; um processo impessoal, mas que afetava sua vida pela iminência do que poderia acontecer. A ameaça que ronda seu futuro também contribui para seu cansaço, confronta permanentemente seus esforços de autodeterminação. "Tô esperando a resposta, porque se o juiz chega e me dá uma, me decreta uma prisão eu vou ser presa (...), vamos ver o que eles vão resolver".

Ainda sem resposta da institução dos homens para seu discurso em prol da sua inocência, assim como em busca do tratamento para seu filho, Joana apega-se à outra instância, à ordem divina. Não mais a Joana-religiosa, mas a Joana-que-crê-em-Deus, em algo superior, além de nós, que encontra sentido para uma vida que nem sempre merece ser vivida: "foi Deus que mandou ele depois de tudo isso porque sabia da barra que eu ia enfrenta né, então já manda a pessoa". Refere-se ao filho mais novo, que lhe dá apoio e de quem se orgulha. É na continuação da vida do filho que enxerga a de sua própria, “porque se não fosse por esse menino aí eu acho que eu já tinha abandonado tudo", apesar de cansada continua a batalha pela autodeterminação adotando como principal arma o próprio discurso, a ação mais do que a fala.

\section{O grupo Mãos na Massa e a Joana-cooperada}

Como Joana ressalta em sua história contada, como filho preso, dependendo da Joanamãe-dedicada-justiceira para sobreviver na cadeia, a Joana-trabalhora-provedora, estivera sem possibilidade de concretização: “tinha que abandonar ele... eu não podia abandona ele (...) aí eu 
tive que abandonar o serviço". Diz ela que se não fora por essa circunstância que lhe fora posta, "tava aí empregada".

A entrada no grupo Mãos na Massa se deu justamente quando, com o filho solto, estava "sobrando um tempo". Márcia, sua conhecida de outras histórias, da Associação de Mulheres, convidou-a para participar do grupo que estava se formando: "aí eu fui indo e fui ficando...”. Nas reuniões da rede do Jardim Jaqueline, da qual surgiu o projeto de trabalhar com segurança alimentar e geração de renda, fora "umas duas vezes", "depois não fui mais, não dei muita importância né", o que parecia ter mudado no momento da entrevista, a rede era vista como um "movimento" em que pode ser ouvida e junto com o grupo construir propostas, soluções, que, com mais força, podem adentrar outras instâncias:

“(...) vou entrar de novo porque eu tô com um problema meu lá com um terreno já tem seis anos lá que eles tão jogando muito lixo e eu acho que pra mim resolver isso aí eu tenho que entrar na rede, né, pra eu tá ali no movimento, pra eu tá falando minhas proposta e vendo algumas também que podem fazer lá naquele terreno, porque tem muito, lá é um terreno baldio, tem dono mas a prefeitura pode comprar aquele terreno, sei lá o que pode fazer, pode fazer uma entidade lá... é eles falam de creche, mas eu acho que ta precisando mesmo aqui no Jaqueline é um asilo, não tem nenhum..."

A conexão de seu problema com os das outras pessoas e com o contexto do bairro, assim, está claro para Joana, bem como a força alcançada pela ação coletiva, superior a quando individual. Se a Joana-mãe-dedicada-justiceira nascera em defesa de causas próprias e de seu filho, mostrava-se agora a Joana-que-articula-se-em-prol-dos interesses-seus-e-da-comunidade. Metamorfose essa vivenciada a partir do trabalho em grupo, que encontrou insumos na Joanacooperada, com sentido emancipatório na medida em que desemboca no encontro de ressonância à expressão de sua subjetividade, em que a liberta do desgaste de toda energia aplicada ao grito no vazio; passagem da ação individual desesperada à ação coletiva organizada.

Sim, o contexto para tanto, as condições objetivas para a metamorfose, para que a soma de mudanças quantitativas pudessem inaugurar o salto qualitativo, parecem ter sido oferecidas pelo processo de formação da cooperativa Mãos na Massa. Passemos a essa história.

Quando chegou às reuniões do projeto, recém-unidos os outros participantes, Joana deparou-se com a discussão a respeito de qual atividade econômica seria desenvolvida. Encontrou aí, já, a primeira oportunidade de trazer sua experiência e de colocar sua vontade para 
o grupo: com base na vivência com o neto, sugeriu que produzissem barrinhas de cereal, "porque eu gosto muito dessas barrinhas... eu gostava mas comprava muito pouco, né (...) quem comprava mais era meu neto, então eu fui mais por causa dele né, todo lugar que eu saia com ele, ele queria uma barrinha então foi assim que eu fiquei conhecendo as barrinhas que tem por aí”. Aceita a proposta, era essa a atividade produtiva realizada pelo Mãos na Massa, a partir da ideia de Joana, da discussão em grupo a respeito e com o suporte da ITCP-USP e do Instituto Pólis, o trabalho ao qual dedicavam-se não era a produção de simples barrinhas, mas de um produto que "é uma delícia, eu gosto e todo mundo gosta, criança, todo mundo."

A Joana-cooperada tem, assim, duas bases principais para impulso, a possibilidade de ser ouvida pelo grupo e a partir do grupo, e o interesse pessoal pelo aprendizado. $\mathrm{O}$ fato de ter estudado pouco, a oportunidade de estudar deixada em Minas Gerais, é trazido com pesar que encontra acalento no aprendizado do processo de formação. Encarado como necessário para a ação do presente e do futuro, Joana planeja, projeta, lança-se à frente no tempo munida com esses novos instrumentos: “como eu já tive um restaurante eu falei assim, é uma boa porque aí eu já aprendo mais, quem sabe mais pra frente se a gente abre um comércio pra algum dos meus filhos, eu já sei mais como que administra assim... na parte da... como que se fala... matemática do... as finanças."

Outra expressão de si mesma realiza-se também com a Joana-cooperada, a Joana-vendora, sempre em contato com outras pessoas, oferecendo um produto: "gostava do trabalho, eu adoro trabalhar com vendas. Desde pequena minha família tudo trabalha com umas frutas de pão, pegava laranja às vezes pra poder vender." No grupo Mãos na Massa foi essa a função assumida por Joana. Além disso, a participação na cooperativa é para ela uma ação concretizada em um produto, físico, palpável, capaz de deixar sua marca na história. Mais do que gerar receita e renda, a cooperativa é a esperança de permanecer apesar da inexorável mortalidade.

“(...) eu disse olha eu estou no grupo aqui porque eu preciso de fundar alguma coisa, pra dizer que eu fiz alguma coisa porque eu não sou mais criança não, então pra mim é interessante dizer nossa aquelas barrinhas lá foram nós que desenvolvemos, não é? Vocês também, não é? Você ver uma barrinha na praça e sentir nossa eu tive aquele projeto, não é não?”

\section{O trabalho em grupo e autogestão}

"Trabalhar em grupo" é definido por Joana como algo que lhe faz bem, que colabora para que os ambientes de trabalho e da casa, da família sejam aproximados, para que a artificial 
divisão entre vida cotidiana e vida de trabalho seja enfraquecida e para fortalecimento do mundo da vida: "é bom porque pra mim eu tô na minha casa, mais gente, todo mundo amigo ali. Eu não tô, nem acho que saí fora de casa, entendeu? Tá ali, toda hora você conversa, você belisca alguma coisa você vê como é a vida nossa aí, né?”.

A autogestão tem participação direta nessa equação experimentada na cooperativa. Mencionada por Joana como a administração do próprio tempo pelo trabalhador, a autogestão é relacionada à possibilidade de que ele elabore seu próprio planejamento, da produção e da vida, considerando aquilo que lhe parece prioridade e levando em consideração os direitos e deveres seus e dos outros: "e não tem assim, é nos mesmo que administramos, sabemos que a gente não pode perder o nosso tempo porque nós estamos tirando o nosso próprio, né? Então todo mundo tem que trabalhar no conjunto, não dá muito serviço pro outro, tem que ser bem amigo, todo mundo fazer sua parte. Eu acho muito legal."

A diferença de não ter patrão é traduzida por "trabalhar mais à vontade", no ritmo do grupo, conversando e descansando quando preciso, mas logo Joana faz o contraponto apontando que não podem relaxar muito, que precisam de atenção, já que "trabalham com alimento". Questiona-se se essa atenção necessária não é conflitante com o estar à vontade; temendo as consequências da falta de controle, Joana tem uma ideia, assume para si que a instalação de uma câmera na cozinha do CRSAN, onde passarão a produzir, seria a alternativa entre o patrão e a confusão. Preocupados com a câmera, imagina que cada um controlará a si mesmo já que se algo for feito fora das regras e da receita todos saberão ao assistirem a gravação. Além da função de vigia, assistir à fita, depois, permitiria que aprendessem com os erros cometidos. Interessante que a consciência que Joana menciona, "a gente tem que ser mais consciente, prestar mais atenção nas coisas", viria de fora, representada por essa ferramenta, com uma muleta que depois seria interiorizada.

A vigia, antes centrada na figura do patrão, aquele a quem se deve satisfações e que castiga o erro, é transferida para os cooperados: "pra saber que tá vigiando a gente próprio e trabalhar sem esquecer de nada...!". O peso desse papel de chefe de si mesmo e do grupo que é parte da personagem cooperada, convivendo com o papel do trabalhador-que-vive-de-sua-forçade-trabalho, incomoda Joana e transforma aqueles que o assumem com afinco em “cricri”. É assim que fala de Ana, por exemplo, quem está sempre achando erros ou defeitos nas tarefas desenvolvidas pelos outros. Por isso, a câmera parece-lhe a libertação em relação a esse fardo, 
tanto para os que são criticados, quanto para aquele que assume o controle, sem prejudicar o resultado do trabalho coletivo: "você já entra se já sabe que você tá sendo filmado, se já fica mais na sua postura, né? (...) A gente tando sozinho, você uma coisinha caiu no chão você quer beliscar, mas se a gente tiver em uma cozinha mesmo industrial, você não pode fazer (...) vai ser bom pra gente policiar mais a gente próprio né?”.

São muitas as diferenças em relação à experiência, como trabalhadora e dona dos meios de produção, vivenciada em seu restaurante. Apesar do resultado, antes lá, também depender de seu trabalho, de seu esforço, de também ter sido permitida a união entre vida cotidiana e trabalho, a determinação, por Joana, de seu tempo e processo de trabalho, como cooperada passa a ser um dos sujeitos atuantes nessas decisões e determinações. É nesses acordos, deveres, direitos e resultados compartilhados, justamente na multiplicidade de atores, repertórios e interesses envolvidos que se baseia as principais novidades em relação às experiências anteriores de Joana.

A maior complexidade do empreendimento coletivo é refletida na fala de Joana sobre as "finanças". Embora entenda o aprendizado como útil para qualquer negócio ou projeto, ela aponta que o coletivo exige um conhecimento maior, mais ferramentas para a gestão: "o meu dava pra mim administrar bem do jeito que eu administrava, mas o problema é que eu trabalhava só com os meus filhos lá, não tinha funcionários... você trabalha com funcionários é outra coisa, com o grupo também".

Desafiador, o trabalho em grupo requer, portanto, novo aprendizado, elaboração de novo repertório, e traz em sua dinâmica novos elementos, se alguns positivos logo a princípio, outros mais difíceis. É nesse sentido que Joana destaca “alguns atritos" derivados da falta de interesse de alguns cooperados pelas barrinhas e pelo projeto compartilhado. O envolvimento aquém do esperado, a não identificação, e por isso, a falta de entrega, não poderiam ser resolvidos, segundo Joana, nas reuniões, pela conversa: "eu acho que num grupo a pessoa que não tá satisfeita tem que sair fora.. não pode prejudicar o grupo, né... e eu tô vendo pessoas aí que não tá satisfeita e tô vendo que acho que vai sair."

O ponto é que para Joana a falta de interesse pelo produto do trabalho coletivo simbolizava a desvalorização do projeto comum e o enfraquecimento da identidade coletiva. Da mesma forma como seria difícil vender um produto do qual não se gosta, seria um problema doar-se em um esforço coletivo cujo produto final não traz orgulho, não faz sentido. 
“(...) ela fala que ela faz barrinha, mas ela nem come... como que você produz uma coisa e não come? Você vai vender aquilo de que jeito? (...) Não pode, você acha? Você não vai crescer no grupo, porque eu sou a produtora de barrinha, e eu tô te oferecendo a barrinha, aí você fala "ahh é saborosa", aí eu falo que nem como, eu nem sei nem que sabor tem, você vai compra essa barrinha? (...) eu acho que uma pessoa dessa não pode ficar no grupo, a não ser que ela fosse da parte da administração, qualquer outra coisa... que não envolvesse essa parte da alimentação mesmo, de degustação...e ela se.. porque o grupo é isso... se eu não posso ir a outra tem que ir e se ela for aí num congresso, igual ao Carlos, o quer que ela vai fazer lá? Ela não sabe que sabor tem nenhuma barrinha daquela, e aí pronto, já acabou com o nosso grupo."

A Joana-cooperada-que-encontra-se-no-trabalho-coletivo entende que o grupo é feito de conexões e se um não pode realizar determinada função, todos os outros terão um pouco mais de responsabilidade sobre as tarefas que a compõem. Joana vê-se como parte do Mãos na Massa e reconhece, em análise que faz sobre esse sujeito coletivo que se forma, os deveres muito dissonantes assumidos por algumas pessoas em relação à participação de outras: "nesse grupo nosso, que é de todo mundo, quem segura a maior barra aí é o Carlos, (...) porque nos congressos quem vai, tudo só sobra pra ele... é fazer compra, ele tem que estar junto, e é tudo...”.

Sabe que, assim como aconteceu com ela em seu restaurante, quando alguém assume uma carga pesada demais, é difícil manter-se soberano de si mesmo, determinar os próprios movimentos; sente-se isolado na jornada e a tendência é que se canse e que busque outro contexto em que se tenha maior autonomia. Conta Joana que a parte mais difícil não estavam sendo discussões e tomadas de decisões coletivas, "pra mim tá sendo bom", o que consumia suas energias era, sendo a responsável pelas vendas desde que elas começaram a acontecer, fazer vendas pequenas e depois ficar controlando os pagamentos, "é uma pra um fulano, aí fulano não pagou você vai atrás, aí você fica né... isso aí cansa, te embanana muito”.

A Joana-cooperada reforça a ponderação das diretrizes da Igreja Evangélica, traz nova racionalidade para o diálogo com a Joana-que-partilha-da-comunidade-evangélica e ganha voz ao decidir que apesar de "ser chato, porque é um homem e uma mulher", iria com Carlos nos próximos eventos, representando o grupo, se mais uma vez não tivesse mais ninguém para acompanhá-lo. Afinal "nós somos um grupo e a gente tem que enfrentar esse tipo de coisa, se eu soubesse eu teria ido porque ir uma pessoa sozinha não faz nada.” Parece-lhe contraditório que, como grupo, uma pessoa esteja sozinha em momentos importantes como esses, choca-se com os 
que considera os valores que fundamentam o trabalho coletivo, ou pelo menos aqueles que foram assumidos por Joana como pauta dessa vivência: “eu já falei até pro Carlos, falei assim ó, da próxima vez você não vai sozinho, tem que arrumar qualquer outra pessoa pra ir, é lei, é o nosso grupo, a gente não pode fazer isso...”.

A personagem cooperado não implica no mesmo comprometimento para todos, enquanto alguns "jogam tudo pro alto e sai”, doam o tempo necessário para que as encomendas sejam entregues, outros têm o envolvimento limitado por outros de seus papéis, de esposa, mãe e avó em sua maioria. "Porque as outras têm marido, as outras têm horário (...). Chega hora de ir embora o povo larga até barrinha queimando e vai embora (...), tem as meninas que têm o marido chega àquela hora tem que tá a janta na mesa." Difícil encontrar um ritmo e um tempo consensuado de trabalho, entre encontrarem-se apenas duas vezes por semana, por algumas horas, e cinco dias por semana, para a produção e a formação eram diversas as possibilidades e preferências.

Joana encontrava-se no subgrupo dos que tinham a cooperativa como projeto de vida, e o choque entre as disponibilidades se fazia principalmente pela existência dos extremos, um dos quais essa dedicação total que acaba por desprender-se inclusive do grupo, desconsiderar o processo participativo, democrático de tomada de decisão.

"Eu tenho a minha casa também, mas se eu estou fazendo um serviço, eu vou fazer o meu serviço eu não tenho criança comigo eu tenho os meus netos mais eles têm mãe e pai. Os meus filhos o caçula eu já casei então se eu quiser virar a noite vendendo barrinha eu posso isso se eu aguentar se eu for num evento que vai ficar a noite inteira eu posso ficar a noite inteira não tenho mais nada que me impede entendeu? (...) Então eu não tenho marido, Márcia não tem marido e Carlos não é casado. (...) Eu falei assim, se o grupo quiser ficar sentado o dia inteirinho eu vou ficar? Eu não posso."

É assim que a Joana-cooperada-dona-de-seu-trabalho-de-seu-tempo-autodeterminada oscila entre a riqueza do trabalho em grupo, a diversidade, o aprendizado, a satisfação que ele lhe traz, e a marcha em seu ritmo individual e guiado por sua própria bússola.

Riqueza que já se fazia sensível no Mãos na Massa. Comparando essa experiência com a sua anterior, como dona e trabalhadora do restaurante, Joana conclui que a colaboração de todos para um mesmo objetivo faz com que ele seja atingido mais rapidamente, com menor desgaste de cada um: "tô achando bom, é até melhor porque o serviço é rapidinho. Vamos supor... eu quando 
eu trabalhava com o meu restaurante e eu pegava uma lasanha pra eu fazer, eu tinha que começar ela do começo ao fim (...) agora não, você faz uma parte, no grupo, até ela é feita em todo o grupo, você entendeu?". O mesmo funciona com as barrinhas de cereal, nesse caso "uma espreme o limão, outra faz isso, outra faz aquilo.. então a barrinha tá feita pela mão de todos, e eu acho que o mais importante... o mais rápido...”.

A importância da prática para a mudança cultural que o trabalho em grupo e que a autogestão requerem está presente no discurso de Joana, ela fala de um processo de aprendizado em que aos poucos uma nova forma de trabalhar e de relacionar-se passa a ser possível. Ana é o exemplo trazido; segundo a narradora, ela, que sempre trabalhara sozinha em sua própria casa, aos poucos integrava-se ao grupo, entregava-se na produão coletiva. Joana mesma conta que apesar de trazer uma vivência anterior, a do trabalho no restaurante, em que, se não fosse a colaboração dos outros, não conseguiria entregar "umas cento e cinquenta, cento e sessenta marmitex" por dia, a única coisa que faziam "em grupo" era fechar os marmitex, todo o restante, o que implicava maior responsabilidade, ficava unicamente a seu cargo. Assim, também ela estava aprendendo a atuar em uma organização do trabalho em que todas as tarefas são divididas, em que se espera que todos tenham responsabilidades equivalentes: "hoje em dia não, se você lava o arroz, outro põe no fogo, outra faz outra, e vai indo e outro termina."

Aprendizado esse que, advindo principalmente da prática, da vivência em grupo, parece ser uma fagulha importante para a metamorfose de Joana na medida em que a Joana-cooperadaque-confia-nos-outros entra em cena. A empolgação com a experiência está conectada à novidade de poder partilhar as responsabilidades, as tarefas com os outros; na produção o grupo vinha mostrando que poderia contar com a colaboração, que não estava sozinha. Nessa sensação Joana se apega, sente pertencer e enxerga os resultados da colaboração: “ah, eu acho legal. Muito bom. Muito bom porque a gente faz um monte de coisas num instante sabe? Quando você se perde o outro já, tá ali cobrindo, é muito legal. Nossa, é uma produção fantástica"

É no Mãos na Massa em que experimenta essa mudança, em que começava a ter espaço a Joana-solidária-nos-esforços-e-nos-ganhos, a Joana que experimenta estar entre pessoas que oferecem potencialidades e limitações, assim como ela, e que, por isso, assumem os mesmos direitos e deveres. Sua casa continuava funcionando no modelo antigo, morando com o filho, usuário de droga, e com o ex-marido, alcoólatra, Joana concentrando todos os deveres e todos os direitos: "tá dando certo, eu administro tudo, pago tudo que a gente compra, faço compra faço 
tudo e sai briga porque a pessoa bebe acha que gasto muito dinheiro, pego o dinheiro dele. Se eu deixar o dinheiro na mão dele ele vai beber tudo né?’”.

Enquanto em casa sabe que o conflito direto, por meio da conversa e da argumentação, não é possível, poucos avanços deve gerar, no grupo ela queria, sentia falta da discussão aberta. No episódio em que todos repartiram as barrinhas que haviam sobrado de um evento para venderem-nas em outros espaços e um dos membros do grupo recusou-se a levar sua parte, todos incomodaram-se, mas ficaram quietos, "ninguém falou nada. (...) acho que não quis falar porque já tava final de ano e tal. Já tinha acabado a reunião e tudo, então ia ficar igual uma atrito ali... deixa isso né?". Joana esperava que no retorno ao trabalho, no começo do ano seguinte, a conversa fosse retomada, já que haveria o momento da prestação de contas das vendas, seria o gancho para que o conflito iminente fosse realizado.

A questão que Joana parece trazer aqui, princípio assumido por ela como a base para a autogestão, e que estava em risco, é justamente igualdade de direitos e deveres fomentada quando todos sentem-se igualmente trabalhadores e donos do empreendimento, do projeto coletivo. Joana concordou com o grupo ao definirem que todos, incluindo eles mesmos, pagariam o mesmo preço pelas barrinhas se quiserem levá-las para vender, "eu compro o preço que tá lá fora porque sou consumista das barrinhas e vou comprar, né? (...) Porque é meu negócio eu tenho que falar bem pelas minhas barrinhas, né?”. Assim, seu maior esforço reverter-se-á para si mesma, já que é um dos cooperados; é também por isso que se coloca como guardiã dos acordos feitos pelo grupo, contra qualquer tentativa individual de ser exceção à regra em prol dos interesses pessoais: “(...) porque aquele dinheiro é do grupo. Nós estamos tirando de nós próprios, né? Então não pode ser assim."

A força da Joana-justiceira já conhecemos antes, a personagem vivia ainda, forte, de mãos dadas à Joana-trabalhadora-cooperada, com a energia voltada à defesa do pacto coletivo, das regras e valores compartilhados. Joana-justiceira abraçava toda a cooperativa, sob sua proteção o que era seu-do-grupo-seu misturava-se, era uma coisa só.

As outras Joanas: a Joana-cooperada e um grupo de novas personagens

A cooperativa é vista por Joana como o argumento, o projeto, o espírito que impulsiona o grupo para a ação: "o grupo em si é bom, mas é um grupo que fica ali parado, mas agora uma cooperativa ela vai crescer." É a organização cooperativa que oferece perenidade ao grupo por meio da conformação de um objetivo comum, em prol do qual se dão as atividades e ações 
coletivas, aquelas que geram renda e garantem a continuidade da vida, e essas que ficam para a história como notáveis feitos e que desencadeiam outras realizações. Assim que "vamos supor.. chega um certo tempo eu vou ficando mais velha, não dá pra mim trabalhar, mas eu já... já fiz o movimento de gera uma cooperativa e já tem mais outras pessoas que já fez o curso já podem entrar e vai crescer você entende?".

A produção na cooperativa, a atividade produtiva, é elemento agregador, forte, do grupo que se uniu, já início, com essa perspectiva, de produzir e gerar renda, e que é transversal aos diversos interesses e incômodos. Joana conta que quando tiveram que produzir uma grande quantidade de barrinhas em pouco tempo, pressão agravada por terem horário para usar a cozinha emprestada, que as reclamações e o comportamento "cricri” deram uma trégua e todos deram seu melhor, colaboraram uns com os outros.

"Olha, foi bom, melhor do que trabalhar as quatro horas. Foi, as pessoas ficaram assim muito... porque é muita coisa que tinha que fazer, porque acho que num grupo precisa ter serviço para a pessoa desenvolver. Aí todo mundo começou desenvolver o seu serviço, acabou que a gente não percebeu, foi muito bom. (...) Ninguém brigou... não deu tempo pra brigar (...)".

Ao mesmo tempo em que "foi a melhor coisa que a gente fez", em que a dinâmica adotada para que a meta fosse cumprida trouxe à Joana a sensação de sintonia entre o grupo e de libertação em relação à vigia e ao olhar reprovador, trouxe mais uma vez à baila a preocupação pela sua ausência, em relação às consequências dessa liberdade deixada pela certeza de que ela mesma apenas é responsável por aquilo que faz. Ao papel do "cricri” Joana atribui importância e relembra que uma câmera deve exercê-lo. É essa a Joana-que-busca-autodeterminar-se e que, ao mesmo tempo, é a Joana-que-ainda-não-confia-completamente nos outros, nem em si mesma.

A Joana-cooperada enxerga a continuidade do projeto por outros cooperados que ainda virão e, vivendo suas próprias personagens, darão vida aos Mãos na Massa. Sua vontade era que esses novos cooperados adentrassem o grupo já naquele momento para que começasse a “crescer", produzir mais, vender mais, participar de mais congressos, feiras, oficinas, mais liga para o coletivo, mais matéria para sua confiança em construção; “igual agora mesmo a gente tá até querendo conversa com [os formadores] pra vê se já dá outro curso pra outras pessoas que queiram entra nesse grupo nosso, porque nós vamos crescer...”. 
Para esse projeto que já ocupava grande parte de seu tempo e repercurtia, aos poucos, nas outras esferas de sua vida, para o cooperativismo, Joana queria trazer seu filho, imagina-o entre tais novos cooperados; em busca de uma oportunidade de trabalho e renda, a participação na cooperativa é um caminho que lhe agradaria, a ela, como Joana-mãe. Como Joana-cooperada, para o grupo também enxerga benefícios, aponta que o filho "é um bom motorista, conhece a cidade inteira entendeu? Eficiente mesmo, porque desde doze anos que ele dirige. Seria uma boa, porque vai rápido... sabe tudo né?".

Aqui também a Joana-mãe e a Joana-cooperada parecem fortalecer-se, articuladas e não sobrepostas. Reafirmando o pacto grupal, indica o respeito às regras de entrada como condição para que o filho faça parte: "vai ter que ser do nosso grupo, vai ter que fazer o curso pra tá dentro da empresa, não querem pegar ninguém de fora". Como mãe Joana enxerga que fazer o curso representaria para o filho mais do que saber do que se trata o trabalho em grupo, o cooperativismo, a economia solidária, o início de um novo projeto de autonomia, o rito de passagem para que ele também possa ter os mesmos direitos e deveres que os outros, estar entre iguais, encarado como um homem pleno, inteiro e capaz, não como "o filho da Joaninha. Ah não porque tá dando boi para ele, aí... ah não, de jeito nenhum, porque lá todo mundo é igual, na empresa, na cooperativa, né?”. Que o filho também tenha a oportunidade de dar vida a uma nova personagem, a um outro "outro".

Isso porque no processo de contrução coletiva do Mãos na Massa ela mesma, Joana, pudera alterizar-se, dar vida a outras "outras"; tentara, inclusive, concretizar literalmente seu outro "outro", buscou reconhecimento ao seu nome de batismo, Maria Antônia; nome pelo qual nunca fora chamada, já que desde pequena identificaram-lhe logo, pelas suas características físicas, por Joana. Tentativa vã, construindo o Mãos na Massa junto com alguns conhecidos de longa data, houve resistência à mudança repentina. Para eles era a Joana da Associação de Mulheres, do dia a dia do Jaqueline, que se via em outra situação e que assumia novas facetas, aos poucos, mas era a Joana que conheciam e reconheciam pelo que tem de singular.

O curso ao qual se refere é o de formação em cooperativismo e economia solidária, oferecido para o Mãos na Massa pela ITCP-USP e pelo Instituto Pólis, reconhece que é necessário pelas diferenças entre suas próprias experiências anteriores, usadas como base para sua interpretação, e a que vivia na cooperativa em formação. Era preciso que os novos 
cooperados compreendessem essas novidades que viveriam, essa nova proposta de organização do trabalho e de vida.

"Então a gente precisa de pessoa qualificada pra trabalhar... que fez o curso (...) [senão] entra aí depois fica um mês e quando sai... e como que a gente vai fazer? (...) A gente não pode contratar ninguém fora do nosso curso. (...) A cooperativa não, a cooperativa é aquelas pessoas, eles vão sair, pedir uma demissão só se ficar doente, se não puder mais trabalhar, vamos supor, eu já tô ficando um pouco velha, eu tô cansada, eu vejo que não dá mais pra mim trabalhar eu peço minha demissão, mas aí eu ponho outra pessoa no lugar né..."

Com aproximadamente um ano de trabalho junto ao grupo, aos poucos essas diferenças e semelhanças entre a organização cooperativa e as outras ficam claras, ganham sentido pela experiência, pela vivência com o grupo e com os formadores. Joana-cooperada traz os termos, os significantes de seus mais de 50 anos de vida antes de dar vida a essa nova personagem; recorre a eles para explicar o funcionamento dessa nova forma de trabalhar e de relacionar-se. $\mathrm{O}$ desligamento da cooperativa, "demissão" nas palavras de Joana, não lhe parece ser tão simples, tão automático, quanto quando se é um empregado, o compromisso ultrapassa a venda de mãode-obra, envolve uma organização que nasce do coletivo, um movimento, um projeto que, sem qualquer um, pode não ser mais viável. Essa é também, certamente, uma das razões para que Joana se sinta insubstituível, única nesse projeto, valorizada em sua singularidade.

A preocupação com a formação de outras pessoas para o trabalho na cooperativa passa pelo desligamento de alguns membros no passado recente e no presente, reduzindo consideravelmente o grupo e alimentando a perspectiva de que isso pode continuar acontecendo, já que Joana mesmo falava da falta de comprometimento, de interesse, de gosto pelo trabalho do Mãos na Massa da parte de alguns. Passa também pela ideia de que ela mesma poderá desligar-se em breve, assim como todos os outros que possuem uma certa idade e cansar-se-ão em algum momento; não haver jovens compartilhando do projeto ao qual dedicava-se preocupava a Joanaque-lança-se-à-eternidade pela ação, que junto a Joana-cooperada enxerga a cooperativa para além da mortalidade das mulheres e homens que a estão criando.

“(...) a gente queria preparar uma pessoa, principalmente um jovem, né, que estuda mais do que a gente, que tem mais facilidade pra né, pegar as coisas, pra ficar naquele grupo pra administrar, nós sabendo, a hora que dá alguma coisa... nós vamos saber, a gente vai saber entender tudo da administração. Mas a gente está, bom no meu ponto de vista, não sei os outros estão igual eu, estou pensando assim, de preparar uma pessoa para 
isso, pra ficar mais ou menos naquela área ali, de contar, de computador porque se eu tô lá na cozinha e vou no computador não vai da certo as duas coisas!"

Outro traço da organização cooperativa do trabalho, o aprendizado de todos sobre todas as áreas do negócio, propiciado pela formação e pelo rodízio de tarefas, fortalece uma outra personagem, a qual também ganha impulso pela articulação com a Joana-cooperada: a Joana-quequer-falar-por-si-mesma, que, em seu projeto de autonomia, participa da construção das regras e da tomada de decisão. As duas dão as mãos e trazem à baila a importância de conhecer da “administração" à produção, mesmo que se atue em apenas uma ou algumas delas no dia a dia. Com base nessa percepção, Joana-cooperada entende que todos devem participar das áreas mais estratégicas do empreendimento, como as vendas e recusa-se a aceitar que uma das cooperadas não acredite no produto e, por isso, não possa vendê-lo.

O que se percebe é que tal nova personagem, a Joana-cooperada, na medida em que se forma e transforma-se, requer que outras também existam dando-lhe suporte. A Joanaproprietária que é responsável pelos resultados do negócio, cujo "salário" depende de seus próprios esforços: "você tem que vender é o nosso salário também, todo mundo tem que correr, que no final do mês todo mundo quer salário, né?”. A Joana-empreendedora, que acredita no próprio empreendimento e enxerga que ele depende de suas ações e dos outros cooperados: "você não viu o pai do Leandro lá, que pegou o salário comprou tudo de moeda pros caras telefonar pedindo a música do cara, para ele crescer? É a mesma coisa que a gente tem que fazer com as nossas barrinhas.”. A Joana-cliente-consumidora do produto que ela mesma produz, que come, ela e toda a sua família, as barrinhas de cereal: "se você quiser crescer você tem que começar a consumir de casa (...). Que lá em casa eu vendo muito, mas se eu tenho alguma produção que levo num instantinho comem tudo. (...). Eu falei, se eu tivesse dinheiro vocês nem precisava levar essas barrinhas, eu levava, eu comprava tudo.” .

Também, a Joana-que-reúne-o-trabalho-e-a-vida-cotidiana, que fala sobre os benefícios da barrinha, sobre os objetivos do grupo Mãos na Massa em sua casa, entre os amigos, na rua e que se sente, junto ao grupo, entre amigos, compondo uma nova família: "Você tem que apostar no que você faz, (...) fazer os poucos o pessoal consumir. Igual meu neto, ele adora barrinha então o amiguinho dele também vai gostar que ele vai incentivar, vai indo, vai indo, vai mostrar que não é igual qualquer barrinha produzida no mercado, certo?”. São várias personagens que se 
complementam nascidas ou potencializadas pelo papel de cooperada que Joana vivia à sua maneira, frente a uma nova objetividade que lhe permitia ser outra Joana, dar voz a novas necessidades, desejos, interesses realizados em sua participação no grupo e na representação dele em outras instâncias; Joana outra que aos poucos conseguia expressar-se claramente para o grupo e inaugurar espaços para outras Joanas.

Papel esse que só faz sentido e personagens essas que apenas ganham vida por existir o grupo, o projeto coletivo, a cooperativa em formação, o exercício da autogestão. O grupo já fazia parte de seu projeto de autonomia, do empoderamento em relação ao seu presente e ao seu futuro, em relação a seu projeto de vida. O pertencimento antes buscado na Igreja, na Associação de Mulheres, no restaurante em que oferecia comida aos trabalhadores do bairro, tinha, agora, no Mãos na Massa novo caldo, diferentes nutrientes.

\section{O cooperativismo e a renda}

$\mathrm{O}$ acesso à renda acabou por ser o fator determinante do perfil do grupo que se formava quando conversávamos, Joana e eu: todos com mais de 40 anos, com alguma fonte de renda além do grupo e por isso, sem desespero para que o empreendimento assumisse essa função. Já houvera jovens no grupo, mais no início, saíram porque tinham que trabalhar para garantir a sobrevivência, "saiu do grupo porque ele é jovem não tá entrando dinheiro ele não pode ficar no grupo (...) eu fico porque tenho renda, né?”. Essa foi a razão para a desistência de parte do grupo inicial, no final de 2008, depois de mais de um ano de formação, fizeram uma retirada de $\mathrm{R} \$$ 100,00 para cada cooperado.

Não precisar da renda gerada pelo trabalho na cooperativa para as necessidades básicas não siginifica que Joana não tivesse essa renda potencial como um dos impulsos para compartilhar esse projeto, "porque eu preciso porque sempre dinheiro quando vem é bem vindo não é não? Tudo que você ganha com seu próprio suor é bom você estar trabalhando e pra mim na minha idade não tem coisa melhor que trabalhar." $\mathrm{O}$ dinheiro como recompensa pelo trabalho é elemento que a caracteriza como trabalhadora em uma idade em que estaria excluída do mercado de trabalho, descanso compulsório de aposentada. A Joana-cooperada-trabalhadora é a articulação que lhe permite ser reconhecida e reconhecer-se como alguém que vive do seu

próprio esforço, que faz a vida, personagem que compõe afirmativamente seu projeto de autodeterminação. 
"Porque na idade que a gente entrou, eu já estou chegando nos 60, aí você vai o quê? Vai endurecendo, não é, quanto mais movimento você faz você distrair pra você é um... você vive melhor o trabalho. (...) E você estando trabalhando não você vai movimentar e diz, não eu vou fazer isso aqui porque amanhã eu tenho que ir lá, não é não? Tem que ter objetivo.”

As expectativas de Joana para o ano seguinte em relação a essa forma de reconhecimento de seus esforços, forma que caracteriza, em nossa sociedade, o trabalho, eram positivas: "espero que o ano que vem nós já tenhamos o nosso salário oitocentos dividido pra cada um e mais o décimo terceiro, que seria mil e seiscentos cada pessoas certo?”. Em sua fala reflete-se a percepção de que, a partir de determinado momento, o tamanho das sobras dependerão apenas do esforço de cada um dos cooperados, de seu empenho, já que "a barrinha tá sendo muito bem aceita lá no comércio".

Joana-que-planeja-o-futuro quer "evoluir", comprara um carro "novinho, 2009”, ainda não com as sobras da cooperativa, e quer "ir trocando de carro", não vai ficar "andando de ônibus, andando de num sei o quê, sendo que tenho condições de evoluir." Merecedora de mais do que a sobrevivência, de conforto, de viver bem. Joana trabalha para viver bem. Se ainda não faz parte financeiramente dessa equação, nesse futuro imaginado, próximo, a Mãos na Massa tem seu papel reservado, proporcionar sim dinnheiro para tudo que se pode comprar:

“(...) porque antigamente nós estávamos produzindo 8 formas por semana e nós já estávamos em 1 salário, (...) já estava tirando $\mathrm{R} \$ 150,00$ todo mês. Tava bom, não é, porque a gente, o que, trabalhava um dia só pra produzir, no outro dia a gente vinha mais pra reunião. (...) E se a gente trabalhasse um mês inteiro, uma semana inteira? Foi aquilo que eu te falei, dava pra tirar uns seiscentos, mais que o salário mínino."

A Joana-vendedora terá participação fundamental na construção desse futuro, como já sabe. Não fica parada, segue, às vezes em disparada, realizando a Joana-impulsiva-em-seu-rimopróprio, "e outro comércio e outro, e outro", outras acompanhando-se do grupo, a Joanasolidária, que se reconhece no coletivo, "a gente podia pegar umas duzentas barrinha por dia, porque eu vendia 50 ou mais por dia. Ia pegar mais ou menos isso."

Os recursos financeiros necessários à cooperativa representavam também um dos elos com as organizações de apoio. Por isso, trabalhavam não apenas para gerar renda para o grupo, também para que em breve pudessem ser independentes nesse quesito. Um fundo de reserva havia sido criado, por sugestão dos formadores; Joana-que-busca-autoderterminar-se aos poucos 
apropriava-se da ideia, entendia a importância do fundo, "vamos ser independente, por isso mesmo só tiramos aquele fundo pra deixar, porque nós não sabemos o que vai acontecer né?”.

\section{Joana-cooperada e a organização de apoio: disputa pela determinação}

O empoderar-se do empreendimento é um processo lento acompanhado pelo desenvolvimento da confiança em si mesmo e no grupo, de que é possível autogerir a cooperativa. Construção cotidiana, se para Joana essa confiança apresenta-se bem estruturada por um lado, encontra-se ainda frágil por outro. Junto à consciência sobre a importância da autonomia, do afastamento das organizações de apoio em algum momento breve, há o temor de que "na hora que sair eu não sei se a gente vai da conta de tudo isso não...".

Além da insegurança em relação à gestão do negócio, área mais distante do repertório que trazem, cada cooperado, para o grupo, a preocupação que maior energia consumia-lhe era em relação à persistência do grupo em si mesmo. Joana sentia que poucos faziam muito pelo grupo, e que, se isso já atrapalhava a construção coletiva no presente, poderia ameaçar a existência, concreta do grupo e simbólica de cada cooperado, em algum ponto do futuro: "não posso investir tanto assim, porque nós somos um grupo, todo mundo tem que ajudar, senão ao invés de eu crescer vou falir só eu sustentando". O que se tornaria pior com o afastamento em relação às organizações de apoio, já que os formadores ainda carregavam o peso de algumas tarefas que a maior parte do grupo não se dispunha a assumir, e cumpriam o papel de estabelecer a liga entre os indivíduos e seus interesses diversos, maiores que os coletivos, pelo processo de formação; esse ainda era vínculo determinante da relação estabelecida entre os cooperados e destes com os formadores.

A relação de poder pouco equilibrada, tendendo a gangorra para o lado do formadores, fundamentava-se não apenas na concentração de tais funções, também do capital necessário ao investimento inicial e aos custos operacionais da cooperativa. Os recursos do projeto implementado pelo Instituto Pólis em parceria com a ITCP-USP cobriam quase que a totalidade desses custos e despesas, como a matéria-prima para a produção, os equipamentos que eram aos poucos comprados, embalagens; isso também aplicar-se-ia ao rótulo das barrinhas. Esse era o núcleo, ao menos declarado, da insatisfação de Joana, como vendedora sentia falta do rótulo com as informações do produto, mas não podia agir por conta própria, sabia, porém que não era o grupo seu co-aprovador e executor de ações para resolver a questão, aqueles que são apontados 
como barreira são os formadores: "eu trouxe ele pra ela fechar o negócio. Mas quem tem o dinheiro é que paga não é?”.

O conflito posto nasce dessa relação de dependência ancorada em algumas fontes de poder ainda mantidas pelas organizações de apoio, ao mesmo tempo em que o grupo, ou alguns de seus membros, queriam valer suas próprias opiniões e desejos. Se por um lado declarado, já que explode diante de uma situação que não pôde ser disfarçada, por outro o conflito barrado por falta de material para que se desenvolvesse: negado o diálogo aberto em que todas as cartas são postas na mesa. Pelo menos assim parecia a Joana, a qual me dizia não saber o motivo da discordância da organização de apoio em relação à produção dos rótulos naquele momento. Joana teria levado até o grupo, em uma reunião, um designer que se predipôs a elaborar o rótulo, a recusa teria partido dos formadores, no grupo, pelo que conta a Joana-cooperada-que-encontraapoio-no-coletivo, estranhara a situação estabelecida: “a Joana tá certa, você não falou que a gente podia fazer, que as barrinhas são nossa, fomos nós que fizemos ela crescer, vocês estão aqui como nossos professores, mas nós temos que querer, a gente precisa de um salário não é? $\mathrm{E}$ a gente não pode fazer nada, vai ficar esperando vocês fazerem? Se a gente encontrou vamos fazer né?".

Esse enxerto da fala de outro cooperado traz o epicentro do conflito que se estabelece, mas é abafado, como uma brasa impedida de queimar. O multifacetado embate de ideias e sentimentos dá-se em cada um dos envolvidos, formadores e cooperados, de um lado convivem a colaboração para a construção da autonomia por parte do grupo, apresentada como uma necessidade, por parte dos formadores e a ligação que eles mesmos estabeleceram com o Mãos na Massa, com as barrinhas, com o projeto em si, tomando para si uma parte do protagonismo dessa história. De outro, chocam-se a vontade de alcançar esse nível de autonomia e o medo da responsabilidade que virá com ela, o receito pelo incremento no trabalho, nas tarefas, na dedicação requisitada por essa autonomia. A resistência por mudar o ponto de equilíbrio de uma relação que se acomodara em determinado arranjo vinha, como reflete esse episódio, de todos os lados envolvidos.

Assim, pela narrativa de Joana, parece que de algumas decisões o grupo ficava alheio, o que trazia uma pitada de incompreensão ao processo de formação: "tinha feira que a gente tava indo que a gente vendia seis barrinhas, porque as mais fortes a gente não ia sabe?”. A alienação fundava o sentimento de incapacidade e, por sua vez, reforçava a dependência: "[a gente não ia] 
porque eles não ajeitavam pra nós, eu não sei porque, (...) os lugares melhores gente não pode ir." Soma-se aí uma pitada de estranhamento originada pela falta de comunicação, pela apresentação dos fatos como dados e não do construir-se, do dar-se: "é porque é da USP é do movimento deles, é estranho esse negócio [de fazerem o rótulo com alguém de lá], não é?”.

Se não era pelo debate aberto, pela comunicação clara, que a dinâmica da relação estabelecia-se, acaba por ser na disputa fundamentada na ação em prol dos interesses de cada parte. A ausência do diálogo é a falta do compartilhar, imposssibilidade do objetivo coletivo, cada um por si, avanço do agir estratégico sobre as relações no processo de formação: “aí eu fui lá duas vezes, e nem falei (...) não falei, fui lá duas vezes, e vendi bastante barrinha. (...) Como ela disse que eu estava pondo os pés pelas mãos eu não quis falar nada no grupo você entendeu?"

Por fim, um tanto de desconfiança: "é, agora, a não ser que eles estão querendo vender a patente das nossas barrinhas. Por isso que não quer dar o rótulo pra gente." Resultado o desmoronamento do projeto coletivo, feito em pedaços que precisarão ser ressignificados, para Joana a angústia pelo contrassenso da afirmação do papel de dona, protagonista, autogestora , "porque a gente, foi nós que fundamos o grupo", e a dependência da realização de seus planos em relação ao outro que se encontra fora do grupo, "aí eu fico todo dia te enrolando, olha, mês que vem tem rótulo, é só esse mês, mês que vem já tem rótulo".

$\mathrm{O}$ rótulo, questão emblemática à qual Joana agarrou-se para afastar-se do grupo e comunicar sua insatisfação; depois de falar abertamente de sua posição, de reclamar as dificuldades nas vendas, de agir por si só e receceber o apoio do grupo, tudo isso sem desdobramentos na situação objetiva, o caminho encontrado, no limite, pela Joana-em-busca-deautoderminar-se, participando da elaboração das regras e da arbitragem delas, foi deixar a Joanacooperada de lado, não a superando completamente, mas afastando-se do espaço em que encontrava seu apoio concreto, na realidade objetiva da cooperativa em formação.

O afastamento do grupo foi uma ação de protesto, o episódio do rótulo, ícone de um conjunto de descisões tomadas como imposições pela impossibilidade de participar delas, de fazer-se representar nelas: "eles tiraram vínculo com o ponto do Pólis, (...) disse que não podia mais ir vender lá e lá a gente vendia bastante.” Ao mesmo tempo, a definição de que a luta pela realização de seu projeto de autonomia estava além de uma personagem, fortalecia-se para vida, articulação, substituição das personagens às quais Joana dava vida; se antes personagens foram repostas por um período, carcereiras da prisão de Joana em determinada situação que não mais 
merecia ser vivida, agora a Joana-cooperada colocava-se em prol, à disposição de um projeto em contínua construção, em constante metamorfose: "eu disse então olha eu tô saindo fora."

Mais do que o protesto, em sintonia com a luta por autodeterminar-se, Joana tomava a sua saída, a existência da própria Joana-cooperada, como arma, como manobra para assumir para si algum poder de negociação. "Eu só volto quando essas barrinhas estiverem com rótulo. Antes disso não."

\section{Os planos para o futuro}

Em meio à narrativa Joana fala do futuro, no qual a cooperativa tem diversos papéis. Quando diz que os aprendizados em gestão aplicaria em um outro negócio, deixa claro que seria para o seu filho, "porque eu já tenho o meu grupo". Seus planos são de ficar aí, fazer parte, participar do desenvolvimento da cooperativa e, quem sabe até trazer o filho para o grupo: “(...) daqui a uns dia vai viver todo mundo bem. Eu acho que todo mundo vai dar conta de comprar seu carrinho novinho, né? E souber administrar direitinho dá."

Joana referia-se ao Mãos na Massa como elemento importante de sua felicidade no presente, "eu tô contente viu", e considerava, antes da questão do rótulo das barrinhas vir à tona, duas alternativas de saída do grupo, a quebra do pacto coletivo, "fazer coisa errada para ser expulsa", ou a morte, "todo mundo pode morrer a qualquer hora...". Ao longo dos meses seguintes, como já sabemos, essa perspectiva foi tomando outras formas.

A Joana-cooperada fica cansada, aos poucos perde o viço, "vai desanimando, vai desanimando". O desgaste relaciona-se, ironicamente, à força com que Joana vive essa personagem; enquanto outros membros do grupo têm outras prioridades, ela mesma nos contou, Joana mergulha nas atividades que entendia necessárias ao desenvolvimento da cooperativa. "Eu não lavava mais a casa, não fazia mais nada. (...) Porque, é reunião hoje, feira não sei onde, (...) aí eu deixava as minhas coisas sem fazer.”

Os desencontros em relação ao rumo que as organizações de apoio conferiam ao projeto também contribuíram, evidente, "aí depois eu fui desgostando, sabe quando você desgosta de uma coisa assim, não tem mais ânimo?”. A demora em ter o rótulo, especificamente, atingiu tanto Joana porque impactava no reconhecimento que o trabalho do grupo, que o seu trabalho alcançava na relação com os outros, com o mundo fora da cooperativa. Joana-cooperadavendedora das barrinhas concentrava esse contato com o exterior, se antes era alimentada pelos elogios que os consumidores teciam para o produto, pelo interesse pelo projeto em 
desenvolvimento, pela aceitação, as experiências de desvalorização do produto eram vividas como a desvalorização de seu trabalho e de si mesma: ela representava as barrinhas, o reconhecimento delas era o reconhecimento da Joana-cooperada.

“ (...) falei assim: 'o senhor não vai levar hoje?’ E ele disse assim: ‘não, a minha mulher também faz em casa'. O que ele quis dizer com isso? Que eu estava fazendo barrinha e vendendo lá, porque estava fazendo em casa. $\mathrm{Eu}$ falei assim, 'mas cara você viu como que é...?' (...) Eu não vou produzir porque tem um monte de gente produzindo, produzir barrinha pra vender sem rótulo pra quê? Eu não vou fazer isso, porque quem sai aí mostrando a cara sou eu, não volto de jeito nenhum."

Afastada do grupo, sente falta da vivência que lhe proporcionara sentir-se parte, pertencer, enraizar-se, atribuir novo sentido ao trabalho, à comunidade, ser outra e acreditar na repercussão de suas ações para além de sua individualidade. Trata a questão com pesar, “ah, eu já estava tão acostumada com o pessoal, aí foi como se fosse uma família. Então eu senti que se tivesse um pouco desmamada, mas vai fazer o que não é?”. Não sente apenas pelo seu futuro, teme pelo futuro do Mãos na Massa, ameaçado o projeto que ofereceria uma alternativa, novo sentido, para aqueles que viriam depois, tantos outros que ainda poderiam juntar-se ao grupo: "mas isso não importa, o desempenho, e o nosso grupo tava muito bem formado. Tudo pessoas legal. É uma pena desmanchar ele.” Disposto a representar o grupo nos diversos espaços e a vender as barras de cereal agora havia apenas Carlos, "porque as únicas pessoas que estão ficando não tem condições de venda."

A respeito das experiências que virão, dos novos cenários de futuro, Joana gostaria de envolver-se em outra organização cooperativa de trabalho, dar continuidade à contrução de relações solidárias, à produção em grupo, à vivência da autogestão. “Ah, eu preferia numa cooperativa. Uma cooperativa tipo o nosso, o nosso grupo assim. E a gente faz e a gente desempenha porque sabe que vai dá resultado, você entendeu? (...) A gente sabe onde a gente pode procurar, onde vai dar lucro. Como vai dar a renda se produzir, entendeu? (...) Vem pra nós.” Joana não optou por superar a Joana-cooperada-vendedora, “eu preferia trabalhar na parte de vendas", mas encontrar outras condições objetivas em que possa articular a realização dessa personagem ao seu projeto de autonomia, a outras personagens importante ao sentido emancipatório já antes encontrado à metamorfose de sua identidade.

Pelo que representou essa experiência, pela força que ainda tem essa personagem que a Joana-que-nunca-volta-atrás, "porque esse mesmo de eu voltar aí você viu eu não volto nunca da 
onde eu saí é incrível”, talvez seja superada. O retorno ao Mãos na Massa não é negação, é possibilidade afirmada: "eu posso até voltar se a cozinha tivesse tudo montadinha, tudo legal, se fizer um projeto legal.” Afirmação contida no envolvimento ainda real, no sentir-se dona do que virá. "Agora espero que eles façam a cozinha lá e que reforma tudo e que fica igual aqui porque aqui, porque eu acho gostosa essa casa atrás não é? Eu posso até voltar.” 


\subsection{As questões vividas pelo e com o grupo Mãos na Massa}

Ao longo do trabalho com o grupo Mãos na Massa vivenciei junto com os futuros cooperados algumas situações importantes, marcos no desenvolvimento do grupo e do empreendimento. Alguns desses momentos puderam ser apreendidos pela observação participante e representados por palavras em meu caderno de campo; outros, certamente, foram apenas sentidos, vividos dentro do grupo, com emoções e pensamentos confusos, sem clareza suficiente para serem logicamente recapitulados.

É sobre isso esse subcapítulo, sobre o que pude compartilhar da trajetória do grupo a partir das oficinas de gestão semanais. Ao longo dos meses o esforço foi por captar as mudanças pelas quais passava o grupo, como um sujeito coletivo em formação, com atenção indispensável para isso aos sujeitos individuais que a ele davam vida; o mergulho no indíviduo, no entanto, foi guardado para as entrevistas de histórias de vida. Materiais complementares, portanto, caderno de campo e entrevistas.

A fim de ressaltar as fases dessa formação que pude acompanhar, sugiro passarmos por três momentos organizados a partir de comportamentos mais comuns dos sujeitos individuais, pela exístência e diferentes forças dos objetivos em comum, pelo empoderamento do grupo em relação à cooperativa e seus resultados.

\section{a. Momento inicial - conglomerado de interesses individuais}

Logo que começamos as oficinas de gestão e que comecei a construir uma relação com cada um envolvido no Mãos na Massa, o que encontrei foram pessoas que haviam aderido ao projeto por motivos distintos e que, assim buscavam algo diverso. Em razão disso, conformar um grupo parecia algo fora da pauta, muito distante ou muito pouco concreto. Os formadores contavam que já tinham realizado atividades com foco na exposição dos interesses individuais, na percepção das conjunções e no reconhecimento do outro, isso ao longo dos meses anteriores de

formação. Concordavam que se fazia importante dar continuidade a esse trabalho, por isso propus-me a inserir atividades lúdicas, jogos cooperativos, entre os temas de gestão das oficinas.

Especialmente nos primeiros encontros, era difícil realizar essas atividades com o grupo, a demanda era pelo trabalho "prático", por aquilo com o qual conseguissem identificar ligação direta com o negócio. Ilustrações disso são as vezes em que os jogos eram propostos ao final da oficina, quando restavam poucos minutos para o horário de término do encontro, e parte do grupo 
preferia ir embora, resolver outras questões. Quem permanecia eram, em geral, os mesmos, entre eles comumente Márcia e Luís participavam das dinâmicas, puxando, inclusive, as discussões que se seguiam, sobre a experiência.

Nesse mesmo sentido, havia o incômodo, declarado em particular, não abertamente, de uma parte do grupo em relação aos que aproveitavam as reuniões para "contar estórias", para falar sobre espisódios vividos ou que se tinha ouvido falar a respeito, colocar suas opiniões. A reclamação era de que isso "atrasava" as discussões mais importantes, cansando os outros, fazendo com que se distraíssem e perdessem-se na conversa. Muitos raros os momentos em que incômodos como esses eram trazidos à tona, oferecendo a oportunidade de discussão aberta com as posições colocadas. Formam-se segmentos de grupo, subgrupos no Mãos na Massa de acordo com as afinidades mais aparentes ou com a familiaridade que tinham uns com os outros antes do projeto, pela convivência em outras instâncias da comunidade. As reclamações e opiniões mais polêmicas circulavam nesses segmentos, por vezes chegavam aos formadores.

Quando por fim colocavam-se as contraposições para todo o grupo, aproveitando o espaço coletivo, compartilhado, as reações eram diversas; alguns deixavam a reunião tamanho o desconforto. Em uma ocasião em que a discussão beirou o caos, todos reclamando e jogando responsabilidades e pretensas culpas sobre os outros, Márcia preferiu ir embora, dizia não entender porque tudo não era mais simples, porque todos não ofereciam o que poderiam dar de si à cooperativa e se focavam no que tinha que ser feito para as vendas, afinal era por isso que estavam ali. A diversidade era complexa demais e dava trabalho. Márcia era uma das que colocava sua opinião nas reuniões sobre os diversos assuntos e com as quais uma parte do grupo nunca concordava ou desconsiderava, para eles sem valor nenhum.

Contando histórias, estórias ou oferecendo opiniões, era nítido para todos que sempre os mesmos participavam; esses mesmos instigavam os outros a participarem mais, incomodavam-se por não saberem o que estavam pensando, pela responsabilidade sobre as decisões não divididas. Os outros rebatiam, então, que não tinham "nada a acrescentar", por isso o silêncio. Nesse momento, Joana era uma dos que quase não se colocavam nas reuniões.

Fato é a heterogeneidade do grupo: Márcia tinha maior dificuldade em acopanhar as discussões e exercícios mais abstratos e, era a mais animada com o projeto e com as oficinas, admirava-se de como as ideias estavam tornando-se realidade e de quantas coisas novas estavam aprendendo. Ana fala muito, sem paciência para ouvir os outros e Maria ligava-se à prática, 
achava por demais cansativos os raciocínios teóricos, questionava o processo de formação. Luís sempre trazia contribuições ricas e diversas para as discussões a partir de histórias suas ou de conhecidos, nem sempre diretamente relacionadas ao tema em discussão. Ana e Maria punhamse, por vezes, impacientes e posicionavam-se baixinho, apenas para quem estivesse ao seu lado. Os casos de Luís foram, gradativamente, cansando alguns do grupo e ele passou a ser pouco ouvido.

Joana e Carlos quase não falavam, mas quando o faziam eram ouvidos em silêncio e com atenção; ao final de uma das oficinas Joana fez um comentário essencial para a resolução de um problema e para o andamento do grupo. Carlos pouco contribuía com as discussões, mas sempre se dispunha às tarefas práticas, fora dos horários de reunião e de produção, àquelas que ninguém, além dele e Márcia, propunham-se a realizar. Ao seu lado, Cristina era conhecida por suas reclamações feitas em particular e por um pessimismo constante e desanimador.

Simone era quem tinha mais dificuldade em acompanhar as discussões sobre a gestão do negócio, mesmo em relação à produção quase não se posicionava, mas estava sempre presente, pontualmente. Quando tinha oportunidade contava sobre sua vida. Era assim que se expunha e era olhada pelo grupo.

Os níveis de entrega de tempo, de trabalho, de dedicação ao grupo eram também diversos. $\mathrm{Na}$ medida em que o empreendimento exigia mais disso tudo, essa diferença entre disponibilidades ficava evidente e aqueles que tinham as expectativas frustadas em relação aos outros começavam a incomodar-se e, por outro lado, os que não estavam dispostos a assumir o projeto mais intensamente passavam a sentir-se cobrados. Um episódio ilustra esse conflito, houve um baile na comunidade simultâneo a uma das oficinas, alguns queriam estar lá, no baile, mas atenderam, com pesar a responsabilidade de estar como grupo, outros faltaram à reunião.

Assim, o que passou a ser nomeado de "falta de comprometimento" aparecia constantemente como eixo de reclamações e de conversas propostas pelos formadores. Vale trazer um exemplo dessa dinâmica do grupo: quando começaram a fazer compra da matériaprima para a produção junto aos formadores da ITCP-USP, Márcia foi a única que compareceu no sábado, para acompanhar os formadores, conforme o combinado, os outros faltaram embora tivessem combinado de estar junto. Como consequência, Márcia e um dos formadores tiveram que carregar grande peso e desistir de parte do que gostariam de comprar. $\mathrm{O}$ acontecimento foi enfaticamente criticado, principalmente por duas cooperadas, as quais, porém, não chegaram a se 
oferecer para participar nessa empreitada. Sem uma nova dinâmica traçada, acordada, a discussão permaneceu abstrata, a ser digerida individualmente.

Por sua vez, como contraponto, Márcia compartilhou a experiência de ter ido às compras com empolgação, parecia ter apreciado o exercício. Afirmou que conseguiria repetir a tarefa sozinha e que não havia grande diferença entre os preços dos varejistas da Zona Cerealista, portanto a pesquisa de preços poderia ser realizada com menor frequência, simplificando o processo de compras. Essa foi uma de suas contribuições importantes para o grupo durante a reunião; se não era ainda reconhecida pelo grupo por suas colocações, passava a ser por seu empenho, por suas ações em prol do coletivo.

Se atuando individualmente de acordo com seus interesses e gerando resultados, assim para o grupo, não era problema para Márcia e para mais alguns cooperados, atuar como parte de um grupo era problema: nos dias de produção cada um chegava em horários diferentes, como, segundo uma cooperada, "não dá para ficar parado esperando", os que chegavam mais cedo começavam a produzir, mas como há um processo produtivo desenhado pelo grupo em que uma tarefa depende das outras para que o resultado seja o esperado, os que chegavam depois ficavam perdidos. Eram comuns erros de receita, o que deixava todos frustrados.

Os atrasos para os encontros passaram a ser pauta constante de conversas e de novos acordos, refletindo a busca mais ampla de uma sintonia entre os membros do grupo, a demanda pela conformação de um grupo efetivamente. O movimento que se seguia era de adotar, generalizadamente, um certo desleixo em relação aos compromissos grupais, se não era possível que todos dessem um passo em direação ao doar-se mais, foi dado um passo no sentido oposto; aqueles que chegavam na hora, por exemplo aos poucos chegavam mais tarde, já sabendo que os outros também o fariam. Em uma das oficinas apenas uma das cooperadas, chegou na hora e justificou-se comentando que chegara "cedo" porque estava em outra reunião ali perto. O atraso havia sido instituído pelo grupo.

Determinada semana nosso encontro teve que ser cancelado porque o grupo participaria de um evento, conversamos a respeito da reposição, mas a tentativa de encontrar outro dia da semana para realizar o que tinha sido planejado não teve sucesso. A maior parte dos presentes mostrou-se preocupado com outros compromissos e chegou-se à conclusão de que seria difícil encontrar outro dia em que todos pudessem dedicar-se à cooperativa, mesmo que, por outro lado, transparecessem a preocupação com a parte da pauta dos encontros que deixaria de ser discutida. 
Claramente não era a perspectiva de gerar renda o problema, como se poderia imaginar em se tratando de um grupo em formação, o grupo dificilmente tinha estoque das barras de cereal, toda produção do único dia de produção da semana era vendida sem dificuldade. A questão parecia ser o sentido que aquele projeto tinha para cada um, sentido individuais ou ainda sem sentido.

O envolvimento superficial de alguns, ainda sem dar vida a uma personagem dotada de expressão de si mesmo no espaço da cooperativa poderia, ter em parte, a influência de ainda não terem seu lugar de produção e de encontro, de estarem na cozinha emprestada de uma organização local onde não podiam assentar seus materiais e matérias-prima e de onde estavam sempre na iminência de $\operatorname{sair}^{135}$. Em sua outra face refletia-se na dificuldade em determinar o quanto deveria ser produzido, em acertar a receita, em seguir o planejado; refletia-se na dificuldade em apropriar-se de qualquer das áreas do negócio, na resistência em assumir a autogestão.

Embora tivessem muitas ideias surgidas, inclusive, de visitas a outros grupos, de feiras e eventos, a transposição para a prática era bicho de sete cabeças. O desejo pela interação direta com a comunidade, mirando a segurança alimentar, era um desses projetos, para além da produção, que voltava à pauta de vez enquanto e parecia animar a todos, mas também não sabiam como levá-lo adiante, como realizar ações voltadas ao ambiente fora do grupo casando-as como tempo restrito, com as prioridades de cada um, e com a produção das barrinhas.

Esse era um ponto de comunhão que não poderia ser perdido; desde o início era afirmado nos encontros do grupo que o objetivo principal do Mãos na Massa não seria a venda, ela seria a consequência de um trabalho mais amplo, voltado ao fortalecimento da segurança alimentar na comunidade. Relevante esse decisão a ponto de direcionar o perfil do grupo que se formava: acima de 35 anos, com outras fontes de renda, mesmo que, por vezes, escassas, e com atuações, anteriores ou paralelas em organizações comunitárias.

Para realizar o que parecia ser o ponto de convergência dos sujeitos individuais, começaram a implementar a ideia que surgira em uma encontro com os formadores, passaram a oferecer "oficinas” em alguns eventos que já faziam parte da agenda comunitária. Tais oficinas,

\footnotetext{
${ }^{135}$ A questão do espaço para produzirem, onde se reunirem e para identificarem-se com era tratada com certa frequência, nesses momentos vinha à tona o Centro de Referência (CRSAN) que estava em reforma e cuja cozinha experimental poderiam usar. No entanto, era preciso recordar, nessas ocasiões, que esse é um espaço público e que seria dividido com outros grupos.
} 
promovidas pelo grupo sobre Segurança Alimentar em feiras e eventos pelo bairro e fora dele ${ }^{136}$, foram, desde o início, fonte de energia para o grupo. Sentiam-se recompensados com o sucesso que a atuação alcançava e com a atuação de todo o grupo: comentavam que todos que passavam pela barraca queriam participar, conhecer, reconhecer e falavam uns dos outros ressaltando o que tinham feito de positivo. Alguns diziam-se abertamente surpreendidos com o desempenho dos outros junto ao público. As oficinas eram levadas como momento de brincadeira, de interação, de descontração e assim acabavam vendendo todas as barrinhas.

\section{b. Segundo momento - quando o conflito adentra o coletivo}

A passagem do conflito do âmbito particular, das bordas para o centro da roda, foi paulatina e inevitável. Os desconfortos não mais cabiam no espaço do individual, do telefonesem-fio e transbordavam para o espaço coletivo. Isso apenas era possível porque aos poucos esse coletivo era formado, ainda tímido, mas já percebido intuitivamente por cada um. Ganhando esse corpo que se formava, o incômodo chegava ao centro com certo atraso em relação ao fato gerador, depois de haver rodado as beiradas.

A observação é de episódios como a da discordância trazida por Cristina a respeito da forma de pesar as ameixas e de mensurar o suco de limão. Esse tema, embora sem relação com a discussão que se desenvolvia na ocasião, foi trazido com insistência pela cooperada, a qual se colocava na posição de vítima-incompreendida, já que o grupo havia discordado de seu modo de executar essas tarefas na semana anterior. A reação dos outros membros foi tentar voltar ao assunto em pauta, dizendo que aquele não era o momento. Não houve diálogo.

$\mathrm{Na}$ oficina seguinte Cristina voltou à questão que ainda lhe incomodava, era impossível não discutir isso, ela não permitiria. Chegou-se então ao ponto nevrálgico da questão: o que a deixava tão insatisfeita era a forma como outra cooperada a havia tratado, depois, colocado de forma mais geral, como falava com todos, de forma muito impositiva.

A Cristina-vítima-incompreendida era trazida a mim, em particular, pela boca de Ana, bem como hábito de confessar suas insatisfações apenas para uma pessoa, informalmente, nunca para o grupo todo propondo uma discussão a respeito. Nessa ocasião, Ana fazia o mesmo contando em particular, "à boca pequena", mas aos poucos o assunto foi ganhando a roda e o grupo passou a requerer que as insatisfações fossem compartilhadas.

\footnotetext{
${ }^{136}$ Algumas foram realizadas na Cidade Universitária e em encontros das incubadoras tecnológicas de cooperativas populares, por exemplo.
} 
O que antes poderia ficar contido a uma relação entre dois, atingia, então, os outros, tomava outra propoções. A rixa entre Ana e Márcia era expressa em "pequenas alfinetadas" comuns nas reuniões; Ana arrumou uma aliada nessa rixa, Maria, quando Márcia falava as duas faziam careta, por vezes cortavam a fala e propunham um avanço na discussão. Dinâmica que parecia, nessa altura, incomodar a todos embora a reação não fosse coordenada, mas individual: alguns expunham interesse no que Márcia tinha para colocar, outros reclamavam desses comportamentos para os formadores, outros ainda permaneciam mais quietos do que costume, com medo de também terem suas falas repelidas.

Os jogos cooperativos e dinâmicas lúdicas, propostas desde o início do trabalho com o grupo com o objetivo de promover a superação do entraves no processo de formação do grupo, e de colaborar com a criação de novas personagens a partir dessa experiência, por cada cooperado, começavam, nesse momento, a ganhar a participação sincera, quase a serem desejados. Nessas atividades eram sublinhadas as dinâmicas próprias do grupo e a forma de atuação de cada cooperado: Márcia frequentemente liderava o grupo, Ana buscava soluções práticas, as mais rápidas possível, ao não encontrá-las, ou não movimentar o grupo todo, irritava-se, os que ficavam constantemente calados, assim permaneciam enquanto os outros, Márcia, Ana, Cristina e Luís, falavam todos ao mesmo tempo. Carlos e Joana pouco falavam, mas por vezes assumiam a liderança sem ou com poucas palavras, eram ouvidos e respeitados.

A relação também com o conteúdo das conversas mudava. A grande maioria do grupo anotava, nesse momento, os principais pontos discutidos sobre a gestão da cooperativa. Por outro lado, as atividades que passaram a ser propostas entre os encontros, "tarefas de casa", não eram realizadas pela maioria do grupo, a principal justificativa era esquecimento; para poucos o empreendimento tinha lugar na vida fora das reuniões, na relação com as outras personagens a de cooperado não se destacava pelo cumprimento do acordado nas reuniões ou pela dedicação de tempo e de energia a tarefas relacionadas à cooperativa. Se assumia forma em outras esferas da vida expressava-se por outros caminhos.

Embora utilizassem os processos e ferramentas de gestão do negócio, desenhados por eles em nossos encontros, qualquer demanda que surgia fora do período já programado de trabalho com o grupo era um entrave. Assim que a compra de matéria-prima era perigo, diante da demanda colocavam seus infindáveis compromissos como empecilhos para participar, a participação em eventos e feiras, um problema e as pesquisas a serem feitas fora do âmbito das 
reuniões, improváveis. Real para a maioria do grupo, os outros começavam a cansar-se de assumir todo o corpo da cooperativa em formação que precisava crescer para fora da sala de reunião e da cozinha da produção.

No que concerne à produção, depois de resolvidos os primeiros desentendimentos e que cada um alcançava a segurança sobre determinadas tarefas, havendo trabalhado por algum tempo na mesma função, inaugurou-se o rodízio de posições. O rodízio refletia-se nas reuniões do grupo; aos poucos os encontros passaram a ser melhor organizados, o primeiro momento era sempre de coordenação dos assuntos do dia e dos informes. A cada encontro duas pessoas do grupo eram encarregadas dessa função. O rodízio não era confortável, apresentava o desafio da mudança quando uma finalmente se apropriava de uma uma certa função, assim tinha-se que começar de novo. Por outro lado, mostrava-se mecanismo importante de tomada do empreendimento pelo grupo, caminho para o sentir-se dono e para que o temor do afastamento das organizações de apoio pudesse, aos poucos, tornar-se menos amendrontador.

Era com a ajuda dos outros que cada um assumia novas tarefas, passando pela dificuldade inicial da mudança e descobrindo o que mais gostam e o que não lhes apetece fazer. Joana, por exemplo, não gostava de cortar a massa no formato das barrinhas. A situação de Ana, no entanto, preocupava a ela mesma e tornava-se pauta dos cafés entre os cooperados: não tinha encontrado algo que lhe desse prazer em meio a todo o processo produtivo, dizia que "queria gostar mais do trabalho e das reuniões". Estava buscando encontrar essa realização, mas ainda sentia tudo como obrigação.

Para o grupo isso foi associado à situação socioeconômica um pouco melhor de Ana em relação ao resto do grupo, então a não necessidade de gerar renda a partir do projeto. O fato de seu marido ter um emprego considerado bom, que garantiria a qualidade de vida satisfatória para a família, seria para o grupo a razão desse desinteresse pelo trabalho. Interessante essa visão considerando que outros do grupo, embora talvez não contassem com a mesma situação financeira de Ana, também não precisassem da renda resultante da cooperativa para a sobrevivência. Parece ser esse um modelo de diferenciação replicado a partir da organização societal, trazida para dentro do grupo: a classe social baseada no nível econômico, poder de consumo. Na busca por um fundamento para o desinteresse em relação ao empreendimento coletivo, recorreram a esse mesmo elemento. 
A independência em relação à ITCP-USP e ao Instituto Pólis ainda constituía tema difícil para o grupo. Márcia era uma das que entendia que estavam longe de estar preparados para isso. As oficinas realizadas junto comigo entravam na mesma dinâmica: diziam, os cooperados, serem assuntos demasiados para discutir, muita novidade sobre assuntos difíceis, com os quais não estavam acostumados e que, portanto, era pouco o tempo que tínhamos juntos e reduzido o número de oficinas. Em parte verdade, a gestão do empreendimento era novidade, mas, nesse momento, ainda faltavam mais da metade das oficinas e o planejado era que depois continuassem a discussão e a prática dos mesmos assuntos com os formadores. O receio aqui parecia relacionado à dificuldade de imaginar o futuro em que o apoio estivesse nos outros cooperados, no grupo, de considerar a consistência de algo que ainda se formava, de encontrarem uma meta, com prazo preestabelecido, sobre a qual não tinham pleno controle. Mas também, a resistência por perder o acesso a recursos advindo dessas instâncias, organizações, pessoas que os apoiavam, como capital para a compra de matéria-prima e equipamentos e a participação garantida em determinadas feiras e eventos.

A heterogestão e a autogestão eram retomadas, em suas aproximações e incompatibilidades, em diversas situações, com diferentes roupagens. Em um dos encontros, em que falávamos de controle dos processos, Márcia ficou muito incomodada com o termo “controlar". Luís contou, então, uma lembrança de um chefe seu, em uma empresa industrial, que dava ordens aleatoriamente, mudando de ideia por impulsos e sem esclarecimentos, ninguém entendia suas razões, mas todos obedeciam sob pena de demissão. Por vezes, segundo Luís, quem mais se esforçava na linha de produção era demitido. Assim, "mandar" e "controlar" pareciam ser termos muito próximos e a discussão caminhou para as relações de poder, as razões para uns mandarem, outros obedecerem, e as repercussões para cada lado.

Uma preocupação do grupo era como resolver a equação entre o mando / obediência, que não queriam mais, e o controle, que acreditavam ser importante para que a produção tivesse um bom nível de qualidade, com algum padrão. Como o controle pode se dar participativamente, não sobre as pessoas, tornando-as heterônomas, mas sobre as tarefas e resultados, de forma que todos construam essa forma de controle e modifiquem-no sempre que sintam necessidade. Foi um debate importante, indicador de certo avanço no projeto de autogestão. Embora alguns não estivessem muito confiantes a respeito da viabilidade desse ideal no dia a dia da cooperativa, estavam convencidos de que tentariam e começavam a buscar ferramentas para tanto. 
Apesar dos conflitos mal resolvidos, da micropolítica ainda com caráter de fofoca, sem posicionamentos claros, e da resistência a assumir responsabilidades, as relações de confianças começavam a delinear-se. O grupo logo deparou-se com a questão da receita das vendas das barrinhas de cereal: não poderiam continuar sendo guardados, em dinheiro, pelos formadores da ITCP-USP, e nem serem distribuídos inteiramente entre os cooperados. O entendimento sobre a necessidade de guardar parte dos recursos para compra de matéria-prima para as próximas produções, pagamento de despesas diversas e para reinvestimento no negócio e neles mesmos (fundos) foi rapidamente compreendida. Recorriam ao repertório de suas finanças pessoais, das contas de casa e da reserva que tentavam fazer para imprevistos familiares.

A solução para a urgência em abrir uma conta bancária foi resolvida sem grandes delongas, as declarações apontaram a confiança em qualquer pessoa do grupo. Márcia e Carlos acabaram por se candidatar e abriram a conta em conjunto; era esperado que os dois e talvez Luís o fizessem, eram eles quem costumavam oferecer-se para a maior parte das responsabilidades que esperavam por um sujeito-voluntário. Gradualmente, nisso que estamos chamando de segundo momento do grupo, Joana foi aproximando-se dos dois em tudo que se relacionava à venda das barrinhas. Ela, Márcia e Carlos eram, agora, referência no Mãos na Massa quando se tratava de interagir com qualquer outro ator, sejam os fornecedores, bancos, clientes, consumidores e organizações do bairro. Pilar esse forte, de sustentação às suas novas personages, de cooperados e todas as que a partir dela fortaleciam-se ou poderiam nascer: sujeitos-cooperados-representatesdo-grupo, personificação da cooperativa.

Falava-se, então, com certa frequência, sobre a importância de todos saberem de tudo o que acontece na cooperativa e da necessidade de se ter as principais decisões e informações documentadas, para que todos possam acessá-las. Uma preocupação eram as regras de funcionamento, principalmente as de entrada e saída do grupo, isso é, a delimitação do dentro e do fora, da linha de interface com o ambiente e o quão "protegidos" estão em relação a ele. Passavam-se a enxergar em suas intersecções, na unidade a partir do comum, apesar das diferenças e queriam assegurar a permanência desse sujeito coletivo que se formava para além dos indivíduos que o compunham. Nesse momento o futuro espalhava-se pelas discussões, os planos e ações passsavam a ser mais presentes que o passado.

O reconhecer-se grupo começou a aparecer em diversos momentos, quando definiram que sempre que um acabasse suas tarefas deveria ajudar os outros nas suas e quando começaram a 
dedicar-se, assumidamente, à construção do objetivo comum, da razão de estarem ali. O tema despontava em meio a conversas variadas e alguns aproveitavam a oportunidade para colocar para todos suas motivações para comporem o Mãos na Massa e as expectativas em relação à experiência.

\section{c. Terceiro momento - em que o grupo e os sujeitos-cooperados conformam-se}

A maior preocupação do grupo em relação à entrada de novos cooperados dizia respeito à formação, como transmitir para esses trabalhadores o que vinham discutindo há mais de um ano. O debate sobre a importância de terem materiais prontos, para mostrarem para os entrantes, e pessoas responsáveis pela formação inicial e pela educação contínua começava a ganhar corpo.

O rodízio de tarefas passou a ser aplicado também nas funções gerenciais, mas ainda com dificuldade, resistências, dois passos adiante, um de volta atrás, por serem novidade recente, por estarem, os cooperados, menos familiarizados com elas. Formaram-se coordenações que ficariam por alguns meses com cada área do negócio e depois trocariam o aprendizado com as outras a respeito das diferentes vivências. Márcia estava na contabilidade, Joana em vendas, Luís em comunicação.

Com o passar dos encontros o grupo passou a desempenhar as tarefas propostas para a oficina seguinte, mesmo que a maioria ainda timidamente, na briga entre as tarefas que preenchiam seus dias antes do sujeito-cooperado, e as que eram, então, requeridas à sua formação. A exceção era Cristina, a qual, geralmente, dizia ter feito algo, sempre com resultado negativo, mas não o que havia sido combinado com o grupo. Carlos destacava-se pelo empenho, levantando informações de mercado para além de seu entorno, já pensando nas barrinhas em outros contextos; segundo Ana ele seria o mais animado, embora todos estivessem igualmente "engajados".

Nesse período surgiu, pela ITCP-USP, uma encomenda enorme de barrinhas para um congresso, o que deixou o grupo preocupado, especialmente Ana e Maria nervosas. Segundo a formadora da incubadora, no encontro para produção da semana anterior Ana teve um "ataque" porque haviam mudado a temperatura do forno e ela não tinha sido consultada a respeito. Porém, ela é uma das que mais reclamava dos momentos de planejamento da produção, instituídos às 
quartas-feiras, antes de iniciar a produção propriamente dita. O grupo, ou parte dele, que não atribuía grande importância aos momentos de discussão, planejamento e tomada de decisão coletivos, percebe, em um episódio de pressão por uma grande produção em pouco tempo, o papel de tal planejamento.

Esse primeiro momento em que outro nível de dedicação à produção foi exigido pelo compromisso assumido em relação ao trabalho no Mãos na Massa trouxe à baila uma discussão que vinha rondando o grupo: o envolvimento com a cooperativa seria sempre meio período, alguns dias na semana, ou ganharia espaço na vida dos cooperados? Conversa difícil essa, sem muitos dizeres, comunicação ainda por gestos, expressão corporal, silenciosa. Ana foi a que mais incomodou-se, contraditoriamente à sua preocupação em relação à entrega, é quem menor disponibilidade tinha para outros dias de produção e de formação. Ainda sem possibilidade de consenso, a discussão ficou ali, ao lado, acompanhando o grupo nos passos seguintes, amadurecendo.

Produziram o total combinado e entregaram ao cliente a encomenda, outro pedido grande veio na sequência. O sucesso do produto, resultado do trabalho do grupo, instaurava a contradição, sendo positivo, claro, talvez positivo demais para o papel que a cooperativa desempanhava ainda para alguns. Nessa fase Maria dizia-se muito cansada, elocubrando se continuaria na cooperativa já que o projeto ganhava corpo e eram requeridos outros dias de encontro para a produção. Luís afastava-se do grupo, sua participação não tinha como principal motivador a renda gerada, mas a busca por reconhecimento como parte de um grupo, o sentir-se parte importante para algo maior; o projeto tinha seu caráter de trabalho produtivo reforçado nesse momento, era escassa a oportunidade de propor ações como as envolvendo segurança alimentar comunitária.

O sujeito-cooperado perdia força frente às novas condições objetivas e Luís começava a ocupar seu tempo com outras atividades, outros grupos, eventos, viagens. Em determinada ocasião, já no final de meus encontros programados com o grupo, Luís pediu um afastamento temporário do Mãos na Massa, concedido.

Márcia assumia uma posição de liderança nas reuniões, colocando-se de forma segura mesmo quando não conhecia os assuntos em pauta, sempre a partir de sua experiência empírica, valorizando sua vivência. Joana continuava engajada nas vendas, sua maior preocupação era com 
a embalagem: levantava com insistência que era preciso ter um rótulo, com os componentes nutricionais das barrinhas para que conseguisse entrar em outros pontos de venda, maiores.

Sobras maiores começavam a surgir, as primeiras retiradas foram possíveis e o fundo da cooperativa crescia aos poucos. O desafio era a independência em relação às vendas veiculadas pela ITCP-USP e pelo Instituto Pólis, assumindo o contato direto com organizadores dos eventos de economia solidária e encontrando outros compradores assíduos, além dessas organizações. Com as retiradas, alguns animavam-se e voltavam-se, com maior afinco, aos planos para o futuro, seus e do grupo, sempre ganhando novos contornos, como Márcia e Carlos; outros não estavam satisfeitos, não encontravam no projeto o espaço esperado, mesmo que não assumidamente, para suas novas personagens, para suas particularidades, desejos e interesses, na luta por reconhecimento precisavam de um passo em outra direção. Assim, questionavam o pertencimento ao grupo e não lançavam-se ao futuro, a preocupação era com o presente. O dinheiro, ao mesmo tempo em que era importante e bem vindo, conferia um clima diferente ao grupo, mais sério, por vezes cisudo, era como se viesse de mãos dadas a uma responsabilidade incompatível com brincadeiras.

A autonomia em relação às organizações de apoio, bem como o término dos encontros de gestão comigo, era assunto corriqueiro agora para o grupo. Os cooperados tocavam frequentemente o tema com perguntas sobre os possíveis cenários na tentativa de obterem respostas acolhedoras, ao mesmo tempo em que se empenhavam no esforço de planejar-se para a próxima fase. Por vezes o assunto era empunhado como ameaça de um cooperado para o grupo como um todo, legitimando um descontentamento em forma de bronca, ou, para algumas pessoas em especial, apontando que, se continuassem com o comportamento tal, não haveria continuação da história dos sujeitos-cooperados sem os formadores. A independência do grupo era adotado nos projetos de autonomia individuais e coletivo, eles passavam a interconectar-se; o assunto ainda era carregado de angústia, mas entrava como calço desse projeto que se formava, conformava, transformava.

Por outro lado, ainda era realidade o lugar emrprestado, concedido como favor, aos encontros do Mãos na Massa, o que determinava os dias passíveis de reuniões e perpetuava uma sensação de não pertença, de transitoriedade. Levavam a maior parte dos ingredientes e materiais para casa depois da produção e traziam de volta no encontro seguinte, ao guardarem-nos em casa por vezes esqueciam parte e surgiam discussões a respeito de quem havia perdido uma ou outra 
coisa. O grupo sonhava com a cozinha experimental do Centro de Referência, um lugar que lhes permitiria determinar os dias, horários, períodos de produção, referência contanste nas conversas sobre esse tal futuro de todos e de cada um, por vezes parecia tão perto, outras distante.

\subsection{Processo de formação - indicadores, sugestões práticas e pontos de atenção}

Ao longo na análise das narrrativas de Márcia, Joana e Luís algumas questões buscaram ser compreendidas como indícios do sentido da metamorfose da identidade vivida pelos sujeitos no pertencimento e atuação no grupo, questões que podem nos indicar se o impulso é em direção à emancipação ou à reposição de ideologias, classificações, relações e personagens. Questões essas que foram usadas como apontamentos não apenas para o olhar ao grupo que se forma para a construção da cooperativa, mas também para as experiências vividas anteriormente pelos sujeitos, fundamentais para que seja possível aproximarmo-nos da maneira como eles chegam a esse novo grupo.

Assim chegamos a uma proposta de indicadores, a partir do referencial teórico apresentado até aqui em diálogo com a experiência de campo, junto ao Mãos na Massa, e com o material levantado nas entevistas de história de vida, que podem ser usados pelo próprio grupo, pelos formadores ou qualquer outro que acompanhe a formação e desenvolvimento do grupo autogestionário. O objetivo é incentivar que a reflexão a respeito do rumo que o empreendimento está tomando, se o de propiciar condições para o desenvolvimento humano, para o fortalecimento dos projetos de autonomia, do empoderamento dos sujeitos que dele participam, o destaque ao mundo da vida ou se replicam as mesmas relações e movimentos de fora, típico do sistema societal capitalista.

A reflexão é fundamental no processo de formação, é preciso quebrar o ritmo comumente tomado na implementação de projetos, mesmo sabendo que as metas quanti e qualitativas precisam ser alcançadas no prazo determinado; mesmo que o cronograma, símbolo da lógica estabelecida entre as organizações de apoio e seus apoiadores (financiadores dos projetos) seja opressor. Esse é um grande desafio. Talvez seja preciso um ritual estabelecido pelos formadores e pelo grupo, podendo ser proposto por qualquer uma das partes: com determinada frequência fazse o exercício de olhar para si e para o grupo, mais profundamente que o de costume.

As questões podem ser agrupadas a partir de seis perspectivas para a qual podemos olhar para a dinâmica estabelecida entre grupo, sujeitos-cooperados, formadores (organização de 
apoio) e ambiente mais amplo, além do grupo e da organização de apoio: ambiente formado e possibilidades oferecidas pelo grupo; tipo de socialização experimentada; repercussões subjetivas às objetividades encontradas; sentido encontrado para a metamorfose da identidade; relações com o exterior do grupo; a organização de apoio e o papel dos formadores.

Claro que são apenas apontamentos, não são exaustivos e nem precisam ser compreendidos na organização proposta.

- Ambiente formado e possibilidades oferecidas pelo grupo

○ Bases para o compromisso grupal, razões para estarem ali.

- Espaço encontrado para a palavra e ação de cada um e de todos - que espaço é esse, quais suas características e limitações.

- Sobrevivência garantida pela cooperativa ou de outra forma.

- Abertura / valorização da diversidade de experiências, conhecimentos e interesses.

- Organização do trabalho - quebra da separação entre o que faz e o que pensa e dos juízos de valor envolvidos nessa divisão.

- Estímulo, processos e iniciativas de aprendizado contínuo, oportunidade de que todos sejam aprendizes e tutores, dependendo do tema em pauta.

- Negociações de significado que fazem parte da micropolítica, o que trazem sobre o movimento do grupo, como vêm à tona.

- Tipo de socialização experimentada

- Tipo de reconhecimento que está sendo propiciado a cada um dos sujeitos reconhecimento legal, afetivo, solidário - de personagens pressupostas ou novas personagens.

- Papéis possíveis, encontrados no grupo e criados pelos cooperados.

○ Possibilidade de ouvir e de ser ouvido, como um igual.

- Oportunidade de compartilhar símbolos e significados, de apresentar aqueles que traz e construir novos.

- Possibilidade de ser visto e de enxergar o outro em sua totalidade, além de rótulos.

- Espaço encontrado para o conflito, para a contraposição de ideias e de interesses por meio do diálogo.

- Constante revisão das interpretações por meio da consideração de novas visões, de outras possibilidades não antes pensadas. 
○ Relações estabelecidas marcadas pela gratuidade e não condicionalidade.

- Espaço e experiências comuns identificadas e capazes de oferecer suporte ao sentimento de pertença e de permanência.

○ Ideias e sentimentos associados, por cada sujeito, ao grupo, à vivência no grupo.

- Repercussões subjetivas às objetividades encontradas

- Mudanças nas representações a partir de disputas políticas e contradições superadas no grupo.

- Superação de situações traumáticas e de contextos interiorizados e enrijecidos pelo vivenciar de relações de outro tipo.

- Transformação na forma de ver a si mesmo, das imagens associadas a si, refletida na maneira como se posiciona no grupo.

○ Consciência sobre sua singularidade e sobre as transformações experimentadas.

- Empoderamento - participação das decisões e donos de suas próprias escolhas, do que merece ou não ser vivido.

○ Identidade coletiva - se formada e como representada por cada sujeito.

○ Existência de planos para o futuro, individuais e coletivos.

○ Reflexão contínua sobre a autogestão, o consumo solidário, em um processo de educação.

○ Relação entre autogestão e heterogestão - desejos e representações em relação às duas vivências.

- Sentido encontrado para a metamorfose da identidade

- Espaço para os desejos e interesses individuais na vivência grupal, podem realizar-se apesar das divergências e diferenças.

- Rituais sociais em que a diversidade pode entrar em cena e rituais pelos quais as diferentes ideias podem ser apresentadas, reconfiguradas, recriadas.

○ Consciência sobre as transformações vivenciadas como indivíduo, sujeito.

○ Vivência do papel de cooperado - personagens que ganham vida ou são fortalecidas, repercussões para o movimento em que vinha até então a identidade, maleabilidade do papel e de seus pressupostos.

○ Superação das contradições encontradas e possibilidade de alterização, dar vida àquilo que também se é, mas que ainda não era conhecido e reconhecido pelo outro. 
○ Orientação por si mesmo na participação no grupo e reconhecimento dessa autodeterminação.

- Participação efetiva na construção das normas no trabalho e na vida em geral, deixando a posição de obediência, de aceitação.

○ Relação estabelecida com os rótulos aos quais se esteve atrelado sem correspondência subjetiva.

○ Representação e valorização de si mesmo em relação ao outro, em posição de igualdade, nas diversas circunstâncias sociais.

○ Percepção sobre sua singularidade, semelhanças e diferenças em relação aos outros.

- Relações com o exterior do grupo

○ Valor do grupo em relação ao exterior - superação da tendência à inferiorização do projeto alternativo à organização preponderante do trabalho e das relações.

- Valor atribuído às atividades ligada à casa e ao bairro, além do trabalho que gera renda.

o Visão crítica - olhar para o contexto como formação sócio-histórica, não predeterminado ou individualizado.

○ Engajamento na mudança da realidade ampliada - intervenção ativa no ambiente em que se vive.

○ Abordagem nos planos coletivos, para o grupo, para a cooperativa, do envolvimento de mudanças estruturais, além da ocupação dos interstícios do sistema.

- A organização de apoio e o papel dos formadores

○ Incentivo ao rodízio de tarefas e de papéis, incluindo o próprio papel do formador ou facilitador das reuniões.

○ Base em que se legitima as ações externas, de fomento, as sugestões e as propostas feitas ao grupo.

○ Participação, e de que forma, nas decisões vicerais do empreendimento.

○ Direção percorrida pelas decisões e ações, de onde partem e como ressoam na relação grupo-formadores.

○ Pontuação clara dos interesses institucionais da organização de apoio, apresentação dessas particularidades nas negociações.

○ Ganho de autonomia pelo grupo em relação à organização de apoio - diminuição do medo do distanciamento. 
○ Articulação com outras organizações apoiadas, contribuindo para a diversidade de visões e de ideias no processo de formação.

○ Fomento à igualdade de posições e da participação de todos.

○ Proposição e incentivo ao rodízio de tarefas e papéis dentro do grupo.

○ Instrumentalização do processo de tomada de consciência, da luta por "ganhar a sociedade", pela visão e atuação crítica.

- Discussão sobre cidadania, direitos e deveres, como acessá-los.

○ Abordagem de questões macro, estruturais, além da formação do grupo e do empreendimento autogestionário.

Importantes, aqui, considerações sobre dois aspectos sobre os quais somos levados a refletir a partir do material sistematizado nessa pesquisa: o papel das organizações de apoio, mais especificamente dos profissionais que atuam como formadores junto aos grupos na construção da autogestão e as condições externas, anteriores ou além do empreendimento, necessárias ou catalisadoras do exercício autogestionário.

Em relação ao primeiro ponto, gostaria de trazer alguns desses elementos para reflexão à tona, propor que seja realizada antes e durante o trabalho de formação, nos rituais de planejamento dos núcleos de formação e em alguns encontros com os grupos. Está claro que essa reflexão é ainda mais importante no acompanhamento das cooperativas exógenas, grupos que ainda não possuem, no início do processo, uma identidade coletiva conformada e assim força para colocar sua visão e seus próprios interesses com a mesma força, em pé de igualdade, aos das organizações de apoio. São grupos esses, ainda, em que o apoio da organização externa pode ser tomado como a razão para o grupo existir, ou a base para que o empreendimento caminhe; assim o medo do desligamento pode contituir uma relação de submissão, mesmo que sem a intenção ou consciência de cada uma das partes envolvidas.

Para evitar que essa relação, antes já vivida, na maior parte das vezes, pelo cooperado e por qualquer cidadão da organização societal vigente, para que não se corra o risco de, em lugar de um processo de emancipação, fomente-se uma história de dependência, de subordinação, de desiquilíbrio de poder, a reflexão constante é indispensável. Também para que verdades assumidas possam ser questionadas, para que haja espaço para a construção de uma visão de 
mundo a partir do questionamento e da consideração da própria subjetividade, alguns elementos são relevantes para a dinâmica do processo de formação:

- Incentivo do compartilhamento dos objetivos pessoais em compor o grupo, em integrar esforços de formação da cooperativa, para que a diversidade de interesses possa ser conhecida, para que possam ser reconhecidos como legítimos e, alguns deles, sejam evidenciados como comuns. Esse processo mostra-se importante para que um projeto coletivo seja, aos poucos, construído e para que uma identidade coletiva tenha o caldo para existir. Os formadores podem, nesse sentido, propor momentos em que isso aconteça, a princípio com a utilização de exercícios lúdicos, de jogos e dinâmicas por meio dos quais se torne mais fácil mostrar-se, falar sobre si mesmo; mais adiante no processo de formação do grupo a proposta e o exercício podem ser mais diretos, de uma conversa aberta sobre as motivações de cada um.

- Estabelecimento de espaço e condições para a exposição e realização do conflito. Para que as dissonâncias sejam trazidas à tona e à consciência, os formadores podem propor que questões que aparecem, geralmente, como reclamações, incômodos, sejam levadas aos momentos e espaços coletivos, reuniões, assembleias, encontros. Processo esse catalisador da formação do grupo ou do fortalecimento dos laços que aos poucos são criados; ao contrário dos mecanismos em vigor em na vida cotidiana, no trabalho e no que se chama política, que se prestam ao abafamento do conflito, propiciar que ele seja encarado e seus componentes compreendidos são incentivos ao amadurecimento do coletivo e ao desenrolar do movimento dialético por meio dos quais os dilemas grupais são superados e o grupo avança ao encontro de seus objetivos.

- Que atenção especial seja oferecida aos temas economia solidária, cooperativismo e autogestão não é novidade, no entanto, não basta que estejam no holofote no início do processo, nos primeiros meses de trabalho com o grupo e depois essa discussão seja adormecida em prol de outros assuntos também importantes e da própria produção e venda. Conceitos e reflexões sobre temas que são o arcabouço para um novo modelo de produção e de relacionamento precisam acompanhar a prática como constante no processo de formação. As organizações de apoio sabem bem como fazê-lo, mas 
podem deixar essa motivação ser engolida por outras demandas que parecem mais prementes no trabalho com o grupo.

- Proposição e persistência na realização do rodízio de tarefas necessárias ao empreendimento e ao desenvolvimento grupal entre todos os futuros cooperados. É por meio desse exercício que se pode experimentar diversos pontos de vista e compreender as diferenças de interesses. Também essa prática propicia que a valoração das atividades, socialmente constituída, enrijecida e replicada, seja repensada com base na vivência, na experiência humana. A divisão entre trabalho manual e intelectual, bem como a hierarquia estabelecida, pode ser contestada, transformada. Além disso, é por esse exercício que as habilidades e vocações podem ser descobertas ou afirmadas e que se pode escolher entre os papéis disponíveis na cooperativa.

- Incentivo ao questionamento de respostas trazidas automaticamente ou de premissas assumidas sem que precisem ser mencionadas, dadas como verdade. Tanto o papel de questionador pode ser assumido, ao menos inicialmente, até que outros também o assumam, pelo formador, perguntando os "porquês" de conclusões, de fatos, de dados trazidos nas reuniões, como a proposição de discussões a respeito de processos históricos, como as diversas organizações do trabalho já experimentadas, são medidas válidas nessa missão. Desse exercício é possível que posições mais críticas em relação ao contexto sejam visitadas e que dispositivos estruturais, como a luta de classes, sejam considerados.

- Proposição de conversas sobre o futuro. Elas podem ser começadas com imagens nas quais o futuro é expresso por meio de desenhos, descrições, ou de qualquer outra forma. O futuro de cada um pode, aos poucos, incluir perspectivas sobre o grupo e sobre a cooperativa; além de refletir o papel conferido ao projeto coletivo no projeto de vida dos sujeitos, esse exercício cria oportunidades para que o futuro da própria cooperativa torne-se pauta trazendo força ao processo de formação de grupo.

- Inclusão dos direitos e deveres, da cidadania, na pauta do programa de formação. Essa discussão parece ser positiva para o que Beatriz (2007) chamou de intrumentalização da tomada de consciência, assim como para que uma postura de 
luta pelos interesses seja assumida no lugar da aceitação, da resignação, da insatisfação a partir de uma perspectiva individual, isolada.

- Articulação do grupo, da cooperativa, com outros grupos apoiados pela organização propiciando a troca de experiências, de ideias e a organização inter-grupos para a superação de problemas compartilhados e para influenciar dinâmicas e mecanismos externos, do contexto. A multiplicidade de visões e de ideias ainda maior que é trazidas por essa articulação é positiva para a consideração da diversidade como riqueza. Ainda, é possível que essa troca com outros grupos colabore com conferência de novo sentido à cooperativa, como componente de um movimento, da economia solidária, extrapolando a função de geração de renda, chegando a um projeto econômico, social e político.

Com o mesmo objetivo, há pontos de atenção a serem considerados pelos formadores como prevenção de riscos, de lugares comuns em que o trabalho de formação pode recair. Pontos que podem ser trazidos aos rituais das organizações de apoio em forma de questionamento para reflexão que pode ser, até mesmo, feita individualmente, sem que respostas precisem ser dadas ao grupo.

- Sobrevalorização do conhecimento acadêmico ou institucional em relação ao conhecimento empírico e intuitivo. Sem que estejam conscientes disso, os formadores podem assumir um discurso positivista embasando uma possível posição de liderança na tomada de decisões em relação ao próprio grupo. Essa relação tende a ser assumida, logo de início, pelo grupo, valorizando aqueles que alcançaram um nível de educação formal mais alto que a maior parte dos cooperados, por isso, mais do que não alimentá-lo, é importante que os formadores contribuam para sua quebra, transformação. Ao contrário, o risco maior é que esse mesmo discurso seja assumido pelos representantes da organização de apoio para influenciar de forma mais contundente o rumo do empreendimento de acordo com o que acreditam ser o melhor para o grupo, o mais coerente em relação às suas interpretações sobre os princípios da economia solidária.

- Não participação direta nas discussões e tomadas de decisão viscerais para o empreendimento. É evidente que os formadores terão suas visões particulares e institucionais sobre o momento e o dilema enfrentado pelo grupo, e que são atores presentes na equação, 
no entanto, a proposta é que seja feito o esforço de menor intervenção possível, de que informações sejam trazidas se demandadas pelo grupo, mas não oferecidas para que determinado caminho seja escolhido. O próprio grupo, provavelmente, requerirá a posição dos formadores como determinantes em suas decisões, para que se sintam mais seguros e confortáveis, por isso mesmo que, cada vez mais, os formadores devem tentar abster-se para que o sentido da tomada de decisão seja invertido, assuma a direção do grupo para a organização de apoio.

- Cuidado com a forma como o afastamento entre cooperativa e organização de apoio é abordado junto ao grupo. O temor em relação a esse movimento que se trata, opostamente, de uma conquista, do alcance de um novo patamar pelo grupo, pode ser a base para o acirramento dos laços de dependência, do estancamento do desenvolvimento coletivo. Atitudes de boicote, mesmo que não pensados, à mudança nos laços com os formadores podem entrar em cena, como criação de novas demandas e envolvimento dos formadores em questões que poderiam ser discutidas e decididas autonomamente. O que parece ser mais indicado é que esse novo patamar não seja tratado como ameaça, como possibilidade de abandono, de situação de desamparo.

Da mesma forma como a educação continuada, entendida como um processo de reflexão e de informação para a posição crítica em relação a verdades dadas e construção de uma compreensão própria de mundo, é indispensável entre os cooperados ao nascimento e desenvolvimento da autogestão, ela é fundamental aos profissionais que se ocupam do apoio à formação desses empreendimentos. A formação continuada precisa ser real também para esses profissionais, cultivada nas organizações de apoio para que eles mesmos possam atuar como sujeitos políticos conscientes de seu papel, de seus interesses, oportunidades e limitações de suas atuações.

Questão que permanece e que levo até o fechamento dessa dissertação é qual o potencial ou o limite inerente ao trabalho de formação de criação de um microambiente propício à autogestão, isto é, em que estejam presentes as condições necessárias à participação de todos os membros do grupo na elaboração de decisões coletivas, tomadas entre iguais, a partir da consideração dos diversos interesses e posições. Microambiente esse mergulhado em meso e macro contextos, nos quais ainda imperam a organização heterogestionária e a dominação do 
capital, do econômico, sobre as outras instâncias. Como e em que medida se pode fomentar uma mudança cultural, requerida pela autogestão, é uma questão que se coloca em conjunto com aquela assumida como disparadora dessa pesquisa: se a vivência autogestionária pode contribuir para que um sentido emancipatório seja adotado na metamorfose constante da identidade do sujeito-cooperado. Para que haja a autogestão vimos que algumas condições são necessárias, entre elas vivências prévias, trazidas pelos sujeitos. 


\section{Consideracões Finais - o fim de um texto, o início de uma nova história}

Se o cooperativismo exógeno apresenta-se como única alternativa para que alguns possam laborar, para parte dos cooperados acaba constituindo-se em mais do que isso. Alternativa também de trabalho com potencial de inaugurar o palco para a ação ${ }^{137}$. Palco como conjunto das condições objetivas requisitadas para que, as necessidades de sobrevivência atendidas, as experiências, interesses e desejos individuais encontrem sentido em cena justamente pela presença de outros atores, pelo reconhecimento da particularidade de cada um integrada na diversidade do coletivo.

O enraizamento e o pertencimento ${ }^{138}$ parecem poder, sim, serem alcançados no grupo formado em prol do estabelecimento de uma cooperativa de trabalho; se adeptos por razões diversas ao empreendimento, os sujeitos-cooperados-em-formação podem construir objetivos comuns e criar um projeto para o futuro traçado no trabalho produtivo e na relação que esse novo sujeito coletivo potencialmente estabelece com a comunidade. Potencial todo esse contido no vira-ser de uma relação entre sujeito invíduo-grupo-sociedade que rompe com o padrão em geral replicado, com a dinâmica violenta de subjeição das expressões e necessidades subjetivas a uma realidade tida como dada e imutável, que se mostra magnânima na imposição da ameaça de aniquilação biológica e simbólica da vida humana.

A nova relação que pode ser inaugurada parte do reconhecimento legal e solidário ${ }^{139}$ propiciado pelo espaço coletivo quando caracterizada pelos princípios da economia solidária pode, por sua vez, fundamentar a autovalorização, a confiança em si mesmo, e a retomada da voz para fazer-se representar; voz que pode alçar voos, tornar-se grito de autodeterminação, compondo um avanço no projeto individual, por vezes coletivo, de autonomia. As cooperativas exógenas de trabalho têm este como elemento central: é pelo chamariz da oportunidade de trabalho que, como já sabemos, muitos aderem a um projeto sobre o qual pouco sabem a respeito. A atração é por um trabalho que se imagina semelhante ao encontrado antes, formatado em emprego ou em trabalho informal; é aos poucos que uma proposta que encontra escassa referência nos repertórios individuais parece ganhar sentido para alguns. Em torno da atividade

\footnotetext{
${ }^{137}$ Labor, trabalho e ação com o sentido atribuído por Hanna Arendt (1964).

${ }^{138}$ Conceitos propostos por Cris Andrada (2005).

${ }^{139}$ Axel Honeth (2007).
} 
produtiva, um conglomerado de indivíduos reúne-se, para que ela funcione sentem a necessidade de organização que depende de cada um, de ocupar o espaço da determinação das tarefas e processos que não será preenchido por outrem, mas observado, considerado, regulado por todos os outros; aos poucos pelo que passa a se chamar grupo.

Essa auto-organização, como identificamos no Mãos na Massa, dificilmente forma um círculo perfeito, equidistribuído sobre o grupo, essa é uma construção processual, pautada pelas vivências e significações particulares, encontradas por cada sujeito-cooperado. De qualquer forma, mesmo com o espaço de determinação mais centrados em alguns, frágeis ocupações para outros, parece ser a partir dessa experiência de organização para o trabalho que se torna viável a organização para outras atividades e ações, como as oficinas de fortalecimento da segurança alimentar na comunidade. Foi a partir da organização e vivência da produção coletiva que o grupo abriu-se à discussão e ao planejamento da gestão do empreendimento, a partir dessa prática que principíos, valores, ideias passaram de abstratas a concretas. Ideias, princípios, valores que, se dotados de sentido inauguram uma nova forma de relacionar-se para além da cooperativa, além do grupo, nas outras esferas da vida.

Pelo fortalecimento do mundo da vida ${ }^{140}$ no âmbito do trabalho o agir interesseiro enfraquece-se também nos outros palcos; vemos que na organização cooperativa do trabalho o contrário é igualmente possível, que o mundo da vida fortalecido nos outros âmbitos contagiem a convivência do grupo, isso porque é uma organização do trabalho que propicia isso que, ao contrário da organização capitalista, não oferece mecanismos e ferramentas de incentivo ao entendimento do outro como meio para o alcance de determinados fins. Também porque a divisão entre trabalho e vida cotidiana é ilusória, ideológica; trata-se da mesma pessoa, do mesmo sujeito que visita o filho na cadeia e vai à feira de economia solidária, que participa das reuniões sobre as diretrizes políticas do Mercosul e assiste televisão com os netos, que adota uma criança que vivia do lixo e compra matéria-prima para a produção das barras de cereal, que planeja as oficinas de gestão que ganham vida junto ao grupo e escreve sobre a história de vida de seus sujeitos-cooperados.

O repertório com que se chega à costrução da autogestão, ou pelo menos a essa proposta, formado a partir de todas as experiências vividas até ali e ali, naquele momento, a todo momento, repertório constantemente em formação, transformação, o qual a própria experiência no grupo

\footnotetext{
${ }^{140}$ Conceito proposto por Jungen Habermas (1983).
} 
passa a compor, garante que a resposta de cada um à mesma proposta, ao projeto da cooperativa, seja única. Repertório esse singular, particular, é fonte para o sentido conferido ao cooperativismo, à autogestão, à economia solidária em determinado projeto de vida. Mesmo que o projeto de vida possa ter sido retomado e reconfigurado a partir dessa experiência, o sentido emancipatório pode estar no afastamento em relação ao grupo pela ausência de sentido encontrada frente ao trabalho cooperativo junto a tal grupo, em certo projeto coletivo. Assim, enquanto alguns repertórios em contato com a autogestão fortalecem esse exercício, ganham nova energia de vida, outros podem chocar-se e lançar-se em outra direção.

Um sentido muito peculiar, único, exclusivo foi conferido à experiência junto ao Mãos na Massa, ao grupo, aos formadores, ao processo de trabalho e à gestão, por cada um dos sujeitos ouvidos nessa pesquisa. Um sentido específico também foi conferido por mim à vivência junto ao grupo. Pelas oficinas de gestão, foi-me possível compartilhar determinado período da história do grupo, da história de cada um que ele compunha e da minha própria história de vida.

Se foi-me permitido, pelas oficinas, reuniões e eventos junto ao grupo, ver personagens de cada um em cena, personagens que apareciam a partir do papel de cooperado em formação junto com a cooperativa, foi pelas entrevistas de história de vida, ouvindo e interagindo com as lembraças de cada um dos três sujeitos, Luís, Joana e Márcia, que pude reunir indícios sobre o movimento dessas persongens: novas, antigas, fortalecidas, fragilizadas, com ou sem espaço. Metamorfose constante, dotado ou não de sentido emancipatório. A complexidade da compreensão desses indícios une a interpretação dessas lembranças com os olhos dos sujeitos daquele momento, com as personagens de então, compondo uma narrativa que provavelmente não seria a mesma de alguns dias antes ou depois, à minha própria interpretação.

Foi nesse encontro de encontro de inúmeras personagens e infindas variáveis que se combinam em infinitos vires-a-ser, que foram buscadas e traçadas respostas à questão que impulsionou essa pesquisa: “a vivência autogestionária em cooperativas de trabalho exógenas serve de impulso para que a metamorfose constante da identidade ${ }^{141}$ dos sujeitos cooperados encontre sentido emancipatório?”. Lançando-se a ela, dotada do referecial teórico já conhecido e da convivência com os sujeitos, ambos em construção ao longo da pesquisa, a análise das narrativas de história de vida de três sujeitos da cooperativa em formação, Mãos na Massa, é a matéria-prima para o explorar das possíveis respostas, para o avanço, que se propõe, a respeito da

\footnotetext{
${ }^{141}$ Fenômeno descrito por Antônio Ciampa (1987).
} 
inter-relação entre o cooperativismo autogestionário, que coloca em prática os princípios da economia solidária, e a identidade como metamorfose constante.

As personagens-cooperada são, apesar das trajetórias semelhantes entre os três sujeitos, percursos alegóricos das classes socioeconômicas em diversos sentidos desfavorecidas brasileiras, dos quais muitos representantes são migrantes da área rural para os centros urbanos, representações particulares da repercussão subjetiva de um ambiente objetivo em formação: da cooperativa de trabalho Mãos na Massa. Cada um traz para esse ambiente um caminho de frustrações e vitórias na luta pela autodeterminação, avanços e retrocessos em seus próprios projetos de autonomia.

Para Márcia, sua história junto à do grupo em formação ofereceu nova energia à Márciaque-busca-pertencencimento-no-coletivo e à Márcia-assitencialista-que-dedica-secompletamente-ao-outro, à comunidade, essa vivência não parece ter inaugurado um sentido novo para sua metamorfose de identidade, mas oferecido novo impulso a esse caminho em trilha, o econtro a mais um projeto em que a Márcia-agente-de-saúde pode diversificar suas atividades, angariando parte de seu disputado tempo dividido entre as inúmeras atividades no Jardim Jaqueline. A Márcia-cooperada pôde existir, ganhou corpo, pelas experiências sociais anteriores, com base na atuação em outros programas e projetos enfocados na assistência aos que estão em pior situação no Jardim Jaqueline. Caminho de tal forma traçado a partir da articulação das personagens que Márcia trazia à nova situação objetiva, à favela.

Retomando algumas de suas personagens, protagonistas de sua narrativa de história de vida, temos indícios das direções seguidas, idas e vindas, do movimento de identidadade de Márcia. A Márcia-bicho-do-mato, que ganha vida ainda nos primeiros anos de vida por não encontrar, Márcia, espaço para existência entre os homens, coexiste com a Márcia-serelepe, criança brincalhona e criativa que solta no mato tem todo o espaço, toda a liberdade para criar. Por um mecanismo, uma artimanha, encontra uma forma de ser olhada pela família, de destacarse pela diferença, é a Márcia-que-chama-a-atenção-pela-doença; ela articula-se às outras personagens de tal forma que uma nova ganha incentivos para concretizar-se, a Márcia-queenxerga-o-mundo-por-seus-mistérios. Personagem essa que, por sua vez, articulada com as outras, especialmente com a Márcia-doente, oferece insumos à Márcia-espírita-que-crê. Enquanto as primeiras personagens vão perdendo espaço, a doença, o mistério e o espiritismo continuam, por longo período, compondo a identidade de Márcia. 
Movimento esse, até aqui, em que personagens são repostas e outras surgem sem aparente mudança de sentido; sentido esse que não diríamos emancipatório, considerando que as condições que não merecem ser vividas, que negam reconhecimento à Márcia, que tendem a impedi-la de posicionar-se entre os homens, não são superadas, mas são encontrados atalhos, mecanismos, artimanhas para que seja possível conviver com elas, permanecer humana apesar delas. Permanece-se em um nível de consciência próximo ao que Habermas (1982) nomeia como um "hedonismo ingênuo". As contradições não haviam sido superadas quando Márcia muda-se da fazenda para a cidade, frente às novas condições objetivas é a Márcia-serva que ganha vida de mãos dadas à Márcia que vive de favor. Situação mais lomítrofe porque não há fuga, não é possível o perder-se no mato, situação em que nada mais lhe pertence, nem ela mesma.

A tentativa de mudança dessa situação, a greve de fome na tentativa de superar a Márciaserva-que-vive-dos-restos, não se configura um passo em direção à sua autonomia, chama a atenção para as condições restritivas em que se encontra, para uma violência que lhe é insuportável agora, mas que se faz como outra violência; sem conseguir dar um passo adiante em sua libertação, Márcia dá um passo para trás, talvez na estratégia de ganhar distância, correr de mais longe e ganhar mais impulso para a mudança. Em sentido semelhante, Márcia busca o caminho do casamento, instituição de um outro explorador, reposição da mesma personagem que apenas assume novas formas, Márcia-esposa-serva-sem-voz. A doença volta a ser a expressão de sua humilhação, do aniquilamento simbólico para o qual caminhava.

Parece ser pela descoberta do espiritismo que pode começar a mudar o sentido da metamorfose de sua identidade. Márcia-médium-especial constitui-se na possibilidade de nova interpretação de sua história, de articular-se com os homens por suas semelhanças e, principalmente, diferenças. Ainda sem possibilidade de colocar-se na posição de capitã de sua vida, determinada pelos mistérios de outro plano, além da vida, é a mudança para São Paulo, o trabalho como empregada doméstica, que terminam de compor o trampolim para um salto qualitativo: Márcia-empregada-rebele e Márcia-em-busca-do-que-merece-ser-vivido caminham juntas na procura por outra organização do trabalho, colocam-se no papel ativo na superação de uma contradição que não merece ser vivida, Márcia-capitã-de-sua-vida começa a desenhar-se.

É no sentido emancipatório da metamorfose de sua identidade, movimento com idas e vindas, avanços e retrocessos, que pôde nascer a Márcia-confiante-e-segura-de-si, que vai além da luta pela sobrevivência, que busca-conhecimento como matéria-prima para a sua interação 
com o ambiente e com o outro de forma altiva, na posição de quem olha também e não apenas procura ser olhado. A Márcia-que-trabalha-para-melhoria-da-comunidade, que econtra sentido para o seu trabalho na relação com o outro e com o mundo. Sujeito do olhar, o julgamento do que não merece ser vivido ganha dimensões comunitárias quando Márcia depara-se com a favela; ela mesma torna o agente da mudança que quer para si e para todos. A mesmice não marca mais sua história, mas a mesmidade entre ser-fazer-pensar; são diversas personagens que se formam, articulam-se com ou substituem outras personagens, de acordo com as novas experiências desse caminho trilhado a partir de seu projeto de autonomia.

Márcia-mulher-mãe-militante-agente-de-saúde, Márcia-que-dedica-se-ao-outro, Márciaque-percebe-na-ação-coletiva-maior-impacto, Márcia-que-busca-um-grupo, Márcia-cooperada. No Mãos na Massa encontra um grupo em formação, o tema saúde, a proposta da dedicação à comunidade, da construção coletiva do conhecimento necessário à autogestão, ideias essas com que Márcia conecta-se rapidamente, que ressoam em seu universo; vivência essa, na cooperativa em formação, que parece dar novo impulso à sua metamorfose em sentido emancipatório à qual já antes se lançara. A Márcia-cooperada é um avanço na medida em que oferece a posição, antes buscada, de quem participa da elaboração das normas do coletivo, dos projetos do grupo e, claro, da organização do trabalho. O impulso vem da autogestão.

Quem nos conta sua história é a Márcia-que-assume-os-fatos-como-suas-decisões, que traz para si a responsabilidade por sua própria vida, não apenas por ser agente da cooperativa autogestionária em construção, mas também por isso. Seus planos para o futuro envolvem outras personagens, Márcia-disposta-ao-novo, expressão de si mesma no mundo; passam pelo trabalho e pela ação coletiva, pelo engajamento na mudança do que não merece ser vivido, na participação na elaboração das regras e nas decisões, na determinação de si mesma, talvez pelo cooperativismo, é possível que não pelo Mãos na Massa.

Para Luís, o período de sua história junto ao grupo, nesse projeto, já era tomado, no momento de sua narrativa, como uma passagem, transitoriedade dotada de sentido, em convergência com seu projeto individual de autonomia, a uma metamorfose a partir da ação na construção de outros níveis de consciência já antes inaugurada; atividade no mundo, consciência e identidade no embalo de uma posição ativa perante a objetividade. A trajetória marcada pela atuação política de Luís funda tantas personagens que têm em comum a militância pela autodeterminação e pela construção de um mundo mais justo, mais humano, fortalecida pela 
certeza de que existem outros cenários, tão possíveis quanto os encontrados em sua história. Mais significativo, nesse sentido, no momento da entrevista, que a participação no Mãos na Massa, era sua atuação como representante do Brasil no grupo do Mercosul Solidário, coordenado pelo Pólis, na rede do Jardim Jaqueline, ou suas viagens como portas e janelas para outras realidades, confirmando sua certeza de que um outro “outro” sempre é, mais que possível, necessário.

Portanto, é o Luís-que-considera-o-contexto-mais-amplo nas reflexões sobre o passado, o presente e nos planos para o futuro que adentra a cooperativa autogestionária em construção. $\mathrm{O}$ entendimento de si mesmo como sujeito político vem de bem antes, da percepção de que a vida na lavoura em Califórnia não era digna para os que não tinham a posse da terra, eram portanto dominados por uma lógica desumana. Essa consciência é a base para o Luís-que-luta-pelo-queacha-certo, para além das regras vigentes. O notícia de que outras formas de organizar as relações sociais eram tão reais quanto aquele que vivia em outro tempo, em outros lugares, vinda de suas conversas sobre o comunismo, expande seus horizontes, é insumo para sua consciência crítica, para o Luís-inconformado. Assim que o combustível para o Luís-sujeito-político é, desde cedo, o Luís-ligado-ao-que-acontece-no-mundo.

Luís-sujeito-político apenas pôde ganhar corpo pela superação do Luís-arrendatárioexplorado, em articulação com o Luís-que-busca-viver-de-acordo-com-seus-valores e que, para tanto, supera uma situação que não merecia ser vivida. Movimento esse incompatível com o discurso que culparia a ele sobre as barreiras encontradas à realização de sua humanidade, com a ideologia que enfraquece o sujeito diante da relação dominação enrijecida. Em um salto qualitativo o Luís-arrendatário-explorado cede lugar ao Luís-trabalhador-empregado, que alcança direitos estabelecidos e socialmente reconhecidos pelo contrato que regula a venda de sua força de trabalho.

É pelo trabalho que Luís insere-se na sociedade de outra forma e pelo qual busca, por longo período uma objetividade em que sua subjetividade tenha expressão pela mesmidade entre atividade, consciência e identidade. É a história do Luís-trabalhador-empregado que acompanhamos ao longo de grande parte de sua narrativa e que trás nova materialidade à sua consciência de classes. O sindicato configura-se como canal para a participação na construção das regras, para a luta pela concretização de sua própria moral; Luís-sindicalista que oferece realização ao Luís-sujeito-político. 
Ao mesmo tempo é pela condição de quem-vive-da-venda-de-sua-força-de-trabalho que o Luís-enquadrado-no-sistema-positivo depara-se com uma nova contradição: o embate entre sua moral e seus desejos e os pilares da organização capitalista heterogestionária do trabalho. $\mathrm{O}$ conflito com o instituído vivido subjetiva e objetivamente que impulsiona sua mudança constante de emprego e de chefe, mantendo-se no limite do sistema de trabalho em voga, sem questionar a hierarquia em si, sem encontrar caminhos, portanto para sua superação, para o salto qualitativo.

O Luís-empregado que busca a autoderminação possível no limite do sistema torna-se o Luís-aposentado que com a sobrevivência garantida liberta-se do sistema produtivo e tem de encontrar novos cenários para as suas personagens. Retoma a ligação com a natureza e com a terra em uma ONG ambientalista ao mesmo tempo em que dá os primeiros passos em uma nova direção para a realização do Luís-sujeito-ativo-na-mudança-do-contexto-objetivo. Como aposentado, tem tempo e energia liberados a serem integralmente investidos na busca constante por conhecimento, pelo novo e pelo outro "outro".

É o Luís-politicamente-engajado-explorador-que-busca-o-conhecimento o principal veículo de concretização de sua moral e da constante transformação dessa mesma moral e de seu avanço em sentido à universalidade. Essa trilha não enfraquece seu entendimento de que é com base nos empreendedores-capitalistas que o desenvolvimento do país se dá, que um mundo melhor pode ser produzido. O Luís-sujeito-político-com-visão-crítica não passa por aí, por isso fazer parte do Mãos na Massa conecta-se com a metamorfose de sua identidade mais pela interação com a comunidade do que pela autogestão do trabalho, mais pelo pertencimento a um grupo do que pelo complemento na renda.

O Programa Mercosul Solidário oferece-lhe o contexto do grupo, o objetivo e o projeto coletivo, o enraizamento em sua comunidade e em seu país, junto com a oportunidade de viajar e conhecer o além desse contexto. É por aí que encontra a possibilidade de fazer história, experiência que oferece mais importantes insumos às suas novas personagens que o projeto da cooperativa em construção. Interessa-lhe mais o conhecimento, acompanhar o desenvolvimento da economia solidária do que a vivência do cooperativismo.

O Luís-que-se-autodetermina-pelo-trabalho-com-sentido-e-pela-ação que escolhe se afastar do grupo Mãos na Massa, o Luís-aventureiro-curioso-sempre-aprendendo precisa continuar seu caminho levando consigo novos aprendizados, a riqueza da experiência vivida com esse grupo. Caso em que a superação do Luís-cooperado dá-se em prol do sentido emancipatório 
encontrado para metamorfose de sua identidade, movimento para a qual a participação nos primeiros passos do exercício autogestionário parece ter oferecido impulso.

Diferente ainda da articução subjetividade-objetividade realizada, a partir da personagem cooperada, por Márcia e Luís, é a desenvolvida a partir da experiência de Joana na formação da cooperativa Mãos na Massa. A vivência da construção da autogestão é trampolim para um salto qualitativo; diferente dos outros dois sujeitos-cooperados, a deixa para a mudança de sentido na metamorfose de sua identidade. A Joana-cooperada e a nova articulação que essa promove entre suas outras diversas personagens fazem da atuação junto ao grupo, ou ao segmento de grupo junto ao qual passa a construir uma identidade coletiva, caminhada em direção à emancipação: com contribuições positivas à sua luta por autodeteminação, ao alcance de um novo nível de consciência e de um novo patamar de atividade no mundo. Colaboração ao avanço em seu projeto de autonomia.

Experiência essa que abre o espaço procurado para a expressão de personagens antes abafadas, para facetas de sua subjetividade sufocadas pelas condições objetivas até então enfrentadas. Se Joana é guerreira sempre no embate declarado contra o que não merece ser vivido, é no Mãos-na-Massa que a luta encontra ressonância no mundo objetivo, é a partir da cooperativa que Joana pode enraizar-se em outra comunidade que não a envangélica; é com base no trabalho coletivo que a Joana-representante-de-vendas dá as mãos à Joana-que-vive-de-suaforça-de-trabalho e que, fortalecendo a Joana-que-segue-serve-afirma-a-si-mesma, e que, aos poucos, supera a Joana-que-se-cala diante daquilo com o que não concorda.

A relevância de sua contribução para o grupo e para a cooperativa oferece matéria-prima para a negação da Joana-submissa-em-posição-inferior que sabe menos, que tudo tem a aprender e, por isso, nada tudo tem que aceitar passivamente. Uma história de recusa ao reconhecimento afetivo e legal em casa e nas instituições que regem nossa organização societal, no grupo Mãos na Massa Joana é ouvida e ouve, condição essa um salto qualitativo.

Se a Joana-justiceira em articulação à mãe-dedicada e à Joana-que-quer-falar-por-simesma nascera em defesa de causas próprias e de seu filho, alcançava agora outro patamar, para a ação, com a Joana-que-se-articula-em-prol-dos interesses-seus-e-da-comunidade. Mudança de sentido marcada pela passagem da ação individual desesperada à ação coletiva organizada, pelo enraizamento no grupo e na comunidade. 
São diversas as personagens que junto à Joana-cooperada pautam a mesmidade entre atividade, consciência e identidade da Joana-sujeito-ativo-no-mundo, personagens que se fortalecem como dobradiças que trazem nova integração entre objetividade e subjetividade. A partir do projeto e da vivência coletiva são alimentadas a Joana-em-busca-de-conhecimento, a Joana-que-encontra-sentido-no-trabalho-coletivo, que-contrói-nova-racionalidade-para-asdecisões, dotada-de-deveres-e-direitos, que-confia-nos-outros, solidária-nos-esforços-e-nosganhos, justiceira-em-defesa-do-pacto-coletivo e que-constrói-uma-história-para-além-da-sua, para os cooperados que ainda virão; a Joana-cooperada-dona-de-seu-trabalho-de-seu-tempo-fazhistória e age para que outros também possam encontrar na produção autogestionária das barrinhas a oportunidade de alterização junto à outra organização do trabalho e das relações.

As histórias de cada um desses três sujeitos na vivência do cooperativismo autogestionário em construção denunciam a cadeia de potenciais, infindas variáveis, que criam uma experiência única de cada um; não apenas porque são inesgotáveis os repertórios que trazem para o trabalho e para o projeto coletivo, mas também porque o grupo e o empreendimento formado por esse coletivo são também peculiares pelo ambiente em que se fazem, pela dinâmica estabelecida entre os diversos atores.

Outra evidência trazida pelas histórias ouvidas é a significante influência da relação com os formadores, com a organização de apoio, nessa dinâmica e no caminho trilhado pelo grupo. A reflexão constante a respeito dessa relação por parte dos formadores, considerando o papel assumido junto ao grupo em cada atividade, discussão, decisão, faz-se fundamental para que o objetivo de fomentar grupos de trabalho autogestionários solidários, autônomos e independentes mantenha-se o norte. O risco de que, nas cooperativas exógenas, a relação de dominaçãoobediência ancorada no poder do capital e na concentração do capital e, portanto, do poder, seja replicada na relação entre organização de apoio e grupo em formação mostra-se real; que a ameaça do desemprego transforme-se na ameaça pela aniquilação da alternativa de renda e do projeto coletivo.

Percebemos também, ao olharmos para o sujeito que faz o grupo e o cooperativismo no dia a dia, que o afastamento em relação ao projeto não é necessariamente um sinal de retrocesso, pelo contrário, pode ser um passo importante no que concerne à realização do projeto de autonomia, o que parece ter se dado tanto na trajetoria de Luís quanto de Joana. Pode representar a superação de certa contradição entre valores, interesses ou mesmo a busca pela 
autodeterminação e a dinâmica instaurada no grupo. É possível que seja positiva na procura por condições objetivas, outras em que haja espaço para personagens que ali não são reconhecidas.

Mesmo quando a construção da autogestão parece efetivamente estar em avanço, pode ser vivida, não se trata necessariamente de um ambiente propício ao sentido emancipatório para a metamorfose da identidade dos sujeitos-cooperados. A posição da personagem-cooperada em meio às outras personagens, o impacto de sua articulação para o movimento da identidade está diretamete ligada à conexão que se dá entre as condições objetivas oferecidas pelo grupo e pelo projeto, em determinado momento, e o repertório, as expectativas, as representações trazidas ao grupo pelo sujeito, incluindo aí os formadores. Da mesma forma, a autogestão depende, para concretizar-se em atividade, da ressonância alçada na subjetividade dos sujeitos. No mais, a cooperativa não é a única organização capaz de oferecer incentivos a esse movimento, pelo contrário, ela parece ter esse potencial fortalecido pelas experiências coletivas anteriores de seus membros quando pautadas pelo mundo da vida, sobressalente em relação ao agir estratégico, quando propícias à expressão e valorização das individualidades.

A peculiaridade de ser uma cooperativa exógena trouxe ainda, ao Mãos na Massa, outro desafio: o partilhar de objetivos comuns e a construção de um projeto coletivo, base para a existência de um grupo, para a formação de uma identidade coletiva. Alguns conheciam-se de longa data, outros não, apenas haviam esbarrado nas ruas do Jardim Jaqueline, outros. Partindo daí, da mesma forma como a atuação das organizações de apoio foram fundantes da junção dessas pessoas em um mesmo espaço, sob o guarda-chuva de um projeto, faz-se indispensável para que os objetivos individuais sejam colocados na roda e para que gradualmente concedam significado a objetivos compartilhados. Esse processo tende a ser longo e exige atenção continuada, metodologia e ações consistentes ao longo do tempo. Apenas um grupo de fato pode gerar o ambiente coletivo capaz de trazer à tona e de reconhecer o que há de singular e de comum em cada sujeito.

Entre as trajetórias particulares no que têm em comum ao cruzarem, cada ator, a historia do Mãos na Massa, encontra-se a minha própria, da pesquisadora-agente que tangenciou as trilhas de cada um ao seu modo específico. O movimento de minha identidade também encontrou repercussões da autogestão em construção pelo e com o grupo; interação essa que também compõe a dinâmica em jogo, que influi nas histórias de cada um de nós. Foi por essa experiência que, por minha vez, pude superar questões e deparar-me com outras. A Mariana-mestranda- 
administradora-facilitadora-de-oficinas é personagem que tomou forma semana a semana, ressignificou outras personagens, apenas trazida à consciência ao longo da redação deste texto. Personagem que fortalece a Mariana-que-procura-caminhos-para-interferir-no-mundo, a administradora-que-trabalha-no-terceiro-setor, que encontra na psicologia uma nova posição de onde enxergar e interagir com esse mundo. A pesquisa ofereceu novo cenário à administradora, veio daí a percepção de que essa personagem não precisa ser sufocada pela negação de uma organização do trabalho desumanizadora, pela frustração no encontro de sentido por esse caminho. Mariana que, assim como Luís, Joana e Márcia, quer encontrar seu vetor, o canal pelo qual sua voz faça-se ouvir para transformar a realidade concreta na medida em que novas personagens clamem por espaço em cena.

Muito temos em comum, muito temos de particular Luís, Joana, Márcia e Mariana; a luta por reconhecimento, apesar dos contextos distintos, a experiência comum do trabalho estranhado e alienado, mesmo que diversos os repertórios, a busca por alternativas a padrões e distribuições enrijecidas de poder, em relações diferentes, violência com implicações específicas para cada um de nós. O caminho dessa pesquisa concretiza, em si, a procura pela renovação: um trajeto sinuoso, cheio de idas e vindas, desenho abstrato. A cada leitura, novo tema, capítulo, um novo universo no qual mergulhar, um novo perder-se para depois encontrar-se outra. Pesquisa orgânica, texto em metamorfose constante enquanto elaborado, revisado, reescrito; outro a cada leitura, em cada leitor.

Texto que não pretende encerrar o assunto, mas trazer novos insumos à discussão. Exploramos facetas que a questão adquire em três histórias de vida, para três sujeitos que participaram ou participam da formação da cooperativa exógena de trabalho Mãos na Massa. Apontamentos foram feitos em relação ao que podem ser indícios de um contexto, de um grupo, de um processo de formação que ofereçam condições, oportunidades mais consistentes para que um novo impulso seja encontrado à metamorfose constante da identidade com sentido emancipatório. Podem ser eles pauta para a reflexão do próprio grupo, das organizações de apoio, de todos juntos.

Pergunta que possui tantas respostas possíveis quantos sujeitos-cooperados houver, quantas histórias de vida tiverem em seu percurso o exercício da autogestão, mas que podem ser influenciadas pelo percurso seguido na formação do empreendimento. Considerando que o número de cooperativas, e de sujeitos cooperados, vem crescendo consideravelmente em todos os 
Estados Brasileiros desde a década de $90^{142}$, reforça-se aqui a relevância da reflexão a respeito dessas variáveis e do papel das organizações de apoio por todos os atores que fazem a Economia Solidária.

Sabendo que o cooperativismo e a economia solidária não são caminhos para a totalidade, longe da unanimidade, indício positivo de que talvez não estejamos nos guiando para uma próxima verdade absoluta violenta como a que nega, é preciso considerar que abalar uma estrutura estabelecida, um sistema tão forte que já se tornou o fim em si mesmo, passa por ganhar novas instâncias. Para tanto é preciso ganhar escala e consistência; que personagens anamórficas $^{143}$, exigindo um reconhecimento pós-convencional, possam vir à tona e que, articuladas e integradas, em rede, alcancem novos patamares de impacto de suas ações como sujeitos políticos. A economia solidária e o cooperativismo têm importante papel nesse desafio.

Se para Deetz (1992) a liberdade é impossível, sempre haverá formas de dominação em uso de forma que o fim de uma desemboca em outra, a luta deve ser para que, ao menos, caminhe-se em direção a um mais alto "nível de consciência", chegando o mais próximo possível da emancipação. Embora acorrentados à caverna, coloca-se como dever a busca pelos rasgos de luz (PLATÃO, 2006), que o exercício crítico seja incansável, que os da revisão dos valores e princípios assumidos e replicados, questionados. Não é utopia a mudança do ponto de equilíbrio da relação capital-trabalho, não é ilusão a força da vida para retomar as rédeas do processo sóciohistórico da humanidade. Utopia é crer no exercício crítico, no ocupar-se com os valores e princípios, quando se anseia pelo alimento de hoje e teme-se pelo de amanhã.

Essa pesquisa é alegoria que segue tantas outras, anteriores, servindo-se de seu ritmo de suas cores, ao mesmo tempo em que é carro abre-alas para tantas outras e para as muitas personagens que as povoarão, prólogo para novos capítulos, para tantas outras histórias e estórias.

"A ideia do grupo, a coisa cooperativa... conforme eu estou dizendo para você, isso pode voltar a ser uma coisa viável, justamente porque você viu que a globalização fracassou. Isso aqui é a globalização. E sabe o que aconteceu com ele? Ele queimou, ele deu defeito, eu levei para consertar, não tem conserto. Porque não tem a peça. (...) Trabalhar em grupo não é fácil, porque as opiniões são muito divergentes. Por exemplo, você está vendo a minha opinião, você viu que eu discordando de um monte de coisas. Isso aqui, por exemplo, a pessoa diz "não tem problema, é um

\footnotetext{
142 Fonte Sistema Nacional de Informações em Economia Solidária, Ministério do Trabalho e do Emprego. Disponível em http://www.mte.gov.br/ecosolidaria/sies.asp\#. Acesso em 19/11/2010.

${ }^{143}$ Conceito utilizado no sentido trazido por Juracy Armando Almeida (2005).
} 
ferro de passar roupa". "Ah é? Quantos empregos nós perdemos para a China?". Eles querem comprar a nossa soja em grão, eles não querem comprar o nosso óleo de soja, nem a nossa farinha de soja. Nem a ração do bagaço da soja. Ele não quer comprar, quer comprar a soja bruta para levar e gerar emprego lá. Então você precisa entender de tudo, que ali... Não vou dar palpite no seu serviço, mas ali vocês podem bem especificar isso aí. (...) E você montar uma cooperativa. Eu acho que o sistema de cooperativa no Brasil tem tudo para dar certo. Agora, ele não pode entrar para o lado político e não deixar o sindicato envolver muito também porque, infelizmente, envolve interesses pessoais e não do grupo em geral."

Luís (2009) 


\section{Referências Bibliográficas}

ADORNO, T. W. Mínima moralia. São Paulo: Atica, 1992.

. Negative dialectics. Londres: Routledge, [1967] 1990.

ALBARRAN, L. N. e RAMIREZ, M. R. Revolución agraria y cooperativismo en Cuba. Havana: Ed. de Ciências Sociais de Havana, 1989.

ALBUQUERQUE, P. P. “Associativismo, Autogestão e Moeda Social 2”. In: CATTANI, A. D. (org.) A Outra Economia. Porto Alegre: Veraz, 2003.

ALENCAR, E. Nova abordagem cooperativista-cooperativa como um instrumento de contraposição. Lavras: UFLA-DAE, 1993. 9p. (Apostila).

ALMEIDA, J. A. M. Sobre a Anamorfose: Identidade e Emancipação na Velhice. Tese de Doutorado em Psicologia Social. PUC-SP, 2005.

ANDRADA, C. F. O encontro da política com o trabalho: história e repercussões da experiência de autogestão das cooperadas da UNIVENS. Dissertação (Mestrado), Instituto de Psicologia, Universidade de São Paulo, 2005.

ANTUNES, R. Os sentidos do trabaho. São Paulo: Boitempo, 1999.

. (Org.). Neoliberalismo, Trabalho e Sindicatos: Reestruturação Produtiva no Brasil e na Inglaterra. $2^{\text {a }}$ edição. São Paulo: Boitempo, 1998

. Adeus ao Trabalho?: Ensaio sobre as Metamorfoses e a Centralidade do Mundo do Trabalho. São Paulo: Cortez, 1995.

ARENDT, H. Entre o passado e o futuro. São Paulo: Perspectiva, 1972.

. "A tradição e a época moderna" In ARENDT, H. Entre o Passado e o Futuro. São Paulo: Editora Perspectiva, 1992. p. 43-68.

. Homens em tempos sombrios. São Paulo: Companhia das Letras, 1999.

. A condição humana. Rio de Janeiro: Forense Universitária, 1993.

. "Labor, Work, Action" (texto de 1964 apresentado em uma convenção na Universidade de Chicago), in The Portable Hannah Arendt. Ed. \& Intor by Peter Baher. New York: Penguim, 2000.

ARRIGHI, G., HOPKINS, T., \& WALLERSTEIN, I.. Antisystemic Movements. London, 1989.

BAKHTIN, M. Marxismo e Filosofia da Linguagem. São Paulo. HUCITEC, 2002. 
BARLEY, S. R. Gurus, hired gums, and warm bodies: itinerant experts in a knowledge economy. Princeton, N.J. Oxford, 2004.

BAUMAN, Z. Por uma Sociologia Crítica. Um ensaio sobre o senso comum e emancipação (trad. Antônio A. Cirurgião). Rio de Janeiro: Zahar, 1977.

A Sociedade Individualizada: vidas contadas e histórias vividas. Jorge Rio de Janeiro: Zahar Editor, 2001. . Sociedade Individualizada. Rio de Janeiro: Zahar Editor, 2008.

BEATRIZ, M. Z. Os Sentidos da Economia Solidária: os caminhos da construção da autonomia coletiva e organizativa. Tese de doutorado em Psicologia Social, Pontifícia Universidade Católica de São Paulo, 2007.

BECK, U. e BECK-GEMSHEIM, E. Individualization, Institutionalized Individualism and its Social and Political Consequences. Londres: Sage Publications, 2002.

BENDASSOLI, P. Trabalho e Identidade em Tempos Sombrios. Letras e Ideias: 2007.

BERGER, P. e BERGER, B. "Socialização: como ser um membro da sociedade". In M. M. Foracchi e J. de S. Martins. Sociologia e sociedade: leituras de introdução à sociologia. Rio de Janeiro: LTC, 1977.

BERGER, P. e LUCKMANN, L. A construção social da realidade: tratado de sociologia do conhecimento. Petrópolis: Vozes, 1990. 247 p.

BERNARDO, M. H. Trabalho duro, discurso flexível: uma análise das contradições do toyotismo a partir da vivência dos trabalhadores. São Paulo: Expressão Popular, 2009.

BERNARDO, J. Reestruturação Capitalista e os Desafios para os Sindicatos. Lisboa: Mimeo, 1996.

BIHR, A. Da grande noite à alternativa: o movimento europeu em crise. São Paulo: Boitempo, 1998.

BOURDIEU, P. A economia das trocas simbólicas. 5 ed. São Paulo: Perspectiva, 1998.

BORGADUS, E. S. Princípios da cooperação. Rio de Janeiro/São Paulo: Lidador, 1964.

BOSI, A. Cultura brasileira e culturas brasileiras. In: Dialética da colonização. São Paulo, Companhia das Letras, 1992.

O Tempo Vivo da Memória. Cotia: Ateliê Editorial, 2003. 
. Cultura e desenraizamento. In: BOSI, A., org. Cultura brasileira - temas e situações. São Paulo, Ática, 1987. p.16-41.

BOSI, E. Memória e sociedade - lembranças de velhos. São Paulo, Companhia das Letras, 1994.

. Simone Weil - a razão dos vencidos. São Paulo, Brasiliense, 1982.

BURSZTYN. M. O poder dos donos. Petrópolis: Vozes, 1985.

CIAMPA, A. A estória de Severino e a história de Severina. São Paulo: Brasiliense, 1987. . “Políticas de Identidade e Identidades Políticas”. In DUNKER, C. I. L. \& PASSOS, M. C. (orgs). Uma Psicologia que se interroga: ensaios. São Paulo: Edicon, 2002. p. 241. . A identidade social como metamorfose humana em busca de emancipação: articulando pensamento histórico e pensamento utópico. Trabalho apresentado no XXIX Encontro da Sociedade Interamericana de Psicologia - SIP. Lima, mimeo, 2003.

CERTEAU, M. A invenção do cotidiano: artes de fazer. Petrópolis, Vozes, 1994.

COLE, G.D.H. Historia del pensamiento socialista. V. I, Los Precursores (1789-1850). 3.ed. México/Buenos Aires: Fondo de Cultura Economica, 1964.

CULTI, M. N. “O cooperativismo popular no Brasil: importância e representatividade”. In: CONGRESO EUROPEO DE LATINOAMERICANISTAS, 3., Amsterdam. Holanda, 2002.

CORAGGIO, J. L. (org.). La Economía Social desde La Periferia: contribuciones latinoamericanas. Coléccion Lecturas de Economía Social. Buenos Aires: Editorial Altamira, 2007.

COSTA, M. Marchesini. Cooperativas populares como forma de combate à pobreza. São Paulo: Relatório final do PIBIC/CNPq, 2002.

DEETZ, S. "Disciplinary Power in the Modern Corporation". In: AVESSON, M e WILLMOT, H. Critical management studies. Sage: 1992.

DELEUZE, Gilles. “Controle e Devir”. In: Conversações (1972 - 1990). Rio de Janeiro: Editora 34, 1992.

DEJOURS, C. e ABDOUCHELI, E. "Itinerário teórico em psicopatologia do trabalho". In: DEJOURS C., ABDOUCHELI, E. e JAYET, C. (org.). Psicodinâmica do trabalho contribuições da escola dejouriana à análise da relação de prazer, sofrimento e trabalho. São Paulo: Atlas, 1994. 
DELGADO, N. G.; ROMANO, J. O. Sobre o fórum social mundial. Rio de Janeiro: CPD/UFRRJ. 2003. (Apostila).

DURHAM, E. R. A caminho da cidade. A vida rural e a migração para São Paulo. São Paulo, Perspectiva, 1978.

DUSSEL, E. Ética de la libertación. Em la edad de la globalización y de la exclusión. Madrid: Editorial Trotta, 1998

ENGELS, F. Do socialismo utópico ao socialismo científico. Rio de Janeiro: Edições Horizonte, 1945.

ESTEVES, E. G. Sócio, Trabalhador, Pessoa: negociações de entendimentos na construção cotidiana da autogestão de uma cooperativa industrial. Dissertação (Mestrado) - Instituto de Psicologia - Universidade de São Paulo, São Paulo, 2004.

FAUSTO, R. Marx: lógica e política. São Paulo: Brasiliense, 1983.

FERRAZ, A. L. M. C. Dramaturgias da autonomia. Tese de Doutorado. Faculdade de Filosofia, Letras e Ciências Humanas (FFLCH). Universidade de São Paulo, 2005.

FOUCAULT, M. Arqueologia do Saber. Rio de Janeiro, Ed. Forense, 1997. . A ordem do discurso. São Paulo, Loyola Ed., 1998.

- A Verdade e as Formas Jurídicas. Pontifícia Universidade Católica e Nau Editora, Rio de Janeiro Évora, $3^{\text {a }}$ edição, 2005.

GAIGER, L. I. “A economia solidária no RS: viabilidade e perspectivas”. In: CEDOPE

São Leopoldo: CEDOPE, 1999. v.10. (Série Movimentos Sociais e Cultura, 15).

. "Os caminhos da economia solidária no Rio Grande do Sul”. In: SINGER, Paul; SOUZA, André Ricardo de. A economia solidária no Brasil: a autogestão como resposta ao desemprego. São Paulo: Contexto, 2000a.

. (Org.) Sentidos e Experiências de Economia Solidária no Brasil. Porto Alegre: UFRGS Editora, 2004.

GALEÃO, L. G. Estudo crítico dos fundamentos ontológicos da psicologia comunitária e suas consequências epistemológicas. Projeto de ingresso no RDIDP. Instituto de Psicologia da USP - Departamento de Psicologia Social e do Trabalho. Concurso para professor doutor para a disciplina Psicologia Social 1: Maio de 2009.

GAIGER, L. I (Org.) Sentidos e Experiências de Economia Solidária no Brasil. Porto Alegre: UFRGS Editora, 2004. 
GOFFMAN, E. A representação do eu na vida cotidiana. Rio de Janeiro: Vozes, 1999. 233 p. GONÇALVES FILHO, J. M. Passagem para a Vila Joanisa: uma introdução ao problema da humilhação social. Dissertação de Mestrado em Psicologia defendida na Universidade de São Paulo (USP), 1995.

. Humilhação social - um problema político em psicologia. Psicol. USP. 1998, vol.9, n.2,

pp. 11-67. Disponível em: http://www.scielo.br/scielo.php?script=sci_arttext\&pid=S010365641998000200002\&lng=en\&nrm=iso. Acesso em 08/04/2010.

GREY, C. Career as a Project of the self and labour process discipline. In: PULLEN, A e LINSTEAD, S. Organization and Identity. London and New York: Routledge, 2006.

GUIMARÃES, G. (Org.). Ossos do ofício. Rio de Janeiro: ITCP/COPPE/UFRJ, 1998. . "Por uma tecnologia do trabalho". In: . Sindicalismo e cooperativismo. São Paulo Rio de Janeiro: ITCP -COPPE/RITCP's/ UNITRABALHO, 1999a.

- Sindicalismo e cooperativismo. São Paulo/Rio de Janeiro: ITCPCOPPE/RITCP's/UNITRABALHO, 1999b.

GUIRADO, M. Psicanálise e Análise do Discurso. São Paulo, Suinmus Ed., 1995.

HABERMAS, J. Para a reconstrução do materialismo histórico. Brasiliense. São Paulo, 1983. . Pensamento pós-metafísico. Rio de Janeiro: Tempos Brasileiros, 1990. 271 p. . "The New Obscurity". In: The New Conservantism: Cultural Criticism and the Historians’ Debate. Cambridge: Polity Press, 1989.

. “Técnica e Ciência como “Ideologia””. In: Os Pensadores. São Paulo: Abril, 1975. . The Theory of Communicative Ation: "Reason and the Racionalization of Society", Vol. I. Londres: Poliy Press, 1991. . The Theory of Communicative Ation (The Critique of Functionalist Reason), Vol. II. Londres: Poliy Press, 1992.

. Passado como Futuro. Traduzido por Flávio Beno Siebeneichler. Rio de Janeiro: Tempo Brasileiro, 1993 (originalmente publicado em 1991).

- "Notas sobre el desarrollo de la competência interactiva". In HABERMAS, J. Teoría de la Acción Comunicativa: Complementos y estúdios previos. Traducción de Manuel Jiménez Redondo. Madri: Ediciones Cátedra, 1989 [originalmente publicado em 1974]. 
. "A crise do Estado de bem-estar e o esgotamento das energias utópicas. In HABERMAS, J. Diagnósticos do tempo: seis ensaios. Traduzido por Flávio Beno Siebeneichler. Rio de Janeiro: Tempo Brasileiro, 2005. p. 9-36. [publicado originalmente em 1985]

HEGEL, G. W. F. Princípios de Filosofia do Direito. Tradução de Orlando Vitorino. São Paulo:

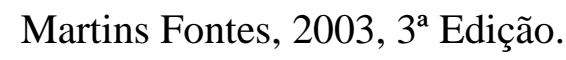

. Introdução à História da Filosofia. Tradução de Antonio Pinto de Carvalho. Coimbra: Portugal, 1974, $3^{\text {a }}$ Edição. [ discurso proferido originalmente em 1816]

HERMET, G. Cultura e desenvolvimento. Petrópolis: Vozes, 2002.

HINKELAMMERT, F. El asalto al poder mundial y la violência sagrada del império. San Jose, Costa Rica: DEI, 2003.

HOLLOWAY, J. "A note on alienation". In. Historical Materialism, n. 1. London School of Economics, Londres, 1997.

HOLZMANN, L. Operários sem patrão: gestão cooperativa e dilemas da democracia. São Carlos: EdUFSCar, 2001.

HONNETH, A. The Struggle for recognition: the moral Grammar of social conflicts. Cambrige: MIT, 1996

IBASE/ANTEAG. Autogestão em avaliação. Rio de Janeiro/São Paulo: Anteag. 2004.

ICAZA, A. M. S.; TIRIBA, L. "Economia popular". In: CATTANI, A. D. (Org.). A outra economia. Porto Alegre: Veraz, 2003.

JUVENAL, T. L. Empresas Recuperadas por Trabalhadores em Regime de Autogestão: Reflexões à Luz do Caso Brasileiro. Rio de Janeiro: Revista do BNDES, V. 13, N. 26, P. 115-138. Dez. 2006.2 Disponível em: http://www.bndes.gov.br/SiteBNDES/export/sites/default/bndes_pt/Galerias/Arquivos/conhe cimento/revista/rev2606.pdf. Acesso em 05/06/2010.

KHEL, M. R. A Morte do Sentido. O Estado de S. Paulo: 3 de abril de 2010.

LANE M. Introdução In. GUARSCHI, P. Psicologia Comunitária. Petropolis: Vozes, 2000

LANE M. Introdução In LANE M. Psicologia Social: o homem em movimento. São Paulo: Atlas, 1984.

LAUSCHNER, R. Administrações publicas cooperativas. Revista Perspectiva Econômica, São Leopoldo, v.19, n.43, p.55-72, 1984. (Série Cooperativismo, 13). 
- Autogestão, cooperativismo e capitalismo. Revista Perspectiva Econômica, São Leopoldo, v.17, n.12, p.57-116, 1982. (Série Cooperativismo, 36).

LENIN, V.I. "Sobre a cooperação". In: . Obras escolhidas. Rio de Janeiro: Alfa-Omega, 1980.

LIMA, A. F. de. Sofrimento de indeterminação e reconhecimento perverso: um estudo da construção da personagem doente mental a partir do sintagma identidade-metamorfoseemancipação. Tese de Doutorado em Psicologia Social. PUC-SP, 2009

LUKÁCS, G. Ontologia do ser social: Os princípios ontológicos fundamentais de Marx. Tradução Calor Nelson Coutinho. São Paulo: Ciências Humanas, 1979.

MARCHINGTON, M., GRIMSHAW, D., RUBERY, J. and WILLMOTT, H. (eds.). Fragmenting Work: Blurring Organizational Boundaries and Disordering Hierarchies. Oxford: OUP, 2004.

MARCUSE, H. Razão e Revolução: Hegel e o advento da teoria social. Rio de Janeiro: Paz e Terra, 2004

. Reason and Revolution: Hegel and the rise of social theory. Boston: Beacon Press, 1969. . Eros e Civilização. Rio de Janeiro: LTC, 1999.

MARX, K. O Capital, Vol. 1/1. Rio de Janeiro: Civilização Brasileira, 1971. . O Capital, Vol. 3/6. Rio de Janeiro: Civilização Brasileira, 1974.

- Capítulo VI Inédito de O Capital: resultados do processo de produção imediata. São Paulo: Editora Moraes. 1985.

. "Manuscritos Econômicos e Filosóficos de 1844". In: MARX, K.; ENGELS, F. Coleção Grandes Cientistas Sociais. Ática: São Paulo, 1989.

. Chapter Six. In: MARX, K. e ENGELS, F. Collected Works, Vol. 34 (MARX: 1861-4).

Londres: Lawrence \& Wishart, 1994.

. "De la Crítica de la filosofia del derecho de Hegel” In: MARX - Escritos de juventud. México: Fondo de cultura econômica, s.d.

MEAD, G. H. Mind, Self and Society: from the standpoint of a Social Behaviorist. London: University Chicago Press, 1992 [publicado originalmente em 1934, Editado e republicado por Charles W. Morris em 1962]. Espíritu, persona y sociedad. 3a. Ed. Buenos Aieres: Paidós, 1972. 393 p. 
. The Mechanism of Social Consciousness. In Journal of Philosophy, and Scientific Methods. Vol. 9, n. 15. Jul., 1912. p. 401-406.

MEAD, G. H.; MORRIS, C. W. The philosophy of the act. Chicago: University of Chicago, 1938.

MERLEAU-PONTY, M. Fenomenologia da percepção. São Paulo: Martins Fontes, 1999 (Originalmente publicado em 1945).

MÉSZAROS, I. Marx: A Teoria da alienação. Rio de Janeiro: Zahar, 1981. . Beyond Capital (Towards a Theory of Transition). Londres: Merlin Press, 1995. . Philosophy, Ideology \& Social Science. Sussex: Wheatsheaf Books, 1986.

. MÉSZÁROS, I. “A ordem do capital no metabolismo social da reprodução”. In: Ad Hominem - Revista de filosofia, política, ciência da história. n. 1, t. 1. São Paulo, Estudos e Edições Ad Hominem, 1999, p. 83-124.

NAVES, M. Marx: ciência e revolução, $1^{\mathrm{a}}$ edição. Coleção Logos, Editora Unicamp e Editora Moderna, 2000.

NETTO, J.P. "Introdução". In: Miséria da filosofia. São Paulo: Ciências Humanas, 1982. . Capitalismo e reificação. São Paulo: Ciências Humanas, 1987.

OLIVEIRA, P. de S. O lúdico na Cultura Solidária. São Paulo: Hucitec, 2001.

OLIVEIRA, B. A. M. As Cooperativas Populares e Seus Desafios, Limites e Possibilidades: Casos de Cooperativas da Cidade do Rio de Janeiro. Tese de Doutorado. Rio de Janeiro: Instituto de Ciências Humanas e Sociais, UFRJ, 2006.

OLIVEIRA, F. de. Os sentidos do cooperativismo de trabalho: as cooperativas de mão-de-obra à luz da vivência dos trabalhadores. Porto Alegre: Psicologia \& Sociedade, v. 19, n.spe, 2007. PEDRINI, D. M. "Bruscor, uma experiência que aponta caminhos”. In SINGER, P. \& SOUZA, A. (Orgs.). A Economia Solidária no Brasil: a autogestão como resposta ao desemprego. São Paulo: Contexto, 2000.

PEYREFITTE, A. La société de confiance. Essai sur ler origines du développement. Paris: Odile Jacob, 1998.

PLATÃO. A República. v 1l. São Paulo. Martins Fontes: 2006.

PINHO, D. B. Cooperativas e desenvolvimento econômico. São Paulo: Pioneira, 1962. . Doutrina cooperativa nos regimes capitalista e socialista. São Paulo: Pioneira, 1965. . Economia e cooperativismo. São Paulo: Saraiva, 1977. 
PRADO, J. L. A. “Teoria da Sociedade ou Teoria da Comunicação?”. In PRADO, J. L. A. Brecha na Comunicação: Habermas, o Outro, Lacan. São Paulo: Hacker/CESPUC, 1996. p. 213-275.

QUIJANO, A.. “Sistemas alternativos de produção?” In: SANTOS, B. S. (Org.). Produzir para viver: os caminhos da produção não capitalista. Rio de Janeiro: Civilização Brasileira, 2002. p.475-514.

RANIERI, J. A câmara escura. Alienação e estranhamento em Marx. São Paulo: Boitempo, 2001.

REICH, R. The Work of Nations. Nova York: Vintage Books, 1991.

RIFKIN, Jeremy. O Fim dos Empregos: O Declínio Inevitável dos Niveis de Emprego e a Redução da Força Global de Trabalho. São Paulo: Makron Books, 1995.

SANTOS, B. S. Pela mão de Alice: o social e o político na pósmodernidade. São Paulo: Cortez, 1995.

. (Org.). Produzir para viver: os caminhos da produção não capitalista. Rio de Janeiro: Civilização Brasileira, 2002.

SASS, O. Crítica da Razão Solitária. A Psicologia Social segundo George Herbert Mead. Bragança Paulista: Editora Universitária São Francisco, 2004. 303 p.

SATO, L. Astúcia e ambiguidade: as condições simbólicas para o replanejamento negociado do trabalho no chão de fábrica. São Paulo, 1997. 198 p. Tese (Doutorado) - Instituto de Psicologia, Universidade de São Paulo.

. "Djunta-mon: O Processo de Construção de Organizações Cooperativas". Psicologia USP, São Paulo, v. 10, n. 2, p. 219-225, 1999.

SATO, L. \& ESTEVES, E. Autogestão: possibilidades e peculiaridades de um processo organizativo peculiar. São Paulo: ADS/CUT, 2002.

SEN, A. O desenvolvimento como expansão das capacidades. Revista Lua Nova, São Paulo, n.28/29, p.313-333, 1993.

Desenvolvimento como liberdade. São Paulo: Companhia das Letras, 2000.

SENNET, R. The Corrosion of Character: The Personal Consequences of Work in the New Capitalism. Nova York: Norton, 1998.

. Rua e Escritório: Duas Fontes de Identidade. In: HUTTON, W. On The Edge - Living with Global Capitalism. London: Jonathan Cape, 2000. 
SINGER, P. "Economia Solidária: um modo de produção e de distribuição”. In: Singer e Souza (org.). A Economia Solidária no Brasil. São Paulo: Editora Contexto, 2000.

. Introdução à economia solidária. São Paulo: Perseu Abramo, 2002.

SOUZA, A. R. (Org.). Economia solidária no Brasil: a autogestão como resposta ao desemprego. São Paulo: Contexto, 2000.

SPINK, P. "O resgate da parte”. Revista de Administração, São Paulo, v. 26, n. 2, p. 22-31, abril / junho, 1991.

. “A organização como fenômeno psicossocial: notas para uma redefinição da psicologia do trabalho. Psicologia \& Sociedade, v.8, n.1, p. 174-92, 1996.

TERTULIAN, Nicolas. Le Concept D’Aliénation chez Heidegger et Lukács. In: Archives de Philosophie - Reserches et Documentation, 56, jul.-set., Paris, 1993.

TIRIBA, L. V. "Economia popular urbana: sua diversidade, actores y agentes". In: Economia Popular y crisis del trabajo asalariado: de las estrategias de supervivencia a al producción de una nueva cultura del trabajo. Madrid: Tese de Doutorado em Sociologia Econômica e do Trabalho - Faculdade de Sociologia e Ciências Políticas, Universidade Complutense de Madrid, 1999.

- "A economia popular solidária no Rio de Janeiro: tecendo os fios de uma nova cultura do trabalho". In: A economia solidária no Brasil: a autogestão como resposta ao desemprego. São Paulo: CONTEXTO, 2000.

TIRIBA, L. e PICANÇO, I. (orgs.). Trabalho e educação: arquitetos, abelhas e outros tecelões da economia popular e solidária. Aparecida: Ideias \& Letras, 2004.

TOMANEY, J. “A New Paradigm of Work Organization and Technology?”. In: AMIN, A. PosFordism: a Reader. Blackwell Oxford, 1996

TRIVIÑOS, Augusto N. S. Bases teórico-metodológicas da pesquisa qualitativa em ciências sociais : ideias gerais para a elaboração de um projeto de pesquisa. Porto Alegre: Faculdades Integradas Ritter dos Reis, 2001. 151 p.

WEIL, S. A condição operária e outros estudos sobre a opressão. Rio de Janeiro, Paz e Terra, 1979.

. O enraizamento. Bauru: EDUSC, 2001

. A gravidade e a graça. São Paulo, Martins Fontes, 1993.

VAINER, C. “O presente de um futuro possível”. In: GUIMARÃES, G. (Org.). Sindicalismo e cooperativismo. São Paulo/Rio de Janeiro: ITCP -COPPE/ RITCP's/ UNITRABALHO, 1999. 
VERONESE, M. V. (Org.) Economía solidaria e subjetividad. Colección Lecturas sobre Economía Social. Buenos Aires: UNGS / Altamira, 2007. Veronese e Guareschi (2005)

VERONESE, M. V. e GUARESCHI, P. "Possibilidades solidárias e emancipatórias do trabalho: campo fértil para a prática da psicologia social crítica”. In: Psicologia \& Sociedade. vol.17, no.2. Porto Alegre Mai/Ago, 2005.

VIEIRA, F. M. Coerência e aderência da economia solidária: um estudo de caso dos coletivos de produção do MST em Mato Grosso do Sul. Tese (Doutorado em Economia) - USP, 2006.

WAGNER, E. S. Hannah Arendt e Karl Marx: o mundo do trabalho. São Paulo: Ateliê Editorial, 2002. 


\section{Endereços eletrônicos:}

ALIANÇA COOPERATIVISTA INTERNACIONAL, site institucional, endereço: www.ica.coop.

ATLAS DA ECONOMIA SOLIDÁRIA NO BRASIL (2006). Disponível no site do Ministério do Trabalho e do Emprego: www.mte.gov.br. Acesso em 19/10/2009.

CULTI, M. N. O Cooperativismo Popular no Brasil: Importância e Representatividade. Artigo escrito para Ecosol, disponível em: http://www.institutoapoiar.org.br/imagens/bibliotecas/texto_1_COOPOP.DOC+O+COOPER ATIVISMO+POPULAR+NO+BRASIL:+Import\%C3\%A2ncia+e+Representatividade+Maria + Nezilda+Culti1\&cd=3\&hl=pt-BR\&ct=clnk. Acesso em 20/10/2009.

ÉTICA, RESPONSABILIDADE SOCIAL, ECONOMIA SOLIDÁRIA E COMÉRCIO JUSTO, blog, endereço: http://etica-social.blogspot.com/2007/07/as-redes-de-economia-solidria-nobrasil.html. Acesso em: 13/09/2007.

FINEP - Financiadora de Estudos e Projetos, site institucional, endereço: http://www.finep.gov.br/. Acesso em 05/05/2010.

FÓRUM BRASILEIRO DE ECONOMIA SOLIDÁRIA, site institucional, endereço: http://www.fbes.org.br/index.php?option=com_docman\&task=cat_view\&gid=98\&Itemid=216 . Acesso em 30/08/2009.

GONÇALVES FILHO, J. M. Humilhação social - um problema político em psicologia. Psicol. USP, São Paulo, v. 9, n. 2, 1998. Disponível em http://www.scielo.br/scielo.php?script=sci_arttext\&pid=S0103$\underline{65641998000200002 \& \operatorname{lng}=e n \& n r m=i s o}$. Acesso em 08/04/2010.

INSTITUTO PÓLIS. Site institucional, endereço: http://www.polis.org.br/. Acesso em 20/10/2009.

ITCP-UFRJ. "Princípios Básicos do Cooperativismo". Disponível no Portal do Cooperativismo Popular: http://www.cooperativismopopular.ufrj.br/princ_basico.php. Acesso em 17/08/2009.

ITCP-USP. Site institucional, endereço: http://www.itcp.usp.br/?q=taxonomy/term/36. Acesso em 20/10/2009.

MANCE, E. A. Ética, Responsabilidade Social, Economia Solidária e Comércio Justo.Artigo disponível em: http://etica-social.blogspot.com/2007/07/as-redes-de-economia-solidria-nobrasil.html. Acesso em 20/10/2009.

MATIAS, B. (2004) Cooperativismo social é a nova geração de cooperativas no mundo. Artigo disponível no site:

http://www.administradores.com.br/noticias/cooperativismo_social_e_a_nova_geracao_de_co operativas_no_mundo/1385/. Acesso em 19/10/2009. 
MINISTÉRIO DO TRABALHO E DO DESENVOLVIMENTO SOCIAL. Atlas de Economia Solidária. Disponível em http://www.mte.gov.br/sistemas/atlas/tabcgi.exe?AtlasGEOSP2.def. Acesso em 19/10/2009.

MINISTÉRIO DO TRABALHO E DO DESENVOLVIMENTO SOCIAL. Documentos do Processo de Tomada de Contas Anual. Disponível em http://www.mte.gov.br/tca_contas_anuais/2006/senaes.asp. Acesso em 08/05/2010.

MINISTÉRIO DO TRABALHO E DO DESENVOLVIMENTO SOCIAL. Sistema Nacional de Informações em Economia Solidária, Ministério do Trabalho e do Emprego. Disponível em http://www.mte.gov.br/ecosolidaria/sies.asp\#. Acesso em 19/11/2010.

MONDRAGÓN CORPORACIÓN COOPERATIVA, site institucional, endereço: http://www.mcc.es/esp/contacto/faqs.html. Acesso em 05/10/2007. Acesso em 05/09/2009

PNUD. Relatório Emprego, Desenvolvimento Humano e Trabalho Decente - A experiência brasileira recente. Lançado em 2008 por três agências da ONU: CEPAL (Comissão Econômica para América Latina e Caribe), OIT (Organização Internacional do Trabalho) e PNUD. Disponível para download em: http://www.pnud.org.br/administracao/reportagens/index.php?id01=3034\&lay=apu. $\quad$ Acesso em 19/10/2009.

PREFEITURA DE SÃO PAULO, site endereçO: http://www.prefeitura.sp.gov.br/cidade/secretarias/subprefeituras/butanta/. Acesso em $18 / 06 / 2010$.

SECRETARIA DE AGRICULTURA, IRRIGAÇÃO E REFORMA AGRÁRIA, site institucional, endereço: http://www.seagri.ba.gov.br/origemcoop.asp. Acesso em: 13/09/2007.

RIQUE, M. Os Pioneiros de Rochdale e os Princípios do Cooperativismo. Artigo disponível em http://www.itcp.usp.br/drupal/node/208. Acesso em 17/08/2009 


\section{- Anexo 1 - \\ Transcrição entrevistas de história de vida: Márcia, Luís e Joana}

As três entrevistas são compostas por duas partes, dois momentos de conversa com os sujeitos:

Parte I - dezembro de 2008

Parte II - outubro de 2009, momento da devolução da parte 


\section{Parte I}

\section{- Márcia -}

Ea: - Então, você estava falando que tem memória de muito pequena...

Márcia: - A minha memória... Olha, eu lembro da minha avó, como ela era, parece que eu estou enxergando agora. Ela carregava água dentro de uma cuiona assim, cheia de cabacinha cheia de água, punha nãoa cumbuca e aí enfiava a roupa assim, e eu pequena. Minhas irmãs brincando comigo, botando para pular do braço de uma para o braço da outra...

E: - Onde você morava?

M: - Eu morava no interior, no mato, na roça.

E: - Interior de São Paulo?

M: - Interior do Piauí. E eu lembro do meu irmão mais velho doente, lembro da minha irmã mais velha, Maria do Socorro que era quem me colocava em cima da mesa para pular, sabe? E lembro de uma grande festa que teve... Hoje eu sei que era festa, naquele tempo eu não sabia o que era. E minha mãe saiu andando, aquela multidão dançando, e eu entrei ali no meio, me perdi. E fiquei chorando no meio daquele povo dançando. Depois eu não vi mais, acho que me botaram para dormir, não sei mais de nada. Lembro dessa irmã minha doente, ela casou, foi morar em outro lugar.

M: - ... Casou, eu acredito que essa festa fosse do casamento dela. Porque depois eu lembro que ela casou, eu fui passar uns dias com ela, que ela era muito apegada a mim, não outro bairro. Depois adoeceu, voltou para dentro de casa. Ela um dia me chamou para sairmos andando pelo meio da roça, achamos uma "melanciinha", fora de tempo, e ela pegou aquela "melanciinha" e comeu. Aí ela piorou e desse negócio ela morreu, mas eu não vi ela morrer. Esse outro irmão mais velho adoeceu também, ficou lá em casa doente, e eu lembro da morte dele, lembro como se fosse hoje. E eu era pequena, lembro que eu era pequenininha assim, gordinha, um toquinho de gente, sabe? Mas muito levada.

E: - Você era a mais nova de todos?

$\mathrm{M}$ : - Eu sou a caçula.

E: - Quantos irmãos você tem?

M: - Tenho dez. Foram onze, mas o primeiro nasceu morto, deu uma dor na perna e paralisou a perna. Depois ela teve mais dez, eu sou a mais nova. Meu irmão, no dia em que ele faleceu, 
lembro como se fosse hoje a hora que ele faleceu. Eu não sei que doença que ele tinha, que ele pedia para deitar no chão. Fazia uma cama de areia, aquela areia fininha, para ele deitar. Naquele dia ele queria ir para a rede. Nós tínhamos cama. Colocaram ele na rede, ele deitou para um lado, e ele não levantava sozinho. Levantou sozinho, aí quando deitou para o outro lado... Que eu ficava sempre ali por perto. Ele já estava morrendo, aí também não vi mais o que fizeram com ele. A minha avó do mesmo jeito, eu lembro que me levaram no braço para pedir a benção para minha avó quanto estava falecendo, e eu vi ela me abençoando, falando baixinho, aí morreu, e eu não vi mais nada. E aí o tempo passou, vou dizer uma que você vai morrer de dar risada.

E: - Quando seus irmãos morreram você tinha mais ou menos quantos anos?

M: - Isso é que eu não sei te dizer. Eu tenho uma irmã que eu vou procurar, a idade dessas festas que tiveram, o tempo, e o tempo que a minha avó morreu, para eu poder saber quantos anos eu tinha. Porque eu acho que se eu tivesse uns dois anos, eu tinha muito.

E: - Nossa!

M: - Eu era muito pequenininha. Era tão pequenininha que um dia eu fiz uma arte, minha mãe estava servindo comida, eu estava na mesa, tinha umas visitas almoçando lá, e minha mãe colocou minha comida. Eu falei "Eu não quero farinha", aí minha mãe colocou farinha. Quando minha mãe colocou farinha, eu falei "Eu não quero farinha", e eles escutando de lá da mesa, aí minha mãe ficou lá se mexendo para dar um jeito de me dar uma outra comida sem farinha, e eu sei porque ele levantou e me pegou, foi a única surra que eu levei dele. Ele usava uma correntinha assim de amarrar o facão, ele tirou aquela correntinha, eu fiquei pendurada e ele me batendo. Aquele senhor que estava lá com ele pediu, "Não bate na menina", porque todo mundo gostava de mim. Foi lá e pediu "Não bate nela, pára de bater na menina”. E eu sei porque ele me bateu, hoje eu entendo porque eu estava errada. Se fosse minha mãe, no ia fazer nada, mas meu pai veio...

E: - Seu pai trabalhava na roça?

M: - Na roça.

E: - E sua mãe era dona de casa?

M: - Minha mãe era dona de casa. Fiquei lá um tempo. Meu pai trabalhava com "mandiocada", com engenho, com moagem, com cana, sabe? Para fazer rapadura. Tinham vezes, não lembro o bairro, tinha um outro lugar que a gente tinha que ir, ficava uns meses trabalhando, meu pai trabalhava fora, chegava a trabalhar de final de semana pra outras pessoas, outros fazendeiros, 
que nós não éramos fazendeiros. Tínhamos nosso terreno, mas não éramos fazendeiros. E ele trabalhava em outras fazendas, inclusive a do Benedito Filho que, quando ele faleceu... Ele não existe mais, nem meu pai, nem ele, mas foi uma família que nos trouxe para a cidade.

E: - De São Paulo?

M: - Não, do Piauí. São Francisco do Piauí. E até hoje tem gente da família morando nesse retiro. E hoje meu pai não existe mais, mas tem casa na cidade, que deram terreno.

E: - Por que vocês saíram da fazenda e foram para a cidade? Você lembra da razão?

M: - Quando meu pai mudou do Baixão, que era a nossa terra, para o Curralinho, Curralinho era uma fazenda desse patrão dele. Nós saímos do Baixão, fomos morar no Curralinho. Quando eu cheguei no Curralinho... Porque minhas primeiras irmãs, meu pai contratava os professores para dar aula em casa. No meu tempo já não podia mais contratar professor, já tinha escolas perto. Aí ele me mandou para a cidade, eu e outra irmã. Eu fui morar com a minha madrinha, e a minha outra irmã foi morar com outra família, que era muito amiga dele, para estudar na cidade. Nós fomos morar em Itapecerica da Serra.

E: - Só vocês duas?

M: - Só nós duas. Quando eu me entendi como gente, já havia uma outra menininha do meu tamanho, e ela me chamava de neném, eles adotaram uma menina da minha idade.

E: - Os seus pais adotaram uma menina da sua idade?

M: - Da minha idade. E ela me chamava de neném e eu a chamava de Lucinha. Ela me chamava de neném porque quando ela chegou ela me achou neném. E esse apelido, até hoje, tem gente que me chama de neném.

E: - Você já era um pouco mais velha aí, devia ter uns cinco anos...

M: - Não. Quando eu me entendi eu já via aquela menininha lá. Uma menininha cagona, como ela cagava. Dormia, cagava. Cagava na roupa e era cheia de verme. Eu lembro que vez minha mãe deu remédio para ela, ela botou um "vermão" desse tamanho que saiu arrastando. Lembro como se fosse hoje. Ela era sonâmbula, hoje eu sei o que é sonâmbula, ela levantava e saía andando no meio da casa dormindo.

E: - E ela era pequenininha também?

M: - Pequenininha também, nós crescemos junto.

E: - Adotada? 
M: - Adotada. Mas eu não me importei com nada disso, a gente se dava super bem. Agora, a minha irmã mais velha que eu três anos, ela tinha um ciúme mortal de mim, me maltratava, era sempre a dondoquinha, eu sou a mais nova, mas eu não tenho traço de dengosa. Já ela era toda dondoquinha com meu pai. Ela é bem moreninha, mais do que eu, mais para preta, e eu mais clara, eu nasci bem branquela, os cabelos, não bons, mas aqueles cabelos vermelhos. Mudou bastante. Mas eu era meio sarará, eu tenho uma filha que lembra eu quando eu era mais nova, a pele mais branca. Por causa disso ela tinha ciúme de mim e me maltratava.

E: - Ela te batia?

M: - Batia. Se, por exemplo, a minha mãe me desse uma roupa dela, ela tirava. Meu pai, que Deus o tenha lá onde ele estiver, puxava muito o saco dela, sabe? Nunca meu pai me colocou na perna para me dar um carinho, e minha mãe não podia, porque minha mãe tinha aquele problema na perna, não podia ficar pegando ninguém no colo. Só se estivesse sentada e viesse e sentasse no colo dela, mas eu não sentava no colo da minha mãe porque, para mim, eu ia machucar ela.

E: - Você tinha medo?

M: - Tinha medo de sentar no colo dela e eu ser pesada e machucar. Eu não sentava por isso. Meu pai nunca me pôs no colo, mas ele foi um bom pai. Mas eu também sou meio esquisitinha, toda vida eu quis ser grande, muito inteligente, naquela idade tudo isso, eu devia ser uma menina que não ia com ninguém, eu acho. Esperta, todo muindo gostava de mim, era o xodó de todo mundo. Acho que por causa disso minha irmã ficava mais... Sabe? O povo chegava lá, "Deixa eu levar a Vicencinha comigo", e eu ia com todo mundo. Todo mundo que queria me levar eu ia, passava uma semana, um mês, aí me trazia. O outro chegava, me levava. Eu fiquei assim. Tanto que quando eu fui morar com minha madrinha eu tinha 9 anos, chorei muito na terra, na areia quente sem ter chinelo...

E: - Sem ter chinelo?

M: - Sem ter chinelo. Eu não tinha. Eu não sabia nem se a gente podia pedir um chinelo para o pai, nem nada. Eu vim conhecer escova de dente depois que eu fui morar na cidade.

E: - Você não tinha escova de dente?

M: - Não tinha escova de dente, nem sabia que existia escova.

E: - Vocês não escovavam os dentes?

M: - Não escovava os dentes. Sabe como a gente limpava os dentes? Com rapa de juá. Amargava para caramba. 
E: - É uma folha?

M: - É uma raspa de uma árvore. É até medicinal essa árvore. A gente usava aquelas coisas nos dentes, para limpar o que ficava no meio. Eu fiquei doente uma época, com febre, frio. Eu fiz até uma arte uma vez, eu dei um susto em todo mundo. Eu doente e aquele febre, morava no Curralinho, e ali era um monte de criança junto, e eu e a Lucinha não nos dávamos bem com aquele monte de criança, nós queríamos brincar só nós duas. Eu peguei uma febrona, que a febre tinha gora de chegar.

E: - Como assim?

M: - Todo dia, na virada do sol, quando o sol estava se pondo. Eu sei que eu fiquei abatida, abatida, abatida, quando foi um dia eu estava mole, mole, mole, me deu vontade de cuspir, sabe quando junta saliva na boca? E aí eu digo, eu não vou cuspir, fiz porque eu quis, sabe? Aí minha irmã mais velha que já se foi também... Mais velha do que eu, não mais velha de todas. Entrou no quarto e me viu babando. “Corre! A menina está morrendo! A menina está bando!”, mas eu não estava sentindo nada não. Eu só estava com preguiça, aí começou a falar que eu estava morrendo, aí eu continuei assim mole, babando.

E: - Todo mundo achou que você estava doente?

M: - Todo mundo achou que eu estava passando mal, que estava morrendo. E aí correram e me limparam a boca, e eu fiquei toda mole, só assim me pegaram no colo, não é?

E: - Deu certo.

M: - Deu certo. E eu era muito esperta. Naquela época tinha uma dança que chamava baião. Meu pai ia nesses baiões, levava minha mãe e me levava também. Quando chegava lá, menina, caía nesse baião, eu vinha de lá, vinha cheia de bala, chiclete. Eu começava a dançar, o pessoal me achava bonita dançando, compravam bala, ficavam me agradando, e todo mundo naquele xodó. Porque eu não tinha vergonha de nada, ia com todo mundo. Lá no baião dançando, no meio dos adultos.

E: - Pequenininha?

M: - Pequenininha no meio dos outros dançando baião, e dançava direito. Quando chegou a gora ele me colocou... Minhas irmãs trabalhavam em outra fazenda, colhendo feijão, colhendo algodão, e lá nessa fazenda tinha uma escola. Elas iam trabalhar e me levavam para estudar nessa escola, eu comecei a alfabetizar lá, depois parou esse serviço, minha irmãs que trabalhavam lá, 
uma ficou doente, não pôde mais trabalhar, a outra foi para a cidade grande trabalhar, hoje ela mora em Recife. Que é o amor da minha vida. E eu tive que ir para a cidade.

E: - Para estudar?

M: - Para estudar.

E: - E a sua irmã foi com você? Uma das irmãs.

M: - Minha irmã também, a Pedrina, foi para a cidade estudar.

E: - Não é aquela que tinha ciúmes de você?

M: - É aquela que tinha ciúmes de mim. Eu já estava com nove anos. Foi quando eu fui conhecer chinelo, andar calçadinha. Meu pai comprava calçado, mas aquele calçado só para sair. A gente ia à roça, trabalhava, ia caçar pelo mato, ia para roça descalço. Era ruim quando chovia, eu lembro como se fosse hoje. Quando chovia, tinha aquela estrada de terra, você pisava naquela lama, aí descia quando batia naquelas pedrinhas, como doía! E na areia, andando na areia quente. Eu andando na areia, ficava correndo na pontinha dos pés, e pisava não matinho aqui, não outro matinho ali.

E: - Você tinha que aguentar.

M: - Tinha que aguentar e não reclamava. Eu não sabia que tinha que chegar no pai e dizer "Pai, está queimando meu pé”. Eu não sabia. Depois que eu estava morando com a minha madrinha...

E: - Você não falava muito com seu pai?

M: - Só a benção que a gente pedia, quando acordava, quando dormia, quando comia, rezava, a gente pedia a benção, se estivesse junto, e quando ele começou a trabalhar em outra fazenda... Só quando ele falava com a gente. Às vezes ele chegava e trazia bala, recebia e caía fora. Nossos pais conversando, ninguém ficava perto, todo mundo ficava de longe, não tinha esse negócio de todo mundo ficar passando pelo meio e escutando história de mais velho. E quando os mais velhos faziam alguma coisa que ele batia, eu corria em cima chorar, fazia o maior "auê", aí ele vinha me bater também. Mas eu só chorava, sabe?

E: - Sua mãe falava mais com você?

M: - Minha mãe falava mais. Minha mãe percebia que dava a entender que ele não gostava muito de mim, sabe? E minha mãe não podia fazer o que ela tinha vontade de fazer, tanto que hoje eu estou aqui em São Paulo, agradeço ela. Por ter me doado para minha mãe verdadeira que é minha mãe natureza, não é? Que eu vim conhecer aqui em São Paulo, hoje eu já entendo isso. Por 
incrível que pareça eu nunca tive tempo para sentar e pegar um livro para estudar, porque o pouco que eu sei eu aprendi com o suor do meu rosto.

E: - Mas você foi para a cidade para estudar?

M: - Para estudar. Mas fui morar com minha madrinha, entendeu? Ele tinha um comércio lá na cidade, tinha terrenos, propriedades e cultura. Eles plantavam. E naquela época tinha massa de milho, fubá de milho no pilão, pisava o arroz no pilão para tirar a casca, e tudo isso eu carregando lenha na cabeça, fogão de lenha, aquelas panelas de ferro para deixar todas limpinhas, era tudo assim. Carregando água na cabeça.

E: - Você trabalhava bastante?

M: - Eu trabalhava bastante. Pegava muito peso, inclusive eu tinha uma dor nas costas que eu acredito que foi do peso que eu peguei. Eles botaram 80 quilos na minha cabeça, para eu levar uns três quarteirões para o mercado, o comércio... Aquela caixa pesada. Depois que eu aprendi a ler que vi o número na caixa, 80 quilos. Eu tinha uns 10, 11 anos. Eu cheguei lá, meu padrinho veio tirar aquilo da minha cabeça, parece que a cabeça estava enfiando dentro do corpo. E eu fiquei com essa dor nas costas...

E: - Para o resto da vida.

M: - Estou contando aqui hoje para você. Que eu me lembro, são coisas que eu me lembro. E tinha aquele negócio de levar comida na roça, eu ia para a roça também para semear. E nunca tive mordomia, nunca tive boas roupas, nunca tive bons calçados, minha madrinha me dava caderno velho das filhas dela, me dava pedacinho de lápis. Ela não comprava caderno novo, livro novo para mim. Tudo coisas das filhas dela, que já eram mais adiantadas e foi ficando, e eu ia estudando.

E: - Mas você ia para a escola?

M: - Mas eu ia para a escola. Lavava roupa no rio, nos poços, puxando água do poço para lavar roupa. Tinha uma senhora empregada que não ia com a minha cara, e ela me maltratava, me xingava. Levantava cinco horas da manhã para ir para aquele pilão, queria que eu tivesse força para naquilo igual ela.

E: - Com 11 anos?

M: - Com 11 anos... 10, 11 anos. E ela queria que eu tivesse força para bater naquilo lá igual ela. Ela me xingava, sabe? E eu não falava nada.

E: - Isso em outra casa? 
M: - Ela era empregada da minha madrinha. E ela tinha outras meninas também, aí vieram mais duas meninas estudar. Porque as pessoas do interior mandavam os filhos para casa de conhecidos, amigos, na cidade. E foram mais duas meninas para lá. O negócio começou a a ficar ruim, e eu como a mais velha me acarretei de muita responsabilidade. Então eu tomei responsabilidade muito cedo. E aí eu não tive esse negócio de ir ao baile, de ter amiguinha, ficava em casa. Eu brinquei muito quando estava com a minha madrinha, jogava bola, brincava na rua, no quintal. Não existia um quintal de amigas para brincar de casinha, mas quando tinha tempo, fim de semana, domingo, feriado, nós fazíamos isso. Eu com as filhas delas e minhas amigas, brincávamos assim. Nunca brigamos, nós dávamos super bem, eu e as meninas dela. Só que ela tinha uma mania que, quando comprava uma coisa nova para mim, se ela pagasse 10 reais, falava 30 .

E: - Por quê?

M: - Acho que para valorizar, sabe? Depois que fui crescendo e fui vendo os valores das coisas, e comecei... "Por que ela fala isso?". Ela falava, comprei tanto desse tecido. E junto com eles, morava um irmão que um comércio, uma grande loja, era uma das maiores lojas de tecido que tinha, e ela comprava na loja dele. Ela chegava e dizia para a gente que tinha pagado tanto, depois nós víamos o homem vendendo lá por tanto, bem menos. Porque ele ia vender mais caro para ela? Só porque era para nós?

E: - Claro que não.

M: - Claro que não. E quando as pessoas falavam assim "Só está pronto para comer, na hora de comer...". Minha filha...

E: - Seu padrinho?

M: - Meu padrinho tinha essa mania. Se eu escutasse meu padrinho ou minha madrinha falar isso, eram uns três dias sem querer comer. Eu colocava na minha cabeça que se eu não comesse... Eu casei com 16 anos e ainda achava que se eu parasse de comer eu ia santificar. Ouvia falar de santo, aí eu dizia, não vou comer que é para santificar, para eu sair do meio disso aqui. Esse povo que não me entende.

E: - E você não comia?

M: - Eu ficava sem comer.

E: - Quase sumiu? 
M: - Ficava sem comer para virar uma santa. Eu tratava todo mundo bem, sabe? Eu era assim. Minha madrinha era muito rígida, e agradeço muito a Deus por ela ter sido assim, por não ter criado eu largada na rua. Também não fui criada pedindo nada. Foi difícil, mas nunca ficamos sem comer. Nunca ficou um dia para não comer qualquer coisa, alguma coisa tinha para a gente comer. Passar fome é quando não tem nada. E na minha madrinha a gente se alimentava bem, mas tinha aquele hábito de ficar falando. Quando ela dava alguma coisa para a gente ficava só falando "porque eu paguei tanto para fulano", quando a gente ia ver, não era nada daquilo. E eu não entendia porque ela tinha que falar isso. Aí eu fui me pôr mocinha, tinha as minhas amigas... E: - Morava onde a sua irmã?

M: - A minha irmã na casa de uma ricaça também. Era diretora do colégio naquela época. Não sei o que ela fez com ela, que ela chamava de madrinha. Acho que deve estar até viva, não sei. Morava com ela.

E: - E vocês não se falavam muito?

M: - Nós não nos falávamos muito. Dava muita coisa para ela, comprava roupa, comprava calçado, comprava perfume para ela. E minha madrinha não me dava nada disso. E ela não trabalhava como eu. Lá também tinha empregada. Eu estudava e ajudava. A empregada terminou casando, e eu tomando a responsabilidade da casa.

E: - Você começou a fazer tudo?

M: - Comecei a fazer tudo e ser responsável por tudo que as outras meninas faziam. Eu virei babá de marmanja, porque as outras era grandes. Tudo que eu fazia, se eu quebrasse uma asa de uma xícara, um copo, um prato... Ela chamava Joaninha, e eu falava meio atrapalhada, para chamar Madrinha Joaninha, eu chamava "Marraninha". "Marraninha, eu quebrei um prato", "Marraninha, quebrei a asa da xícara", perdi isso, quebrou aquilo. Eu contava tudo. As outras faziam as coisas e não falavam. Quando ela descobria aquilo mal feito, ela brigava comigo porque eu tinha que prestar conta. Aí acho que comecei a ficar adulta muito rápido, muito cedo. Foi quando um dia eu cheguei na casa da Dona Ida, fui lá ver minha irmã. Ela foi mostrar as coisas, um vestido novo, e eu só usava roupa velha das filhas dela. Ela tinha uma filha mais velha que estudava em outra cidade e as roupas iam ficando velhas, ia fazendo roupa nova para ela, as que não serviam mais, ela remodelava para mim. Principalmente para mim, porque as outras não queriam. As outras diziam "não quero", e eu não falava. Até porque ela era minha madrinha de verdade, as outras não eram. Sabe aquele negócio de pecado? Não pode responder para madrinha, que morre, vira 
bicho, um monte de barbaridade, e eu acreditava. Que não tem nada a ver o respeito com tanta coisa que falavam para mim. E aí eu aceitava tudo, não falava nada para as outra para aceitar, e eu aceitava. E meu pai dava ordem para ela me bater. Os pais das outras não davam, até porque não era afilhada de verdade.

E: - E ela te batia?

M: - Nunca me bateu porque não quis, porque eu mereci.

E: - Por que você mereceu?

M: - Porque eu fiz umas birras com ela. Eu ficava sem comer... Um dia mesmo, eu estava com três dias sem comer.

E: - Nada?

M: - Nada. Porque escutei ela negando comida, aí eu fiquei sem querer comer, porque eu achava que ia aguentar a vida inteira sem querer comer. Eu achava que eu aguentava. E eu não lembro de me sentir abatida não.

E: - Que coisa. Três dias é bastante.

M: - Muitas vezes eu ficava sem comer. Quando ela veio descobrir, nem sei com quanto tempo estava. Aí contaram para ela, e ela me fez comer. Nesse dia ela não me bateu porque ela não quis, porque eu fiz uma birra feia com ela. Grandona já, 11, 12 anos, por aí. Ela devia ter me batido, não é?

E: - Não.

(risos)

M: - Mas eu tinha minhas razões, não é? "Por que você não quer comer?", "porque eu não quero". Mas ela sabia por que, se tocava que eu tinha ouvido alguma coisa. Toda quarta-feira matavam gado, todo mundo comprava aquela carne fresquinha.

E: - Você matava?

M: - Não. O pessoal matava para vender, na quarta-feira, Que a maioria era de sábado e domingo. Feira era de sábado. Aí era quando tinha tudo isso. Não tinha açougue. Era tudo carne fresquinha, fim de semana, sábado e quarta-feira eles matavam. Aí todo mundo comprava carne fresquinha e faziam aquelas comidas com carne fresca. Um dia de quarta-feira, que a Dorita estava lavando roupa, no Mandacaru, era a empregada. Eu estava sem livro, eu pedi para estudar na casa de uma amiga para uma prova. Eu fui estudar lá e quando eu cheguei já estavam tirando a comida, aí escutei quando falaram que só chegava na hora de comer. Foi a primeira e última vez que saí para 
estudar em casa de amiga, porque eu não tinha amiga. Eu escutei, aí ela falou que era para eu levar a comida para a Dorita. "Come e vai levar a comida para a Dorita”. Ela fez o prato e deixou, ela foi para lá, eu só catei o prato que era para eu comer, a comida que era para levar para outra que estava no rio lavando roupa, saí de fininho. Ela já sabia que eu estava sem comer, alguém me dedou para ela. "Você já comeu?", eu falei “não, não quero". Isso nãoa boa, não fazia cara feia, não fazia nada. "Mas não quer por quê? Você está com fome, pensa que eu não sei que você está sem comer?". Ultimamente eu vinha escutando essas conversas, não sei de quem era, mas eu escutava, até apropria empregada eu escutava falando isso. Eu detestava esse negócio, ou você faz ou não faz. Mas eu fazer uma coisa para você e ficar falando aquilo? É horrível. E eu não adotava esse tipo de coisa, porque até hoje eu não adoto. Se tiver que fazer para mim, faça. Mas não pensa que vai me falar depois. Principalmente coisa de comida, come não tem nem como vomitar.

E: - Não tem como devolver.

M: - Não tem com devolver.

E: - Nem é para devolver.

M: - Nem é para devolver, não tem como devolver. E a pessoa dá um prato de comida para ficar alegando que deu comida? Não dá. Haja coração para aguentar essas coisas. E aí minha filha, ela tinha comprado rapadura nova... Aquelas rapaduras cheiJoanas, gostosas, as primeiras que fazem na época. Ela tinha comprado e tinha dividido os pedacinhos de rapadura. Tinha botado o meu em cima da tigela com a comida da mulher. Eu não peguei essa rapadura.

E: - Não pegou?

M: - Não peguei. Ela levantou da mesa, "Vai almoçar Márcia para poder ir. E João Luís vai com você". Que era um negrinho que ela criou. Aí foi que vi que em cima da tigela tinha um pedacinho de rapadura que era para mim. Aí eu fiquei em pé, aí as lágrimas começaram a cair, eu não fazia careta, não fazia nada...

E: - Só chorava.

M: - As lágrimas desciam que chegava a lavar. Que eu nunca vi chorar tanto. "Márcia, vai comer", e eu fiquei em pé, as lágrimas descendo. Ela me empurrou, aí lá onde eu parei eu fiquei. "Caminha menina, vai comer que eu não quero te bater. Será possível que eu vou ter que te bater?". E me empurrava de novo, onde eu parava eu ficava.

E: - Você não queria comer mesmo. 
M: - Eu não queria comer mesmo. Me pegou pelo braço, me botou lá no pé da pia, onde estava o meu prato, uma mesa, nem me lembro mais o que era, e eu fiquei lá. "Come menina". Eu comecei a mexer com a comida, só para ela ver que eu estava mexendo. "Come direito Márcia. Eu vou sentar na mesa e vou comer. Você que me saia sem comer! Hoje é o dia que eu vou te bater. Compadre Sebastião falou que eu posso te bater, e eu vou te bater”. Deixei a comida lá e lavei a mão. Aí o João Luís era para ir comigo, eu senti um medo tão grande. Deixa eu te contar. Eu peguei aquela tigela e botei na cabeça e fui embora. Longe esse riacho Mandacaru, eu não aguentava. Eu fui até lá com esse pedaço de rapadura em cima da tigela e o bicho não caiu.

E: - Nossa...

M: - Quando eu cheguei lá, a Dorita lavando roupa. Quando eu peguei a vasilha para dar para ela, só fui botar perto dela na pedra e aí vi aquela rapadura. Taquei na pedra com tanta força que o bicho esparramou.

E: - Por quê?

M: - Não sei. Me deu raiva, eu peguei aquilo, aí escutei ela falando "vixe, essa aí está danada hoje”. Aí voltei, um sol quente, Mariana, que chegava a tremer. Aquela estrada de terra, aquele mato, aqueles Carnaúba. Muito calor! E a Dorita "Essa hoje ninguém mexe com ela".

E: - E o João Luís junto?

M: - O Zé Luís, eu deixei ele, eu saí não falei nada com ele, que era para eu ir sozinha. Quando minha madrinha viu o menino “João Luís, você não era para ir com a Márcia?”. "Mas ela não me chamou". "Vai trás dela!". Ele era muito apegadinho comigo, sabe? Era ele e o filho dela mais novo que era tudo juntinho, um preto e um branco. O que ela criava e o que era dela de verdade. Um era Antônio, e o outro Zé Luís, Antônio era o dela, e o Zé Luís era o pretinho. Preto, preto, preto, aqueles dentes branquinhos. E tinha vez, quando ele chorava, os olhos ficavam vermelhos. Eu estou vindo de lá para cá, emburrada. Aquele sol quente, quando levanto a vista aquele trem preto na minha frente, assim distante, sabe? Aqueles dentes assim abertos, o menino em pé no meio da estrada, não sol quente que tremia assim, aqueles dentes assim abertos, chorando. E eu ouvia falar do cão que é preto. E eu tinha feito mal criação para minha madrinha, eu tinha medo. E caramba! E agora? Será que é o cão? Vai que é o diabo que está ali. Meu coração bateu, eu fui chegando perto, devagarzinho, até que eu reconheci que era o menino. Parado no meio do caminho, chorando, e aquele olhão vermelho, naquele terror de sol quente, e quase eu não reconheço o menino. Quando eu reconheci, “João Luís!”, aí eu abracei, e ele chorando, aí acabou 
a raiva. Aí eu fiz "João Luís, você fica escondido, não chega junto comigo não”. Isso foi a maior farra quando eu cheguei lá, aí acabou, porque quando eu cheguei "Cadê João Luís?", "Não sei”. "Ele não foi contigo?", "Não. Ele não foi comigo, eu fui só". "E agora, onde eu vou achar o menino?". Aí eu comecei a rir, aí o Luís apareceu, eu fui contar essa conversa, aí foi todo mundo dar risada e acabou a raiva. O pior de tudo é que eu já estava ficando mocinha, começando a crescer, aí minhas amigas mais velhas namoravam Se vissem pegar na mão de um homem, já começavam a falar das meninas. Eu ficava tímida, digo, não vou pegar na mão de rapaz nenhum, porque vão falar de mim também. Eu fui criada assim, tudo que eu via os outros fazerem que falassem mal, eu já não fazia. Que era para não falar aquilo de mim também, entendeu? Completei 14 anos, completei 15 anos, não namorava, não ia a lugar nenhum. Para ir aos bailes tinha que ir com uma pessoa mais velha para levar, sabe? Só com as pessoas amigas da família, tinha que ir um mais velho para levar todo mundo. Quando foi um dia, eu fui à casa da Dona Ida, e a minha irmã me mostrando um bocado de coisa, um vestido novo, já feito, um para fazer, de um tecido amarelinho. E me mostrou um corte de tecido que meu pai tinha comprado para ela naquele dia. Meu pai tinha passado lá em casa, mês de junho era mês de festa junina, e eu não tinha uma roupa nova. Minhas amigas todas tinham roupa nova para sair arrumadinha, eu não tinha. às vezes eu tinha roupa que era remodelada, estava nova para mim, mas eu sabia que tinha sido remodelada da outra para mim. Daí eu pedi, "pai, compra um vestido para mim, uma roupa para mim”. Sabe o que ele me respondeu? Eu nunca tinha pedido nada para ele, nem uma bala, eu não podia nem pintar a unha porque meu pai não queria.

E: - Nem você, nem suas irmãs?

M: - Ninguém. Negócio de namorar, não namorava. Se o rapaz pegasse em nossa mãe, eu nosso ombro, acho que dava até morte. Então ninguém namorava. Pedia em casamento, já casava. Eu pedi, ele falou assim para mim "Eu não vou roubar", aí tudo bem. "Eu não tenho dinheiro filha, não vou roubar", nunca vi meu pai com essa expressão, com ninguém, mas comigo ele fez isso. Por incrível que pareça... Isso foi cedo, aí quando foi de tardezinha eu fui à Dona Ida, quando cheguei lá, a minha irmã me mostrou o vestido novo, e me mostrou um corte que meu pai tinha dado para ela naquele mesmo dia. Para mim ele respondeu isso, para minha irmã ele comprou. Ela fez um vestido de corpinho, de saia, de manga três quartos porque estava na moda, a coisa mais linda, lembro como se fosse hoje. Ainda sobrou tecido que fez uma sainha justa para mim, porque eu era gordinha, ficava estourando minhas banhas dentro daquela sainha apertada. Fiquei 
sentida com aquilo, aí eu falei só comigo, ariando os copos, a gente ariava um monte de copo de alumínio que quase não tinha copo de vidro, era tudo de alumínio, e a gente ariava com areia, não era nem com bombril. Tinha um lugar que pegava areia limpinha, ariava os alumínios, ficava uma belezura, você se enxergava nos alumínios. E eu ariando aquele monte de copo, comecei a chorar, e falei comigo, o dia em que um rapaz quiser me namorar, eu vou namorar com ele, vou casar, que é para eu sair do meio das moças. Ficar dentro de casa, porque casou, pronto! Era só com o marido.

\section{E: - Ficou presa.}

M: - Era como uma prisão. E eu passei por esse processo. Pelo menos não vou ficar sofrendo por vontade de sair com as amigas e não poder porque... Eu não trabalho para ganhar dinheiro, e meu pai faz uma coisa dessas comigo. Quase eu morri de chorar, e falei isso do fundo do meu coração. E: - Mas você falou para alguém, ou para você mesma?

M: - Para mim mesma. Mas eu deixei sair, eu não falei só com o raciocínio. Eu falei.

E: - Você pronunciou.

M: - Pronunciei. E tinha um rapaz lá que é o pai dos meus filhos, tinha outro rapaz lá que era irmão dessa Dorita, que foi casado com minha sobrinha que eu acabei de criar, que esse menino era doido por mim, e eles trabalhavam fora juntos. Teve uma festa dessas de festa junina, teve festejo não sei aonde, lá no bairro que eu nem me lembro mais o nome, e a minha madrinha deixou nós irmos para esse baile, porque era amigo, tinha leilão, aquela coisa toda. Nós fomos para essa festa, eu com cara de garotinha. E lá esse Seu Jonas, que é o pai dos meus filhos, tinha vindo de lá, desse outro bairro, onde eles estavam trabalhando, junto com esse rapaz, e trouxe um bilhete desse rapaz para mim. Isso foi na mesma semana que aconteceu, eu falei isso no sábado e, seu eu não me engano, foi nesse mesmo sábado à noite que eu fui para esse baile.

E: - Foi com uma roupa qualquer?

M: - Com uma roupa qualquer, uma roupa que tinha mesmo. Que as pessoas faziam a festa, mandavam convite para deixar a gente ir à festa, ela deixava, a gente ia.

E: - Era aniversário?

M: - Eu nem sei o que era. Festejo, leilão, essas festas que eles faziam assim. Mas me parece que ela deixava mais a gente ir à festa quando era tempo de política. Aquelas festas de campanha, aí ela mandava a gente ir, sei lá... Ganhar alguma coisa. Para não dizer não para as pessoas, aí deixava a gente ir. Era quando a gente saía mais. Esse cara estava lá, aí ele foi me entregar o 
bilhete, e ele também tinha vontade de ter alguma coisa, de me namorar. Eu com 15 anos e ele com 22.

E: - Era mais velho.

M: - Bem mais velho. Ele chegou e me chamou para dançar, eu fui dançar com ele. Ele começou a falar do Galdino que tinha mandado uma carta. Antes de me entregar a carta ele começou a me xavecar, sabe? Eu nunca disse que queria casar com ele. Foi logo falando em casamento, não foi nem namorar. Eu fiquei com aquela coisa, nunca disse sim para ele, eu sei que ele pegou no meu pé, que foi a pior coisa que aconteceu na minha vida. Eu era uma menina responsável, de confiança, todo mundo queria uma menina como eu, nunca dei trabalho, nunca perdi um ano. Cansei de chegar do rio, já estava lavando roupa, aquela trouxona de roupa lá. E pegava os livros, ia para a escola, nunca tive tempo de estudar, e nunca perdi um ano. Eu fiz até a quinta série.

E: - E o que aconteceu com esse moço?

M: - Ele começou no meu pé, sabe? Pediu ao meu padrinho para namorar comigo, e eu falando para ele não pedir, isso foi pouco tempo, naquela lenga-lenga danada, e eu não gostava do cara. Eu achava ele antipático, gostava de outros meninos lá. Eu gostava de outro, do Afonso que era meu parente. E ninguém gostava do Afonso porque diziam que era vagabundo, que não trabalhava. E naquela época, quem era vaqueiro, nossa senhora! Tinha uma profissão... E ele era vaqueiro. E outro cara que era namorado de uma amiga minha, na mesma época, mas eu gostava dele e ele gostava de mim. Nós nunca namoramos, se gostava, o homem era danado, ele era bem assim comigo. Um dia eu dei uma tapa tão grande, ele era motorista, viajou com a mão inchada, porque ele entrou lá em casa, eu estava na frente do espelho, um espelho pequeno, e eu vi quando ele entrou, na pontinha do pé, de brincadeira. Aí ele pegou e em beijou. Eu dei um murro tão grande no braço dele, que inchou. Ele viajou para Floriano, quando chegou, não sei quantos dias, mostrou o bração inchado do muro que eu dei porque ele me beijou. Mas ele namorava outra, amiga minha.

E: - Aí não dava.

M: - Não dava. Eu gostava dele, ele gostava de mim, mas não dava.

E: - E esse outro moço que gostava de você, que te pediu em casamento...

M: - Esse outro nós nos gostávamos mesmo, se tivesse dado para nós namorarmos, nós namorávamos. Eu gostava muito do Afonso, e ele gostava de mim, mas ninguém queria. Minha família, minha madrinha não queria que eu namorasse ele. 
E: - Ninguém gostava dele.

M: - Não queriam que eu namorasse o Afonso porque diziam que era vagabundo.

E: - Aí você desistiu.

M: - Não foi para frente. Nem eu fui feliz no casamento, nem ele foi feliz no casamento. Aí quando foi um dia... Posso contar? Tem tempo?

E: - Pode.

M: - Vou te contar o pior da minha vida, o vacilo maior que eu dei na minha vida. Quando esse cara pediu para namorar comigo, ele teve a liberdade, chegava em casa, sentava na porta, eu servia um cafezinho, ele entrava. Ele ficava sentado de um lado da mesa, e eu do outro. Se não falasse comigo eu não dava uma palavra. Não tinha beijo, não tinha nada. Às vezes ele mexia em mim debaixo da mesa, eu chutava pra lá. Sabe uma coisa assim esquisita? Porque eu não queria. Ele foi me pedir em namoro para o meu padrinho, sem ordem minha. Eu falei que não queria, não dei "sim" para ele.

E: - Mesmo assim ele foi.

M: - Mesmo assim ele foi. Desse mesmo jeito ele foi me pedir em casamento para o meu pai. Ele montou o cavalo, selou o cavalo e foi para o interior pedir minha mão em casamento para o meu pai. Eu dizia para ele não ir, ele foi.

E: - Seu pai deixou.

M: - E meu pai deu. Minha mãe não gostou, minha irmã não gostou, mas meu pai deixou. Meu pai se apaixonou por esse cara, amor à primeira vista. Que ele tinha um blábláblá minha filha, que eu vou te contar.

E: - Falava bem?

M: - Falava bem.

E: - Vou pegar água, você quer?

M: - Quero. Pega a verdinha para você que é mais bonitinha, e a vermelhinha para mim. Essa verdinha eu comprei ontem lá na Herbalife.

E: - Bonita.

M: - Ele me pediu em casamento. Depois essa coisa toda com esse casamento, esse vai e vem com esse casamento. Aí minha madrinha não queria que eu casasse com ele.

E: - Sua madrinha não queria? 
M: - Não queria. Quando foi um dia, eu estava menstruada, e estava gripada. E lá tem um mato que aqui também tem, chama buchinha, que era uma buchinha pequenininha, que é bom para remédio. Estava muito gripada e peguei aquela buchinha para desentupir o nariz, api fui para essa festa. Era um jogo muito famoso, muito grande, dois times fortes jogando lá na fazenda. Tinha esse jogo e tinha a festa. Minha madrinha deixou eu ir, olha a responsabilidade! Daí para frente... $\mathrm{Eu}$ era uma criança também, com 15 anos eu comecei a namorar o cara, uma menina pequenininha, ele do tamanho dessa casa de grande, e já macaco velho. Namorador, tinha não sei quantas namoradas, eu não sabia, mas até aí. Mas eu não gostava do cara, e o cara falava, antipático. Caramba, será que casar é isso mesmo? Quer saber de uma coisa? Vou casar que é para poder namorar. Eu sentia vontade de namorar, de saber o que era namorar. E tinha aquelas coisas... Vou ter que casar, porque não me deixam namorar. Que inocência, que barbaridade que fiz comigo.

E: - Pois é.

M: - Aí eu fui para essa festa. Quando eu cheguei lá teve um jogo, depois do jogo foi um leilão que quase não acaba mais. Eu com dor de cabeça, peguei um pó quente, aquela poeira, que era aquele campo de terra, sabe? Aquele pó quente, aquele calor, eu menstruada e gripada. E esse tal desse Jonas, quase não via ele. Foram nove mocinhas, amigas, e mais o meu tio Eusébio.

E: - Ah, seu tio foi junto.

M: - Foi junto. E eles foram também, o Jonas que é o pai dos meus meninos e o Edmilson que era namorado da Cristina, amiga da gente. Foram nove mocinhas. E as outras não tinham namorado, só nós. Garanhão os dois, não era nem parentes, mas como a mãe do Jonas era mãe solteira, as pessoas até falavam que o pai do Edmilson era o pai do Jonas, mas não era. Ele é filho de outra família. Parecidíssimo. Garanhão que só vendo para crer. Mas até aí eu nem sabia da vida dele direito, estava conhecendo o cara.

E: - E não estava gostando muito.

M: - Não estava gostando muito. Depois fomos para o leilão e o homem sumiu. Aí vinha uma amiga "Márcia, o Jonas está com a Diquinha ali, debaixo dos cajueiros onde está a sela, no maior amasso".

E: - O Jonas era o...

M: - Era o Jonas. Eu nem ligava. Desacordada, com dor de cabeça. Vieram as nove meninas, e para completar, esse Galdino, que tinha mandado recado para mim por ele, estava junto. Que o 
Galdino era a fim de mim, era pretinho, feinho, mas eu preferia ter me casado com Galdino. Pelo menos eu já conhecia, e era um bom menino, um bom rapaz. Casou com a minha sobrinha que teve problema de saúde, foi parar em coma, aí não deu certo. Mas hoje são amigos.

E: - Não deu certo o casamento, mas são amigos?

M: - São amigos. Era boa pessoa. Ele foi viver a vida dele, ela foi viver a vida dela, veio viver aqui em São Paulo e hoje são amigos. Ele vai a casa dela. E aí esse Galdino estava lá também na festa. Foi o único que chegou em mim, "Márcia eu não acredito no que está acontecendo com você, eu acho que você não merece isso. O Jonas está com a Diquinha mesmo, no maior amasso ali. Você não vai fazer nada?". Eu digo "Não". Ele arrematou um frango, do tamanho dessa cadeira, aí mandou me entregar, dizia elogios. Ele lá namorando a outra, e mandou o frango para mim. Digo, não minha filha, pode levar para ele, eu nem recebi, não vou segurar frango para ninguém não.

(risos)

E: - O que eu vou fazer com um frango?

M: - O que eu vou quere fazer com um frango? Arrumadinha para uma festa vou ficar carregando frango?

E: - Que situação.

M: - Que situação. Não quero frango não, pode ficar. Não vou segurar frango para ninguém.

E: - Aí devolveu?

M: - Ela disse "ah, vou cuidar do frango", aí ela ficou com esse bicho, até que achou um lugar, quando chegou na casa da festa. Na hora de ir para festa ele desgrudou dela e veio junto comigo. Eu digo, "você estava namorando com a Diquinha, vá pôr o braço no pescoço dela". Já estava pedida para casar, só estava faltando aliança. Foi uma tragédia esse casamento.

E: - E ele falou o quê?

M: - Simplesmente eu dei um chega para lá nele, depois ele sumiu de perto de mim, chegamos na casa da festa. Começamos a dançar eu e a Cristina, veio o irmão da dona da casa, o maior gato, um morenão no jeito, e o irmão do tocador, do sanfoneiro, eu fui com o moreno e a Cristina foi com o outro. Todo bonitinho, uns gatinhos. Para esse lado aí, já que ele estava namorando a outra... Nunca briguei com mulher nenhuma por causa de homem, porque eu acho que não é justo. Se ele está comigo e me deixa para ficar com outra, a partir daquele momento já não sirvo mais. Então ninguém é de ninguém, eu nunca adotei isso. Ele me pediu para casar, mas se a outra 
está dando uma oportunidade para ele que eu não tenho para dar, eu não vou me importar, eu não vou atrapalhar, mas também não vou ficar sem dançar. E comecei a dançar com o cara. Dancei uma parte, dancei duas, na terceira, o povo começa a tocar aquele forró lá, não pára nunca. Eu sei que foi passando, teve uma hora que quando parou foi bem na porta da sala da casa, que eu olho para dentro, eles estavam sentados nãoa colcha grande de farinhada, no maior amasso. Ele com a Diquinha, uma brancona, grandona igual a ele, família de gente rica. Vixe Maria! Estou é fora! Estou falando "Vixe Maria!" agora, naquela vez não falei nada, nem passou isso pela minha cabeça. Simplesmente parou ali, quando eu olhei que eles estavam nuns agarros, soltei a mão do cara e entrei na sala. Quando eles viram que era eu desgrudaram um do outro que nem quiabo. Fiz de conta que nem vi. Fui no pote peguei um pouco de água, saí por uma outra porta que ia para cozinha para fazer que ia tomar água, não ia tomar água, sabe? É só para ele ver que eu vi. Que todo mundo tinha falado e eu não fui lá ver, mas ali eu vi. Quando eu fiz assim com o copo deu aquela dor fina, uma dor fina, gelada, correndo assim... Sangue do nariz.

E: - Por quê?

M: - Não sei, estava menstruada, tinha cheirado aquele troço que é muito forte. E ainda passar... Que eu não fiquei com raiva, mas não sei o que deu, deve ter sido algum choque, alguma coisa. E se eu não gostava dele não tinha nem porque ficar com raiva, mas eu tinha um compromisso com ele, ele tinha me pedido em casamento. Foi muita falta de respeito. Ele estava interferindo na minha vida, estava atrapalhando minha vida. Ainda bem que não deu um derrame. As oito meninas entraram atrás de mim, já pensavam que eu ia brigar. Nesse tempo já tinha mulher que brigava com as outras por causa de homem. "Está saindo sangue do nariz!", correram, pegaram uma baciona, encheram de água e me botaram para ficar lavando aquele sangue, até que estancou. E o cara não saiu da porta. Ele sumiu. Estancou aquele sangue, nem ele nem ela estavam mais ali. Não vi mais a cara dela na festa. Ele sumiu, depois ele apareceu, eu estava dançando. Quando eu saí de lá, estancou o sangue do nariz, aí o rapaz, o morenão estava lá na porta me esperando. Quando eu saí ele já pegou na minha mão, eu já comecei a dançar com o cara. Depois ele apareceu e teve a cara de me pedir para o cara.

E: - Não acredito.

M: - Eu falei, "não, deixa eu terminar essa parte, depois nós conversamos”. Quando a parte terminou ele já estava ali na minha cola. Pegou no meu pé porque queria dançar comigo, eu empurrando ele para lá. Eu não queria dançar com ele, praticamente eu terminei, para mim tinha 
acabado. Na minha cara?! Que cara é esse? Ele ficou insistindo, me atrapalhou em dançar com o outro que eu estava gostando. Quer saber de uma coisa? Antes que dê uma briga aqui, eu vou embora. Porque eu não vou dançar com ele colado que nem namorado. Não é justo eu deixar o cara e ficar dançando com ele, só porque ele me pediu em casamento. Mas eu naquela época não tinha palavra, não falava como hoje. Eu queria resolver tudo no silêncio, eu agia, eu não explicava. Eu pensava para falar, mas não falava. Não sei se foi bom, ou se foi ruim. Foi bom, porque eu estou aqui viva, não é?

E: - Acho que sim, deu certo.

M: - Deu certo. Aí eu fui lá no tio. "Tio, vamos embora porque está muito boa a festa, mas para mim a festa acabou. O Jonas estava com a Diquinha, agora a Diquinha foi embora, ele quer ficar comigo. Fica enchendo meu saco. Não quero, vamos embora”. E a minha amiga com o frangão lá na sacola, e ela comendo esse frango, destruiu o frango. Nós viemos embora, ele veio junto. À pé, e era longe. Ele veio junto, olha a cara de pau. Quando ele ia chegando perto de mim eu atrasava, ele recuava, eu passava. Aí começou a botar sangue pelo nariz também.

E: - Também?

M: - Também. Que nós dois tínhamos um negócio que quando um adoecia, o outro adoecia, até nós casarmos era assim. Parece que tinha um vírus que saía de um ia para o outro. à parti desse dia começou esse negócio, essa parceria com a saúde. Mas não entendo, não sei explicar o porquê disso. Muito estranho, eu nem sei o que pode ser, porque eu passei por tanta coisa esquisita, podia ser sequela disso, as coisas que eu desconhecia. Chegamos em casa, ele sumiu, passamos 15 dias sem ele ir lá em casa. Eu dei por terminado. Ele ia na casa da vizinha, ficava até não sei que horas, que era a namorada daquele que me deu o beijo, que era minha amiga, a Socorro. Ficava até não sei que horas na casa da Socorro falando de mim, e não ia lá em casa. A minha madrinha começou a desconfiar, que achava que ele estava namorando a Socorro, mas eu não falei para ela o que tinha acontecido. "Você já percebeu Márcia, que o Jonas não está mais vindo aqui? Fica até não que horas na casa da Socorro, conversando com ela...”. E eu não falava nada. Até que quando foi um dia ele chegou lá em casa, sentou na porta, e ficou conversando com meu padrinho e minha madrinha. Eu saí para servir o café das nove horas, ele estava lá sentado. Eu servi café para ele também. Meus padrinhos entraram, eu fiquei conversando com ele, e aí tocou o barco. Era para nós casarmos em outubro e minha madrinha estava mudando para Floriano. Eu tinha um cabelo comprido, bem cuidado, bem bonitinho. Não fiquei com nenhuma foto de lembrança. 
E: - Nenhuma?

M: - Nenhuma, porque eu fiquei tão decepcionada que eu não conseguia nem olhar para aquela foto. Uma criança, linda. Uma situação daquela...

E: - Dá até desgosto.

M: - Eu digo, não vou querer essa foto. Eu tirei do corpo e tirei do casamento. Parecia um anjo nas garras de um demônio, era o que eu via na foto. Isso é casamento? Aí minha filha, eu tinha umas coisas, tinha criação, lá na fazenda do meu pai. Ele não tinha nada, nem saúde. Trabalhava hoje para comer amanhã. Muito trabalhador, honesto, mas ele não tinha nada. Morava com a mãe. Na semana que ele trabalhava ele tinha dinheiro, na semana que ele não trabalhava não tinha. E serviço era difícil, não existia esse negócio de funcionário, pagar mensal, tudo diário. Serviço lá era assim. Ele, muito trabalhador, não ficava sem trabalhar, mas faltava. Não tinha economia nenhuma. Minha madrinha ia para Floriano e ia levar a Do Carmo, que era uma das meninas que morava lá também. Eu falei "Do Carmo, fala para madrinha que você não quer ir, para eu ir para Floriano". Eu tinha ouvido ele dizer que... Porque era assim, as mocinhas quando noivavam, iam trabalhar em Floriano, outra cidade para fazer o enxoval do casamento. Porque na cidade onde eu morava não tinha serviço assim. Nós combinamos assim, ela falou para madrinha que não ia, e por que ela não me levava? Eu ia casar, e também me dar a oportunidade de conhecer Floriano. E eu fui. Mas sabe por que eu pedi? Porque eu o vi falando que se noiva dele fosse para Floriano, fosse para cidade diferente, para se arrumar para casa, ele não queria mais porque ela não ia voltar mais virgem.

E: - Que coisa.

M: - Ah é? Então é por aí que eu vou me livrar dele. Eu fui para Floriano. Com sete dias que eu estava em Floriano, recebi carta do homem morrendo apaixonado, com saudade de mim. Eu nunca acreditei nele. Eu usava bobs, touca, porque meu cabelo é ruim, mas se eu cuidar dele fica bonito. Ele falou "seu cabelo está bonito, se e eu tiver uma noiva com um cabelo bonito desses...", nós não éramos nem noivo, quanta viagem, "e ela cortar o cabelo, eu acabo o casamento". Menina, quase raspei o cangote. Depois chorei, como eu chorei por causa do meu cabelo. Mandei meter a tesoura no cabelo sem dó. Ele foi trabalhar, ele vinha de quinzena, quando ele voltou eu estava com o cabelo parecendo um menino, só faltou eu passar gilete no cabelo.

E: - E ele? 
M: - Não falou nada. Assim que eu fazia, eu agia para me defender.

E: - E aí vocês casaram?

M: - Na hora de fazer o enxoval meu pai teve a audácia de falar para o cara que não podia comprar o sapato do meu casamento.

E: - Porque não tinha dinheiro.

M: - Que era para ele comprar o sapato do meu casamento. Você acha? É demais da conta. Por isso eu digo que meu pai não gostava de mim. O pior é que tudo que meu pai fez comigo ele pagou.

E: - Depois ele sofreu?

M: - Sofreu as consequências. Ainda hoje não sei o que tem comigo, que mistério é esse, que as pessoas que tentam me prejudicar, terminam se prejudicando. Todo o mal que me deseja vai para a pessoa. Eu não desejo mal para ninguém, Deus é por todos. Acho que de raiva por não poder me afetar, terminam ficando doente. Porque com meu pai aconteceu. Aconteceu comigo também, aquela burrice que eu falei que ia me casar. Sabe o que eu falei? O dia que um rapaz quiser namorar comigo, eu vou namorar e vou casar nem que seja para sofrer muito mais. Por que eu não falei outra coisa? Eu chamei a coisa para cima de mim. Eu não sofria, às vezes a gente é feliz e não sabe. Sofrimento eu fui ter depois com o casamento.

E: - Como foi seu casamento?

M: - Foi muito ruim. Ele falou que meu pai tinha falado isso para ele, eu falei "não senhor". Eu já estava em Floriano, ele me escreveu para falar que meu pai não estava querendo me arrumar para casar, e tinha pedido para ele comprar o sapato. Eu digo "não, não é para comprar. Se ele não puder comprar sapato de casamento para mim, não caso, ou então... Não estou correndo da justiça para casar". Aí eu fiz uma carta para o meu pai e mandei dizer isso. Que se ele não pudesse me arrumar para casar, que eu não estava correndo da justiça para casar. Para ele entender que eu não devia nada para o cara, ele estava pensando que eu era o que? Que eu já tinha ficado com o cara? E: - E aí seu aí seu pai pagou o sapato?

M: - Eu falei "Eu não quero que ele compre sapato nenhum para mim. Se o senhor não puder comprar o sapato do meu casamento, eu não estou correndo da justiça para casar. Se não puder casar agora, casa depois". Meu pai ficou sentido, minha irmã ficou sentida, que disse que filha dele nunca tinha feito isso, que filha dele nunca tinha acabado um casamento, que não pega bem. Foi aquele "auê" danado, praticamente me forçando a casar com o cara. Nem que tenha que 
vender alguma coisa mima lá, mas eu não quero sapato dado por ele para eu me casar. Mas para manter a palavra do meu pai, no lugar de eu me casar em outubro, quando ele viu que eu estava pegando muito em cima, e ele era esperto. Era para casar em outubro, casei em julho. Com essas coisas eu fiquei doente, com uma cólica que eu chegava a fazer coco de sangue. O médico não descobria, tomava remédio. E era eu e ele com essa bendita cólica, e febre. Eu e ele com a mesma doença.

E: - Que coisa.

M: - Eu perdida, sem saber o que estava acontecendo na minha vida. Eu não entendia. Minha madrinha não queria o casamento, e só meu pai queria. A mãe dele não queria, e só ele e meu pai queriam. Minha mãe não era contente com o casamento.

E: - Ninguém queria, só os dois.

M: - Se ele dissesse "Minha filha não vai casar com você". Você via que eu era indefesa, inocente, inexperiente. Meu pai tinha que ter me defendido. Me empurrou para cima do cara. No dia do casamento eu passando mal e ele também. No dia do casamento, aquela coisa acontecendo, não entendi nada. Casei, no mesmo dia já me levou para a casa da mãe dele, não tinha casa pronta para nós morarmos. Fiquei na casa da mãe dele, aí tinha uma irmã que morava lá, tinha uns meninos, ela estava grávida. Não se conhecia, não tinha tido nada.

E: - Ainda não. Mas já tinha casado?

M: - Já. Mas na casa da mãe dele não tinha como a gente namorar nem nada. Nem sabia o que era namorar. Abraçar, beijar, não sabia. Uma menina, casei com 16 anos. Ele dizia que me amava, que não podia viver sem mim, só que eu não sei o que era amor. Perto de onde ia para Floriano, tinha uma igreja, ele começava a falar lá na ponta da rua, assim como daqui lá no Ipê, eu já escutava a voz do cara. Falando alto, eu me trancava no quarto e pedia para dizer que eu não estava lá. Que diacho de casamento foi esse?

E: - Você não gostava mesmo dele.

M: - Não.

E: - E ele gostava de você?

M: - Eu acho que gostava mesmo. Ele tinha umas três namoradas além de mim, e ainda gostava de uma mulher lá que era casada, mas era sem vergonha. A mulher tinha tido uma filha dele. Depois que nós casamos, a mulher teve uma filha dele que é da idade da minha segunda filha, a Rita. Eu não sabia nem namorar, ia namorar na casa da mãe dele? Eu só conversava. Não sabia 
nem planejar uma vida, a casa, o que ia comprar, o que tinha, o que faltava comprar. Eu não sabia de nada disso, eu estava dormindo no tempo. Perdida. Eu estava sentada na porta com ele, se ele não falasse alguma coisa, eu não falava nada, ficava lá sentadinha.

E: - Quieta.

M: - Quieta. Eu não abria a boca para nada. Ia falar o que? Eu não gosto de você, você é antipático. Que eu não sentia nada pelo cara?

E: - Você ficou na casa da mãe dele um tempão?

M: - Fiquei uns oito dias na casa da mãe dele. Enquanto terminava a outra coisa onde a gente foi morar. Quando foi um dia, nós estávamos sentados, umas sete horas da noite na frente da casa e a irmã dele me chamou lá dentro para mostrar as roupas, o enxoval de bebê. Ele tinha deitado nas cadeiras e botado a cabeça nas minhas pernas, pela primeira vez na vida. Foi justamente na hora que ela me chamou e eu dei graças a Deus, porque eu estava morrendo de vergonha, aquele homem deitado no meu colo. Pode? Quando ela me chamou eu fui correndo. Fiquei lá, fiquei, fiquei, fiquei, até quando todo mundo entrou para dormir. Na casa da mãe dele não tinha lugar para ficar escondido. Dormia todo mundo junto. Não sei se ele dormiu, sei que eu dormi. No outro dia o menino mais velho dela estava doente, foram dar um remédio ruim para o menino, ele não queria tomar o remédio. Esse cara ficou louco. Nós tínhamos que ir para roça para colher legumes, comer milho. A Dona Adelaide ia, que era tia dele, e eu ia também, junto com ele... Não! Eu não ia. Esse cara brigou com a irmã, bateu, puxou facão, bateu com o facão na mesa, coisa que eu nunca tinha visto na minha vida. Briga assim. Meu pai não brigava com a minha mãe. Fui criada na casa da minha madrinha, outra educação. Ninguém via essas coisas. Xingando, ameaçou que ia bater na mãe dele. O menino era filho dela, estava doente precisava tomar o remédio, não tinha nada a ver. Mas com raiva. Ciúmes porque eu tinha ido conversar com eles, tinha deixado ele sozinho lá na frente. Eu me desesperei, comecei a chorar, aí a irmã falou "Vamos com a gente lá para a roça". Fiquei três dias com febre, acho que era emocional essa doença minha. Três dias na roça, três dias com febre.

E: - E ele também ficou doente?

M: - Ele não ficou doente dessa vez. Ela tinha uma menininha, bonitinha a menininha, e ela usava um vestido tão fininho. Nessa época a gente ouvia falar em espiritismo, mas era muito segredo, muito mistério. Vou voltar um pouquinho atrás. Quando eu era criança, antes de eu ir para a cidade, quando eu estava morando naquela fazenda Curralinho, minha mãe fazia esteira, fazia 
artesanato com palha de carnaúba. E meu pai tinha uma vazante em outro lugar, longe. Ela tinha que terminar um surrão, um negócio que faz de artesanato, que põem legume dentro para transportar. "Márcia, vai lá no Baixão buscar um pouco de carnaúba, para eu terminar o surrão para o seu pai levar, que ele vai de madrugada". Fui eu e a minha sobrinha buscar esse negócio. Tinha um marido de uma prima minha que estava com uma doença esquisita, e disse que era espiritismo. Eu fui na casa dela, quando chegou o homem estava lá. Eu disse "vamos ficar aqui para ver o que o homem tem, para ver a doença do homem”. Eu fiquei lá, o sol esquentou, as duas de pé descalço, tinha que passar por uma barragem de pedra, tudo quente. "Marcinha, você não vai agora, deixa esfriar para você poder ir". Ela deu o almoço para nós, mas não tive o prazer de ver o homem doente. Eu cheguei em casa, minha mãe já estava no caminho gritando. Coitadinha! Ela andava com muleta. Eu tinha notado, às vezes eu fazia arte, ela queria me bater e eu não deixava. Ela não podia andar para me pegar rápido. "Espera aí Márcia”, quando ela chegava perto de mim eu saía. "Quando teu pai chegar ele vai te bater”, só que ela não falava nada. Nesse dia que eu fiz essa de sair de manhã e chegar cinco horas da tarde, ela já estava lá no caminho atrás de mim. Eu cheguei, falei por que nós tínhamos demorado, e ela não me falou nada. Quando chegou em casa ela brigou comigo, ela sentou não banco, eu cheguei e sentei pertinho dela. Ela estava com a correia do cinto, da cor da saia, mas nesse dia ela me bateu até dizer chega.

E: - Bateu para valer.

M: - Para valer. Depois de tanta coisa que eu fiz que não dava nada, naquele dia bateu por tudo que tinha que bater. Naquele dia eu tomei uma iniciativa, nunca mais vou fugir da minha mãe quando ela for me bater. E nunca mais ela precisou me bater. Eu coloquei na cabeça o seguinte, eu não vou correr, mas também não vou sair do lugar, onde eu estiver ela vem e me bate. Porque eu achei que era judiação. Por que eu demorei? Por que eu não obedeci minha mãe? E não é todo mundo que pensa assim quando é pequena. Isso já uma coisa bem adulta para mim. Nunca mais ela me bateu, só foi essa. Mas se tivesse necessidade, ela ia me bater e eu não ia sair, nem ela, nem meu pai. Quando ele chegou dessa colheita de legumes, mudamos para a casinha. E tinha uma casa de espiritismo lá. Eu morria de medo desse troço. Um trem que ninguém via, eu não entendia. Elas iam não lugar, um salão que tinha lá, cantavam umas músicas, e a menininha aprendeu a música. Eu via aquela menina cantando aquela música, eu achava tão bonito, e decorei a música. Quando eu mudei para a casa nossa mesmo, ele ia trabalhar, eu ficava sozinha, 
bordando, fazendo crochê, fazendo minhas coisinhas de casa, arrumando a casa e cantando aquela música. Eu comecei a sentir coisa. Eu criava galinha, eu começava a cantar parecia que vinha uma pessoa andando. Aquele vento baixinho parecia barulho de pé. O vento rodeava a casa, e as galinhas voavam, pareciam que tinham visto um bicho. Eu olhava, não via nada, e cantando. Começou a me dar febre, e dor de estômago, comecei a me sentir mal. Foi uma rodada de 10 moças que se casaram nesse dia e eu tive filho por último, quando eu fui ter filho, as outras todas já tinham tido, já estavam grávidas de novo. Já tinha tido um filho, já tinha abortado outro. Perdido, sabe? Eu demorei, também não morreu nenhum até hoje, graças a Deus, nem era para morrer.

E: - Teve quantos filhos?

M: - Tenho nove.

E: - Nove com esse mesmo marido?

M: - Com esse cara. Quando foi um dia, um sol, um calor. Minha mãe tinha me dado uma esteira de artesanato de palha de carnaúba, fiquei deitada lá no terreno, a lua bonita. Ele dormiu, mas eu não dormi, porque estava com a impressão que ia chegar alguma coisa ali e ia me afetar, um sentimento de que alguma coisa ia me atacar ali. Eu disse "Jonas, vamos entrar. Eu não estou gostando nada, estou com medo". Entramos. E ele, muito espertinho, que ele tinha medo de morto e a nossa casa ficava de frente para o cemitério, dava para ver até as sepulturas lá dentro. Era alto, dava para ver os túmulos lá dentro. Nós dormíamos de rede, não tinha cama.

E: - Por que não tinha cama? Não tinha dinheiro para comprar?

M: - Não tinha dinheiro para comprar cama, e todo mundo dormia em rede, cama não era nem preocupação, era muito quente, muito calor. A rede dele era passada no fundo do quarto e a minha que ficava na frente, do lado da porta. Tinha duas redes, tinha uma grande e tinha uma fresquinha de lona, eu estava com essa rede. Como ela já estava meio velinha, eu amarrava um pouco baixa, tinha medo de acontecer alguma coisa e eu cair. E eu deitada ali não conseguia dormir. Entrou, mas deixou a porta aberta, e eu que estava na frente da porta. Se eu estava com medo, como eu ia dormir? Não dava. Eu naquele sufoco, eu vi quando chegou um homem na porta e foi abaixando, quando abaixou ele virou um cachorro. Sabe um cachorro quando está bem cansado? Ficou aquele cachorro nos meus ouvidos, eu fiquei ali parada e querendo sentir o ar da boca do cachorro. Lá tinha raposa, que nos dias de calor ela ficava doida, mordia. Eu já estava com medo e acontece um troço desses. Eu fiquei dura na rede. Ele deu um grito, ele deu um grito 
e eu fiquei paralisada, dura, e fiquei respirando igual o bicho. A cabeça começou a doer, parecia que ia explodir. E eu não conseguia falar, ele levantou da rede dele, pegou nos meus braços, quando ele pegou nos meus braços ele ficou em pé. E ele “o que foi? O que foi?”, eu não conseguia falar. Quando eu comecei a sentir esse troço, acabou, eu virei o cachorro. Só pode. Eu que estou falando isso agora, mas naquela época não entendi nada, hoje é que eu deduzo. Acabou, eu não vi mais nada. Não tinha o que fazer, eu não quis mais deitar na minha rede, fui para a rede com ele. Parecia que eu estava pegando fogo, uma febre de repente, que ele não aguentava. Sabe aquele lençol bem grande de casal? Teve que colocar um lençol daquele entre eu e ele na rede porque ele não aguentava. Quando foi madrugadinha eu fui acalmando, veio aquele cansaço, aí ficou só a dor de cabeça. Ele tinha que trabalhar, me levou, deixou na casa da minha sogra. Eu passei o dia todinho deitada, sem comer, sem beber e só assim [respiração acelerada], e a cabeça doendo. Quando chegou do serviço "vamos levar ela no Antônio para ele benzer”, um espírita, sabe? Aí vai me levando para lá, e eu morria de medo. Para ir para lá eles não iam pela rua, eles iam por um desvio no meio de um bairro, no meio do mato que tinha próximo a cidade, para poder chegar na casa dele, porque era proibido. Não sei por que, era tudo proibido. Fui nãoa boa, quando chegou lá naquele riachinho... Quando chegou naquele riachinho eles iam me segurando, porque eu estava agoniada e não dava para andar sozinha, um segurando de um lado, outro do outro. Eles foram me ajudar a passar e eu já estava boa. Fiquei boa no caminho! O riachinho era aqui, tinha que saltar aquela aguinha, do outro lado já era a casa. Antes de atravessar o riachinho eu fiquei boa. "Para onde vocês estão me levando?". "Levando no Antônio, você estava doente, com febre, com dor de cabeça, nós vamos te levar lá para ver o que ele fala". "Ai meu Deus do céu, não vou não", "você vai”. Eu fui. O Antônio estava lá, foi fazer as coisas dele, começou a doutrinar e aí baixou um trem lá, cantando a mesma música que a menininha cantava. Cantava e batia com a cabeça na mesa, eu não vou dizer a letra porque coisa ruim não é bom a gente ficar falando. Esse homem ficou doido, esse bicho pulava e foi outra pessoa amparar. Até que desceu um outro trem nele, que um senhor da Boa Trindade, que dizem que é bom. Se tornou meu amigo, me ajudou. Eu nesse dia não tive como fugir. Eu tinha um medo do Antônio que eu passava longe dele. Tudo na casa da minha sogra, uma dor de dente que se tinha ia para esse Centro Espírita para benzer. Uma criança estava com uma caganeira, tinha que ir benzer. E as músicas que cantavam eram só essas, eu tinha sido criada de maneira completamente diferente, não sabia, cantava como música normal, e eram bonitas as músicas. Eu 
gostava de cantar, não sabia que prejudicava. Falou que tinha me levado para ver, porque eu tinha ficado assim, assim, assim. Ele virou para o Jonas e falou assim "manda ela cantar a música que ela vive cantando que ela fica boa". Zoando comigo. "Que música?". "Manda ela cantar, ela vive cantando uma música. Música de quem não tem o que fazer, que anda vagando, ela começa a cantar e vem, porque não tem o que fazer. Chegou cansado porque a vida dele é essa, é correr em cima e embaixo. Ele é do mal, ele veio te fazer o mal, por isso vive cansado".

E: - E a música você nunca mais cantou?

M: - Nunca mais cantei. Ele me benzeu, me ensinou umas músicas. "Quando você lembrar daquela, você canta essa. Porque eu vou te defender". E você acredita que ele cantou e eu decorei aquelas músicas? Só uma vezinha.

E: - Rápido.

M: - Rápido.

M: - Vou resumir um pouco que é muita coisa. Mas aí foi aonde eu conheci essa parte espírita. Uma parte da minha infância muito importante que não contei, eu era fissurada pelo mato, quase os bichos do mato me levaram embora.

E: - Você era apaixonada por mato.

M: - Onde eu via uma árvore grande, aquilo para mim se tornava um estado, eu queria ficar naquela árvore. Subia naquela árvore, cada galho era uma cidade. Eu comia coisa do mato, tinha uma batatinha que eu cavava no mato, comia aquilo. Que era umas das vezes que eu merecia apanhar. Fazia casinha de brincadeira no mato, aquela sombra ali era minha moradia. Derrubava galho para fazer balanço de pau. Ficava para lá, até quando foi um dia... Eu dizia "Lucinha, vamos caçar caju”, não importava se era caju, se não era, nós íamos para o mato. Quando foi um dia, nós fizemos uma saída dessa, fomos caçar castanha, porque dava o caju, depois vinha época da castanha. Do cajueiro caía muita castanha, a uma pedra dentro das folhas, só que junto daquela pedra não tinha uma folha. Aquela pedra assim no chão e aqui tudo tampadinho de areia, com se aquela areia afastasse as folha para longe daquela pedra. Ficava aquela pedra aqui, e aquele limpo, como se um palmo ao redor daquela pedra. E me chamou atenção. A Lucinha catando as castanhas e eu olhando aquela pedra. Peguei a pedra e levantei, quando eu levantei, uma cobra embaixo. Aí eu chamei a Lucinha, fomos embora. "Nós não vamos mais para esse lado Lucinha, amanhã nós vamos para o outro lado”. Fomos para o outro lado, nós íamos longe de casa, podia a onça comer nós. Tinha onça, tinha cobra e nós íamos muito longe de casa. Aí acho que foi Deus 
para intimidar a gente, porque acho que a gente estava correndo perigo. Como é que eu vou mexer naquela pedra para me assustar com aquela cobra? Não tinha um buraquinho, mas a cobra estava lá embaixo, ergui a pedra, vi o bicho. Eu era pequena nessa época, não tinha nem ido para a cidade ainda. Tinha oito, nove anos. Logo em seguida desse acontecimento eu fui para a cidade. Dessa vez eu acho que quase me levaram embora não sei para onde. Meu destino era mato. Fomo para o outro lado. Aí fomos até um riacho longe que tem. Quando nós estávamos indo tinha uns papagaios em cima de uma pau, eu andava sempre com um pano, roupa de manga comprida nós não tínhamos. Eu usava saia, quando começou a nascer os peitinhos... Quem primeiro deu fé foi meu primo, outro bairro longe, só de saia caindo aqui. Minha mãe me mandava botar aqui, caía, parecia um índio. Ele falou para a mãe dele falar para mim que eu não podia mais andar sem blusa que eu já estava começando a brotar, igual feijão. Como eu chorei. Longe de casa, não tinha nem roupa para pôr. Pode uma coisa dessas? Eu parecia um índio bravo, um caboclinho, um índio, um negócio. Quando eu cheguei no riacho tinha um velho que disse que corria atrás das mulheres. Eu cheguei do outro lado do riacho não banco de areia com o homem deitado, antes da gente ir vimos os papagaios. "Lucinha, e vou subir, vou pegar o papagaio e jogar dentro do lençol para nós levarmos", hoje em dia não tem criança com intenção assim. Você acha que o papagaio ia me deixar pegar ele? E lá vou eu subindo para pegar o papagaio, quando eu ia perto ele voava. Achei mais lindo eles voarem. Desci e fomos embora. E eu fiquei curiosa, como é que fiz isso? Como é que eu sou burra, que não sei que papagaio voa? Eu mesma falando comigo, não falei nem com a minha irmã. "Vamos lá naqueles pés de caju perto do riacho". Que era um riachão que tinha, sabe? Que tinha tudo quanto era bicho, cobra, onça. Depois que eu fui ter medo de onça, até aí eu não tinha. "Lucinha do céu! Você está vendo aquele homem deitado na areia?", ela me disse que estava vendo. Só que depois ela confessou para mim que não viu nada. Eu volto para trás correndo, quase matei a bichinha de correr. Era quase da minha idade, não sei, nunca liguei muito para isso. Eu me apressei para ir embora porque para mim o homem ia vir atrás. Não sei se já aconteceu com você. Sabe o cachorro quando está com frio, que o dono fica agoniado, que fica ganindo, chorando, no meu pé, direto. Eu ouvia a pisada dele atrás de mim, ouvia o grunhido, como se fosse um cachorro precisando de alguma coisa. "Lucinha, vem um cachorro grunhindo atrás de nós, você está escutando?". "Estou”. Perna, perna, perna, nesse dia nós não pegamos nenhuma castanha. Foi o último dia. Antes disso meu irmão ia caçar os animais e eu ia com ele, porque eu tinha medo do bicho comer ele. Eu só tinha um irmão. Ele tinha que me levar 
junto que era para proteger ele. Um dia nós estávamos passando embaixo de um pé de cajá, não sei se você sabe o que é, só tinha uma cajá em cima desse pé. Eu pulei três vezes e peguei a cajá, tirei toda aquela pelinha.

E: - Fininha, não é?

M: - Fininha. Aí pus na boca, quando eu fiz assim a bicha desceu e me entalou. A bichinha não queria descer e nem subia. Corri, passei na frente do meu irmão ele viu que eu estava engasgada e bateu nas minhas costas, a bicha desceu.

E: - Engoliu inteira.

M: - Desceu, com caroço, com tudo. Só tinha uma. Depois disso que foi o negócio da cobra, o negócio do cachorro, do homem na areia.

E: - Depois você virou espírita?

M: - Já vamos chegar lá. Foi a última vez que eu fui para o mato. Eu ia para o mato todo dia, queria viver no mato. Foi quando chegou a oportunidade de eu ir para a cidade, daí foi quando aconteceu tudo aquilo que eu já te contei.

E: - Qual foi a oportunidade de você ir para a cidade?

M: - Para estudar.

E: - Aquela outra cidade, não para São Paulo.

M: - Não para São Paulo. Eu voltei para contar essa que foi muito importante, para poder chegar lá onde o bicho me fez ficar doente. Nessa época chegou o circo na cidade. Você está me entendendo?

E: - Estou entendendo.

M: - Estou emendando de novo.

E: - Você voltou para a história do rio, da canção.

E: - Do rio, da canção, da música e daquele cansaço que eu tive. E aí a casa do Antônio de novo. Ele fez aquilo tudo e eu fui para casa boa. Eu aprendi as musiquinhas e nunca mais cantei aquela música. Chegou o circo na cidade. O Jonas vinha do trabalho e ele também tinha uma tendência de povo espírita se dar com ele. Encontrou o senhor Aurélio e o senhor João, que era o chefe, era o palhação. O senhor João entrou na cidade, ele era espírita, e viu logo toda barbaridade da cidade, toda imundice. Viu todas as possibilidades, os perigos. E ele teve que fazer o trabalho dele lá na cidade de São Francisco. Um dia o Jonas vinha do trabalho e encontrou ele, começaram a conversar, perguntou se ele não conhecia alguém espírita que ele pudesse fazer um trabalho. 
Porque ele estava fazendo o trabalho dele, o circo, e a cidade tinha um clima muito pesado, e ele ia ter que fazer um trabalho para poder facilitar o lado dele. Circo é muita coisa, eles são cheios de mistérios, de enigmas. Precisa estar bem para conseguir fazer as peças. E estavam encontrando muito peso, muita dificuldade. Aí ele falou "tem o Antônio ali, que ele não é legalizado, mas ele entende, ele é espírita”. Aí ele levou o Seu João lá no Antônio. Conversa vai, conversa vem, ele perguntou para o Jonas “você é casado?”, ele falou “não". Negou que era casado. Que ele não admitia ser casado, dizia que era solteiro. Casou, a mãe nunca deu o direito dele viver direito comigo, porque era grudada nele 24 horas. Porque ele tinha que conversar comigo, porque eu tinha que resolver tudo com a mãe. A mãe era um elo entre eu e ele e foi o motivo da nossa separação. Toda ruindade, o motivo foi causado pela mãe dele. As mulheres, eu não vou brigar por causa de ninguém, quem quisesse que desse para ele. Não estava nem aí, não me faltando nada. Não me importo, só que eu também não ligo, não me prendo. Ele falou que não era casado, "Você pensa que me engana? Você é casado com uma mulher assim, altura tal, cor tal. E se você quer saber, vou te contar a infância dela. Ela é médium de nascença, ela tem uma mediunidade muito forte, e quando ela era criança os caboclos quase carregaram ela. Se não fosse caboclo tal, ela não estava aqui, não era sua esposa hoje, e era uma menina muito especial. Você está de parabéns! É uma grande mulher".

E: - E ele?

M: - E aí contou todo o meu percurso, de tudo contou para ele, só não da cajá. Mas do bicho que eu vi, tudo. Minhas artes, que eu gostava do mato, que eu me assustava com isso. E vim parar depois que não sei quem me assustou no mato para eu ir para casa. Depois eu fui encaminhada para a cidade para estudar. "Ela nunca lhe contou isso, não é? Mas quando você chegar lá, pergunta para ela que ela vai te contar".

E: - E era tudo verdade.

M: - Mariana, foi uma surpresa, um susto tão grande que meu coração quase saiu pela boca. E: - Imagino.

M: - Quando ele chegou, que me contou isso... Porque se eu tivesse contado para ele eu podia dizer "Foi você que contou para o homem". Até aí eu não acreditava em nada. A partir daí foi que eu comecei a entender que existe essa parte espiritual, que hoje eu entendo mais ainda da espiritualidade que todos nós somos. Que o espiritismo é o pensamento e a imaginação. O espiritismo é um bem aparente, é um bem que faz o mal e faz o bem, que é pensamento. E a 
imaginação é o mal puro. É aquele que faz o mal porque acha bom fazer o mal, aquele que é o demo admitido. E que todos nós temos essas partes, a única coisa é que você tem que procurar se defender. Naquela época eu não sabia de nada disso. João combinou com Antônio e com o Jonas para ir no pobre onde tinha o salão do Seu Luísão, onde eles iam. Que era lá onde eles cantavam essas cantigas que os meninos cantavam e que eu também aprendi. Que passei por esse sufoco. Nós fomos com ele para lá. Quando o Jonas chegou e me contou, quase deu um troço do susto. E tive que confirmar que era verdade. E aí já fiquei sabendo que ele falou que eu era médium, que por isso eu tinha facilidade das coisas acontecerem comigo.

E: - Aí você entrou para o espiritismo?

M: - Não entrei. Saltei essa, que é por isso que hoje ainda tenho barreira na minha vida, não desenvolvi essa parte. Marcamos um dia com o Seu Luísão. Lá no pobre tinha o salão do Seu Luísão que só fazia o bem, e tinha o salão da Maria que era ruim. Ela fazia o mal, ela matava os outros. Fazia coisa e matava as pessoas, matou o marido dela, e matou uma filha.

E: - Que horror.

M: - Com trabalho. Bebia querosene, chegava não lampião, pegava e virava. Bebia aquilo ali e não tinha nada. Muito ruim. Quando ela ficou sabendo que o Seu João, que a equipe do circo e nós íamos para o Luísão, ela jogou uma coisa no Seu Luísão e deu uma caganeira de sangue nele e ele não pôde nos receber, para nós irmos para a casa dela. Fomos para a casa dela. Nessa altura eu não tinha filho, nunca tinha tido nada, não tinha engravidado ainda. E o Jonas dizia que eu era estéril, que não ia ter filhos. E eu tinha muita dor de estômago, uma dor terrível que eu não sabia de onde vinha, chegava a embolar. Ele começou a fazer o trabalho, e eu lá desconfiada, vi umas coisas, e o Antônio baixando o negócio lá, e ele só tragttiuubalhava na linha branca. Ele com um copo d'água fez uma consulta com uma mulher e chamou a mulher que fez o trabalho para a outra no copo d'água, só não mostrou a cara. Mostrou a mulher daqui para baixo, com vestido amarelo aberto na frente de botão. E o vestido todo mundo conhecia, todo mundo conhecia a mulher que estava matando a outra, que estava fazendo trabalho para a outra. Quando foi chegando meia noite... E ele chamava as coisas dela e não queriam vir, porque era ruim e tem um determinado tempo. Quem trabalha só na linha branca não trabalha de dia, só trabalha de noite. Porque os da linha negra trabalham de dia, mas a força deles... Eles se intrometem toda hora, mas a força maior é durante o dia. Quem trabalha de noite precisa de luzes, de dia não precisa, eles já são das trevas mesmo. Trabalhar durante o dia é porque quer fazer alguma coisa para prejudicar 
alguém, senão não precisa. Antes da meia noite a pessoa pode trabalhar, quando der meia noite e meia tem que parar porque se não parar cruza a linha. Quando cruza a linha, a branca com a negra, aí começa a cair coisa ruim no meio do trabalho. Já cruza, já vai abrindo cratera e já vão se aproximando de quem é frágil, as pessoas que estão abertas. Quando era 20 para meia noite ele nos chamou e mostrou a corrente. Estava a corrente branca no copo d'água. Achei bonito demais ver aquilo.

E: - Dava para ver?

M: - Dava para ver. No copo d'água ele nos mostrou. Ele não atuava no corpo dele, ele conversava com o Sininho, como se ele estivesse aqui e a coisa aqui. Me desculpe, é a expressão que eu estou usando agora, aquela coisa lá que eu não sei o que era, falava com ele e ele falava com a gente. Ele era um mensageiro, ele não se apossava, como tem muita gente que baixa. Ele não, ele conversava com aquela entidade e passava para a gente. A gente via ele conversando e passando. "Até agora não vi nada da dona da casa, não me apresentou nada que preste, porque tudo que ela vê são coisas ruins"... Não! Ele falou assim que as entidades dela deviam ser muito ruins "porque não apareceu nenhuma até agora". "Mas vem ver, se aquela ponta preta ali encostar aqui na branca, vocês vão ver que vai cair”. E eu vou apurar o trabalho até lá para ver quem ela é. Até aí ele já tinha descoberto que tinha sido ela que tinha adoecido o outro. E já que ela tinha nos levado para a casa dela, ele tinha por obrigação saber quem era ela. Ela estava se defendendo porque não queria mostrar. A gente segurou até dar abertura para poder descer para ele saber quem era. Quando aquela ponta da corrente negra encostou na branca a mulher caiu. Desceu um troço lá e ela já foi direto no lampião, virando, bebendo. Já foi lá no canto pegou uma garrafa de cachaça e na boca da garrafa, virou. "Eu sei quem é você. Você veio mas você não vai ficar". Aí já deu uma lição de moral nela, sabe? Escrachou. "Você fez isso com o rapaz para poder me trazer para sua casa”. Deu uma chacoalhada nela, ela se emburrou, foi lá para o quintal, sentou não pau e ficou lá sentada até ele terminar. Acho que foi ele que colocou ela de castigo, só pode. Sei que ela foi para lá e ficou até ele terminar. O Antônio caiu uma coisa também lá, dizendo que era uma coisa e era outra. "Não é você, você está querendo me enganar". Foi expulsando essas coisas ruins. E na hora da consulta descobriu da mulher, que eu achei muito interessante isso. "Não vou dizer que é, vou chamar aqui ela no copo d'água e vocês vão ver quem é. Todo mundo ficou sabendo quem era na hora. E eu na hora da consulta, ele falou que o meu problema não era 
nada demais, eu não ia engravidar tão cedo por causa desse problema e passou um remédio. Fiquei tomando aquele remédio e depois que eu engravidei.

E: - Então funcionou.

M: - E falou que a minha dor de estômago era por causa de uma fruta que eu tinha engolido. Eu saí com meu irmão, passei embaixo de um pé de fruta, só tinha uma fruta, e eu dei dois pulos, no terceiro eu peguei a fruta... Mulher, eu já era casada. Criança, andando com meu irmão.

E: - Nossa. Isso é chocante.

M: - "E você engoliu a fruta, e aí provocou essa dor no seu estômago". Uma fruta, e eu não consegui lembrar. "Uma fruta amarela". E eu não lembrava. "A primeira letra da fruta é um C". Quando ele falou isso eu me vi direitinho, lembrei na hora. Estava com meu irmão, peguei uma cajá e engoli. "Você vai tomar isso e isso. Quem sabe depois desse tratamento você possa engravidar". E foi dito e feito, aí não parei mais. Tinha nove filhos, e o homem ruim demais, tão ruim que eu não vou falar das ruindades dele. Uma tragédia.

M: - São Paulo... Todo mundo vinha da minha terra para cá, e eu não queria vir para São Paulo.

E: - Por que todo mundo vinha?

M: - Eu nunca vi, porque São Paulo parece que tem açúcar. Lá da minha cidade, tinha muita gente que estava aqui em São Paulo, parentes meus, irmão, sobrinho. Aqui em São Paulo era cheio de parente meu, mas era o único lugar que, não sei por que, eu não queria vir.

E: - Não tinha vontade.

M: - Não tinha vontade de vir para São Paulo, se tivesse que sair, eu queria sair para outro lugar. Brasília, Rio, outro lugar, mas para São Paulo eu não vir não sei porque. Porque a minha família vinha para São Paulo e trabalhava, trabalhava, trabalhava, e eu não via nenhum futuro, mas eu não entendia esse lado da vida, que dinheiro não é tudo. Eu tive a oportunidade de vir. Vim praticamente para agradar minha mãe, que já estava em cima de uma cama para morrer, que de fato ela se foi.

E: - Ela estava morando em São Paulo?

M: - Não, lá no Piauí. E eu vim porque eu tinha separado do pai dos meninos, ele praticamente me jogou fora de casa, eu aceitei. Porque enquanto ele me maltratava, eu me preparava para a separação. Eu me desligava dele, cada patadinha, uma coisinha que ele me fazia, uma coisinha entre aspas.

(voz de criança) 
M:

Está proibido vir falar com a gente agora, depois nós vamos ver o desenho.

(risos)

M: - Ela não vai deixar a gente fazer essa entrevista.

M: - Fica lá na sua mesa. Só essa vez, se tornar a aparecer aqui, eu não vou nem reclamar nada, eu vou te pegar e levo para a Néia.

M: - E aí quando ele viu que eu não ia mesmo voltar para ele mais...

E: - Mas ele que quis que você fosse embora?

M: - Nós nunca tivemos boa vida, ele nunca se entendeu comigo.

E: - Você me contou.

M: - Foi uma tragédia esse casamento, que eu casei, não sabia nem porque estava casando. Eu acho que só foi para ter meus filhos, que é tudo o que tenho na vida. Mas em termos de casamento...

E: - Foi ruim.

M: - ... Foi horrível.

E: - E aí vocês se separaram.

M: - Casei sem saber nem o que estava fazendo. Nem gostava do cara, achava o cara antipático, não sei com é que aconteceu uma coisa daquela. Que foi daí onde começou aquela revolta que eu te falei. Que eu fiquei revoltada e não consegui me perdoar.

E: - Eu lembro.

M: - Ele me maltratava, eu ficava com raiva de mim. Ainda bem que nunca passou pela minha cabeça de eu fazer... Nenhuma besteira.

E: - Ainda bem.

M: - Ainda bem, graças a Deus, que Deus me protegeu, porque eu cheguei não momento de querer que o mundo abrisse e a terra me engolisse, eu pensava assim, sabe? Saía andando pelos lugares, naquela tentativa de sair andando pelo mundo, não voltar nunca mais, aí depois quando eu lembrava da minha mãe e meus filhos... Os filhos até nem tanto, mas quando eu lembrava da minha mãe que não podia me procurar, que ela tinha um problema físico, parava em algum lugar, começava a chorar, e aí eu voltava para casa.

E: - Você ajudava sua mãe nessa época?

M: - Não, eu não ajudava. 
E: - Você estava longe dela?

M: - Não, ela morava na fazenda, e eu na cidade. Mas eu ia lá ver ela, mas não vou dizer assim "ajudava", porque eu fiz muito pouco por ela, sabe? Eu não considero nem uma ajuda.

E: - Você fez o que você podia.

M: - Eu fiz o que eu pude, mas não considero uma ajuda. Eu tinha esse sonho de ajudar, e se Deus me permitir, eu ainda vou fazer na morte deles. Vou cuidar nem que seja do túmulo deles, cemitério que está abandonado naqueles matos lá. Se eu puder um dia, ainda vou fazer isso, realizar esse sonho, agradecendo, o que eu não pude fazer em vida. Porque eu não tive muita oportunidade de cuidar dos meus pais.

E: - Entendi, daí sua mãe estava mal.

M: - Ela estava mal, aí ela começou a ficar sabendo, "ah o Jonas falou que vai matar a Márcia", "o Jonas falou que vai matar a Márcia, vai bater e vai machucar". Ela não podia fazer nada, meu pai já velho também, tinha que ir na cidade, e ficar cruzando. Ela morria de medo de chegar a notícia de que ele tinha me matado, tinha me batido, tinha feito alguma coisa assim, e que ela não pudesse fazer nada, ou que o meu pai chegasse a se agredir com ele. Entendeu? Aí ela foi e pediu para eu vir para São Paulo. E eu não conseguia entender, eu falei "mãe, por que a senhora quer que eu vá para São Paulo? E se eu for para São Paulo e ficar que nem os outros que nunca podem nem vir visitar a senhora, que não têm condição".

E: - Não têm dinheiro.

M: -"Não têm dinheiro para vir nem lhe visitar". Aí ela falou, "filha, vai. Se eu morrer e não te ver mais, você não me ver mais, eu fico contente. Eu fico mais contente do que se eu estiver aqui em cima dessa cama e ficar sabendo que o Jonas te machucou, que fez alguma coisa, e eu não poder fazer nada". Aí foi quando eu tomei a iniciativa de vir, com o meu filho mais novo de um aninho e cinco meses. Foi um sofrimento que eu não quero para ninguém, que eu vim despedaçada deixando nove filhos para trás. O mais velho revoltado com o que acontecia na vida, com a separação, começando a beber com 16, 17 anos. Um dia eu estava nãoa casinha, tudo eu fazia economia para arrumar dinheiro para mim, eu morava nãoa casinha que não tinha água, nem luz. Meu pai escolheu, ele falando "Quanto a casa eu não digo nada, se você for para a casa da Pedrina, o Expedito é gente muito fina, vai para lá". A Pedrina era justamente aquela minha irmã que não admitiu eu ter vindo.

E: - Que tinha ciúmes de você? 
M: - Que tinha ciúmes de mim. E todo mundo que vinha de lá para cá, parente mais próximo, ficava na casa dela. Ficava até poder... Sabe? E ela era um amor de pessoa, mas eu acho que toda a privacidade que ela sofreu das outras pessoas, ela jogou para fora tudo em cima de mim, da minha família. E aí eu tive que vir para São Paulo, deixar nove filhos, um filho que foi rejeitado na barriga por toda a família.

E: - Por quê?

M: - O pai dizia que não era filho dele. Quando eu engravidava, ele ficava louco, ele ficava caçando pai para os meninos.

E: - Nossa.

M: - E esse ele chegou a dar o nome, disse que era filho do prefeito. Olha só, filho do prefeito! Ah se é hoje! E aí todo mundo rejeitou o menino, depois que o menino nasceu, a xerox do homem.

E: - Igualzinho.

M: - Igualzinho.

E: - Seus outros filhos ficaram com ele?

M: - Ficaram com ele, com as duas famílias, tanto parte de pai como da minha parte. E o menino ficou com minha cunhada, irmã do pai dele. Já pensou? Passar pelo que eu passei, ter que deixar meu filho na casa do próprio homem que rejeitou ele, porque eles se davam super bem, desentendimento da minha cunhada com ele sempre era para me defender, mas eles se davam super bem.

E: - Aí você veio com seu filho mais novo.

M: - Aí eu arrumei tudo, quando eu falei que vinha, a minha cunhada... Para eu arrumar dinheiro para ir embora, porque eu não me desfiz de nada meu, não sei mais tudo o que eu deixei lá no Piauí, eu só não deixei casa. Mas tudo que eu tinha de casa eu não trouxe nada. Fiz um trabalho e ganhei um dinheiro para vir embora. Eu não deixei porque eu vim para passar três meses.

E: - Ah, você ia voltar?

M: - Eu trabalhava, tinha um empreguinho. Ainda lavava roupa para fora, para aumentar, que eu estava morando de aluguel. Quando eu tomei a decisão de vir, eu saí do aluguel, fui morar nessa casinha para economizar o dinheiro.

E: - Trabalhava com o quê?

M: - Eu trabalhava nãoa creche, como merendeira. E eu lavava roupa, dava aula. 
E: - Aula de quê?

M: - Aula particular de alfabetização, ainda cheguei a dar aula até para o Estado. Por causa do bendito pai dos meninos, terminei perdendo uma oportunidade e hoje... Ia estar aposentada.

E: - O seu primeiro trabalho foi qual? Foi de merendeira?

M: - Não, eu era monitora do Mobral, dava aula. E era substituta do Serviço da Supervisão Global, INSUG também.

E: - O que é isso?

M: - O INSUG é... Porque tem a supervisora global, INSUG é a pessoa que substitui essa supervisora. Ela vem de mês em mês para pegar as fichas, para fazer o trabalho do fechamento do mês.

E: - Na escola?

M: - Na escola de alfabetização Mobral. Eu era monitora, dava aula e já fazia essas reuniões mensais com as outras monitoras, fazia o papel para mandar para a supervisora global. Eu tinha dois salários, de monitora e de INSUG.

E: - Esse foi seu primeiro trabalho?

M: - Não, meu primeiro trabalho lá foi de arrumadeira no sindicato.

$\mathrm{E}:-$ Com quantos anos isso?

M: - Isso eu tinha uns... Acho que foi em 77.

E: - Você ficou quanto tempo?

M: - Fiquei pouco tempo porque eu peguei uma hepatite muito forte, de último grau e quase não me recuperei. Foi pouco tempo.

E: - Aí seu segundo trabalho foi no Mobral.

M: - Mas aí eu já dava aula particular em casa. Mas como eu era muito procurada e o pai dos meninos tudo para me derrubar, ele atrapalhava tudo.

E: - Sempre ele atrapalhava seu trabalho?

M: - Sempre ele atrapalhava.

E: - E você gostava desses trabalhos todos?

M: - Eu gosto, eu amo.

E: - Qualquer um deles você gostava?

M: - Qualquer um deles. Agora eu estou mais na área de saúde, porque depois que eu terminei o segundo grau, que eu vi a loucura que é ser professora. 
E: - Loucura por quê?

M: - Por causa das crianças. Marmanjo. Os absurdos que eu vi as professoras aguentarem agora quando terminei. Eu fiquei assim... Acho que vou para outro lado, porque tanto gosto de dar aula, de passar o que eu sei para os outros. Eu gosto de passar ensinamento. Eu tanto gosto disso, como eu gosto também da parte de saúde. Cuidar de doente.

E: - Você sempre gostou disso?

M: - Sempre gostei disso. Sempre eu fui uma pessoa de confiança, lá eu não tinha muita coisa, mas eu era... Olha que a pessoa pegar outra para escrever uma carta com seus assuntos pessoais, isso para mim é uma grande confiança.

E: - Você fazia isso.

M: - Eu fazia isso. Escrevia carta para as pessoas, eu ia muito na igreja católica, rezava muito, iam fazer terço nas casas, me chamavam para ir tirar o terço. A Márcia tinha que estar no meio de tudo.

E: - O pessoal da comunidade confiava em você?

M: - Confiava muito em mim. A criação, a educação que eu dava, o jeito como eu criava meus filhos, com todo aquele problema. Eu não deixava o problema da convivência minha com o pai dos meninos atingir ninguém, nem meus próprios filhos, é por isso que hoje está todo mundo aí, não tem nenhum revoltado, a ponto de fazer besteira da vida. Porque eu não deixava, sempre que eu via eles quererem fazer besteira da vida, eu já ia "eu sou eu, e você... Ele é meu marido, nada disso vai the atingir. Você é filho dele, você não pode ir contra seu pai. Deixa que quando a mãe não aguentar mais a mãe sai”. E foi isso que aconteceu, eu não aguentei mais. Eu saí para trabalhar, quando eu cheguei... Porque eu trabalhava na prefeitura e fui convocada para participar de um coquetel, para ganhar dinheiro e participar do coquetel. Coquetel dos funcionários, e eu fui uma das convocadas para fazer o coquetel, para ganhar também. Eu acho que ele tinha inveja, acho que tinha ambição, porque eu era de um meio diferente, mas ele já me achou não meio diferente. Sou de família humilde, mas eu fui criada por família melhorzinha e eu me adaptei, sempre eu convivi com pessoas... Sempre eu me encostei nãoa árvore que tinha sombra. Seu eu preciso saber de alguma coisa, eu não posso me misturar com que não tem aquele conhecimento para passar para mim, como aqui em São Paulo. Cheguei aqui no Jaqueline, já fui logo me entJoanando, conhecendo o movimento...

E: - Mas volta um pouco. 
M: - Porque essa parte eu não vou nem me estender, porque eu acho que já falei para você que quando eu cheguei aqui no Jaqueline estava tudo parado, fui eu que...

E: - Não contou. Eu quero saber disso, isso é importante.

M: - Acho que é muito importante.

E: - Só me conta um pouco essa parte do seu trabalho. Você começou como arrumadeira, depois foi trabalhar...

M: - Trabalhava como INSUG em monitora.

E: - No Mobral?

M: - No Mobral.

E: - E depois?

M: - Quando esse bendito prefeito se candidatou, falei com ele, votei para ele, queria que ele ganhasse mesmo. E o pai dos meus filhos votou com outro partido. Aquilo criou uma guerra. Eu nunca fui de discutir com ninguém, eu faço o que tenho que fazer, quem quiser brigar, espernear, que esperneie. Eu não sou de discutir. Eu digo, agora eu vou pegar firme, porque eu estava sentindo que ele tinha estragado a oportunidade do Estado, daí eu comecei a dar aula, dei aula um mês.

E: - O que ele fez?

M: - Ele brigava, ficava falando um monte de barbaridade, que eu não estava trabalhando, que eu estava sendo... Um monte de palavra que eu não vou nem te falar.

E: - Sei. Xingava.

M: - Que eu estava era dando não sei para quem.

E: - Tinha ciúmes.

M: - Ciúmes. Ele não colaborava com nada e não deixava ninguém colaborar. Tinha criança pequena. Só destruiu. Não era para eu estar aqui, ou era, não sei, Deus sabe.

E: - Não dá para saber.

M: - Não dá para saber. Eu sei que aconteceu isso. No dia desse coquetel... Eu era monitora e INSUG. De tanto ele falar que eu estava grávida do prefeito, chegou nos ouvidos dele. Aí o que ele fez? Ele fez uma coisa que ainda bem que ele já morreu. Porque eu tinha um propósito de vir para São Paulo... Depois que eu não voltei mais, aí eu tomei essa iniciativa de, já que eu não voltei, estou aqui, eu vou me capacitar para chegar lá e calar a boca daquele prefeito.

E: - Por quê? O que ele fez? 
M: - Porque hoje com o conhecimento que eu tenho, com essas reuniões, que eu estou com vocês, essa coisas aí, que eu participo de muita coisa, eu converso até com o presidente da república, nãoa boa. E naquela época, sabe o que ele fez comigo? Porque eu não tinha carteira assinada. Simplesmente, minha comadre Diquinha me chamou, que ele era assessor dela que tinha ganhado. Simplesmente ele pegou uma das monitoras, que eu era INSUG dela, eu supervisionava, colocou para fazer o meu serviço, e colocou uma outra pessoa, uma outra monitora...

E: - Para fazer o seu outro serviço.

M: - Para fazer o meu outro serviço, e não me deu nenhuma satisfação.

E: - Nem te avisou?

M: - Nem me avisou, não me chamou para conversar, nem nada. Ele tinha medo de conversar comigo por causa do monstro do pai dos meninos.

E: - Entendi.

M: - Para ser sincera, até a polícia me negou ajuda por causa do pai... Porque eu tenho bronca de polícia. E sempre que eu precisei dos infelizes, são covardes. Não encara.

E: - Medo? Mas seu ex-marido era tão...

M: - Não encara. E quando vai encarar... Ele era muito violento, sabe? Mas a polícia para que é? Não é para esses casos?

E: - É.

M: - Porque para mim sempre eles não me atendem como devem? Sempre eles dão uma chance para o lado do erro, e aí eu não confio. Confio muito mais nesses meninos que a gente vê aí, que diz que é da pesada, confio muito mais neles do que na própria polícia. Porque eu nunca precisei da polícia para ela ser real.

E: - Depois quando você saiu desse colégio, o que você foi fazer?

M: - Diquinha mandou me chamar, eu fui. "Comadre, está acontecendo uma coisa assim, assim. Tiraram seu emprego, Dr. Alfredo tirou seu emprego, mas eu acertei com ele para ficar lhe pagando todos os meses, mesmo sem trabalhar até... Porque a senhora fez um trabalho bonito, a senhora nunca perdeu trabalho, sempre a senhora teve capacidade para fazer o trabalho". Nunca eu fiz um trabalho errado. Mandava minhas fichas todas bonitinhas para supervisão. E quando a supervisora vinha, eu é que recebia ela, eu quem organizava tudo, as outras monitoras para participar daquilo. Eu ia fazer a minha ficha e ainda ia ajudar as outras que tinham dificuldade em 
fazer as fichas. E ajudava. E quando ela ia embora, deixava aquela carga, aquela responsabilidade em cima de mim, eu ganhava. "Então eu falo da senhora ficar recebendo mesmo, até aparecer um outro serviço para a senhora fazer". Ai, que decepção que eu fiquei. Ficou sem merendeira na creche. Foram convocadas as mães, cada dia ia uma mãe. Como eu estava... Eu comecei a dar aula particular, a casa enchia. Eu dizia, vou dar aula particular, a casa enchia de gente. Eu nunca alfabetizei uma criança por ter dificuldade na escola.

E: - Você gosta de dar aula?

M: - Gosto. Eu gosto de dar aula. Se eu voltar para lá... Por isso que eu quero aprender Inglês. Porque quando eu voltar para lá, com os cabelinhos brancos, dando aula de Inglês, é o meu sonho.

E: - Que ótimo.

M: - É meu sonho.

E: - Deve precisar mesmo, não deve ter professora.

M: - Aí eu fiquei muito decepcionada depois disso. Porque quando eu tinha tomado a iniciativa comigo mesma, eu tinha falado comigo mesma, agora, Jonas nenhum me segura. Vou fazer tudo que eu quero. Aparecem muitos cursos para fazer quando a gente está sem trabalho, e às vezes eu não ia fazer por causa dele. Às vezes nós estávamos em treinamento e ele mandava me chamar, que não sei quem estava morrendo. Quando eu chegava em casa era só para me agredir, para brigar comigo porque eu estava lá.

E: - Só para te atrapalhar?

M: - Só para me atrapalhar. E aí eu tinha tomado aquela decisão, ele não vai me atrapalhar mais.

E: - Nessa época você estava de merendeira?

M: - Não. Ainda não estava de merendeira. Foi quando eu tomei essa decisão que estava tendo um anúncio, porque ia sair esse grupo, ia ter uma capacitação para monitora, e ia ter capacitação para supervisora, eu era INSUG. Era uma substituta, então, eu fazendo essa capacitação, eu podia ser a supervisora...

\section{E: - Do colégio?}

M: - Do colégio, do Mobral. Porque era do Mobral essa parte, eu já não estava mais dando aula na escola. No meio do estágio, tive que parar porque o homem estragou tudo. Aí eu fiquei com o Mobral. Era para eu estar sendo umas das melhores lá da minha cidade, se ele não é esse monstro. E: - Você ia ter feito bastante coisa. 
M: - Eu tive oportunidade, tanto de dar aula, como de estudar. O que eu concluí aqui depois de 36 anos, eu podia ter concluído lá. Já estava aposentada.

E: - Você fez esse curso para supervisora?

M: - Fiz. De alfabetizadora, eu tenho até.. Só não tenho mais porque... Só se estiver lá em casa ainda. Fiz o curso de alfabetização, de primeiros socorros, fiz curso de horticultura...

E: - Tudo lá?

M: - Tudo lá.

E: - Na sua cidade.

M: - Na minha cidade.

E: - Você conseguiu trabalhar de novo ali?

M: - Não. Foi quando eu soube dessa história, que ele tinha me cortado do emprego. Fiquei muito chateada. E aquilo só comigo, não tinha para quem eu falar. Foi quando a comadre Diquinha me falou isso. Aí eu fiquei indo para colaborar na creche. Um dia chegou na creche, eu estava passando, ela me chamou. "Comadre, a senhora não quer ficar trabalhando na creche como merendeira?". Eu estava recebendo todos os meses, morta de vergonha. Recebendo o dinheiro sem trabalhar, para mim não era nada bom e nem bonito, se eu tinha capacidade de estar exercendo aquele serviço.

E: - Você ficava com vergonha?

M: - Ficava com vergonha quando ia receber o dinheiro, mas eu ia, precisava. Aí eu falei "aceito". Olha onde eu estava, caí para merendeira. Eu fui de merendeira, aí o dinheiro da merendeira não dava, não estava dando. E o homem ruim, ele tinha prazer de ver a gente sofrer. As professoras começaram a mandar bilhetinho, para lavar os uniformes das crianças, que não lavava porque não encontrava sabão. O dinheiro que eu ganhava não dava, era pouco. Mas isso aconteceu no intervalo de eu receber. Eu saí de um, cortou aquele, e trabalhando na merenda, na escola. Só que não dava, faltava. E ele não comprava sabão. Tudo que eu mais gostava eram as crianças, ele não comprava. Enquanto isso a gente era um bocado de porco, preso não chiqueiro, que ele pudesse jogar qualquer porcaria lá, só para a gente ficar preso. Muito egoísta com as crianças. E quando tirava para agredir a gente...

E: - Você ficou quanto tempo trabalhando de merendeira?

M: - Eu nem sei quanto tempo eu fiquei. Eu sei que eu fiquei trabalhando de merendeira até quando eu vim para São Paulo, não me lembro quando eu comecei. 
E: - Você veio para São Paulo mais ou menos quando?

M: - 87, 88 que eu vim para São Paulo.

E: - Você veio de ônibus com seu filho pequeno...

M: - Aí eu não trouxe meu filho, foi o pior.

E: - Você veio sem nenhum filho?

M: - Deixa eu te contar. Aí foi quando eu passei muita vergonha. Ele começou a receber bilhetinho para lavar a roupa das crianças, e eu não lavava porque não tinha sabão. Mariana, cansei de pegar trouxa de roupa e ir para um barreiral que tinha perto, ou ir para o rio, porque não tinha água encanada, porque ele não ia pegar água para não dar mordomia para mim. Para eu pegar essa água era um sofrimento, tinha que enfrentar a fera, que até ameaçar de morte me ameaçava, mas eu encanei a água lá para casa, que melhorou bastante. Só que depois que eu encanei a água virou pouca e acabou. E eu ia sem nem uma pedrinha de sabão, Mariana, lavar a roupa dos meus filhos só com água. Que tinha uma pilha. Ele fazia xixi na rede, para não dormir mais naquela rede, e tinha que lavar.

E: - Você lavava só com água.

M: - Eu ia lavar só com água. Porque o homem não podia dar sabão.

E: - Nossa, que pessoa ruim.

M: - Para ele, estava me dando mordomia, estava me embelezando. Ele queria me escravizar para eu virar um lixo, porque era para homem nenhum me ver. Tudo ciúme. Estava um dia lá na creche, quando uma amiga chegou, ela trabalhava na prefeitura. Ela chegou, "Márcia, você sabe de alguém que lava roupa para fora?", eu falei "olha, eu não sei de nenhuma, mas se você quiser dar para eu lavar sua roupa. Não sei lavar bem não, mas eu quero, porque eu estou precisando". E: - Aí ela deu.

M: - Aí comecei a lavar roupa. Depois que eu passei a lavar roupa para a Rita, a própria Fátima Fontes.... Fui lavadeira da própria Fátima Fontes, que eu era INSUG dela, entendeu? Que ela ocupou o meu lugar, e eu caí. Eu não gosto nem de lembrar disso que me dá um nó na garganta, mexe muito. Maior decepção que eu passei na minha vida. Eu cheguei a lavar roupa para a Cleonice, que era subordinada minha, e depois eu fui lavar roupa para ela, porque eu precisava. Quando eu comecei a lavar roupa, ele para não aparecer, a mulher de Jonas lavando roupa para fora, tentou me proibir. Tentou me proibir merendeira, tentou me proibir de dar aula, tentou me proibir lavar roupa. Aí eu digo, "meu filho, ou tudo, ou nada. Você não está mais morando com 
aquela criancinha, aquela bebezinha que você casou com ela. Agora eu cresci, eu sei o que é certo, o que é errado. Não preciso de sua preocupação". Ele me ameaçava, aí eu tive que parar de dar aula, porque eu estava dando aula um dia. Estava com umas seis, oito crianças dando aula. Nisso o homem chegou, virado na fera, gritando do nada, ameaçando de me agredir. Eu pensei que o menino estava em cima de uma cerca, essa cerca de madeira, de pau em pé, não sei se você já viu na vida, uma cerca que faz, é de pau assim que você pode cair, se estrepar não pau daquele. Aí eu parei de dar aula, tive que parar.

E: - Muito arriscado, não é?

M: - Muito arriscado. Aí eu parei de dar aula. Eu não posso dar aula que não é decente, vou lavar roupa. Fui lavar roupa de propósito, porque é uma maneira...

E: - Mas você não gostava de lavar roupa, então?

M: - Não gostava. Eu botava aquela trouxa de roupa lá no centro da cidade, na cabeça, e vinha com a trouxa de roupa na cabeça e fazendo crochê, que era para não olhar para ninguém.

E: - Tinha vergonha?

M: - Eu tinha vergonha.

E: - Por quê?

M: - Porque eu era uma professora, tive a oportunidade de ser professora, eu era monitora, vivia nãoa sala de aula, sendo bem aceita pelos meus alunos, nãoa sala de monitores ajudando eles a preencherem as fichas para mandar para a central do Mobral, e de repente me vêem com uma trouxa de roupa, lavando roupa. Aí passava aquela roupa toda, aí vinha aquela coisa de roupa passada. Foi uma maneira de eu mostrar para a população que eu não era aquela pessoa que achavam que eu era. Porque muita gente via, achava que eu era a mulher mais feliz do mundo, porque eu não demonstrava o sofrimento.

E: - Depois perceberam.

M: - Muita gente começou a perceber. Às vezes ele dava escândalo no meio da rua, e as pessoas começaram a perceber. Às vezes ele me agredia em casa e saía pela rua afora falando, e as pessoas começaram a perceber que as coisas aconteciam. Mas quando aconteceu a separação, ainda teve gente que chorou lágrima de pingar no queixo porque eu tinha separado de um homem bom daquele.

E: - Como foi então que você veio para São Paulo? 
M: - Só que toda a vida eu tive um dom de psicologia, e ele vivia indo embora e voltando. A última vez que ele saiu, ele ameaçou que se chegasse e eu estivesse em casa ele me matava. E eu fiquei em casa. Mariana, acredite se você quiser, esse mundo que a gente vive aqui é um inferno, eu vivia um inferno de vida.

E: - Quando ele voltou você estava lá...

M: - Nessa viagem que esse homem foi, a casa virou uma assombração, aparecia bicho, era galinha andando pelo meio da casa.

E: - De onde vinha?

M: - A gente criava. Não sei, esse bicho vinha voando. Acho que ele foi embora e só foi mexer com coisa ruim lá para o lado do Pará, acho que para me perseguir, acho que para dar um fim em mim. Ele era ruim no extremo.

E: - Amor e ódio por você.

M: - Ele nunca me amou, ele casou comigo porque ele não me usou, ele não teve o prazer de me conhecer como mulher antes. Ele era aquele tipo de homem garanhão que comia todas que ele namorava, e eu ele não conseguiu. Então eu coloquei isso na minha cabeça que só pode ter sido, porque não tem como a pessoa morrer de amor por outra e, de repente, antes dele me conhecer como mulher, ele já mostrou a fera que ele era. Enciumando de mim com a irmã dele.

E: - Como é que você saiu dessa vida? Como você saiu desse inferno?

M: - Me apegando com Deus, Divino Espírito Santo, o pai dos pais, a mãe das mães. Eu era católica, como até hoje sou, não me apegava mais com santo nenhum, porque não me ajudavam. Se eu existo, tem que ter uma causa para eu existir. Se eu faço tudo para ser boa, todo mundo me acha boa, responsável, um caráter bom. Por que o pai dos meus filhos fala um tanto de coisa dessas de mim? Por que? Um homem trabalhador, um homem responsável, honesto, bom para Deus e o mundo, mas para mim ele era um demônio.

E: - Você saiu da casa como?

M: - Eu não podia ir na casa dos meus pais, eu era uma prisioneira. Era do serviço para casa. Eu ia para a roça com ele trabalhar, e a hora que chegava em casa ele já vinha brigar comigo porque queria comida pronta. Você entende?

E: - Vamos passar para frente.

M: - Vamos passar para frente, senão não chega em São Paulo nunca. Chegou a ocasião... Eu passei por tudo isso para informar você o que aconteceu na minha vida. 
E: - Você decidiu sair e vir para São Paulo.

M: - Vim para São Paulo porque minha mãe adoeceu. E eu já estava percebendo que... Um dia ele agrediu minha filha, Socorro, tirou sangue da menina.

E: - Que horror.

M: - Agrediu a filha, tirou sangue da menina. Nesse dia ele brigou, bateu em gente, quase matou a menina. Ela teve que sair correndo por dentro de roça, de noite. Perigo de cobra morder a menina. Eu sei que quando ela chegou lá em casa machucada, sangrando, ameaçou o filho que ia lá em casa acabar com tudo, que meu filho teve que encarar ele, dizer que não ia, que se fosse iam se pegar os dois. Depois que meu filho me contou tudo, sabe? Que ele ia lá para casa, que sabia que a Socorro podia estar lá em casa. Eu sei que esse homem rodou, brigou com um homem, ralou o carro do homem com o facão, aí foi preso. E eu lá na minha casa, você acredita que a família dele ainda teve a audácia de dizer que eu era culpada disso?

E: - Não acredito.

M: - Que ele foi preso por minha causa. Só que quando a menina chegou lá em casa sangrando, eu peguei a menina e fui dar parte, fiz um B.O.. Ficou sangue derramado na garagem da Socorro, que era filha dessa mulher que eu lavava roupa para ela. Ele foi preso, depois foi solto, a gente já separado. Mas a separação foi assim, naquele dia do coquetel... Que ele vivia fazendo isso comigo, só que as pessoas de minha confiança, que me respeitavam, porque eu temia se viesse me dar um conselho, eu fraquejar. Eu já abri o jogo para todo mundo, passei mais de um ano sem abrir minha boca para ele. Um dia ele me bateu com o facão. Eu já estava dizendo, não vou brigar, porque ele vivia ameaçando que ia me matar. E eu falei para ele, "você não vai me bater, você não vai me matar, porque não tem porquê você me matar, eu não faço nada para você me matar. Não estou fazendo nada de errado. Eu não brigo contigo, não te cobro em nada”. Chegar e me matar assim a sangue frio? Não tem condição. Aí ele ficava pior ainda. Eu digo, não vou discutir. Fazia comida, fazia tudo, só que eu deixei de levar comida para ele. No começo da gravidez do menino, eu acho que ele não via a mãe dele, porque todo esse sofrimento, a culpada foi a mãe dele.

E: - Por quê?

M: - Só tinha ele de homem. Ela era muito apegada, ela não queria o casamento, não conseguiu interditar o casamento, e eu muito ingênua, não entendia de nada, para agradar o meu pai, eu casei. 
E: - Mas conta como você foi para São Paulo.

M: - Vamos deixar um pouco para trás. Eu sei que passou tudo isso, nos separamos. Depois da separação eu ganhei o menino. Depois que eu ganhei o menino foi esse negócio dessa brigaiada toda, ele foi preso e o escambal. E quando eu vim para São Paulo, como eu te falei, foi um pedido da minha mãe, eu vim para passar três meses. Deixei esse emprego lá em aberto, ficou seis meses me esperando.

E: - O emprego de merendeira.

M: - O emprego de merendeira, ficou seis meses me esperando. E eu vim para São Paulo e não voltei até hoje.

E: - Mas chegando em São Paulo como foi?

M: - Cheguei em São Paulo, eu tive uma referência tão tenebJoana de São Paulo, que eu tinha medo até de abrir a boca. Disseram que aqui ladrão roubava a gente, que o tarado tarava, e tanta conversa feia, e eu morria de medo. Sem nunca ter ido nãoa cidade grande, a única cidade que eu conhecia na minha vida era a cidadezinha que eu morei.

E: - Nunca tinha saído de lá?

M: - Nunca tinha saído de lá para lugar nenhum, nem à passeio, e vim direto para São Paulo. Cheguei aqui em São Paulo tinha que encarar um monte de coisa, caçar emprego.

E: - Para onde você foi? Você foi para casa da sua irmã?

M: - Fui para casa da minha irmã, lá comi o pão que o diabo amassou.

E: - Ela não queria que você ficasse lá?

M: - Não. Ela tem um negócio estranho, ajudei muito, graças a Deus, não sei se valeu a pena para ela, porque quando mais se faz, mais quer. Eu sei que chegou o momento, quando eu comecei a trazer meus filhos... Comecei a trazer os meninos mais velhos, ia trazendo, porque já dava para trabalhar também. Aí eu trouxe a Miriam Milagres.

E: - Você mandava a passagem elas vinham?

M: - Elas vinham. Eu viajei de lá para cá, eu mandava a passagem e a pessoa trazia.

E: - Mas você já estava morando sozinha nessa época?

M: - Não. Eu estava na casa da minha irmã, mas ela era a primeira a dizer para eu buscar os meninos.

E: - Entendi. 
M: - Mas chegou o ponto dela dizer... Ficou muito tumultuado, ela falou que se eu desse o dinheiro, o Expedito ia dividir a casa para deixar uma parte para mim. Peguei o dinheiro do meu emprego, que era pouco, e quando era fim de semana, sábado, domingo, eu fazia faxina para rever mais esse dinheiro. Eu dei o dinheiro para ela dividir a casa, para fazer dois cômodos para mim. Quando eles fizeram, alugaram para uma outra pessoa, eu continuei morando com eles. A coisa foi ficando ruim, porque diminuiu mais a casa ainda. E toda a vida eu tive esse sangue doce das pessoas me procurarem, sabe? Amigas das meninas, aí se tornavam minhas amigas. Tudo que era fim de semana, não tinha para onde ir, aí amontoava tudo lá. Às vezes eram amigas dela mesma. Dava oportunidade, já conhecia porque era amiga dela, depois que me conhecia...

E: - Ficava sua amiga.

M: - Ficava minha amiga, aí ficava aquele clima, sabe? Eu trabalhava a semana inteira, trabalhava à noite, das duas às 10 .

E: - Você trabalhava com o quê?

M: - Nãoa empresa lá em Itapecerica. Metalúrgica.

E: - O que você fazia?

M: - Quando eu saí de lá eu era operadora, trabalhava na linha.

E: - De produção.

M: - De produção. Na resistência, e arrumando coisinha de peça, reajustando peça.

E: - Esse foi seu primeiro emprego em São Paulo?

M: - Não, minha filha. Eu trabalhei de doméstica, uma decepção desgraçada.

E: - Como foi?

M: - Foi péssima a experiência.

E: - Por quê?

M: - O primeiro emprego foi lá na Vila Mariana, um casal de portugueses, quando eu cheguei lá, tudo bem. Quando eu vi, a mulher separando, levou a bandeja, colocou o prato, talher, o copo, uma caneca, e falou aqui você pode usar. O que é isso? Não entendi nada. Mas você sabe, a corda arrebenta para o lado mais fraco. Será que eles têm nojo de mim? Será que eles acham que eu tenho alguma doença contagiosa? A gente só pensa assim. Estranho, nunca tinha trabalhado assim.

E: - Não entendia. 
M: - Não entendia. Eu era cozinheira, eu era faxineira, eu arrumava a casa e passava a roupa. Ela lavava a roupa, depois eu passei a fazer tudo. Mas eu demorei pouco lá, uns seis meses. Ela assinou minha carteira não mês, no outro eu já fui embora. Era como se o salário estava 10, e ela deixou cinco.

E: - Você foi para outra casa de família?

M: - Fui para outra casa de família. Só que depois eu fui me adaptando... Era assim, o casarão deles lá era uma mansão, e tinha uma casinha nos fundos, tinha lavanderia, uma escadinha e a casinha lá nos fundos, onde eu passava roupa e onde eu dormia, onde tinham minhas coisas. Eu não entendia porque no café da manhã eu tomava café lá embaixo, porque tinha a copa assim, e eu nãoa mesinha aqui do lado, tomava café ali. Na hora do almoço eu tinha que subir e comer lá em cima, na janta tinha que comer lá em cima, podia estar chovendo, eu tinha que passar naquele terraço com chuva e comer lá em cima.

E: - No seu quarto.

M: - Lá no meu quarto.

E: - Por quê? Eles não queriam que você comesse junto.

M: - Eu acho que não queriam. E por que no café da manhã podia? Almoço e janta não podia. E eu não entendi isso. Ela tinha uma irmã, a Dona Ofélia, que tinha um problema na perna, que tinha um aparelho...

E: - Um andador.

M: - É. E ela gostava muito de cozinhar. Ela disse que queria cozinhar e aí pediram para eu descer, para ajudar ela. Aí foram se acostumando comigo, estava tudo muito bem. Aí eu disse, quer saber de uma coisa? Assim como eu posso ter uma doença para pegar neles, eles também podem ter uma doença que pegue em mim. Teve uma festa de aniversário, eles me ofereceram um copo que não era meu, e eu não tomei. Aquele monte de parente dele, amigo, tudo lá bebendo naqueles copos mal lavados, vem me dar?

E: - Daí eles estranharam?

M: - Aí depois veio outra pessoa com muita insistência, aí minha bandeja estava lá dentro do armário, com minhas coisinhas arrumadas, peguei aquilo, despejei no meu copo, e tomei no meu copo. Só que quando eu soube do salário que ela colocou na minha carteira aquele pinguinho ali, que acho que foram 13 cruzeiros, bem menos que o salário, ah não! Aí apareceu uma outra oportunidade, daí eu fui. Essa era muito boa, demorei muito, era um apartamento, ela não tinha 
criança, tudo rapaz, moço, moça, vivia quase todo tempo fora, ia para a casa do namorado. Ela saía de manhã, os filhos chegavam de noite, o outro estudava em Belo Horizonte, o outro estudava não sei onde... Todos trabalhavam e estudavam, ninguém ficava em casa. Fazia congelado. Era só para cuidar da casa, arrumar e cozinhava um feijão fresquinho quando dava vontade, não queria comer congelado, fazia um arroz fresquinho. De três em três meses ela enchia os freezers de congelados. Me ajudou muito, me deu muita roupa, calçado. E não me pagava tão mal.

E: - Daí você ficou um tempo?

M: - Fiquei um tempo lá. Vou e trago uma amiga do Piauí, aí arrumei emprego para essa bendita lá perto de mim. Aí ela conheceu uma outra coisa ruim, que era amiga da patroa dela, e essa mulher falou de mim para ela, e ela estava precisando de uma pessoa para cuidar do filho dela, e que me pagava $\mathrm{X}$, o triplo. Eu conversei com a Dona Célia, ela foi muito boa, muito compreensiva, falou "Márcia, eu não posso aumentar seu salário. Vai, vai com Deus, você precisa". Fui, saí da Dona Célia, e fui trabalhar com essa mulher. Lá eu comi o pão que o diabo amassou.

E: - Por quê?

M: - A mulher... Sabe essas baianas doidas, que vêm da Bahia, dos cafundós do Judas, faveladas, que conhecem um alemão riquíssimo dono da CCE, diretor da CCE. Conheceu essa mulher favelada...

E: - Casou.

M: - E essa mulher grudou nesse homem, uma moreninha bonita para ele, aquele alemão grandão, brancão. E aí o que a mulher fez? Já se socou dentro da mansão do homem, o homem morava sozinho, já engravidou desse homem, ele era louco para ter um filho, e eu fui para lá. Eu acho que ela mexia com droga, agora que eu sei que era droga. Porque eu via o comportamento dela, essa mulher fazia eu parar de trabalhar para ficar no escritório conversando com ela, e eu nunca entrei na dela. Quando ela viu que eu não entrei na dela, eu vi ela pegar um negocinho na geladeira, colocar na boca e ficar muito... Sabe? Essa mulher não parava em casa, todo dia o homem saía de manhã, ela saía atrás.

E: - E menino ficava com você? 
M: - O menino ficava comigo. Ele não comia, não tinha força nem para chorar. Comecei a cuidar do menino, a coisa mais lindinha ficou o bichinho. Eu não sei que diabo que ela usava, um dia ela jogou um pó em mim.

E: - Um pó?

M: - Um pó em mim. E ela falou "Nunca fiz isso com ninguém para não conseguir resultado". Não sei que pó era aquele, ela jogou no meu rosto

E: - Que coisa louca.

M: - Ela tentou me hipnotizar, e eu deixei só para ver.

E: - E não conseguiu.

M: - Só que ela não conseguiu. E eu não era quem eu sou hoje, mas ela não conseguiu. Ela não se conformou porque não conseguiu me hipnotizar. Eu não sei o que ela queria tirar de mim.

E: - Já tinha passado um tempão, não é? Você estava em São Paulo, já tinha desistido de voltar.

M: - Já. Ainda estava morando com a minha irmã. Eu já tinha passado por esses dois empregos.

E: - E por que você desistiu de voltar para a sua cidade? Você gostou daqui?

M: - Eu nunca voltei para minha cidade porque não tive condição de voltar.

E: - Dinheiro.

M: - Nunca tive dinheiro suficiente. Eu vim de lá por um caso que não existe mais. Hoje se eu quiser ir eu vou, mas tem um negócio aqui em São Paulo que eu tenho que resolver. Resolvendo, posso até não ir embora, mas eu vou dar um tempo, vou viajar.

E: - Vai tirar umas férias.

M: - Vou tirar umas férias, vou para o Piauí, aí não sei se eu vou voltar. Aquilo que eu te falei, que eu vou atribuir o tempo perdido, cuidado que eu pretendo fazer.

E: - Seus pais.

M: - Eu estava na patroa ruim.

E: - Aí você saiu...

M: - Eu sei que chegou um dia que ela ia sair, aí ela me beijava, beijava o menino, e ela foi beijar o menino, ele quase vomitou na cara dela, ele não estava gostando mais dela.

E: - Gostava de você.

M: - Só gostava de mim. Ela ia pegar o menino, ele chorava, não queria ir com ela. Não sei o que deu na cabeça dela, que ela começou a enciumar do menino comigo. Quando foi um dia, ela disse que ia dar comida para o menino, mudou seu jeito, começou a ficar em casa. Era sopa, que eu 
deixava os pedacinhos porque é bom para exercitar o maxilar. Ela foi ver o menino, e o menino botou a mão na boca, toda criança põe a mão na boca. Ela "pá", tira essa mão da boca que você não é filho de cachorro não. O menino entornou um choro com a boca cheia de comida, que eu pensei que o menino ia asfixiar. Nove filhos eu criei, estava ajudando o filho de uma irmã, tinha experiência. Eu falei “ô Magda, não faz isso com ele, pode engasgar e morrer”. Quando eu falei isso, ela veio para cima de mim como um leão furioso, aí nós discutimos feio. Ela me mandou embora. Eu falei “então empresta uma mala, uma sacola”. “Ah, não vou, não empresto”. Eu sei que não arrumou, aí eu chorei muito, aquela humilhação. O que ela fez? "Hoje você não vai, você só vai amanhã". Ela saiu, conversou com o marido, eu acho, e no outro dia ela saiu e ele ficou. Eu tinha que me arrumar para ir embora. Arrumei tudo, arrumei uma malinha que eu tinha levado, mas não cabiam minhas coisas. Entreguei a carteira para ela dar baixa, porque ela me pagava bem. Arrumei as coisas naquela malinha. Depois que eu acabei de arrumar tudo, aí ele entrou no quarto. “É sua mala?”, eu falei “é”. “Abre ela para mim”, abri a mala, maior naturalidade, nem desconfiei de nada. Tira isso, tira aquilo, tinha um envelope de uma carta que eu tinha recebido, e tava lá aquele envelope. Ele mandou tirar tudo que tinha dentro do envelope. Tive que abrir tudo que tinha, desdobrar tudo que tinha dentro da mala para ele ver.

E: - Para ver se não estava levando nada.

M: - Para ver se eu não estava levando nada. Ela tinha falado para ele que eu tinha pegado dinheiro, eu não saí para gastar com nada, se tivesse pegado, tinha que estar ali. Tinha falado para ele que tinha roubado uma máquina fotográfica, e tudo isso eu vim saber depois que eu voltei para lá de novo.

E: - Você voltou para lá?

M: - Ainda voltei para lá. Ela tinha uma natureza que era estranha, sabe? Um jeito de ser muito estranho.

E: - Mas me conta, você saiu de lá, foi embora...

M: - Ele estava no quarto, fui me trocar no banheiro, ele falou para não trancar a porta do banheiro. Não! Eu me troquei no quarto, aí fui no banheiro pentear meu cabelo e pegar o que eu tinha no banheiro. Ele disse para deixar a porta do banheiro aberta. Eu digo, "mas até para fazer xixi eu tenho que deixar a porta aberta?". "Não. Encosta um pouco". Encostei um pouco a porta, fiz xixi, depois abri a porta e fiquei ajeitando o cabelo com a porta aberta. Dei tchau, fui embora. Aí depois tinha que voltar para pegar a carteira e o resto das coisas. No dia que eu voltei ela me 
chamou de volta. Ela falou para eu voltar depois de uns 15 dias, aí nesses 15 dias eu consegui uma vaga na Pompéia, metalúrgica. Eu tinha feito entrevista, só faltava chamar. Quando eu voltei para buscar as coisas e receber, ela me pediu para voltar. "Eu volto, mas não quero na minha carteira".

E: - Por quê?

M: - Porque eu já ia entrar no outro serviço. Eu fiquei, foi muito boa, e depois que eu voltei, a faxineira dela falou para mim porque ela tinha feito tudo aquilo. Porque tinha sumido um dinheiro, não sei quanto, era pouco dinheiro, era um valor de uns 20 reais, acho. E disse que tinha sumido uma máquina fotográfica, ela estava achando que tinha sido eu. E aí eu acho que ela achou, caiu a ficha, descobriu que não tinha nada a ver.

E: - Voltou atrás.

M: - Voltou atrás. Depois ela me chamou. "E se prepara que ela vai te chamar para voltar. Se ela te chamar, fica. Você não deve".

E: - Ela te chamou, você voltou.

M: - Eu voltei, mas eu digo "mas eu vou em casa". Eu voltei em casa, deixei minha coisas lá, voltei com duas mudas de roupa. Fiquei com um avental. Tirava uma, lavava outra. Porque qualquer hora eu ia embora. Para não ter mais aquela decepção de não ir embora por não ter uma sacola para levar minhas coisas. Não dá. Eu voltei, mas não passei 15 dias...

E: - Te chamaram.

M: - Me chamaram para a outra empresa. Telefone tocou, eu atendi. Só falei assim "olha, minha filha está passando mal". Era a empresa me chamando. "A minha filha está doente, eu estou indo embora e não vou voltar".

E: - E ela?

M: - "Ah, você não pode fazer isso comigo". Eu digo "ah, minha filha está doente, quem tem que cuidar sou eu". Mas era mentira, era para eu entrar na empresa. Nunca mais, graças a Deus, botei a vista em cima, fiquei traumatizada com emprego doméstico. Nunca mais trabalhei de doméstica.

E: - Você não gostou dessa experiência?

M: - Não gostei dessa experiência, foi péssima.

E: - Não gostou por causa de tudo isso, não é? 
M: - Por tudo isso. E o pior de tudo é que eu fui trabalhar com uma pessoa que não sabia arrumar uma casa, não sabia fazer uma comida, e vinha me dar ordens. Por quê?

E: - Você pensava isso na época?

M: - Eu já pensava isso, era muito ruim você ter que fazer uma coisa errada, porque tem que fazer para agradar a patroa. E depois que você termina de fazer, a infeliz chega e diz que não está bom. E você termina fazendo do jeito que você tem que fazer. Aí é que ela vai entender que você está certa. Você trabalha duas vezes, nãoa coisa que você já podia ter feito uma vez.

E: - Como foi na empresa?

M: - Na empresa foi muito bom, eu gostava, fiz muita amiga, mas sempre assim na minha, tímida. Uma paixão à primeira vista, um negócio impossível.

E: - Com um cara que trabalhava lá.

M: - Um cara que trabalhava lá. Foi muito gostoso aquilo que eu senti, sabe? Era muito divertido, eu dava risada de mim mesma. Mas eu fui forte, não... Sabe quando você bota o olho no cara, o cara bota o olho em você, e um gosta e o outro gosta? Mas nem eu podia chegar nele, nem ele podia chegar em mim.

E: - Por que não?

M: - Ele era casado. E lá na empresa, um monte de meninas que já conheciam ele, dava em cima dele. E ele foi se ligar logo nãoa pessoa errada também, porque naquele tempo eu ainda era muito traumatizada, não queria nem saber. Quando eu chegava na empresa que ele não estava, para mim não tinha ninguém na empresa. Quando ele estava, Ave Maria! Eu trabalhava o dia inteiro, a noite inteira se fosse possível.

E: - Feliz da vida.

M: - Quando ele estava por perto era muito bom.

E: - E o trabalho? Era bom de fazer?

M: - Era bom de fazer. Eu me adaptei rápido, aprendi muita coisa, a mexer em outras máquinas.

E: - Tinha chefe?

M: - Eu comecei como auxiliar e já era operadora quando eu saí. Quando fui mandada embora, não foi só eu, foi uma turma, época de corte mesmo.

E: - E sua relação com seu chefe era boa?

M: - Era boa. Me adorava, sabe? Me chamava de Má, Marcinha. Má foi na empresa, muita gente me chama de Má hoje, foi nessa empresa que me colocaram Má. 
E: - Você ficou quanto tempo lá?

M: -Quase dois anos. Um ano e nove meses.

E: - Saiu quando foi mandada embora e foi para onde?

M: -Fui mandada embora de lá, aí eu conheci o Jóquei Clube aqui, comecei a trabalhar no Jóquei Clube.

E: - Aqui no Jaqueline?

M: - Não. Cidade Jardim. Arrumando escritório e apartamento lá dentro do Jóquei. Quando eu saí de lá, entrei nãoa empresa filiada ao Jóquei Clube, aí passei quase cinco anos.

E: - Fazendo o quê?

M: - Eu fazia tudo. Eu fui contratada para cozinhar para seis pessoas, quando eu saí tinham 14 pessoas e eu tomava conta de todo departamento. Quando eu já não estava aguentando mais, eu pedi para o Léo e ele contratou uma faxineira, uma vez por semana. Muito grande o departamento, eu já não estava aguentando mais. Mas ainda hoje ele é meu amigo. Eu saio de lá, ele falou "precisou de mim, me procura". Esse foi um patrão pai, ele me pagava bem. Fazia um mês que eu estava com ele, minha mãe faleceu, e ele mandou eu ir ver minha família.

(interrupção)

E: - Ele deu dinheiro para ver a família. Você não foi.

M: - Eu fui.

E: - Você foi?

M: - Fui. Quase eu não acabo de pagar esse dinheiro. Me descontando tudinho, cheguei na Joana, falei "aumenta mais, senão não vou pagar o Léo nunca". Ainda aceitou eu deixar minha filha com 14 anos no meu lugar.

E: - Ela ficou lá trabalhando.

M: - Ficou lá.

E: - Por que você saiu?

M: - Eu saí porque foi mudando de secretária, gerente... que ele era o dono. Aí entrou uma capeta lá, que nem um furacão. Pisou na cabeça de todo mundo, parece que ela tinha ciúme do Léo comigo. Porque eu cuidava dele como uma mãe cuida de um filho, eu chegava, queria um suquinho, queria um lanche. Ele "Má, toma tanto, compra isso, isso, isso para mim". Uma laranja, alguma coisa, eu fazia um suco. E aí quando ela entrou, até para eu atender esses 
cuidados que eu tinha com o patrão, ela queria que eu fosse pedir para ela para fazer isso pelo Léo.

E: - Entendi, ela queria se impor.

M: - Ela queria se impor. Então ela pisou em todo mundo, em mim ela não conseguiu. Ela começou a ficar apreensiva, sabe? Até que quando foi um dia, ela inventou um churrasquinho de final de semana, e o telefone começou a tocar, e ela "não atende, não atende". Eu digo "eu vou atender sim, vai que é o Léo que está ligando". Eu fui, atendi o telefone, vai que é uma pessoa doente, que morreu, eu vou atender sim. Eu vou atender o telefone, era o Léo.

E: - E aí?

M: - Dando uma ordem. Pedindo para eu ficar até mais tarde que ia chegar um material 10 horas da noite.

E: - Você ficou?

M: - Eu não gostava porque ela fazia questão... Na frente do Léo era assim com o Léo, por trás... Eu sou contra isso. Emprego é passageiro, não está gostando... Eu sempre sou assim, ninguém é de ninguém. Não deu certo, cada qual para o seu canto.

E: - É só um trabalho.

M: - Amo meus filhos, Mariana. Mas se disser assim “mãe, eu quero viver com fulano... porque ela é a pessoa da minha vida". "Vai, meu filho. Boa sorte". Se houver algum defeitinho, "É a pessoa da tua vida, mas ela é assim, assim, assim. Depois você não venha reclamar dela, porque eu estou te avisando. Ela é isso. Eu estou vendo, abre o olho, ela é isso, isso, isso, você não viu ainda”. Isso aconteceu com meu filho mais velho. Ele meteu a cara, e está lá, aguenta!

E: - Depois que você saiu desse emprego...

M: - Depois que eu saí desse emprego, graças a Deus, lá no Léo tive a oportunidade de... Comecei a pedir a Deus, Deus me ajuda, me dê uma oportunidade de eu trabalhar. Estão passando os anos e eu não aguento trabalhar em casa de família. Eu passei por um vexame desse, porque não dá para te contar detalhe, minha vida dá um livro desse tamanho.

E: - Mas desse lugar você gostava do trabalho, gostava do chefe.

M: - Gostava do trabalho, gostava do patrão, de todos os outros funcionários, essa única que não dava para engolir. Ela não vinha para cima de mim, mas ela atacava por fora. Ela atacava aquela menina ali que é indefesa. Eu já trabalhava com venda, comecei a trabalhar com jóia, e essa empresa virou praticamente minha casa. Eu morava em Itapecerica da Serra e trabalhava aqui em 
Pinheiros, Cidade Jardim. Às vezes tinha que chegar encomenda para o Léo, ele pedia para eu ficara para receber, eu dei todos os meus endereços de contato para as empresas lá, eu recebia meus produtos lá, eu ficava lá até mais tarde, separando, fazendo entrega, fiz uma clientela boa aqui em Pinheiros, no Jóquei. Eu trabalhava na empresa e trabalhava para mim. Foi uma porta que se abriu.

E: - E você gostava de fazer essas vendas?

M: - E eu gostava de fazer essas vendas. Ele me pagava pouco, falava no pagamento que ele me pagava pouco. Mas eu nunca falei dele porque ele me pagava pouco, ele me pagava pouco, mas ele podia me pagar hoje, se eu precisasse de um dinheiro amanhã, ele não perguntava quanto eu queria. Ele só falava, vai lá, fala com a fulana fazer o cheque para você. E nem me perguntava quando eu ia pagar e como eu ia pagar. Tem uma pessoa melhor do que essa para eu trabalhar?

E: - Mas aí quando você saiu, me conta.

M: - Quando eu saí...

E: - Ficou trabalhando com vendas.

M: - Com vendas. E aí quando eu saí, tem uma passagem aí que eu não vou te contar, vou saltar essa porque... Aí eu fiquei trabalhando com vendas, quando eu saí da empresa já estava morando aqui no Jaqueline.

E: - Ah, você já tinha mudado para cá?

M: - Já tinha mudado para cá. Apareceu um homem na minha vida, um senhor chamado Francisco Roberto, ele tinha um apelido, chamava Passarinho, um amor de pessoa, um cearense. A gente começou a se dar bem, e ele comprou esse barraquinho para mim aqui no Jaqueline. No ano que eu mudei para cá, foi quando me deram férias, porque eu nunca tinha tirado férias, recebia férias, mas trabalhando. Aí ela me deu férias, eu já estava trabalhando no leilão também, ganhava bem. Ganhava pouco no escritório, mas no leilão compensava. Cada leilão 50 reais. Dois, três leilões na semana era 150 reais.

E: - Ajudava.

M: - Ajudava muito. Já tinha saído do aluguel, já estava morando no barraquinho aqui. Quando foi um dia eu fui lá para me informar sobre o leilão, porque eu estava de férias e ela nunca me chamava para o leilão. Ela falou para mim que ia me mandar embora, porque eu estava muito cansada... Menina, dei uns três pulo dentro desse escritório de alegria, porque eu ia me ver livre daquela coisa. Fiquei com dó do Léo, mas aí o Léo falou para mim, "ah você vai embora, mas 
qualquer coisa que você precisar, conta comigo". Tanto que eu fui embora e até hoje ele me autoriza para eu entrar no Jóquei a hora que eu quero.

E: - Ah, que legal. Ficaram amigos.

M: - Depois que eu saí da empresa dele, quase faliu. Foi roubada não sei quantas vezes, a própria capeta lá... Esqueci até o nome da coisa. Estava roubando ele. No fim das contas, quando ele foi descobrir, ela estava saindo com mais dinheiro do que ele. Quase faliu. Ainda hoje eu diria que ele está "pendengando", não se estabilizou.

E: - Você foi fazer o que?

M: - Fui trabalhar só com vendas. Eu conheci a empresa aqui desses produtos. Hoje eu trabalho com Herbalife.

E: - E tem esse escritório.

M: -Aí aluguei isso aqui. Está bagunçado porque eu estou arrumando ainda.

E: - Para trabalhar com saúde.

M: - Par eu trabalhar com saúde, baseado na segurança alimentar.

E: - Mas me conta, que eu acho que é importante, essa parte do movimento social, de como você entrou nisso.

M: - Como eu entrei nisso, foi assim. Quando eu cheguei no Jaqueline... Porque eu nunca tinha morado em favela. Ouvia falar favela, "pinguela"... Um negócio que eu não sei que diabo que é. É “pinguela” que fala?

E: - Não sei, nunca ouvi falar.

M: - Viela. Favela e viela. E eu não sabia que danado que era. Eu morei na minha irmã, não era favela. Eu não saía, era de casa para o trabalho. E depois fui morar de aluguel, também não era favela. Quando eu vim para o Jaqueline, era favela, favela, favela. Não tinha esse tanto de maravilha que tem aqui não, filha.

E: - Era bem pior?

M: - Ali na Sebastião Gonçalves, para sair cedo, na chuva, tinha amarrar um saco de plástico até aqui.

E: - De terra que tinha?

M: - Na rua do shopping, lá em cima. Ali onde é o shopping era mato, e assim por diante. Muito mato aqui ainda.

E: - Era favela mesmo. 
M: - Eu já tinha esse dom de trabalhar com serviço social, porque o projeto Rondon foi para o Piauí, e eu fiz o primeiros socorros, curso de alfabetização, horticultura...

E: - Você estudou isso lá?

M: - Fiz todos esses cursos com o projeto Rondon. Que foi de São Paulo para o Piauí, para a minha cidade. Eu fiz esses cursos, montei farmácia comunitária, criei a horta comunitária...

E: - Tudo na sua cidade?

M: - Mas o bendito do homem não deixou eu ir para frente com nada. Assustava todo mundo, que não pode fazer um trabalho social sozinho, tem que ter um grupo. As pessoas não podiam ir lá em casa, eu não podia sair para trabalhar que ele ficava... Eu já tenho no sangue essa coisa de trabalhar assim e de ajudar o próximo.

E: - Você gosta disso?

M: - Eu gosto disso. Eu ouvia falar em criança catando comida no lixo, eu não acreditava. Gente catando lixo para comer aqui em São Paulo, eu não acreditava. E foi aqui aonde eu vi.

E: - Você viu que era verdade.

M: - Aí eu vi que era verdade. Eu vi criança pegando coisa no lixo. Ali onde tem o campinho hoje, ali era um mato cheio de lixo. Ficavam até não sei que horas aquelas crianças lá, inclusive uma que eu me apeguei com ela, que foi a primeira criança que eu tirei da rua, tarde da noite, fui procurar a família, ela morreu com câncer no pâncreas. Como eu sofri com a morte daquela menina.

E: - Muito triste.

M: - Muito triste. Vai saber se não era de ficar inalando aquela fumaça toda, comendo porcaria, e a mãe mora lá em cima, na viela atrás da minha casa. Deixar a bichinha assim... 10 horas da noite eu estava com a menina na rua, chegava a estar fedendo, aquele monte de moleque, e a bichinha lá no meio. E vi outras coisas assim, eu trabalhava nessas empresas, com venda, e quando a gente trabalha a gente ganha muita coisa de brinde. Fica muita coisa que às vezes a pessoa faz o pedido e não leva. Aí vai estocando aquele monte de coisa, tinha bastante coisa e eu estava investindo em mercadoria, porque eu estava querendo ir para o Piauí e abrir uma lojinha no Piauí. Roupa, calçado, produtos não perecíveis, eu estava fazendo um estoque, que eu estava toda iludida que eu ia para o Piauí naquele tempo.

(interrupção)

E: - Como você começou a se envolver? 
M: - Aí o que eu fiz? Quando eu cheguei aqui no Jaqueline só tinha um movimentozinho privado lá no Bairro da Esperança, só lá, por causa do Betinho, ainda começando a brotar.

E: - Você que procurou saber? Você que foi atrás deles?

M: - Aí quando eu cheguei, que eu vi aquela situação, eu digo, meu Deus, o que eu vou fazer para ajudar esse povo? Essa é a favela, agora eu estou dentro do negócio, o que eu vou poder fazer? Estou com tanta coisa em casa, mas para fazer alguma coisa, tinha que fazer virar dinheiro. Porque não ia adiantar nada eu dar uma roupa, um calçado. A pessoa quer comer.

E: - Claro.

M: - Está vestido, está calçado, mas está com fome.

E: - Não adianta.

M: - Não adianta. O que eu vou fazer? Eu digo, vou procurar, deve ter alguma pessoa aqui nessa favela que já teve algum movimento, alguma organização, alguma coisa. Aí eu comecei a procurar. Quem é o responsável por esse lugar? Ah, é o Seu Joaquim. Aí me falaram, ele é assim, assim, assim, assim. Deu todas as características dele. Quando foi um dia, eu estava subindo, ali no local onde hoje é o shopping, era mato. Eu ia subindo e ele também. Aí eu "ô moço, como é o nome do senhor? O senhor é o Seu Joaquim?”, “sou eu mesmo”. "O Seu Joaquim que trabalhou na associação aqui?", e ele falou "sou eu mesmo". Aí eu fiz a proposta para ele. Ele falou "olha, está tudo parado...", aí foi me contar a história, abandonaram tudo e ele pegou aquele documento, que ele era o vice-presidente, e guardou tudo, porque jogaram, ninguém quis saber mais de nada. A decepção foi tão grande que ninguém quis saber de nada, jogaram tudo para o ar. Ele pegou essa papelada e guardou. Eu digo “então, vamos renovar esse estatuto, levantar essa situação, porque a gente precisa trabalhar para fazer alguma coisa. Estão acontecendo coisas desagradáveis aqui e a gente pode fazer alguma coisa". Naquela época tinha o Pacheco que era vereador, tinha todo aquele povo que trabalhava com ele...

E: - Vocês foram atrás do Pacheco?

M: - Fomos atrás do Pacheco. O Pacheco e um advogado que chama Miguel. A gente começou a reunir esse povo, fizemos a associação, levantamos a diretoria, registrou tudo bonitinho, começamos a trabalhar. Já estava ocupando o resto da sede. A gente ocupou a sede, começou a trabalhar, daí começou. Trabalhei cinco anos como tesoureira do Seu Joaquim, só que a gente não podia fazer nada, ele não tinha nenhuma proposta que agradava. A gente fazia as propostas para 
eles, para fazer os projetos, eles diziam que tudo bem, vamos fazer, quando chegava na hora ele não confiava no papel na mão da gente.

E: - De onde vinha o dinheiro?

M: - Nessa época não vinha dinheiro de lugar nenhum. Nós fazíamos festa, fazíamos bingo, para conseguir dinheiro e a gente tirava do nosso bolso, depois corria atrás.

E: - E que tipo de projeto vocês faziam?

M: - Não. Não chegamos a fazer nada. Quando chegava na hora, vamos pegar o leite, vamos trazer o leite para cá. Quando chegava na hora, eu corria atrás de todas as coisas para trazer o leite, quando chegava na hora do cadastro, Seu Joaquim tinha que estar junto, tinha que trazer o documento, tinha que assinar, autorizar, que era o presidente, ele não assinava, não autorizava. Aí eu briguei com ele e o abandonei, depois de cinco anos. Porque ele nem trabalhava, nem me deixava trabalhar. Aí não dava. Deixamos ele para lá. Foi quando eu liguei para o Doutor Miguel, conversei com ele lá no Bairro da Esperança. E aí já tinha outros movimentos lá, e o pessoal começando a se mexer, todo mundo. Eu conversei com Eliane, pedi para ela me emprestar a casa da criança um pouquinho, para eu falar com o Doutor Miguel, que era o advogado que estava com a gente. Eu fui, eu o advogado, a mulher do Seu Joaquim e a Eliane. Aí eu passei para ele que tinha que parar de trabalhar com o Seu Joaquim, porque não estava dando, ele não estava querendo ir para frente. Eu tinha um monte de projeto, um monte de coisa para desenvolver, mas com ele na presidência não ia dar porque ele não assinava. Aí ele falou "Márcia, o que você quer fazer é bom para a comunidade. Como é bom para a comunidade você tanto pode como deve fazer seu trabalho independente da vontade de morador. Se tiver como levantar um movimento seu, independente, por que não?”. Ele foi embora eu falei, por onde eu vou começar? Porque eu saí da diretoria, mas continuei trabalhando na sede. Até porque ele não tinha autoridade, chegava lá o pessoal estava com a sede ocupada ele corria e me chamava. "Márcia vem cá! Vamos lá na sede que o pessoal está ocupando". E ele era o presidente, nessas horas eu era boa. Na hora de assinar os nossos trabalhos ele não queria. Para a gente poder buscar benefício ele tinha que assinar. Não é assim que funciona? Ele nem assinava, nem fazia nada. Aí a Eliana falou "Márcia, por que você não trabalha para a Pastoral da criança?”, “o que é isso?”. Pastoral da criança existia há sete anos no Vale da Esperança e ninguém nunca tinha me falado. Eu não sei como funcionava que ninguém sabia. Está vendo ali? É filho do meu trabalho.

E: - Depois eu preciso ver. 
M: - Tenho até o vídeo, mas não tenho a televisão.

E: - Fica para outro dia.

M: - Fica para outro dia. E tenho fotos também que outro dia você vê.

E: - Você começou a trabalhar na pastoral...

M: - Ela falou isso era quarta-feira, no sábado ia ter reunião na cúria. Combinamos, nós fomos. Quando chegou lá eu já anotei tudo que precisava. Precisava de gente, de 20 líderes, eu já arrumei 25. Quando cheguei já fui procurar as pessoas. Sem treinamento nenhum, sem curso nenhum, sem ter capacitação nenhuma. Comecei a trabalhar com a Pastoral da Criança, comecei a divulgar, cheguei a pesar mais de 200 crianças no mês. Naquela época não era regulado como agora, e a gente trabalhava. Tinha 20 líderes. Aí eu peguei Mauricio, peguei um senhor que já faleceu, Seu Joaquim, a Carina, a Cida, duas filhas da Cida, a irmã da Cida, eu sei que eu criei 25 líderes. Eu tinha uns 10 cadernos de visita. No dia da pesagem, da celebração da vida estava cheio. Eu naquela época tinha um dinheirinho, eu estava com a vida um pouquinho melhor do que agora. Se você me arrumasse eu fazia, se você não me arrumasse eu tirava do bolso, e nós fazíamos. Tinha lanche, aí começou o pessoal a ajudar, os comerciantes. A gente via a sede caindo aos pedaços, eu mais aquela Carina fomos de depósito em depósito, comércio, pedindo ajuda para ajeitar a sede. Não tinha banheiro. Hoje é um lixo o banheiro lá, mas tem. Mandamos retelhar, pintamos. Começamos a trabalhar. Aí eu dei asa para um monte de cobrinha. Divulgou muito. Quando eu comecei a trabalhar, pessoal de lá de cima mesmo começou a ficar com olho gordo. A Pastoral tem dinheiro, mas eu vim saber quanto a Pastoral dava depois que eu parei de trabalhar com a Pastoral, porque ela só dava um tanto de ano em ano. O dinheiro da Pastoral nunca deu para comprar nem uma camiseta para vestir, quanto mais comprar um lanche, fazer nada. Só usava esse dinheiro para a passagem para ir para as palestras.

E: - Como você entrou nesse grupo? No Mãos na Massa?

M: - Eu entrei nesse grupo por que... Foi assim, quando eu saí do Seu Joaquim eu tentei montar uma Associação de Mulheres. Foi cadastrado no cartório, tudo bonitinho, mas não foi liberado o CNPJ não sei por que. Eu estava aprendendo. Eu sei que a Beth, a Cida, eram todas da nossa associação. Tempo vai, tempo vem, eu adoeci. Separei desse homem que me trouxe para cá, ele foi embora para procurar meio de vida, estava bebendo muito. Eu pedi para ele procurar recurso, ele foi procurar recurso e até hoje não voltou. Eu fiquei doente, fiquei mais de ano perdendo sangue, perdi sangue até sair aquela água verde. 
E: - Por quê?

M: - Não aceitei tomar sangue, tomei um soro uma vez. Os médicos não descobriram de onde vinha tanto sangue, e eu fiquei boa com oração e fazendo higiene.

E: - Com o que?

M: - Umas cascas. Faz a lavagem, eu tomava um golinho por dia e fazia lavagem vaginal com aquilo e com oração, com leitura.

E: - Daí você melhorou.

M: - Hoje eu estou aqui. É como se tivesse morrido e renascido. Porque eu só fiquei a carcaça e o espírito.

E: - Depois disso você entrou no grupo...

M: - Quando eu estava doente a Beth bandeou para o lado do Seu Joaquim. A Cida, mais Seu Antônio Parente que estava ajudando a gente passaram a mão... Passaram a mão não! Eu entreguei porque pensei que eles estavam comigo. Pegou disquetes da Associação, que a Cida era a vice-presidente, eu era tesoureira, e formou uma associação das mulheres com a Cida presidente. E eu lá sem saber de nada. Nessa época eu já participava em reunião lá na Barra Funda, desse negócio de habitação, essas coisas assim, lá no Paulo VI, onde tinha reunião de negócio de habitação... Eu sempre sonhei em ter minha casa própria, eu já participava das reuniões, quando tinha reunião ali também eu já participava, foi quando começou a Cris... A Vera da Casa da Criança trouxe a Cris aqui no Jaqueline, trouxe a Cris da Pólis. A Cris fez uma palestra aqui com a gente, eu participei. Daí foi que para todo canto onde tinha uma reunião eu comecei a participar. Fui descobrindo as coisas, já estavam acesas, evoluídas, mas interessadas. Quando surgiu esse negócio de segurança alimentar eu já estava trabalhando com Seu Toninho lá na Ação Cidadania. Depois quando eu achei que devia, abri minha Associação, porque ia adquirir mais coisas, porque pegava a dele e pegava a minha. Foi quando peguei a Ana, apresentei a Ana. Saiu a Feira Solidária, lembra? Foi jogada na minha mão pelo Jd. Olímpia. Tive a oportunidade de fazer capacitação de ONGs, capacitação de projetos, eu tenho todo material de projeto. Por isso que de vez em quando eu acerto alguma coisinha lá, sabe? Porque tenho uns cursinhos que me ajudam muito e eu tenho todo esse material. Mas eu tenho um material riquíssimo que podia ajudar muita gente aqui.

E: - O grupo hoje que papel tem na sua vida? Como você está vendo isso? Como você se imagina daqui um tempo? 
M: - Daqui um tempo eu imagino nós como uma cooperativa. Mãos ma massa, vendendo barrinha para todo mundo. Eu vou participar das coisas porque a menina do aprendizado nunca me enche. Fica com a medida do "ter", quanto mais você tem mais você quer. Tenho um real aqui para você, Mariana, você não vai querer?

E: - Claro.

M: - Se você tem facilidade de ganhar mais lucro do que você está ganhando você vai ganhar. Está meio difícil ainda o Mãos na Massa.

E: - Por quê?

M: - Porque ainda tem pessoas que não se adaptaram no objetivo. Acho que dá para você perceber que aqui tem pessoas que ainda estão se encontrando, pessoas que ainda não confiam nem nelas próprias. Isso é muito ruim.

E: - E o que você está achando desse negócio de trabalhar em cooperativa?

M: - Olha, é um dos meus sonhos porque como eu te falei, eu pedi muito para Deus para eu sobreviver sem ter que ter um emprego que possa me mandar embora. Se for para eu viver de faxina eu não vivo porque eu não aguento. Toda vida eu fui péssima faxineira. Por falar nisso eu tenho que dar um jeito nessa janela ali, limpar. A janelinha aí, está muito suja. Eu quero saber se pode jogar água. Eu peguei minhas cortinas dei tudo para minha filha.

E: - Então a cooperativa na verdade você acha bom.

M: - Eu acho bom porque faz parte do meu sonho. Aquela placa que está lá em cima está incluído Herbalife, que depois você venha tomar um chá, aí você vem toma um chá e ainda sai com a pele bem hidratada, é um brinde que eu vou te dar para você poder divulgar meu trabalho. Eu vou te dar o chá e ainda vou te fazer a higienização de pele.

E: - Pode deixar que eu divulgo.

M: - Porque lá tem Espaço Caseiro Vida Saudável Herbalife.

$\mathrm{E}$ : - E as barrinhas entram onde?

M: - Vida saudável e beleza natural. Venha degustar, é as barras.

E: - Entendi.

M: - Deixei suspenso que é para dar oportunidade das pessoas virem falar comigo, se você mastiga tudo e põem lá as pessoas não têm curiosidade, e eu quero falar com as pessoas, por isso que eu fiz assim.

E: - E você está gostando de trabalhar em grupo? 
M: - Eu adoro trabalhar em grupo.

E: - Aprende bastante.

M: - Aprende bastante. A gente dá e recebe, é uma troca de aprendizado. Eu não sei se você já percebeu que quando as pessoas começam a reclamar da palestra eu defendo, porque as pessoas que reclamam são justamente aquelas que vão dar mais dor de cabeça na gente futuramente. Que a pessoa não que aprender, a pessoa não tem paciência, acha que já sabe tudo. Tem pessoas que são inteligentes, mas que se tornam um burrão, que ele não gosta de ouvir, quer chegar e já pôr a mão na massa. 


\section{Parte II}

M: - Na minha vida, e aqui já tem um pedaço, né?

E: - Você tem esse sonho de ter um livro?

M: - Eu tenho esse sonho Mariana.

E: - Mas já é um começo, hahaha

M: - Um pedação olha!

E: - É, então...

M: - Gente...Você trouxe de presente para mim isso aqui?

E: - Trouxe para você, claro ué! Você esta me ajudando...

M: - Obrigado.

E: - E esse daqui ó, também é para você. O que é isso? É um dvd, se você colocar não computador, se alguém tiver um computador e tal, você consegue ouvir a entrevista toda a gravação que a gente fez esta aqui, e também tem todas as fotos do grupo. As fotos que a gente tirou do amigo secreto, tem tudo aqui nesse cd, para você também ter guardado.

M: - Tá bom... Que belo presente gente!

E: - Que bom que você gostou!

M: - Esse é surpresa viu?! Que surpresa boa!

E: - Que bom! Então depois você pode ler com calma também quando você quiser. E aí se você quiser mudar alguma coisa a mais e tal, sei lá, se você leu alguma parte e achar que esta faltando alguma coisa, você me fala que eu ponho. Por quê? Porque agora vai ser o momento que eu vou começar a fazer a análise mesmo das entrevistas, sabe? A escrever o meu trabalho, depois quanto o trabalho tiver pronto também eu trago para vocês. Mas a ideia é que daqui em diante, eu pegue essas entrevistas, à sua, a da Rosa, do Sr. Luís, leia tudo de novo com calma e encontrando assim; quais são as mudanças que vocês viveram ao longo da vida, entendeu?

M: - Ahã.

E: - E daí, sabe oque eu queria também saber? Já que a gente já esta aqui... Como é que esta o grupo, o que aconteceu depois disso?

M: - O grupo depois disso, aquilo que aconteceu com o grupo que eu estou meia triste com a Joaninha que esta afastada, a Nadir parou mesmo de vez e ela esta um pouco devagar, pelo menos 
a última vez que conversei com ela falou que a Joaninha veio aqui ontem me procurar dizendo que tem uma coisa para me falar que é do meu interesse, então tenho que ir lá hoje.

E: - O que será, né?

M: - Não tenho a mínima ideia.

E: - Acho que é do rótulo, deve ser. Porque a Joana ela esta muito ligada a esse negócio do rótulo. M: - E agora que ela passou pelo rótulo, eu também estou passando agora. Foi até bom porque ela quem tomava a frente nas vendas, ela era coordenadora de venda, as primeiras pessoas sobre o rótulo foi com ela e o Carlos. Como só tem o Carlos de homem no grupo, sempre ele sai para as vendas, sempre quando é um lugar mais difícil, ele acompanha quem vai vender. E hoje eu também tive que assumir o trabalho de venda, eu fique nas finanças com o Carlos. E o Carlos nas vendas enquanto a Joaninha esta afastada, porque as outras para vender são mais devagar, entendeu? Se não a gente não consegue ir para frente, e também tomamos uma pressão....

E: - Lá na feira?

M: - É, e foi até bom porque uma nutricionista falou que quem não colocar pelo menos isso, isso e isso vai ser suspenso das feiras.

E: - É mesmo?

M: - Sim! Daí eu falei para a Nadir, e aí que caiu a ficha agora, o porque a Joaninha não quer voltar sem o rótulo. Quantas vezes eu não ouvi isso?

E: - Várias vezes, né?

M: - Várias vezes. Então ela tem razão de dizer... Agora assim, mesmo que não tenha nada haver falar isso, mas como eu estou falando do grupo, eu acho que cabe falar a você que ela é uma pessoa que faz parte do grupo, e ela podia não voltar pra vender.

E: - É que ela acha que não vale a pena só produzir se não tem como vender.

M: - É eu também.

E: - Porque eu conversei ontem com ela.

M: - É, né? Também, porque o que adianta ficar produzindo se não tem saída a venda. Produzir para depois não vender, igual agora que chegou a vez da nutricionista falar que não era para colocar um monte de feira pela frente para a gente fazer, surgindo bastante oportunidade de venda e chegar a nutricionista e falar que se não colocar vai ter que sair, vai ser suspenso. E se tem bastante barra produzida?

E: - Pois é, e o que você faz nesse caso? 
M: - Foi bom essa daí porque sempre eu estou segurando as pontas com a Joaninha. Estamos sem receber nosso pagamento das sobras.

E: - Por quê?

M: - Porque o grupo deu uma falida.

E: - Por quê?

M: - Porque no meu ponto de vista, é que fomos longe de mais no início, nós começamos a pegar as sobras de 100,00 reais que desse valor, já pulou para 150,00 reais. Daí no outro mês pegava 150,00 sem antes sentar para avaliar. Lembra que a gente tinha que fazer aquela avaliação todo mês, para ver como tudo estava? Se chamava balanço, tipo o que as empresas fazem o balanço do que entrou do que saiu... E não foi feito isso. A gente só produzia, vendia, mas nós mesmo, o grupo, nunca sentava para avaliar essas coisas e ver o quanto que podia tirar. Aí então foi tirando até que... quase chegou no vermelho... Então tivemos que parar. A última vez foi no mês de Julho, Agosto, Setembro Outubro e não podemos pegar nada para repor.

E: - Para repor?

M: - Não sei se nesse mês da para pegar, esse fim de ano já dá para pegar alguma coisa. Porque na minha opinião, a gente tem que começar fazendo um levantamento daquilo que tem, dos gastos que tem, do que vai produzir; para poder ver quanto pode tirar $\mathrm{X}$, nem que comece de pouco, começa a tirar menos e sempre deixando uma reserva, no meu ponto de vista, tem que fazer um cálculo que de para tirar $\mathrm{X}$ de cada um, e independente do fundo de caixa, sempre deixar uma reserva do nosso. Mas isso nunca sentamos para tá fazendo isso.

E: - E agora vocês vão fazer isso?

M: - Agora que o Carlos ficou recolhido também, junto com a Joaninha... Tem vezes que ele some e passa cinco sei dias, oito dias que ninguém tem notícias dele.

E: - Por quê?

M: - Bom, ele fala que tem que trabalhar para cobrir as coisas dele porque não esta tendo nada. Mas eu também sou como ele, eu não tenho nada, não tenho aposentadoria, não tenho que me dê nada entendeu? Eu só não pago aluguel daqui porque eu tenho um filho que paga, pois a partir do momento que ele parar de pagar, eu também vou sair daqui. Porque eu já tenho um aluguel de 200,00 reais e não tenho condições de pagar 300,00 reais aqui. Mas a minha alimentação, meu dia a dia, eu e minha filha, o que ele dá pra mim é lucro, é uma responsabilidade individual minha, entendeu? E toda a minha família. Minha família é grande. E minha família graças a Deus 
tem para eles. Mas de vez em quando precisam de mim também, de alguma forma. É difícil vir de lá, mas de vez em quando eu tenho que abrir no sentido de alguma forma estar apoiando. Que nem agora vinda da minha filha, eu não estava preparada para isso, mas mesmo assim eu não deixo. Posso chegar atrasada mas eu vou, entendeu? Se não dá para ir, eu dou satisfação.

E: - É, tem que dar, né?

M: - Sim, tem que dar. E estou preocupada com o Carlos porque eu tenho medo dele abandonar o grupo também. A gente sempre saiu junto, ele reclama muito.

E: - Ah é? E do que ele reclama?

M: - Ah! Ele reclama de tudo... Estou até preocupada, parece que ele não está... sabe? Ele reclama muito...ele se preocupa muito com a vida dos outros, com a vida de jogador de futebol, de novela, de televisão e de não sei o que. E com uma preocupação com o Brasil, que o brasileiro é não sei o que, que é por isso que o brasileiro não vai para frente... Nossa! Haja ouvido para tá... E de vez em quando a gente tem que tá... Ainda bem que eu sou... eu me preparo... E: - É para não ficar mal, né?

M: - Para não ficar mal... De não aguentar e poder entender sem ter que... Né?

E: - E você acha que agora vai sair o rótulo do grupo?

M: - Bom, pelo menos uma etiquetinha para quebrar o galho... Até a nutricionista falou que tinha que fazer pela etiqueta até sair o rótulo. Outra coisa que eu estou achando que as coisas não estão andando bem, não é falando do grupo porque eu sou o grupo porque seu eu for falar do grupo eu falar de mim também, né? É, no meu ponto de vista, estou preocupada com o grupo no sentindo das lutas para melhorar porque a gente trabalha, esta procurando fazer um trabalho em rede, e na hora das participações com os outros grupos o Grupo Mão na Massa esta um pouco devagar?

E: - Como assim?

M: - Por exemplo, se tem uma formação riquíssima aqui no autódromo da Água Branca, sábado e domingo. Até passagem dão, dão comida, não paga nada e a gente ganhou até premiação de rede. E: - É uma formação mesmo?

M: - É uma formação mesmo. E a única que foi do grupo foi eu. Ninguém tem tempo. De lá dessa rede, surgiu uma oportunidade, o grupo Mão na Massa foi um dos três melhores grupos de pequenos negócios que poderia juntar os três para formalizar o grupo, entendeu? A primeira reunião foi lá na faculdade Santo André, e ninguém pode ir. O Verner teve que ir comigo, e tinha que ser o grupo. Uma oportunidade de ouro. Chego lá só eu do grupo. Eu e mais dois grupos. 
E: - E aí?

M: - Nos grupos tinham no mínimo seis pessoas, no outro estava o grupo todo. E no grupo da Mão na Massa só tinha eu... Para mim foi um... sabe? Eu até pensei que não iria falar nada lá. Minha intenção era só ficar ouvindo e copiando as dúvidas e as coisas que eu podia trazer de lá para passar para o grupo. Inclusive eu até tenho anotado na minha agenda.

E: - O que era isso, vocês ganharam o melhor grupo?

M: - Assim, dos grupos que foram incubados e os que não foram incubados, mas que já estão fazendo algumas coisas como artesanatos, uns alimentos, outros bijuterias, sabe? Esses que estão indo nas feiras. O grupo mãos na massa mais dois grupos foi escolhido para juntar os três grupos para formalizar e facilitar porque tem uma despesa para tirar registrar, tirar nota fiscal, CNPJ, tem uma nota. Então, deu a entender assim, que esses três grupos foram escolhidos com esta proposta. De juntar os três que é alimentos, para formalizar esses três grupos. Para poder mostrar para uma cooperativa. Uma cooperativa sem formalizar não existe, tem que ter um documento. Tem que ter tido uma oportunidade boa de vendas, que não tem CNPJ, grandes empresas. Mas elas precisam de nota fiscal. Se me derem uma nota fiscal falsa? Comigo não funciona. Prefiro até sair do grupo, mas isso nunca! Temos que fazer uma coisa legalizada mesmo, então tem pessoas, tem empresas que exige nota fiscal com CNPJ e tudo. Então o objetivo era esse de facilitar para sair o rótulo. Aí fazia a formalização dos três grupos e lançavam o rótulo do seu produto. Cada um lançava o rótulo do seu produto. Foi o que eu entendi. Ai eu marquei tudo direito para trazer pra passar pra eles, teve perguntas lá que eu respondi lá. Mas eu copiei, mas eu não deixei registrado comigo. Uma resposta final. Então eu trouxe para responder junto com o grupo, para que na próxima a gente levar a resposta mais justa do grupo. Até hoje ninguém nunca respondeu essas perguntas. Ainda bem que a próxima que era para ter ido cancelou, e até agora não marcaram mais outra. Não sei se morreu por aí. Porque não falaram mais nada.

E: - Mas acho que vai voltar, né?

M: - Tomara a Deus, porque eu achei muito legal. Achei legal as propostas. Vou até pegar as proposta para você ver.

E: - E como é que você esta sentindo agora, me conta essa sensação.? O que você esta sentindo de estar no grupo?

M: - Eu estou me sentindo muito bem Mesmo com essa coisa que quer me assustar. Mas estou me sentindo bem o suficiente de eu achar que não vai cair. 
E: - Tá acreditando que vai, né?

M: - Estou acreditando que o grupo vai, brotar bastante frutos. Mesmo que ainda ocupando um espaço que não é da gente, tem também o auxílio de referência, porque para mim é uma coisa muito boa. É, eu nunca falei para ninguém, estou falando para você que eu sinto se a gente não deixar esse grupo cair, ele vai ser linha de frente no centro de referência na cozinha escola. E que futuramente a gente pode dar aula com essa mesma formação que a gente teve para outros grupos, entendeu? Poderia chegar o ponto de poder participar até de uma incubadora para ajudar a incubar outros grupos porque não é obrigado a gente ficar só produzindo barrinha. E a barrinha esta sendo muito aceita, todo mundo gosta da barrinha. A preocupação das pessoas é só a rotulagem. Porque até então, ela está aparecendo um produto qualquer, uma barrinha, uma cocada, uma coisa assim sabe? E a gente compra por aí. Só que com a etiqueta que esta sendo colocada agora, a cara já mudou, né?

E: - Ah! Já está colocando as etiquetas já?

M: - Já, estão colocando as etiquetas já. Rapidinho eles deram um jeito e arrumaram uma etiqueta bonitinha, é porque eu não tenho aqui para te mostrar.

E: - Que bom! Então já esta resolvido o problema. Não é o rótulo mas é o começo.

M: - Já é o começo, já é uma etiqueta adesiva, que você tira e cola na barrinha e fica bem mais bonitinha. Os sabores a validade. Esta bem bonitinhas as barras agora.

Ea - Ah, a Joaninha então já pode voltar.

M: - Então a Joaninha já vai adquirir. Sabe o que estava arrumando para ela? Eu queria pegar as barrinhas com os rótulos e levar lá porque ela é uma consumidora de primeira qualidade das barrinhas.

E: - Ela é, né?

M: - Nossa, ela morre de tanto comer barrinha, ela sempre esta comprando para comer. Então estou pensando em pegar umas barrinhas e chegar: "oh Joaninha, você gosta muito de barrinhas e eu tenho um monte de barrinha para vender para você”. Vou fazer essa brincadeira com ela.

E: - Sim leva para ela.

M: - Ela vai gostar da surpresa se alguém não já fez

E: - Acho que ninguém fez. Ela não estava sabendo.

M: - Então, aí eu estou pensando em fazer isso, é que eu estou sem barrinha, as que sobrou da feira ontem o Carlos levou e estou pensando ele vir me trazer essas barrinhas. 
E: - Ele levou para vender.

M: - Não ele levou para lá para a casa do Zé. Ele levou e é muita coisa para um carregar só, aí ele levou as sacolas de barrinha. Senão ia lá hoje. Eu tenho que ir lá ver o que ela quer primeiro.

E: - É... E esse tempo...

M: - O que é mais que você perguntou?

E: - E daí nesse tempo vocês continuaram fazer a formação com a incubadora produzindo e participando das feiras?

M: - Sim isso.

E: - Produzindo e participando das feiras?

M: - É isso, produzindo e participando das feiras... Tem umas feiras aí para a gente fazer. Já estão agendadas e outras para fechar ainda.

M: - Eu não sei. Eu acredito nesse negócio. Não sei se é porque eu já nasci com isso no sangue.

E: - O quê? No que você acredita?

M: - Desde lá da minha terra que eu gosto de aprender, eu gosto de ensinar, eu gosto de sabe? Sempre que eu aprendo alguma coisa eu gosto de passar... Eu gosto de aprender assim, de querer ser alguma coisa na vida. Às vezes uma coisa que parece uma brincadeira igual esse grupo que foi formado, se torna uma grande coisa na vida da gente.

E: - Ah é, já deixa de ser brincadeira, né?

M: - Já deixou de ser brincadeira, né? Então quanto tá deixando de ser brincadeira às vezes o amigo uns espalham pra cá, outros espalham para lá. Nós eramos em 20.

E: - Agora são quantos?

M: - Tá um gato pingado, só tem eu a Cristina, Maria, Carina e o Carlos. Mesmo assim o Carlos some às vezes e ninguém acha ele. E quando vai fazer as coisas vai reclamando muito. Ele me deixa preocupada, sabe?

E: - Sei ele não está feliz, né?

M: - É, ele não esta feliz.

E: - E o que você esta achando de trabalhar em grupo, de trabalhar em uma cooperativa, isso mudou alguma coisa?

M: - Muita coisa... Esse grupo é um sonho que eu estou realizando, parte do meu sonho, você esta vendo? Criar um pequeno negócio e poder trabalhar para você mesmo, é uma coisa que eu sempre pedi para Deus. E trabalhar com gente. Eu acredito que se não fosse os tropeços da vida, 
eu já era uma funcionária aposentada em escola. Eu queria ser professora, e queria ser pelo menos Auxiliar de Enfermagem se não desse para ser Enfermeira. E eu sempre gostei de fazer cursos. Mesmo que não dava para eu ir. Quando surgia uma oportunidade de alguma coisa. Eu fui de um grupo daqui de São Paulo, em 1975 para 1976 lá no Piauí, eu aproveitei o máximo. E: - Do que foi?

M: - Olha eu fiz o curso de horta e cultura, formei uma horta comunitária, só não foi para frente por causa da minha convivência individual com o pai dos meninos que aquele homem... Eu já estava soltando os panos para me libertar porque minha vida era de escrava. Fiz o curso de primeiros socorros, até a farmácia comunitária, tudo faz parte. Porque se um dia eu estabilizar um lugar para... E eu só não tenho isso aqui em São Paulo porque eu não tenho uma certidão. Eu não tenho um lugar para eu administrar. Porque se eu tivesse uma lugar para eu administrar, eu tinha horta no quintal, e eu tinha uma farmácia comunitária para trabalhar aqui na União de Moradores. Entendeu? Se fosse eu lá agora, eu tivesse continuado lá. Tinha uma farmácia comunitária e tudo montadinho. E essas coisas vem em mim assim, Sabe? Porque eu já fiz primeiros socorros, já tinha essa atitude. O lugar era uma cidadezinha pequena lá no Piauí. Eu já tinha esse sonho. E lá eu aplicava até injeção na veia.

E: - É mesmo?

M: - Só com o curso de primeiro socorros, eu que aplicava injeção em todo mundo, fazia curativo, ainda hoje eu faço curativo nas pessoas na comunidade aqui, que precisa, que chega ao meu alcance eu faço e sara!

E: - Vi, e hoje você esta fazendo parte de que movimento? De que organizações aqui na comunidade?

M: - Nenhuma.

E: - Nenhuma?

M: - Só da AMGESP. Que é uma coisa que não esta funcionando porque...

E: - O que é AMGESP?

M: - AMGESP é Associação das Mulheres que futuramente eu vou ser a presidente ou outra pessoa que... No caso quando o documento foi feito, foi aberto firma no cartório e tudo, mas quando foi pedido o CNPJ, não foi liberado o CNPJ.

E: - Entendi. 
M: - Como eu, e outras pessoas do grupo da diretoria estava com o nome no Serasa, achamos que é por isso. Aí eu comecei a trabalhar com café da manhã aqui, em parceria com a Ação e Cidadania porque lá eles aceitavam sem CNPJ. Lá dentro da Ação e Cidadania, teve uma pessoa que lá da Ação que me falou que vai sim, não tem nada haver. Para mim também não tem nada haver, porque como é receita... Não é uma coisa que você vai pagar X, a gente só tem que reconhecer. Não vai pagar nada. Como é que fala essas coisas que a gente não paga, é isento, né? Taxa isenta, então acho que não tinha nada haver, porque se você mostra seu trabalho... E: - Não sei se tem haver...

M: - Não sei porque... Não sei se foi outras pessoas porque nessa associação que a gente fazia isso, tinha a Cida e tinha a Beth, e provaram que não era contente. E depois elas ajudaram a correr atrás, aí eu fique doente, quanto eu... Não sei nem se coloco isso na entrevista, acho que nem é bom colocar. É muito ruim ser traída assim. Daí depois eu fique doente, mas se colocou tudo bem, uma traição. Ele pegou o disquete... sofri pra caramba nesse mundo é tanta humilhação. E eu na palavra ali, eu falei "puxa! Não é todo mundo não viu que aguenta essas coisas. As pessoas que são boas sofre viu?! Quem não tem coração ruim sofre”. E a nossa obrigação é ter paciência com quem pisa na gente. Você acredita em uma coisa dessa? A gente que tem um coração bom, que procura viver um pouquinho a realidade da vida com a palavra de Deus. Temos por obrigação escutar e dizer muito obrigado. Levar um chute igual ao que levei e ainda dizer muito obrigado por me chutar... Só que o meu parente pegou também porque estava junto um apoiando, pegou o disquete da Associação e montou uma outra Associação das Mulheres e a Cida é presidente. Agora estão tudo aí de nariz virado um para o outro. Estava falando hoje na palavra que, quem é de Deus, quem vive a verdade, quem procura viver a verdade... Que tem a proteção divina não precisa levantar a voz nem a mão para bater em ninguém. Porque Deus responde pela gente.

E: - Ahã.

M: - Porque o dedinho de Deus pesa. E agora estão lá ó...

E: - Brigados.

M: - Brigados, entendeu?

E: - Está participando?

M: - Olha, não todas... Até porque tem dias que tem reunião da rede e tem outras reuniões de organização das feiras. Aí quando chega aqui sinto falta do grupo nessa revisão. 
E: - Que revisão?

M: - Revisão de representar o grupo no que é necessário, por exemplo, você tem uma organização que vai ter feira, que vai ter um evento, daí você convida o povo para participar mas para participar tem que participar das reuniões. Porque não pode chegar caindo de para-quedas lá sem saber nem o que vai acontecer. E nessa hora ninguém pode.

E: - Sei.

M: - Até que para ir nas feiras, eles estão começando. A Maria esta começando ir, a Cristina já começando ir a Joaninha... A parte também da Joaninha, ajudou muito nessa parte.

E: - Porque elas tiveram que se envolver, né?

M: - Porque elas tiveram que se envolver. Porque ninguém queria vender nada, minha filha, para produzir tudo bem, mas para sair para vender "não conta comigo", a Cristina e a Maria não queriam nem saber... Hoje até a Maria já esta indo vender, devagar mas, já esta indo. Mas na hora das reuniões....

E: - Ninguém pode.

M: - Ninguém pode... E como a gente vai tomar uma decisão, como é que a gente vai ser um grupo? Tem que ser um grupo gente. Eu não vou responder por todo mundo.

E: - Você já falou isso para eles?

M: - Já falei! Mas continuam nesse negócio. Agora a incubadora, aquela que tem o Zé Luís?

E: - A da GV?

M: - A da GV. Então, ele foi cadastrado lá com eles para às feiras. Porque eles estão fazendo umas feiras.

E: - Lá no centro, né?

M: - É... Na Praça João Mendes. Conseguiu no Mercado Municipal, em outro lugar lá também... Está tudo aqui na agenda. E a minha preocupação é só essa, da Joaninha não voltar e se o Carlos não for mais....

E: - Daí vai ser difícil para você, né? Vai ficar sobrecarregado

M: - Vai ser difícil e vai ficar sobrecarregado. Eu penso no futuro tão bonito... Eu vejo isso aqui crescer... Eu vejo todo mundo tranquilo, tirando o seu salário o seu jeitinho de viver da gente mesmo. Fazendo um negócio legal com segurança. E de repente a gente tá correndo o risco de ver tudo indo por água abaixo não é bom, né?

E: - É não é. 
M: - Eu não sei se os outros estão vendo isso. Mas eu vejo.

E: - Vocês podiam conversar, né? Sobre o futuro, o que cada um vê... Má, me fala uma coisa, se hoje eu te falar assim, que hoje você pode trabalhar em um emprego em uma empresa, normal ou uma cooperativa como esta que vocês estão formando, o que você prefere?

M: - Não emprego normal ou em uma cooperativa? Eu prefiro em uma cooperativa. Porque eu estou mais... sabe? Ultimamente eu estou realizada. Minha última empresa privada, eu saí em 1995. Daí eu trabalho para mim, eu trabalho com produto. Sou representante de uma empresa de cosméticos que dá para ganhar muito dinheiro... Eu não ganho muito dinheiro porque eu gosto desse trabalho social comunitário e você sabe que esse trabalho tira muito o tempo da gente. Mas é assim, essa empresa é um portão aberto que dá para ganhar muito dinheiro. Porque eles dão treinamento grátis e tudo... Eu tive um problema, não sei se você lembra, que eu ficava nas reuniões cochilando?

E: - Lembro.

M: - Lembra? Estava ruim, diabete alta, pressão baixa, estressada, cheia de problemas. Sou estudante da Cultura Racional, preciso de ler bastante pelo menos um pouquinho todos os dias, para entender, cada dia é uma dia. Cada dia tem uma surpresa, tem uma coisa diferente. Na vida da gente, damos de cara com cada coisa que às vezes se não tivermos preparados pode se chocar. E a gente não pode viver assim, temos que estar preparado para o que der e vier nesse mundo. Se nós viemos para este mundo temos que estar preparados para ver, ouvir e se calar. Porque tem vezes que não dá para você ver, ouvir e falar... E tem que ver, ouvir e calar. Não é verdade? E para a gente se preparar para fazer isso, não é fácil! Entendeu?

E: - Entendi.

M: - E não dá para eu sair... Mas essa empresa que eu trabalho com ela, se eu sair todos os dias, Mariana, e vender uma base de... dois produtos que vendem mais, como por exemplo a New Look... Eu só estou vendendo porque as pessoas me pedem, entendeu? Eu não estou saindo para fazer o trabalho. É disso que eu sobrevivo. Mas se eu sair todos os dias e vender um óleo de 32,00 reais, e uma loção de 34,00 reais dá 66,00 reais, vezes 30 , vezes $45 \%$ ?

E: - R $\$ 891,00$.

M: - Não dá para tirar? Se eu vender dois produtos, isso porque é difícil sair para vender. E se você vender um aparelho térmico? E se você vender um kit de 105,00? Se vender uma colônia de 69,00, um desodorante de 44,00. Dá para viver tranquilo. 
E: - Então porque você preferiria a cooperativa, Má?

M: - Sabe porque eu prefiro a cooperativa? Porque eu já estou dentro do negócio, é uma coisa que já esta viva dentro de mim no momento... E empresa privada é uma coisa que eu nunca gostei. E: - Por quê?

M: - Porque eu tenho uma coisa dentro de mim que eu não me acostumei... Porque em empresa privada, sempre tem umas pessoas que gostam de pisar na gente. Tem gente que às vezes está fazendo coisas erradas e não admitem que esta errado. A última que eu tive, tinha uma gerente lá que eu vou te contar...

E: - É?

M: - Fazia um monte de coisas desagradáveis, e ainda queria me matar. Chegou e já me achou bem na minha... Ela me gerenciava, mas eu já sabia o que eu tinha que fazer, não precisava de ser mandada, entendeu? E ela queria que eu fizesse tudo ao contrário do que eu já estava acostumada a fazer. É duro, né? É apavorante isso. Você trabalha em uma casa de família você sabe tudo o que tem que fazer na casa correto e com ética. E a dona de tudo aquilo, é uma pessoa que nunca teve aquilo na vida, perdida. Que não sabe nem arrumar o que é bom... Existe patroa desse jeito. Eu já encontrei uma dess, meu único emprego doméstico. Foi apavorante! Não sabe nem trocar uma fralda do filho, não sabe nem fazer uma sopa para dar para o filho.

E: - Imagino!

M: - E querer mandar em você!? Obrigar você a fazer uma coisa ao contrário, só porque é patroa e quer daquele jeito? Aquilo é... nossa! Me mata! E em outra empresa que eu trabalhei também muito boa, patrão muito bom. Aconteceu isso comigo. Tanto que senão é ela que entrar lá. $\mathrm{E}$ engraçado que só foi ela me mandar embora. Antes dela me mandar embora, ela me deu férias atrasada. Coisa que eu nunca tinha tirado férias... E quando eu estava de férias eu fui lá para saber que dia ia ter leilão, já que eu estava de férias eu poderia trabalhar em leilões. Porque eu trabalha no escritório e nos leilões para ganhar um dinheiro extra. Ela então virou para mim e disse que tinha conversado com o Léo. Ela estava jogando nessa hora. E que eu estava muito atarefada de serviço, porque eu trabalhava lá e já trabalhava com vendas na empresa de cosméticos... Esse Léo me deu uma força muito grande. Eu morava em Itapecerica, e as minhas clientelas eram todas daqui. Guardava minhas coisas de lá. Chegava na empresa a hora que eu queria. Eu vendia folheado, prata e etc. Deixava tudo guardado, dava o endereço da empresa para receber as coisas... E não é todo patrão que permite isso, né? 
E: - É mesmo.

M: - Tinha vezes que trabalhar à noite para mim, trabalhava para ele durante o dia, e à noite eu ia separar os pedidos, etiquetar, eu virava à noite etiquetando, lá mesmo no escritório em um quartinho na empresa... Eu ficava lá, guardava minhas coisas lá. Não é todo patrão que faz isso. E: - Não é mesmo.

M: - Essa abençoada quando entrou, mexeu em tudo. Fez de tudo. E quando ela disse que eu ia ser mandada embora do escritório, e ficar só nos leilões, ela falou isso para eu não desesperar. Mas eu pulei de alegria, porque eu já não estava aguentando mais aquela mulher.

E: - Você adorou?

M: - Eu detesto gente que faz cocô no prato que come. A infeliz lá dentro, trabalhando e ganhando bem, roubando o patrão. E ainda falava mal do patrão na minha cara, e eu não gosto disso...Você quer falar uma coisa de mim, fale direto para mim.

E: - É fala na cara, né?

M: - Sim, fala na minha cara. Se eu puder me defender eu me defendo. Senão pelos menos eu estou sabendo que foi você quem falou.

E: - Jogar limpo, né?

M: - Isso, jogar limpo. Porque se eu tiver que falar uma coisa para você, eu não vou falar para outra pessoa, para depois você ficar sabendo pela boca de outra pessoa que a Má falou isso de você?

E: - E não dá, né?

M: - Não dá... E ela era assim. Então eu saí de lá, ela ficou três meses, estourou a bomba, ela estava roubando o patrão, o coitado faliu e até hoje...

E: - Nossa coitado, levou uma punhalada dela.

M: - Sim, levou uma punhalada dela. E já ela eu não sei o que fez da vida dela. Ô trem ruim! 


\section{- Seu Luís -}

\section{Parte I}

Luís: - Eu gosto de viajar e eu gosto de natureza, por exemplo, cidades grandes... Como diz no caso? Concreto, não está no meu...

Ea: - Não, o senhor não gosta.

L: - Não. Eu gosto de ver obras importantes, mas não sou assim muito admirador de concreto não, sabe?

E: - É. Eu também não vejo muita graça.

L: - Então.

E: - Então Seu Luís, é o que eu falei. Esse meu trabalho é para entender se fazer parte de um grupo como esse que vocês estão trabalhando, se tem alguma mudança para vocês. Para isso, para entender essa parte melhor, eu queria que você me contasse um pouco onde o senhor nasceu. Começando por aí... Se foi em São Paulo, se não foi...

L: - Eu sou natural de Minas Gerais, nasci nãoa cidade por nome de Itapecerica. Aqui tem Itapecerica da Serra, lá é só Itapecerica, tem muita serra, mas não tem serra no nome da cidade. E: - Tem mais serra do que aqui, não é?

L: - É. Eu nasci nãoa família pobre. Nós somos não número de sete filhos, quatro homens e três mulheres. O mais velho já está com 66, 67 anos. E vivi a minha infância, até os 11 para 12 anos em Minas, aí nós migramos para o estado do Paraná. Naquela época já tinha começado o problema do Brasil... Em 62 já tinha começado essa mexida de pessoas, de famílias mudando de um canto para o outro.

E: - Essa migração...

L: - É.

E: - E vocês mudaram por causa de trabalho?

L: - É, por causa da terra, porque a terra ali já estava cansada. Então você já não tinha muito de onde tirar e sustento da família. Nós mudamos para o estado do Paraná. O Paraná naquele tempo estava abrindo ainda, era um estado novo. Nós fomos para lá, foi a família do meu pai e a família do meu tio. Aí fomos para cidade de Califórnia no norte do Paraná, lá nessa cidade nós ficamos morando em terras do meu tio, porque esse já morava lá, esse já tinha ido para o Paraná acho que na década de 40. Ficamos morando nas terras dele de arrendatários, mas nós tínhamos terra em 
Minas, certo? Era uma área bem grande, meu pai vendeu as terras e fomos pro Paraná, para comprar lá, só que chegou lá, ele ficou ouvindo parentes e o dinheiro evaporou.

E: - Ele gastou...

L: - É. Ele não conseguiu comprar nada. Nós ficamos trabalhando de arrendatários nas terras dos outros. Então aí começa um comportamento diferente da minha pessoa. Eu nunca concordei, desde criança, de muito pequeno, eu não concordei com o sistema. É engraçado, porque eu não entendia o que era o governo, certo? Mas eu não concordava com o sistema, de trabalhar assim de...

E: - Para outra pessoa...

L: - Para outra pessoa, aquela condição que meu pai vivia, eu não aceitava aquilo.

E: - Vocês trabalhavam também? Você e seus irmãos?

L: - Trabalhava, portanto que é o seguinte, eu não estudei, naquele período dessa minha infância, você entende? Porque você vê, as escolas... Eram boas as escolas na época, eram boas. As professoras eram bem rígidas, tinha um ensino bom, mas eu entrei na escola muito pequeno. Meu pai deve ter mandado eu para a escola acho que com uns cinco, seis anos. Porque foi assim, essa professora ela era... Nasceu e criou na cidade. É lógico, naquele tempo, raramente uma pessoa da roça, se formava para professor, engenheiro, médico. Sempre eram as pessoas da cidade que tinham mais chance de estudar por causa dos colégios.

E: - E aí ia para lá, não é?

L: - É. E ela estudou, ela se formou para professora, e ela casou com um rapaz da roça, filho de fazendeiro e ela então resolveu dar aula. Ela tinha se formado em professora, resolveu dar aula. Então ela queria montar uma escola, aí o marido dela construiu... Não foi o estado, nota bem como é que eram as coisas naquele tempo. Ela construiu... O marido dela construiu a escola e ela ficou encarregada de arrumar um determinado número de alunos, me parece... Não me lembro como era a lei naquele tempo, acho que para o estado pagar ela, pagar ela como professora. E aí o marido dela saiu pegando tudo quanto era criança para levar para escola. Aí lá em casa ele levou... só lá de casa ele pegou seis. Então eu era muito pequeno e já fui para escola, mal aguentava acompanhar meus irmãos para ir para escola, então nesse período eu aprendi muito pouco, o restante da parte que eu aprendi quando era criança, eu aprendi nãoa escola paga. E aí minha mãe me tirou dessa escola, e me colocou nessa escola paga, não me lembro, mas era um valor muito irrisório. Que era também uma família, que era duma melhor situação, contratou uma 
professora para colocar em casa para ensinar para os filhos. E aí então ele pegou e arrumou vários alunos da redondeza e formou a sala de aula. Veja a inteligência desse senhor, tinha aula durante o dia e tinha o curso noturno, e isso há 50 anos atrás, mais de 50 anos atrás. E então o pessoal pagava para ir e ele pagava o salário da professora.

E: - Entendi. Isso ainda em Minas?

L: - É, isso ainda é em Minas. Aí fomos pro Paraná, lá meu pai não me colocou na escola e eu fui para roça direto, não tive chance de ir para escola.

E: - Nem seus irmãos?

L: - Foi só minha irmã mais nova e meu irmão caçula, essa se formou. Naquele tempo, o curso ia até a quarta série. Hoje... Vamos dizer, a escola primária naquele tempo ensinava o colegial que estão ensinando hoje, certo?

E: - Entendi.

L: - Porque você vê, era tão avançada a escola naquele tempo que ela veio do Paraná, eu que trouxe ela para cá, chegou aqui... Bom, vamos! Depois a gente entra nessa parte.

E: - Aí lá no Paraná foi direto para roça...

L: - Aí eu fui para roça, e trabalhei na roça até os 18 anos, mas sempre divergindo com meu pai daquela situação. Mas como eu era menor de idade, tinha que acompanhar. Fiquei na roça com ele. Aí ele se desentendeu com esse irmão dele... Com o cunhado dele, aí tivemos que mudar. Naquele tempo, Califórnia era uma cidade que eu me lembro da primeira rua que foi calçada... que foi feito o calçamento dessa cidade que era esse paralelepípedo, não tinha asfalto, não tinha rodovia... Tinha rodovia, mas tudo estrada de chão, estrada de terra. Me lembro de quando foi construída a ligação do norte do Paraná com o sul, passando ali por ponta grossa, no norte do Paraná. E a primeira agência de banco que eu conheci, que foi o banco Itaú.

E: - Lá, na cidade?

L: - Que se instalou nessa cidade. Foi o primeiro banco e, talvez, foi o único, se eu não me engano, até hoje, na cidade de Califórnia. Lá eu comecei a acompanhar a política, porque a época de política ela era como se fosse uma festa, tinha comício por todo lado, naqueles bairros afastados, naquelas vilas afastadas, eu comecei a acompanhar política ali. E o meu tio sempre forçando a barra que os parentes que eram eleitores, tinham que votar no candidato que ele apontava. E existiam dois partidos políticos, era o arena e o mdb, existia esses dois partidos. nós 
mudamos devido a divergência do meu pai com ele. Nós mudamos de lá, fomos pro município de Apucarana.

E: - Também no Paraná?

L: - No Paraná.

E: - O senhor tinha algum envolvimento político nessa época? O senhor acompanhava política? Gostava?

L: - Ah, sim! Aí veio um fato curioso na minha vida, nesse período, que me tornou uma pessoa do jeito que eu sou hoje, eu acho. Que é um fato curioso, que dá para você analisar bem, desse fato que eu vou falar agora, de como você molda um ser humano. Na infância você molda ele pro futuro, pro futuro dele, você pode traçar... Por exemplo, essas crianças que estão aí, se você conversar com elas, você molda elas para a vida inteira delas. É fato curioso, por isso que quando se fala, por exemplo, não trabalho igual esse movimento do Chavez na...

E: - Na Venezuela...

L: - Na Venezuela. Do Fidel Castro... Enfim, da China e dos partidos comunistas e socialistas... E do capitalismo também, daquela coisa dos americanos. Eu conheci... Eu levava calçado no sapateiro que tinha na cidade, isso lá em Califórnia ainda, eu deveria ser do tamanho desse garoto que entrou aqui, ou um pouquinho maior, um pouquinho mais velho. Eu deveria ter uns 12 anos, por aí... 12 para 13 anos. E, e ele veio para cá naquela época da revolução russa, então ele veio pro Brasil. Eu conhecia duas filhas dele, mas eu não sei se ele tinha mais, mas as duas filhas dele eram formadas em professora, as duas filhas dele eram professoras no ensino da cidade. E ele falava muito comigo sobre o comunismo, que no comunismo o estado era obrigado a dar estudo. Enfim, quando a criança nascia, praticamente, o pai da criança, a partir daquele momento era o Estado. O Estado é quem tinha que educar. Ele foi conversando aquilo comigo e eu absorvi aquilo, eu comentava com as pessoas sobre aquilo. Naquele tempo já deveria ser 64, por aí, que nós chegamos em 62, deveria ser na época de 64, já tinha havido o golpe militar no Brasil, em 64. E: - É, já. L: - Não é? E aí tava a caça às bruxas. Então ele falava aquilo comigo, e eu coloquei aquilo na cabeça, eu achava aquilo um sistema ideal para o Brasil. Quer dizer, a terra era de quem trabalhava, não existia exploração da terra, vamos dizer assim... comercialmente. O cara cercar um mundo de terra e explorar comercialmente aquilo. Eu fui absorvendo aquilo, certo? Aí nós mudamos para Apucarana, aí ficou longe, não podia ter contato como ele mais, porque para eu ir 
lá para conversar com ele, tinha que ir pra ficar um dia, dois em Califórnia. As cidades, elas faziam divisa, mas o lugar onde nós fomos era muito distante, e naquele tempo não tinha condução, não tinha ônibus. Você tinha que ir a pé, ou de cavalo. Aí eu rompi o contato com ele, mas fiquei com aquilo na cabeça, por isso estou dizendo, ele falou e aquilo...

E: - Entrou.

L: - Entrou. Gravei aquilo na cabeça, e eu fiquei com a ideia do comunismo na cabeça. E hoje... Não vou dizer que eu descarto, mas eu acho impossível... Quase impossível, um país comunista, um estado comunista.

E: - Por quê? Você diz no Brasil?

L: - Em qualquer parte do mundo. Eu acho muito difícil sobreviver. Porque devido aquele problema de religião, das religiões. É muito difícil. Você, pra isso teria que ter uma religião só (nem sei para que tanta religião, porque deus é um só!) teria que... Praticamente, fazer uma lavagem cerebral nas pessoas para aceitarem uma situação dessas de igualdade total. Aí eu fiquei em Califórnia, fiquei em Apucarana com meu pai, com a minha família, continuamos trabalhando de arrendatários. Arrendatário é assim, o dono da terra te dá a terra com a casa para morar. Dava naquele tempo, hoje não dá mais, ele pode até te arrendar a terra, menos moradia.

E: - Aí você se vira, não é?

L: - É. Aí ele deu... Meu pai pegou esse sítio para tocar, era um sítio bem grande, terra muito fértil. Naquele tempo, a serra do Paraná era uma maravilha, o Paraná naquele tempo... Você conhece o estado do Paraná?

E: - Eu conheço um pouquinho só.

L: - Então. O estado do Paraná, no tempo que eu cheguei lá, em relação a outros estados, e principalmente nordeste, Minas Gerais, que São Paulo, que sempre foi um lugar desenvolvido. Mas o estado do Paraná dá uma impressão que, quando você chegava, você chegava em outro país.

E: - Nossa!

L: - É. O estado do Paraná não tinha, vamos dizer assim... pobre, pobre de não ter nada, pobre, mendigo, pessoas pedindo na rua, pedinte, você não encontrava essas pessoas na rua, certo?

Porque lá é o seguinte, se você fazia colheita, faltava mão de obra, inclusive, faltava gente para trabalhar. Se você fazia colheita, se uma pessoa chegava na sua casa, falava para você assim, "você me dá um pouco de café", "você me dá um pouco de milho", "você me dá um pouco de 
feijão, um pouco de arroz", você falava... Tinha certos tipos de cereais, que você falava para ele, "vai lá à roça, pode pegar para você", entendeu? No caso do milho, de café, a pessoa podia ir lá e pegar. Pegasse aquele que sobrou na lavoura, que a pessoa não deu conta de colher. Era tanta fartura! Porco, aqueles porcos desse tamanho assim. O gado você precisava ver que beleza, você não precisava aplicar vacina, você não precisava dar remédio, o bicho... O porco, você não precisava aplicar vacina, não precisava dar remédio, não precisava dar ração. Era uma fartura, galinha você olhava... Chegava naquelas fazendas, naqueles sítios, assim... Aquela "galinhada", assim, dava gosto você ver.

E: - Era farto, não é?

L: - É.

E: - Então o senhor mudou para essa outra cidade, não é?

L: - Então, daí mudei... Mudamos para essa outra cidade, aí veio o caso da porcentagem que eu ia citar. A porcentagem é assim, você pegava a terra para moradia. O patrão não te dava nada, ele não te dava semente, não te financiava, certo? E você entrava com a cara e a coragem. E era $30 \%$ milho, feijão e arroz... Era $30 \%$ o patrão e 70 pra você, mas ele não te dava nada. O café era $40 \%$ para você, arrendatário, e para ele, pro patrão, 60.

E: - Nossa!

L: - Era o inverso o café.

E: - Mas você era obrigado a plantar tudo isso? Arroz, milho, feijão e café.

L: - Sim, o combinado era assim, nas terras mais baixas não podia plantar café. Aonde meu pai arrendou não podia plantar café, porque quando vinha a geada, vinha o frio, a geada... aquela parte baixa... Ela queimava todo o café. Aí não adiantava plantar, você tinha que plantar sempre nas partes mais altas. Nós moramos nesse sítio bastante tempo, e era longe da cidade. A cidade, que era de Apucarana, ficava longe para nós, eu acredito que... Ah, não dá para dizer em quilômetros, acho que uns 30 quilômetros de distância de onde a gente morava, no centro da cidade. A cidade de Apucarana ela vinha assim, fazia embaixo, nesse bico aqui, ela fazia divisa com a cidade de Arapongas aqui, Londrina aqui e Califórnia aqui. Ela fazia divisa aqui com umas quatro, ou cinco cidades aqui nessa margem. Tinha um rio que chamava rio do Cerne, rio que tinha muito peixe e... Na cabeceira... Vou te falar um fato curioso. Na cabeceira desse rio tinha um frigorífico, o maior frigorífico do norte do Paraná, e nós bebíamos água desse rio, não tinha tratamento, que o Paraná não era um estado rico em água. A rodovia que liga Londrina a 
Curitiba, por exemplo, você pode seguir ela até mais ou menos o meio, uns 150 quilômetros, você não passa por cima de um rio, ele vai só pelos espigões, serpenteando, ele não tem uma ponte onde passa o rio.

E: - Que coisa.

L: - Então o Paraná é um estado bem pobre de água. Tem água na época das chuvas, porque chove muito. Aí nós ficamos plantando ali, e ali começou mais uma vez, continuou a minha divergência com meu pai, porque era muita terra, e ele não tinha dinheiro para pagar gente para trabalhar e o patrão também não financiava. Então ele perdia a cabeça. E ia preparando a terra, plantando. Então você começa a preparar a terra em julho, você termina a colheita e começa a preparar a terra para plantar. Em final de agosto você começaria a plantar, e ia plantando, ia plantando. Era muita terra e ele não dava conta, ele ia plantando até aqui, quando chegava aqui, que encerrava o término do plantio, que ele voltava para capinar, e esse que tinha plantado aqui, já estava morrendo no meio do mato. E aí você ficava patinando, e eu não concordava com aquilo, ele não aceitava opinião, até que não... Isso já no ano de... Eu morei lá de 62 a 69, morei pouco tempo, mas nesse período foi suficiente para eu entrar em atrito com ele várias vezes, aí nessa época...

E: - A sua mãe trabalhava também?

L: - A família toda trabalhava, minhas irmãs todas trabalhavam, todo mundo trabalhava. Ai já começou a me dar aquele... Eu já fui completado 16 anos, 17 anos, já entrou aquele negócio na cabeça, "o negócio é sair fora e rodar o mundo", e... "Não dá, não dá pra ficar!” já fui tomando aquela decisão, mas não podia sair porque era menor de idade. Tinha que ficar aguardando, a maior idade, não tinha documento, aí fiquei. Quando foi já chegando os 17 anos, fiz alistamento militar, fui reprovado. Porque era época da ditadura, eles enrolavam você. Não servi. Eu escrevi um documento, uma sugestão para mandar pro ministro da justiça.

E: - Nessa época?

L: - Não, agora, recente. Sobre esse fato que eu não concordo, com o jovem ficar à disposição do Estado dos 17 aos 19 anos. Isso é um absurdo! Isso é uma violência de direito! Porque eu fiquei dos 17 até 18 anos e meio, parece, à disposição do estado. Porque eu fui fazer exame, como eu não tinha desenvolvido físico e eu era baixo, a minha estatura era baixa, eles falavam "julgado incapaz". Quer dizer, quando você é julgado incapaz, eles te reprovam, você não ia servir o quartel, mas você ficava à disposição pro ano seguinte, porque aí você tomava massa corporal. 
Você desenvolvia seu físico e no ano seguinte, você poderia ir e ser convocado, mas jamais eles fazem isso, porque... A minha bronca do estado é isso, é que ele te deixa esse período todo à espera dele e no ano seguinte, ele tem um contingente maior do que aquele que ele tinha no ano anterior, e aí ele simplesmente te rifa, eu acho...

E: - O senhor queria ter sido chamado?

L: - Gostaria. Eu queria servir, e eu acho importantíssimo isso aí. Meu sonho é ver meus dois filhos servirem o exército, sabe? Porque aquilo lá, a pessoa que vai lá... Dizem que hoje não aprende nada bom lá...

E: - É, dizem que não.

L: - Diz que não. Mas eu acho que aquilo ali é uma lição de vida para você dar valor nas coisas. Que ali, você não gosta de feijão, você vai comer feijão. Você não gosta de arroz, lá você vai comer arroz.

E: - Tem que comer...

L: - Não tem escolha. E o filhinho de papai cai lá dentro tem que entrar na linha. Aqueles flanelinhas chegam lá, têm que entrar na linha.

E: - Todo mundo igual, não é?

L: - É. Aí eu peguei, passei por esse período. Nessa época então, eu rompi com meu pai. eu plantei uma roça para mim. Assim, ajudando ele... Era terra demais, aí eu peguei e plantei lá uma área para mim.

E: - Na terra dele?

L: - É, do patrão, terra do patrão. O dono da terra ele tinha armazém de compra de cereais na cidade, ele era atacadista, para você ver. Aí depois ele comprava dos produtores e vendia para outros tipos de armazéns pra exportação, aqueles armazéns de exportação, porque o Paraná naquele tempo já era um dos principais produtores, milho, arroz, feijão e café do Brasil. São Paulo, praticamente, já estava perdendo pro estado do Paraná. A gente sempre via aquelas lavouras de café, aquilo sumia de vista, tudo verdinho. Na época da colheita, vinha gente do Brasil inteiro pra trabalhar no Paraná, e no meio do café era plantado feijão, arroz, no meio do café você colhia milho, feijão, arroz. No meio da lavoura de café você colhia tudo isso. Aí eu plantei essa lavoura e deu bastante milho, bastante feijão, e eu fiz um pouco de dinheiro para mim. Entre aspas, porque, muitas vezes, se o pai precisava, ia lá, "me empresta o dinheiro", e emprestava. Você não via mais o dinheiro, você entende? Era assim que funcionava a coisa. Mas 
eu tinha bastante sorte com as coisas que eu punha a mão, que eu dizia que era meu e ia para frente. Eu estou falando que tinha muita sorte, mas eu não acredito em fator sorte, nem azar, nem...

E: - Acaso.

L: - É, eu não acredito nesses fatos, nessas coisas.

E: - Foi esforço, não é?

L: - É, eu acredito o seguinte, as coisas acontecem na vida da gente aí... Ah sim! Aí vem uma passagem curiosa sobre esse negócio de comunismo. Eu tinha ido na cidade, e cheguei lá, tinha uma loja de material de caça e pesca, era uma loja grande, e tinha uma exposição. O dono da loja era bem curioso, ele colocava umas curiosidades na loja que ficava assim de gente olhando, sabe? Teve uma vez que apareceu lá o casco de uma tartaruga, que pesava 300 quilos o casco, era isso assim o casco, ele pegou o casco dela e fixou assim no teto, mas era enorme o casco dela. E: - Nossa!

L: - É. Uma época aparecia com um osso lá, que deveria ser de um animal pré-histórico, entendeu? Era um osso de costela, que dava para ver que de costela, que ele era curvado assim, o osso acho que dava uns 4 metros de comprimento.

E: - Nossa!

L: - E uma época ele colocou lá uma exposição da moeda do mundo, das moedas de vários países, e eu não sei se tinha de todos os países. Então tinha dólar, iene... Tinha dinheiro de todos, vários países, ali fixado ali. E eu olhei lá, fiquei procurando, procurando... Já veio na minha imaginação o dinheiro da União Soviética. Olhei lá, não vi o dinheiro da União Soviética. Aí eu, muito prosa, naquele tempo era mais prosa do que hoje... Tinha um senhor assim de mais ou menos uns 40 anos, e eu comentei com ele, falei, "engraçado, não é, tinha o dinheiro de vários países, de todos os países, que da União Soviética não fizeram”. Era um país tão falado quanto Estados Unidos, porque eram as duas potências que eram faladas e principalmente... E: - Que competiam, não é? L: - É. E aí eu falei para ele, “então, o dinheiro da Rússia, da União Soviética não tem aqui”. Ele disse assim, "não, mas lá não pode ter dinheiro, lá não pode ter dinheiro, porque lá é comunista" que não sei o quê, não sei o quê. Aí eu pego, na maior inocência, "não, mas eu fiz amizade com uma pessoa assim, assim, nós sempre conversamos e ele falou isso...” Menina! O homem deu voz de prisão. 
E: - Para você?

L: - É, me deu voz de prisão, falou para mim assim, "você está preso e você vai me levar lá na casa dele". Aí eu não sei aonde eu arrumei tanta esperteza, que eu peguei e falei para ele assim... Eu não tinha nem noção desse tipo de coisa, maior, menor, qual era o direito, você entende?

Porque a gente morava na roça, a única coisa que a gente tinha em casa era um rádio velho para ouvir, mas não lia jornal, não lia revista, não lia nada. Aí eu não sabia dos jornais, do rádio, que na época já tinha, mas a gente não ouvia. Eu peguei e falei para ele assim, "não, eu não posso levar o senhor lá porque eu estou longe de casa, eu moro aqui no município, eu estou longe de casa e eu não avisei minha família, eu sou menor de idade". "Mas porque você é menor de idade mesmo é que nós temos que resolver esse negócio hoje". Menina! Mas eu passei um apuro aquele dia, e eu sei que eu dei um chapéu no cara.

E: - Mas ele era polícia mesmo o cara?

L: - Não sei. Não sei dizer o que ele era, mas ele deveria ser uma pessoa muito importante. Eu sei que eu dei um chapéu no cara e saí fora, passei um tempão sem entrar naquela loja.

E: - Sem falar da União Soviética?

L: - Não, eu continuei. Mas aí eu vi que era uma coisa... Aí que foi que eu senti que o negócio era perigoso, entende? Aí, você já ouviu falar na guerra dos... é dez dias? Que teve de Israel com a... E: - A Guerra dos Dez Dias.

L: - Dos dez dias. Então, aquela guerra teve um problema quase semelhante, mais ou menos semelhante, a esse que está acontecendo agora, um blecaute na economia do mundo, quase igual está acontecendo agora. Porque Israel bloqueou o canal de Suez. O canal de Suez é a entrada de mercadorias pro Oriente Médio e saída de combustível da região pro restante do mundo. E Israel fechou o canal de Suez e estava afundando todos os navios que tentavam passar ali, eles...

L: - Tem café, você não quer café? Você toma café?

E: - Tomo sim, mas só se estiver fácil.

L: - Meu café é meio doce, hoje saiu meio doce.

E: - Ah, é?

L: - É. Eu não sou muito de café doce não, sabe? Hoje ele está meio doce.

E: - Isso tudo foi naquela cidade ainda, que você morava?

L: - É, isso aí eu estava na cidade ainda... Não! Isso aí eu estava morando na roça.

E: - Com seu pai, com a sua família. 
L: - Estava com meu pai, aí houve essa guerra na...

E: - Essa Guerra dos Dez Dias, o senhor lembra...

L: - Essa Guerra dos Dez Dias foi o seguinte, ela fechou o Canal de Suez. Toda a economia do mundo parou. O porto de Santos, o porto de Paranaguá ficou paralisado com aquela guerra, mais de noventa dias. Os preços das mercadorias caíram lá embaixo, os armazéns ficaram abarrotados até o teto de milho, de café... Naquele tempo não existia soja, ninguém conhecia soja, você vê, a introdução da soja como ela é recente.

E: - É. Não é?

L: - Um dos problemas sérios da humanidade hoje é a falta de memória.

E: - Ah, concordo.

L: - Por exemplo, esses dias mesmo eu tava comentando com o pessoal aqui, não me lembro quando... Ah foi quando nós fomos lá a Diadema agora, sexta-feira. Nós estávamos comentando sobre a obesidade e eu, na minha opinião, a obesidade está ligada a soja.

E: - A soja? A soja engorda?

L: - Ela está ligada a algum derivado da soja, óleo comestível, alguma coisa porque, você vê, até essa época do consumo da soja, que é muito recente, você não via pessoas tão obesas em quantidade igual você vê hoje. Pessoas acima do peso e obesas... Mas hoje o Brasil está com $40 \%$, não é?

E: - Eu acho...

L: - Pois é... De obesos.

E: - Muita gente.

L: - Só que os Estados Unidos... Nós temos obesidade, lá é obesidade dupla, lá quem é obeso é desse tamanho.

E: - É...

L: - Então, naquele tempo não se falava em soja, ninguém conhecia soja. Aí houve essa guerra fecharam tudo, os preços lá embaixo. Quer dizer, nem de graça... Não era por causa dos preços, nem de graça, os armazéns não queriam, porque não tinha onde estocar. E aquilo ficou parado um tempão. Foi um blecaute, um desastre na lavoura, por todo mundo, acredito eu que naquele tempo teve uma quebradeira danada de empresa. A gente não via jornal, não via nada, nem televisão tinha. E... Ah sim! Um fato curioso que eu vou te contar da minha infância em Minas.Eu quero ir lá fazer essa pesquisa, e se eu fizer essa pesquisa e obtiver resultado positivo, eu vou trazer pra 
você. É capaz que a minha cidade, lá onde eu nasci, seja a décima cidade... A décima primeira fundada em Minas Gerais, que pegou o status de cidade... A décima cidade. E ela também deve estar entre as primeiras cidades que receberam imagens de televisão. Porque, você vê, eu era do tamanho desse mais pequeno aí, do Alan, que tem sete anos agora. Eu assisti televisão pela primeira vez, acho que eu tinha cerca de uns sete anos. A televisão acho que chegou no Brasil em 50,55 não foi?

E: - Não sei.

L: - Não sabe?

E: - Quando chegou a TV eu não sei.

L: - Ah... Não é possível.

E: - É. Não sei não, mas deve ter sido por aí.

L: - Pesquisa pra você ver. A televisão deve ter chegado no Brasil na década de $50 \ldots$

E: - Deve ter sido.

L: - Mas deve ter sido entre 50 e 55.

E: - E aí o senhor lembra disso?

L: - Então, eu assisti porque na minha cidade tinha uma indústria, que foi a primeira indústria de pilhas de rádio que foi construída no Brasil. Porque lá tem o minério, o grafite. Você conhece o grafite?

E: - Ahã.

L: - Então, eu tenho ele aí em estado bruto, para mostrar para as pessoas, só que eu não sei onde está, se não ia te mostrar. E ele é um minério que, nessa cidade onde eu nasci, se você escavar... Tem lugares que ele está a vinte, quarenta metros de fundura... Profundidade. Mas tem lugar que você vê ele por cima da terra. O que dá energia para a pilha é o grafite. O grafite hoje ele é usado em centenas de produtos, como graxa... A graxa de avião, por exemplo, graxa de motores de alta rotação.

É colocado grafite. Essa empresa era uma empresa muito rica. Ela construiu e instalou a primeira antena de televisão, receptor de televisão, da região. Então por isso que as pessoas tinham televisão. Mas eram mais os funcionários da empresa, eu não conhecia outra casa. Outro fato também curioso, essa empresa era de um empresário com uma cabeça, uma mente tão avançada no tempo... Meu pai falava que ele era descendente de húngaro, ele era húngaro. Na empresa já tinha restaurante, ele, os empregados e os filhos dos empregados... Não tinha escola no local, a 
escola era na cidade, ele colocou ônibus, naquele tempo, pra levar os filhos dos empregados pra escola e trazer.

E: - Nossa! Realmente.

L: - Era uma empresa super avançada. E naquele tempo, também as mulheres... Minha cidade seja talvez no Brasil a primeira cidade que teve... Praticamente as primeiras mulheres a trabalhar em indústria. Porque nessa empresa dele, a área de produção interna da empresa... Que ela era uma mineradora, não é? Tinha a parte de extração do minério, e depois tinha a parte da fabricação das pilhas, que era tudo feito ali. E nessa divisão, da fabricação das pilhas, trabalhava muita mulher na época. Naquele tempo, acho que ele já dava emprego pra mais de duas mil pessoas. Você imagina uma empresa naquele tempo com duas mil pessoas trabalhando?

E: - É muita coisa. Mas vocês não chegaram a ter TV então? Sua família não chegou a ter TV? Televisão?

L: - Não. Naquele tempo, nós sem dinheiro... A única coisa que nós tínhamos era o rádio, muito pequeno ainda, muito ruim ainda. Porque aí... Vou continuar agora por que...

E: - É. Você contou da TV. Agora...

L: - Eu contei da TV. Aí fui para...

E: - O senhor estava... Quando o senhor quase foi preso.

L: - Eu consegui me safar, aí vem a história da guerra que eu te falei.

E: - A crise, não é?

L: - Da crise, depois ela normalizou. Deve ter havido uma quebradeira danada, muitas empresas devem ter quebrado, devem ter fechado na época. E então vem a minha época do serviço militar. Eu fui reprovado, fui julgado incapaz, fiquei pro ano seguinte. Eu só ficava esperando pra pegar meu certificado de reservista pra eu sair. Quando eu me preparei... Aí eu mais o meu patrão, quer dizer, o patrão do meu pai, o dono das terras, tivemos um atrito. Aí vem a história da pequenez do empresário, como ele enxerga o pequeno lá embaixo, não é? Eu fiz a colheita, colhi o milho, amontoei o milho... O milho você sabe como é? Que o milho vem na espiga, você já viu espiga de milho?

E: - Sim

L: - Não a gente fala assim porque quem nasce na cidade tem muitas coisas, por exemplo... Têm muitos jovens da cidade que se você perguntar como é que a melancia vem, vai falar que a melancia dá não pé de coqueiro, não é? 
E: - Tem, tem mesmo, é verdade.

L: - Amontoei o milho e fui na cidade. Eu queria ter uma bicicleta, era um sonho. Imagina! Uma bicicleta. Achei a bicicleta pra comprar, de segunda mão. A pessoa falou assim, "eu tenho a bicicleta lá pra vender", aí eu falei pra ele, “como é que você vende a bicicleta?”. Eu tinha uns porcos, que eu não me lembro nem quantas cabeças de porco que eram. Ele falou assim "eu te compro os porcos em troca da bicicleta" e eu falei "tudo bem". Fizemos o rolo da bicicleta, só

que ele não tinha milho pra dar pros porcos. E ele me pediu uns tantos balaios de milho... É uma medida.

E: - Tipo uma cesta

L: - É um cesto desse tamanho assim de bambu, cheio de milho. Não me lembro a quantidade de espiga que vai. Sobre as medidas, por exemplo, da zona rural daquele tempo tinha o litro, tinha o quilo, tinha a quarta e tinha o alqueire.

E: - O que era a quarta?

L: - A quarta é 12 litros, quatro quartas é um alqueire, um alqueire é 48 litros. E o litro, se for líquido é um quilograma... Miligrama, não é? Miligrama.

E: - Se não é o tamanho, não é?

L: - Mililitro, mililitro. Fechei o negócio com ele, de dar tantos balaios de milho, que eu nem me lembro direito quanto que era. Aí eu fui avisar o patrão, fui lá no armazém do patrão, um homem poderoso... Naquele tempo, pra ter um armazém, não é? Ainda me lembro o nome da peça, ele chamava Antônio Hipólito.

E: - Que nome, hein?

L: - Devia ser descendente de italiano... Hipólito acho que é italiano.

E: - Não sei.

L: - Cheguei no armazém dele, cumprimentei, falei " Seu Antônio eu já quebrei o milho, já amontoei”. Mas não falei quanto tinha dado, porque ele não ia confiar na minha medida. Falei pra ele “o milho está lá amontoado, agora eu quero que o senhor vá lá tirar a sua porcentagem porque eu preciso...". Olha que honestidade! "Eu fiz o negócio assim assim”, olha que simplicidade, não é?, “eu comprei uma bicicleta e eu combinei com uma pessoa, no negócio que nós fizemos eu combinei com a pessoa tantos balaios de milho, e agora eu preciso que o senhor vá lá tirar a sua porcentagem pra poder dar o milho pra ele". Olha, seu eu fosse outro eu ia lá mentia e dava pro cara. Pronto! 
E: - Tirava da porcentagem dele...

L: - Ele não estava lá, pra começar. Ele estava na cidade, não estava vendo o que estava saindo da roça. Você precisava ser muito honesto naquele tempo pra agir dessa forma. Ele falou pra mim “como você fez?", aí falei pra ele: "eu fiz assim assim, eu queria comprar uma bicicleta, e achei uma pessoa que tem bicicleta pra vender e fiz o negócio". Aí ele disse, assim "não. O milho é pra vir pra cá em espiga... É pra vir pra cá, pro armazém e aqui vai ser feita a conta, aqui você vai receber sua porcentagem. O milho e pra ser debulhado e vir todo aqui pro armazém.”.

E: - Mas era seu, não é?

L: - Então. Aí começo, eu falei "Seu Antônio eu combinei com ele, eu tenho que tirar o milho da espiga, ele não quer o milho debulhado, ele quer o milho em espiga pra guardar", porque o milho debulhado ele estraga mais rápido, sabe?

E: - Sei

L: - Ele falou pra mim, "não, o milho tem que vir pra cá debulhado e vai ser tirada a porcentagem aqui no armazém", ficamos naquele bate boca, até que eu falei "é o seguinte, o milho está quebrado, está amontoado, o senhor tira a sua porcentagem, a minha porcentagem eu quero em espiga. Agora, é o seguinte, a porcentagem minha eu faço dela... O que é meu, eu faço o que eu quiser, e a parte do senhor também, o senhor faz o que o senhor quiser dela. Se eu quiser tocar fogo na minha parte, é problema meu. Se eu quiser jogar dentro do rio, é problema meu. Como é problema seu também o que o senhor vai fazer com o seu o milho. $\mathrm{O}$ meu vai sair espiga porque eu preciso dele em espiga.".

E: - Mas por que o senhor acha que ele quis atrapalhar o seu negócio?

L: - Não sei. Não consegui até hoje entender esse raciocínio. Posição...

E: - Só pra dominar?

L: - Pra ter o domínio. Aí ele falou pra mim assim, bateu a mão na mesa, "pois de lá não vai sair um grão de milho em espiga, tem que sair todo debulhado, tem que vir aqui pro armazém primeiro, aqui que vai ser tirado a porcentagem." Porque ia ali, eu pagava o preço que ele queria, ele que conhecia de matemática, porque a matemática comercial é diferente da matemática que você usa, porque lá tem quebra, lá tem umidade do milho eles enfiam um negócio lá... Naquele tempo eles não sabiam a umidade do milho... Era tirada a umidade do milho, como quebra. A sujeira que tinha no milho. Porque depois o milho ia passar nãoa máquina, ia ser selecionado pra 
exportação, o milho tinha que ir seco, 100\%. Tem uma graduação, entende? Tanto graus de umidade etc. Se não ele apodrece.

E: - Vocês que trabalhavam na terra não sabiam, não acompanhavam isso?

L: - Não, eu não sabia, não tinha conhecimento. É a mesma coisa hoje do fundo de garantia, quem vai dizer que a empresa depositou o fundo de garantia e que o banco está te pagando? O fundo de garantia com correção etc. e etc.

E: - Tem que fazer a conta, não é?

L: - Se você não tem... Não consegue acompanhar o índice de correção monetária, a variação dessa correção mês a mês. Eles fazem a conta e dão o dinheiro na tua mão.

E: - É de desconfiar, não é?

L: - Você confia, você que tem que confiar neles.

E: - Não tem outra opção.

L: - Não tem outra opção. Você tem que aceitar aquilo. Daquele bate boca ali eu já saí irritado. Eles não podem fazer isso, é meu e eu não estou negando a parte dele, eu estou sendo justo, eu quero apenas justiça. Quer dizer, justiça da parte dele e da parte minha. O que é dele é dele, o que é meu é meu, não é? Saí dali irritado. Imagina! Naquele tempo, hein? Falei, vou procurar um advogado.

E: - Quantos anos o senhor tinha nessa época?

L: - Ah devia ter uns 17 anos. Falei, vou procurar um advogado. Um garoto naquele tempo de 17 anos falar em procurar um advogado era coisa muito rara na roça. Era uma palavra estranha, uma palavra que ninguém conhecia. Embora eu conhecesse, porque meu pai falava. Porque o Estado do Brasil que mais toca demanda é mineiro, o estado de Minas é onde... Você pode fazer um levantamento, é o estado onde os advogados e os tribunais estão empanturrados de processos. E: - Verdade?

L: - É. Por coisas bestas. Meu pai fala de um lugar, lá na nossa cidade, que ficou por nome de Demanda. a demanda ali era entre dois fazendeiros que ficaram tocando demanda um com outro, e a demanda durou 40 anos. Um advogado passou pro outro, o outro passou pro outro, o outro passou pro outro. o juiz morreu, entrou outro juiz e continuou o caso. E ficou por nome de Demanda o lugarejo.

E: - É verdade?

L: - É. 
E: - O povo de Minas então luta pelos seus direitos?

L: - Minas Gerais tem muita demanda. Demanda por demarcação de terra, demanda por água demanda por estrada. Recente... Deve ter uns dois, três anos, eu fui na minha cidade. Toda vez que eu vou lá, eu vou lá na casa onde eu nasci, que só resta o alicerce, porque o alicerce é de pedra então ruiu tudo, menos o alicerce, está lá em pé. E eu gosto de ir lá ver, fico meditando, viajo no tempo, sabe? Meditando ali... A minha infância, enfim. E aí eu fui passar não determinado lugar lá que era caminho. Quantas vezes eu passei ali. Quando eu fui passando o cara fez assim com a mão, "é proibido passar aqui, não pode mais passar aqui". Você vê como a gente pode levar um tiro na cabeça por teimosia, não é? E eu olhei pro caseiro e falei "por que não pode passar?". "Não, é proibido passar, o patrão não quer que passe mais aqui”, quer dizer, ele era empregado, "não pode mais passar aqui, porque não sei o que tal tal tal tal". Tinha piscina na fazenda, certo? Porque a esposa do fazendeiro vai pra lá uma vez por mês, ou uma vez por ano, e vai tomar banho, "é proibido passar gente estranha aqui e ver ela de biquíni na casa dela" aí e olhei pra cara dele, falei "você está vendo aquela serra lá em cima? Eu nasci ali, nasci perto daquela serra. Você está vendo aquelas terras? Aquilo ali pertenceu ao meu pai, pertenceu à minha família. Então hoje, você vai me desculpar, mas hoje eu vou passar por aqui, eu vou passar por aqui porque eu passei centenas de vezes nesse caminho quando eu era garotinho, e ninguém nunca me barrou, então hoje eu vou passar aqui, me desculpa, mas eu vou passar".

E: - E passou.

L: - E falei para ele, "mas eu prometo pra você que a hora que eu chegar lá na cerca de arame eu vou tirar o sapato, vou varrer a terra que tiver, a poeira que tiver grudada na sola do meu sapato, e vou deixar a poeira aqui pra você, porque nem a poeira eu vou levar ,eu só quero passar por aqui. Nesse caminho aqui que eu passei centenas de vezes, de dia, de noite.” Aí passei. Já pensou?

Podia levar um tiro ali, e lá leva.

E: - Leva mesmo não é?

L: - Leva. Lá leva. Aquele lugar lá, se você bater no peito e falar "eu vou passar" o cara diz "você não vai passar" e te derruba.

E: - Ele atira

L: - Aí, fui...

E: - Aí você procurou um advogado? 
L: - Sim. Aí procurei um advogado, na hora o advogado falou "você tem direito sim, é seu, você não está negando a parte dele, eu pego a causa". Você imagina que causa? Que tamanho era essa causa?

E: - Mas não era caro um advogado naquela época? Tinha que pagar o trabalho dele?

L: - Mas você nota bem? O que passava pela minha cabeça já naquela época? Quanto custa uma bicicleta? 100 reais, vamos dizer, uma bicicleta hoje. Ainda mais velha daquele jeito... Entre 50, 60 reais. Imagina eu demandar com o cara por causa de uma bicicleta? Mas eu só não demandei por causa do meu pai. Você acredita que eu demandava com ele por causa dessa bicicleta? Eu ia demandar com ele.

E: - Aí o senhor não demandou.

L: - Fui pra casa. O advogado falou "eu pego a causa". E eu falei pra ele, " tudo bem, eu volto aqui". E fui embora pra casa, cheguei em casa, contei pro meu pai tudo que aconteceu. Foi a gota d'água, meu pai falou pra mim “você vai estragar o negócio meu?" é que meu pai ia reformar o contrato com ele pra mais um ano, meu pai precisava da terra, e ele não queria mudar de lá. Não é? Contei: "fui para cidade conversei, com o advogado e ele não pode mandar no que é meu. $\mathrm{O}$ milho é meu e dele, ele tira a parte dele e a minha parte eu faço o que eu quiser, não sou obrigado a vender o milho para ele". Porque tinha que vender pra ele. Quando eu falei assim meu pai falou pra mim, "como é que você pode falar isso? Você vai abrir demanda contra ele que é o dono do sítio? E nós, como é que fica?", disse duas palavras pra mim, "se você acha que o sítio aqui não serve para você", eu não esperei nem ele terminar o restante da frase. Quer dizer, os incomodados que se mudem, eu falei "tudo bem", só falei isso pra ele, "tudo bem". Baixei a cabeça, não falei mais naquele assunto e esperei. Fui dormir, amanheceu o dia, fui pra casa do meu irmão. Meu irmão mais velho tinha sítio, estava sempre precisando de gente pra trabalhar.

E: - Ah, seu irmão mais velho era dono de um sítio?

L: - Meu irmão mais velho já tinha terra.

E: - Por que seu pai não trabalhava com ele?

L: - Porque era pouca terra, só dava pra ele.

E: - Entendi.

L: - Fui na casa do meu irmão, falei "você está precisando de gente para trabalhar, tudo bem eu vou trabalhar pra você". Porque parece que era época de colheita... "Vou trabalhar para você uns 
dias". Fui em casa, arrumei... Não era nem mala, era uma sacola, um saco de roupa. Fui para casa do meu irmão e fiquei trabalhando com ele até vender o milho, até o milho ser debulhado.Vinha a máquina montada em cima de um caminhão para debulhar o milho. Naquele tempo, eu com 15, 16 anos, pegava saco de milho, saco de feijão, saco de arroz de 60, 70, 80 quilos. Teve uma carga que nós chegamos no armazém dele, colocamos o saco na balança saco, o saco deu 90 quilos. E eu peguei na cabeça aquilo sozinho. A gente pegava em dois, um pegava de lá, outro pegava daqui e levantava. Não sei se você já viu como funciona isso em armazém.

E: - Não

L: - Um pega no fundo do saco, outro pega na boca, levanta aqui, aí o outro que vai carregar, enfia debaixo a cabeça. E leva. Chegava lá, o caminhão era alto. Para você ver, o chegava lá você tinha que levantar o saco, e ainda fazia com ele aqui.

E: - Uma alavanca.

L: - Uma alavanca. Para jogar em cima, para o cara pegar.

E: - E: - Era longe? Andava muito com o saco na cabeça?

L: - Não. O caminhão parava encostado.

E: - Parava perto.

L: - Nós chegamos lá, a sacada era muito grande. A gente enchia até a boca e costurava, ninguém sabia que peso tinha aquilo, porque era pesado no armazém dele. Quando chegou, que botamos aquilo na balança, tinha saco de 90 quilos. Eu com 17 anos pegando saco com 90 quilos na cabeça.

E: - Nossa.

L: - Se fosse hoje você processava o cara, é crime.

E: - É. Não pode

L: - Não pode, até adulto não pode.

E: - Independente.

L: - O peso hoje é 60 quilos, o que eu acho muito ainda. Fomos para o...

E: - Você estava com seu irmão?

L: - Fui pra casa do meu irmão.

E: - Esperou debulhar o milho...

L: - Esperei acertar a questão do milho, dos cereais. Resolveu tudo, eu peguei o dinheiro e...

E: - Foi fácil sair da terra? Você não teve nenhum conflito com o dono do sítio? 
L: - Eu não tive porque era colheita. Colheu, entregou, pronto.

E: - Não tem mais compromisso nenhum.

L: - Não. Ele olha se está tudo ok, você não tem criação, não tem nada para dividir. Aí eu saí e meu pai ficou na terra. Eu fui trabalhar com meu irmão, trabalhei até um certo tempo. Aí quando foi em agosto de 68, teve um casamento. Foi uma prima minha aqui de São Paulo, a gente conversou, eu peguei o endereço dela e resolvi vir embora para cá.

E: - Por quê? O que o senhor esperava encontrar aqui em São Paulo?

L: - Eu não fazia a mínima ideia. Isso aqui pra mim foi um uma surpresa, sabe? Mas São Paulo em 40 anos dobrou. Aliás, mais que dobrou, acho que São Paulo era 30\% do que é hoje, eu acredito. Você sabe que muito menos? Santo Amaro não tinha prédio, dava para você contar os prédios que tinham em Santo Amaro, e era prédio pequeno. O centro da cidade, aquela região do Brás ali, dava para você contar. Era muito pequeno, a grande São Paulo então quase não existia. E: - Mas o senhor veio em busca de trabalho?

L: - Vim.

E: - Principalmente.

L: - Cheguei aqui... Ah! Aí nesse período, antes de eu ir trabalhar com meu irmão, eu fiquei doente e fui para o hospital. Cheguei lá, com esse dinheiro eu paguei a minha internação, porque não tinha médico de graça naquele tempo.

E: - Não tinha?

L: - Não. Que eu me lembre não. Eu paguei a minha internação, o médico queria me operar de apendicite. A medicina pra mim é furada.

E: - Furada?

L: - Furada. Você imagina, eu tinha dezessete anos, o médico lá em Apucarana queria me operar de apendicite.

E: - E não era?

L: - Eu fiquei internado dois dias, aquela dor terrível no estômago. E ele dizendo que era apendicite, que eu tinha que operar. E então eu falei com ele no último dia, falei "Doutor, é o seguinte, o senhor me passa algum remédio pra eu tomar em casa, e eu vou embora". Porque eu não tinha dinheiro pra ficar pagando internação, entende?

E: - Muito caro, não é? 
L: - "Eu vou para casa, se eu não melhorar...". Porque era época de colheita, ia começar a colheita. E eu falei para ele, "se eu não melhorar eu volto. A gente arruma o dinheiro, eu volto e faço a cirurgia. Mas no momento a gente não tem dinheiro pra pagar a cirurgia". O médico me receitou um remédio, que eu nem me lembro o tipo de remédio que era, o nome do remédio. Eu levei para casa, comecei a tomar o remédio, e até hoje... Depois que eu vim pra São Paulo eu tive uma recaída, com o mesmo problema, fui nãoa farmácia, chegou lá... Inclusive era uma mulher a farmacêutica, ela preparou um líquido não copo, me deu eu tomei. Nunca mais voltou a dor, e eu estou aqui.

E: - Nunca teve que operar?

L: - É. Por isso que eu digo pra você que é uma furada. Se eu tivesse o dinheiro pagava. Depois ele ia mostrar, "olha como é que estava inflamado".

E: - Tem dessas coisas.

L: - Em determinadas coisas da medicina. $\mathrm{E}$ aí as pessoas chamam a gente... "Esse cara é burro, o cara não estudou". Mas aconteceu comigo, o cara queria me operar.

E: - Essa experiência.

L: - E eu não fiz a cirurgia, estou aqui até hoje. Vim pra São Paulo, fui para casa dessa minha prima, fiquei lá uns dias. Aí trabalhei não abatedor de aves.

E: - Fazendo o que no abatedor?

L: - Nãoa granja. Eu abatia, coisa que eu não faço hoje nem... Se depender de mim para matar um animal para comer eu não como.

E: - Naquela época o senhor matava?

L: - Eu matava. Eu tinha que matar os frangos. Você abria o bico dele, com uma tesourinha, você cortava. Mas por dentro do bico, e colocava de cabeça para baixo para sangrar. Eu tinha que depenar e depois tinham as mulheres, que abriam, limpavam as vísceras, limpavam tudo. E entregava para o cliente. Ganhava muita caixinha, porque naquele tempo, em São Paulo corria muito dinheiro, certo? Você tirava o valor do seu salário só de caixinha. As pessoas não tinham dó de dar gorjeta. Posto de gasolina... Teve cara naquela época, colega meu, que montou pastelaria, montou comércio aqui com gorjeta de posto de gasolina.

E: - Ah é? E o senhor ficou quanto tempo nesse abatedor?

L: - Fiquei pouco tempo. Eu era um pouco rebelde, vamos dizer assim. Aí saí da granja. E: - O senhor não gostava de lá? 
L: - É. Porque não registrava. Minha preocupação naquele tempo é que não registrava carteira. Aí quando eu tive essa recaída, voltei para o Paraná. Fiquei com medo, fora de casa, não tem ninguém para cuidar de mim, e eu na casa de estranho. Como é que eu vou fazer? Voltei, recuperei, voltei de novo. Mas pra minha casa mesmo, nunca mais eu voltei, nunca mais eu passei mais do que quinze dias na casa dos meus pais. Eu ia lá todos os anos visitar eles, mas assim, de moradia, nunca mais. Vim para cá, aí continuei. Trabalhei de cobrador de ônibus, no tempo em que você cobrava o ônibus em pé, andando dentro do ônibus. Já pensou? Você tinha que marcar a cara de cada pessoa que subia. Enquanto você estava cobrando um, o outro subia, entrava,se mistura lá no meio dos outro passageiros.

E: - Você tinha que ficar esperto.

L: - É. E eu estava treinando. Tinha uma matemática danada pra você ser cobrador de ônibus, tinha um teste ferrado para você trabalhar com matemática, sabe? Imagina eu que estudei pouco?

E eu passei.

E: - Que bom.

L: - É. Nos testes.

E: - Aí o senhor foi cobrador, logo depois que o senhor saiu do abatedouro?

L: - É. Eu fazia a linha Penha /Vila Mariana. Tinham dois preços, até a Praça da Sé era um preço...

E: - Nossa.

L: - Quem ia seguir pagava passagem dobrada. Não me lembro se era dobrada, mas tinham dois preços. Era bilhetinho assim que você tinha que dar pra passageiro.

E: - Complicado mesmo.

L: - Entrava pela porta da frente e saía pela porta de trás. Era diferente de hoje. Acho que é o único lugar do mundo que você vai sempre o contrário. Porque tudo tem uma lógica na vida... O efeito da gravidade. No Brasil, o sistema de ônibus ele é ao contrário da lei da gravidade.

E: - Aqui você entra pela frente e sai por trás.

L: - Pois é, você está andando, você está voltando em vez de estar no sentido horário. Se eu não me engano é o único sistema do mundo.

E: - Não sei.

L: - Foi em São Paulo que foi adotado. Você entra pela porta de trás e desce pela frente. Eu estava praticando linha., aí o cobrador fez um serviço que eu não aprovei. Nós estávamos 
passando pelo Parque Dom Pedro, ali entrou um cara e começou a falar asneira dentro do ônibus. Estava bêbado, começou a encher o saco. O cobrador falou para o motorista, "Abre a porta". Ele estava perto da porta, o cara, quando o motorista abriu a porta, pegou ele pelo braço e jogou ele lá fora, para baixo da escada. O cara caiu lá embaixo, nem sei o que aconteceu com ele, deve ter se arrebentado todo. "Pode tocar", motorista pegou e tocou o ônibus, foi embora. Eu olhei aquilo e falei, "mas você faz isso com as pessoas?", "faço, o cara fica enchendo o saco". Ele fazia isso, não me serve. Imagina jogar o cara lá fora. Eu podia chegar nele e falar, "por favor, desce, não dá pra você ir", mas jogar o cara lá fora?! Trabalhei mais uns três dias, antes de vencer meu período de treinamento eu saí fora. Fui trabalhar de servente de pedreiro na primeira grande fábrica de fogões. Fogões... não sei se você chegou a conhecer. Nem tem mais essa marca. Lá no bairro da Vila Liviera, divisa de São Paulo com São Bernardo do Campo.

E: - O senhor estava morando onde na época? Sozinho?

L: - Nesse tempo eu ainda estava morando não quartinho, lá onde morava minha prima.

E: - Ela estava te alugando um quartinho?

L: - Aliás, eu fui trabalhar não na fábrica, fui trabalhar na construção da fábrica. De peão, de servente de pedreiro, aí eu morava na obra. Não é que nem hoje que tem televisão a cores, tem cama para os caras dormir, tem água mineral, tem almoço e janta gratuitos. Não. Lá você tinha que queimar lata, você tinha que fazer sua comida, você tinha que arrumar um canto para você dormir. Você vivia não estado vegetativo.

E: - Só trabalhando.

L: - Apareceu um mineiro que comia rato. A turma não acreditou que ele comia, ele disse que comia, e foi preparar o rato. Aí foi a gota d’água, a turma teve que...

E: - Ele comeu mesmo?

L: - Ele ia comer. A turma não acreditava que ele fazia aquilo pra comer, e ele foi provar para o pessoal que comia. É cada cena que muita pessoas em São Paulo têm para contar, que você fica pasma. O cara comia rato.

E: - E o senhor aguentou bem trabalhar como... Na construção civil?

L: - Aguentei. Trabalhar em serviço pesado...

E: - Já estava costumado. 
L: - Igual da roça, não fazia diferença. Eu trabalhei nessa firma até um tempo, encerrou o serviço, eles dispensaram o pessoal. Fui para Santo Amaro, saí do centro da cidade, tinha uma irmã que tinha vindo para cá, fui morar com ela. Eu vou te falar, eu trabalhei em muitas firmas, sabe? E: - Mas de construção civil todas?

L: - Não. De construção civil só trabalhei nessa daí. Fui trabalhar nãoa metalúrgica. Nessa metalúrgica eu fui mandado embora por justa causa, foi a única empresa que eu fui mandado por justa causa.

E: - Por quê?

L: - Fui mandado por justa causa por causa de um menor de idade.

E: - De um menor?

L: - De um menor de idade. Porque garoto, a maioria só pensa em brincar. Tinha faltado energia. O gerente era alemão e eles são muito rígidos. Uma disciplina muito rígida na empresa. Acabou a energia elétrica, estava todo mundo parado, mas como eu era ajudante, tinha que ficar fazendo outros tipos de serviços. Eu peguei um tambor. Eles cortavam um tambor desses de óleo para colocar as peças. Nós fazíamos peça para o exército, fazíamos peça de automóvel, um monte de tipo de serviço. Lá eu cheguei a fazer peça pra granada.

E: - Nossa.

L: - Aquela parte de fora da granada, para o exército. Eu cheguei a fazer aquilo ali. Fazia alavanca de cambio. Eu era para ter sido metalúrgico, era pra ter seguido o ramo.

E: - O senhor gostava disso?

L: - Gostava. E aprendi muito rápido o serviço, trabalhava nãoa máquina chamada tornocopiadora. Rapidinho eu peguei o jeito de trabalhar. Moral da história. Nós pegamos esse tambor de gás pra levar pra uma outra seção. Quando voltamos, no meio do caminho, o moleque queria levar o carrinho. E ele não podia pegar aquilo, era serviço para adulto. $O$ menor de idade fazia serviços leves. E ele pegou o carrinho, "eu vou levar, porque não sei, o que não sei o que lá. Deixa que eu levo, vou levar, vou levar". Pegou o carrinho e foi brincando no meio da seção. Tinha um buraco no piso, a roda do carrinho foi dentro daquele buraco. E ele ficou fingindo, como se estivesse fazendo força sozinho. Na hora, o gerente tinha convocado uma reunião, não tinha energia, convocou uma reunião com os chefes. Estava lá, dando orientação, mas de olho... Que era tudo de vidro assim, sabe? E ele estava comandando tudo, de olho, lá dentro ele via tudo o que estava acontecendo. E ele viu o moleque empurrando, e eu perto do moleque, pedindo para 
o moleque me dar o carrinho, para tirar o carrinho do buraco, e o moleque não dava. Quando eu olhei, ele olhou para mim assim firme. Eu olhei para ele, ele apontou o dedo para mim, que eu fosse lá. Tudo bem, deixei o moleque lá com o carrinho e fui lá. Na hora que eu cheguei, abri a primeira porta, quando fui chegando já na segunda porta, ele já estava com ela aberta pra mim. Falou, “por que você está deixando o moleque empurrar o carrinho?”. "Não sou eu que estou deixando, ele que quer empurrar, ele que tomou o carrinho da minha mão e pegou para empurrar" “Mas você não sabe que menor de idade não pode fazer isso?”. Falei, "Sim, eu sei, mas ele quer fazer. Ele quer empurrar o carrinho, não sou eu que estou deixando empurrar”. Ele já estava a fim de mandar alguém embora ali, sabe? Ele falou pra mim, "rua!".

$\mathrm{E}:-$ Assim?

L: - Assim. Apontou o dedo para mim e falou, "rua!". Na maior inocência, falei pra ele, "não entendi, o senhor pode repetir?". "Rua! Você está despedido”. Eu falei, "tudo bem, senhor”, saí. Quando eu fui voltar por aquela porta, disse “por aí não, por aqui!”. E já chamou um dos capangas dele, falou para acompanhar, fui para o departamento pessoal. No caminho fui conversando com o cara, falei "vocês estão me dispensando por quê?". Ele disse "você sabe porque. Você não sabe que moleque de menor não pode pegar peso? Você ficou perto do moleque e o moleque empurrando o carrinho". Eu falei "tudo bem". Andamos mais um pouco, quando chegou perto do departamento pessoal, que ficava do outro lado da rua, eu falei para ele dos meus direitos. Ele falou, “direito? Direito você vai procurar, você está sendo despedido por justa causa". Chegamos no departamento pessoal, conversei com o cara, ele falou, "você está sendo despedido por justa causa".

E: - Quer dizer, saiu sem nada?

L: - Fui embora para casa, voltei no outro dia, todo mundo, até o chefe se propôs a ser minha testemunha. Porque é injusto, porque não sei o que, porque isso não pode acontecer, porque papapapa papapapa. Tudo bem, fui embora. Todo mundo se propôs a ser minha testemunha. Fui ao meu advogado, coloquei ele em cima da empresa. Na primeira audiência não apareceu ninguém, fui lá na firma, falei... Um tinha saído, não sabiam onde ele morava, o outro estava empregado tinha medo de perder o emprego se fosse testemunha...

E: - Não arrumou ninguém?

L: - Fui para a primeira audiência. Chegou lá, nada. Não tinha testemunha. O juiz falou pra mim "Luís, na segunda audiência você tem que trazer testemunha. Se você não trouxer testemunha, 
você perde a causa". Na primeira audiência. Na segunda audiência, eu fui lá pelejei, pelejei, pelejei. Não consegui arrumar testemunha.

E: - Ninguém?

L: - Ninguém. Fui à outra audiência, cheguei lá, cadê? Não tinha testemunha. O juiz falou "Luís, cadê a testemunha?”. "Não consegui trazer”, “tudo bem”. “E a proposta da firma?”. "Qual a proposta da firma?". Aí a firma "nós liberamos fundo de garantia, pagamos férias, pagamos abono...”, tal tal tal tal, “...mas não pagamos aviso prévio”. Aí ele falou "Luís, e aí? Você vai aceitar a proposta da firma? Tem acordo, ou não? Se você não aceitar, na terceira audiência, se você não trouxer testemunha, você perde a causa".

E: - Fica sem nada.

L: - "Você perde a causa, você fica sem nada. Ou você aceita o acordo agora, ou você não tem nada". Na maior inocência, eu falei para ele "eu aceito, pagamento aqui". O advogado falou "não Luís, eu não trouxe dinheiro, eu não trouxe talão de cheque, não trouxe nada. Eu vim aqui pra negociar, eu não posso fazer pagamento aqui”. E eu, não conhecia a lei, bati o pé "não, eu aceito o acordo aqui". "Não Luís, tal dia assim assim a gente vem aqui pagar para você, assim assim assim”. Aí o juiz me orientou... Fazer o quê? Aceitei o acordo, pra poder receber. Depois fui trabalhar na... Não serviço desgraçado. Nesses postos de rua, trabalhei nãoa firma dessas. Lá eu ganhei minha hérnia dos dois lados.

E: - De tão pesado...

L: - De tão pesado que era o serviço. Fui operado de hérnia com 19 para 20 anos. Lá também, quando eu voltei da alta, porque ficava 90 dias afastado, a firma já estava com aviso prévio pra mim. Aí já estava esperto, falei “estou chegando hoje, saí do médico hoje. Você está me mandando embora? E se eu não estiver bem, como é que eu faço? Então eu não vou assinar o aviso prévio", disse para ele. Só que eu já estava morando em Santo Amaro e a firma era lá em Embu Guaçu, então era muito longe, não compensava trabalhar lá. Falei para ele "eu vou trabalhar, você me dá 30 dias de prazo, se nesses 30 dias eu achar que estou bem, eu assino o aviso prévio, sem problemas". Assinei o aviso prévio, quando eu vi que estava bem, podia pegar peso, não estava sentindo dor, avisei para ele, depois ele me despediu, eu saí da firma. Aí vem um fato, novamente sobre o sistema de governo, que toda a vida eu contestei. Nesse período, de tudo isso que aconteceu, lá em Brasília o pau tava comendo. Greves, prisão, assassinato. Os 
comunistas estavam sendo degolados, enterrados em valas comuns, como houve em Perus. Muita gente tinha sido expulsa do país, muita gente presa.

E: - E o senhor assistindo tudo...

L: - E eu assistindo tudo, porque nesse período eu, simplesmente, me afastei, eu não militei. Eu era para ter sido um militante daqueles ferrenhos, pela minha trajetória. Eu era para ter chegado aqui e me engajado, principalmente na área sindical. Mas não, eu fiquei... Assim que eu entrava nãoa empresa eu me filiava ao sindicato dela, sempre fui filiado ao sindicato da categoria. E aí, com 18 dias que eu tinha sido demitido dessa empresa, eu fui preso por vadiagem, nãoa padaria que tem no Jardim Ângela, que até pouco tempo era um dos bairros mais violentos, que era... Não sei se a primeira, ou a segunda padaria que tinha no Jardim Ângela, no ponto final do antigo ônibus Jardim Ângela. Dez horas da noite eu estava lá com o irmão do cunhado da minha irmã, dois jovens ali tomando uma cerveja, e a cerveja inclusive a gente estava pagando, de repente, chegou a rota. A rota naquele tempo metralhava mesmo. Fechou as quatro portas da padaria, metralhadora na mão, "mãos pra cima, todo mundo". Tinham pessoas ali que tinham ido comprar cigarro, sem documento, sem nada, foi preso. RG não era documento naquele tempo, documento era carteira de trabalho registrada. Se estivesse sem registro também não valia como documento, valia a ficha da empresa, naquele período. Isso que eu estou te contando... Faz um resumo disso aí para você ver, e conversa com pessoas da minha época para você ver. Documento naquela época era registro em carteira, a única folha que servia era aquela que estava registrada, o restante era papel. Pediram o documento. Eu andava com todos os documentos, carteira profissional, RG. Ele olhou e foi folheando a minha carteira. Tanto tempo em tal firma, tanto tempo em tal firma. Função, sempre servente, ajudante. “Abre a mão”, pegou minha mão, olhou. Puxa! Eu fiquei 90 dias parado, me recuperando da cirurgia, minha mão estava lisa igual a mão de um padre. Ele disse pra mim que eu não gostava de trabalhar. Olhou na carteira, servente de pedreiro, e com a mão lisa desse jeito. "Você não é chegado em trabalho, não é?". Chamou o comandante deles, "Sargento, olha a situação desse rapaz aqui, ele não é muito chegado em trabalho não. Olha a mão dele, parece a mão de uma moça. Olha a carteira dele.”. O Sargento olhou a carteira, falou “Realmente, ele não é muito chegado em serviço. Sobe lá!”. E eu fui preso com RG, com carteira profissional, com 18 dias da baixa, por vadiagem, na época do Maluf, detesto o Maluf. Porque você nota bem, hoje se prenderem pessoas por vadiagem que estejam no serviço informal, sem carteira registrada, muitas vezes sem documento, ou com o documento que o cara trabalhou 10 
anos atrás e até hoje não conseguiu emprego mais... Se fosse prender precisava construir uns 100 Carandirus, não precisava?

E: - Precisava. Não, e não pode, o que é isso?

L: - Pois eu fui preso por vadiagem. Pegou mais uma turma lá e nós ficamos, acho que uns seis ou sete dentro daquele chiqueirinho.E aí o filho da puta do policial ficava na traseira da viatura, batia e falava "senta!", você ia sentar, que não dava nem para sentar ali, aquele monte de gente. A hora que eu sentei, ele falava "levanta!", aí você levantava, "senta!”. Zoando.

E: - Não acredito. Que horror.

L: - Você imagina a hora que chegasse na delegacia, o que a gente ia passar, a humilhação que o preso naquele tempo sofria. Mandava você levantar, como é que você ia levantar com aquela coisa daquela altura assim?

E: - Ficava torto, não é?

L: - Você ficava assim. Veja o autoritarismo deles. De repente ele falou, "Nós recebemos um comunicado para atender uma ocorrência muito grave, hoje vocês vão escapar”. Então o que nós estávamos fazendo que nós fomos presos? Nós estávamos sendo detidos por que?

E: - O senhor ficou quieto...

L: - Fiquei quieto, fiquei na minha. Pelo amor de Deus! Já estava rezando, já estava pensando “Será que eu vou voltar vivo para casa? Vou voltar inteiro para casa?”. Porque nãoa daquelas, eles podiam levar a gente para frente, ali na M'Boi Mirim, e fuzilar todo mundo.

E: - Eles faziam isso?

L: - Faziam. Fuzilavam, jogavam gasolina, tocavam fogo. Colocavam droga... Não, droga naquele tempo não tinha, naquele tempo não circulava esse tipo de coisa, ainda não. Aí bateu a coronha na traseira, “desce todo mundo, seu vagabundos! Hoje vocês vão escapar, mas se nós pegarmos vocês aqui de novo, vai todo mundo em cana.". Descemos, ainda agradecemos o filho da puta. Fui lá, falei com o irmão do cunhado da minha irmã, falei para ele "você estava esperando o que? O filho da puta...”, falei desse jeito assim para ele, “estava esperando só a viatura sair, fazer o que?’. E realmente, o que ele ia fazer? E ele estava com o documento registrado, você entende? Eles não colocaram a mão nele. Eu falei, “eu nunca mais volto nessa padaria, só entro aqui para comprar pão, mas para outras coisas...”. Porque era obrigado ir ali comprar pão, só tinha ela. Mas de noite, eu não entrava mais nem que me pagasse. Mandou nós descermos, descemos, eles foram embora atender a tal da ocorrência, que devia ser coisa muito 
grave para nos deixar ali. E aí eu tomei uma bronca ferrenha do Maluf. Maluf naquele tempo deve ter mandado matar muita gente.

E: - Ah, com certeza.

L: - Maluf, se fosse investigar os crimes que ele mandou praticar em São Paulo, pela polícia, pelos direitos humanos ele ia puxar na cadeia muito tempo. No Brasil não puxa coisa nenhuma. Depois desse período, eu deixei a indústria metalúrgica e um colega estava trabalhando na indústria de plástico, falou que estava precisando. Fui para lá, trabalhei nessa firma um ano e meio. Naquele tempo, plástico ainda era importado, o grão do plástico era importado ainda, a matéria prima. Comecei a trabalhar com plástico, embalagem de colchão, travesseiro, esse tipo de embalagem. Com um ano e meio a firma não quis me promover, era assim... Sempre eu me ferrava. Eu estava trabalhando, já tinha pegado muita prática, já tinha um ano e meio. Já tocava máquina sozinho, já fazia tudo sozinho. Entrava uma pessoa novata, eles colocavam comigo para eu treinar. Quando o cara estava bem prático mesmo, que eu podia ficar mais à vontade, eles pegavam aquela pessoa, transferiam para outra turma e colocavam outro novo para ficar comigo. E eu era só para dar instrução para os caras, certo? E salário mesmo...

E: - Igual.

L: - Igual. Eu continuava ajudante. Conversei com eles, ficaram enrolando, falando que iam me promover. Eu carregava um peso daquelas bobinas, dessa grossura assim, 40, 50, 60, 70 quilos. Você tinha que colocar aquilo no lombo, descer uma escada de 18 degraus, com aquilo no ombro para colocar na balança para pesar. Porque a máquina fazia o plástico, eles enrolavam lá em cima. Aí achei que não dava mais, comecei a ir nas empresas pedir teste, você era um simples ajudante, mas a empresa dava teste para você fazer. Eu vi que eles estavam de má vontade comigo, e isso era um final de ano. O dissídio nosso... Nós tínhamos aumento em janeiro. Quando foi em novembro, eu comecei a sair nas firmas para fazer teste. Um dia cheguei lá, conversei com eles, estavam em reunião. Eram dois irmãos, eles eram três sócios, dois irmãos e mais uma pessoa. Os dois eram judeus, eram donos do cacau, e o sócio era uma pessoa formada em Administração de Empresas. Eles fizeram um acordo com essa pessoa... Mas deveria ser descendente também de judeu. Judeu não dá boi para qualquer um. Deveria ser descendente de judeu. Até o nome dele, chamava Teseu. Já era um nome judaico. Embora os dois, um deles chamava Jorge, que não tem nada a ver.

E: - É, nem todos têm nome... 
L: - Eles deram sociedade para ele, de igual para igual, você entende? O cara pegou um boi, uma boiada.

E: - Uma boiada. Pelo trabalho, não é?

L: - E ele então administrava a empresa, e um era gerente de vendas, o outro gerente industrial.

Eu vi falando, “ah, nós vamos arredondar ele”, você entende? Mas em janeiro era o dissídio, isso era em dezembro. Eu pensei comigo, mas em janeiro vai ter dissídio, o aumento que ele estão querendo me dar é o mesmo que o dissídio, não vai alterar nada. Cheguei lá embaixo, esperei, o gerente de produção desceu, “e aquele papo lá Seu Jorge, de me arredondar? É o seguinte, vocês estão de má vontade comigo, eu estou bom de pedir a conta para a empresa". Ah, para que eu falei isso? Judeu, se ele tiver um voto de confiança em você, ele te leva longe, agora se ele tiver dúvida, ele te poda na hora. Na hora em que eu falei isso, ele falou assim: "toda a chance, toda a oportunidade que você tinha nessa empresa, você perdeu nessas palavras que você falou aí”. Eu falei "tudo bem", saí. No dia seguinte, comprei os jornais, olhei, tal firma assim está pedindo tal tal tal tal, e eu fui. Ia nãoa, ia noutra, dava para você escolher naquele tempo.

E: - Tinha um monte.

L: - Tinha. Uma queria me contratar, mas queria colocar uma responsabilidade muito grande em cima de mim, sabe? Saí fora. Fui nãoa outra, cheguei lá, o cara me deu o teste, terminei de fazer o teste, colocou lá, “aprovado”. Mandou pro departamento pessoal, cheguei lá, apresentei documento, o chefe do departamento pessoal olhou... Era uma firma grande, só mulher naquele tempo trabalhava, quase mil mulheres. Era o maior fabricante de tampas de frascos da América Latina.

E: - Nossa.

L: - Chamava Perticamps, era de um francês. Apresentei para ele o papel que ele olhou, falou "você foi aprovado no teste", só que o cara falou para mim, “quanto você quer ganhar?”. Eu não tinha nem conversado com os colegas lá dentro, quanto que eles ganhavam... Você entende? Eu fiquei assim pasmo, o que eu vou falar para o cara? Se eu não sei o salário que a empresa paga, não sabia a faixa de salário. Que naquele tempo, uma empresa pagava um salário, a outra pagava outro. A que tinha 100 empregados era um salário, a que tinha 1000 era outro salário. Ele falou para mim “quanto você quer ganhar?”. Eu falei “eu não sei a faixa de salário de vocês aqui”. Sabe o que ele falou para mim? Eu ganhava 300... 260 cruzeiros, devia ser 1000. Se você vê minha carteira profissional, você fica pasma de ver a carreira de zero. 
E: - Sério?

L: - É. Um dia desses, eu estava vendo um documentário sobre a inflação de anos da década de 70, 60. A inflação era uma coisa absurda. O valor do dinheiro era milhões, "ah, fulano de tal ganha tantos milhões".

E: - Não comprava nada.

L: - Não valia nada. Era o dinheiro do Paraguai.

E: - E o senhor ia ao supermercado acabava?

L: - É. Chegava lá, "quanto é essa geladeira?", "essa geladeira custa 2 milhões".

E: - Era um absurdo, não é?

L: - No dinheiro tinha isso. Uma nota de 10 mil reais... Você já viu a nota de 10 mil reais?

E: - 10 mil cruzeiros.

L: - 10 mil reais, não! 10 mil cruzeiros.

E: - Sim.

L: - Pois é, aquela carreira de números.

E: - Não acaba mais.

L: - Ele falou para mim, “Luís, 600 está bom para você?”. Você imagina, 260 para 600.

E: - Daí você não acreditou?

L: - Eu não acreditei. Eu falei “600?”, ele “é”. Eu falei “tá bom”, ia dobrar meu salário. Entrei na firma e fui trabalhando, trabalhando, trabalhando. Eu trabalhava quatro por dois, eram quatro dias seguidos 12 horas e ficava dois em casa, de dia. Depois você voltava, trabalhava quatro noites, ficava mais dois dias em casa. Revezava esse ciclo. Eu trabalhei nessa empresa três anos e meio. Nos três anos e meio, veio a mesma polêmica da perseguição.

E: - Que polêmica?

L: - Da perseguição do empregado dentro de uma empresa. Tinha uma pessoa que nós trabalhamos juntos, desde que eu cheguei, ele já estava lá. A gente se dava igual irmão, que veio o caso também de eu ser polêmico por causa de religião. O cara era da igreja Assembleia de Deus, ele era pastor. Morava lá para os lados de Jandira, e ele era uma das pessoas com grande conhecimento da empresa, sabe? E lá eles não pegavam chefe, quando saía um, eles não pegavam outro de fora, eles promoviam uma pessoa ali de dentro. E ele já estava na lista de promoção. Aí saiu um encarregado, nós mesmos, os operadores se reuniram e foram falar com o supervisor, que ele era uma pessoa que se dava com todo mundo, todo mundo gostava dele, e nós dois éramos 
parceiros. Nós tomávamos conta de uma carreira de máquinas, eram várias máquinas para cada operador. Se eu levava uma maçã, nós partíamos no meio, nós tínhamos uma consideração enorme um pelo outro.

E: - Vocês eram amigos?

L: - É. E eu era a única pessoa dos colegas de serviço que ele levava na casa dele. Que ele levou na casa dele para conhecer a família dele. Esse cara me traiu. Nós falamos que ele era a pessoa indicada, que era a pessoa que se dava com todo mundo, que era uma boa pessoa. Foi promovido. Quando ele foi promovido, 90 dias depois, ele colocou na cabeça que eu tinha inveja dele. Enquanto ele não me viu pelas costas...

E: - Ele não sossegou.

L: - Ele não sossegou. Um dia deu um problema na máquina. Tinha coisa que eu não tolerava mesmo, você entende? Deu um problema na máquina, eu o chamei. Ele chamava Benedito, a gente chamava ele de Dito. “Dito, deu um problema na máquina...”. E era assim, não podia parar a máquina a não ser que desse problema dela quebrar, ou faltar energia. Mas se ela tivesse funcionando e desse um problema, você só podia parar com a ordem do chefe, porque era tudo relatado. Você tinha uma ficha ali que você tinha que marcar a hora que ela parou, qual foi o motivo, se é elétrico ou mecânico. Quando voltava... Chamava a pessoa para consertar, consertava, tinha que marcar a hora que começou a produzir, porque você ganhava por produção. Ele vem... Eu não sei se eu estou falando muito, a hora que você quiser encerrar... E: - Não, pode continuar.

L: - Ele veio, eu falei para ele, "a máquina está com defeito, aconteceu isso e isso". "Ah, tudo bem, eu vou dar uma olhada". Mas ao invés dele falar "pára a máquina e verifica o que está ocorrendo... E eu vou lá ver o que está ocorrendo", ou ele fosse lá na hora. Ele falou “depois eu vou lá olhar". E a quebra que dava ali, se fosse quebra de material era anotada na sua ficha como prejuízo para a empresa. Fui lá umas três vezes, ele “eu vou lá ver”. A quebra ia para o meu nome, não para o nome do filho da puta. Era coisa que eu podia resolver, mas eu não podia pôr a mão sem a ordem dele, você entende?

E: - Claro, se desse algum problema.

L: - Eu sabia resolver o problema, o que eu fiz? Fui lá, tirei a peça, troquei, com a máquina funcionando, tudo certinho, porque o problema era externo. Resolvi o problema e peguei a pela, louco de raiva, e joguei. Ele estava assim paradinho, joguei do lado dos pés dele. 
E: - Daí pronto.

L: - Aí ele pulou para cima, olhou assim, foi lá “ah, e aí?”. Eu falei, “já arrumei, já está funcionando". “O que era?", “aquela peça lá que eu joguei, estava com defeito e eu já arrumei, está resolvido o problema”. Era de noite, imagina, trabalhando à noite. À noite dava um sono do cão, e você tem que lidar com uma situação dessa. Saímos de folga naquele dia, fiquei os dois dias em casa, quando eu voltei para trabalhar eu estava sendo demitido por justa causa, novamente.

E: - Mais uma vez.

L: - A minha ficha era tão limpa na empresa, sem atraso, sem falta. Levei um atestado médico uma vez porque eu fiz uma cirurgia no nariz... Acho que foi, uma cirurgia no nariz e então fiquei afastado 15 dias. Mas não tinha atraso, não tinha suspensão, não tinha faltas graves. A minha ficha era tão limpa que o chefe do departamento pessoal falou, "Luís, o que você aprontou lá?". Eu falei, "não aprontei nada". Ele falou, "mas o que eu recebi aqui é para te mandar por justa causa”. Eu falei, “vocês estão malucos da cabeça? Não fiz nada, não matei ninguém, eu não esquartejei ninguém, que estória é essa?". O cara foi tão correto comigo que ele falou, “olha Luís, então vamos fazer o seguinte, você vai para casa e volta amanhã e eu vou lá, fazer um levantamento para eu saber o que aconteceu com você. Porque na sua ficha não tem nada que desabona você”. Você imagina? Um chefe de departamento pessoal, de RH, falar isso para você, para um funcionário. Ele está ali para cumprir a ordem que vem lá.

E: - Do chefe.

L: - O cara era muito correto. No dia seguinte eu voltei, ele falou para mim, "olha Luís, a ordem que eu tenho é essa mesmo, te despedir por justa causa. Mas vamos fazer o seguinte, a firma só não vai te pagar o aviso prévio, mas o restante a firma te paga tudo, te libera tudo. Mas o aviso prévio, você vai ter que abrir mão dele”. Era praticamente uma justa causa, o restante você recebe mesmo. Porque naquele tempo não tinha essa lei que tem hoje de receber o fundo de garantia. Aí... Não vamos entrar nesse detalhe. Eu saí da empresa...

E: - Foi procurar outra coisa...

L: - Fui procurar. Fiz uma ficha não laboratório lá em Santo Amaro. Que que era uma área muito boa no Brasil de trabalhar, a área de indústrias químicas. Pagavam muito bem, portanto que você pode ir aonde tem um laboratório para você ver o estacionamento deles. Têm estacionamentos amplos, a maioria das pessoas que chegam ali tem carro do ano. Mas com uma promessa, eu 
tinha que estudar, porque quando ela me perguntou, a pessoa que estava me entrevistando, "como é que funciona a máquina que você operava?". Porque eu falei para ela, "olha, trabalho com temperatura, com grau, tantos graus... Você regula, $100^{\circ}, 200^{\circ}$ ". Ela se interessou. Todo mundo fala em desemprego hoje, naquele tempo, nãoa seleção de mais de 50 candidatos, nós ficamos em três. Cheguei em casa, deu uma confusão lá, não sei o que aconteceu com um documento que eu tinha que levar, não achei o documento, perdi a segunda entrevista. Ela me falou na primeira entrevistam você tem que me prometer uma coisa, você tem que continuar estudando.

E: - Você estava estudando nessa época?

L: - Não estava estudando. Ela disse que eu tinha que estudar.

E: - Voltar a estudar.

L: - É, voltar a estudar e fazer pelo menos o primeiro grau, que eu não tinha. Eu falei para ela, “tudo bem”. Me comprometi a estudar, mas aí não pude voltar por causa do documento. Perdi, aí comecei a perambular por aí, e vai nãoa firma, vai noutra. Eu trabalhava 15 dias nãoa firma, não dava certo. Aí, uma coincidência. Fui trabalhar nãoa firma de plástico, que meu ex-chefe da Perticamps era gerente. Quando o cara me viu... Na outra firma ele era conhecido por Francisco, ou Chicão, não me lembro direito. Era uma pessoa muito boa. Por várias vezes que eu tive atrito na empresa, porque eu queria sair. Porque eu ganhava menos que os mais velhos, e eu ia reclamar de salário. Ele falava para mim, "fica, eu vou resolver sua situação". Então nós dois tínhamos um certo relacionamento. Teve uma vez que eu queria sair para trabalhar nãoa alpargata. Alpargata, naquele tempo, já tinha banco lá dentro, e ele não deixou. Chego lá nessa firma... Ele tinha saído na minha frente, quando eu saí, ele já tinha saído. Eu fiquei acho que uns quatro meses... Ah sim, e quando eu saí da Perticamps eu fiz uma turnê pelo Brasil. Eu recebi uma boa indenização, aí eu fui para Minas Gerais, eu fui para Goiás.

E: - Sozinho?

L: - É. Uns três meses só rodando. Aí, nessa época que eu falei que eu quis sair da empresa, ele não quis deixar, depois eu saí, mas ele já tinha saído antes de mim. E ele, que eu saiba, lá na Perticamps, ele não era doutor, não era formado em nada. Quando eu chego nessa empresa, seis meses depois que eu tinha saído, eu encontrei ele lá, e todo mundo falando assim "Doutor Francisco", "Engenheiro Francisco".

E: - Ele tinha se formado? 
L: - Eu fiquei boiando. Eu fiz a ficha, fiz teste, fui aprovado em tudo, vou lá no departamento pessoal. Quando eu chego lá, tinha o escritório da empresa, era tudo junto, ele estava lá. Quando ele me viu, falou “o que você está fazendo aqui?". Eu falei, "estou procurando emprego". Ele falou, "por que, você saiu de lá?", falei "saí". Ele falou, "tem vaga sim".

E: - Que bom.

L: - Mas já tinha feito ficha, feito teste, tudo. Só ainda não tinha visto ele. Começo a trabalhar na empresa. Uma empresa totalmente desorganizada, uma baderna danada.

E: - Empresa do quê?

L: - De plástico. Mas eles trabalhavam para empresas grandes, trabalhavam para a Johnson's... E: - Vendiam para empresas grandes.

L: - Empresas ricas, empresas grandes. Mas muito desorganizada, eu comecei a trabalhar na empresa e achei aquilo uma baderna, sabe? Imagina. Eu trabalhava na Perticamps que era tudo organizado, tinha controle de qualidade... O chefe de produção do meu horário era um simples inspetor de qualidade, o cara não conhecia nada do serviço. Ele conhecia de qualidade, mas de operacionalidade das máquinas, não conhecia. É diferente, você sabe que esse plástico aqui ele está na medida, é de qualidade, mas você não sabe como é que a máquina que faz ele funciona. Você não...

E: - Não sabe o processo.

L: - O processo. E o cara queria ficar dando palpite, sem saber o que estava falando. E eu, já com uma experiência daquela, não concordava. Aí os caras falaram, "Francisco está vindo", "Dr. Francisco está vindo". E eu pensava comigo, para mim é Chicão, só que eu não me aproximei dele, você entende? Ele ficou no lugar dele, eu fiquei no meu lugar. Eu trabalhei 30 dias na empresa, porque não deu a chefia. Eu não sujei a barra do cara, porque ele não era engenheiro, não era nada.

E: - Ele estava mentindo?

L: - Eu não sei se ele estava mentindo, mas eu nunca soube que ele estivesse estudando. E lá ele era doutor. Não me aproximei dele, para dizer "eu conheço o fulano e ele vai me dar proteção aqui dentro". Eu não fiz nada disso. Com 30 dias, eu me desentendi com o cara por causa de um serviço. Cheguei nele falei, "você não sabe o que está fazendo rapaz, isso aqui não é assim, isso aqui é desse jeito. Não dá para fazer do jeito que você quer que faça". "É, que não sei o quê", eu falei, "então faça você, tchau e benção", com um mês de serviço. 
E: - E o cara ficou bravo...

L: - Fui para o escritório, quando eu fui pedi a conta, ele falou, "mas você está louco rapaz?

Chegou aqui ontem, você já quer sair, fica com a gente". Implorou para eu ficar com eles. Eu falei, "não, estou saindo". Aí eu falei de cara para ele, "os seu encarregados lá embaixo não sabem trabalhar, os caras não conhecem nada do serviço, rapaz". Falei para ele desse jeito. "Não dá para trabalhar com eles, Francisco", mas sem intimidade. Saí, e ele deve ter ficado bravo com os caras. Quebrei, quebrei cabeça para trabalhar em firmas de nome. Porque eu queria trabalhar em firmas grandes.

E: - Por quê?

L: - Porque você tinha mais chance de se promover, e o meu sonho, o meu intuito era crescer, ser promovido dentro de uma empresa, não queria ficar ali empurrando carrinho. E também não era assim tanto de mandar, nunca fui uma pessoa de gostar de mandar. Ah sim, e na Perticamps tem um fato curioso, que às vezes tem gente que me condena, porque acha que eu sou autoritário. $\mathrm{Na}$ Perticamps entrou para trabalhar comigo, naquele tempo estava uma falta de mão de obra, e eles pegaram um cara que dormia debaixo do viaduto Pompéia, do viaduto Antártica, ele era morador de rua. $\mathrm{O}$ cara tinha um mau cheiro, que ele chegava perto de você, você se sentia mal. Colocaram para trabalhar comigo de ajudante. E eu tolerei esse cara, saiu de lá porque quis. Comia igual lima nova o cara, dava até dó, e eu aconselhava ele. Até quando foi por fim, ele já tomava banho, já trocava de roupa, ia bonitinho. Já teve gay, trabalhei com gay, que eu também tolerei a pessoa, os colegas tiravam sarro, me alugavam, eu falava "ele é um ser humano igual os outros. Se ele serve para a firma, a firma contratou ele, deixa ele trabalhando aí". E: - O senhor não se incomodava.

L: - Não. O cara trabalhou enquanto quis e saiu da empresa, não por minha causa. Foi na Pulman que trabalhou esse que era homossexual, o cara trabalhou comigo 4 anos. Fui trabalhar na Pulman, eles tinham contratado um engenheiro. A Pulman tinha montado uma divisão só para produzir embalagem para o consumo da empresa. Então eles compraram o que tinha de mais moderno no mundo da indústria de embalagens. Eles compraram máquina italiana, máquina de embalagem italiana. As máquinas de solda e corte americanas, e a impressora também italiana. E montaram o que tinha de mais moderno nessa área, eles gastaram uma fortuna para montar a firma. Então o que ele fez? Também contratou um engenheiro, exclusivamente para cuidar desse setor, era um setor que tinha umas 15 pessoas trabalhando, no setor de embalagem. Eu cheguei lá, 
eu era um simples operador, tinha vindo das outras firmas como operador. Cheguei lá, ele tinha contratado para colocar nas máquinas, pessoas que tinham sido encarregadas em outras firmas. Eu fui o único que entrei como operador, mas os outros entraram com salário... Porque naquele tempo tinha aquele negócio que não podia rebaixar salário, então o cara veio de lá com um salário de 2000 reais, e o salário do operador era 1000, ele não podia rebaixar para 1000, tinha que pagar os 2000. E os caras entraram com o salário lá em cima, só eu entrei com salário mais baixo. Comecei a trabalhar, com dois meses ele mandou o que estava no segundo turno embora. Aí ficamos em dois, fazendo 12 horas. Passados uns meses, o engenheiro pisou na bola, o engenheiro arrumou uma briga no trânsito. E o engenheiro também não conhecia nada, era só teoria. Você está estudando, não é? Coloca em prática, teoria não funciona. Por exemplo, ser engenheiro que trabalha com esse serviço, tem que ter conhecimento de todo o processo produtivo. Não adianta só ter a teoria, principalmente hoje. O que aconteceu com ele? Ele trabalhava nãoa empresa muito grande, mas era só assinar papel. Ele falava para nós assim, “ah não está bom, o material não está bom, pára a máquina”. Nós éramos operadores, nós tínhamos conhecimento técnico do funcionamento operacional da máquina. Ele falava "pára a máquina", mandava desmontar aquilo tudo, imagina a firma, com um equipamento caríssimo daquele montado, e parado.

E: - Parado.

L: - Até que ele arrumou uma confusão no trânsito... A gente já estava cansado de ver ele fazer burrada, mas não podia falar com o dono da firma, ele era o chefe, ele era o engenheiro. E: - Tinha que respeitar.

L: - Tinha que respeitar as ordens dele, mas nós sabíamos que aquilo não estava certo. Aí ele arrumou uma confusão no trânsito, foi dar um soco no cara, o cara tirou o corpo, ele enfiou a mão no capô do outro carro, quebrou a mão. Ficou com a mão enfaixada e ia lá na firma, ficava lá mexendo, dando palpite. Até que um dia o médico falou para ele, "você vai ficar aleijado da mão se você não ficar de repouso". Ele simplesmente achou, porque era engenheiro, ficou em casa acho que uns 15, 20 dias, sem dar notícia para a firma. E nesse período, o que nós sabíamos, nós aplicamos, o nosso conhecimento, e as máquinas funcionaram direitinho e produziu. Aí ele voltou a trabalhar, quando ele voltou, mais de 20 dias sem dar notícia, quando ele voltou o dono da firma chamou ele, falou "está dispensado". Chamou eu e o outro rapaz, falou para nós, "vocês assumem a responsabilidade de tocar isso aqui para mim?”, nós falamos “assumimos”. Porque 
quando eu cheguei nessa firma, eu pedi para fazer um teste na máquina, isso era praxe. Você chegava nãoa firma, o cara levava você para conhecer o equipamento dele...

E: - Para ver se você sabia.

L: - E fazer o teste, para ver se você tinha conhecimento daquela máquina. E eu fui tratar com o dono da firma, era ele que atendia a gente, e ele falou para mim assim, "não adianta eu levar você lá, porque você nunca viu uma máquina dessas na sua vida”. Aí eu falei “deve ser uma máquina muito importante", no dia que eu cheguei lá eu falei, "realmente", eu não sabia nem apertar um botão na máquina.

E: - Totalmente diferente.

L: - Totalmente diferente, moderníssima, era coisa de última geração. Aí ele, muito sistemático, e eu também sistemático... Eu sei que aí ele perguntou se nós assumíamos a responsabilidade de tocar os equipamentos, a gente assumiu. Aí nós começamos a tocar a máquina.

E: - E vocês foram promovidos?

L: - Aí ficou a diferença, eu ganhava um salário aqui, e o outro ganhava aqui.

E: - Ah, mas aí não pode.

L: - Ficou aquela diferença de salário, e eu sabia que existia essa diferença, ele veio de outra firma como encarregado, e eu entrei como operador. Aí depois de mais de 6 meses, me parece, ou 1 ano, é que eles me igualaram com ele. Mas isso foi na marra, eu cobrando, eu falava assim "Fulano ganha mais do que eu, e nós fazemos o mesmo serviço, isso não é justo". Porque lá você podia falar com o patrão, sabe?

E: - Lá tinha mais abertura...

L: - Eu fui falando, fui falando, até que eles passaram a me igualar com ele, aí nós passamos a ter o mesmo salário. Aí eu trabalhei lá 21 anos, nesses 21 anos tive vários atritos com o dono da firma. Porque ele era descendente de português, boca suja, e ele tinha mania, jogava pedra em você... Tinham duas coisas que você podia falar com ele se ele te perguntasse, "aquilo ali está bom?", “essa peça aqui está boa?”. Tinham duas coisas que você podia responder para ele, “está boa", ou "está ruim", "mais ou menos", não tinha no vocabulário dele. Porque se você falasse “está mais ou menos", ele falava “estou te pagando para você fazer bem feito, se não está bom, faz de novo". E eu tive uns atritos com ele por causa disso, porque uma vez ele me chamou de burro e não me deu direito de defesa, eu fiquei insistindo, ele saiu, me deixou falando sozinho e foi embora. Aí veio aquilo, não aguentei, não consegui trabalhar, saí... Isso eu tinha pouco tempo 
de serviço, acho que tinha uns seis meses de serviço. Eu saí para falar com ele, os colegas todos falaram, "você está louco, rapaz? O homem vai te mandar embora. Esse homem não aceita imposição de ninguém, não aceita confrontação, ele vai te mandar embora". Eu falei "se mandar tudo bem, não tem problema, mas se eu não falar com ele não vou conseguir trabalhar. Ele não me deixou falar, só ele falou, ele não me deu direito de defesa". Os caras ficaram lá acho que pensando, "esse cara está na rua". Eu cheguei, ele estava distribuindo serviço para os mecânicos, naquele tempo ele ainda tomava conta de tudo. Produção, manutenção, vendas, compras, tudo era com ele, e já trabalhavam mais de 1000 funcionários na empresa, já pensou o cérebro daquele homem? Se o Brasil tivesse 10\% dos empresários com a mentalidade daquele homem, isso aqui era um paraíso. Empresa 100\% brasileira, ele falava que não recebeu nenhum centavo de banco, nem empréstimos do governo, portanto que não tinha nada daquele negócio de ficar visitando governador, prefeito, festinha com políticos não. Só na época do Collor que ele se ferrou.

E: - Se ferrou?

L: - Ele apoiou o Collor, foi fazer passeata com o Collor. O Collor quando assumiu prendeu o dinheiro de todo mundo.

E: - Se arrependeu.

L: - Acho que ele se arrependeu, foi a primeira vez que ele apoiou político e se ferrou.

E: - Viu que não era a dele mesmo.

L: - Sabe o que aconteceu? Eu saí, fui lá falar com ele, cheguei lá ele estava nãoa roda distribuindo serviço para os mecânicos, os encarregados. Quando ele me viu, porque eu não fazia parte daquelas reuniões de distribuição de serviço. Ele passava todos os dias na seção e cumprimentava a gente perguntando, “está tudo bem aí?”, “está tudo jóia”, e ia embora. Se tinha um problema, se eu falava “aconteceu isso e isso", aí ele pensava, “faz assim, assim, assim”. Ele era um homem que ele pagava as pessoas para não ter dor de cabeça. E eu fui lá falar com ele, quando ele me viu, eu era estranho ali naquela reunião, quando ele me viu ele parou a reunião. Ele parou, dirigiu a atenção para mim, “o que foi Luís?”. Eu falei, “posso falar com o senhor?”, "pode". E eu falei "olha, à partir de hoje eu vou pedir para o senhor uma coisa, não me chame de burro, porque o senhor não me deu o direito de resposta, só o senhor falou”. Quando ele levantou o dedo pra dizer "mas você é burro mesmo", eu também levantei a mão para ele, eu falei "parado lá, o senhor não me deu o direito de resposta. O senhor simplesmente falou o que o senhor queria falar, virou as costas para mim e foi embora. O senhor não me deu direito de resposta. Eu tenho 
sim o direito de falar, eu tenho direito de resposta". Ele caminhou para o meu lado, bateu no meu ombro e falou "você está nervoso, volta, vai trabalhar". Ele não disse "tudo bem, fala", ou desculpa, ou coisa assim. Mas ele veio, bateu no meu ombro e mandou eu trabalhar. Que ali a firma era grande, podia falar "você está despedido, eu não tenho obrigação de te ouvir, eu sou dono da empresa, aqui trabalha quem eu quero", podia ter me respondido isso. Ele veio, bateu no meu ombro, falou assim “você está nervoso, vai trabalhar”. Voltei, cheguei os caras estavam lá, “o que aconteceu?”, "não aconteceu nada. Mandou eu vir tocar a máquina, mandou eu trabalhar". Cheguei lá, aí refresquei a cabeça, sentei, arejei a cabeça, olhei... Eu fazia isso, eu tinha esse hábito, dava um problema na máquina, eu tentava um tempo para resolver o problema, não resolvia, aí eu saia, dava uma volta, arejava a cabeça, aí voltava, examinava, via todos os pormenores, porque estava acontecendo aquilo, entende? Às vezes, só nisso aí eu já ia lá onde estava o problema, resolvia e pronto, e trabalhei com ele...

E: - 21 anos.

L: - Trabalhei com ele até aposentar.

E: - E como é que o senhor chegou nesse grupo? No grupo Mãos na Massa.

L: - Então, no grupo Mãos na Massa, aconteceu o seguinte. Devido eu estar aposentado, eu parei de trabalhar, depois que eu saí da firma, fui para Sorocaba, trabalhar em Sorocaba em indústria de embalagem mesmo. Continuei no mesmo ramo, aí eu tive que parar porque eu me separei e minha mulher cuidava do meu pai, meu pai era uma pessoa com 90 anos, 100\% cego, ela disse que não podia mais, a gente se separou, ela não quis mais ficar com ele. Aí eu falei, vou parar de trabalhar e vou cuidar dele, como é que eu vou pagar uma pessoa para cuidar dele? O preço que cobram por aí... Eu resolvi abandonar o emprego, já estava aposentado mesmo, e fui cuidar dele, e aí eu fiquei muito ocioso. Tentei desenvolver um trabalho junto a uma... Deve ser uma ONG, mas na época não tive essa informação se era, ali na Ponte da João Dias, uma empresa que tem ali de jardinagem, eles mexem com adubo orgânico, e fazem plantio de árvores na beira da marginal, eles que estão jardinando a Marginal Pinheiros. Eu andei lá durante uns quatro, cinco meses, participando dos trabalhos de jardim, de adubação orgânica, e achei muito interessante o trabalho deles. Visitei a estação experimental de tratamento de água do Rio Pinheiros, não sei se você já teve a oportunidade de conhecer. Eles tiram a água do rio Pinheiros e te mostram dois copos. Um copo que foi tirado da água do rio Pinheiros e outro copo depois que a água é passada no sistema, você vê a diferença 100\%. Eles tiram a poluição da água 95\%. E aí eu fiquei muito ocioso em 
casa, ficava aqui o dia inteiro, aí eu fui chamado para participar de um trabalho lá no centro de referência sobre horta orgânica e medicina caseira.

E: - Quem te chamou?

L: - Foi uma senhora que mora perto aqui. Não me lembro mais o nome dela, era a segunda, terceira casa. Comecei a frequentar lá, conheci o pessoal do Pólis.

E: - Que estava lá dando aula.

L: - É. Conheci a Mariana, conheci a Jane, já passou muita gente ali. Já passaram dezenas de pessoas ali, tem uma outra que inclusive está no Polis até hoje, no momento eu não lembro do nome dela, mas uma pessoa muito envolvida também. Eu sempre... Porque eu nasci e me criei na roça, então eu conheço bem da natureza, e amo a natureza. Eu me interessei pelos trabalhos, fui com o Pólis para Argentina, para o Paraguai, para o Uruguai.

E: - Nos encontros.

L: - É. Fui para o Chile, fui para o Rio de Janeiro com eles, já fui para Diadema duas vezes, já fui lá para Uberlândia, naquela cozinha experimental que tem lá, das freiras. Aqui no Butantã já participei de várias reuniões, vários eventos, lá no Pólis também já participei de vários.

E: - E aí o senhor começou a participar de vários grupos além do da horta, é isso?

L: - É. Eu comecei a participar da horta, comecei a participar desse da medicina caseira, participei desse trabalho do Mercosul, que tem várias revistas aí, tem um material grande. No Mercosul nós tivemos oportunidade, embora os latinos, os argentinos, paraguaios, chilenos, devido eles falarem o mesmo idioma, eles estão mais entJoanados. No Mercosul, eles estão mais entJoanados do que nós aqui do Brasil. Porque eles são em maioria, porque lógico, o Brasil é um país desse tamanho, tinham 36 pessoas lá... Juntando eles todos, não dá metade do Brasil, e eles tinham 80\% das pessoas que participavam. Mas na Argentina, lá na cidade de Rosário, nós tivemos oportunidade de alterar um... Nas oficinas, em todos esses eventos foi feita uma carta, e essa carta foi enviada para cada presidente de cada país, presidente da república de cada país. Então eram feitas várias oficinas, e então você ia resumindo. Fazia uma oficina grande, depois uma pequena, depois uma mais pequena, até escrever essa carta. E no dia que foi escrita a carta, foi passada no slide da casa para nós lermos, e eu fui lendo, só que estava em Espanhol. Que é um mal, que inclusive foi pedido, acho que deve ter sido corrigido, que agora vai sair em Português e Espanhol. Que nós poderíamos exigir que seja só em Português, porque nós somos maioria, em termos de população. Mas aí ficou combinado que tem que sair em Português e em 
Espanhol. E eu acho a língua espanhola muito simples, muito fácil de entender, em relação a qualquer outra língua, qualquer outro idioma, tirando o nosso, acho que o Espanhol é muito fácil. E eu fiquei acompanhando, lendo, e ali você podia alterar. Se você não concordasse com uma frase daquelas, com qualquer coisa que estivesse ali, você podia pedir para tirar, ou acrescentar. E eu fui lendo, quando chegou nãoa altura lá, apareceu uma coisa que eu achei que não estava bem contemplada, não estava bem específico. E no meio de 300 pessoas, qualquer pessoa de qualquer país ali podia levantar e falar. Então eu levantei sozinho e falei, mas eu falei, é lógico, em nome do nosso grupo aqui do Brasil. Eu olhei aquela coisa que eu achava que precisava melhorar. Eu levantei a mão, parou tudo, aí perguntou para mim o que eu queria falar, "olha, é o seguinte, esse item assim, tal tal tal tal tal, eu gostaria que fosse acrescido isso, isso e isso". "Terminou? Era isso que o senhor queria?", e continuou, ninguém mais falou nada, pode perguntar para o pessoal. Terminou o evento, voltou aquilo novamente para a mesa de discussão, daquele grupo que estava incumbido de escrever, de elaborar a carta. Então, de tudo aquilo, foi alterado só aquilo. Eles voltaram para o computador, refizeram o documento e acrescentou aquilo que eu tinha feito, acrescentou na íntegra, do jeito que eu falei foi acrescido. Aí nós estamos lá no fechamento, festejando, vieram distribuindo, cada pessoa recebia uma carta daquela, um documento daquele, uma cópia. Uma ia para o presidente da república, e as outras distribuídas entre os grupos, e cada país daqueles que estava participando recebia, e cada pessoa ali dentro. Vieram distribuindo a entrevista, aí eu comecei a ler, mas é lógico, estava em Espanhol, eu estava lendo e interpretando ali, mas tinham pessoas ali que liam melhor do que eu. De repente vem uma delas lá que eu não me lembro nem quem foi, “Luís, nós fomos contemplados!", eu falei “contemplados?”, “é, nós fomos contemplados". Porque eu ainda não tinha chegado naquele item, eu falei "como, contemplado?", ela falou “aquilo lá eu você falou, foi aceito na íntegra”. E: - Que legal.

L: - Foi acrescido aquilo. Eu falo em nome do grupo, não estou falando no meu nome. O nosso grupo tem esse... É lógico, nós ajudamos a elaborar todo o documento, mas lá no meio foi acrescido mais esse item do grupo do Brasil. Que é assim, eu coloquei que a natureza... Por exemplo, se você tem uma fazenda, e você quer preservar uma espécie de animais, de plantas, o governo te dá condições, financeira. Por exemplo, você tem uma fazenda e você fala assim, aquela da fazenda, eu vou deixar o mato crescer, para criar bicho, criar pássaro, animais, e tal. E lá eu não vou mexer, eu vou fechar aquilo, vou isolar aquilo lá e vou deixar aquilo esquecido. 
Você não paga imposto daquilo lá, daquela área que vai ficar. Porque aquilo ali não está te rendendo nada, você não tem lucro nenhum dentro daquela área, você não está explorando ela comercialmente, ela está lá para uma reserva, então você é isento de imposto daquele terreno, daquela faixa de terra. Ou de repente você fala assim, "eu quero preservar uma espécie de animais, mas eu preciso de uma ala reservada para preservar esses animais", você ter condições às vezes até de receber financiamento, ter licença do IBAMA, enfim, facilidade de acesso a esses documentos e isenção de impostos.

E: - Muito legal isso.

L: - Eu coloquei que é dever do Estado financiar a preservação da natureza, se ele não faz a parte dele, aqueles que fizerem, você isenta de...

E: - E aí o senhor se sentiu bem de ter feito uma diferença.

L: - Sim. Eu me senti bem de ter colocado a minha expressão lá, e também de ter colaborado com esse documento, porque esse documento é capaz que ele já esteja sendo usado pelo IBAMA.

Porque às vezes a gente fala assim... Puxa vida, você lê às vezes determinadas coisas, que lá no meio tem uma frase lá que alguém falou, o nome dele não está lá, por exemplo, o meu nome não foi para lá, e o nome do Brasil também não foi para lá. Eu fiquei tão empolgado que eu dei esse documento para os professores lá, porque eu estava terminando o Primeiro Grau, o pessoal ficou muito empolgado, os professores, porque eu falei que eu fui para a Argentina participar desse trabalho, e a maioria dos professores são envolvidos com o meio ambiente. Eu falei, eles falaram “traz a carta para a gente ler”, e eu sei que nisso aí ela sumiu, e eu não tenho, já lutei para conseguir uma cópia dela, você acredita que eu não consigo?

E: - Seu Luís, quando o senhor voltou a estudar? Depois de aposentado?

L: - Sim, eu terminei o Primeiro Grau depois de aposentado.

E: - O senhor quis voltar a estudar, voltou por conta própria...

L: - Quis voltar, voltei por conta própria. Voltei mais por conta do Mercosul, porque quando eu fui para lá é que eu vi... O que serve para você que está estudando, está se formando, a importância de você saber um segundo idioma, depois do seu. Aliás, um não, você viu ontem aquela reportagem? Você assistiu a Luciana Gimenez ontem? Passou umas reportagens lá da China, você fica encantado das coisas que existem da China assim... Não daquela modernidade, eles não passaram da modernidade, mas lá é praticamente a Idade da Pedra, as coisas que os caras 
fazem. Umas reportagens lá, ele estava falando de pessoas que nunca saíram daquele lugarejo, pessoas que não têm uma roupa para vestir, andam descalças e sabem falar 14 idiomas.

E: - Nossa!

L: - Você quer mais?

E: - Seu Luís, e como é que começou o Mãos na Massa? Daí o senhor ficou sabendo pelo Centro de Referência...

L: - Eu estava lá e eles já tinham começado o grupo Mãos na Massa, mas você sabe que as pessoas desistem. Desiste muita gente porque as pessoas vão muito pelo imediatismo, você sabe disso. Economia solidária não país do tamanho do Brasil, é muito escassa. Determinados tipos de trabalhos sociais, de inclusão social, no Brasil são muito difíceis por causa da extensão do país. Eu até falo das facilidades, que muitas pessoas acham que não. Eu não estou falando do Nordeste, estou falando da região Sul, Centro-Sul e da região Norte. Da região Norte também, por exemplo, uma pessoa que vive em determinadas regiões da Amazônia e do Mato Grosso, ela vive de comer mandioca, de comer milho, feijão, que é mais fácil de plantar. E ela não precisa da tecnologia para viver, você entende? Ela vive lá nãoa condição de nômade, e ela vive ali bem, eu acho até que vive bem, porque existem os recursos naturais ainda. Existe a pesca, a caça, o cultivo de pequenos espaços, a criação de porcos, de aves. Isso ela pode fazer e ela não precisa de concreto. Então a economia solidária, nos países mais pequenos, por exemplo o caso do Chile, vamos colocar o Paraguai, Argentina já nem tanto, Uruguai também.

E: - Uruguai é mais fácil.

L: - É. Ela é mais fácil de ser implantada porque as pessoas têm menos recursos, então ela se apega a esses meios dos quais ela pode trabalhar em casa. Ela pode produzir alguma coisa em casa e vender. Agora eu vou te dar um exemplo, antes de ontem eu fui na casa da minha irmã e ela tem uma cunhada que mora no Paraná, uma vez por semana, as duas cunhadas se reúnem, uma na casa da outra e elas vão fazer pães caseiros para vender, lá na cidade de Apucarana. Elas fazem uma cestona enorme de pães, não sei quantos pães elas fabricam, e durante a semana elas vendem aqueles pães, e vende tudo, você entende? Então existem condições. O problema da economia solidária nãoa cidade igual São Paulo, é que você vê, aqui as pessoas sobrevivem de catar lixo. Agora está vindo uma crise aí, que a economia solidária vai ter uma expansão enorme. Você viu que as empresas de material reciclável estão todas fechando. O único material ainda que 
está sendo vendido é o PET, esse continua em alta, certo? Mas o ferro, o alumínio... O alumínio chegou a 4 reais um quilo de latinhas, agora sabe quanto está? 80 centavos.

E: - Mas por que o senhor acha que na economia solidária em São Paulo a pessoa tem que catar lixo? Qual é o problema?

L: - Não, não é. O que eu quero dizer é o seguinte, que as pessoas deixam de procurar aprender alguma coisa para ter uma renda, para ir lá e catar o lixo, porque lá ele cata o lixo todo dia.

E: - Mas por que o senhor acha que ele prefere catar o lixo do que ir para economia solidária?

L: - Por causa da facilidade, não precisa sair para vender nada, para comprar nada, ele acha o lixo no meio da rua, vai juntando e vende. Então é por isso que a gente tenta implantar uma economia solidária em São Paulo, e você chega não ponto que você vê as pessoas desistirem.

E: - E para o senhor, como está sendo fazer parte?

L: - Então, eu pedi um afastamento de dois meses. Falei para eles que eu iria ficar uns 2 meses fora, que meu cunhado mudou para Parada Inglesa, ele morava em Lindóia e ele mexe com água mineral, ele já está nesse ramo há quase 10 anos. Ele foi gerente de uma empresa muito grande de água mineral, inclusive a empresa que levou ele para lá, pagava aluguel e tudo, mas ele agora está como vendedor, está querendo montar um negócio de água mineral e me chamou para trabalhar com ele. 


\section{Parte II}

E: - Então o senhor foi trabalhar com água, não é? Com seu cunhado.

L: - Ele me convidou, meu genro meu convidou, ele está pensando em montar uma dessas distribuidoras de água, ele quer montar uma coisa grande. Porque ele tem o fornecedor, Águas Lindoya. Aí ele quer montar esse negócio de água, ele me chamou, eu estou esperando. Aí eu saí, eu tinha umas coisas em andamento também, queria fazer umas viagens, uns passeios também. Minha mãe morreu já faz uns 10 anos e a gente quer trazer os restos mortais dela para ficar lá onde meu pai está enterrado, também eu tenho que cuidar disso aí, e tem que ser eu. Estou tentando arrumar tudo isso, e aí eu vou ver, se isso aí não vingar, então eu volto para lá porque eu não sei se o que eu estou aprendendo lá eu vou tocar para frente, eu vou colocar em prática, você entende? Mas me fez muito bem. Nesse tempo que eu fiquei lá, eu preenchi meu tempo, eu conheci pessoas, produzi coisas, e tudo que se aprende é útil.

E: - Agora, o senhor prefere trabalhar nãoa empresa mesmo do que trabalhar na cooperativa?

L: - Eu toda a vida defendi o sistema cooperativista, por exemplo, a humanidade agora...

Inclusive eu deixei um objeto aqui para te mostrar, porque você é jovem e você tem uma vida pela frente.

E: - O senhor também.

L: - Uma vida comercial, você vai trabalhar.

E: - Ah, entendi.

L: - Você vai se envolver com trabalhos, você fez Economia, não é?

E: - Fiz Administração.

L: - É. Administração e Economia está...

E: - Perto.

L: - Interligado. Por exemplo, o mundo passou por várias turbulências. Você teve a guerra. Há pouco tempo teve aquele monte de crises, crise asiática, México, crise da Europa, no mundo está sempre passando por turbulências econômicas. Quando começou... O sindicalismo teve culpa nisso aí. Quando começou a globalização... Você nota bem, eu falo assim porque eu já li muito, nessa firma que eu trabalhava, eu lia jornal todo dia, eu comprava jornal e levava, o dono da firma passava, eu estava sentado na mesa, estava tudo correndo bem, tudo funcionando. Ele passava, eu estava lendo o jornal, ele me cumprimentava e ia embora. Então eu lia jornais todo 
dia, e eu ficava sabendo de tudo que ocorria no mundo, através do jornal, porque televisão não tinha tempo de assistir. E eu sempre fui contra a globalização. Eu participo desse trabalho do Mercosul...

L: - Por exemplo, eu sou contra a globalização, eu sou contra esses tratados que nem o tratado do Mercosul, a comunidade econômica européia e, se dependesse de mim, do meu palpite, aquilo que aconteceu não tinha acontecido.

E: - Por que o senhor é contra?

L: - Porque você não pode transformar o mundo nãoa nação só, certo? Uma vez houve a unificação, o que vai acontecer? Os pequenos vão ficar mais pequenos, e os grandes vão ficar mais grandes. Porque é a ideia deles, a ideia do Mercosul não nasceu no Paraguai, nasceu no Brasil, interesse brasileiro, de exportar, de vender e de comprar deles pelo menor preço. É dos grandes, não é dos pequenos. Eu sou brasileiro, se eu fosse paraguaio, eu estaria defendendo o Paraguai, meu país. Eu sou brasileiro e acho que isso não funciona para os pequenos, para o Brasil pode funcionar, mas para ele não funciona. Por exemplo, Portugal para entrar na comunidade econômica européia, os países ricos tiveram que emprestar dinheiro para o povo, injetar dinheiro em Portugal, porque Portugal é uma coisinha desse tamanhozinho, não tinha nada. Para poder aumentar o PIB dele, para poder igualar para poder entrar. Então, quer dizer, ele se endividou, porque eles não vão dar dinheiro de graça para o Estado. O que acontece com os tratados de mercados, é vender, vender e vender. Agora, por exemplo, você anota bem isso que eu estou te falando. No grupo europeu, no tratado europeu de mercado livre, quem está sofrendo mais lá? São os pequenos. Porque os grandes eles têm economias sólidas. A Alemanha é um país que tem grandes laboratórios, grandes indústrias de automóvel. Cada automóvel da marca Volkswagen que a gente vê no Brasil, vai parte do dinheiro para lá. Da Mercedes Bens vai parte do dinheiro para lá. Do laboratório da Bayer, um comprimido que você toma para dor de cabeça, parte vai para lá, porque é multinacional. Esses países estão com as suas economias sólidas e bem controladas. Então, o que acontece? A corda vai arrebentar para o lado mais fraco. Qual o país lá que está praticamente falindo, que o povo está indo para a rua? Finlândia. É a Finlândia? E: - Não sei.

L: - É um paisinho pequeno que tem lá naquela região bem fria.

E: - Seu Luís, me fala uma coisa. A sua participação no grupo Mãos na Massa o senhor acha que mudou alguma coisa, no jeito de trabalhar, ou não? 
L: - Mudou assim, que vocês têm ideia da coisa cooperativa. A ideia do grupo, a coisa cooperativa. Mas, conforme eu estou dizendo para você, isso pode voltar a ser uma coisa viável, justamente porque você viu que a globalização fracassou. Eu guardei esse ferro para mostrar para você. Você sabe onde esse ferro foi fabricado? Você conhece essa firma?

E: - Mallory. Conheço.

L: - É uma firma que para todo mundo é 100\% nacional, não é?

E: - E não é? Não sei se é nacional.

L: - A firma é, mas você sabe onde esse ferro foi feito? $\mathrm{Na}$ China.

E: - Com a mão de obra chinesa.

L: - Isso aqui é a globalização. E sabe o que aconteceu com ele? Ele queimou, ele deu defeito, eu levei para consertar, não tem conserto.

E: - Porque não tem a peça.

L: - Porque não tem a peça. É. A globalização falhando, não deu certo. As empresas brasileiras, os americanos se ferraram com a globalização, depois que criou essa ideia. O Brasil também se ferrou. Sabe por que? Por que a China só cresce? Porque todas as firmas estão mandando fazer isso aqui lá na China, por causa do salário deles.

E: - Mão de obra barata.

L: - A mão de obra é barata e eles ainda têm bastante matéria prima. Esse ferro é feito lá, chegou aqui... Eu não compro mais dessa marca, para mim essa firma aqui pode falir, eu não compro mais nada dela.

E: - Acabou.

L: - Esse é o problema da globalização.

E: - Mas me fala um pouco como é que foi para o senhor, como é que foi fazer parte do grupo, se deu tempo de sentir alguma coisa, como é trabalhar em grupo.

L: - Trabalhar em grupo não é fácil, porque as opiniões são muito divergentes. Por exemplo, você está vendo a minha opinião, você viu que eu discordando de um monte de coisas. Isso aqui, por exemplo, a pessoa diz "não tem problema, é um ferro de passar roupa", "ah é? Quantos empregos nós perdemos para a China?”. Eles querem comprar a nossa soja em grão, eles não querem comprar o nosso óleo de soja, nem a nossa farinha de soja.

E: - Claro. 
L: - Nem a ração do bagaço da soja. Ele não quer comprar, quer comprar a soja bruta para levar e gerar emprego lá. Então você precisa entender de tudo, que ali... Não vou dar palpite no seu serviço, mas ali vocês podem bem especificar isso aí. O que é uma cooperativa, um trabalho compartilhado, um trabalho cooperativo, e uma indústria que, de repente mandar buscar isso aqui, tem um funcionário, só tem o depósito aqui para distribuir os produtos. E você montar uma cooperativa. Eu acho que o sistema de cooperativa no Brasil tem tudo para dar certo. Agora, ele não pode entrar para o lado político e não deixar o sindicato envolver muito também. Porque, infelizmente, envolve interesses pessoais e não do grupo em geral.

E: - Essa dificuldade.

L: - Eu notei, durante esse período que eu estive lá, eu acho que eu tive uma boa convivência, do grupo. Aprendi muita coisa, inclusive sobre a pare administrativa mesmo, eu te falo francamente, as pessoas que ficaram no grupo, elas passaram a ter um conhecimento de montar, por exemplo, uma lojinha, um bar, qualquer tipo de estabelecimento e gerenciar ele com o conhecimento que elas estão tendo ali, você entende? Porque a gente vê aquela planilha de custos, aquilo ali...

E: - Pode ser usado em outro lugar.

L: - Pode. Você pode aplicar aquilo ali nãoa chácara, não sítio.

E: - E o senhor conviveu bem com o grupo, e está saindo agora porque gosta de trabalhar com outra coisa, que não é barrinha de cereal.

L: - E outra, eu já estou aposentado, se eu ficar ali desenvolvendo o trabalho com o grupo, eu não necessito... A renda que eu tenho como aposentado não dá para eu fazer tudo que eu quero. Eu gosto de viajar, você está vendo, eu não sou uma pessoa que tem luxo, você vê minha casa, é simples, eu não vou, por exemplo, como eu vejo muitas pessoas que eu conheço aqui no bairro, moram bem. Você conhece o Ernani, não é? O Ernani ontem estava falando para mim que tem um cara que está gastando... Está fazendo um serviço ali, ele falou para o cara "você está louco, um lugar desse aqui você está gastando um dinheirão desse para fazer uma casa". "Não. Mas eu gosto de coisa bem bonita, eu gosto de coisa boa que não sei o quê lá”. Tudo bem, no caso aqui, por exemplo, a casa aqui é muito boa a estrutura, se eu aplicar aqui, tudo bem, é garantido. Mas lá não é garantido.

E: - Não é dele, não é?

L: - E o cara está fazendo. Mas eu sou assim, para mim é o seguinte, tem um lugar para eu morar, está bom. Nós não temos luxo, nunca me iludi, por exemplo, de comprar um carro de luxo, essas 
coisas assim. Mas o que eu ganho de aposentadoria, dá para eu viver. Então eu não preciso de uma renda complementar para a minha aposentadoria, para viver da forma que eu vivo não. Então ali seria mais para... Participei do grupo para me manter ocupado esse tempo, tudo que você aprende é útil. Agora, o que eu aprendi até agora, se eu ficasse no grupo, e a cooperativa deslanchasse, é lógico que eu ia participar, é lógico que eu vou continuar, não é mesmo? Porque além de eu estar preenchendo meu tempo, ocupando meu tempo, eu tenho resultado também. E: - Mas o senhor acha que vai deslanchar, ou o senhor está meio desesperançoso? L: - Eu comentei com você a respeito do que existe no Brasil. No nordeste, por exemplo, existem vários tipos de trabalhos solidários lá que hoje até exportam seus produtos. É o caso das rendeiras do Ceará, é o caso do artesanato de Tocantins.

E: - Capim Dourado.

L: - Aquele Capim Dourado lá. É o caso das cocaleiras, quebradeiras de coco do Piauí. Você já viu aquele trabalho também?

E: - É um trabalho bonito.

L: - Então. Eu assisto vários documentários sobre...

E: - Grupos que deram certo.

L: - Sobre esses grupos de economia solidária, e eu assisto um canal aí também que poucas pessoas assistem. Você assiste a NBR?

E: - Não.

L: - A TV do governo federal. Então, a NBR passa esses documentários sempre. Aqui tem TV a gato, viu? Não é TV a cabo.

E: - Mas por que o senhor acha que lá dá certo?

L: - Por causa da necessidade, as pessoas não têm alternativa.

E: - O senhor acha que se as pessoas tiverem que escolher, então elas não vão querer?

L: - Não, você nota bem. Essa pessoa está lá, aí ela arrumou um emprego, ela sai.

E: - Mas por que elas preferem arrumar um emprego do que trabalhar em grupo?

L: - Por causa do imediatismo, ela precisa de dinheiro hoje, entendeu?

E: - Entendi. Para não ter que esperar.

L: - E você sabe que ali, ela vai, ela está aprendendo, ela está formando, e daqui 1 ano ela vai ver o resultado. É por isso. 
E: - E a questão de não ter patrão, o que o senhor acha? O senhor conseguiria voltar a ter patrão, a ter chefe? O que o senhor acha que as pessoas preferem? Porque na cooperativa você não tem patrão, é o grupo.

L: - Nãoa explicação dessa aí que você está dando... Olha, aí é a TV Senado, aqui é a NBR. NBR, televisão do governo federal.

E: - Nunca vi, não conhecia.

L: - Você quer ver? Aqui eles passam tudo que acontece dentro do governo federal. Aqui tem uma programação que é o maior barato, à noite ela transmite programas para a América Latina, ela transmite em Espanhol.

E: - Dá até para aprender a falar Espanhol.

L: - Você assiste, por exemplo, jornal da Venezuela, você assiste jornal da Argentina, passa as notícias. Eu vou deixar aí só para você ver, vamos ver o que vai passar agora. Muitas coisas que eles estão passando, estão sendo gravadas por causa da... Quer ver? "Em dezembro, volume de vendas...", pesquisa.

E: - Eles passam os dados, não é?

L: - É. Vamos ver o que vai passar depois. Aí passa folclore, artesanato.

E: - Ah é jornal.

L: - Está vendo? É documentário, olha, 17... Olha, congresso nacional... Teve uma outra aqui também... TV Justiça. Eu assisto vários julgamentos. TV Justiça eu acompanho... Essa aí é a TV Justiça.

E: - O senhor gosta dessas coisas.

L: - Os julgamentos, você vê ao vivo por aqui.

E: - Uma cooperativa, olha.

L: - É. Aí, olha.

E: - Bem na hora. Então, Seu Luís, vou ter que ir embora, vou ter que trabalhar agora. Acho que era isso mesmo, eu queria mais ver como o senhor entrou para a cooperativa, o senhor me contou. L: - Eu entrei por esse motivo que eu contei.

E: - Mas o senhor acha ruim ter chefe? A sua relação com chefe sempre foi...

L: - Minha relação com chefe sempre foi de conflito. E é mais fácil você ser mandado, do que mandar. Mandar é uma função muito ruim.

E: - O senhor acha? 
L: - É uma função, em termos financeiros, boa. O chefe sempre ganha mais, mas o chefe é sempre questionado. $\mathrm{O}$ chefe ele está sempre sendo tachado de chato, de mandão, de autoritário. Por mais razão que ele tenha, ele sempre é mandão.

E: - Sempre odiado.

L: - A minha função, por exemplo, nos últimos 21 anos que eu trabalhei, a minha função foi essa, então eu sei muito bem.

E: - Ah então o senhor fez outro papel.

L: - Eu sei muito bem o que eu estou falando.

E: - Entendi.

L: - Eu cheguei a ter que mandar pessoas embora porque não tinha mais condições de relacionamento. A pessoa às vezes me desafiava em autoridade, confiando às vezes em parente que trabalhava na empresa, trabalhava em outro departamento da empresa. Então ele me questionava, então ele falava "a coisa é assim, assim". "Não, mas não é assim, é assim, assim". "Ah é? Então tudo bem", deixava...

E: - Tinha que mandar embora.

L: - Tinha que mandar embora. Já teve caso também do dono da empresa chegar e falar para mim... E ele é o seguinte, não contava a sua profissão, o seu trabalho, importava se ele olhasse para você e não gostasse... Não sei, de alguma coisa em você, falava "manda embora". O seu profissionalismo para ele não tinha nada a ver, trabalhava na empresa acho que quem ele simpatizava, não sei, ele tinha um comportamento esquisito. Então aconteceu também de eu chegar e ele falar "manda aquele cara lá embora". Aí ele ia embora, eu ficava raciocinando, por quis mandar essa pessoa embora? O cara trabalha bem, o cara não me dá problema, o cara corresponde àquilo que a empresa exige.

E: - Espera.

L: - Espera dele. Por que eu vou mandar o cara embora? Mas ele pedia, ela era o dono da empresa, tem que mandar. Não dependia só de mim, eu tinha que passar para o meu superior a ordem. Chegava no meu superior e falava... Que abaixo do dono ainda tinha mais uma pessoa. Mas para mandar o cara embora, ele não ia lá falar com o cara, ele falava diretamente com você, que estava com as pessoas ali trabalhando. Eu chegava lá, "olha, Seu Manoel...”, ele chamava Seu Manoel. "Seu Manoel disse que é para dispensar fulano de tal”. Então aconteciam coisas assim, daquela pessoa discordar da ideia dele. Discordava, falava "por que ele quer mandar ele 
embora?”. Eu falava “não sei, ele pediu para mandar”, "mas o cara é bom?”, “é”, “o cara trabalha direitinho?", “trabalha”, “não dá problema?", “não”. Aí o cara falava assim, “então eu vou arrumar um outro lugar para ele, vou mandar para outro lugar, pego uma pessoa de lá e transfiro para ocupar o lugar dele".

E: - Para resolver.

L: - É. Para segurar o cara. E isso às vezes demorava, porque dentro de uma empresa, aquela burocracia ali de ter que mandar aviso para o outro setor, para o outro setor liberar o fulano, se a pessoa está de acordo em trabalhar naquele horário. E nisso aí levava dois, três dias. Ele passava ali, o cara de novo trabalhando. Ele chegava para mim, "por que você não mandou fulano embora?". Eu tinha que falar, falava “eu já passei, aquilo que o senhor me falou, eu encaminhei para fulano de tal, ele está avisado". Sabe o que ele fazia? Ele ia lá, toda seção tinha um telefone, ele ia lá no telefone, ligava, "por que você não mandou o cara embora? Escuta, você quer que ele vá, ou você quer ir?".

E: - É difícil.

L: - Você entende? Isso aconteceu no meu setor uma vez só. Ele fez isso aí, passou, viu que o cara estava trabalhando, isso na década de 80 que era ruim de emprego, sabe? Pediu para mandar o cara embora, eu avisei para outra pessoa que tinha direito de fazer isso, e o cara demorou. Veio com esse mesmo papo de transferir ele de setor, porque tinha setores que ele passava meses sem ir lá, entende? Lá você podia colocar o fulano, porque até ele passar lá, ele esquecia da cara do sujeito. O cara demorou para arrumar outro lugar para ele, ele passou e viu o cara de novo trabalhando. "Por que você não mandou fulano de tal?", falei "Seu Manoel, eu já passei para fulano de tal, agora eu estou aguardando a resposta dele”. Ele correu lá no telefone, falou com o cara, aí o cara.... Ele só fez assim com o telefone, meteu o telefone no gancho, quase que voou pedaço para cima. Dali a pouco, o telefone tocou de novo. Aí ele foi embora, o telefone tocou de novo, "Luís, manda fulano de tal descer no departamento pessoal”. Fui lá, cheguei no fulano de tal, "para você ir lá no departamento pessoal”. Quando se fala em departamento pessoal, já vem logo a preocupação. Você está trabalhando, vem um aviso para você ir ao DP, você já fica logo preocupado. "O que eles querem comigo?", falei "não sei”. Você tem que ficar neutro, tanto do lado da empresa, como do lado do funcionário. O cara foi, 10 minutos depois, o cara chegou, “puxa, o que eu fiz? Puxa, me mandaram embora Luís. Por quê?”. Eu falei vVocê foi dispensado?", "fuii", "sinto muito, mas eu não posso fazer nada". 
E: - Você não acha difícil isso?

L: - Isso é uma punhalada que você leva. O cara está trabalhando ali, te obedece, faz tudo que você manda o cara fazer, não chega atrasado, uma pessoa ordeira, e de repente vem uma ordem dessa para você dispensar o cara. Não é por motivo de serviço, porque se fosse por motivo de serviço eu mesmo dispensava o cara, não é mesmo? Apenas porque o cara invocou, disse para mandar o cara embora.

E: - Uma situação muito difícil.

L: - Aquilo deixava você...

E: - Sentido.

L: - Sentido. Mas você tinha que cumprir, e o cara queria arrancar de você um motivo. Como é que você vai explicar para o cara? Você falava assim...

E: - Não tem motivo.

L: - O que eu falava era assim "aqui quem manda é a empresa, eu não posso fazer nada. Isso aqui é uma empresa, a decisão que é tomada lá em cima, aqui embaixo nós não podemos fazer nada". Então eu falava assim, "a decisão deles é de cima para baixo, quando chega aqui, é para dispensar, a gente tem que fazer isso. Quer dizer, tem que passar para vocês o que vem lá de cima". Era só isso que eu fazia.

E: - Seu Luís, obrigada! 


\section{- Joana -}

\section{Parte I}

Entrevistadora: - Começando pela sua infância... Qual é sua primeira lembrança, do que você lembra? Onde você morava? Se era com seus pais, como que era sua família?

Joana: - Eu, na minha primeira infância, o que eu lembro e assim mesmo uma parte que a gente vai crescendo e vai vendo contar, né? Escutando o que a gente falou quando era criança e vai, né... Então foi assim... Eu nasci nãoa fazenda, era do próprio do meu pai, né... Vivi até uns cinco anos.

E: - Na fazenda?

J: - É... Só que antes disso eu me perdi no mato, eu saí pra dar um passeio, que eu não gosto de ficar sozinha, já viu meu jeito, né? Parado... Gosto de andar, gosto de... Aí eu saí, fui dar um passeio assim nãoa tarde, né?

E: -Na fazenda mesmo?

$\mathrm{J}$ : - Na fazendo mesmo. Eu tinha dois anos e meio e, e tinha bastante gente que cuidava de mim, tinha minha mãe pagava uma babá porque ela trabalhava, né? E tinha, eu tinha mais três irmãs mais velhas do que eu, não, tinha duas mais velhas, eu e mais um bebê, outra era bebezinho, né? Aí tudo bem, aí tinha que ter uma pessoa pra olhar, e ela ficava despreocupada porque essa pessoa era eficiente, cuidava da gente muito tempo, né? Mas tudo bem, e esse dia eu cismei, de passear sozinha, né? Sumi lá, peguei meus vestidinho, vesti, nem calcei sapato, que eu saí descalça, e saí pro mato, né? Assim nãoa faixa de umas quatro horas da tarde, e assim que eles contam né... Aí tudo bem andei, andei, fiquei, fiquei a noite inteira e não voltei pra casa, porque eu não sabia mais voltar né... Saí.

E: - Se Perdeu?

J: - Eu me perdi. Aí tudo bem, fiquei a noite inteira no mato, aí disse que deu aquele temporal, sabe esses temporal que tão dando pra lá, né? Nessa época aí, disse aquelas enxurradas.

E: - Onde essa... Onde era a fazenda?

J: - Em São Roman, é uma, é depois de Pirapora, em Minas Gerais, na beira do Rio São Francisco, era a fazenda do meu pai, aí ele foi pra essa cidade, que é... A gente morava na fazenda, não era bem na cidade, né? Ele foi pra cidade. Como ele era muito conhecido, porque ele que abastecia a cidade e tudo, de carne, de leite, de tudo, né? Da fazenda nossa. Aí todo Entrevista de História de Vida Joana 
mundo foi, os policiais, nessa época não tinha bombeiro ainda, né? Os policiais, as pessoas todas foram me procurar, mas passaram a noite inteira na mata, mas não conseguiram encontrar.

E: - Nossa!

J: - Aí o dia amanheceu, todo mundo procurando, não pararam, né? O desespero era demais, aí foi, foi, foi e já foi caindo pra tarde e tudo, foram me encontrar era quatro horas, quase cinco horas da tarde do outro dia.

E: - Nossa!

J: - Já estava passando de vinte e quatro horas, e assim mesmo eles me encontraram porque eu saí e o Rio São Antônio tem um costão, né? Assim tipo uma praia e lá embaixo era um canal que passam os vapor, né? Os carros passam tipo na Dutra passa, né? Aí eu cheguei nesse limpão e tava com sede, vi o rio do meu lado fui beber água ainda era bem embaixo, né? Pra mim chegar no rio eu ia pular, né? Logicamente porque não dava era uma altura daqui lá embaixo.

E: - Nossa!

J: - Porque era canal de vapor, aí tudo bem... Quando eu cheguei nessa área e lá que era tudo aberto aí eles me viram, né? Tinha cachorro, tinha todo procurando, tinha farejador tudo segurando. Aí eles, os cachorros, começou a latir eles me viram, sabe? Aí, correr pra me pegar, me chamaram, o pior é que eu não queria voltar. Olha... olha minha... minha ideia de criança, né? Eu não queria mais aquele pessoal.

$\mathrm{E}:-$ Com quantos anos isso?

$\mathrm{J}$ : - Com dois anos e meio.

E: - Dois anos?!

J: - É do tamanho da menininha.

E: - Gente!

J: - Tamanho dessa menininha aí.

E: - Você queria embora?

J: - Queria embora... Aí eu comecei correr, aí meu tio acabou me alcançado uns cavalos e tudo, aí meu pai tinha duas primas que era vaqueira e tava procurando, também ajudando, né? Aí foi o jeito deles me pegar no laço, né? Porque ninguém conseguia, disse que eu correia mesmo, que não sabe com eu consegui.

E: - Nossa!

J: - Incrível, né? Aí as duas falou assim... Nós vamos jogar o laço duma vez porque elas era 
assim, elas só trabalhava junta as duas, uma jogava, ela jogava o laço direto, as duas junto, porque se uma falhasse a outra pegava, entendeu? Então elas chogaram juntos os laços e me pegaram no laço.

E: - Pela cintura?

$\mathrm{J}:-$ Foi. Me laçou e foi assim que...

E: - Que voltou!

J: - Que voltei, mas diz que eu chorava tanto, aí diz que eu tava com os pés tudo furado em espinho.

E: - Nossa!

$\mathrm{J}$ : - Aquele febrão sabe? Vermelhinho porque no mato, né? Bicho picando, que lá tem todo tipo de inseto, cobra, onça, tudo... tudo... tudo... tudo... tudo... é uma mata mesmo! Mata fechada, e eu tava assim, né? Aí o negócio foi esse, aí eu voltei pra casa né? E só que depois disso meu pai teve que sair da fazenda porque ele disse que todo dia eu falava que ia embora.

E: - Todo dia?

J: - É...

E: - Você lembra por que você queria embora?

J: - Não eu... minha família era uma família boa, me tratava bem, não faltava nada em casa, tinha tudo.

E: - Que estranho...

J: - Estranho, eu queria ter liberdade, eu queria passear, entendeu? Sozinha, principalmente só, olha que coisa.

E: - Que na fazenda já era grande, né? Você já tinha liberdade, então você queria ir embora de lá mesmo né?

J: - É... Não tinha nem vizinho perto de mim, não tinha, na nossa fazenda do meu pai não era, só ela.

E: - Era fazenda do quê?

J: - Fazenda de gado, lá tinha gado, tinha todo tipo de coisa, lá na nossa ele só comprava sal e alho e açúcar, porque açúcar tinha rapadura, né? Mas assim pra criança não dava açúcar, não dava rapadura, né? Porque disse que da dor de barriga em criança, dava m ais açúcar, então tinha que comprar e o olho também porque a gente fazia manteiga e banha de porco, todos esses negócios, que matavam tinha lá, que trabalhavam, né? E o sal porque não tinha jeito, mas o resto 
tudo é fabricado lá, não tinha falta de nada.

E: - E sua mãe trabalhava com o quê?

J: - A minha mãe, ela orientava os pessoal, porque meu pai tinha muito trabalhador, então tinha que dar comida, almoço, janta, é tipo um bandejão, sabe? Então ela tinha que tá dando, administrando, então ela não tinha tempo de cuidar da gente, ficava no serviço, né? E assim o meu pai falou assim: então tudo bem, eu fico na fazenda e você vai pra cidade com as menina, né? Era quatro meninas... Não tinha menino. Tudo bem ele alugou uma casa lá, a gente ficou na fazenda... na cidade e na casa da fazenda. Aí...

E: - E você já era um pouco mais velha?

J: - Aí eu já tinha uns cinco anos, também não foi tanto por causa minha porque aí eles tinha, pois mais segurança, né? Porque eles não ia deixar uma criança dominar, né? Ninguém pode deixar pai nenhum pode deixar isso acontecer, mas se as outras meninas que já tavam é... Maior tinha que ir pra escola e de qualquer jeito tinha que ir pra cidade.

E: - Que lá na fazenda vocês não estudavam?

J: - Não, não estudava, não tinha escola, ali era fazenda mesmo, só tinha nós lá.

E: - Então vocês ficavam lá brincando fazendo outras coisas?

$\mathrm{J}$ : - É, brincando... Era só nisso tinha muito espaço, o espaço era muito grande, tinha todo tipo de brinquedo, todo tipo de fruta, tudo natural, daí a gente não sentia falta de nada, né?

E: -Só você, né? Que queria ir embora?

J: - Só eu que queria ir embora. As outras não, as outras adoravam ficar, mas eu não, eu era impossível assim nesse ponto sabe? E eu é porque eu não sou muito ficar acomodada naquele local você entendeu? Não lugarzinho só, eu gosto sempre de tá explorando, vendo coisas sabe?

E: -E aí na cidade você mudaram pra essa casa?...

J: - Então nessa casa fiquei lá um tempo, aí que a nossa vida mudou, a gente acostumada com aquele vidão sabe como é que é, né? Não falta nada aquela coisa lá. Aí tudo bem! Aí aconteceu que minha mãe começou a se engraçar com uma pessoa lá, olha só.

E: -Um moço da cidade?

$\mathrm{J}$ : - É, um moço da cidade. E essa pessoa então era assim meu pai fornecia, ele tinha um frigorífico, o meu pai fornecia o boi pra ele, meu pai que era o fornecedor. Então começou aquilo ali, aquele namorico quando pensou que não o negócio era sério, ficou sério, aí começou, aí veio à separação deles, né? 
E: - Seu pai descobriu e aí separou?

J: - É... bem ele não queria separar, então ele falou assim "a gente luta...”, porque o meu pai é assim ele é conservador, sabe? "A gente luta na cidade e continua a família, porque eu tenho mesmo os meus filhos, minha família, não quero perder, né? Então você sai fora, eu tento esquecer isso aí, né? E vamos cuidar da nossa família que já tá feita, né?”. Aí tudo bem, mas ela não aceitou... ela queria mesmo é ficar com outra pessoa. Aí tudo bem, aí a família foi a zero, né? Acabou. Aí foi, aí nessa época eu já tava o que? Com nove anos...

E: - Tava estudando lá?

J: - Tava estudando, é nessa época foi... As minhas irmãs, já tinha uma com 14 anos, outra com...

Outra com 12 e eu com nove a outra com sete e nasceu um menino e então, foi por isso que nasceu essa criança o meu pai, quando nasce à criança o meu pai faz... Eu vou registrar... Porque nosso... Nasceu é todo mundo registrado, não tem esse negócio de... De passar tempo não, nasceu hoje ele já ia no cartório e registrava. Aí tudo bem. Ele vai e registrou esse menino. Ela "não registra não, que não é filho não do senhor, hein?". Aí ele se assustou.

E: - Nossa. Aí que ele descobriu?

J: - Ele nem descobria nada, porque ele era muito, sabe? Ele era muito... A pessoa então confiava, sabe? Aí ele descobriu, aí falou assim "não, tadinho da criança, que é isso meu Deus, tenho meus quatro filhos e vou deixar destruir minha família por causa de uma criança só que não tem nem culpa?". Ele falou assim "de jeito nenhum, vou registrar e dar pra ele meu nome", ela não deixou mais ele foi e registrou...

E: - Registrou?

J: - É registrou, falou assim nós vamos embora, tal, tal, mas não aceitou. Aí ele falou assim. Agora não tem mais jeito, né? Aí ela foi ele passou, já tinha passado os pés no nome dela, porque essa pessoa só queria... Que nessa época ele já tinha até comprado uma casa na cidade, né? Aí acho que ele tava a fim, de... Porque meu pai tinha... Era muito bem de vida, sabe? Aí acho que ele tava querendo uma partezinha, né? Achou melhor cantar a mulher do cara pra conseguir, né? Sabe como é que é, né? Aí tudo bem... Aí ele já tinha passado uma parte da herança pra ela, porque eles não eram casados no civil, era só no religioso, então ele, o meu pai, sempre é como eu te disse, conservador queria sempre as coisas, né? Olha gente vai casar no civil porque a gente já tem filho, né? Na hora de casar no civil minha mãe não queria.

E: - Ela não queria casar? 
J: - Não. Ah, aí foi, né? Ele pega, ela fala... Ela fala pra ele "assim não, então tudo bem, eu caso com você no civil se você passar a casa da cidade no meu nome". Né... Porque seria tudo dela, né? Ele não tinha intenção nenhuma. Ele passou, mas ela já tava com outro. Aí depois que ele passou, aí foi dessa vez que aconteceu tudo quando eles se separaram, aí tudo bem a casa da cidade é sua, você fica. Ele falou, "agora eu saio da fazenda e vou embora, né? Levo meus filhos, que eu vou levar, e você fica ai com quem você quiser ficar". Aí tudo bem, nesse trajeto aí, que ele tá tentando fazer esse negócio, né? De fazer de tudo, vai uma pessoa no que ele vem da cidade, da fazenda pra cidade, vem uma pessoa ali na fazenda e põe fogo, no baú, sabe? Que ele lá guarda tudo no baú, né? Então, os documentos, tudo isso, aquelas coisas né? Até roupa ele guardava assim não tinha guarda roupa, aí tacaram fogo e queimou tudo, aí ele volta, quando chega tá aquele incêndio.

E: - Nossa!

J: - Pronto agora não tem mais nem um documento da fazenda não tinha. Foi essa pessoa que mandou queimar. Então tudo bem não tem nem um documento, né? Aí tudo bem, ficou né? Aí ele disse assim, mas, ainda tem o cartório, né? Que é tudo registrado, tudo registrado meu sempre foi conservador. Aí quando chega no cartório, não é que eles queimou o cartório também...

E: - Não acredito!

J: - Tudo!

E: - Que isso?!

$\mathrm{J}:-\mathbf{E ́}_{\ldots}$

E: - No mesmo dia colocaram fogo?

J: - Não... Passou um tempo, quando viu que ele tava descobrindo que ele tava atrás, você sabe que cidade pequena tudo corre, né? Aí deu um jeito de ter um incêndio lá, mas eu não sei, você não sabe como é que eles fazem aqui também é a mesma coisa, né? Isso vem de longe, né? $\mathrm{E}$ aconteceu isso aí e queimou a parte dos documentos. Muita gente perdeu terra sabe? Então isso aí são essas pessoas que querem ser dono da cidade que faz isso aí, porque essa pessoa, o irmão dessa pessoa era... é o...coisa... como é que é, meu Deus do céu, que falam aqui fora, não era o... o escrivão. Ele era irmão dessa pessoa que minha mãe estava gostando, sabe? Então é isso, ele, quando eles queriam tomar alguma coisa, eles fazia isso, e não tinha mais como a pessoa reclamar, né? Como você vai reclamar se não tem o documento na mão?

E: - Não tem prova né? 
J: - Não tem prova. Aí todo mundo conhecia meu pai, meu pai era uma pessoa muito conhecida, mas nessa hora ninguém dá mais crédito, né? Que tá sabendo que o cara tá caindo, né? Aí tudo bem, meu pai falou assim: o jeito que tem é eu vender o que tem, né? Pegou, ajuntou tudo e vendeu tudo de porteira fechada. Sabe como é.. Que ele ia fechar se dar o lance né... . Quem deu o lance ali na hora, o dinheiro e pegou a fazenda.

E: - Pegou a fazenda toda com tudo dentro?

J: - Tudo dentro. Perdeu a metade, porque perdeu mesmo, né? E foi embora e o dinheiro foi comprando coisa, foi embora da Pirapora, comprou uma casa, dois terrenos, alguma coisa lá nessa outra cidade, arrumou outra pessoa, casou, viveu muito bem. Uma mulher de ouro, aquela que devia ser minha mãe. Menina! Todo mundo fala de madastra, né? Mas essa minha não tenho o que reclamar.

E: - Vocês foram junto com ele, as quatro?

J: - Não. Pior que não.

E: -Não?

$\mathrm{J}$ : - Ele levou as mais velhas e ela não deixou, minha história é comprida menina, por isso que eu falei pra você. Aí minha mãe não deixou, porque não deixou eu ir nem a minha irmã nem o outro, né? Nós ficamos em três.

E: - Ele só levou a mais velha?

$\mathrm{J}$ : - Só as mais velhas.

E: - Ah, tá!

J: - É, porque é perigoso pra nós, você sabe esse tráfico aí de menina, né? O meu pai era sempre de olho na gente não deixava nada de mal acontecer, então falou assim: essas mais velhas eu levo, essa outra, eu tinha nove anos e os outros parece que era seis era menor, essa aqui eu deixo porque são pequenas corre risco, mas, nem tanto né? Aí eu pra essa cidade aí tudo bem eu fiquei, mas só que aí eu falei assim: eu não fico aqui, e eu adorava meu pai. Você sabe que eu gostava mais de meu pai do que de minha mãe?

E: - É...?

J: - Você já viu criança, acontecer uma coisa dessa? E minha mãe me tratava bem. Mas eu não gostava dela.

E: - Mas, você já sabia dessa história toda naquela época, né? Que sua mãe tava com outra pessoa... 
J: - Já. Depois dos nove anos já sabia.

E: - Sabia?

J: - É... Já tinha pois isso na cabeça, só que eu não aceitei vim embora. Porque eu não aceitava, eu achava que a nossa família tinha que ser unida do jeito que era. E não podia acontecer aquilo. Então ele foi embora e levou as meninas e falou assim: nossa, mas porque levou só elas e eu fiquei, né? Aí ele conversou comigo, você vai ficar, porque você vai cuidar dos seus irmãozinhos aí depois eu volto pra te buscar. Mas ficou, foi passando o tempo e ele tava demorando voltar, aí eu falei assim, ah não espero mais não. De jeito nenhum. Aí né? Passou um vapor e de lá ele mandou uma passagem pra mudança toda.

E: - O vapor era o navio?

J: - É o navio... Pra minha mãe ir com a mudança inteira, assim mesmo depois que ele foi lá pra essa cidade. Ela não quis. Com as coisas tudo embalado já, os móveis tudo, ela não quis ir, aí eu falei assim: “ah não vai não? Espera aí, a primeira oportunidade que eu tiver, eu vou”. Aí fiquei nãoa boa, ajudando em casa e tal, aí quando chega uma época.

E: - Você trabalhava não? Só estudava?

J: - Não. Só estudava. Chegou uma época que, tem uma senhora que morava em Pirapora, nessa cidade onde meu pai estava, e ela tinha uma fazenda lá também, nessa cidadezinha, né? E ela foi né? Ela tinha um jipão sabe? Esse jipão porque pra lá tem que ser isso, estrada de terra, né? E foi ela e o motorista, aí eu fiquei pesquisando, né? Porque cidade pequena, a hora que chegou uma pessoa de fora você já sabe que chegou, né? Aí eu pensei: poxa vida! A lá minha chance de ir embora.

E: - Nossa! Com nove anos?

J: - Nove anos. Aí eu falei assim: tudo bem, essa semana eu vou embora daqui. Vou ficar com meu pai. Aí tudo bem. Fiquei atrás da mulher, pesquisando, as conversas dela, o que ela ia fazer, quando que ela ia embora. Sabe? Aí fiquei sabendo de tudo. No dia de ir embora sabe o que eu fiz? Entrei atrás do jipe e fiquei lá, nem respirava.

E: -Não acredito!

$\mathrm{J}:-$ Verdade.

E: - Você não levou nada com você?

J: - Nada, só a roupa do corpo. Aí cheguei, né? E... e a mulher foi embora, não sabia, quem que vai revistar um carro né? Era cidade pequena. Foi embora quando chega perto da cidadezinha, sei 
lá, acho que eu muito sufocada, comecei dar porque eu tenho essa crise de tosse, acho que é por causa disso, sabe? Aí me deu aquela crise de tosse, aí a pessoa, disse: ué, uma criança aqui dentro? Foi ver lá dentro lá atrás. Eu disse, e agora já chegando à cidade de Pirapora, disse não posso voltar mais, né? Aí eu falei assim, não. Você me deixa na casa da minha tia. Eu vim pra ficar perto da minha tia, porque a minha mãe, ai eu contei a história, né? Ela falou assim: tudo bem, como minha tia também era muito conhecida na cidade, Pirapora. Que era diretora, lá do Caio Martins, de todos os colégios, né? E tinha que passar na frente da casa dela pra atravessar o rio, porque é Pirapora e Piraporinha, minha tia morava em Piraporinha, bem na avenida. Aí eu disse assim você me deixa na casa da minha tia, passa o telefone pra minha mãe faz o que você quiser, né? Mas eu quero ficar na casa da minha tia. Ela me deixou lá e também falou, passou um telegrama, nem tinha telefone, era só telegrama sabe? Só tinha um telefone só na cidade. Aí passou um telegrama pra minha mãe, que me encontrou dentro do jipe já chegando, né? $\mathrm{Na}$ cidade, contou toda história e me deixou na casa da minha tia.

E: - Que susto que essa mulher deve ter levado, hein?

J: - Menina... E eu, eu sou peralta desde, desde pequena. Aí ninguém me pega sabe? Eu, eu tenho lá, não sei, minha mente muito evoluída, não sei por que, que é assim. Aí tudo bem. Aí meu pai chegou, minha tia mandou avisar meu pai que eu estava na cidade, né? Mandou me chamar e ele me levou, só que nessa época ele já tava trabalhando não, pegou uma obra muito grande e não podia levar eu pra obra, pagou uma pensão pra eu ficar, porque não ia deixar eu na casa da minha tia, que minha tia não tinha nada a ver com isso. Aí pagou uma pensão, daí eu fiquei na pensão uma semana só. Fugi de lá também, a hora que saiu o primeiro caminhão que ia pra obra que meu pai estava, entrei dentro e fui embora.

E: - Mas seu pai, ele tava casado nessa época?

J: - Não. Nessa época ele ainda não tava casado, ele tava tentando voltar pra minha mãe, e ela não queria.

E: - Entendi! Seus irmãos tavam com ele?

J: - Tavam com ele. Só as duas, não estava com ele, tava em pensão também...

E: - Tava em pensão também.

J: - Aí sabe essa, como não tem, você paga uma pensão, e a criança fica ali, vai pra escola e tudo, assim que ele fazia com a gente. Aí como ficou muito difícil pra ele, aí ele já tinha casa comprada, só que a gente não podia ficar né... Ele investiu dinheiro logo pra não se acabar sabe? 
Aí depois ele arrumou... Depois disso, aí eu peguei, fui pra lá onde meu pai estava trabalhando e aí ele falou assim: eu não posso ficar com você aqui. Eu falei assim eu não vou ficar na pensão de jeito nenhum, não vou ficar. Aí foi a época que ele pegou e montou uma casa, e ajuntou com nós três, depois conseguiram casar, né? Aí casou logo no começo, porque eu não dava sossego, né? Aí, olha só, ele casou e ele achava que a gente tava atrapalhando ele, que eles casaram de novo, né? E a minha madrasta é dessas pessoas, que ela te dava tudo, tudo na mão, entendeu? Mas que fosse assim, que fosse pra você se servir, assim... A comida não, ela tinha que servir você, ela lavava a louça, te dava até toalha de banho para se enxugar. Você vê que pessoa que era sabe. Ela sei lá, ela, era mesmo pra servir as pessoas.

E: - Ela gostava né?

J: - É... Gostava disso daí, não deixava mais fazer nada. Aí tudo bem, né? Aí eu resolvi passear, nós fomos mais a minha irmã mais nova, né? Aí a outra já cresceu, casou com dezesseis anos, casou jovem a mais velha. Ainda tá casada até hoje. Aí eu mais a outra minha irmã viemos aqui pra São Paulo, pra trabalhar, porque chegou a hora da gente trabalhar, Lá não tinha serviço, e lá não tem serviço.

E: - Vocês se formaram no terceiro colegial, é isso?

J: - Não, não chegamos não.

E: - Você ficaram, vocês estudaram até a oitava?

J: - É... Até a oitava, depois eu terminei aqui, o colegial, em São Paulo. Eu, ela, essa minha irmã mais velha. A outra, a outra mais velha se formou, lá mesmo, antes de se casar. Mas nós não, nós viemos aqui pra São Paulo, chegamos aqui nos fomos trabalhar em casa de família porque não tinha outro jeito...

E: - Vocês vieram sozinhas, só vocês duas?

$\mathrm{J}$ : - É, como a gente era crente, como eu fiquei muito... muito assim, com essa separação dos meus pais, aí eu fiquei crente da Congregação Cristã. Eu tinha 13 anos.

E: -Lá quando você morava com sua mãe? Ah não com seu pai?

J: - É... Não, quando eu morava com meu pai ainda. Aí você fica muito sozinha, você quer um apoio pra alguma coisa, né? Aí eu achei ali, porque era muito bom pra mim, fui, fiquei. Sabe?

E: - Mas como você chegou lá na igreja, alguém te contou como era?

J: - Alguém me contou, eu posso contar esse pedacinho também?

E: - Claro! 
J: - É porque é um pouco assim estranho, é que eu sou pouco estranho, sabe? Você vê, na hora aí você vai ver os momento meu, que você vai poder tirar porque alguma coisa eu mudo direto pra outra já.

E: - Você muda rápido, né?

J: - Mudo rápido, aí, né? Eu fui na igreja, me convidaram pra mim ir na igreja, eu fui. Chegando na igreja, eu olhei todo mundo lá sentadinho ouvindo cantando, falei assim, nossa que lugar legal, né? Achei muito legal, e foi indo. E me senti muito bem, sabe por que eu não gostava de ir na igreja católica por causa dos santos.

E: -Por quê?

$\mathrm{J}:-$ Por causa dos santos, as imagens, eu tinha medo daquelas imagens.

E: - Desde pequena?

J: - Desde pequenininha, desde quando eu ia com minha mãe. Não entrava. Entrava assim, segurando a mão dela assim, ó. Mas não soltava.

E: - E seus pais eram católicos?

J: - Todos eram católicos

J: - Minha mãe é até hoje católica, meu pai... Aí depois de um tempo meu pai também passou a ser crente. Minha mãe ainda é católica. Meu pai quando ele morreu já era crente também dessa igreja que foi gostou, né? Vendo toda dificuldade que tinha passado e a gente, que era pra nós ter ir ido pro mundo aí fora, né?

E: - Huhum.

J: - Tudo que aconteceu... Não, não nós ficamos aquelas meninas ali acho que foi por causa da igreja sei lá mais doutrina, né? Então achou muito bom, ficou agradecido e gostou.

E: - Mas quem te levou pra essa Igreja foi uma amigo?

J: - Foi uma amiga, uma senhora. É ela já morreu, eu chamava de irmã Leni.

E: - Humhum.

J: - Uma pessoa muito legal. Mas vai menina na igreja ali, que também acho que eles ver essas meninas sem mãe às pessoas quando são conscientes se preocupa, né? Assim pode acontecer alguma coisa, pode começar a namorar, pode, né? Ter uma mãe ali por perto, então alguns vizinhos se preocupam. Então acho que a maior preocupação dela foi essa, assim vamos ocupar o tempo das meninas com alguma outra coisa e mais diferente... Porque a católica nessa época não fazia muito isso não, que aquelas as pessoas queriam na igreja, que era educado pelos pais, mas si 
no caso disso que aconteceu com nós não tinha um acompanhamento para amparar. Não tinha uma pessoa assim "nossa aquela família tá separada vamos ver o que tá acontecendo". Agora não já acontece isso né? Acho que eles acompanham as famílias como no nosso caso e tudo, mas antigamente... Aí a gente achou bom e fui me batizei, né? Porque eu encontrei apoio nessa igreja, pra mim vim de lá pra cá de Minas pra São Paulo.

E: - E por que São Paulo? Por que você escolheu a de São Paulo?

J: - Ah porque lá é assim, quando a gente mora no interior, São Paulo pra nós é outro país diferente não é nem aqui no Brasil.

E: - Quem diz, só ouviu falar...

J: - É! Então São Paulo era muito bom, que São Paulo era isso, São Paulo era aquilo, eu falei assim: "Eu tenho que ir pra São Paulo, né? Porque..."

E: - Foi você que teve a ideia?

J: - Foi! Aí chamei a Ana, 16 anos né? Ela falou assim, tudo bem então nós... né? A outra já tinha casado, eu falei "nós vamos ficar aqui fazendo o que? Meu pai tá casado também né?”. Muito bem casado que nem precisa mais da gente, a minha irmã é casada. Eles estavam cuidando bem do meu tio que tinha, eu falei "vamos embora procurar a nossa vida, né?". Como a gente tinha de preferência que era crente e tal. Então a gente veio pra uma casa aqui na Pedreira de uma pessoa, que essa pessoa foi uma vez lá fazer uma visita na igreja lá em Minas e deixou o endereço né? Aí a gente com esse endereço, a gente vai procura essa pessoa, né? Como referência.

E: - A única pessoa que você conhecia aqui em São Paulo?

J: - Conhecia, assim eu nem conhecia a esposa dessa pessoa conhecia só o senhor que tinha ido. Ele foi nãoa missão, né? Eu falei "tudo bem a gente chega lá a gente conhecendo a família". Aí nós viemos, aí nós chegamos, nossa mais eu não acredito, que tem duas Pedreira aqui né? Antigamente aqui é Pedreira e tem um outro lá pro lado de Santo Amaro.

E: - Ahã.

J: - Nossa menina aí nós chegamos na rodoviária nós pegamos um taxi e deu o endereço pro taxista né? a noite ainda. Aí tudo bem, a gente falou assim "a gente não conhece a cidade, mas com endereço e tudo ele leva a gente na casa toma um táxi tá em casa, né?’”.

E: - Uhum.

J: - E foi a nossa confiança pegamos o táxi e demos o endereço, mas não sabíamos que tinha duas Pedreiras dois bairros com o mesmo nome. Aí o cara vai pro lado de Santo Amado e anda a Santo 
Amaro inteirinha e não acha essa rua.

E: - Nossa!

J: - A Rua Solange, acho que era Solange, não sei.... Agora já até mudou de nome, e não encontrou, ninguém encontrou, aí tudo bem eu falei assim: “e agora?”. Aí vai olhando em mapa, olhando em tudo, pergunto, pergunto, aí o cara falou assim "e agora vou deixar vocês na rodoviária de novo" e a gente falou "você não pode, porque eu não posso fica na rodoviária porque, uma que nós não temos dinheiro pra voltar pra nossa cidade, nós tamos com dinheiro contado o único dinheiro certo, né?".

E: - Uhum.

J: - E outra que a gente não conhece mais ninguém aqui, você que é taxista não consegue achar o endereço, como que a gente vai fazer? Aí ele folou assim " olha seja lá o que Deus quiser. Seja lá o que Deus quiser eu vou desligar esse taxisi...” taxismo, como que é?

E: - Taxímetro...

J: - Taxímetro. Vou desligar e nem vou de cobrar mais de vocês, que vocês não têm mais nenhum dinheiro pra me pagar do jeito que tô vendo vocês falar. Aí lá vai o cara fazer a mesma coisa, que vai fazer querer saber por que, quem era essa pessoa que a gente tava procurando. Como uma pessoa vem duas pra cá e não tem família aqui e quem eram essas pessoas? A gente vai falar pessoa crente da igreja tal, tal e falou, "pronto também sou crente". da mesma igreja nossa o taxista.

E: - Sério?

J: - Sério!

E: - Ahã.

J: - Ai pronto falou assim, "já tá desligado e não me devem nada, vamos procurar esse endereço pra vocês".

E: - Resolveu ajudar.

J: - Foi e ajudou e encontrou que era aqui, que nem eu conhecia.

E: - É aqui, né?

J: - É naquele morro lá. Aí chegou deixou, deu uma saída, nossa a família maravilhosa. Nossa Mãe a mulher ficou... Nossa!

E: - É?

J: - É! Recebeu nós de braços abertos e tudo. E nós ficamos por aí, fomos trabalhar em casa de 
família tal, tal.

E: - Como foi que vocês começaram a trabalhar em casa de família?

J: - Então daí começou a contato porque ela não tinha... Não podia ficar com a gente dentro de casa, porque todo mundo é pobre, né? Faz as... ajuda as pessoas mas certo tipo de coisas também de sustentar direto não pode, né? E ela era arrumou os contatos com as pessoas aí que sabia, aí arrumaram um serviço pra gente. Trabalhei, Mariana, em um monte de casa.

E: - Foi você pra uma casa e sua irmã pra outra?

J: - Pra outra. Nunca ficava li. Depois a gente via a referência dessa casa final de semana, né? Vinha pra isso, segunda-feira ia pro serviço de novo. Quando a gente precisava andar sozinha, eu andava perdida tinha que tomar um táxi. Que às vezes a gente sai de ônibus pra conhecer a cidade, né? Mas depois não acertava mais voltar, tomava um táxi. Pegava o endereço certo e assim fomos, né? Aí nós fizemos nossa família aqui.

E: - E como foi trabalhar em casa de família?

J: - Olha trabalhar em casa de família pra mim foi bom. Só não foi melhor porque eu queria estudar, que eu vim pra cá pra mim estudar porque o meu plano era ser médica!

E: - Ah é?

J: - Então eu acho que aqui cidade grande logo estudar me formar e ser uma médica.

E: - Desde quando você queria ser médica?

J: - Toda vida, desde pequena minha vontade era ser médica.

E: - Uhum.

J: - Aí, né, nossa cheguei aqui eu fui fazendo, porque eu trabalhei ali na Consolação pertinho do Hospital das Clínicas tinha estágio, tinha escola, tinha tudo ali, né? Eu pedi pra essa minha patroa me deixar estudar ela não deixava não de jeito nenhum...

E: - Por quê?

J: - Durante o dia tinha que trabalhar e eu só tinha oportunidade de estudar a noite, ela falou assim você nessa idade sua, eu vou deixar você sair daqui a noite? Eu tô sendo responsável por você. Eu não vou poder te buscar, te levar e te buscar. E eu vou dar a chave da minha casa na sua mão pra você entrar de noite? Achou que a casa ia ficar aberta também, né? Eu falei assim não, não vai de jeito nenhum. Ou estudava ou trabalhava. No momento pra mim foi trabalhar que eu não ia ficar na casa de parente. Na minha casa era muito bom, mas meu pai já tinha perdido tudo. Eu ia ficar na casa dele o quê? Só vivendo né, então não dá, né? Então não dava tinha que fazer o 
futuro. Aí tudo bem é o jeito que tem de trabalhar, né? Fui trabalhar comecei a namorar aí não tem outro jeito de fazer se não estuda só trabalhar.

E: - Você se dava bem com essa família dessa mulher com a...?

J: - Com essa pessoa aí?

E: - Onde você trabalhava.

J: - Dava porque essa pessoa era Italiana, estrangeiros, tá? Quando vem pra cá, eles te exploram bastante, né? Mas te dá o quê? A oportunidade, você depende da casa, entendeu? Te trata bem. E pra mim o jeito que tô não tem o que fazer, vou ter que aguentar isso aí. Então pra mim era melhor do que eu sair dela e fosse pra outra casa que tivessem ali na cidade, mas a gente no serviço não ia ser legal pra mim. Por que nessa casa só era um casal, entendeu?

E: - Uhum!

J: - E lá eu cozinhava junto com a mulher. Tudo que eu ai fazer ela tava junto porque era assim, você limpava ela passava o dedo.

E: - Nossa!

J: - Desse jeito. Então era tudo junto ali, fosse embora... Uma que eu não tô muito sozinha, se eu quebrasse ou sumia alguma coisa aqui eu não vou nem ser presa. Porque também tem isso, né?

E: - Tem!

J: - Você trabalhar na casa dos outros. Então pra mim é melhor se ela tá no meu pé tudo o que acontece ela tá sabendo o que tô fazendo.

E: - Uhum.

J: - Não pode me acusar de nada. Eu fui ficando... fui ficando, quantos anos fiquei nessa casa? 17 anos!

E: - Nossa, seu primeiro emprego?

J: - Não, Aí eu... Esse aí não, eu tive outros empreguitos pouquinho. Esse aí foi quase o último.

E: - Ah, os outros você foi ficando pouco tempo?

J: - Pouco tempo fui ficando, mas não ficava muito. Por isso eu nem registrei. Era coisa de semana, porque eu vinha, vinha do interior e a pessoa quando vem do interior ela não sabe fazer nada, nada... nada... nada. Tudo que você faz aqui tá errado. Então você fica na casa e ainda mais que você veio do interior e as pessoas antigamente tinham muito medo, assim, entendeu? Tinha casa que eu chegava... Sabe uma vez eu trabalhei ali na Rebolças que a mulher ela não tinha filhos só ela e o marido. Ela experimentava pessoas, uma dia eu fui limpar em baixo só tinha... 
Você sabe que tinha de baixo ela... Tapete, era todo encapetado mas ela põe um saco plástico por cima pra não sujar o carpete sabe como que, né? Tinha que pisar em cima do plástico. Em baixo desse plástico ele pois um bolo de dinheiro...

E: - Por quê?

J: - Pra ver que eu pegava o dinheiro.

E: - Armadilha?

J: - Armadilha. Eu limpei a sala, limpei a sala... Eu podia mexer esse dinheiro ai, mas se eu deixar esse dinheiro aí ela vai falar que eu nem limpei essa sala, você viu?

E: - Uhum.

J: - Pois eu vou pegar esse dinheiro e a hora que ela chegar eu entrego o dinheiro pra ela e foi o que eu fiz. Aí ela chegou, ela chamava Érica, um negócio assim, acho que é um negócio eu já até esqueci o nome da mulher. Ela chega e o marido dela era ótimo gostava de exploração não era japonês também mais a mulher era triste. Aí ela chegou, fui pois o almoço, né? Servi o almoço pros dois, aí eles terminaram de almoçar eu falei assim, "olha limpando a sala de jantar eu encontrei esse dinheiro. Por que esse dinheiro tava de baixo do carpete lá de baixo do plástico, da mesa?". Eu era muito... Quando eu tenho que falar eu falo na hora. "Você esta me experimentando?". Que é a maneira de eu falar porque não sabia falar de outro jeito. "Você esta me experimentando, tá pensando que sou ladrona?". Eu falei logo eu falei assim, Porque você presta bem atenção da próxima vez que você por eu vou pegar.

E: - Você falou assim?

J: - Falei pra ela. "Você não me experimente mais, tá?".

E: - E ela?

J: - Ela ficou toda, o marido dela "toma isso aí é pra você aprender tá vendo".

E: - Gostou!

J: - Gostou, eu falei assim no certo é você deixar a pessoa, né? Quer vigiar põe uma câmera, qualquer coisa mais não fique fazendo porque olha uma pessoa que vem do interior estar sem dinheiro e ver um negócio daquele ali, ó, às vezes vai até na simplicidade "nossa a pessoa que nem tá precisando nem quer...".

E: - É, né?

J: - Lógico! Às vezes pega até porque tem muitos que acontece isso, né? Eu falei assim “eu só não peguei o seu dinheiro porque eu sou crente,viu?”. Ainda falei pra ela. A minha religião é só 
quero o que é meu. Até que me deu vontade ainda falei pra ela do jeito que eu estou precisando até que me deu vontade de pegar que eu estou precisando de umas roupinhas, que quando você vem do interior você vem com essas roupinhas tudo simples e você chega aqui não dar pra usar que as roupas aqui é muito diferente é tudo de costureira, sabe? Até mais roupas, né? É de fábrica então é tudo diferente, eu quase nem podia sair na rua porque as minhas roupas não davam nem pra sair.

E: - Por quê? Mas era...

J: - Era roupa boa mais era diferente da roupa dos outros.

E: - E ficavam olhando?

J: - É ficavam todo mundo olhando porque agora no meu ponto de vista agora minhas roupas era até muito mais chique. Seria o que uma roupa de butique.

E: - É uma roupa feita pra você, né?

J: - É uma roupa feita pra mim que ninguém tinha igual. E eu me sentia mal porque eu fala a sim nossa senhora eu que tô diferente, entendeu a pessoa não sabe, né? Eu falei assim pois é quase que eu ia comprar tudo de roupa, ponha lá de novo pra você ver.

E: - Quantos anos você tinha quando você começou a trabalhar com essas pessoas?

J: - Ah! Eu tinha 14 anos.

E: - Nossa! Cedo, né?

J: - É muito novinha, né?

E: - Muito!

J: - Aí fiquei, fiquei aguentando todo esse desaforo até que eu caí nas mãos dessa aí, porque essa aí foi a única melhorzinha.

E: - Nossa! O resto foi tudo assim?

J: - Tudo pior por isso que eu nem falei... Que não dava nem pra falar.

E: - Pior como assim o que aconteceu que...

J: - Pior de tudo nossa! Você tinha aquele quartinho que nem respirava muito aquele banheirinho aquela coisa esquisita. Essa mesma japonesa ela levantava cinco horas da manhã fazia eu lavar roupa cinco horas da manhã.

E: - Nossa!

J: - Eu falava assim... Ela falava assim pra mim: “ olha, eu que sou a patroa vou trabalhar porque você vai ficar sem trabalhar". Eu falei assim mas vocês são duas pessoas só porque que eu tenho 
que lavar roupa esse horário? Um frio danado, porque lá no interior não fazia frio aqui antigamente caia geada agora não tá bom, né?

E: - É melhorou.

J: - Melhorou, mais antigamente você podia deixar uma água lá fora no outro dia amanhecia aquela pedra de gelo, ai ela fazia eu lavar. Regaça a manga e vai lavar, pra massacrar mesmo.

E: - Gente...

J: - Assim. Você faça ideia os pacientes dessa pessoa...

E: - Era boa, né?

J: - É!

E: - Cair na mão dela tá ferrada.

J: - Tá ferrado. Aí foi indo eu sai de lá e também não ficava muito tempo não, a hora que eu via pessoa assim... Uma que eu não era costumada mesmo, minha casa era diferente, entendeu? Era pobre lá na minha cidade pra mim era uma das melhores, entendeu? Tem gente bem pior que eu. Eu vim pra cá eles iam fazer assim o que fazia comigo achei que era muito...

E: - Seu pai te ajudava?

J: - Não depois que a gente veio pra cá ele não ajudava, porque depois ele ficou pobre também. O dinheiro que ele tinha ele comprou essas terras lá, né? Pra investir né? O que ele ganhava só dava mesmo pra viver lá. Se fosse pra gente ficar junto com ele dava, ele dar uma comida, uma roupa, uma casa tinha entendeu? E estudar que era o plano dele era esse, mas só que nós achamos que aqui a gente ia crescer mais, só que se a gente tivesse ficado lá com ele, a gente não ia ter muitas coisas. A gente tinha aqui roupa, sapatos essas coisa, entendeu? Mas ia ter o estudo, que isso aí a gente ia ter mesmo.

E: - Uhum.

J: - Minha tia era diretora tinha acesso em todos até os melhores colégios de lá. A gente achou que... falar de São Paulo achou que aqui era tudo diferente. E depois que a gente chega aqui em São Paulo que volta, você não se acostuma mais no local, mesmo aqui sendo tão ruim, você não se acostuma lá.

E: - Não consegue mais voltar?

J: - Não consegue, eu voltei não gostei mais dela tive que ficar aqui mesmo ou seja, vou ficar aqui. E continuo aí.

E: - Aí você ficou passando de casa em casa desde 14, daí você encontrou essa Italiana que foi a 
melhor delas? Você ficou um tempão né?

J: - Sair eu saí de lá, eu saí pra montar meu próprio negócio, de lá eu montei esse restaurante ficou um tempo. Depois disso trabalhei mais em casa de família, foi a última que trabalhei.

E: - Como é que foi isso você saiu da casa dela pra montar um restaurante?

J: - É eu peguei, eu falei assim, "bom já sei cozinhar, sei fazer alguma coisa" porque lá pegava muito no pé sabe? Tinha... que eles tinham essa mania. Esse negócio de passar a mão eu acho até legal porque você faz o seu serviço perfeito né? Se a pessoa não morde, você não faz, você relaxa, né?

E: - Uhum.

J: - Ela não, eu achei que ela era assim um pouco enérgica, mas me ajudou muito nisso, porque aí eu comecei a fazer as coisas mais perfeitas né?

E: - Uhum.

J: - Se eu não fizesse, eu sabia que ela ia ver e fazer eu fazer de novo. Tipo rodapé tinha que passar o pano e era tudo assim tudo limpinho... Ela tá me pagando...O certo é eu fazer o serviço direito, bem feito assim que ela gosta. E foi indo, foi ficando ela me tratava bem, fazia alguma má criação, mas me tratava bem, como gente melhor do que os outros, né?

E: - Ahã.

J: - E foi ficando depois, pouca gente, não tinha esse excesso de gente, né? A única coisa que ela não fez pra mim foi não deixar eu estudar, não sei também porque também que não queria que eu crescesse, porque essas pessoas tem essa, se você estudar não vai ser mais empregado.

$\mathrm{E}$ : - É isso...

J: - Entendeu? Então antigamente, tinha muito isso acho que não foi nem por eu sair só, a preocupação do vim, você entendeu?

E: - Ahã.

J: - O porquê que ela não queria que eu crescesse mesmo. Eu falava assim, tudo bem, mas de qualquer jeito eu não sou burra, eu vou... dar um... aqui por enquanto tá bom pra mim, melhor do que isso é impossível. E foi ficando, foi ficando até um certo tempo eu falei, não vou sair já cansei né? E depois tinha minha vó velhinha também que eu tive que tomar conta dela, que eles não me deixavam eu falar que ia sair, não eles até aumentava o meu salário.

E: - Ah é?

J: - Muito bem. Esse negócio de salário, eles me pagavam muito bem. 
E: - Aí você ajuntou um dinheiro?

J: - Ajuntei depois eu construí minha casa, comprei carro, fiz muita coisa. Porque eu ganhava, tinha meu marido que trabalhava ganhava o dele. Por isso que eu não saia do serviço.

E: - Daí você tava casada nessa época?

$\mathrm{J}$ : - Eu arrumei um namorado né?

E: - Quando foi no...

J: - Quando eu entrei nessa casa aí dos italianos dos quatorze anos até os 16 anos, eu fiquei ali um mês em um, um mês no outro que não dá nem pra lembrar as casas, né? Até que caí nessa daí. Aí eu fiquei já estava com 16 anos, aí fiquei, né? Eu também não era muito namoradeira não, era muito de igreja, que a gente ficou sozinha esse tempo, eu não fazia muita, eu não tinha muita amizade não, sabe? Amizade era mais restrita. Eu ia sair lá dessa casa pra igreja, ia voltava. Essa pessoa nem sabia que eu era crente.

E: - Depois que a senhora entrou?

J: - Eu nem falei nada que antigamente se você falasse que você não era católica também tinha...como se fala...? As pessoas não gostavam muito não, você nem trabalhava na casa.

E: - Ah é?

J: - É! Então eu nem comentava, certos tipo de coisa assim eu nem comentava não, deixa quieto.

E: - Aí se saia pra ir pra igreja e voltava?

J: - Voltava, tinha nada na minha folga só, que a folga era sábado depois do almoço voltava na segunda. Aí saía vinha pra cá congregavam bastante gente que na cidade passeava muito, né? Ia no Brás aquela igreja muito grande que a gente ia na mocidade, que só vai rapazes lindos, né? Então a gente... A minha amizade era essa. Aí eu conheci esse rapaz que eu namorei, casei, né? E: - Na igreja se conheceu?

J: - Na igreja... Aí ficamos casados só que, ele não era crente ele me conheceu e queria namorar comigo.

E: - Onde ele te conheceu?

J: - Ele me conheceu aqui no bairro, aqui no Japeri

E: - Ele já tinha te visto aqui?

J: - E ele falou assim "olha quero namorar com você, você quer namorar comigo?". Eu falei "olha eu...". Ele era um rapaz bonito vou dizer né, assim fisicamente era uma pessoa legal. Eu falei assim "eu não vou namorar com você porque eu sou crente e eu não vou namorar com pessoas 
que não é crente". Que tinha medos, entendeu? Sabe como que é né? E eu já fui criada com meus pais então eu não tinha instrução nenhuma, criada em casa de famílias não te falam nada. E: - É.

J: - Só acha que você é uma pessoa que sai com qualquer pessoa aí da rua aí eles põe mais coisas em cima de você.

E: - É... Piora né?

J: - Piora a situação. Então aí ele falou assim "escuta aqui o que um rapaz crente tem de diferente de um católico? Que diferença é essa?". Eu falei assim "bom, tem uma diferença” eu falei "a diferença é essa eu namoro com eu você, eu gosto de ir na igreja, né? Os meu contatos são outros, o seu é bar, é cigarro, é bebida, não tenho contato com essas coisas, nossa. Então é só por isso eu não quero namorar com uma pessoa que tá fumando, tá bebendo perto de mim não gosto disso", ele falou assim "mas é só isso, tão simples assim?". É simples sim, que meu caminho é um e o seu é outro.

E: - E aí?

J: - Menina no outro domingo, isso no final de semana, no outro final de semana quando eu chego aqui o cara não tinha batizado na minha Igreja?

E: - Não acredito!

J: - Verdade da pra você acreditar não negócio desse?

E: - Ele tava realmente empenhado, né?

J: - Tava! Aí veio "e agora você aceita meu pedido de namoro?". Mas porque não já te falei. "Eu sei, mas agora sou crente". Desse jeito, eu falei assim. "Eu não acredito", ele falou assim a tia comprou até um terno.

E: - Tava de terno?

J: - Tava de terno. Ai eu falei "eu não acredito", aí veio uma pessoa falou assim, "é verdade". Uma pessoa da igreja que batizou foi no Brás, na igreja do Brás lá que batiza sabe e se batizou lá na nossa igreja. Eu falei assim, como eu já tinha falado essa conversa, eu não posso mais voltar atrás. Se ele já é crente, eu falei assim "agora você vai cumprir as normas da igreja, né? Principalmente não fumar, não fazer essas coisinhas assim que prejudica as pessoas, né?”. Porque beber você pode beber, fuma também você fuma, mas se você não quer uma pessoa que fuma, você não vai fumar se você quer ficar com essa pessoa não por causa de religião, então bom minha palavra é essa. Aí ele deixou de tudo, mas foi só enquanto nós se casamos, depois de dois 
anos voltou tudo entendeu? A cachaça, cigarro, bar e é pinguço até hoje.

E: - É?

J: - É!

E: - Aí vocês namoraram um tempo...

J: - Nós namoramos uns oito meses!

E: - Ele foi o seu primeiro namorado?

J: - Foi daí... foi, primeiro namorado, não tinha namorado.

E: - Namoraram oito meses e casaram?

J: - Casamos, aí passou um ano e pouco, tive o primeiro filho que é o Hugo que tem trinta e quatro anos, depois de dois anos veio... Engravidei do Fábio que tem trinta e dois, aí parou. Aí já começou a começar essa vida torta e não usava drogas esse tipo de coisa não, mas bebida não é uma...

E: - É!

J: - Eu também falei assim: “oh! Não dá para fazer família não.” Eu também não quis muito filho não, sabe? Ai dois já tá bom demais toma anticoncepcional e tudo e não operei até hoje, mas dei meu jeito pra não engravidar, né!

E: - Ahãm.

J: Aí tudo bem. Quando passou assim uma época que a gente já, já tinha uns... Pelo menos uns seis anos que eu tomava anticoncepcional, comecei, assim me sentir mal, sabe? Ficar um pouco esquecida das coisas, nervosa. Aí falei assim: “aí isso deve ser o remédio, né? Faz muito tempo que eu tô tomando". Fui no médico e falei para ele que ia parar. Ele falou assim: "pode ser que você engravide, né? Você parando assim, tudo bem." "Não tem problema não, eu nem vou sair com ninguém que é para eu não engravidar, não. Aí vou ter cuidado”. Aí tudo bem passou esse tempo... Quando passou, que vê, acho que uns... mais de seis anos, aí engravidei desse menino aí. Esse outro aqui eu tive com vinte e dois anos.

E: - Ah, é? Engravidou do... Como é que ele chama?

J: - Henrique. O outro é Henrique. Só que aí é os três meninos, nunca tive menina só filho homem, sabe? Aí tudo bem, mas nós já não tava legal não. Ficava nesse vai não vai. Sabe? Aí, pois quando eu engravidei, aí ele não aceitou, porque aí ele já tava dando as banda dele, com uma mulherada. A Senhora sabe como são os homens, né?

E: Ahã. 
J: Aí viu que eu tava grávida. E ia voltar? O outro mais novo tinha..., o caçulinha tava com 12 anos.

E: - Ahã.

J: - Aí falei assim: "puxa vida agora tomo ferro, né? Porque cuidar de um bebê , aí começa, começando". Aí falei assim: "já que é assim você não quer aceitar o bebê...". Ele falava que não era filho dele.

E: - Ah, que horror.

J: - É!

E: - Uhum...

J: - "Ah esse menino não é meu não". Eu falei assim: "moço se você acha que não é, é até uma boa porque aí já é bom porque a gente já separa aqui mesmo". Aí tudo bem. Foi assim. Fiquei desgostando, não sabe? Mesmo que sou crente. Minha religião não permite nós se separar, nos casamos, né? Não permite, mas depois de tanta humilhação. Você engravidar e o cara falar que o filho não é dele já é uma humilhação grande, né?

E: - É com certeza.

J: - Isso aí não tem justificação. Aí fui falei tudo bem melhor vamos pra frente então você fica na sua que eu fico na minha e foi ficando assim, assim até que eu falei "oh! Quer saber de uma eu vou lá pedir o divórcio, não é não?".

E: - Vocês moravam juntos ainda aí?

$\mathrm{J}$ : - Ainda moramos.

E: - Ainda moram?

J: - Mora. Cê vê como que é as coisas, né? Aí né, a gente já tinha construído essa casa, né? Com o meu dinheiro, que eu ganhei, que eu fui busca e eu investi... né? Eu falei assim: "eu não vou sair da casa porque eu tô separando de você, quem tem que sair é você". Ele falou assim: "eu não saio", ele é dessas pessoas paradão sabe. Ele não compra nada, se não for eu para resolver, ele não resolve.

E: - Que ele... ele trabalhava com o quê?

J: - Ele era mecânico. Mecânico de automóvel.

E: - Uhum.

J: - Agora ele tava trabalhando fazendo uns bicos de pedreiro. Mas ele é aposentado já, né. Aí eu falei assim tudo bem então, a casa é grande. A gente fez um sobrado bem grandão, três casas, 
porque eu tive três filhos, eu falei assim pelo menos a moradia eu vou dar.

E: - Uhum.

J: - Né. Aí eu falei assim por enquanto que os meninos não... Só tinha um casado, morava na casa, eu falei assim: "você fica na casa mais o outro filho e eu fico com o caçula". E ele falou assim nós dividimos uma casa, cada um mora em uma ficamos lá na mesma casa. Aí você tem uns dez anos que a gente divorciou. Aí, e continuo, né. Foi até o meu filho e falou assim: "olha a gente não vai se separar as casas". Eu sei o que a pessoa quer beber, vai beber. Eu vou vender a casa e dar a metade pra ele... pra ele destruir?

E: - Né...

J: - Eu disse não eu fiz um.... Tô fazendo um futuro pros meus filhos, né.

E: - Claro.

J: - Eu falei assim "a casa eu não vendo" e ele não quer sair, então a gente mora na casa. Só que eu achei um desaforo... um desaforo muito grande porque eu morando na minha casa toda cheia de cuidado, fazendo a limpeza, tudo, tudo, das outras casas se não tinha caído os pedaços. Aí eu falei assim, ele estava bebendo muito, tanto ele como esse outro meu filho mais novo. O mais novo não, o do meio. Que o mais novo não bebe e nem fuma, faz faculdade é uma pessoa completamente diferente, não se envolve com nada. E esse do meio começou a se envolver sabe? Depois vendo pai sabe como é que é? Que é o Fábio eu não sei se você chegou a conhecer o Fábio não.

E: - Não.

J: - Ele veio lá da rua mais você não tava aí. É um rapaz até bonito, sabe.

E: - Uhum.

J: - Mas é sem juízo.

E: - Esse tem uns trinta e.....

J: - Trinta e dois anos. O outro é casado. Aí inclusive se envolveu com a polícia, foi preso, foi dessa vez que eu mudei de casa e disse assim você fique aí que eu dava as ordem que ele cumpria, né? Aí ele foi preso, esse de vinte e dois anos porque o policial chegou jogou droga dentro do meu carro e prendeu ele.

E: - Nossa!

J: - Levou o carro embora, que eu perdi o carro.

E: - Policial daqui do bairro?

Entrevista de História de Vida Joana 
J: - É! Aí do DENAP, aqui da Azevedo Marques.

E: - Puxa...

J: - Inclusive este delegado foi preso também depois que descobriu tanta coisa que ele fez, sabe? Tá preso ele e os policiais. Roubaram meu carro e não me devolveram até hoje, mas tem processo ainda aberto e a droga não era do meu filho porque eu vi os caras jogando... Todo mundo viu, sabe? Não era dele e ele usa, não é que usava, usa porque a pessoa que é usuária não adianta se não fizer um tratamento não larga, né?

E: - Uhum...

J: - Então ele se envolveu com esses negócios aí de usuário e ele usa cocaína eles jogaram maconha até inclusive eu falei "oh, se fosse cocaína tudo bem, mas ele não usa mais ele não usa maconha, porque maconha pra ele é fraca ele usa é a cocaína mesmo pra enlouquecer, entendeu?”. Enlouquecer ele e a família, geralmente é o que eles fazem, aí não tem jeito.

E: - Mas aí seu marido, ele, ele morava com seu marido?

J: - Morava com meu marido.

E: - Seu marido via ele usando e tudo?

J: - Via, mas bêbado também, né? Vou fazer o quê?

E: - Uhum.

J: - Mas isso é contradição porque eu sou crente e eles querem ir contra mim.

E: - Uhum.

J: - Você entendeu como que é? Que achar quer que, pisar e eu, eu fico na minha porque eu to, né? Aí tudo bem, aí eu voltei falei assim "não! Então eu vou cuidar". Cuidei desse outro ficou preso três anos porque aí quando caí negócio de droga não adianta você falar principalmente se for a mãe falar a mãe não tem que puxa a brasa pra sardinha do filho.

E: - É...

J: - Eles não acreditam eles não acreditam nisso, você pode ver tá falando a verdade, aí ele ficou três anos preso eu nessa luta aí em que quase morri que tô desse jeito acabada por causa disso que eu tava uma pessoa bem conservada.

E: - Na luta de tirar ele da prisão?

J: - De tirar e visitar e levar coisas. Porque é assim, quando a pessoa tá presa você, você levar um sabonete você não pode levar um sabonete só você tem que levar pra eles e pras pessoas que estão com que... Ninguém leva. 
E: - Hum hum...

J: - Sabe como que é você então você tem que manter aquilo ali, ele já prende a pessoa mesmo pra isso pra você manter a cadeia.

E: - Ah é?

J: - É...

E: - Foi pensado já.

J: - Já pensado coisa lá decretado.

J: - Por que se não fosse não tinha esse negócio do jogo, porque se o governo prende a pessoa ele, ele assume aquela pessoa ali dentro, né não?

E: - Uhum

J: - Eu mesmo, eu se eu fosse a justiça eu faria isso, ia fazer assim: oh, eu prendi essa pessoa, ele estava errado, ele está preso pra recuperação, então aqui ele só vai usar o que eu ofereço a ele, não vou aceitar nada de fora. E lá não é assim, você tem que levar roupa, você tem que levar comida, você tem que levar tudo. Eles dão, mas só dão comida de cachorro lá, quando chegar o final de semana você tem que levar alguma coisa, e levar bolacha, e levar isso pra eles fazerem estoque pra comer durante a semana.

E: - É! Aí seu filho ficou três anos lá?

J: - Três anos, um ano aqui no CDP da Vila Prudente aí eu ia todo final de semana, todo final de semana, sem carro, o carro que eu tinha tiraram, tinha que ir de ônibus, me roubaram o carro.

E: - Você trabalhava?

J: - Não! Eu nesse tempo eu trabalhava só em casa mesmo. Eu já fechado o restaurante não tava mais e era só serviço de casa mesmo, aí sustentamos ele foi, ia todo dia, fui todo final de semana, levava as coisas e tudo. Eles lá não acharam que tava bom passaram ele pra, aí fizeram uma rebelião, aí não sei se eu posso contar.

E: - Pode, pode...

J: - Posso? E de lá eu já mudei pra cá.

E: - Pode contar tudo que quiser.

J: - Porque isso aqui é a coisa que mais me magoa que eu tô te falando, você entendeu? Então, aí minha filha, eles pegaram e... Como eu sou um tipo de uma pessoa assim que meus filho eles nunca ficaram doente. Esse outro, esse ai que eu te falei que é envolvido com esse negócio de droga, é uma doença que arrumou na rua! 
E: - Huhum.

J: - Mas não foi vindo de casa, não foi vindo de berço. Não foi. Aí porque na minha casa é assim, eu gosto de cuidar deles direitinho, né?! A tanto da parte limpeza como da alimentação, da saúde, mas a saúde... Eu cuido deles não com remédio, com alimentação. Tudo eles sabem do dia a dia, você entendeu? E meus filho, a única coisa que eles pegam é só gripe, não tem outra doença. E eu acho que eu... Como eu acho que eu faço as coisa direitinho pra eles sempre que é o certo. Mandaram lá pra cadeia, acharam que levar comida de cachorro pra eles com é mesmo eu tenho o marmitex até hoje que eu processei a comida tá processada ali.

E: - Você pegou a comida e aí abriu um processo contra a... Porque era horrível a comida.

J: - E eles falam, e mostram aí na televisão esta comida maravilhosa, acho que até mesmo você já viu. E não é nada daquilo que eles mostram. Eles mostram a comida que eles comem. O marmitex que vai é pra eles, não mostram do preso.

E: - A do preso é um horror.

J: - É um horror. A bisteca, é aquele osso cru. Não vai nem carne, só o osso.

E: - Nossa.

J: - Aquele arroz e aquele feijão mal cozido, e aquele osso. É tipo comida de cachorro. É só uma pessoa que vai lá dentro que vê e sabe, e o pior é que não pode falar. Porque se você falar você é denunciada e você acaba na cadeia também. Entendeu? E eu como sou impulsivamente você tá vendo como eu sou, né?

E: - Uhum.

J: - Eu sempre acudi. Aí tudo bem. Aí eu disse assim ó: "vocês prendeu meu filho, eu vi que a droga não é dele, vocês devia ter me dado uma ajuda, porque meu filho aprendeu a usar droga na rua porque vocês não limparam a rua." Porque a criança nasce, os pais cuidam, mas a justiça não cuida. As ruas é assim, em toda esquina tem uma droga pra vende, criança com cinco anos usa. Não é?

E: - É.

J: - Enquanto você tá ali com o filho debaixo da sua asa tudo bem, mas quando tem que sair um pouquinho que você tem que deixar ele andar com os pés dele aí vai direto pra droga. É o não é? E: - É.

J: - A maioria. Então eu falei assim: - Eu não aceito, porque meu filho tá precisando de um tratamento, e vocês não dá um tratamento pro menino, vocês só dão a droga. Você entendeu? 
E: - Tanto que na cadeia ele continuava usando droga?

J: - Mais ainda, porque lá na cadeia tinha mais do que aqui fora. Aí minha filha, nisso de levar a comida, né, como eu tava te falando que eu cuido nessa parte aí, né, fazia a comida muito bem feita, levava a comida que você olhava assim, comida boa mesmo, que na minha casa não tem miséria não não sabe. Eu sou pobre, mas minha comidinha é comidinha boa. Aí, né, a moça ainda punha na tapauer transparente, porque não pode ir em outra tapauer, então eles chamavam minha tapauer de Titanic, lá vem o Titanic. Aí eu levava pouco de arroz, só não levava feijão porque azeda e também por que ele não gostava muito de feijão uma parte arroz, maionese, carne, tudo as coisa por cima queijo picado que ele gosta de queijo. Punha queijo picado, salsinha enfeitava o negócio ficava bonito sabe parecendo o Titanic mesmo. (risos) Aí, né, a mulher começou a irritar comigo.

E: - A mulher da cadeia?

J: - Da cadeia lá, a superiora lá que administra a entrada do julgo dos alimentos, né. Aí ela falou assim "Óia, da próxima vez, você não vai entrar com esta comida aqui”. Eu falei assim "Mas por quê? Olha minha tapauer é transparente, eu não trago nada que não possa trazer, vocês tão vendo aqui. Você pode olhar de um lado que você vê do outro". Pode ver. Que ele ainda mistura tudo, E: - Uhum

J: - Pra vê se acha alguma coisa lá dentro. Aí ela falou assim "não, não é por isso não. Você sabe por que que você não vai trazer? Porque eu que sou eu não como este tipo de comida. Por que que um vagabundo preso vai comer?".

E: - Hummmm.

J: - Desse jeito eu falei isso com ela, "só que eu faço esse tipo de comida pro meu filho, vagabundo é essa turma da tua laia que jogou droga dentro do meu carro, é por isso que meu filho esta aqui. E eu faço essa comida pro meu filho e você não vai nem sentir o cheiro você tá pensando que eu vou deixar aqui pra você comer? Não vou não. Eu trago pra ele, de lá de dentro ele pode dar pra quem ele quiser, porque as pessoas que esta lá dentro de ser igual a ele que vocês jogaram na cadeia porque os otários tá tudo aqui fora, vocês não prendem otários", eu falo logo na cara você entendeu? Ela achou, minha filha, ela não gostou aí falou "é mesmo?" Limpou a mão "você vai apanha um bocado aqui porque lá ninguém pode ir",ela não sabe que eu e ela não sabe que já tinha tirado a marmitex lá de dentro.

E: - Já tinha tirado? 
J: - Já por que uma semana antes eu falei por falar, já que eu tenho que trago comida aqui pra vocês, eu posso eu posso levar uma comida desse pro menino comer lá fora, né?

E: - Uhum...

$\mathrm{J}$ : - Ai eles disse você pode me dar uma marmitex dessa pra eu comer aqui dentro uma semana antes, aí aconteceu isso que eu tô te contando aí ele falou assim "não mãe eu vou te dar não" eu nem tinha visto essa comida ainda que elas comiam" não mãe não vou te dar por que você nem pode ver a comida que a gente come aqui, eu disse "Não agora eu quero ver", e ele não, não esconderam o marmitex, porque no dia de visita chega outra comida que eles nem come lá.

E: - Uhum.

J: - Esconderam, aí eu fiquei de olho, dei um jeito de entrar lá dentro, e peguei um marmitex, nem meu filho sabia que eu tinha tirado o marmitex. E consegui sair com ela lá fora. Não porque lá dentro... você entendeu? E na saída ainda tem revista, aquela loucura, aí foram lá dentro, saí, levei e já tinha até denunciado o marmitex sabe. Aí tudo bem, mas ela não sabia, até esse ponto ela não sabia, aí ela limpou, e voltou pra trás, e ela limpou as mãos...

E: - Que ia te bater.

J: - E ela falou: - Você vai apanhar na cara. E eu pensei, eita vou mesmo?? Porque lá eles batem nas pessoas, você não pode falar sso, e é por isso que ninguém reclama. E eu falei assim “Ó, só tem uma coisa, essa cara aqui ó, tem trinta, tem cinquenta e quatro anos, ela nunca levou um tapa”. E eu falei assim "Eu jurei, que o primeiro que bater vai morrer".

E: - Você falou pra ela?

J: - Falei, e lá tava cheio, gente policia e tudo, que eu vi aquelas câmera tudo ligada, né. Aí eu falei assim. E ela disse pois é, agora você vai apanhar mesmo, e eu disse "Pois então liga tudo que é câmera, porque você quando vier vai morrer aqui dentro agora, você não vai morrer lá fora não". E eu disse assim "Eu não preciso de arma pra matar ninguém, eu tenho duas mãos, e vou te matar agora aqui dentro, é você bater e morrer".

E: - E aí?

J: - Aí ela viu que eu ia matar ela mesmo. Aí ela falou assim: - Ah é?? E eu falei assim: - Tá aqui a cara, bate. Mandei ela bater. Ela falou assim: - Não, vou fazer melhor, e pegou um papel em branco e disse: - Você assina o seu nome e o nome do seu filho, que eu vou mandar dar uma surra nele e depois um castigo, e vou suspender você e você vai ficar um mês sem trazer nada pra ele, aí quero ver como é que ele vai viver aqui. 
E: - Hã...

J: - E eu disse assim: - Ah é? Então tá. Você escreve qualquer coisa aqui em cima que eu não sou nenhuma analfabeta, que eu não vou assinar nenhum papel em branco, e o nome dele você vê lá no computador. O nome dele tá aí porque você não vai lá? Entendeu? E ela falou:’Você não vai assinar não?” E eu falei assim “Não, não vou . Então ela falou assim: “Então eu vou fazer melhor ainda. Eu vou fazer uma rebelião e vou por tudo que acontecer aqui nas suas costa e nas costa do seu filho e vou manda ele pra cadeia pra ser morto" deste jeito. E eu falei assim: "Vai mesmo?" E eu falei assim: "Olha, eu não acredito que você vai fazer isso. Porque ele tá aqui porque o policial jogou droga dentro do carro. Além de roubar meu carro ainda roubou o filho. Tá aqui e eu acredito que você possa fazer isso. Então já que você vai fazer isso mesmo eu nem vou entrar, a briga nossa acaba por aqui, eu vou pegar minhas coisas por na sacola e vou embora."

E : - Hum run.

Entrevistado : "Não a senhora vai entrar! Eu já registrei a comida.” E eu disse: “de jeito nenhum, eu vou te denunciar, se você falou você vai fazer".

E : - Hum run.

Entrevistado : - Aí tudo bem, Peguei minhas coisas, botei na sacola e me mandei, e ela foi atrás de mim até no portão me xingando, porque as câmeras ficam gravando, ficam tudo ligada. E eu não falei nada, né. E ela ainda atrás de mim, disse: "Você quer o endereço? De onde se faz a denuncia." E eu disse: "Não minha filha, não precisa, São Paulo eu conheço inteirinha". Aí eu vim embora, cheguei em casa, porque eu tava com muito peso e vim de ônibus, deixei a sacola em casa, já enfiei tudo dentro do freezer e voltei e fui na corregedoria da Alves, né? Quando eu chego lá pra fazer a denuncia ele falou assim: "Ah dona, não é aqui não. A senhora tem que ir na corregedoria da Barra Funda que é lá que é a corregedoria dos presídio. E lá só funciona de segunda a sexta."

E : - Putz!

Entrevistado : - É, e este dia era um dia de sábado. E eu falei assim: "mas como que é que pode ser, não é de ser hoje que é dia de visita, hoje é que acontece as coisa tá fechado. Corregedoria tem que ficar aberta vinte e quatro horas. Principalmente o dia de visitas, que é o dia que acontece." E eu falei assim: "E agora pra eu fazer esta denuncia? Porque a moça falou que eu ia virar cadeia e este povo o que eles fala eles fazem. Entendeu? E se ir pra cadeia de hoje pra manhã?" 
E : - Hum run.

Entrevistado : - Não vai ficar isso nas minhas costa? Ele falou assim:”É". E eu falei: “O senhor tem que fazer uma denúncia." Ele falou assim: "Olha, eu não posso te dar nada por escrito, porque não é aqui que registra isso, mas tem as câmeras aí, né? Se a senhora tá falando, quem sabe, vai servir de um dia de prova pra senhora", não me deu nada. Aí só me deu o endereço pra eu ir lá, né, que tinha mudado que tinha de ser lá na Barra funda eu falei Barra Funda eu conheço. Aí ele falou a senhora vai segunda-feira. Tudo bem eu voltei pra casa pedindo a Deus pra essa mulher não fazer nada.

E: - Rezando.

J: - Aí peguei o contato com meu filho não tive, e ele ficou nervoso por que não recebeu visita e o pessoal já falou que tinha saído briga lá, né, porque tem uns que vão lá pro lugar que ele está, né vários raios, eles chamam de raio é raio de... E eu falei assim: "alguém já falou, mas ele não tinha contato, não tinha como contar nada." Aí, eu resolvi sair, segunda-feira eu fui e não consegui, porque lá dão senha sessenta senha quando eu cheguei lá embaixo já tinha acabado.

E: - Nossa!

J: - Aí o guarda falou assim: - Mas a senhora volta, e vem amanhã, né, e tenta chegar cedinho. Aí eu madruguei fiquei lá na fila, a hora que eu cheguei tinha acabado de novo a senha.

E: - Putz.

J: - Pois não acredito, e isso já era terça feira. E eu disse: “Ó moço não tem jeito não, vou ter que fazer uma denúncia, não pode isso aí, já era pra eu ter feito. Porque se eu fizer a denúncia depois que acontece o caso não adianta mais.”

E- É.

J: - Não é? Aí ele falou: "Bom, se a senhora quiser ficar esperando aí tem gente que desiste, quatro horas termina o expediente, se alguém desistir eu te dou uma senha."

E: - Mas você ficou?

J: - Fiquei, até quatro horas. Aí eu chego lá, bem acho que tinha senha, eles faz mesmo... você sabe como são essas pessoa, faz pouco caso das pessoas. Aí "dona sobrou uma senha aqui, a senhora quer a senha?" Eu falei: "Claro". Aí eu entrei pra falar com a advogada, quando cheguei lá, ela toda com aquela vontade, de receber, sabe como é que é, né. Aí falou assim: "Ah não dona, a senhora tem que voltar amanhã. Porque a senhora tá precisando assim, a senhora quer fazer uma denúncia, a senhora tem que escrever, tem que ser uma denúncia por escrito. Não pode, não 
pode fazer uma denúncia assim não." E eu falei: "Por que não? Você não pode escrever? Falando com a pessoa e escrevendo?"

\section{E- Uhum.}

Entrevistado- E ela disse: "Não tem que ser da senhora." E eu disse: "como? Eu tenho que escrever não computador ou nãoa máquina de escrever? Como que é isso aí?” E ela disse: “não senhora, tem que ser do seu próprio punho.” E eu disse: “ué, e eu preciso voltar amanhã pra mim fazer uma carta do meu próprio punho?"

\section{E- Faz agora, né?}

Entrevistado- "O meu punho tá aqui minha filha, só tá faltando o papel que eu não trouxe, até caneta eu tenho. Se você me der um papel para eu escrever...”. Ela me eu o papel eu escrevi a carta pus tudo lá na carta que é pra mandar par um juiz. Ela falou "tudo bem agora quando for sexta-feira a senhora pega uma autorização pra mim entrar lá.” Eu falei assim: "eu não vou de cara assim porque eu vou brigar com pessoal, eu tenho que levar algum papel, né? Alguma autorização.” Aí ela falou: “então você vêm aqui pegar uma autorização pra eu ver o resultado da carta o que o juiz vai achar.” Aí tudo bem, marcou pra sexta-feira e eu fui embora. Quando eu chego em casa, isso na terça-feira, quando eu chego em casa tava aquele reboliço na televisão aquele quebra quebra, aí eu falei assim: “o que tá passando aí?”. Aí meus fillhos sabia que eu tava com aquele medo danado "não mãe é que tamos assistindo um filme aqui mais é filme muito de, de guerra eu vou tirar que a senhora tá muito nervosa, vou passar pra outra coisa" e eu muito cansada chegava nem ia assisti televisão porque eu tava muito cansada eu ia tomar um banho comer alguma coisa e ia dormir, sabe?

E: - Hum hum.

J: - Aí falei assim tudo bem, nem me liguei naquilo, bem que era rebelião que tava acontecendo... E: - Nossa! Lá na cadeia...

J: - Na mesma cadeia que ele passou ali no quebra quebra. Tem uma hora que você tem que sair doido, se você não sair você morre aí naquele quebra quebra quebra quebra, aí eu não fiquei sabendo nada, ninguém contou pra mim isso, tava pensando que era televisão nada que eu tava meia doida já . Aí quando foi na sexta-feira normal saiu o papel chegando aqui que papel a moça chega lá e dá qualquer coisa aqui é seu papel. Tornei "oh moça aqui tem nada que identifica comigo não!’. E foi isso que eu perguntei pro juiz “tem nada esse coisa que é minha não!”. Aí ela falou assim: "é sua sim"; "então lê se é eu que não tô conseguindo entender o que tá escrito aí, 
né?". Ela foi ler "não tá escrito não essas coisas não". Aí ela falou assim: "ah tá! Mas escuta aqui sua carta, é sua carta eu não entreguei não, nesse dia". "Como você não entregou? A sua carta?". "Ah, minha carta? É não entreguei porque tava tendo a rebelião no dia que... Depois a hora que você saiu daqui que a gente foi ver a rebelião tava acontecendo".

E: - Você não sabia?

J: - Não eu não sabia. Na hora que eu tava escrevendo a carta, fazendo a denúncia, o pau tava comendo na cadeia lá, a muié tinha virado tudo, tinha mandado virar a cela... Aí acho que a mulher ficou com medo de entregar a carta, né... Ela devia ter entregado não sei como não entregou, não entregou. Aí, nesse dia que eu fui fazer a denúncia subi lá pra cima fui fazer direto que eu fui mostrar a denúncia... Aí que começo sabe, aí pra lá até que eles deram um papel, uma autorização e tudo, né eu nem pude ir na cadeia nesse final de semana porque a cadeia tava toda quebrada e ia ter visita, e eu falei assim...

E: - E ele foi transferido?

J: - Foi, aí a moça essa advogada aí que eu escrevi a carta aí pra ela, ela falou que eu não tinha escrito eu falei assim, escrevi sim, escrevi e depois sabe o que eu fiz... Eu tinha posto a senha lá sabe, tinha dado a senha pra moça e depois sabe quando vem uma coisa assim, pega a senha pega a senha pega a senha em sua cabeça, eu disse meu deus, eu não vou pega aquela senha mas eles tem que ter um controle aí, enfia na minha cabeça... Aí eu peguei e pus na bolsa...

E: - E aí?

J: - Aí ela bateu o pé firme e disse, aqui ó... E essa senha aqui o que foi e eu falei assim... Eu te dei a senha e depois veio uma voz e mandou eu pegar a senha e eu tive que pegar a senha... É porque ia acontecer isso, né? Senão eu não ia entregar minha carta, a senha tá aqui ó... Aí foi assim que eu consegui fazer pra Deus e eu consegui tirar tudo o que já tinha posto nas minhas costa e nas costa do meu filho, né...

E: - Conseguiu?

J: - Consegui, consegui porque aí ela mandou, mas demorou, mas demorou. É um trajeto muito grande, você tem mais tempo, né?

E: - Tenho!

J: - Tá, aí demorou... Aí tudo bem, né... Aí fiz a denúncia tal tal, quando eu... Depois disso eu não visitei o meu filho mais nem uma vez nessa cadeia... Não, visitei uma vez só...

E: - Uhmm. 
J: - Só uma vez depois disso... Aí passou uns 15 dias, teve a visita, voltou ao normal de novo... Aí eu tava com o meu papel, aí eu fui lá, né? Visita ele e tal, né... Aí eu lá cheguei olho pra mim assim "é mas você tá suspensa, você não pode visitar seu filho".

E: - Uhmm..

J: - Sua suspensão é de um mês...

E: - Uhmm..

J: - E eu falei assim "ah eu tô suspensa mesmo, você falou, você lembra que você falo que você ia vira a cadeia... Você virou, né, também a cadeia...".

E: - Uhmm...

J: - Aí ela me deixou, falou assim ó "deixa esta aí por último que e eu que vou buscar", e ó, todo mundo passou na minha frente. Passaram, foram embora o pessoal, depois foi que ela veio e disse "oi, tem que se abrir comigo". E a revista que ela tinha levado com ela a marmita, misturou tanto que a maionese começou a virar água. Nossa! E eu falei assim ó: "minha filha, que você tá procurando a, aí dentro? O que você tá procurando aí eu não trago, não trago nada na comida não. Eu entro pela porta lá ó, e é vocês que levam.” Você tem que falar o certo, né? E: - É.

J: - Aí ela falou assim: "não, tudo bem", e eu falei assim: "ê, pára de misturar a roupa" e ela falou assim: "e por quê? Você tá achando o quê?". "Pode misturar a vontade, chego lá eu jogo fora. Porque se você mandar esta comida não tem porco lá dentro pra comer essa comida.”

E: - Hum.

J: - Aí ela falou assim: "ah, mas você vai levar." E eu falei assim: "você pode ir." E eu falei pra ela: "você pode misturar bastante que na hora que você terminar eu jogo tudo no lixo." Ela falou assim: "não vai jantar? Você vai entrar com ela." E eu falei assim: "eu posso até entrar, isso vindo de você porque você é autoridade, mas chego lá eu jogo dentro do vaso e dou descarga, ele não vai comer esta comida aqui toda misturada. Porque meu filho não tá acostumado a comer isso aí.” Aí tudo bem, foi lá, "quem vai te revistar é eu”, eu disse: "e a revista?".

E: - Hum.

J: - A revista é que o bicho pega. Aí chega lá tira a roupa, você fica peladinha.

E: - Que coisa...

J: - Essa, essa presilha sai, você abre a boca, você põe a língua pra fora, você bem abre as pernas. É a pior coisa que você tem que fazer. 
E: - Nossa!

J: - Aí você veste a roupa e vai embora. Aí fez a revista, aí pode ir. Aí eu pego a marmita, e daí boto um ovo, pra dá pra ele. Aí sabe o que ela fez? Ela me deixou por último pra ver em que área em que eu ia. Que ela não sabia quem era o meu filho.

E: - Uhum.

J: - Até essa época aí, entendeu? Aí quando eu tô lá dentro, tô conversando com Fábio, mais não canto, aí o Fábio falou assim: "nossa! Mas o Coringa, recebeu uma visita”. E eu disse assim: “visita de quem? Da Vanessa?". Disse: “é a Vanessa que nós brigamos. Quê que ela tá fazendo aqui dentro?". Tá com cara que, um Coringa que fica naquele, como é que é o cara da faxina que é o manda chuva de lá que veio...

E: - Uhum.

E: - Todo lugar tem um, e aquele que é o manda chuva lá de dentro deve ser policial disfarçado. E: - Uhum.

J: - Que é pra dar os movimento de dentro do raio pra ele lá fora, sabe?

E: - Hum, sei.

J: - E os meninos lá, essas pessoas que fica lá eu sempre falei que tinha essa pessoa lá dentro, e eles acham que não têm, confia muito nele nem, nem tem como falar isso. Aí eu falei assim: "não Fábio, ali, olha lá, é coisa deles, né? E a moça tá ali fora, a superior, como é que é, a policial, é policial disfarçada." Aí ele falou assim: “ah é mãe?” Porque eles não conhecem essas pessoas, os funcionários lá. Ele disse assim: “é mesmo? Então fique aqui quietinha que eu vou lá quebrar as perna dela. É agora que nós mata ela aqui dentro."

J: - Ele disse que os funcionários não podem entrar lá dentro. E eu disse: "tu não vai fazer isso porque eu já denunciei ela e se você fizer isso aqui, eu sei que vai falar pra todo mundo que vai matar a moça. Aí pronto, aí fica do jeitinho que ela quer."

E: - Uhum.

J: - "Então não vai fazer nada. Deixa ela falar o que ela tá querendo falar, que eu acho que ela tá querendo é falar pro cara que quando tiver rebelião ela vai mandar vocês tudo pra outra cadeia." E: - Uhum.

J: - E foi o que ela vai fazer. Deixa ela fazer, né? Só que eu já fiz uma denúncia e a gente vai ter que sair fora, né? Aí tudo bem, ele ficou na minha porque eu obedeci. Aí ela foi conversou, conversou com ele, aí eu não tive mais contato. Quando dá na quinta-feira, chega um rapaz lá 
que, que, sei lá, ele teve um contato com a mãe dele, porque lá tem celular não bloqueado, né. Teve um contato com a mãe dele e essa mãe dele e eles pediram pra me avisar que tinham mandando o Fábio de lá, e eu não sabia pra onde tinha ido.

E: - É.

J: - Porque tava no presídio, não tinha saído de lá. Aí começou a pressão, "então pra onde vocês mandou?”. “Ah, mandamos pra Bauru...”.

E: - Hum.

J: - Né, que é a cadeia de lá, que tinha mandado pra Bauru. Aí eu disse: "mas por que vocês mandaram eles pra lá sem me avisar?”. Pedi um monte de explicação que eles não quis... Não me responderam nada, porque eles não respondem. Menina eu fiquei das sete da manhã até a hora que eu fiquei rouca, era mais de nove horas, sem falar nada, só telefonando pras cadeias, procurando onde que esse menino tava, e não encontrei.

E: - Nossa!

J: - Aí, quando foi, amanheceu o dia, eu falei assim: "não, nós vamos, vamos procurar." Peguei o carro, saí correndo, porque meu carro era emprestado, e fui, e falei assim: "eu vou primeiro a Bauru, porque foi pra lá que eles mandaram”, só que eu tinha ligado pra Bauru e eles disse que não tava lá. Porque eles não dá explicação pra ninguém, pra pessoa enlouquecer, os parentes sabe.

E: - Uhum.

J: - Aí chegando lá, ele estava lá, num quadradinho que é a metade disso aqui. Todo de grade, sujo, e tinha uns bichinho que subiram, subiram, fedendo, porque nem banho eles não tomam. Quando saí assim que eles tavam, de longe não podia nem arribar o braço, você sabe que se não tomar banho você fede.

E: - É.

J: - O menino tava com tanta fome que chega tava verde, porque não come. Lá eles dava nada pra eles, porque eles foram pra morrer.

E: - Nossa!

J: - Então os cara já tinha avisado, que a cadeia só tem bicha, só tem bicha, só viado.

E: - Hum, sei.

J: - Então, mandaram que era pra eles estuprar eles lá embaixo e matar, e eles não quiseram descer, mandaram dezoito pra essa cadeia, eles não quis descer, e ficou lá. Disse agora vai, disse, 
aí vocês vão descer, porque não têm pra onde vocês irem, porque ele não queria descer, ficou lá. Aí fui visitar eles né, no dia que eu fui lá, encontrei né, não levei nada, nem uma maçã pro menino comer. Aí chegando lá tinha seis agentes, e falou assim ó: "nós somos seis pra cuidar desse pedaço, e lá tem mais cinco homens eles vão subir, eles não querem descer, mas vão subir, e eles vão chegar aí e vão matar eles e a gente não vai poder fazer nada, porque eles não querem descer e hoje é o último prazo deles."

E: - Hum?

J: - Eu falei assim: "como que é o último prazo? Vocês têm que fazer alguma coisa." "Por quê?" Porque aí ele falou assim: "mas eles estão aqui pra pagar a dívida da rebelião. Eles mataram duas pessoas de lá nessa cadeia aqui, no dia da rebelião. Então mandaram eles pra cá pra pagar a dívida...”. Sabe como é que é, né?

E: - Sei.

J: - Aí eu falei assim: “assim, ah então é isso? Mas eles não quiseram mandar a pessoa certa. Porque a pessoa certa que tem que pagar uma dívida aqui é a Ivaneis. Que é a carcereira de lá. Então tinha que ter mandado ela pra eles, porque eu tô aqui com o papel de autorização vocês pode mandar isso pra outro lugar até nós resolver o caso deles e de todos esses rapazes aqui não tem nenhum culpado, só ela, está aqui o papel.” Fui lá, mostrei, aí que eles conseguiram transferir eles.

E: - Conseguiram?

J: - Consegui, porque senão ia ter outra rebelião, entendeu? Aí eles deixam os presos toma conta da cadeia, agente ver falar aí resolve, não resolve nada eles mesmo que fazem a rebelião os funcionários...

E: - É mesmo?

J: - É. Eu tô te falando porque eu vi aconteceu comigo e processei, processei mesmo. Aí tudo bem, fui lá e consegui mandar pra Jaquenima acabou de tirar a pena dele na Jaquenina. O menino era tão bom, tão bom que ficou... A pena dele era pra tirar seis anos, com três anos ele saiu. Veio, quando pensa que não de um dia aí ele tá chegando em casa e eu nem sabia que ele vinha pra casa, aí eu pensei que ele deixava o dinheiro lá né, aí deu um dia de noite lá eu falei "você tá de liberdade condicional", ele falou "nossa não tinha nem ônibus pra vim embora", ele falou assim “tô mesmo? Então eu vou embora, a minha mãe deixou um dinheiro aí e eu vou de avião", pegou o avião e veio pra cá, porque é pertinho, né! 
E: - Uhum!

J: - Disse que ele pagou cento e vinte e não sei o quê e eu já tinha deixado um dinheiro com ele. Vê que eles são tão danados, que como que a pessoa tá presa se tem que deixar dinheiro lá? E eu deixava direto.

E: - Tem que pagar, né? Se está preso...

J: - Tem que pagar. Aí como ele tinha dinheiro na carta...

E: - Aí chegou e ele tá lá na sua casa?

$\mathrm{J}$ : - Tava na minha casa.

E: - Desde então.

$\mathrm{J}$ : - É, e este processo ainda tá rolando, porque depois que o processo dele passou não tem mais nada que acabou, só que eles têm que pagar ainda porque ele ficou preso e eu quero a indenização. Ainda não foi terminado porque quem tá processando agora é eu.

E: - Por quê?

J: - Por causa disso aí. Ah essa mulher moveu uma ação, um processo pra mim lá no Ipiranga. Aí eu chego lá tô processada.

E: - Não entendi!? Mas como? Falando o quê?

J: - Falando que eu desacatei a autoridade, menina quase que eu fui presa! E já tive dias... Agora eu tô esperando a outra aí, né. Isso ao já tá quase com uns... Isso foi no ano de dois mil e... Dois mil e um, já tá quase com....

E: - Que absurdo!

J: - Já tem tempo menina! Já perdi até a conta. E o negócio ainda tá rolando.

E: - Que absurdo!

J: - Um dia lá eu tive que ficar bonito, o Juiz se levantou pra me prender.

E: - Ih. E aí?

J: - Aí eu falei assim: “não". Então eu perguntei pra ele "por que eu vou ser presa?" Ele falou assim: "Dona Joana, a senhora fica, a senhora quietinha, a senhora tá desrespeitando, a senhora tá acostumada a desrespeitar autoridade eu vou te dar voz de prisão, né, vou te dar voz de prisão" e levantou e foi em direção do advogado que tava do lado do estagiário. Aí eu falei assim: “e eu posso saber o porquê eu tô sendo presa?". E ele falou assim: “pode, porque a senhora fez gesto obsceno pra mim. Você fez assim.” Ele disse que eu fiz gesto obsceno pra ele.

E: - Ahhh... 
E: - E então eu disse pra ele: "ah é senhor Juiz? Então e a condenação do pessoal lá qual vai ser?" Porque eu fiquei foi pra lá. Eu tive um filho de parto normal, sustentei ele, nunca precisei um centavo do governo, a não ser a vacina pra para, para, como é?

E: - Paralisia infantil.

J: - Porque sabia quando não tinha a gente tinha que comprar. Agora eles dão, né? Mas quando não tinha a gente tinha que comprar na farmácia. Eles não davam leite, não davam sapato, não davam nada pra criança. E eu falei assim: "a única coisa que vocês fizeram agora depois que eu criei meu filho, vocês vem prender meu filho. Os policiais mostram a carteirinha, entendeu? Mostra que é policial, joga a droga no seu carro, prende o seu filho. Você fica pelada na frente do seu próprio filho, que eu tive de parto normal, já, já fiquei pelada também, e agora você vem me prender porque eu fiz um gesto obsceno, você sabe que eu fiz gesto com a mão?”. Eu disse: “Gesto obsceno é você ficar pelada na frente do seu próprio filho. Viu?" Aí ele, ele aceitou sabe. Aí eu falei assim: "Então você vai ter me indenizar por isso. Porque aí ó, tem filme aí e o resto é dos presos, da família dos presos." Só pode ser isso, a intenção... Pra que que eles querem tanta mulher pelada? Mulher então, porque os homens também ficam pelados. Meus filhos nenhum foi visitar ele. Não, foi, um casal foi.

J: - O meu, o meu ex marido não ia visitar o filho porque chega lá ele achava que era uma falta de vergonha do que fazer, né?

E: - Claro.

J: - Tirar o pênis pra fora, ficar, fazer, acontecer. Ele disse: "Como que faz isso com um homem?". O meu filho, o mais novo eu nem lembrei, ele se sujeitar a um negócio desses porque senão ia até morrer. Né?

E: - É.

E: - Não dá pra fazer um negócio destes. Será possível que não tenha um aparelho que você passe na pessoa que, é porque a droga entra e é os funcionário que leva. Não é preso não, e se alguma mulher de preso leva é porque eles deixam passar.

E: - E você falou tudo isso pro juiz?

J: - Falei. E disse: "ó juiz, o problema é esse, porque eu fui conhecer droga foi lá dentro da cadeia. Eu não conhecia droga aqui fora. Eu ouvia falar em maconha, estas coisas, e via passar na televisão. Mas eu fui ver o negócio lá dentro, que todo lugar que você entra tem um saquinho. Em todas as cadeia você sobe assim nas beliche pra você subir em cima, você tem que ficar 
desviando seu pé porque senão você pisa em cima do saco da coisa."

E: - De tanto que tem?

J: - De tanto que tem.

J: - O pessoal fica tudo drogado lá dentro, porque se eles deixar a pessoa normal eles não ficam preso, eles ranca a cadeia, eles quebra tudo. Então, eles acham melhor drogar as pessoas.

E: - É mais fácil, né?

J: - E fica ali, né? Escondendo, pra dizer, ah, é a família dos presos que levam, sendo que é eles que autorizam levar. É porque se eles não autorizar e deixar aquele pessoal drogado, eles não ficam lá dentro. Eles não conseguem fazer cadeia pra prender porque eles quebram direto. E: - Uhum.

J: - Você acha que se você é uma pessoa normal você vai ficar presa? Você fica um dia, dois, depois você se revolta. Até os animais revolta, foi isso que aconteceu no presídio...

E: - É.

E: - Aí eles enchem eles de cocaína e deixa lá, um monte de animal, e eles gostam de ficar lá, porque aquilo lá...

J: - Aí ele pegou, mandou prender, depois chega com essa contra justiça, senhora desacatou autoridade, porque, por isso que eu falei essas coisas. Aí eu disse assim: "ué, não deixar, não apanhar na cara é desacatar a autoridade? Mas uma pessoa apanha na cara quando ele merece. Eu, eu, se eu não apanhei na cara até essa idade agora pra frente ia ser impossível.” E: - Ah.

J: "Ou vocês acham que vocês põem meu filho lá e eu vou levar droga na cadeia? Ia ser uma traficante? Se eu fosse... Se eu fosse traficante vocês podiam bater na minha cara, e eu ia ter que aceitar, tava fazendo coisa errada, né?"

E: - Uhum.

J: - Aí então ele falou assim: "então tudo bem, como a senhora desacatou a autoridade, e não veio à audiência...”. E eu faltei à audiência porque eles puseram a audiência lá no Ipiranga.

E: - Hum.

J: - Eu assinei em tanto fórum que se eu sou processada, vocês têm que me processar na minha região, tem a Barra Funda, tem o Forte dos Pinheiros que pertencem a nós aqui, né?

E: - Uhum.

J: - Você vai me pular pro outro lado do mundo? E eu falei assim: "eu vim, mas quando cheguei 
lá a audiência tinha acabado de acabar, e eu vim e assinei a audiência, sabe por que eu não cheguei na hora? Porque vocês roubaram meu carro, eu tinha um carro. Se não tivessem roubado meu carro eu tinha chegado na hora, eu vim de ônibus, eu não posso pagar jatinho.” Né? Eu falei logo... Interessante. Aí ele marcou essa outra audiência e como já tinha dado tudo certo ele achou que agora é assim. "A senhora fica presa, fica presa, ou então vai dar alguma cesta básica para alguma entidade, ou vai trabalhar em algum serviço voluntário de qualquer entidade aí, durante este um ano."

E: - Hum.

J: - Pra pagar este castigo, porque diz que eu fui contra a autoridade. E eu disse assim: "oh seu Juiz, o problema tá aí, não vou fazer nenhuma das três." Falei logo na cara dura. Aí o cara fica doido, e eu olho na cara dele e falo: "eu não vou fazer nenhuma das três sabe por quê? Pra começar cesta básica eu não... Nem aposentada eu sou, e já tô com idade aqui de 55 anos. Não tô conseguindo nem mais trabalhar pra eu sobreviver, eu tô precisando de cesta básica. Entendeu??" Trabalhar de graça? Disse eu: "olha só minhas mãos, mão calejada de tanto trabalhar pra me sustentar e sustentar meus filhos. Né?"

E: - Uhum.

J: - Que... E eu ainda vou trabalhar de graça pro Estado, sendo que ele já roubou meu filho que é a coisa mais importante pra mim, por causa de algumas gramas de maconha? Porque se eu soubesse que maconha dava tanto dinheiro eu tinha plantado uma roça de maconha ao invés de ter um filho. Falei assim mesmo. É verdade. Agora, eu vou trabalhar de graça pro Estado? Eles tá aí cheio de marra, eles tão aí com a mala cheia de dinheiro e eu ainda vou dar o meu suor pra eles? Eu disse: "não, de jeito nenhum, e ficar presa eu posso até ir, eu concordo em ficar presa. Depois que vocês vê tudo estes processos que tão dentro desta pasta minha, aí eu vou ter certeza. E ainda tem essa proposta lá, que resolve que ainda tem que resolver esta questão, não sabe?” E: - Uhum.

J: - Aí eu falei assim: "aqui tem advogado, cassado, fez duas audiência no fórum da Barra Funda, que eu processei e vocês não fizeram nada com ele. Dei meu carro, que vocês roubaram, o policial que jogou droga lá e meu carro tá roubado e veio meu IPVA com tudo pra mim pagar, e o carro tá circulando. Quem é que tá circulando com o carro?"

E: - Ah, não acredito no que você tá dizendo!

J: - Tá. O IPVA tá lá na minha casa eu devia ter trazido pra você ver 
E: - Mas não dá pra você parar, sei lá, não tem como não fazer isso?? Não pagar, como...

J: - Mas eu não pago, tá acumulando você entendeu? E eu vou levar tudo lá pra os policias puxar, quem tá usando é quem vai pagar. E eu falei pra eles: "vocês vão pagar meu carro, e ainda com juro e correção monetária e com esta despesa aqui. Pra vocês ver, eu cheguei tarde aqui, eu devia ter pegado um táxi pra vocês pagar.”

E: - Uhum.

J: - "Eu tenho um carro que foi roubado pela justiça e a indenização do meu filho, depois que vocês fizer isso vocês podem me prender. E a minha também", eu falei. "Porque eu não vou criar um filho, e depois ficar pelada pra me verem na cadeia não, por causa de maconha. Você entendeu? Sendo que lá dentro tem muito mais que aqui fora, porque ele fuma, porque agora até maconha ele fuma lá dentro. Quando não tem cocaína ele fuma maconha, lá dentro da cadeia.”

E: - É um absurdo, né?

E: - É, aí ele falou assim: "então tudo bem, como a senhora veio na outra reunião, na outra audiência, eu vou (eu assinei né, cheguei no fim, não compareci, mas eu assinei), eu vou marcar uma próxima audiência." E marcou uma. "Só que a senhora vem com advogado, até com advogado, bem, advogado bom viu. Porque se a senhora não vier com um advogado, a senhora vai pra trás das grades, presa." E eu disse assim "o senhor vai pagar advogado, mas eu não vou, então eu vou lá no Estado e pego um." E eu falei assim: "vocês? Devem ter um advogado bom pra me oferecer, né não?”. Pior, né?!

J: - Lógico!

E: - É!

J: - Fui lá na Barra Funda, lá aonde eles oferece advogado, fui lá e peguei, cheguei lá e já pedi, eu falei assim oh: "vocês me dão o melhor advogado que vocês tive aí porque eu vou ser presa, e ele tem que me defender."

E: - E aí?

J: - Aí me deram um advogado sabe da onde? Da Mooca... hehe e eu morando aqui... tô indo na Mooca com tanto advogado que tem aqui... Fui lá nesse escritório, um advogado muito legal, né...

Só fui esse dia que eu falei com ele e encontrei com ele lá na audiência do fórum da Barra Funda, da Barra Funda não, do Ipiranga... Que deve ter uns dois anos. Nunca mais tivemos contato depois disso aí... Como que chama.. Flávio... Flávio Lopes... tem até meu sobrenome... E: - Uhum... 
J: - Um advogado novo, muito legal, me defendeu na boa... Cheguei lá contei a história pra ele... Eu falei assim ó, acho que ele tinha o que... Uma semana só de preço.. Eu falei assim ó... "Você tem uma semana só de prazo tá? Vê aí no computador como que tá minha situação e corre atrás porque o cara disse que vai me prender".

E: - Uhum!

J: - Aí ele correu... Eu acho que ele é bom porque ele fez alguma coisa... Presa eu não fui, mas o juiz tava decre... Ia decreta minha prisão minha porque eu sou pouco bocuda você viu, eu tenho que falar as coisas... Porque se você não fala você... As pessoa lá porque o país tá desse jeito... Porque eles não falam.

E: - Todo mundo aceita, né?

J: - Todo mundo aceita! Não porque... É seu juiz você não pode fazer nada... Ele achou ruim porque eu falei que... Eu devia ter plantado pés de maconha... Eu falei assim "pois é, mas devia mesmo porque é a única coisa que dá dinheiro". Um ser, uma pessoa é menos do que uma maconha, umas graminha... Foi 18 de maconha. Meu filho ficou três anos na cadeia, acabou com a minha vida, acabou com tudo... Daí eu falei assim “é porque tem muito, não é não?”. Então você tem que chegar no ponto certo...

E: - Ou porque a pessoa não vale nada...

J: - A pessoa não vale nada... A droga tem mais valor do que a gente.. E: - É.

J: - Não vale nada... Aí o cara foi lá me correu atrás... Aí sabe o que ele descobriu? Desse pessoal, ele descobriu que o pessoal, essa mulher que queria bater na minha cara, essa gente lá... Ela pegava os preso de noite e botava pra roubar pra dividir...

E: - Humm!

J: - Ti juro, era aquele tráfico lá dentro, por isso que era aquele lenga lenga lá dentro... Aí né.. Eu tô lá eu... Eu fui, né... Fui cedo pra lá e fiquei lá esperando, cheguei bem cedo porque assim... Tem que chegar porque lá é longe, né... Eu sai daqui sete hora da manhã, a audiência era uma hora da tarde.

E: - Nossa!

J: - Cheguei lá meio-dia e fiquei esperando. Aí eu falei assim ó "deixa eu ser sincera porque... né" e o advogado chegou e falo assim ó "a senhora pode ficar tranquila porque eu descobri cada uma desse pessoal que você não vai nem acreditar, e o pior, com a denúncia que você fez na Barra 
Funda não tem mais ninguém trabalhando lá, até o diretor mandaram embora da cadeia...”. E: - Nossa!

J: - Arrumou um advogado bom, né... Quando chegou a hora da audiência começou sabe... Esse restante dessa audiência... Desse dia, eu não fiquei sabendo porque de lá a gente se despediu, ficou pra gente entrar em contato e o contato deles demora, né?

E: - É.

J: - Um ano, dois anos, dez anos... E vai até quando eles quiser... Até hoje não me procuraram... E: - É, demora.

J: - E, chegando essas pessoas, falaram que ele convocou todo mundo, o diretor, todo mundo lá do CNP lá do Ipiranga, do Ipiranga não, do Tamandateí. Convocou tudo os funcionários dessa época e eu via porque eu conheço os funcionários, iam entrando e eu não falei nada... Porque dessas outras audiências que tem eu não levo advogado, porque se leva você não fala nada, porque se fala você vai se presa, é só o advogado que fala.

E: - Uhum!

J: - E eu gosto de eu falar minhas coisas, eu gosto de debate ali, você entendeu? Porque eu sou boca dura. Aí eu tô lá, né... Nessa audiência eu não falei nada, só tomaram depoimento meu, né, que foi sobre comida, como aconteceu isso, eu falei assim "eu levava assim minha sacola bem cheinha" e falei toda essa coisa que eu já te falei aí...

E: - Uhum.

J: - Então se eu tenho culpa foi isso que eu fiz, né... E não deixei ela bater na minha cara... E aí foi tomando o depoimento de todo mundo, inclusive fez com o moço, aí quando a pessoa... Aí chamava a pessoa pelo nome... quando a pessoa acabava de dar o depoimento dele ele perguntava: "você ainda continua no serviço?" que foi o advogado que pediu que ele perguntasse lá "você ainda continua trabalhando lá no CDP?" Não, ele foi é demitido... todos eles, não tem ninguém trabalhando lá.. e o advogado falou assim, "aqui é aonde você vai ganhar a questão porque se eles fossem o bom funcionário eles tavam trabalhando lá."

J: - E foi todo mundo demitido por causa da sua denúncia que fez... E eles foram lá e viram que tava errado...

E: - É!

J: - Aí tirou todo mundo de lá...

E: - Putz, que história, né? 
J: - É. Uma história, e esse ainda tá...

E: - E ainda tá resolvendo, né?

J: - Tá, tá sim!

E: - E ainda tá esperando a resposta...

J: - Tô esperando a resposta, porque se o juiz chega e me dá uma, me decreta uma prisão eu vou ser presa, porque eu falei na cara dura dele, falei mesmo, eu falei assim ó: "se eu vou ser presa eu tenho que saber porque, por droga não posso se presa porque lá dentro tem muito mais...”. E falei um montão...

E: - Vamos ver agora.

J: - É, vamos ver o que eles vão resolver, tá pra resolver esse caso dele, porque meu filho tá limpo na rua... Tá arrumando serviço, não tem problema nenhum... Só que ele não é traficante, mas que ele é usuário é... E eu não posso negar que é.

E: - Continua sendo?

J: - Continua sendo, eu preciso de um tratamento porque eles tem que contratar uma ajuda.

E: - Uhum..

J: - Porque a gente, a família, acaba com a família...

E: - Acaba...

J: - Eu tenho esse meu filho aí ó, caçula, que eu peço a Deus todo dia por ele... Que eu nem sei como ele é assim, é Deus mesmo, que é muito grande, muito bom... Que o menino é aquele benção de Deus. Também ele ia até estudar pra psicologia sabe? Só não estudou porque não conseguiu... Eu não posso pagar porque é muito caro.

E: - É muito caro.

J: - Ele esperou dois anos pra vê se conseguia vaga, mas não conseguiu. Aí eu tô pagando administração de empresa aqui fora pra ele porque... Aí depois quando ele fizer essa faculdade aí, ele vai trabalhar, ganhar um pouco melhor pra pagar a outra, porque ele quer mesmo é psicologia. Porque ele fica nessa história toda que não abre a boca, e só tentando entende... E esse fica quieto ele tá me ajudando... Porque se ele tivesse parado aí pronto.

E: - Aí você ia ficar nervosa...

J: - Ia ficar, porque é o caçula... Se ele fica falando coisas eu fico achando que ele vai fazer, não é não? Então quer dizer, que isso aí pra mim eu falei assim "você vai da um bom médico porque pra mim você tá sendo já um médico..." 
E: - Uhumm

$\mathrm{J}$ : - Eu acho que foi Deus que mandou ele depois de tudo isso porque sabia da barra que eu ia enfrenta né, então já manda a pessoa, por isso que eu falo, às vezes vêm pessoas na vida da gente que já tá... Tem que vir, não adianta, porque se não vier... Tem que fazer a parte da sua vida... Continuação de sua vida..

E: - É.

J: - Porque esse aí mesmo, porque se não fosse por esse menino aí eu acho que eu já tinha abandonado tudo, eu já tinha deixado essa turma aí...

E: - Com certeza...

J: - Mas como ele, eu olho pra carinha dele aquela pessoa que não merece sabe... eu fico aí fazendo tudo por causa dele, tudo essas coisas...

E: - E o restaurante, como é que foi?

$\mathrm{J}$ : - O restaurante...

E: - Você saiu da casa da mulher, você tava falando, juntou um dinheiro e abriu um restaurante, sozinha...

J: - Abri, abri um restaurante, aqui na minha casa mesmo porque como eu tenho um sobrado e o meu sobrado é caído pros fundo, e só sai pra uma casa na rua, né?

E: - Uhmm.

J: - Aí eu falei assim... A gente ficou morando nas casas de baixo, e na de cima eu fiz restaurante.

E: - Uhmm.

J: - Aí eu falei assim, "como a gente não vai pagar o aluguel né, dá pra gente montar o negócio", e deu mesmo, ganhei bastante dinheiro, não deu pra enrica, porque trabalhando em sua casa não tem como porque, assim, chegava aquela mesa bonita que eu ia receber uns 40, 50 reais de porção, uma cerveja e tal, meu marido chegava lá, tomava um copo de cerveja e dizia: "essa mesa é minha". E o que que eu ia fazer? Nada, né...

E: - Como?

J: - Não podia faze nada né? Se eu fosse cobrar de novo ele ia e insistia que a mesa era dele e se eu fosse brigar eu perdia as clientelas porque eu tô brigando...

E: - E ele não pagava?

J: - Ele não pagava, porque aí ele falava assim "não porque eu já te dou, já te dou..." sabe o que ele me dava? O dinheiro que ele recebia ele gastava tudo lá... Porque como eu tinha entrava 
dinheiro, como ele via que entrava dinheiro, ele pegava o dele e gastava na gandaia sabe, aí ele trazia a cesta básica porque antigamente eles davam um ticket, e trazia a cesta mesmo, porque você ia em qualquer supermercado e trocava.

E: - Uhum.

J: - E o ticket de refeição era a única coisa que ele trazia, porque ele levava a marmita já, né, porque eu trabalhava com comida...

E: - É, claro né, e era restaurante de comida por quilo?

J: - Por quilo, é.

E: - Aí ficou quanto tempo esse restaurante?

J: - Ah, eu fiquei uns cinco anos com esse restaurante aí.

E: - E você que fazia tudo?

J: - Fazia tudo... Foi a única coisa que segurou minha barra nessa época porque o dinheiro dele ele gastava então se eu não trabalhasse com isso aí como que eu ia viver e cria meu filho? Eu falei assim, eu tinha que acabar desse menino crescer porque o pequenininho era pequeno demais, nessa época ele tinha quatro, cinco anos... Muito pequeno, e eu pra mim sair pra trabalhar eu não podia deixar ele.

E: - Uhum.

J: - Eu falei assim, o negócio é trabalhar em casa porque pelo menos eu tô em casa, né...

E: - Uhum.

J: - E eu fiquei trabalhando, o restaurante dava dinheiro, ninguém nunca ficou doente, nunca tive assalto, nunca recebi cheque sem fundo... Tem gente que fala, né... Eu até que administrei o negócio muito bem... Às vezes até trocava cheque, eu tava com dinheiro, aí segunda-feira tinha os pedidos né, porque todo dia tinha um pedido né, tinha coca, trabalhava com cerveja...

E: - Uhum!

J: - Tinha os pedidos das bebidas que entrava... E eu podia fazer o pagamento com cheque, porque eu tinha, como é que se diz... O cadastro, então podia dar um cheque, porque mesmo que o cheque voltasse sem fundo eles voltavam pro meu comércio né, sabiam que iam ser reembolsado, mas nunca voltou nenhum, e eu tratava lá com bandido, esses que diz que é bandidão feio. Nunca voltou cheque nenhum, nunca me passaram a perna, nunca ninguém brigou no meu comércio, nunca caíram no chão porque eu já punha a plaquinha, no meu restaurante de jeito nenhum podia na hora da comida, se quer uma dose de uma bebida mais forte podia beber, 
mas se chegasse lá bêbado nem entrava. Eu dizia assim não, se você já vem bêbado de outro lugar não, pode ir embora daqui.

E: - Uhum!

J: - Né...

E: - E nem ficar, né...

J: - Não, e nem fica também, né... Esse negócio aí nunca tive problema não... Aí eu fechei mais por isso, porque eu tava muito cansada, sabe?

E: - Sei.

J: - Muito, aí sobra só os pepinos que tem vez que não tá trabalhando... Daí só sobra pra alguns... O Carlos, né... Esse Carlos segurou uma barra aí..

E: - É!

J: - Nesse grupo nosso, que é de todo mundo, quem segura a maior barra aí é o Carlos, é o que vai ter que ser mais bem visto nesse grupo, você sabe por quê? Porque nos congressos quem vai, tudo... Só sobra pra ele, é fazer compra, ele tem que estar junto, e é tudo... Então, era o que acontecia comigo lá, tudo o que só sobrava era pra mim, e eu como era dona tinha que fica sustentando a peteca ali, né... E foi indo até a hora que eu cansei, falei assim "vou fechar, o ponto aqui é meu, não vou vender o ponto porque eu não vou querer restaurante aqui porque é em cima da minha casa, e eu trabalho porque eu sei trabalhar, não vou deixar uma pessoa por coisa por todo lado por cima da minha casa, né?".

E: - É...

J: - Né, não vai dá, não passei o ponto pra ninguém, fechei, não fechei a firma, fechei o restaurante, a firma continua aberta, né, que eu tinha firma aberta ainda...

J: - E tá aí, vou deixar pra caducar, não vou fechar a firma.

E: - Você só fechou o restaurante mesmo.

J: - Só.

E: - E aí depois que você fechou o restaurante você foi trabalhar... Aí você fica em casa mesmo, trabalhando na sua casa?

J: - Aí fiquei em casa, é, aí meu filho já tinha casado, foi chegando os netos... Eu fui ficando por ali, e o tempo foi passando sabe?

E: - Uhumm...

J: - E aí eu não fiz mais nada, fiquei fazendo uns biquinhos, vendendo algum produto em revista 
sabe, pra sair alguma rendinha, né?

E: - Uhum.

J: - Fiquei ali... Aí depois logo veio esse negócio da cadeia do meu filho, eu tive que corre atrás... E: - Ah é, foi logo depois do restaurante.

J: - Foi logo depois do restaurante, fazia dois anos que eu tinha fechado o restaurante, aí veio até esse Recomeçar de Novo da prefeitura.

E: - Ahhh.

$\mathrm{J}$ : - Eu fiz isso aí...

E: - Fez? e como é que foi?

J: - Eles me chamaram duas vezes, uma vez foi lá no Santo Amaro pra trabalhar lá no Santo Amaro, em escola e eu podia vim pra escola aqui do bairro, só que foi na época que meu filho tava preso, e eu recusei, falei assim ó “eu não posso, no momento eu não posso", porque se eu fosse trabalhar eu não podia visitar ele, tinha que abandonar ele... Eu não podia abandonar ele.

E: Não dava, né.

J: - Aí eu tive que abandonar o serviço, porque senão tava aí empregada.

E: - Que coisa, né...

$\mathrm{J}$ : - Foi.

E: - E aí você ficou, daí você ficou um tempo, então nesse tempo foi chamada pelo Recomeçar de Novo, mas não foi... E como é que foi esse grupo, como é que você começou com o Mãos na Massa?

J: - O Mãos na Massa foi assim... Porque aí eu sobrando um tempo, né? A Márcia me chama, vamos vender os produtos da Matuslife e tal tal, e eu falei assim ó “ah, já que eu tô com tempo é bom porque aí eu compro uns produtinho pra mim e não preciso ficar tirando do bolso né, com a comissão...". Aí fui vendendo e tal, e foi indo, entrando, e um dia eu ia na rede, aí foi e ela falou lá, e tá formando esse grupo, você não que entrar e tal, aí eu fui indo e fui ficando...

E: - Mas e como é que você começou a ir em reunião da rede?

J: - A reunião da rede... Eu fui uma vez, não... Como foi que eu fui na reunião da rede? Eu fui uma vez lá embaixo no... No como que chama ali no...

E: No Centro de Referência?

J: - No Centro de Referência... Eu fui uma vez lá..

E: - Conhecer? 
J: - Conhecer. Aí fiquei fazendo parte, aí depois não fui mais, não dei muita importância, né. E: - Uhum.

J: - Aí eu comecei a ir no grupo e agora eu tô voltando de novo... Fui agora umas duas vez e vou entrar de novo porque eu tô com um problema meu lá com um terreno já tem seis anos lá que eles tão jogando muito lixo e eu acho que pra mim resolver isso aí eu tenho que entrar na rede, né, pra eu tá ali no movimento, pra eu tá falando minhas proposta e vendo algumas também que podem fazer lá naquele terreno, porque tem muito, lá é um terreno baldio, tem dono mas a prefeitura pode comprar aquele terreno, sei lá o que pode fazer, pode fazer uma entidade lá... E eles falam de creche, mas eu acho que tá precisando mesmo aqui no Jaqueline é um asilo, não tem nenhum... E: - Não tem nenhum?

J: - Não, que eu saiba não, porque diz que tem um ali mas só tem um portão...

E: - Aí você começou a participar dessa discussão do que fazer com o centro e tal, e aí nessas reuniões foi que te chamaram pra fazer o Mãos na Massa?

J: - Foi.

E: - Quem te chamou?

J: - Quem me chamou... Aí já tava o grupo quase formado.

E: - Ah... já tavam trabalhando...

J: - Não tava trabalhando ainda tava só discutindo ainda, não tinha discutido nem o que ia fazer ainda.

E: - Tá...

J: - Foi aí que eu ajudei a discutir sobre as barrinhas porque eu gosto muito dessas barrinhas, eu gostava mas comprava muito pouco, né?

E: - Uhum!

J: - Quem comprava mais era meu neto então eu fui mais por causa dele né, todo lugar que eu saia com ele, ele queria uma barrinha então foi assim que eu fiquei conhecendo as barrinhas que tem por aí, através dele, né? E aí a gente ficou, foi ficando foi ficando... E até como eu já tive um restaurante eu falei assim, é uma boa porque aí eu já aprendo mais, quem sabe mais pra frente se a gente abre um comércio, algum dos meus filhos, eu já sei mais como que administra assim... Na parte da... Como que se fala... Matemática do...

E: - Finanças?

J: - As finanças... É muito bom né, tô aprendendo bastante... É que o meu dava pra mim Entrevista de História de Vida Joana 
administrar bem do jeito que eu administrava, mas o problema é que eu trabalhava só com os meus filhos lá, não tinha funcionários... Você trabalha com funcionários é outra coisa, com o grupo também... Você via aí que era, como que é né, essa demanda que é...

E: - Então no grupo eles tavam tentando achar o que fazer, é isso... E quem te convidou foi o pessoal da Incubadora, do Pólis?

J: - Então, eu chegando lá, né... Que eu fui convidada pela Márcia, foi a Márcia que me apresentou.

E: - Ah foi a Márcia.

J: - E eles me aceitaram no grupo, a Nadir também né, a Jane, o Werner.

E: - E isso foi quanto tempo?

J: - Olha faz um tempo, mas você sabe que eu nem marquei, eu devo ter marcado em algum caderno lá, mas eu não lembro bem, mas deve ter mais de um ano.

E: - Mais de um ano.

J: - É, porque no Natal passado eu já estava no grupo.

E: - E aí como é que foi a sua entrada, foi difícil? O que você tá achando de trabalhar em grupo?

J: - Olha, eu tô achando bom sabe, tem alguns atritos assim, mas vai dar pra gente ir lá, porque eu acho que não grupo a pessoa que não tá satisfeita tem que sair fora.. Não pode prejudicar o grupo, né... E eu tô vendo pessoas aí que não tá satisfeita e tô vendo que acho que vai sair.

E: - Ah é...

J: - A gente não vai tirar. A gente não tá aqui pra excluir ninguém, a própria pessoa que não gosta, porque tem uma pessoa aí que não gosta mesmo, você tá vendo que ela não... Eu vou até fala o nome, posso falar?

E: - Pode...

J: - Porque não adianta a gente mentir, a Ana mesmo, ela fala que ela faz barrinha, mas ela nem come... Como que você produz uma coisa e não come? Você vai vender aquilo de que jeito?

E: - É...

J: - Não pode, você acha? Você não vai crescer no grupo, porque eu sou a produtora de barrinha, e eu tô te oferecendo a barrinha, aí você fala "ahh é saborosa", aí eu falo que nem como, eu nem sei nem que sabor tem, você vai compra essa barrinha?

E: - É, não vai me convencer...

J: - Então tá, então eu acho que uma pessoa dessa não pode ficar no grupo, a não ser que ela fosse 
da parte da administração, qualquer outra coisa.

E: - É, pode ser...

J: - Né... Que não envolvesse essa parte da alimentação mesmo, de degustação... E ela se... Porque o grupo é isso... Se eu não posso ir a outra tem que ir e se ela for aí não congresso, igual ao Carlos, o quer que ela vai fazer lá? Ela não sabe que sabor tem nenhuma barrinha daquela, e aí pronto, já acabou com o nosso grupo.

E: - E fora esses conflitos assim, que tem às vezes, tem alguma coisa que é difícil de trabalhar em grupo, ou você tá achando tranquilo?

J: - Não, eu tô achando bom, é até melhor porque o serviço é rapidinho. Vamos supor... Eu quando eu trabalhava com o meu restaurante e eu pegava uma lasanha pra eu fazer, eu tinha que começar ela do começo ao fim.

E: - Uhum.

J: - E agora não, você faz uma parte, no grupo, até ela é feita em todo o grupo, você entendeu? É igual as barrinhas, uma espreme o limão, outra faz isso, outra faz aquilo... Então a barrinha tá feita pela mão de todos, e eu acho que o mais importante... O mais rápido...

E: - E é isso que é mais rápido, né?

J: - É.

E: - E essa parte de tomar conta das coisas, de discutir, de tomar decisão em grupo, como é que tá sendo isso?

J: - Pra mim tá sendo bom, o que que eu tô um pouco embananada mesmo é com essa venda das barrinhas porque por enquanto a nossa produção tá pouca e tá saindo de uma, de duas, então isso, é uma pra um fulano, aí fulano não pagou você vai atrás, aí você fica, né... Isso aí cansa, te embanana muito. E quando tá aquela produção grande você vai vende de mil, você vai fazer as entregas grandes, então isso aí é... Aquela nota fiscal aí não vai ter problema nenhum, né? Isso que tá cansando é só isso aí, né?

E: - Uhum...

J: - Essa demanda aí dessas minorias...

E: - E porque que você falou que o Carlos tava carregando o grupo muito no começo?

J: - É porque tudo que vem, tudo fica pro Carlos fazer.

E: - Ah é?

J: - É, se tem um congresso, igual ao do Rio de Janeiro, ninguém pode ir, escalaram o Carlos, 
certo? Ele não falo nada, né?

E: - Ele vai...

J: - Aí fica... E só sobra pra ele, é o que pode... Agora essa outra aqui de Campinas, ficou do Antônio ir junto, nós até pensamos que o Antônio ia junto, mas ele foi sozinho porque de última hora o Antônio não pode ir e eu falei assim, se eu soubesse, ia ser chato, porque é um homem e uma mulher, mas tudo bem, nós somos um grupo e a gente tem que enfrentar esse tipo de coisa, se eu soubesse eu teria ido porque ir uma pessoa sozinha não faz nada. Nós fomos no congresso aqui da USP nós fomos em três, e foi difícil, o Werner me ajudou, a Nadir ajudou... Pro Carlos ir sozinho nesses lugares aí... E ele foi aqui, acho que foi em Brasília, lá no Rio de Janeiro parece que eles venderam tudo as barrinhas, agora aqui em Brasília eu escutei, que eu vou dizer, uma conversinha aí de que ele devia ter vendido mais barrinhas...

E: - Ah... Não acredito, você ouviu isso?

J: - É, porque ainda sobrou, devia ter vendido tudo... Como que uma pessoa sozinha... ele tem que ir no banheiro, tem que comer...

E: - É...

J: - Sozinho pra fazer tudo...

E: - É...

J: - É, né? Porque grupo já é grupo pra isso mesmo, então uma pessoa só não pode estar sozinha, tem que tá pelo menos dois.

E: - Uhum, você acha isso importante então?

J: - Eu acho... Eu já falei até pro Carlos, falei assim ó, da próxima vez você não vai sozinho, tem que arrumar qualquer outra pessoa pra ir, é lei, é o nosso grupo, a gente não pode fazer isso... E vai carregar uma pessoa só porque ele fica ali o que... Às vezes ele tem que ir no banheiro como é que ele faz? Se ele tá vendendo, tem aquele movimento, ele vai deixa a banca sozinha? Não pode. E: - E essa questão de ser uma cooperativa, foram vocês que decidiram? Você participou dessa discussão?

J: - Participei... Eu acho que é bom ser uma cooperativa porque o grupo, o grupo em si é bom, mas é um grupo que fica ali parado, mas agora uma cooperativa ela vai crescer. Vamos supor, chega um certo tempo eu vou ficando mais velha, não dá pra mim trabalhar, mas eu já, já fiz o movimento de gerar uma cooperativa já tem mais outras pessoas que já fez o curso já podem entrar e vai crescer você entende? 
E: - Uhum.

J: - E eu acho que o bom seria isso aí, né?

E: - Ser uma cooperativa mesmo...

J: - Uma cooperativa. Igual agora mesmo a gente tá até querendo conversar com a Nadir pra vê se ela já dá outro curso pra outras pessoas que queiram entra nesse grupo nosso, porque nós vamos crescer.

E: - Uhum.

J: - Então a gente precisa de pessoa qualificada pra trabalhar... Que fez o curso.

E: - É, com certeza...

J: - A gente não pode contratar ninguém fora do nosso curso.

E: - É.. Tem que saber né? O que é o cooperativismo...

J: - É...

E: - Pra consegui escolhe se quer fazer parte ou não, né?

J: - É!

E: - Porque às vezes a pessoa entra e nem sabe o que tá fazendo, né?

J: - Não sabe, entra aí depois fica um mês e quando sai... E como que a gente vai fazer?

E: - Daí pra vocês é ruim, né?

J: - É ruim porque aí já vai ter que pagar dias, vai ter que, né... A administração já tem que, já tem que logo contratar outra pessoa mandando outra embora né, e o grupo não, a cooperativa não, a cooperativa é aquelas pessoa, eles vão sair, pedir uma demissão só se ficar doente, se não puder mais trabalhar, vamos supor, eu já tô ficando um pouco velha, eu tô cansada, eu vejo que não dá mais pra mim trabalhar eu peço minha demissão, mas aí eu ponho outra pessoa no lugar, né... E: - Uhum..

J: - Né, pra continuar aquela cooperativa, não tirando uma pessoa lá de fora, uma já do nosso meio ali, uma que já fez o curso.

E: - É..

J: - A pessoa pode até fazer o curso e não entrar logo não querendo entrar, mas que tenha o curso igual nos tamos fazendo...

E: - Tá preparada, né?

J: - Tá preparada, a hora que a gente precisar são aquelas pessoas que a gente vai chamar.

E: - Uhum. 
J: - Inclusive estes que estão aí ó... Os outros que começou junto, a gente que vê se eles voltam a fazer porque a gente vai precisar, principalmente do Deílson porque na contabilidade por enquanto eles tão entrando aí, o Werner, a Nadir, você, todo mundo junto, a hora que sair eu não sei se a gente vai da conta de tudo isso não...

E: - É, vocês vão dar conta sim, mas tem que se prepara bem, né?

J: - É, e a gente queria preparar uma pessoa, principalmente um jovem, né, que estuda mais do que a gente, que tem mais facilidade pra né, pegar as coisas, pra ficar naquele grupo pra administrar, nós sabendo, a hora que dá alguma coisa... Nós vamos saber, a gente vai saber entender tudo da administração. Mas a gente está, bom no meu ponto de vista, não sei os outros estão igual eu, estou pensando assim, de preparar uma pessoa para isso, pra ficar mais ou menos naquela área ali, de contar, de computador porque se eu tô lá na cozinha e vou no computador não vai da certo as duas coisas!

E: - É...

J: - Eu devo saber mexer nele, sabe toda administração da empresa, mas não preciso tá ali diário, tem que ter uma pessoa diária pra fazer isso aí. Acho mais certo, você não acha?

E: - Eu acho que sim, tem que discutir isso com o grupo pra ver, né?

J: - Faz sentido e não tinha nada melhor do que ele. Ele saiu do grupo porque ele é jovem não tá entrando dinheiro ele não pode ficar no grupo.

E: - É...

J: - Eu fico porque tenho a renda, né?

E: - É por enquanto dá pra levar, né? Mas daqui a pouco vocês vão ter que começar a viver disso, né? O que você espera da cooperativa pro futuro, como é que você imagina o grupo? O que você acha que vai acontecer?

J: - Olha eu espero porque esse final de ano agora a gente tirou um dinheiro você viu, né? Você tava aí, né?

E: - Tava.

J: - Tirou aquele dinheiro, um salário pra cada um. Se for ver foi pouquinho foi 100 reais pra cada um. Eu espero que o ano que vem nós já tenhamos o nosso salário 800 dividido pra cada um e mais o décimo terceiro, que seria 1.600 cada pessoas, certo? Se nós trabalhar direitinho o ano inteiro final do mês... Todo mês nós vamos ter cada um com um salário de pelo menos de 600 reais porque dá pra ser, a barrinha tá sendo muito bem aceita lá no comércio. 
E: - Tá!

J: - E no final do ano nós temos que ter um décimo terceiro pro nosso pessoal, não é não?

E: - É, com certeza. E a incubadora também, né? Vocês vão ser independentes, né? Daqui a um tempo!

J: - É vamos ser independente, por isso mesmo só tiramos aquele fundo pra deixar, porque nós não sabemos o que vai acontecer, né? Que ficou um dinheirinho ainda bom lá. Dava pra gente ter tirado um dinheiro melhor, mas é melhor a gente deixar pro final, deixa.

E: - É melhor se preparar pra frente!

J: - Por enquanto a gente não tá comprando nada de mercadoria...

E: - E o que você tem se sentido de mais diferente de trabalhar em grupo no lugar de trabalhar na empresa ou na casa de família aonde você trabalhou? No seu restaurante, quais são as maiores diferenças?

J: - Olha, trabalhar em grupo pra mim é bom porque pra mim eu tô na minha casa, mais gente, todo mundo amigo ali. Eu não tô, nem acho que saí fora de casa, entendeu? Tá ali, toda hora você conversa, você belisca alguma coisa você ver como é a vida nossa aí, né?

E: - Uhum.

J: - E não tem, assim, é nos mesmo que administramos, sabemos que a gente não pode perder o nosso tempo porque nós estamos tirando o nosso próprio, né?

E: - Uhum.

J: - Então todo mundo tem que trabalhar no conjunto, não dá muito serviço pro outro, tem que ser bem amigo, todo mundo fazer sua parte. Eu acho muito legal.

E: - Diferente de ter um patrão, né?

J: - Muito diferente, a gente trabalhar mais à vontade. Daqui uns dias a gente tem que ter um pouco mais de atenção com as coisas. Agora nós pode conversar, mas quando começar nossa cozinha nós vamos ter câmera para gravar as coisas, vai precisar pôr, né, porque nós vamos trabalhar com alimento.

E: - É!

J: - Então a gente tem que ser mais consciente, prestar mais atenção nas coisas.

E: - Ter muita preocupação, né?

J: - É, preocupação, porque as vezes a gente se distrai, um anel no dedo, um brinco, que foi o que as nutricionistas falou que não pode, não pode ter nada disso. Então tem que... Por isso mesmo 
que eu acho que a gente, quando a gente mudar para a nossa cozinha, vamos pôr a câmera, pra saber que tá vigiando a gente próprio e trabalhar sem esquecer de nada...!

E: - Vocês vigiariam vocês mesmas?

J: - É, eu que tô com essa ideia agora, ainda não falei nada com ninguém. Não é bom isso aí? E: - É...

J: - E cada um você não precisa ficar falando, você... Você já entra se já sabe que você tá sendo filmado, você já fica mais na sua postura, né? Tem vez que a gente tando sozinho, você uma coisinha caiu no chão você quer beliscar, mas se a gente tiver em uma cozinha mesmo industrial, você não pode fazer, você tem que jogar aquilo no lixo, você não pode levar.

E: - Não pode levar.

J: - Não pode. Então isso aí vai ser uma coisa boa pra nós, né? Até mesmo uma câmera pra gente saber que a gente tá sendo vigiado agora e evitar esses tipos de coisinhas, né? Que acontece com a gente. A gente policiar mais a gente próprio, né?

E: - E hoje em dia você trabalha quanto tempo, como que tá? Você faz a produção de quarta com eles é isso?

J: - É de quarta e de segunda!

E: - São os dois dias que vocês se encontram?

J: - É e esses dias na produção que a gente teve essa entrega na USP a gente trabalhou mais alguns dias meio tempo.

E: - Daí vocês trabalharam mais tempo juntos?

J: - Foi!

E: - E como foi isso?

J: - Olha, foi bom, melhor do que trabalhar as quatro horas. Foi as pessoas ficaram assim muito... Porque é muita coisa que tinha que fazer, porque acho que grupo precisa ter serviço para a pessoa desenvolver. Aí todo mundo começou desenvolver o seu serviço, acabou que a gente não percebeu, foi muito bom. E depois imagine que a gente ainda tinha horário pra entregar a cozinha, né?

E: - É aí tem que correr, né?

$\mathrm{J}$ : - Tem que correr, deu muito certo!

E: - Ninguém brigou? Tudo tranquilo?

J: - Ninguém brigou... Não deu tempo pra brigar, nem para a Ana que gosta de reclamar, sabe? 
E: - Nem pra isso deu tempo?

J: - Nem pra isso, foi ó, a melhor coisa que a gente fez foi essa produção para a gente aprender um pouquinho melhor, que as vezes a gente acha aquele outro é cricri, é cricri porque não tem tempo de prestar atenção. É igual a câmera que tô te falando, ela que vai ser a cricri nossa. Vai filmar tudo, né? Porque nós tiver uma produção grande nós não vamos ter tempo de prestar atenção nem na gente próprio, que as vezes você vai fazer isso errado, a hora que você ver o filme, "ó lá o que fiz errado".

E: - É você percebe, né?

J: - Percebe. A gente fica mais atenta. É igual a Ana, também se ela ver até mesmo... Se ver esse trabalho todo nosso aí conjunto correndo, pra ela eu acho que ela nem deve prestar atenção, mas nós todo prestamos atenção que ela não implicou com ninguém. Até a louça que você vai lavar, ela acha que a gente não lava a louça direito. Assim é um tipo de um... Você sabe o que é? Ela vive na casa dela, acho que ela sozinha, ela tá acostumada a fazer todo serviço!

E: - Uhum.

J: - Entendeu? E não tá acostumada a trabalhar em conjunto, com o grupo!

E: - Aprendendo, né?

J: - Aprendendo, então tem isso também. Acho que ela é um pouco cricri por causa disso aí.

E: - Você já tinha trabalhado em grupo antes?

J: - Não, eu só trabalhei assim lá no meu restaurante porque lá era assim, sabe? Quando chegava, porque eu servia feijoada também, eu mandava umas 150, 160 mamitex, levava... Todo sábado então assim, nós tinha que trabalhar em grupo porque por exemplo, um punha feijão, outro arroz, não sei o que lá, um fechava e outro ia na caixa. Então era todo mundo porque era muita coisa e a gente tinha que ter produção, né? Uma pessoa só não poderia fazer. Eu pegar o mamitex e pôr tudo fechado não poderia fazer aquilo, não dava conta. E em grupo é bem melhor, tudo que era feito em grupo então eu trabalhei nessa época, né? Deu tudo certo, a única coisa que a gente fazia em grupo era isso, né? Era na hora de fechar os marmitex, mais a cozinha a comida, fazia mais o pesado era eu.

E: - Você ficava com o mais pesado pra você?

J: - Se eu fosse fazer um arroz eu tinha que começar desde o começo, lavar o arroz, porque a gente usava um lavador que hoje em dia não dava mais, né? Lavar o arroz, fritar alho, até cozinhar. Hoje em dia não se você lava o arroz, outro põe no fogo, outra faz outra, e vai indo e 
outro termina.

E: - É agora você tá trabalhando no Mãos na Massa, né? E você continua morando na mesma casa com seus dois filhos e seu marido?

J: - É.

E: - Só que você divide uma casa com seu filho mais novo?

J: - Não agora, isso eu tenho que te falar. Como teve esse problema do meu filho ter sido preso eu falei assim, ele foi preso por isso porque deixei eles muito na casa só, você entendeu? Então agora eu peguei aluguei as outras casas inclusive até comprei um carro, um carro até novo!

E: - Ah é?

J: - É comprei o carro novinho da concessionária um Fiat 2009, comprei do ano mesmo, que eu quero ir trocando, né?

E: - Uhum.

J: - Então eu falei assim, eu fico com essas casas tudo parada aqui então eu vou alugar essas casas já que não recebi meu carro ainda e vou comprar não poso ficar andando de ônibus. Eu vou pegar o dinheiro desse aluguel e vou pagar a prestação do carro e nós vamos morar juntos, porque vou ficar aumentando serviço pra mim?

E: - É...

J: - E andando pra trás!

E: - É.

J: - Andando de ônibus, andando de não sei o que, sendo que tenho condições de evoluir. E fiz isso, aí eu peguei aluguei todas as casas, passei a morar na casa só, que nós tamos morando nós quatro na casa só até meu ex-marido, que ele briga demais. Eu falei assim, você não faz comida, não faz não quem faz sou eu, então você vai ficar aqui.

E: - Claro...

J: - Não é não? Eu falei assim, a casa nós não vamos vender, então vamos morar junto meu filho.

E é assim que a gente tá vivendo.

E: - E tá dando certo?

J: - Tá dando certo, eu administro tudo, pago tudo que a gente compra, faço compra, faço tudo e sai briga porque a pessoa bebe acha que gasto muito dinheiro, pego o dinheiro dele. Se eu deixar o dinheiro na mão dele ele vai beber tudo, né? Esse dinheiro que trabalha aí por fora, que ele faz bico aí por fora. ele ganha bem, sabe? Ele fala, mas ele bebe tudo de cachaça, ele dá, distribui... 
E: - E seus filhos estão trabalhando também?

J: - Tem o mais novo que trabalha e estuda, faz faculdade em Taboão, de administração, né? E tá trabalhando na Leroy Merlin.

E: - E o outro filho tá tentando, né?

J: - Tá tentando porque como ele foi preso as empresas não dá crédito

E: - É difícil, né?

J: - É difícil e eu queria abrir um negócio pra trabalhar assim, mas se eu for abrir um negócio, já que ele tem esse problema do cheiro, não vai adiantar nada, só vou dar dinheiro na mão dele.

E: - É, provavelmente, né? Ele precisava se tratar antes.

J: - Porque o negócio pega o dinheiro vivo ali você tem que se administrar seu próprio negócio, então não tem jeito o dinheiro entra primeiro na sua mão. Aí eu não posso fazer isso, por enquanto ele tá tentando arrumar um serviço. Melhor você arrumar um serviço trabalhar de empregado primeiro pra você se doutrinar, depois eu vejo o que faço.

E: - Você pretende abrir um negócio do quê?

$\mathrm{J}$ : - Eu, pra ele, não é pra mim não!

E: - Ah pra ele trabalhar, você ficaria no grupo?

J: - Porque eu tô no meu grupo, eu já até tive uma conversa com ele. Falei, ó, se você quiser agora no grupo, agora não tá dando dinheiro não, mas se mais pra frente você quiser entrar no grupo é só você fazer o curso, porque lá precisa ter motorista, de fazer entrega, porque agora não tem, mais para frente nós vamos precisar comprar um carro para empresa, pôr motorista, não é?

E: - Vai ter que fazer entrega, comprar coisa...

J: - Lógico vai ter que ter uma pessoa, vai ter que contratar uma pessoa. E essa pessoa que vão contratar vai ter que ser do nosso grupo, vai ter que fazer o curso pra tá dentro da empresa, não querem pegar ninguém de fora.

E: - Isso vocês já discutiram, né?

J: - Já discutimos, isso mesmo pode ser meu filho ele é um bom motorista, conhece a cidade inteira entendeu? Eficiente mesmo, porque desde 12 anos que ele dirige. Seria uma boa, porque vai rápido... Sabe tudo, né? Mas eu tando no grupo na cooperativa pra você entrar você tem que fazer parte dele. Porque eu não vou carregar ele na minhas costas, entendeu?

E: - É né, senão não tem porquê...

J: - Porque chega lá, ó é o filho da Joaninha. Ah não porque tá dando boi para ele, aí... Ah não, de 
jeito nenhum, porque lá todo mundo é igual, na empresa, na cooperativa, né? Então tem que fazer esse curso e saber que tem que ser responsável. Se ele quiser entrar eu falei assim, agora não vai dá dinheiro não, mas daqui a uns dia vai viver todo mundo bem. Eu acho que todo mundo vai dar conta de comprar seu carrinho novinho, né? E souber administrar direitinho dá.

E: - É tem que saber, né?

J: - Tem que trabalhar porque se nós abrir um negócio lá na praça você tem que ter barrinhas, você viu que era muita barrinha, né? Tava todo mundo reclamando que não tem mais barrinhas. Você vê, todo mundo já tava pedindo barrinha lá do serviço da minha nora. Eu falei assim, agora só depois que a gente começar a trabalhar. Porque tinha essas que a gente fez, mas já acabou porque a Márcia ficou com vinte, que a Ana não quis ficar, porque o negócio foi isso, sobrou sessenta barrinhas, aí nós falamos assim, "olha então amos dividir entre nós cada um leva um pouco pra vender porque é nosso, né? Nosso grupo, nosso dinheiro". Aí a Ana já falou "eu não levo porque não gosto disso e não vou vender pra ninguém".

E: - É aí fica difícil, né?

J: - Difícil! A Maria é uma ótima pessoa, aquela menina ali é uma menina que eu... Aí tudo bem, a Maria levou um pouco, a Cristina levou também, o Luís, o Carlos, a Carina, eu, Márcia, todo mundo só não Ana, Ana não levou, todos levaram. Aí que nós fizemos, ia fazer ela levar? Ela tinha que saber que nós tavamos dividindo pra gente vender, entendeu? Nós tinha que pegar a parte dela, mas ela não quis, ninguém falou nada. Comentar tá sendo agora que eu tô fazendo. Eu sei que todo mundo sentiu isso, só tô expondo porque tá gravando.

E: - E por que você acha que ninguém falou nada?

J: - Acho que não quis falar porque já tava final de ano e tal. Já tinha acabado a reunião e tudo, então ia ficar igual uma atrito ali... Deixa isso, né?

E: - Ninguém quis falar pra ela naquela hora?

J: - É ninguém falou nada, nem comentou aquele assunto ficou do jeito que ela falou, eu só tô comentando agora, é ruim. Eu não gostei que ela tinha que ter pego as dez dela. Aí a Márcia falou assim, escuta, e agora o que a gente faz? Vamos dividir eu levo 20 você leva 20. Eu falei assim, pra mim tanto faz porque eu, se eu levasse toda essa sobra que sobrou... Aí a Ana falou assim, mas eu não vou levar pra eu levar essa sobra vocês tem que fazer mais barato porque isso é uma sobra. Eu falei assim, não é sobra esse aí a gente fez pra vender no congresso e não vendeu. A sobra que a Nadir vende mais barato lá na ITCP é porque as barrinha quebra, aí ela vende mais 
barato. Ela não vai vender uma coisa quebrada pelo mesmo preço, porque geralmente ela tinha que dar ou deixar pra degustação, não podia nem vender. Ela vende porque o grupo tá começando arrecadar o dinheiro, né?

E: - Uhum.

J: - Ela vende mais barato, a 50 centavos, tá bom, né? Aí, mas essa nossa tá inteirinha, embaladinha, direitinha, não vai fazer diferença porque quando começou foi eu mesma que perguntei, eu perguntei bem mais na proposta, mas nunca desfiz disso até agora, porque eu fiz a proposta. Eu falei assim, então tudo bem. Eu fui uma das primeira que tava comprando barrinha era só a Nadir e levando pra lá, acho que uma das primeira que quis comprar... Eu disse, bom quero comprar umas barrinhas, mas pra mim vocês vão vender mais barato. Aí todo mundo numa voz só falou não, é igualzinho vende lá fora. Era o que eu queria, não falei nada tava querendo isso mesmo. Tudo bem se não concorda eu compro o preço que tá lá fora porque sou consumista e vou comprar, né?

E: - Uhum!

J: - Porque é meu negócio eu tenho que falar bem pelas minhas barrinhas, né?

E: - Claro, é sua também, né?

J: - Lógico. Porque eu vou pagar mais barato? Se eu gosto da coisa eu posso até paga mais caro, né? Aí tudo bem, ficou nisso aí, agora como ela diz que é sobra era o direito de cada uma levar, às vezes ela queria comprar uma barrinha, achou uma barrinha cara por 80 centavos, e queria comprar dez centavos a menos. Não, não tem que fazer a menos, eu falei assim, menos não vai fazer porque as barrinhas não tão quebrada e ela pode vender até daqui a seis meses ela pode ser vendida que não vai estragar. Que já foi incubada, já sabe que pode vender, né?

E: - Uhum.

J: - É tem essa validade por enquanto, tá lá do jeito que estar. Então, se não vender ela agora a gente pode deixar ela aí pra gente vende ela por 80 centavos.

E: - Mais pra frente.

J: - É ela falou assim, não vou levar. Eu falei assim, tudo bem!

E: - Não levou!

J: - Não levou e não fizemos diferença, não fizemos porque o próprio grupo tá sabendo do negócio, porque que ela não fez? Tá querendo furar o olho do outro, porque aquele dinheiro é do grupo. Nós estamos tirando de nós próprios, né? Então não pode ser assim. 
E: - Daí todo mundo ficou quieto então, deixou pra resolver mais pra frente?

J: - É ninguém falou nada sobre isso, mas eu já tinha dado a jogada antes pra mim chegar no final. Você viu como eu mudo de história, demora, mas eu chego onde eu quero. Eu fico quieta, mas passa um ano, passa dois, eu chego naquele lugarzinho onde comecei...!

E: - Já preparou, né?

J: - Já preparei.

E: - Deixou claro e depois só lembrar disso.

J: - Aí é só lembrar, eu quis fazer isso, eu perguntei se ele concordassem, porque eu queria comprar, mas é melhor o mesmo preço, tá bom.

E: - Então é igual pra todo mundo...

J: - Igual pra todo mundo, eu concordei porque é bom porque aí não vai ter diferença. A produção deu tanto, é o mesmo preço pra quem vendeu...

E: - É o justo, né?

J: - O justo, não vai da diferença no dinheiro, na contabilidade. Porque aí, porque vendeu pro funcionário, vendeu pro funcionário, mas é o mesmo preço o dinheiro dele tá ali.

E: - É são todos cooperados, né?

J: - É!

E: - Então tá vendendo bastante barrinha nessa empresa?

J: - Ah vende, lá em casa... Então isso que ia falar, aí ficou como achou que era um grupo todo mundo deve levar, porque isso aí é até bom pro grupo crescer, que senão fica aí que como o Carlos, deixando as coisas todas com o Carlos, porque antigamente quem tava levando barrinha era só Nadir, Nadir tá certo que é uma professora, tem nada a ver que tem que vender as barrinhas somos nós, né?

E: - Uhum...

J: - Que eu sei que ela tava muito cansada, assim, você já percebendo na cara dela, né? Então porque eu sei que não é fácil não, né? Aí a gente falou isso mesmo pra dividir o grupo pra todo mundo, para ninguém ter muita responsabilidade com as barrinhas, porque se a gente faz uma produção grande, 5.000 barrinhas nós temos que vender essa barrinha. Você tá ali, você tá vendo o final do mês chegando e as barrinhas amontoadas o que você vai fazer?

E: - Problema, né?

J: - É você tem que vender é o nosso salário também, todo mundo tem que correr, que no final do 
mês todo mundo quer salário, né? Você vê, a Ana ficou toda feliz porque recebeu dinheiro, mas é a única que não compra barrinha e nem vende.

E: - É.

J: - Entendeu? Ela não tocava nesse ponto. A gente não pode só querer receber o dinheiro!

E: - Vocês vão ter que decidir isso, né?

J: - Vamos ter que decidir. Você não viu o pai do Leandro lá, que pegou o salário comprou tudo de moeda pros caras telefonar pedindo a música do cara, para ele crescer? É a mesma coisa que a gente tem que fazer com as nossas barrinhas.

E: - É verdade... Essa história é boa.

J: - É! Você tem que apostar no que você faz, se você quiser crescer você tem que começar a consumir de casa. Fazer os poucos o pessoal consumir. Igual meu neto, ele adora barrinha então o amiguinho dele também vai gostar que ele vai incentivar, vai indo, vai indo, vai mostrar que não igual qualquer barrinha produzida no mercado, certo?

E: - Uhum.

J: - O tipo dessa menina aí ela tá andando pra trás, e no nosso grupo ninguém pode andar pra trás não.

E: - É vocês vão ter que da uma puxada nela pra trazer ela junto com o grupo.

J: - É! Agora no ano que vem, acho que todo mundo deixou essa questão aí da barrinha parada porque ano que vem vai retornar. Na primeira reunião vai ter retomar esse assunto aí. Nós vamos dar conta das barrinhas que levou. As minhas graças a Deus chegou lá.

E: - Uhum!

J: - Entendeu? Que lá em casa eu vendo muito, mas se eu tenho alguma produção que levo num instantinho comem tudo. Quando eu vou procurar pra vender já não tem mais.

$\mathrm{E}:$ - Come mesmo?

J: - Come, lá em casa comem. Eles gostam muito a de maçã, da de banana, de não sei o quê. Vai comendo as que têm, a hora que acaba as outras que ele não gostam comem do mesmo jeito.

E: - É incrível, consomem... A sua própria família consomem as barrinhas.

J: - Consomem. Eu falei, se eu tivesse dinheiro vocês nem precisava levar essas barrinhas, eu levava, eu comprava tudo.

E: - Uhum!

J: - Ia fazer uma cestinha lá pro Natal no final da noite não tinha um todo mundo já tinha comido. 
O problema que não posso investir tanto assim, porque nós somos um grupo, todo mundo tem que ajudar, senão ao invés de eu crescer vou falir só eu sustentando. Eles também tem que comprar e vender.

E: - Foi você que sugeriu pra ser barrinha o produto ser barra de cereal?

J: - Olha, eu fiz muito, eu fui uma das primeiras que falei, que bati o pé que eu queria barrinha de cereal!

E: - É porque barrinha de cereal?

J: - Porque eu gosto de mastigar essa coisinha assim...!

E: - Você gosta de comer?

J: - Gosto de sentir mastigando mesmo sabe?

E: - Daí você achou uma boa fazer isso?

J: - Eu gosto assim de tá em algum lugar comendo, eu compro essa pipoquinha, sabe essa pipoquinha de saquinho vermelho de arroz, aquilo é duro, né?

E: - É durinho!

J: - Eu gosto daquilo!

E: - De mastigar!

J: - Eu adoro coisa pra mastigar, eu, se ela fosse mais molinha eu não ia gostar. Eu gosto do creccrec, sabe? Cereal, porque é aquela coisinha durinha, né? E pra mim eu tô contente viu, do grupo eu só saio se eu ficar doente, expulsa acho que eu não vou ser porque eu não vou fazer coisa errada para ser expulsa, né?

E: - Não tem porque, né?

J: - Não tem porque ou então posso morrer assim, sem um motivo, né?

E: - Todo mundo pode morrer a qualquer hora...

J: - Mas por enquanto, você viu o marido da menina lá que morreu?

E: - Uhum... Você viu? Que escândalo, né?

J: - É, eu até já falei para o meu filho, ó, toma cuidado. Uma vez eu levei desse jeito, nossa já me deu tanto trabalho aqui no Bandeirantes, eu levava ele direto. Você sabe que essa veia aqui cresce, eu tive que sair correndo. É, ele só não morreu porque a gente socorria, chegava lá o médico já sabia, né, o que era, já cuidava logo.

E: - Foram muitas vezes?

J: - Muitas vezes, isso aqui era direto, era toda hora ele na farmácia pra tirar pressão. 
E: - E hoje em dia tá igual?

J: - Não agora ele melhorou mais, tá um pouco melhor. Mas essas pessoas que usam, um dia que ajunta aí a turma, aí vai querer usar bastante, é o que aconteceu com o cara lá da overdose.

E: - Daí perde o controle, né?

J: - É igual eu, eu tenho ele aí, mas eu não posso confiar muito. A qualquer hora tá acontecendo a mesma coisa!

E: - E pior que é...

J: - Eu falo assim, nossa filho você tão bonito, rapaz grande. Você vê é um rapaz bonito, mas é assim. Pra começar fica assim, vai acabando...

E: - Destrói, né?

J: - Destrói tudo.

E: - Obrigada Joana, você falou Antônia seu nome é Joana Antônia?

J: - Não meu nome... Ainda tem outra coisinha pra você por aí na gravação. Meu nome de Joana, sabe o que que é? Diz que eu era um bebê, cabelo nunca tive é esse pouquinho mesmo. Disse que era um bebezinho carequinha que não tinha um só pêlo na cabeça, parecia uma joaninha.

E: - Ahhh!

J: - Vermelhinha, sabe?

E: - Quando você nasceu?

J: - É, aí todo mundo chegava, nossa mais parece uma joana, nossa mas parece uma joana. Aí meu nome ficou Joana!

E: - Ficou mesmo registrado Joana?

J: - Meu nome é Maria Antônia.

E: - Sério Joana? Mais aí todo mundo te chamava de Joana?

J: - É, todo mundo e ficou até agora grande que, pois meu apelido, apelido cola ali na família... A família joga pra frente.

E: - Nossa que divertida essa história.

J: - Uma vez já voltou telegrama quando meus filhos era pequeno, aí antes eu não ligava muito pra essas coisas, né? Todo mundo Joana, Joana, nem ligava em ver nome, documento. Uma vez chegou um telegrama e voltou!

E: - Que não tinha ninguém com esse nome!

J: - Não! Não tinha ninguém lá com Maria Antônia não! 
E: - Confusão, hein?!

J: - É!

E: - Aí ficou te chamando de Joana, e você prefere Joana ou você gosta mais de Maria Antônia?

J: - Olha eu gosto mais do nome verdadeiro!

E: - É?!

J: - Esse nome Maria Antônia, nome é do meu pai Antônio, sabe?

E: - Ahã.

J: - Que ele se chamava Antônio e ele gostava muito... Nossa, quando nós nasceu, quando eu nasci ele falou assim, vou por o meu nome nela, é pois. Tanto tem isso que eu me acho Antônia e tem esse outro menino que chama Antônio esse que não é filho dele que ele registrou.

E: - Ah, chama Antônio também?!

J: - Também já tem um tempão. Até inclusive quando ele era vivo eu perguntei: "olha o Antônio é seu filho porque você deu o dele, o nome seu pra ele assim, né? E eu também não sou sua filha?". Eu fiz essa pergunta, ele falou assim “não você é minha filha querida, fiquei tão feliz quando você nasceu, que eu falei assim, vou dar o nome dessa menina, porque tinha a primeira era uma menina, a segunda uma menina, a terceira uma menina... Não, é demais, vai ter que chamar Antônia".

E: - É!

J: - "Vou pôr meu nome, quem sabe vem um menino na próxima."

E: - Aí ele pegou esse menino também e colocou Antônio.

J: - Pôs Antônio nos dois filhos dele. Eu Maria Antônia e o outro se chama Antônio!

E: - Entendi, mas virou Joana...

J: - Virou Joana, meu nome é Joana!

E: - Todo mundo te chama de Joana, Joaninha!

J: - Todo do mundo, todo mundo. Você vê aqui no grupo eu dei o nome de Antônia mais no fim acabou como Joana, que a Márcia já me conhecia, já sabia do meu apelido...

E: - Não teve jeito?

J: - Não tem jeito!

E: - Nem aqui você conseguiu!

J: - Não consegui.

E: - É Joana mesmo 
J: - É Joana mesmo e vai crescendo esse negócio aí, né?!

E: - Mas tá bom, acho que deu pra falar bastante coisa, né?!

J: - Nós ficamos quantas horas?

E: - Duas horas e meia...

J: - Meu relógio parou, agora ele começou... 


\section{Parte II}

J: - Tem um rapaz aqui na prefeitura que ele fazia rótulo, ele trabalhava com isso. Então eu fui vender barra e acabei vendendo pra ele, e eu falei assim, olha, só que a nossa barrinha tá sem rótulo, só que nós estamos com dificuldade. Ele falou, “ah, mas por quê? Eu faço isso aí”.

E: - Ele faz rótulo?

J: - Faz, e ele é da USP. Ele trabalha aí na prefeitura e trabalha na USP. Ele chama Ernesto.

E: - Mas onde você ia vender que precisava de rótulo?

J: - Não, nós estávamos querendo o rótulo, porque ultimamente...

E: - Ah, tá, você foi atrás do rótulo.

J: - Por que você vê, ultimamente isso tudo que tá acontecendo aí, você vê, o menino comeu a pizza quase morreu. Vai que come uma barrinha, fica doente e fala que foi a barrinha. Como é que a gente vai ficar? Então se a gente vai vender uma coisa assim, é melhor a gente tá segura, ainda mais a gente que trabalha com segurança alimentar. Eu achava melhor o rótulo. Aí eles ficaram sempre enrolando, ah, a gente vai fazer, a gente vai fazer. Você viu, não é? Você tava lá no grupo você viu. Aí tudo bem, aí eu pensei, bom, não custa nada eu levar no grupo, aí eu falei um dia: "olha Nadir, a gente encontrou uma pessoa, fui eu e Vicente, não fui eu sozinha...".

E: - De onde é essa pessoa. É daqui mesmo?

J: - É ele ficava aqui mesmo com o Wellington. Todo mundo conhece, eu coloquei ele no grupo. Vê se ela escreve.

E: - Mas onde você o conheceu, aqui?

$\mathrm{J}$ : - Na prefeitura.

E: - Ah, tá.

J: - Aí, como é que é, no Sale, não, foi na prefeitura mesmo no Sale lá em cima sabe? Ele trabalha no, tipo nos computadores lá em cima. Aí eu conversei com ele e perguntei se ele não queria aparecer aqui pra fazer uma demonstração dos, como é que chama... Os folders que eles tem. Ele trouxe tudo pra mostrar. Ele falou, posso sim. Ele trouxe tudo aqui na cozinha. E chegando lá a Nadir não gostou nada.

E: - Por quê?

J: - Porque disse que eu estava passando os pés pelas mãos, não falou na frente do cara, falou depois. 
E: - Tava fazendo o quê?

J: - Passando os pés pelas mãos. Porque não podia gente tomar essa atitude. Eu disse, eu não fiz o rótulo, eu só trouxe a pessoa, porque vocês estão sentindo dificuldade de encontrar... E nós tinha dinheiro pra pagar. Porque nós tinha quase 5.000, então dava pra gente fazer com nosso dinheiro. Não precisava nem mexer no dinheiro do projeto, porque o que a gente queria era o rótulo.

E: - Vocês tinham quase 5.000 no fundo é isso?

J: - De todos não é, inclusive o Luís não pegou nem um centavo desse dinheiro. Nem ele e nem a Ana.

E: - A Ana saiu?

J: - Ana morena. A Ana saiu.

E: - Por quê?

J: - Por causa disso. Ela tava no dia, aí ela já saiu logo encima. Aí uns 15 dias ela já pulou fora. Aí ela falou, vocês estão enrolando a gente, vocês não quer dar o rótulo, então eu não vou perder meu tempo. Porque eu não posso trabalhar com alimento sem rótulo. Até uma bala doce tem. Não é? E vocês tinha tirado tudo pra nós, tudo direitinho. Ensinou como que a gente ia administrar, e as nutricionistas tirou tudo, não é? Pois tudo as propriedades da barrinha. O que custava fazer o rótulo?

E: - Mas por que eles não queriam fazer você acha?

J: - Não queriam não, não querem fazer rótulo, a verdade é essa.

E: - Mas por que você acha, qual é a explicação?

J: - Ah, eu não sei não. Eu acho que a explicação, não sei...

E: - Porque é estranho.

J: - É, eu também acho estranho. Quando o Alexandre saiu do grupo, você conheceu o Alexandre? Ele já deixou o rótulo pronto. Era só imprimir.

E: - Estranho Joana.

J: - É. Isso tá estranho.

E: - Bom, a Nadir falou então que não concordou, mas o resto do grupo concordou, o resto do grupo queria o rótulo?

J: - Não, todo mundo queria o rótulo.

E: - O grupo todo tava a favor do rótulo? 
J: - O grupo todo. O grupo era a favor. Só que a única pessoa que bate o pé, é a Nadir, Luís que não fala, mais fica na dele, já percebeu, quer cair fora. Porque ele não é muito de falar sabe, dar opinião.

E: - Não...

J: - Ele fala muito dos projetos, quando entra projeto ele conversa. Ele é bem tímido, mas nesses assuntos ele conversa. Mas não dá opinião, se quer ou se não quer, agora é a Ana, o Carlos, eu e o Luís. O resto concorda com tudo. Se ficar pra lá e pra cá sentada o dia inteiro eles vão ficar. Você entendeu? E a gente não concorda porque, a Márcia coitada, todo projeto que põe ela entra no meio. E não sabe nem o que vai dar no final.

E: - Ela nem pergunta?

J: - Não, ela pega todos os bondes, ela quer sair em todas, entendeu? E eu vim por causa dela. Mas depois eu vi que não tem futuro eu não vou ficar num lugar, não é, assim.

E: - Mas você acha que não tem futuro por causa do rótulo?

J: - Por causa do rótulo, porque a gente vai ficar a vida inteira só vendendo em feira, esse negócio a gente tem que abrir um negócio porque essas barrinhas estão muito bem demonstradas e o pessoal gosta delas.

E: - Então Joana, mas é muito ruim você desistir disso, porque é um projeto seu também.

J: - É, mas o problema meu, eu estive até conversando, e quem mais eu conversei foi com Carlos.

E: - Carlos continua?

J: - Carlos continua porque o Carlos foi o que mais investiu nisso aí.

E: - Ah é?

J: - É. Em todos os pessoal do grupo foi o Carlos que sempre esteve presente em todas as viagens, Rio de Janeiro, aqui em Campinas, todo lugar que é pra viajar foi o Carlos que foi. Ele que demonstrou o negócio, então quer dizer que ele é o cabeça. Do resto do grupo, de todos nós. Quando os outros não vai, só sobra pro Carlos. Ele tá indo. E ele quer ficar porque ele investiu tanto, e quer ver o futuro do grupo.

E: - Mas você também investiu muito não é?

J: - É. Eu investi, mas não tanto quanto ele, mas eu falei assim, eu só volto quando essas barrinhas estiverem com rótulo. Antes disso não.

E: - Ah, mas aí você pensa em voltar? 
J: - Porque a gente, foi nós que fundamos o grupo. Das barrinhas não é? Nós tivemos a receita desde o começo.

E: - Então, por isso é uma pena não é?

J: - É, agora, a não ser que eles estão querendo vender a patente das nossas barrinhas. Por isso que não quer dar o rótulo pra gente.

E: - Não, não é isso não. Não é isso, eles estão querendo ajudar mesmo, mas eu não estou entendendo, ela não explicou porque ela não queria o rótulo agora, nada disso?

J: - Ela disse que tem uma pessoa da USP que vai fazer o rótulo, que não pode fazer agora mas a Márcia tá indo pra Santo André, atrás desse rótulo. Na faculdade, tem uma faculdade lá, tem uma pessoa que faz rótulo, ela se desloca daqui, paga condução pra ir lá pra Santo André.

E: - Mas porque ela não faz com esse moço da prefeitura?

J: - Porque a Nadir não quer.

E: - Mas ela quer com o cara de Santo André?

J: - É porque é da USP é do movimento deles. É estranho esse negócio não é?

E: - Nossa. Muito estranho.

J: - É estranho. Aí digo, na frente do Ernesto ela não falou nada, só não fechou negócio com ele. Eu trouxe ele pra ela fechar o negócio. Mas quem tem o dinheiro é que paga, não é? Aí ela não fechou, ele trouxe uns rótulos bonitos, mas não se falou nada, quando o cara foi embora aí ela falou. Ela ficou nervosa.

E: - Mas ela falou na frente do grupo?

J: - Foi, foi aí que a Ana falou, e por quê? A Joana tá certa, você não falou que a gente podia fazer, que as barrinhas são nossa, fomos nós que fizemos ela crescer, vocês estão aqui como nossos professores, mas nós temos que querer, a gente precisa de um salário, não é? E a gente não pode fazer nada, vai ficar esperando vocês fazerem? Se a gente encontrou vamos fazer, né? Aí pronto. Aí vem Nadir e disse, ah, é assim? A Nadir ficou meio irritada, falou um montão lá, eu não sei mais o que ela falou, eu disse então olha eu tô saindo fora. Aí um dia a gente combinou uma reunião, e a Ana pensou que era lá embaixo no CRSAN. E ficou esperando, mas nós estávamos aqui. Ah, ela ficou muito nervosa. E ela não apareceu mais.

E: - Ah é?

J: - É, foi a última vez que ela veio...

E: - Logo depois ela desistiu também? 
J: - Foi, desistiu não apareceu. Nunca mais eu a vi.

E: - A Maria continua?

J: - A Maria continua. A Maria, a Carina, a Cristina, a Márcia e o Carlos só. Porque depois, aí uns dois meses que a Ana saiu, eu saí. Porque tava, eles tiraram vínculo com o ponto do Pólis, e a gente vendia tudo, já toda quarta, não sei se era a quarta ou a quinta.

E: - Tiraram o quê?

J: - A nossa venda lá do Pólis.

E: - Por quê?

J: - Ah, disse que não podia mais ir vender lá. Que era pra mandar as barrinhas. E lá a gente vendia bastante. Eu já cheguei a vender R \$90,00 num dia.

E: - Mas continua vendendo lá?

J: - Agora, depois que eu saí, disse que eles voltaram a vender. Aí reveza a Cristina fica lá uma hora, mas as meninas não fazem, ia eu e o Carlos, a gente chegava na faixa de umas três, três horas lá e ficava até fechar o Pólis. Que tem reuniões, tem tudo, e a gente vendia bastante lá. O pessoal adora. Adora as peças. Aí disse que ficou dois dias. A Helenice me deu a maior força, nossa... Levou, apresentou nós no começo em todas as salas, a Helenice foi muito legal com a gente.

E: - Joana, e depois que você saiu do grupo, quando foi que você saiu? Sabe?

J: - Ah, não sei não. No caderno deles lá está escrito, você tinha que ver com a Márcia. Qualquer dia você telefonar pra Márcia...

E: - Eu vou encontrar com Mácia amanhã.

J: - É, então você pede, que o caderno de presença está.

E: - Mas faz tempo?

$\mathrm{J}$ : - Faz uns dois meses.

E: - Dois meses?

J: - É. E eu nem liguei pra reunião, porque eu tinha umas coisas pra resolver, eu só assinei o caderno, não tinha vínculo. Eu não tinha vínculo, e podia só assinar o caderno.

E: - E aí o que você sentiu de sair assim?

J: - Ah, eu já estava tão acostumada com o pessoal, aí foi como se fosse uma família. Então eu senti que se tivesse um pouco desmamada, mas vai fazer o quê, não é? Eu não vou ficar andando 
em volta de mim mesma, mexendo nas coisas sem fazer. Eu não lavava mais a casa, não fazia mais nada.

E: - Por quê?

J: - Porque, é reunião hoje, feira não sei onde. Tinha feira que a gente tava indo que a gente vendia seis barrinhas.

E: - Nada, não é?

J: - Nada. Porque as mais fortes a gente não ia, sabe? Teve um evento aí no Ibirapuera, chegamos lá tava tudo as barracas armadas, de todo mundo, a nossa não. A gente devia tá lá.

E: - Por quê?

J: - Ah, porque eles não ajeitavam pra nós, eu não sei porque.

E: - E não valia a pena ir nessas feiras então?

J: - Nessas aqui ultimamente não, porque as feiras mais fortes onde a gente queria ir era lá na USP, que lá a gente vendia bastante, tem lá em frente ao bandejão que vende bastante, mas a gente não pode ir, não pode ir, os lugares melhores gente não pode ir.

E: - Mas porque não pode?

$\mathrm{J}$ : - Ah, não sei porque.

E: - Quem disse que não pode?

J: - Ah, a Nadir que fala que não pode.

E: - E ela não explica porque?

J: - Não, porque tem que fazer um contrato, tem que fazer um, não sei, tem que fazer um monte de coisas. É tudo burocracia deles lá, tem que fazer o contrato com aquela pessoa, se inscrever. Aí eu falei, se inscreve, põe a gente no site, se inscreve aí, né, faz alguma coisa. Então a, como que ela chama, é...

E: - E aí não dava não é? Daí então vocês não podiam ir na feira e foi desanimando não é?

J: - Vai desanimando, vai desanimando. Aí eu deixava as minhas coisas sem fazer, chega no dia tinha que, tinha vez que o dinheiro que a gente vendia, não tava dando nem pra pagar a condução. Aí depois eu fui desgostando, sabe quando você desgosta de uma coisa assim... Não tem mais ânimo. Eu saía com as minhas barrinhas eu vendia tudo.

E: - Onde você vendia?

J: - A gente vendia em todo lugar. Vendia pras minhas amigas, eu passava sempre, eu ia no ali no parquinho do Alfred Besnc, e na volta a gente ia até a prefeitura andando, então parava em algum 
ponto, vendia nesses motel, vendia pras minhas amigas, eu tenho as amigas que trabalham, sabe? Elas compravam cinco, dez. E já ia ajudando, você entendeu? Aí a gente vinha andando, eu mais Márcia até na prefeitura.

E: - Vendia tudo?

J: - Vendia tudo. Nós tudo vendia tudo na prefeitura. O Sr. Osório que é o engenheiro da prefeitura lá, sabe? Ele compra, toda vez que eu ia ele comprava bastante. As amigas dele. Depois tem a, como é que ela chama, esqueci o nome dela agora, ela trabalha no Sasc. Você conhece aquela turminha, não é?

E: - Não.

J: - Márcia vai te falar amanhã. Eu esqueço o nome dela. Não lembro esqueci. Ela apresentou nós lá na sala também, a gente vendeu muito bem, do outro lado de cá da prefeitura, sabe?

E: - Sei. Vendia tudo? E você gostava do trabalho?

J: - Tudo. Gostava do trabalho. Eu adoro trabalhar com vendas. Desde pequena minha família tudo trabalha com umas frutas de pão, pegava laranja as vezes pra poder vender.

E: - É uma vendedora.

J: - Eu sou, eu gosto do que eu faço, vendo bem, sabe. Mas pra mim vender assim não dá. Você tá vendendo, vamos ficar, nós vendemos seis mil de barrinha, mas sem ver o controle, porque quem tá com o controle é a Márcia. Não sei agora, mas nós vendemos tudo isso, só boca a boca. Sem rótulo sem nada. Agora eu fico vendendo um tanto de barrinha, olha que não foi fácil vender duas barrinha por um real e 50. Até dar 5.000 é muita barrinha pra vender, não é? Aí eu fico todo dia te enrolando, olha, mês que vem tem rótulo. É só esse mês, mês que vem já tem rótulo, ia vender pra mesma pessoa.

E: - Mas por quê? A pessoa perguntava?

J: - Perguntava, e o rótulo, não saiu ainda?

E: - Ah é?

J: - Aí um dia eu fui vender, lá no, eu nem falei pra ela sobre isso aí, porque eu já estava um pouco cheia de estar falando as coisas e ela sempre reclamando, aí eu fui vender lá no Jardim São Paulo, e olha que é longe...

E: - Nossa, é longe mesmo. 
J: - Saímos daqui seis horas, lá no Jardim São Paulo, porque tem o Silvio, e tem o Sabão, como é que é o nome lá do comércio, Sabão, eu não lembro, esqueci o nome do coisinha lá... Eu tô assim, eu esqueço tudo.

E: - Eu também tô assim, eu esqueço.

J: - Sabão Natural, olha o nome, tão fácil, não é? Então ele convidou, eu conheci ele lá no COCS, e ele falou assim, olha, eu tenho um comercinho, acho que é na terça-feira, eu falo tipo uma feirinha, um comércio assim, só que era fechado. Aí ele barateia tudo as coisas. Aquelas mercadorias que já está, já vai estragar, vamos supor, se ficar mais uns três dias estraga. Então ele vende tudo mais barato pra vender. E eu fui lá, mas a mercadoria é tudo coisa boa, sabe? Aí ele me falou dessa proposta, se você quiser ir, vocês vão vender barrinha, ficam lá na porta, e eu tenho bastantes freguês, aí vocês demonstram as barrinhas e o que vocês vender é de vocês. Aí tudo bem, eu falei com a Nadir ela, "ah, mas é muito longe, e não sei o quê", aí ela queria comprar pra mim vender lá, mas eu falei, pra mim vender aqui dentro precisa do rótulo. Aí é só entregar, mandar entregar pra eles. Um de nós. Aí tudo bem. Aí eu fui lá duas vezes, e nem falei pra Nadir, no dia ela ficou, porque acho que ela conversou com Gildo e o senhor falou, porque claro, acha que é uma coisa, aí o Silvio deve ter falado com ela e ela ficou me pressionando, "ah, mas não sei o que o Silvio, mas não sei quem". Eu disse "pergunta pro Carlos que eu nem sei do que você tá falando". Não falei. Fui lá duas vezes. E vendi bastante barrinha.

E: - Lá mesmo?

J: - Lá mesmo, na porta, porque não pode vender lá dentro, porque se vender o fiscal passa lá e, então quer dizer que, igual tá aqui, uma mesa tá aqui, igual você estava sentada naquele banquinho, ele punha uma mesinha pra nós punha na mesinha e nós ficava lá. Aí se o fiscal chegasse a gente não ia falar que era dele. Ué, se a pessoa tá vendendo aqui tá na rua, não é?

E: - Vendia bastante?

J: - Vendia bastante, aí na ultima vez que eu fui teve eu falei assim olha a próxima vez que a gente vier... Porque eu já tinha conversado com o Ernesto e já era pra estar com os rótulos e na próxima vez que a gente vier a gente já vai trazer os rótulos. Quando eu fui lá estava sem rótulo de novo aí a moça... Aí o senhor disse que já tinha comprado daí eu virei e falei assim o senhor não vai levar hoje e ele disse assim “não, a minha mulher também faz em casa”. O que ele quis dizer com isso? Que eu estava fazendo barrinha e vendendo lá. Porque estava fazendo em casa. Eu falei assim, “mas cara você viu como que é?”. É do jeitinho que eu estava pensando que o 
pessoal pensa, não é pensamento estranho meu, você entendeu? Então se ele falou isso é porque acho que eu estava tirando, que não era uma coisa séria da USP que estava sendo desenvolvida e ele estava copiando de algum projeto, aí eu falei assim, olha eu não vou mais e eu falei pro Carlos, "olha Carlos se você quiser ir você vai", o Carlos andou indo lá umas vezes.

E: - Mas o grupo sabia que vocês estavam indo lá, o grupo concordava?

J: - Ninguém, não nós não falamos pra ninguém.

E: - Ah não por quê?

J: - Eu não falei porque foi depois disso aí do Ernesto, você entendeu? Como ela disse que eu estava pondo os pés pelas mãos eu não quis falar nada no grupo você entendeu? Eu falei pro Carlos assim, “olha Carlos a gente vai fazer com a evolução das vendas depois nós pegamos e já vende pra ele, já faz o contrato e tudo bem”. Nós fizemos o contrato pra ele, ele é lá do Pólis não tem nada diferente ele esta na rede, mas lá é muito bonito, qualquer dia você tem que ir lá como Silvio, aí você ia tirar muita coisa disso aí porque ele tem o mapa ele entrega tudo as mercadorias das feiras da pessoas que produz lá vamos supor coisa natural vem tudo pra eles aqui sem veneno sem...

E: - Sem agrotóxico

J: - É que eu tenho a língua enrolada e não dá pra mim falar, aí vai tudo coisas naturais, sabe? E ele ajuda muito o pessoal, é deve fazer com as nossas barrinhas e é bom pra gente também.

E: - Mas aí precisava do rótulo?

J: - Precisava do rótulo porque tudo que pega é assim discretamente com rótulo ou não, ele vende couve-flor vende tudo, tudo em mercadoria assim, verduras, legumes, vende grãos também tem tudo lá tem até nozes de produção natural todos os produtos muito legal.

E: - E como foi sua saída? Daí você conversou com o grupo você veio em uma reunião e avisou como foi?

J: - Eu só falei assim eu só vou vender barrinha só volto a fazer agora quando tiver rótulo nas barrinhas.

E: - Mas isso você falou em uma reunião.

J: - Foi não dia que eu assinei e falei assim olha eu não...

E: - Aí o que falaram pra você?

J: - Não falaram nada, eles já me chamaram e tal, a Márcia direto me chama e diz que tá precisando de mim pra fazer esse serviço, eu não vou produzir porque tem um monte de gente 
produzindo, produzir barrinha pra vender sem rótulo pra quê? Eu não vou fazer isso, porque quem sai aí mostrando a cara sou eu, não volto de jeito nenhum eu ando pra todo lugar se alguém te parar aí quem vai pra cadeia é eu. Até eles falarão não eu não mandei vender aqui então eu vou esperar ele sair não adianta, é ou não é? Então quem vai se ferrar vai ser eu então eu não vendo. E: - Mas o grupo continua produzindo bastante?

J: - Continua produzindo, mas não sei se é, porque antigamente nós estávamos produzindo oito formas por semana e nós já estávamos em um salário, quem não tirou esse salário porque não quis receber, foi si o Luís que saiu antes e não quis receber. E a Ana. Foi os dois que não pegou nadinha.

E: - O resto tá ganhando um salário então?

J: - Não. Agora eu não sei, mas até o último que deu pra tirar foi $\mathrm{R} \$ 100,00$, mas já estava tirando $\mathrm{R} \$ 150,00$ todo mês.

E: - R\$ 150,00 por mês? Cada um?

J: - É, cada um. Tava bom, não é? Porque a gente trabalhava um dia só pra produzir, no outro dia a gente vinha mais pra reunião.

E: - Nossa, então tava ótimo.

J: - E se a gente trabalhasse um mês inteiro, uma semana inteira? Foi aquilo que eu te falei, dava pra tirar uns 600 , mais que o salário mínino.

E: - Entendi. Dava pra vocês tirarem uns $\mathrm{R} \$ 600,00$ se trabalhasse todos os dias não é?

J: - Dava até mais. Porque a gente trabalhava assim, vamos supor que o Silvio pegasse uma encomenda, ele ia pegar, porque a barrinha tá com validade de um mês. A gente podia pegar por um mês ou 15 dias. A gente podia pegar umas 200 barrinha por dia, porque eu vendia 50 ou mais por dia. Ia pegar mais ou menos isso. E outro comércio e outro, e outro. Eu ia fazer um contratinho também porque eu tinha um amigo lá na USP, lá naquela lanchonete da USP. E até que eu mandei uma demonstração pra ela lá, pra ver se tava interessado em por lá dentro. Mas sem o rótulo tinha que vender lá dentro mesmo.

E: - Entendi, também tem que ter o rótulo.

J: - E nós perdemos tudo isso, porque quem demonstrou tudo perder uma coisa só por causa do rótulo? O rótulo que não demorava nem um mês pra sair. Tava tudo prontinho, quando o Alexandre saiu daqui tava tudo pronto. E eles ficavam só levando rótulo pra ver. Não importa, o 
tamanho é o tamanho que vai caber lá na barrinha. E eu vejo toda, olha chiclete tem caixinha, tem embalagem, as nossas barrinhas não tem nada. Uma barrinha daquela...

E: - E ela é tão gostosa, não é...

J: - É, ela é uma delicia. Eu gosto e todo mundo gosta. Criança, todo mundo.

E: - Joana, esse tempo que você ficou no grupo, você ficou trabalhando em grupo e tal, não é? E você achou que trabalhar em grupo foi ruim, foi legal, que você acha que foi bom?

J: - Ah, eu acho legal. Muito bom. Muito bom porque a gente faz um monte de coisas não instante, sabe? Quando você se perde o outro já, tá ali cobrindo, é muito legal. Nossa, é uma produção fantástica.

E: - Então você voltaria mesmo, não é? Só não volta por causa do rótulo?

J: - Só por causa do rótulo. Eu não vou vender assim não.

E: - Tá, e me fala só mais uma coisa, se você tivesse opção de trabalhar, de ter um emprego numa empresa mesmo ou trabalhar numa cooperativa como essa e qual você preferiria?

J: - Eu preferia trabalhar na parte de vendas.

E: - Na parte da venda, mas o emprego mesmo ou numa cooperativa?

J: - Não emprego assim...

E: - É normal. Uma empresa com patrão.

J: - Ah, eu preferia numa cooperativa.

E: - Preferia numa cooperativa?

J: - Uma cooperativa tipo o nosso, o nosso grupo assim. E a gente faz e a gente desempenha porque sabe que vai dá resultado, você entendeu? Vamos supor, esse mês nós tiramos $\mathrm{R} \$ 150,00$, mês que vê, nós queremos tirar $\mathrm{R} \$ 300,00$. A gente sabe onde a gente pode procurar, onde vai dar lucro. Como vai dar a renda se produzir, entendeu?

E: - Que daí a renda vem pra vocês, não é?

J: - Vem pra nós.

E: - Essa que é a diferença você acha?

J: - É assim: eu tirei R\$ 150,00 esse mês, se eu trabalhar uma hora ou duas a mais, eu vou tirar $\mathrm{R} \$ 300,00$. E todo grupo que vai, vai empenhar naquilo. E agora você trabalhar por mês não, você vai trabalhar duas horas de hora extra não vai valer nada. Não é não? Você vai ganhar por hora? E nós só ganhamos por produção. Mas isso não importa, o desempenho, e o nosso grupo tava muito bem formado. Tudo pessoas legal. É uma pena desmanchar ele. 
E: - Mas você acha que vai desmanchar?

J: - Não sei não. Porque as únicas pessoas que estão ficando não tem condições de venda. Porque pra produzir, você tem que produzir, mas você tem que vender...

E: - É, claro.

J: - Não é? Não adianta produzir uma coisa que não vende. Por isso que eu não venho. Adianta produzir? Aí quem vai ficar, a única pessoa que pode vender ali, que tem condições mesmo porque ela joga tudo pro alto e sai é a Márcia. Porque as outras têm marido, as outras tem horário, as outras têm vida, você entendeu? Chega hora de ir embora o povo larga até barrinha queimando e vai embora.

E: - Então só ficou a Márcia?

J: - Só. Antigamente as meninas, ia todo mundo embora só ficava eu, Carlos e Márcia. Aí nós tinha que embalar o resto que ficava, o resto que faltava, que dava o destino pras barrinhas. Todas, todo mundo ia embora. Sobrava nós três, e agora só tá sobrando ali o Carlos, é o único que tá fazendo.

E: - Ah, tem o Carlos também, não é?

J: - Ficava nós três, agora eu saí. Nossa nós já ficamos várias vezes, uma vez a gente tinha umas pra fazer, e a gente tava fazendo aqui ainda. Aí, a menina, eu esqueci o nome dela, ela pediu pra gente. Ela falou assim, "olha, se vocês quiserem trabalhar no sábado, por enquanto não tem atividade nenhuma no sábado, vocês podem vir". Era bem na época do carnaval, eu falei, vamos aproveitar fazer a nossa produção no sábado, que é pra gente ter barrinha, que tinha pouco, sextafeira vender, hein?! Aí tudo bem, a Ana tinha saído, tinha ido não sei pra onde não podia vir, aí nós, entre eu o Carlos, e não sei se a Carina também precisava sair, não pôde vir, falou assim, mas nós três vamos fazer o que dá não é? Nossa, não foi aceito, isso aí depois deu uma polêmica. Nós fizemos a produção toda, depois o Carlos veio mais tarde pra ver como é que tava, sabe, mas não gostaram não. Disse que a gente começou a fazer coisa errada, que a gente não podia fazer isso.

E: - Por causa do grupo.

J: - É, por causa do grupo. Eu falei assim, se o grupo quiser ficar sentado o dia inteirinho eu vou ficar? Eu não posso. Foi o que nós tiramos no grupo. Entendeu? Alguém podia tomar a decisão pelos outros que não viessem. Porque, como se fala, tem as meninas que tem o marido chega naquela hora tem que tá a janta na mesa. Outros são filho que tem que ir pra escola e não sei o 
que. Eu tenho a minha casa também, mas se eu estou fazendo um serviço, eu vou fazer o meu serviço eu não tenho criança comigo eu tenho os meus netos mais eles têm mãe e paí. Os meus filhos o caçula eu já casei então se eu quiser virar a noite vendendo barrinha eu posso isso, se eu aguentar, se eu for não evento que vai ficar a noite inteira eu posso ficar a noite inteira não tenho mais nada que me impede entendeu? É por isso que eu falo que é eu, Márcia e Carlos. Porque nós somos os únicos que podemos fazer isso, as outras não têm condições. A gente vai lá fica lá igual eu e Carlos, nós ficamos nós saíamos, o Pólis fecha dez, dez e meia nós fechávamos a porta e saíamos junto com o pessoal, entendeu? Chegava em casa, chegamos o Carlos não tem nada pra reclamar eu também não tenho, e vendíamos as barrinhas. Agora vai a Carina ou a Maria fazer isso, o marido manda até embora de casa.

E: - É mesmo?

J: - É, porque vai chegar uma hora dessas em casa? Então marido não aceita. Então eu não tenho marido, Márcia não tem marido e Carlos não é casado. Então... As condições nossas são essas por isso que o grupo vai enfrente, entendeu? Por que a hora que um não pode fazer alguma coisa o outro já pode.

E: - É, complementa não é?

J: - Então as meninas ficam na produção, não podem sair os outros, eu mesmo nunca pude sair a noite porque sempre na época de ir para o Rio de Janeiro pra Campinas ou algumas outras cidades é bem no final de semana é época de pagar minha conta, aí eu não posso ir, não posso deixar de pagar, aí quem podia ir era o Carlos.

E: - Aí ele vai, não é? Entendi.

J: - Aí se fosse então mais ou menos no meio do mês aí dava.

E: - Que pena não é, Joana, estava indo tão bem a sua relação com eles e tal. Então foi essa encrenca aí com a incubadora mesmo não é?

J: - Foi, eu acho que foi, porque eu sou assim o tipo de pessoa que tento fazer as minhas coisas certo. Você viu minha entrevista aqui, mas uma coisinha que acontece comigo é como se tivesse trincado um vidro que não cola mais você entendeu? Você viu aqui, não é? Eu lá da minha mãe, da minha casa eu fugi e nunca mais voltei até hoje. Eu sou meia esquisita assim mesmo, não é porque eu quero ser assim e às vezes uma conversa... Um dia eu fui na USP pra ficar lá sem fazer nada, vendi cinco barrinhas porque não tinha nenhum movimento.

E: - Por quê? 
J: - Porque o Carlos diz que tinha uma feira, e a gente vai depois que a feira acabou.

E: - Mas porque vocês foram na hora que a feira acabou?

J: - Eu não sei, não sei porque que é não... Tem coisinha que não é nem pra por aí essas coisas que não tem sentido, não é? Eu também não quero, eles são muito legal, eu também não quero fazer uma coisa, mas se a pessoa promete uma coisa, eles tem que dar aquilo que prometeu. Ele prometeu dar as nossas barrinhas, eu disse "olha eu estou no grupo aqui porque eu preciso de fundar alguma coisa, pra dizer que eu fiz alguma coisa porque eu não sou mais criança não, então pra mim é interessante dizer 'nossa aquelas barrinhas lá foram nós que desenvolvemos', não é?". Vocês também, não é? Você ver uma barrinha na praça e sentir nossa eu tive aquele projeto, não é não?

E: - Muito legal.

J: - É legal, então...

E: - Pra deixar alguma coisa mesmo, não é?

J: - É. Mas assim, não sei porque deu esse fuzuê. Teve um tal de um Lanche Ecológico que a Márcia fala até hoje. Esse lanche ecológico foi desenvolvido aqui e depois disse que acabou, você ficou sabendo não é?

E: - Fiquei.

$\mathrm{J}$ : - E porque que acabou? Deve ter sido que acabou por causa disso.

E: - Não, parece que deu algum problema lá, assim, não fiquei sabendo dos detalhes, sei que aconteceu, e depois acabou.

J: - É, disse que o lanche tava uma maravilha, tava muito bom, inclusive no Pólis uma vez tinha um lanchinho. Do jeito que a Márcia me falava era esse lanche. Ela disse, que faço um lanche maravilhoso, bem ligth, sabe? Agora eu não sei se era esse, poque eu não tava no projeto, nem sei como que era feito.

E: - Eu não sei também.

J: - Diz que acabou, que um cara que tava no projeto, tava até catando latinha por aí. Você entendeu? Devia já ter formado uma cooperativa pra esse cara...

E: - Espaço tem não é?

J: - Tem. Não estão formando mais porque não quer, porque eles começam os projetos. Olha, a gente fica amassando barrinha com a mão, sendo que tem o misturador, tem tudo, eu já fui até ver. Ali na casa que vende esses aparelhos pra indústria, que tem tudo esses aparelhos pra vender. 
Eu pensei, a gente pode comprar os aparelhos. Mas se vocês comprar, vai ficar pro grupo, ninguém pode retirar. Você entendeu?

E: - E daí?

J: - E daí a gente podia deixar. Mas eles não liberam pra gente comprar, tem que ficar ali olha, fazendo as coisas com a mão. Pra que isso? Você a receita lá, não tem um negócio mistura tudo, não fica tudo mais prático? Vem um triturador, você tem que ficar picando banana com a mão. Estamos no tempo da pedra ainda? Não estamos no tempo da pedra, o negócio já evoluiu. E se tem o dinheiro no projeto, o dinheiro é pro projeto, não é não? É pra comprar, eles tinham que deixar nós com a nossa cozinha montada. Era ou não era?

E: - Parece que tá construindo, não é, um Centro de Referência?

J: - Está, tinha que deixar a nossa cozinha montada com nossos aparelhos, pra produzir nossas barrinhas. Com rótulo e tudo. Não é isso que tinha que ser feito?

E: - Não tá acontecendo não?

J: - Não tá acontecendo, agora se não fosse dar tempo, então, a gente tirava a receita da barrinha e deixava um tempo, até formar a cozinha, pra depois a gente voltar, mas não pra gente fazer o que fez, a gente demonstrou fez tudo e agora nós ficamos sem crédito na praça. Não estamos. Porque as barrinhas tá parado. Nós vamos voltar de novo com essas barrinhas?

E: - É, depois volta com rótulo, não é?

J: - Mas aí nós temos que demonstrar tudo de novo.

E: - Será? As pessoas lembram, será que não?

$\mathrm{J}$ : - Esses contatos a gente já perdeu, aqueles telefones, aquelas pessoas.

E: - Perdeu?

J: - Ah, eu acho que perdeu, porque o Luís era do contrato. A Ana era do contrato. Eles saíram do contrato. Os telefones era tudo deles pra você ver. Porque nós tiramos todos, cada um ficou com uma parte, não é? Eu não sei se alguém pediu alguma coisa, alguma barrinha por telefone ninguém nunca... Você vê aqui em frente a escola, no Viana Monteiro, no João Negão, ali em frente aquela pracinha, eu dei meu nome, dei meu endereço e tudo, pra todo mundo, pro bairro inteiro. Mas também eu não reclamo disso porque, porque o pessoal saiu.

E: - É, quem tava cuidando disso saiu não é?

J: - Aí a gente tem que começar tudo de novo, a mesma coisa, vamos ter que por um telefone nosso pra contato. 
E: - No rótulo não é? Isso é importante mesmo.

J: - Nossa, essas barrinhas aqui mesmo dava pra gente fazer. Tá vendendo, vendendo de caixa agora. Caixa fechada não é não?

E: - A rodo não é?

J: - Lógico. Porque eles compram. Vende de tudo, até pipoca. Uma barrinha é dois reais, essa daqui é dois por um e 50 .

E: - Mas Joana, você pode voltar ainda, não é? É só resolver essa questão, que é importante, não é?

J: - Eu posso até voltar se a cozinha tivesse tudo montadinha, tudo legal, se fizer um projeto legal. Eu posso até voltar. Aí depois eles já queriam fazer macarrão, fazer não sei o quê.

E: - Quem queria fazer macarrão?

J: - Eles até compraram uns negócio aí, sabe? Eles compraram. Ele disse que era dinheiro do projeto, ele disse que era dinheiro do projeto, não era nem pra comprar isso aí. Era dinheiro do projeto era pra, projeto nosso não é, só pode ter sido. E diz ele que comprou uma, como que se fala, aquela seladora, aquela seladora que tira o ar.

E: - Mas era pra barrinha não é?

J: - É. Disse que comprou um monte de coisas.

E: - Ah, que bom, não é?

J: - Pra quando a cozinha tiver pronta, vamos ver se vai, vai estar montada mesmo não é?

E: - Ah, estava indo Joana, pode ser, não é? Ainda está andando então isso, não é?

J: - É agora vamos ver se vai dar certo, não é? A Márcia é que sabe mais desse projeto que ela vai fazer as reuniões e vê.

E: - Por que a seladora é importante mesmo, não é?

J: - É que a gente tem a seladora pequena e ele comprou a grande eu acho que é oito os troço lá e vamos ver, não é?

E: - É vamos ver então, espero que você volte.

J: - Agora espero que eles façam a cozinha lá e que reforma tudo e que fica igual aqui porque aqui, porque eu acho gostosa essa casa atrás não é?

E: - Está abandonada, não é? 
J: - Uma cozinha assim tinha que estar vendendo marmitex aqui, eu estaria cozinhando aqui. Você um jogo de panelas todo o tipo de coisa que da pra você, né? Tinha até fechador de marmitex aqui.

E: - Ah é?

$\mathrm{J}:-$ Tem, tem sim.

E: - E porque ninguém está usando?

J: - Eu acho que eles estão mais com projeto e não está a fim e fica nessa, aí não termina porque se você... Porque pra você vender tudo que você trabalha de alimento, se não tiver rótulo, você não vende, não adianta. Eu trabalhei com alimento quando eu tinha um pequeno restaurante em casa, mas eu abri firma, tudo eu tenho firma aberta até hoje você entendeu? Porque qualquer coisa que aconteça eu tenho autorização pra mim funcionar aqui.

E: - Pode voltar, não é?

J: - Não, se por acaso vir uma pessoa reclamar de alguma coisa ali e me leva na justiça no código ou alguma coisa assim, qualquer coisa eu tenho um alvará eu abri uma firma e eu tenho condições, eu não estou fazendo isso liberdade espontânea igual, nós aqui essas barrinhas estão feitas, é igual ao CD pirata se eles forem vender a letra eles pegam nota.

E: - Entendi. Obrigada Joana, então eu vou fazer o seguinte quando estiver pronto o trabalho eu mando pra você, eu trago aqui de novo pra você ter ele final porque aí se você quiser dar uma olhada e tal, mas se for essa a versão final daí eu vou começar a fazer o trabalho em cima disso. Sabe, meu objetivo é ler essa entrevista de novo e ver em qual momento da vida das pessoas que eu entrevistei, você o Luís e a Márcia, tiveram alguma mudança, sabe, o que causou essa mudança, a pessoa mudou de que pra que, mudança mais no sentido do interior da pessoa sabe de dentro, o que vez ela tornar uma pessoa diferente. Então eu acho que a sua entrevista teve vários momentos assim que dá...

J: - Dá pra tirar coisas, não é? Porque esse mesmo de eu voltar aí você viu eu não volto nunca da onde eu saí é incrível.

E: - Não volta, não é?

J: - Até em casamento ou qualquer coisa ó, eu divorciei, eu te contei aqui na entrevista, eu divorciei do meu marido, nós moramos na mesma casa porque nós temos filhos e a casa a gente construiu junto e eu não vou vender a casa que eu quero que fique pros meus filhos, mas voltar a trás como mulher dele nunca mais, nem se ele nascer de novo não volto não. 
E: - Nunca volta atrás, não é?

J: - Não volto atrás... Só da única coisa que eu volto atrás é ser mãe dos meus filhos, que eu nunca posso descuidar disso.

E: - Só faltava também...

J: - É só isso aí, mas o resto nem lembro se eu já voltei atrás de alguma coisa.

E: - É, às vezes é bom não é? Mas as vezes não, quem sabe...

$\mathrm{J}$ : - É por isso que eu demoro tomar uma decisão, você entendeu?

E: - Entendi.

J: - Eu fiquei no grupo aí, muito tempo vendo muita coisa, engolindo muita coisa por causa disso aí por que eu, quando eu tomo uma decisão igual eu te falei aqui... Porque eu preciso porque sempre dinheiro quando vem é bem vindo, não é não? Tudo que você ganha com seu próprio suor é bom você estar trabalhando, e pra mim, na minha idade, não tem coisa melhor que trabalhar.

E: - Por que não? Por que é bom trabalhar na sua idade?

J: - Porque na idade que você... Na idade que a gente entrou eu já estou chegando nos 60, aí você vai o quê? Vai endurecendo, não é, quanto mais movimento você faz você distrai pra você é um... Você vive melhor, o trabalho é que faz isso aí, mas você vai ficar em casa, vai ficar só com problema de sua casa, você senta aqui, você vai lavar uma louça, ah depois eu lavo, vai lavar uma roupa, ah depois eu lavo, não é? E você estando trabalhando não você vai movimentar e diz, não eu vou fazer isso aqui porque amanhã eu tenho que ir lá, não é não? Tem que ter objetivo e você vive melhor uma, como é que é? Uma como é que fala já estou tão cheia de problema na minha idade, sabe? Com um ex marido com um filho nem dormi de noite.

E: - Por quê?

J: - Porque meu marido, desculpa ex-marido, o meu filho, eu já te falei que ele tem problema e cheira, não é?

E: - Ah sim.

$\mathrm{J}$ : - Ele cheira isso aí, e o dia que ele cheira, minha filha, o bicho pega.

E: - Até hoje ele cheira?

J: - Ele chega fica se mostrando assim ó, chamo a policia, a polícia não pode fazer nada não é, chamo só pra ele acalmar um pouco.

E: - Você chama a polícia?

J: - É, tem que chamar não é... Porque ele quebra tudo. 
E: - Que coisa, hein?

J: - Não estou mais aguentando, agora comprou uma cama nova, essas embaúba, porque até cama de ferro ele quebra não tem nenhuma cama, na hora que ele fica nervoso ele quebra cama, guarda roupas.

E: - Quando ele cheira isso, não é? E ele cheira muito, sempre?

J: - Cheira é direto duas ou três vezes por semana e quando isso acontece ele quebra tudo ultimamente. Essa semana passada agora até que eu pus uma ordem em casa, é por isso que eu estou meia sem limites sabe, eu pus uma ordem em casa que meu ex-marido vai dar área agora, eu já estou com as malas dele prontas, ele vai voltar pra casa da mãe dele, vai quarta-feira porque eu falei assim ou você vai embora pra mim por uma ordem nisso, a casa é minha, ou você... Ou eu vou ter que enganar vocês, então é um dos dois.

E: - Por que ele também cheira? Seu marido.

J: - Não, ele bebe.

E: - Ah, ele bebe.

J: - Ele, a hora que ele... Ele trabalha, sabe o dia que ele esta trabalhando é uma beleza, trabalhando você precisa de ver como ele é. Ele era mecânico ele aposentou virou mecânico de carro pesado mecânico assim sabe desses caminhões, guinchos e essas coisas só que ele aprendeu a fazer coisas de pedreiro assim, assentar azulejo, piso e é um bom pedreiro e agora, como ele está aposentado, ele faz bico, mas esses bicos é só pra ele comprar cachaça.

E: - Ele gasta tudo.

J: - Tudo com cartão e aí o dia que não está trabalhando ele vai pro bar bebe o que ganhou no final de tudo deixa só um resto na carteira. Não, é ele é cachaceiro nunca paga dívida, aí vai pra casa, xinga xinga, xinga, fica o dia inteiro xingando. Quando é de noite sabe o que acontece? O outro que já escutou o dia inteiro vai lá e cheira. O dia é de um, e a noite é de outro. E eu tenho eu aguentar.

E: - Mas que saco... E é sempre junto, no mesmo dia?

J: - No mesmo dia.

E: - Ah, então precisa separar eles mesmo.

J: - Aí ultimamente eu estava com meus netos, foi domingo, ou foi sábado. Eu acho que foi sábado. Meus netos estavam em casa, final de semana, até que você me ligou, não é? Aí eu cheguei a operar na terça-feira, sabe? Aí eu estava arrumando a cama pros meninos, eu já tinha 
dado janta pra eles, arrumando a cama pra eles dormirem, aí começou. Ele chegou, eu vi ele meio estranho, pensei assim, ih, eu vou arrumar logo a cama pra vocês, pra vocês dormirem. Tinha um fruteira pequena em casa que tinha umas batatas pequenas, ele começou a pegar essas batatas e jogar nos meninos. Os meninos corriam. Mas jogava com força porque batia na parede a batata estourava.

E: - Gente...

J: - Ele tava nervoso. Aí tudo bem, aí os meninos correram pro quarto do avô deles, aí ele foi atrás e jogou a batata. Aí ele falou assim, não, você não vai jogar batata nos meninos. Eu nem estava vendo que ela tava jogando batata. Eu vi no começo quando ele parou, eu pensei que ele tinha parado. Aí sabe o que ele fez? Ele avançou no pai dele. Avançou no pai dele pra dar uns tapa, aí, os meninos correm, eles vão pra área, que eu tenho uma área lá no fundo. Tinha um roçador, sabe essa foice de roçar mato? Tinha um negócio desse lá menina, porque ele limpa o quintal, ele não pegou a foice pra passar no pescoço do outro?

E: - Não acredito. E aí?

J: - Aí os meninos assustaram, "vó, vai cortar a cabeça do pai”. Aí eu vou correndo, quando eu chego lá, o pai já tinha jogado ele no chão, ele é um velho de 60 anos. Aguentar um rapaz novo... Você não conhece meu filho, ele é enorme. Aí jogou ele no chão, e o outro com a foice na mão, com a foice ele vai matar o pai... Aí eu corri, entrei no meio, não agora, cortar o pescoço com... A mão é outra coisa. Aí eu corri, dei um jeito de arrancar a foice da mão dele, e acalmei o negócio, aí nisso os meninos desce correndo. Aí o meu filho casado mora numa casa embaixo da minha. Meu caçula acabou de casar, acho que você não ficou nem sabendo.

E: - É, me falaram. O Alexandre me falou.

J: - Então, casou, mora lá, porque não dá pra morar junto mesmo. Aí ele sobe correndo, ele e a mulher dele, que já estava dormindo. Aí ele falou pra mim, mãe, eu já falei que o dia que ele pôr a mão no meu pai eu vou matar ele. E ele é serio. Ele é igual eu, o que ele fala ele faz.ele demora falar uma coisa, mas ele só fala o que vai fazer, entendeu? Ele é magrinho mas é esperto. E tem força. Aí ele foi em cima, eu falei, "espera aí, você acabou de casar, você não vai por a mão". Que eu sabia que ele ia matar ele mesmo. Aí eu falei, "não, desce, você desce lá pra casa com a tua mulher e cuida dos meninos pra mim", porque os meninos estavam tudo...

E: - Ai, que dó, não é? 
J: - E eu acho ruim ver eles crescendo vendo isso. É ruim. Depois diz que é a criação que vem de dentro de casa. Os meu eu não criei desse jeito, já ficou... Imagina ser criado vendo isso ao. Aí eu falei, agora vocês vão se acalmar porque se vocês não se acalmar eu vou chamar, eu mandar vocês lá pro hospital da Lapa, o hospital psiquiátrico, mandar pôr em camisa de força, vocês dois. Aí, tudo bem, ficaram calmos, pouquinho, e depois, coisa de cinco minutos, depois ele voltou de novo. Aí ele falou assim, “a senhora protege tanto o Maícom e eu vou dar”... Ah, essa aí eu conheço, olha que gracinha. "Eu vou dar tanto murro nele que eu vou matar ele na porrada." Mas o que é isso Fábio, o que você vai fazer, ele não fez nada. "O que ele tinha que subir aqui?". "Ele tinha que subir sim, você está batendo no pai dele. O seu pai é o mesmo pai dele. Você acha que ele vai deixar você matar o pai dele? Não.” Aí ele disse: “ah é, a senhora tá dando razão pra ele?". Mas menina, ele deu um murro na minha geladeira, dessa redondinha, como é que chama, que a bichinha, a minha é daquela Eletrolux que é redonda na frente, chegou a ficar reta. Eu disse, você tá endoidando. “Eu vou quebrar tudo, isso aqui vai ficar só parede.” Eu falei assim, é, pode quebrar, nem tô aí. Quem vai ficar sem as coisas é vocês, os objetos que tem aqui é de vocês. Eu já tô velha, eu não preciso quase nada. Aí ele ficou brigando, foi preciso chamar a polícia.

E: - É mesmo?

J: - Aí a polícia foi, quando chegou ele já estava mais calmo, e ele sempre acha que tem razão. Aí a polícia falou, “eu não posso fazer nada, porque prender não adianta. Isso aqui é um caso de tratamento". Tratamento você não acha em lugar nenhum. Eles soltam a droga no país, e o estado não dá tratamento pra ninguém.

E: - É mesmo?

J: - O único lugar que tem é o manicômio, você chega lá você sabe como é doido mesmo, não é? Aí piora. Eles tinha que ter um hospital pra internar esse pessoal. Ou então o governo tinha que liberar essa droga. Porque se ele liberasse a droga, ninguém ia entrar nessa, você vai entrar numa coisa que não dá futuro? Eu não tô saindo daqui porque não tem rótulo pra vender? Alguém vai vender droga por quê? Ninguém anda vendendo açúcar. Açúcar é tão barato. Tem pra vender, pra viciar os outros. Eu acho que a cocaína tinha que ser liberada pra não acontecer o que tá acontecendo. Aí eu penso assim, pois é, o Estado que devia liberar a cocaína. Libera todo tipo de droga, e os drogados que tem vai usar até morrer e deixa a família em paz, e outros não ia ficar, 
não é? Porque a pessoa que é drogada, se ele tiver um quilo de cocaína aqui, ele vai cheirar ele até morrer. Não pára, não é?

E: - Não pára...

J: - Não pára, você não vê esses cantores que morrem, eles têm dinheiro pra comprar, e o pobre não tem. É por isso que eles ficam doido. Eles não cheira o suficiente.

E: - Tem que parar, não é?

J: - Tem que parar porque o dinheiro não dá. Aí a polícia chegou eu falei assim, "pois é o negócio é esse, eu não posso fazer nada". "Vocês que tem que entrar em acordo". Pois é, o acordo que tem aqui é esse. É um matar o outro, um vai pro cemitério e o outro vai pra cadeia. Porque não tem nada pra fazer, não é? Você vê que é o que passa na televisão aí. Não tem outro jeito. O único jeito é esse.

E: - Aí seu ex-marido vai sair? Pelo menos isso, não é?

J: - Ele vai sair, eu falei assim, e onde chega agora. Você vai pra casa da sua mãe, e ele fica, porque ele ficando eu vou comer na rua, eu não faço nem comida. E ele vai viver com fome? Ele vai ter que trabalhar. Ele sabe que eu não vou, ele tá lá dormindo. Não deixou ninguém dormir, mas ele tá dormindo, dorme o dia inteiro.

E: - Porque ontem ele tava...

J: - Tava atacado, a noite inteirinha. Agora quando é de noite na hora da gente dormir ele acorda.

E: - E ele não trabalha?

J: - Não trabalha, porque não consegue, não é? A hora que estabiliza um pouco ele arruma um bico pra pagar as dívidas. E assim vai indo...

E: - É Joana, você vai ter que dar uma dura mesmo.

J: - Vou ter que dar uma dura, agora vai ser assim, ele vai quarta-feira, vai pra lá e eu vou tentar resolver dessa maneira. Não vou comprar pasta, não vou comprar sabonete, ele toma quatro banhos ao dia.

E: - Ele?

J: - É, porque fica deitado, não aguenta ficar na cama, não é? Levanta toma banho, vai e deita de novo.

E: - É, precisa fazer alguma coisa, porque a pessoa fica parada assim, aí fica mais doido mesmo. 
J: - Fica mais doido. Agora, ele levanta tem água, tem sabonete e tudo pra ele tomar banho, e a hora que não tiver? Ele vai ter que tomar providências. Então é isso que eu falei, ele vai ter que comer.

E: - Vamos ver o que ele vai fazer.

$\mathrm{J}$ : - Ele vai ter que comer, porque quanto tem comida ele come a noite inteirinha.

E: - Eu vou ver se eu não fico sabendo de algum lugar de tratamento viu, Joana. Aí eu te falo.

J: - É se vocês conseguir pra mim. Porque é uma pena, é um rapaz que você olha assim, na hora que ele tá bom, nem parece, ali na Vila todo mundo conhece ele. E eu agora, o pai dele vai pra lá, e ele vai ficar nesse regime, eu falo assim, “olha, se você me atacar, eu não sou seu pai...” Eu tive você, eu dou um fim em você. Se ele vier em cima de mim igual vai em cima do pai dele, vixi Maria. Eu acabo com ele, fui eu que tive ele, vou deixar ele ficar em cima de mim? Não vou mesmo. Já falei isso pra ele. Eu ainda falei com a polícia, "olha, essa é a última vez que vocês vem aqui, já era bom vocês fazerem uma ocorrência definitiva. Vocês não vão voltar mais aqui, porque agora quem vai olhar ele sou eu."

E: - É um jeito tem que dar mesmo, porque não vai prestar assim.

J: - Se ele não assumir...

E: - Não vai dar certo não é, isso...

J: - Não vai dar, e eu não posso ficar nessa vida não, de jeito nenhum.

E: - É, mas tenta não é, Joana... Tenta mudar. Vamos ver se ele responde. Se eu souber de alguma coisa eu te ligo. Te falo. Mesmo que não seja muito perto, mesmo que seja lá perto do Hospital das Clínicas. Mas aí eu te aviso.

J: - Eu vou até vender o carro, você viu aí, eu falei que eu tinha um carro e tudo, não é? Eu vou vender ele porque eu estou com medo de ele sair por aí, atropelar alguém e matar, sabe como é que é... Então é melhor.

E: - Sei. Esconde a chave.

J: - Já escondi. Não tem mais jeito pra esconder. Eu já te contei que uma vez, acho que já te contei que ele levou o carro numa bocada e deixou lá?

E: - Não.

J: - É, eu tive que ir lá buscar. Com chave e tudo. Perdeu a chave lá.

E: - Não acredito. 
J: - É, acho que ele foi trocar por drogas. E não conseguiu. Lá no Helena Marinho. Maria Helena. Um negócio por aí, ele nem sabia onde que tava.

E: - Nossa, e como você achou?

J: - Porque eu cheguei lá e o pessoal indicou, o pessoal que tava mais perto. Me informou e indicou que tava lá.

E: - Ah a pessoa foi falando...

J: - É, ele tinha chegado em casa, e disse que tava na casa da minha sobrinha, de lá mesmo fiquei sabendo onde ele esteve, e falou assim, “olha, o carro tá lá nesse local, vai lá ver”. Eu cheguei tava lá, não tinha nem mexido. Ninguém pode mexer quando é assim, não é? Porque se pôr a mão já viu...

E: - Que coisa, hein? Mas eu vou ver, Joana, se eu souber de alguma coisa eu te falo. 